\title{
REAÇÃO À COR: \\ A COR COMO FORMA DE EXPRESSÃO
}

FERNANDA MOCERI

SÃO PAULO | 2021 



\section{REAÇÃO À COR:}

A COR COMO FORMA DE EXPRESSÃO

\section{FERNANDA MOCERI}

Tese apresentada ao Programa de PósGraduação da Faculdade de Arquitetura e Urbanismo da Universidade de São Paulo para obtenção do título de Doutora em Arquitetura e Urbanismo

Área de concentração: Tecnologia da Arquitetura

Orientação:

Prof. Dr. João Carlos de Oliveira Cesar

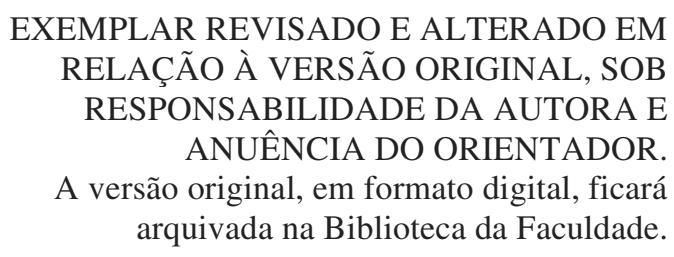

São Paulo, 23 de Setembro de 2021

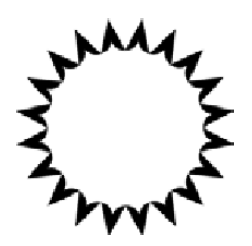

SÃO PAULO 
Autorizo a reprodução e divulgaçăo total ou parcial deste trabalho, por qualquer meio convencional ou eletrônico, para fins de estudo e pesquisa, desde que citada a fonte.

Catalogação na Publicação

Serviço Técnico de Biblioteca

Faculdade de Arquitetura e Urbanismo da Universidade de São Paulo

Moceri, Fernanda

Reação à Cor: a cor como forma de expressāo / Fernanda

Moceri; orientador Joāo Carlos Cesar. - São Paulo, 2021.

$329 \mathrm{p}$.

Tese (Doutorado) - Faculdade de Arquitetura e Urbanismo da Universidade de Sáo Paulo. Área de concentraçăo: Tecnologia da Arquitetura.

1. Cor. 2. Paleta de cores. 3. Levantamento cromático.

I. Cesar, Joāo Carlos, orient. II. Título.

Elaborada eletronieamente airavés do formulairio disponivel em: <http:/www.lau.asp.br/fichacatalografica/s 

À minha alegre, doce e encantadora filha, Nina, com todo o meu amor. 


\section{AGRADECIMENTOS}

Agradeço a minha filha, Nina Moceri, que, assim como as cores, encantame todos os dias.

Agradeço ao Lucio Fleury, pela paciência, por aceitar a minha ausência e por todo o apoio me dado ao longo desse processo.

Agradeço aos meus pais, Maria Luiza e Flávio Moceri, pela confiança e por todos os incentivos.

Agradeço ao meu orientador, Professor Dr. João Carlos de Oliveira Cesar, por esses anos de pesquisa e por todo o conhecimento compartilhado. 


\section{RESUMO \\ Reação à cor: a cor como forma de expressão}

Esta tese tem por objetivo propor uma demonstração de como poderiam ser pensadas e desenvolvidas paletas de cores que expressem a tríplice função das cores: impressionar, expressar e emocionar (GOETHE, 2011).

Para tanto, cria-se, aqui, um método que tem como base o trabalho proposto pelo pesquisador Frank Mahnke (1996), indo desde a relação biológica ao estímulo proveniente da luz, passando pelas associações originárias do inconsciente coletivo e as associações simbólicas conscientes, até serem influenciadas por aspectos culturais e depois pelas referências oriundas da tendência, moda e estilo.

Ademais, os fatores psicológicos e emocionais, conforme proposto por Modesto Farina (1982), colaboram para o entendimento do percurso que a cor, por ser um fenômeno complexo que envolve muitas condicionantes, estabelece com a psique.

Apoiou-se também no trabalho apresentado pelo psiquiatra e psicanalista suíço Carl Gustav Jung, com os Tipos Psicológicos (1971), que mapeia as características de cada categoria elencada por ele e relaciona cada um dos tipos aos atributos de cor de saturação e luminosidade. Para desenvolver a análise de cada uma das categorias propostas por Jung, foi utilizado o sistema sueco de notação cromático Natural Colour System.

Consideraram-se as diretrizes trazidas do universo da tendência, moda e pintura corporal que ditam e influenciam constantemente as relações e os conceitos das tonalidades na sociedade. Para tanto, levou-se em consideração a contribuição deixada pela Hierarquia das Necessidades de Abraham Maslow (MASLOW apud VEJLGAARD, 2008), a Curva de Difusão da Inovação de Everett Rogers (ROGERS apud SANTOS, 2013) e o Modelo de Tendência em Forma de Diamante de Henrik Vejlgaard (2008). Isso porque entender como as tendências surgem e se dissipam, assim como as aberturas e os aceites que despertam nas pessoas e como elas se portam perante tais informações, contribui para o objetivo deste trabalho.

Acrescente-se ainda que as contribuições deixadas por Michel Eugène Chevreul, com a Lei do Contraste Simultâneo (1987), as cores fisiológicas descritas por Johann Wolfgang von Goethe (2011), os contrastes cromáticos e o timbre subjetivo de Johannes Itten $(1961 ; 1970)$ são alicerces desta tese, pois ajudam a compreender a relação pessoal que cada indivíduo estabelece com a percepção, sensação e consciência da cor.

Por fim, foi desenvolvida uma demonstração de como poderiam ser pensadas e desenvolvidas paletas de cores que representem as características, os desejos e anseios das pessoas bem como também respeitem a capacidade criativa individual como aliada à orquestração dessa proposta.

PALAVRAS-CHAVE: Cor; Paleta de cores; Levantamento cromático. 


\section{ABSTRACT \\ Reaction to color: color as a form of expression}

This thesis aims to propose a demonstration of how color palettes could be thought and developed that express the triple function of colors: impress, express and affect (GOETHE, 2011).

To this end, a method is created here that is based on the work proposed by the researcher Frank Mahnke (1996), ranging from the biological relationship to the stimulus coming from light, passing through the associations originating from the collective unconscious and the symbolic conscious associations, until they are influenced by cultural aspects and then by references from trends, fashions and style.

In addition, psychological and emocional factors, as proposed by Modesto Farina (1982), collaborate to understand the path that color, as a complex phenomenon that involves many conditions, establishes with the psyche.

It was also supported by the work presented by the Swiss psychiatrist and psychoanalyst Carl Gustav Jung, with the Psychological Types (1971), which maps the characteristics of each category of color of saturation and luminosity. To develop the analysis of each of the categories proposed by Jung, the Swedish system of chromatic notation, Natural Colour System, was used.

The guidelines brought from the universe of trend, fashion and body painting were considere to dictate and constantly influence the relationships and concepts of shades in society. For this purpose, the contribution made by Abraham Maslow's Hierarchy of Needs (MASLOW apud VEJLGAARD, 2008), the Innovation Diffusion Curve of Everett Rogers (ROGERS apud SANTOS, 2013) and the The Trend Model in the Form of Diamond by Henrik Vejlgaard (2008). This is because understanding how trends emerge and dissipate, as well as the openings and acceptances that awaken in people and how they behave in the face of such information, contributes to the objective of this work.

It should be added the contributions left by Michel Eugène Chevreul, with the Law of Simultaneous (1987), the physiological colors described by Johann Wolfgang von Goethe (2011), the chromatic contrastes and the subjective timbre of Johannes Itten $(1961 ; 1970)$ are the foundations of this thesis, as they help to understand the personal relationship that each indivisual establishes with the perception, sensation and awareness of color.

Finally, a demonstration of how color palettes that represent people's characteristics, desires, as well as respecting the individual's creative ability as allied with the orchestration of this proposal, was developed.

KEYWORDS: Color; Color palette; Color check. 


\section{LISTA DE FIGURAS}

\section{REAÇÃO HUMANA À COR}

FIGURA 1: A pirâmide de Frank Mahnke_P.37

FIGURA 2: Timbre Subjetivo proposto por Johannes Itten_P.49

FIGURA 3: Associações entre cores e formas correspondentes proposto por Johannes Itten_P. 50

FIGURA 4: O berço feito por Peter Keler, em 1922, associando as cores e as formas fundamentais_P.51

FIGURA 5: Cores elementares NCS_P. 59

FIGURA 6: Espaço de cor NCS_P. 59

FIGURA 7: Círculo de cor NCS_P.59

FIGURA 8: Triângulo de cor NCS_P.59

FIGURA 9: Pedaço de grafite natural constituído por folhas em camadas de anéis hexagonais de carbono. Imagem meramente ilustrativa para representar a cor preta_P.69

FIGURA 10: Representação de Satã elaborada na tonalidade preta. O Julgamento Final, Fra Angelico, 1431-1432, Florença, Museu de São Marcos, têmpera em painel_P.72

FIGURA 11: Interior de Oude Kerk, Delf, Emanuel de Witte, 1650, Nova York, MET, óleo sobre madeira_P.75

FIGURA 12: Interior de Oude Kerk, Amsterdam, Emanuel de Witte, 1658, UK, Colchester and Ipwich Museums, óleo sobre tela_P.75

FIGURA 13: Disco de Newton: concebido por cálculos matemáticos baseados nas misturas de cores e a porção que cada uma ocupava dentro do espectro_P.77

FIGURA 14: Man Ray e a supremacia da fotografia em preto e branco. Glass Tears, Man Ray, 1932, Los Angeles, Getty Museum, papel de gelatina e prata_P.79

FIGURA 15: Man Ray e a supremacia da fotografia em preto e branco. Noire et blanche, Man Ray, 1926, Nova York, MOMA, papel de gelatina e prata_P.80

FIGURA 16: O primeiro carro produzido em larga escala, o Ford T, recebeu a cor preta_P.81

FIGURA 17: Henry Ford com o 1921 Modelo T na cor preta_P.81

FIGURA 18: Nitrato de Prata. Imagem meramente ilustrativa para representar a cor cinza -P.83 
FIGURA 19: Arte em grisalha. Peregrinos no monte São Miguel, salvos pela intervenção da Virgem, 1460-1465, Paris, Biblioteca Nacional Francesa_P.86

FIGURA 20: Fundo Reverso: como o cinza médio dos "x", tanto sob o lilás como sob o amarelo, muda de aparência conforme o fundo_P.88

FIGURA 21: Escala de cinza. Josef Albers Greys Steps, Grey Scale, Grey Ladders, Nova York, David Zwirner Gallery, Exhibition view, 2016_P.89

FIGURA 22: Escala de cinza. Josef Albers Greys Steps, Grey Scale, Grey Ladders, Nova York, David Zwirner Gallery, Exhibition view, 2016_P.90

FIGURA 23: O cinza metálico de Anish Kapoor. Random Triangle Mirror, Anish Kapoor, 2016, aço inoxidável e resina_P.91

FIGURA 24: Lead White. Imagem meramente ilustrativa para representar a cor branca_P.92

FIGURA 25: Capilla de las Capuchinas, Luis Barragán, Tlalpan, Cidade do México, 1925_P.95

FIGURA 26: Casa Farnsworth, de Ludwig Mies van der Rohe, 1951, Illinois, Chicago, é um dos maiores ícones da arquitetura moderna e, junto com a forma, tem no branco o seu triunfo_P.98

FIGURA 27: Ball of raw Indian yellow. Figura meramente ilustrativa para representar a cor amarela_P.100

FIGURA 28: Amarelo atrelado a figura divina. Midas Washing at the Source of the Pactolus, Nicolas Poussin, 1627, France, Musée des Beaux-Arts, óleo sobre tela_P.102

FIGURA 29: Rosto de Tutankhamun_P.104

FIGURA 30: $\mathrm{O}$ açafrão, apesar de seu aspecto mais alaranjado, foi muito utilizado para tingir de amarelo_P.107

FIGURA 31: Tingimento em amarelo_P.107

FIGURA 32: O amarelo foi ganhando importância ao longo dos séculos e, no período feudal, apareceu em armas, brasões e desfiles de cavalaria_P.110

FIGURA 33: Modelo gráfico representando as cores da urina_P.112

FIGURA 34: A coloração da urina sendo analisado_P.112

FIGURA 35: Kidney Haematite. Figura meramente ilustrativa para representar a cor laranja_P.116

FIGURA 36: Esboço realizado no ateliê de tecelagem da Bauhaus em 1928 por Lena MeyerBergner_P.119

FIGURA 37: Lena Bergner trabalhando em seu ateliê_P.120 
FIGURA 38: Pigmento Vermelho da Persia. Figura meramente ilustrativa para representar a cor vermelha_P.122

FIGURA 39 e FIGURA 40: Grande bisão vermelho de Altamira, norte da Espanha, descoberto em 1879 que data, aproximadamente, entre 15.500 - 13.500 a.C._P.125

FIGURA 41: O homem de turbante vermelho. Portrait of a Man, Jan Van Eyck, 1433, London, National Gallery, pintura a óleo_P.128

FIGURA 42: Chapeuzinho Vermelho: ilustração datada de 1875, feita por Walter Crane, representando o vermelho da roupa, o preto do lobo e o branco da manteiga que ela levava para a vovó_P. 130

FIGURA 43: Papai Noel veste vermelho a exemplo de São Nicolau. Poster americano de John D. Kelley publicado na revista St. Nicholas, 1825, Nova York_P.131

FIGURA 44: Retrato de Susanna Lunden: vermelho destacando a beleza feminina. Portrait of Susanna Lunden, Peter Paul Rubens, 1625, London, National Gallery_P.133

FIGURA 45: Close dado no rosto de Susanna Lunden para exaltar o rubor da face_P.133

FIGURA 46: Onipresença do vermelho na heráldica nos trajes dos cavaleiros_P.135

FIGURA 47: O vermelho presente nos brasões_P.135

FIGURA 48: Concha contendo o pigmento púrpura. Imagem meramente ilustrativa para representar a cor púrpura_P.139

FIGURA 49: Tecidos tingindos de diferentes espécies de moluscos_P.142

FIGURA 50: Lapiz Lazuli. Encontrado somente no Afeganistão, o azul é extraído para produzir ultramarine. Figura meramente ilustrativa para representar a cor azul_P.144

FIGURA 51: Detalhes da Mesquita Azul, Istambul, Turquia, em tons azulados_P.147

FIGURA 52: A ascensão do azul na tinturaria devida à crescente demanda por essa tonalidade_P.149

FIGURA 53: Diagrama de Goethe apresentando as duas cores prismáticas: amarelo e azul_P.152

FIGURA 54: Campanha publicitária desenvolvida por um fabricante de tintas para uso terapêutico da cor em ambientes de saúde onde observa-se o emprego do tom de azul no teto _P.153

FIGURA 55: Byaku Rok. Imagem meramente ilustrativa para representar a cor verde_P.155

FIGURA 56: A presença do verde na Mesquita de Herat, Afeganistão_P.159

FIGURA 57: O comprimento de onda que produz a sensação de verde é o ponto mais alto da sensibilidade do olho humano_P.162 
FIGURA 58: Guia de plantas e ervas voltado para as propriedades medicinais, culinárias e de tingimento desenvolvido no final da Idade Média_P.163

FIGURA 59: Diagramas desenvolvidos durante o século XVII por diferentes pesquisadores na tentativa de propor a ordem das cores_P.165

FIGURA 60: Pela genealogia da cor proposta, em 1613, por François d'Aguilon, o verde era o resultado da combinação do amarelo com o azul_P.165

FIGURA 61: Wald Bau, Paul Klee, Jucker Collection, 1919, gesso sobre tela transferido para papel_P.170

FIGURA 62: Homage to the Square, Josef Albers, Collection SFMOMA, 1969, óleo sobre masonita_P.170

\section{UMA VISÃO SOBRE TENDÊNCIA, MODA E MAQUIAGEM}

FIGURA 63: Imagem publicada em uma revista de moda da década de 30 sugerindo as tendências que estavam em alta_P.183

FIGURA 64: Coleção de outono-inverno 1937-1938_P.184

FIGURA 65: Hierarquia das Necessidades de Abraham Maslow_P.187

FIGURA 66: Os grupos que formam A Curva de Difusão da Inovação de Everett Rogers_P.190

FIGURA 67: Relação entre os grupos e a quantidade de participantes que formam A Curva de Difusão da Inovação de Everett Rogers P.190

FIGURA 68: Modelo de Tendência em Forma de Diamante de Henrik Vejlgaard_P.193

FIGURA 69: Modelo desenvolvido pelo Textile Color Card Association propondo não somente as cores de tendência, mas como combiná-las_P.202

FIGURA 70: Modelo desenvolvido pelo British Colour Council trazendo a previsões de cores sazonais muito semelhante do que era proposto pelo Textile Color Card Association_P.202

FIGURA 71: O triunfo romano celebrado por Júlio Cesar que cavalga usando uma toga púrpura_P.207

FIGURA 72: A ascensão de tons como azul, amarelo e verde presente na vida cotidiana desde o vestuário até em objetos de decoração_P.211

FIGURA 73: Imagem ampliada da figura 72 para evidenciar os trajes em tons de azul e verde_P.211 
FIGURA 74: O manto azul da Virgem. Ghent Altarpiece, Jan Van Eyck, 1432, Belgium, Ghent, St. Bavo's Cathedral, Ghent, óleo sobre madeira_P.213

FIGURA 75: Retrato de Luis XVI, rei da França, trajado de azul. Louis XVI of France, Joseph-Siffrein Duplessis, 1775_P.215

FIGURA 76: Nesse período, os caçadores foram frequentemente retratados de verde, havendo uma aproximação entre as cores do vestuário com as cores da natureza_P.217

FIGURA 77: As fadas foram frequentemente retratadas de verde, aproximando suas qualidades as da natureza. Green Summer, Edward Coley Burne Jones, 1868, coleção particular, óleo sobre tela_P.217

FIGURA 78: $\mathrm{O}$ amarelo, quando usado, era majoritariamente uma cor feminina. Portrait of a Lady in Yellow, Alesso Baldovinetti, 1465, Londres, National Gallery, têmpera em painel_P.219

FIGURA 79: Essa cor ocupa grande parte dessa obra devido o prestígio que essa cor recebeu nessa época. Fresco of Madonna, Lippo di Dalmasio, século XV, St. Stephen Churches, Bologna_P.221

FIGURA 80: O tingimento de preto se fez possível devido ao emprego da noz de galha que permitiu obter tonalidades uniformes que penetravam profundamente nas fibras_P.225

FIGURA 81: O surgimento do cinza como uma cor de prestígio formando uma nova tríade junto com o branco e o preto. Portrait of a Young Woman in a Pinned Hat, Rogier Van der Weyden, 1435, Berlim, óleo sobre painel_P.227

FIGURA 82: Felipe, o Bom, lança a moda do preto na corte de Borgonha. Portrait de Philippe le Bom, Rogier Van der Weyden, 1445, Chatêau d'Ambras, Innsbruck, óleo sobre madeira_P.228

FIGURA 83: A cor ícone da moral protestante. Portrait of Girolamo Savonarola, Moretto da Brescia, 1524, Verona, Museu Castelvecchio, óleo sobre tela_P.231

FIGURA 84: $\mathrm{O}$ aparecimento de tons mais claros ganha espaço na moda no século XVIII. $L a$ Pastorella, Jean-Honoré Fragonard, 1750-52, Milwaukee Art Museum, óleo sobre tela_P.234 FIGURA 85: Branco cerimonial usado pela rainha Victoria criando tendência dos vestidos de noiva_P.237

FIGURA 86: Nefertiti, aproximadamente 1340 a.C._P.243

FIGURA 87, FIGURA 88 e FIGURA 89: Trotula: coletânea de três livros com o foco voltado para maquiagem e em como preservar e aumentar a beleza_P.245 
FIGURA 90: Pele pálida e translúcida era desejada por muitas mulheres, pois conotava o sentido da juventude, fertilidade e virtude. Portrait of a Lady, Rogier Van der Weyden, 1460, Washington, National Gallery of Arts, óleo sobre madeira_P.251

FIGURA 91: Retrato de Madame Pompadour acrescentando à face um toque de rouge. Marquise de Pompadour at the Toilet, François Boucher, 1758, Harvard, Fogg Museum, óleo sobre tela_P.258

FIGURA 92: Brigitte Bardot com os olhos pintados com rímel_P.262

FIGURA 93: A intensidade do preto nos olhos delineados de Bardot_P.262

\section{A COR COMO FORMA DE EXPRESSÃO}

FIGURA 94: Opções de cores apresentadas para que a pessoa aponte qual é sua cor predileta e preferida_P.278

FIGURA 95: Análise da coloração da pele desenvolvida pela Pantone_P.290

FIGURA 96: Leque de cores, Skin Tone Guide, desenvolvido pela Pantone trazendo as tonalidades de pele_P.290

FIGURA 97: Representações esquemáticas dos tons de pele desenvolvida pela Pantone_P.291

FIGURA 98: Representações esquemáticas colocadas no espaço tridimensional dos tons de pele desenvolvida pela Pantone_P.291

FIGURA 99: Análise da coloração dos olhos_P.296

FIGURA 100: Paleta de cores de cabelo DiColore desenvolvida para realização da leitura das tonalidades dos cabelos feita por comparação_P.297

FIGURA 101: Amostras de cores, Leveza, Sutileza, Profundidade e Impacto, relacionadas às preferências subjetivas agrupadas por saturação e luminosidade_P.306

FIGURA 102: Painel de cores feito em tecidos agrupados por Leveza, primeira fileira, Sutileza, segunda fileira, Profundidade, terceira e Impacto, quarta_P.311

FIGURA 103: Exemplos de paleta de cores e suas divisões contendo as predileções e preferências cromáticas, a Harmonia Objetiva e a Harmonia Subjetiva que pode estar dividida em dominante e subordinada caso haja essa condição_P.314

FIGURA 104: Exemplos de paleta de cores e suas divisões contendo as predileções e preferências cromáticas, a Harmonia Objetiva e a Harmonia Subjetiva que pode estar dividida em dominante e subordinada caso haja essa condição_P.315 
FIGURA 105: Exemplos de paleta de cores e suas divisões contendo as predileções e preferências cromáticas, a Harmonia Objetiva e a Harmonia Subjetiva que pode estar dividida em dominante e subordinada caso haja essa condição_P.316

FIGURA 106: Exemplos de paleta de cores e suas divisões contendo as predileções e preferências cromáticas, a Harmonia Objetiva e a Harmonia Subjetiva que pode estar dividida em dominante e subordinada caso haja essa condição_P.317 


\section{REAÇÃO HUMANA À COR}

QUADRO 1: Cisão esquemática relacionando os fatores psicológicos e emocionais_P. 48

QUADRO 2: Cisão esquemática relacionando as funções psicológicas de Jung_P. 56

QUADRO 3: Tipos Psicológicos de Jung sobrepostos ao espaço de cor NCS_P.61

\section{A COR COMO FORMA DE EXPRESSÃO}

QUADRO 4: Processo criativo proposto pela metodologia de criação de paletas de cores_P.272

QUADRO 5: Relação de perguntas sugeridas para a segunda etapa da primeira fase_P.275

QUADRO 6: Síntese das respostas obtidas na primeira fase_P.283

QUADRO 7: Parte dos códigos do leque Skin Tone Guide traduzidos para o sistema NCS_P.294

QUADRO 8: Parte dos códigos do catálogo DiColore traduzidos para o sistema NCS_P.298

QUADRO 9: Análise da Harmonia Objetiva_P.299

QUADRO 10: Análise dos Contrastes_P.300

QUADRO 11: Tipos Psicológicos e nomenclatura proposta para a Harmonia Subjetiva_P.302

QUADRO 12: Harmonias Subjetivas relacionadas aos Tipos Psicológicos sobreposto ao espaço de cor NCS_P.303

QADRO 13: Integração entre as Harmonias Subjetivas com os Tipos Psicológicos de Jung_P.304

QUADRO 14: Análise da Harmonia Subjetiva_P.309

QUADRO 15: Síntese das respostas obtidas na primeira e segunda fases_P.312

QUADRO 16: Síntese cromática para a seleção de cores das paletas_P.312

QUADRO 17: Quadro síntese_P.314

QUADRO 18: Quadro síntese_P.315

QUADRO 19: Quadro síntese_P.316

QUADRO 20: Quadro síntese_P.317 


\section{LISTA DE FONTES SECUNDÁRIAS CONSULTADAS}

Archdaily Brasil: https://www.archdaily.com.br/

Bauhaus: http://www.bauhaus-imaginista.org/

Bibliothèque de l'Arsenal: https://www.bnf.fr/en/arsenal

Biblioteca Nacional Francesa: https://www.bnf.fr/fr

Blue Mosque: http://www.bluemosque.co/

Carole Jackson: https://carolejacksoncolors.com/

Deposit Photos: https://br.depositphotos.com/

Design in Fine: https://www.design-is-fine.org/

Global Wellness Institute: https://globalwellnessinstitute.org/

Google Arts and Culture: https://artsandculture.google.com/

Harvard Art Museum: https://www.harvardartmuseums.org/

Lisson Gallery: https://www.lissongallery.com/

Moma: https://www.moma.org/

Munsell Color System: https://munsell.com/about-munsell-color/how-color-notation-works/

National Gallery: https://www.nationalgallery.org.uk/

Natural Colour System: https://ncscolour.com/ncs/

Pinterest: https://br.pinterest.com/

Pxhere: https://pxhere.com/

Research Gate: https://www.researchgate.net/

SFMoma: https://www.sfmoma.org/

The Historical Dyer: https://www.thehistoricaldyer.com/

The Metropolitan Museum of Art: https://www.metmuseum.org/

Trend Magazine: https://trendmagazine.co.uk/

Victoria and Albert Museum: https://www.vam.ac.uk/

WikiArt: https://www.wikiart.org/

Wikipedia: https://www.wikipedia.org/

Worth Global Style Network: https://www.wgsn.com/en/ 


\section{LISTA DE SIGLAS}

BCC - British Colour Council

CIM - Comitê de Coordenação das Indústrias de Moda

FAU-USP - Faculdade de Arquitetura e Urbanismo da Universidade de São Paulo

NCS - Natural Colour System

TCCA - Textile Color Card Association

WGSN - Worth Global Style Network 


\section{SUMÁRIO}

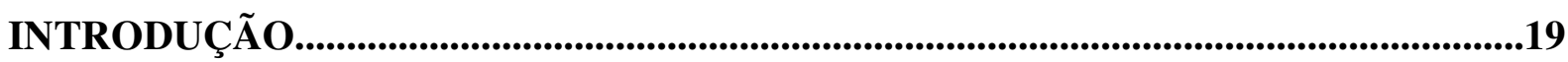

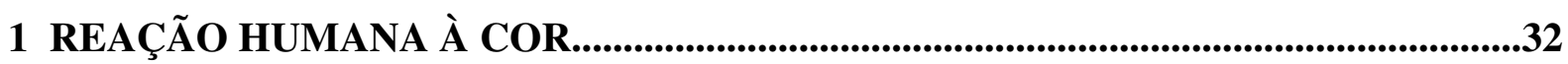

\subsection{A pirâmide de Frank Mahnke_37}

1.2 Fatores psicológicos e emocionais_42

1.2.1 Os tipos psicológicos de Carl Gustav Jung relacionados aos atributos de cor_53

1.3 Fatores simbólicos e culturais_63

1.3.1 As acromáticas_69

1.3.1.1 Preto_69

1.3.1.2 Cinza_83

1.3.1.3 Branco_92

1.3.2 As Cromáticas_100

1.3.2.1 Amarelo_100

1.3.2.2 Laranja_116

1.3.2.3 Vermelho I Rosa_122

1.3.2.4 Violeta I Púrpura_139

1.3.2.5 Azul_144

1.3.2.6 Verde_155

2 UMA VISÃO SOBRE TENDÊNCIA, MODA E PINTURA CORPORAL .0173

2.1 As influências ditadas pela tendência_182

2.2 A cor como influenciadora da moda e da pintura corporal_198

2.2.1 A cor na moda_204

2.2.2 A cor na maquiagem_241

2.2.2.1 $\mathrm{O}$ ato de branquear a pele e as idas e vindas do bronzeamento_250

2.2.2.2 O toque de cor vermelho_256

2.2.2.3 O ponto focal preto e as sombras coloridas_260

3 A COR COMO FORMA DE EXPRESSÃO. .264

\subsection{Estratégia Inicial_273}

\subsection{Levantamento das Harmonias e Contrastes_283}

3.2.1 Análise da Harmonia Objetiva_288

3.2.2 Análise dos Contrastes_299

3.2.3 Análise da Harmonia Subjetiva_300 
3.3 Processo de Criação de Paletas de Cores_309

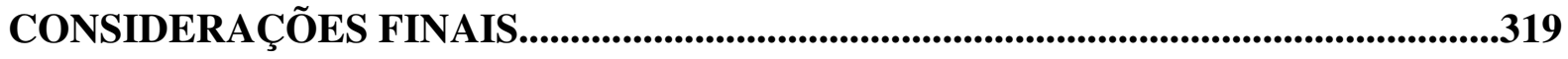

REFERÊNCIAS BIBIOGRÁFICAS GERAIS..........................................................326 


\section{INTRODUÇÃO}

“As cores são ações e paixões da luz. (...) Na verdade, luz e cores se relacionam perfeitamente, embora devamos pensá-las como pertencentes à natureza como um todo: é ela inteira que assim quer se revelar ao sentido da visão".

(GOETHE, 2011, p. 35) 
A cor é um elemento vital, assim como o ar, a terra, a água e o fogo. É uma necessidade essencial e fundamental para a manutenção da vida terrestre. É matéria-prima indispensável à existência, por isso não se pode conceber a vivência dos homens sem estar atrelado a, também, elementos coloridos. Ela afeta a existência humana no âmbito físico, emocional e até mesmo mental e espiritual (ACHENBACH, 2001).

Todos os elementos presentes na natureza, sejam as plantas e os animais, sejam os ambientes construídos, trazem consigo um cromatismo evidente (PIPER, 2008). E os seres humanos, relacionando-se com esses sistemas, permeiam por entre as tonalidades, resultando em sensações que podem ser prazerosas, confortantes e benéficas como também percepções desgostosas, aflitivas e insatisfeitas.

As cores são sinestésicas, pois ao mesmo tempo que fornecem impressões táteis, transmitem a sensação de tornar algo pesado ou leve, quente ou frio, e até mesmo serem comparadas com o som. Mesmo podendo haver discordância entre sociedades quanto aos códigos cromáticos utilizados, em qualquer lugar em que é empregada, a cor tem sempre a tarefa de impressionar, expressar e emocionar (GOETHE, 2011). Segundo Nicholas Humpherey (2009), não importa qual seja a mensagem, sinais de cores geralmente têm três funções: chamar a atenção do observador, transmitir uma informação e penetrar nas emoções de quem as observa e faz uso delas (HUMPHEREY apud MIKELLIDES; PORTER, 2009).

Tanto que a natureza as utiliza como um sistema de mensagens, por isso as tonalidades dos vegetais, das frutas, dos legumes sinalizam se já estão prontos para serem ingeridos. Já as estações do ano informam a transformação ao redor e quando, em alguns países mais distantes da linha do Equador, a paisagem se torna cinzenta, é sinal de que é tempo de preparar-se para o inverno. Ou, por outro lado, quando a paisagem está repleta de verde, deixa indícios de água e, portanto, pouco risco de fome, tranquilizando os seres ao redor.

Dessa forma, as cores são uma grandiosa ferramenta de comunicação, de desafio e de identidade, razão pela qual o homem as utiliza como uma linguagem para dizer algo, desde conotações com o divino, dando sentido aos mistérios da criação e a existência humana (ACHENBACH, 2001), até um misticismo atrelado à cura de doenças e enfermidades (BIRREN, 1961; BIRREN, 1978). Além disso, são carregadas de valores simbólicos, culturais e estéticos, permeando por muitos universos e transpassando os vários períodos históricos que se sucederam (PASTOUREAU, 2011). Não à toa, muitas expressões primitivas que envolviam o uso das cores estavam relacionadas aos enigmas da vida e da 
morte, motivo por que os antigos as consagravam pelo seu significado sublime, estando presente em algumas passagens bíblicas e mitológicas, por exemplo.

Evidências apontam para o fato de que existia um envolvimento das cores com a criação, com o milagroso, com o sobrenatural, por isso elas tanto foram reverenciadas e adoradas como o foram os mantos, os anéis, os colares, as pulseiras e os ornamentos, cujos significados iam além do mero ornamento ou algo atraente. Esses objetos foram usados para obter sucesso nos negócios, proteger o corpo de doenças, espantar maus espíritos, evitar naufrágios, fugir de tempestades e de ataques de animais, além de garantir colheita abundante, caça e pesca satisfatórias (BIRREN, 1978).

Por muito tempo, as cores estiveram conectadas com a cura, colocando os clínicos de um lado e os místicos de outro. O pensamento mais clínico possuía uma tendência mais incrédula e lidava com a doença por meio de uma investigação de causas totalmente naturais. Já os mais místicos levavam em consideração que, seres humanos, assim como as plantas, mudavam suas cores quando adoeciam ou quando morriam. Nesse sentido, as tonalidades da pele, dos olhos, dos cabelos, dos excrementos e da urina eram significativas e indícios do que se passava com quem estava sendo observado. Tanto que, segundo Faber Birren (1961), se a pele do paciente oscilasse para uma tonalidade mais amarelada, poderia ser devido a distúrbios do fígado ou da bile. Agora, se a mudança fosse para uma tonalidade mais branca, ou seja, mais pálida, a enfermidade provavelmente estaria no baço.

Emplastos feitos de plantas, flores e minerais eram eficazes quando os tons e as feridas da tez estavam evidentes e expunham algum desconforto. Assim, vermelho, amarelo e preto tinham grande valor medicinal, pois eram identificados, respectivamente, com febre, peste e morte. Para Birren (1961, p. 23):

\footnotetext{
Avicenna confiava na terapia da cor. Por acreditar que o vermelho movia o sangue, esse tom era usado em profusão e prescrito em inúmeros medicamentos. Branco, por outro lado, era um refrigerador. Poções de flores vermelhas curavam distúrbios do sangue. As flores amarelas curavam distúrbios do sistema biliar, reduzindo a dor e a inflamação.
}

Junto com essas importâncias tanto divinas como relacionada à cura, as cores também estiveram atreladas a outros valores, o que pode ter possibilitado o fato de o homem, por seu amor às cores e em concordância com esses valores a elas oferecidos, ter tentado, desde o princípio, desvendar seus mistérios, deixando de ser uma abstração para se tornar um sujeito em si. 
Vale a pena colocar que os códigos atribuídos às nuances foram emergindo lentamente e sendo vivenciados de modo diferente, segundo as épocas e as sociedades. Com isso, fica posto que não há possibilidade de universalização e de generalização entre os conceitos e valores, pois há diferença entre uns e outros tanto com relação às sociedades como com relação aos conhecimentos e entendimentos existentes (PASTOUREAU, 2017).

Para exemplificar esses fatos, houve sociedades que aceitaram e utilizaram determinadas tonalidades, e outras que não estabeleceram verdades semelhantes em um mesmo período histórico. No entanto, o que importa é a forma como os acontecimentos se sucederam, trazendo impactos e determinando as aberturas, os aceites e, consequentemente, os usos.

Quanto aos conhecimentos e entendimentos existentes, por exemplo, podem ser destacadas as experiências realizadas pelo físico inglês Isaac Newton e a classificação espectral das cores, a ordem adotada proposta séculos antes por Aristóteles, iniciando o espectro pelo branco, depois amarelo, laranja, vermelho, verde, azul, violeta até chegar ao preto (PASTOUREAU, 2019). Somente no século XVII, essa forma de encarar a divisão espectral passou a não ser mais adotada e iniciou-se uma nova fase na organização das tonalidades.

Essa nova maneira de visualizar as cores não deixou espaço nem para o branco e nem para o preto, já que, aos poucos, começou a ser incorporada por toda a sociedade. Tanto que, como afirma Pastoureau (2011, p. 12),

E quantas cores básicas existem? Três? Cinco? Mais? Aqui também, as opiniões diferiam. Alguns autores olharam para trás e seguiram a tradição antiga, notadamente a História Natural de Plínio, que cita apenas quatro: branco, vermelho, preto e o enigmático sil (silaceus), identificado às vezes como amarelo, às vezes como azul. Essa inconsistência explica por que muitos outros autores não se referiram aos textos antigos, mas à experiência dos pintores contemporâneos e sustentaram que havia cinco 'primeiras' cores: branco, preto, vermelho, amarelo e azul. Um pouco depois, depois de Newton ter cientificamente eliminado o preto e branco da ordem das cores, a maioria dos estudiosos passou a aceitar apenas três: vermelho, azul, amarelo. Essa ainda não era a teoria das cores primárias e complementares, formulada posteriormente por químicos e físicos, mas já era a tríade subtrativa moderna que permitiria a Jakob Christiffel Le Blon inventar a gravura colorida em 1720-40.

Vale ressaltar que a oposição entre as cores quentes e frias só ocorreu no século XVIII, a qual se deu de forma puramente convencional e vivenciada de modo diferente entre os períodos históricos. Isso explica por que, durante muito tempo, o azul foi considerado 
quente, por vezes até mesmo a mais quente de todas as cores, e o amarelo foi considerado uma cor fria (GOETHE, 2011).

Já a articulação entre as cores primárias e as cores complementares emergiram lentamente no decorrer desse mesmo século e só se impôs verdadeiramente no século XIX, como esclarece Pastoureau (2011, p. 13):

\begin{abstract}
As noções de cores quentes ou frias, de cores primárias ou complementares, as classificações do espectro ou do círculo cromático, as leis da percepção ou do contraste simultâneo não são verdades eternas, mas somente etapas na história inconstante dos conhecimentos. Não devemos manejá-las sem ponderação, nem aplicá-las sem nenhuma precaução às sociedades do passado.
\end{abstract}

Isso demonstra que as concepções que estruturam as nuances devem e estão em constante transformação, por isso muitos dos conceitos que são válidos nos dias de hoje nem sempre foram usados ou sequer conhecidos. Noções como nome de cores, temperatura, relatividade da aparência da cor, entre tantos outros, teriam que ser revisitados e repensados quanto à base de formulação, forma de utilização e período histórico a que se faz referência.

Assim, pode haver um relativismo de todas as questões que dizem respeito às tonalidades, sendo preciso analisar o contexto e colocá-las, primeiramente, dentro de um tempo e espaço. Em seguida, é preciso verificar suas implicações, pois ela é tanto um fenômeno natural e fisiológico quanto uma construção psicológica, simbólica e cultural, difícil de ser encaixada em qualquer padronização (MAHNKE, 1996).

No entanto, é comum encontrar teorias que tentam estabelecer verdades absolutas ou arquetípicas, impondo uma autenticidade transcultural, muitas vezes colocadas por uma psicologia atada e sufocante. Todavia, quando se trata da cor, das suas definições e das suas classificações, como estão sempre em constantes descobertas e são passíveis de transformações, esse malabarismo se torna falho (PASTOUREAU, 2014).

Mesmo assim, ao longo da história, entre muitas idas e vindas, sempre se analisou o fenômeno cromático, ficando evidente que, para serem despertadas no indivíduo a sensação e a percepção, eram necessárias duas etapas (PEDROSA, 2009). A primeira era composta pelos três elementos: uma fonte de energia luminosa, ou seja, o sol, um objeto capaz de refletir a luz sobre o qual incidisse essa energia e um órgão receptor, constituído pelo par olho-cérebro.

Entretanto, como a sensação de cor não é somente uma construção biológica, uma segunda etapa se faz presente, a qual compreende a junção de uma construção psicológica, 
simbólica, cultural e influenciada pela tendência e moda. Para tanto, o trabalho proposto pelo psicólogo alemão Frank Mahnke (1996), que é uma das bases dessa demonstração proposta por esta tese, relaciona esses aspectos ao utilizar o formato de uma pirâmide dividida em seis partes.

Ademais, outro alicerce desse trabalho é o percurso que a cor desempenha na psique, o qual se divide em dois fatores, conforme elaborado por Modesto Farina (1982). Aqui, é preciso relacionar e compreender tanto o primeiro fator quanto o segundo, pois são eles que antecedem as escolhas e os aceites, ou as negações e as recusas que cada um vai imprimir a cada tonalidade.

Esta tese também se apoiou no trabalho proposto pelo psicanalista suíço Carl Gustav Jung (1971), com os Tipos Psicológicos. De acordo com essa proposta, realiza-se uma sobreposição entre as características que definem cada tipo com as características dos atributos de cores de saturação e luminosidade. Essa forma de análise foi baseada nos indícios descritos por ele, que diferenciam personalidades que partem de forma ágil, certeiras e confiantes ao encontro do objetivo de outras que ponderam e hesitam de forma cautelasa e cuidadosa.

Assim, essa mesma relação também acontece com as cores nas quais não só a relação da frequência emitida pela luz impacta a percepção sensorial. É o caso, por exemplo, dos azuis, que, por terem os menores comprimentos de onda, possuem menor impacto; e os vermelhos, que, por terem os maiores comprimentos de onda, possuem maior impressão. Acrescentem-se, ainda, qualidades de saturação e luminosidade como propositoras de energia e intensidade (PEDROSA, 2009).

Faz-me mister destacar o papel da sensação e percepção cromática que, ao serem decodificadas pelo cérebro, vão sofrer influência da mente, da memória, dos conhecimentos, da imaginação, dos traumas e das frustrações que vão agregar valores às informações da luz previamente emitidas. Tudo isso colabora com os aspectos psicológicos e, consequentemente, com a preferência por determinadas nuances (GUIMARÃES, 2004).

Entretanto, assim como para Silveira (1981) e para Jung (1971), as definições e classificações dos tipos psicológicos não eram a única possibilidade existente, portanto, de modo algum, a interpretação proposta por este trabalho é a única alternativa possível.

É importante considerar também que, em paralelo aos fatores psicológicos, existem os fatores simbólicos e culturais expressos pelas tonalidades às quais as sociedades, ao longo do tempo, atribuem definições e significados. São elas que erguem seus códigos e seus 
princípios, que precisam seus valores, organizam suas práticas e determinam suas implicações, certificando definições e conceitos (PASTOUREAU, 2011).

Para ilustrar esse fato, durante a Idade Média, o vermelho era tido como a cor favorita não só entre mulheres, que encontraram nele o significado da beleza e do amor, mas também entre os homens, que o viam como símbolo de glória, de coragem e de poder. Sendo assim, esse tom foi, em grande parte da história, uma cor masculina, usada para a caça, em torneios e nos uniformes de guerra, vestindo muitos soldados que precisavam ser reconhecidos a distância e causar medo nos seus adversários. Nesse sentido, o vermelho era, simultaneamente, glorioso, ressonante, violento, selvagem e sangrento (HELLER, 2013).

Já durante a Primeira Guerra Mundial, o uso do vermelho tornou-se mais acessível, e os corantes de lábios eram objeto de um verdadeiro consenso de massa. Ao mesmo tempo, muitos testadores de maquiagem foram disponibilizados para servir como guias ou elaborados para a propaganda e pintar os lábios com esse tom era algo que muitas mulheres fizeram em muitos períodos desde a Antiguidade (ELDRIDGE, 2015).

Vale salientar que, nos dias de hoje, os valores agregados às cores, em razão de tantas outras condicionantes, como a velocidade de propagação das informações e o consumismo exagerado, favorecem a necessidade de identidade que são inerentes à própria natureza humana. Não à toa que os estudos de tendência, apesar de trazerem suas origens de outras áreas, desempenham um papel preponderante desde o século passado nesse setor (BLASZCZYK;WUBS, 2018).

Observa-se que esses estudos são criados para definir uma vontade constante de conservação, de prestígio, de inovação, de status, buscando refletir o desejo de um grupo de pessoas. Em se tratando do campo específico da cor, a tendência e a moda são variáveis com um poder muito decisivo. Por isso, os trabalhos propostos pela Curva de Difusão da Inovação de Everett Rogers (ROGERS apud SANTOS, 2013) e o Modelo de Tendência em Forma de Diamante de Henrik Vejlgaard (2008), colaboram para o entendimento de como as tendências surgem e se dissipam pelas camadas da sociedade assim como também a Hierarquia das Necessidades de Abraham Maslow (MASLOW apud VEJLGAARD, 2008) ajuda a entender a necessidade estética como um valor também primordial.

Entretanto, nem uma cor é aplicável a todas as circunstâncias nem aceita por todos, mesmo a sociedade legitimando a preferência por determinadas nuances (VEJLGAARD, 2008). 
É inegável que, mesmo podendo haver divergência entre as cores propostas pelos estudos de tendência e pela moda com as necessidades individuais, a previsão de cores, conforme afirma Blaszczyk e Wubs (2018, p. 35),

era a ferramenta mais importante para a fábrica têxtil, o fabricante de roupas e o varejista que precisava de informações de ponta sobre as cores que provavelmente estariam na moda na próxima estação. "O objetivo da previsão de cores", explicou Jackson, "é fornecer aos comerciantes de moda informações com antecedência suficiente para que se preparem para a demanda".

Essa é razão pela qual os trabalhos de previsão de cores já existem como guias há mais de um século. Tais trabalhos têm como protagonistas o escritório americano Textile Color Card Association, TCCA, que teve seu início em 1914, e o britânico British Colour Council, BCC, cuja abertura data de 1930. Eles tinham como objetivo prever, padronizar e coordenar as opções cromáticas com o intuito de direcionar os fabricantes e varejistas em seus contextos específicos.

Com o passar do tempo e devido à chegada da internet nos anos 90, plataformas digitais foram desenvolvidas para disseminar as tendências, como é o caso da Worth Global Style Network, também conhecida pela sigla WGSN. Essa empresa, por sua vez, tinha como propósito apontar novas práticas de previsão de moda para atender à demanda de seus clientes, exercendo forte influência na sociedade como um todo.

Esses negócios se tornaram tão determinantes e valiosos que, de acordo com Blaszczyk; Wubs (2018, p. 25),

"em 2005, os Worth Brothers venderam o WGSN por 140 milhões de libras esterlinas para uma empresa da mídia britânica, demonstrando que a previsão da moda não era mais um pequeno negócio" (...)

A ascensão e o sucesso da WGSN coincidiram com a revolução da tecnologia da informação e comunicação (TIC), que acelerou dramaticamente a globalização da indústria da moda. O sistema de duas estações primaveralverão e outonolinverno chegou ao fim, pois marcas de moda e varejistas de fast-fashion traziam constantemente novos itens ao mercado. De repente, em todos os cantos do mundo, havia um imperativo para a entrega instantânea de informações visuais de alta qualidade e a WGSN atendeu à demanda. Em 2011, esse analista de tendências online tinha 38.000 usuários em 3.000 empresas, incluindo marcas regionais como C\&A, e marcas globais como LeviStrauss, LVMH e Zara. No entanto, como resultado da estetização dos produtos de consumo na última década, as empresas fora do setor de moda estão mais interessadas em previsões. Com isso, Lufthansa, BMW, Microsoft, Proctor \& Gamble, IKEA e L'Oreal tornaram-se clientes da WGSN. Em 2003, um concorrente mais barato chamado Stylesight, Inc. foi estabelecido em Nova York e se 
expandiu rapidamente. Em 2011, já tinha 25.000 usuários em 2.500 empresas, incluindo Prada, Zara, Bulgari e Abercrombie \& Fitch. A Stylesight, Inc. era a única concorrente real da WGSN no campo da previsão de moda online. Em 2013, a WGSN adquiriu a Stylesight, Inc. para se tornar a maior empresa de previsão de tendências de todos os tempos, com 60.000 usuários em 4.000 clientes.

Esse fato contribui, portanto, para impulsionar esses segmentos, que criaram padrões para diagnosticar como os comportamentos humanos influenciam alguns padrões específicos e que muitas vezes acabam conferindo valor às cores.

Nesse contexto, a maioria dos recursos de previsão, diagnóstico e estudo de tendências foram disponibilizados com o intuito de colaborar com as empresas, diminuindo os riscos. Todavia, essa dinâmica, conforme colocado por Mahnke (1996), tem de ser validada por cada indivíduo que manifesta sentimentos de prazer ou insatisfação, agrado ou desagrado.

Sendo assim, mesmo os prognósticos de tendências oriundas de estudos antropológicos e os inputs provenientes da moda, que são estudos indutivos elaborados pela indústria, dificilmente são válidos em sua totalidade. Isso porque, se não forem consideradas as características intrínsecas individuais objetivas e subjetivas que estimulam as preferências a determinadas cores, seu resultado poderá ser limitado a um curto prazo e sua aplicação falha, caso não ocorra desde o momento de sua concepção (MAHNKE, 1996).

Todos esses fatos e as contribuições deixadas por Mahnke (1996), Farina (1982), Jung (1971), Maslow (MASLOW apud VEJLGAARD, 2008), Rogers (ROGERS apud SANTOS, 2013), Vejlgaard (2008), Chevreul (1987), Goethe (2011) e Itten (1961;1970), entre tantos outros pesquisadores, levaram à pergunta inicial desta tese: seria possível desenvolver um trabalho de criação de paletas de cores que respeitasse todas as condicionantes envolvidas no processo de intrepretação da informação luminosa e os caminhos que são despertados até atingir a consciência à cor?

Essa questão inicial esbarrou em alguns trabalhos já existentes, como os estudos das americanas Carole Jackson, Color Me Beautiful (1984), conhecido como Método Sazonal, e de Mary Spillane e Christine Sherlock, publicada no livro Color Me Beautiful Looking Your Best (1995), conhecido como Método Sazonal Expandido. Essas metodologias, Método Sazonal e Método Sazonal Expandido, tinham como critério fazer uma análise dos tons de pele, olhos e cabelos para, a partir daí, propor uma paleta de cores que mais harmonizasse com cada indivíduo. 
É importante ressaltar que a diferença fundamental entre esses métodos existentes e a demonstração proposta por esta tese é trazer a função primordial das cores. Ou seja, a função delas, aqui, não é servir apenas como um elemento decorativo ou estético, logo não devem ser tratadas meramente como um adorno, um capricho ou uma vaidade. Ao contrário, quando todas as etapas que levam à interpretação forem consideradas, as cores podem exercer uma tríplice função: impressionar, expressar e emocionar (GOETHE, 2011). Tanto que, para Mahnke (1996, p. 13):

os seres humanos podem ser considerados como tendo a visão de cor total, o que deve significar que o espectro é necessário para nossa sobrevivência biológica, e para além disso, psicologicamente. É o psicológico que nos afeta emocionalmente, fazendo as coisas parecerem compreensível, provocante, quente, frio, amigável, excitante, tranquilo, e vários outros sentimentos necessários para a sobrevivência de nossa psique.

Nessa perspectiva, o objetivo primordial deste trabalho é buscar uma forma de expressão vinculada a estas três funções: impressionar, expressar e emocionar (GOETHE, 2011), aliada à necessidade de manutenção e preservação da espécie vinculada ao equilíbrio psíquico. Sendo assim, ao serem selecionadas, tais funções estabelecem uma poderosa força de ação que penetra em diversos níveis da existência à medida que comunicam uma mensagem e despertam percepções, sensações e emoções.

Dessa forma, os indivíduos, ao elegerem, por exemplo, uma cor de uma roupa para vestir, de uma tinta para pintar um quarto, de um revestimento para um armário do banheiro, espontaneamente percorrem os caminhos tanto de modo inconsciente quanto consciente. Por isso, essa escolha manifesta uma interação entre o indivíduo e o mundo em muitas camadas, podendo trazer-lhe benefícios.

Os benefícios que as escolhas cromáticas podem trazer, conforme proposto por este trabalho, envolve fatores de várias ordens. Isso porque, quando as cores selecionadas vão ao encontro da essência individual, elas podem colaborar com a melhora da produtividade, uma vez que, ao ser parte integrante da luz, ajudam a regular as funções metabólicas e evitar estados patológicos, como dores de cabeça, náuseas, falta de concentração, entre outros sintomas (MAHNKE, 1996).

As escolhas cromáticas também podem trazer benefícios de ordem psicológica, já que possibilitam o aumento da autoestima, vinculada à empatia e ao amor-próprio, que são fortes aliados do indivíduo e refletem-se nas emoções e realizações pessoais, ajudando a transformar as experiências (LÜSCHER, 1969). Já do ponto de vista econômico, as escolhas 
cromáticas podem colaborar para a diminuição de gastos com artigos que não refletem os anseios particulares (WRIGHT, 1999).

Esse fator econômico é tão impactante que um estudo realizado pela Global Wellness Institute constatou, em outubro de 2018, que a indústria global do bem-estar foi avaliada em $\$ 4,2$ trilhões de dólares, um crescimento de $12,8 \%$ nos dois últimos anos ${ }^{1}$. Isso prova como estar em consonância com as próprias expectativas é uma procura constante, e o uso de tonalidades que sejam mais adequadas pode ter a finalidade de complementar essa busca.

Ao lado desses dados, uma das características mais impressionantes é que, mesmo antes de a pessoa expressar qualquer comunicação verbal, os outros já emitiram julgamentos a respeito de quem fala. Isso se dá pela maneira como age, como caminha e gesticula, aperta as mãos, estabelece o contato visual e a expressão facial, transmitindo traços e características da personalidade. Conforme pontuado por Carole Jackson (1984, p. 12),

Na década de 1970, o estudo do professor Albert Mehrabian, Silent Messages, provou de forma convincente que as imagens visuais são muito importantes. Descobrimos que o impacto que causamos um ao outro depende: $55 \%$ da aparência e do comportamento, $38 \%$ da maneira como falamos e 7\% do que dizemos. Quer gostemos ou não, é assim que é.

Sendo assim, fica posta a relação intrínseca entre a imagem e o valor que são atribuídas às primeiras impressões. "Se a imagem entra em conflito com a informação que se pretende passar, a pessoa terá uma tarefa hercúlea de transmitir a mensagem certa" (JACKSON, 1984, p.12). Contudo, vale a pena dizer que isso não deve ser nem artificial e nem falsa, mas sim ajuda quando traz indícios e comunica a própria personalidade.

Nesse sentido, é inegável que as cores exercem uma poderosa fonte de ação (GOETHE, 2011), mas quando em desacordo com o padrão compatível, vibrando em frequência diferente da pessoa, podem resultar, a longo prazo, em um estado estressante e exaustivo (JACKSON, 1984).

Portanto, este trabalho percorreu o caminho necessário existente em duas estapas. $\mathrm{Na}$ primeira, a cor provém da fonte luminosa que incide sobre um objeto e estimula o par olhocérebro. $\mathrm{Na}$ segunda, ela contém não só os fatores fisiológicos, inconsciente coletivo e psicológicos, simbólicos, culturais e as influências de tendência e moda, conforme as camadas da pirâmide proposta por Mahnke (1996), mas também os fatores psicológicos e emocionais proposto por Farina (1982).

\footnotetext{
${ }^{1}$ https://globalwellnessinstitute.org/press-room/statistics-and-facts/
} 
Junto a isso, os tipos psicológicos propostos por Jung (1971), conectados às características dos atributos de saturação e luminosidade, colaboram para desenvolver paletas de cores que expressem e comuniquem a mensagem desejada por cada um. Dessa forma, faz-se também necessário verificar os conceitos existentes nesse universo e abrir uma discussão para novas teorias e métodos de aplicação de cores. Para tanto, busca-se correspondê-las de forma objetiva, coerente, lógica e confiável, uma vez que este estudo não propõe uma investigação prática, mas sim uma demonstração de como poderia ser pensado e aplicado um trabalho de cor voltado para a expressão individual.

Assim, esta tese está estrutura em três capítulos. No capítulo 1, Reação humana à cor, procurou-se entender a cor sob os aspectos apontados por Frank Mahnke (1996), considerando as condições fisiológicas, psicológicas, simbólicas e culturais que antecedem à escolha pessoal e os caminhos percorridos pela informação luminosa ao encontrar a psique trazidos por Modesto Farina (1982). Nessa direção, esta pesquisa propõe uma sobreposição entre os tipos psicológicos de Carl Gustav Jung (1971), com os atributos de saturação e luminosidade de cor vinculados à representação criada pelo sistema sueco de notação cromático Natural Colour System.

Ainda no primeiro capítulo, foi percorrido um caminho quanto aos aspectos simbólicos e culturais da cor e como as sociedades foram-se portando e estabelecendo verdades no decorrer dos períodos históricos que se sucederam. Isso porque, algumas vezes, enquanto alguns conceitos de outrora reverberam até os dias atuais, outros se perderam no decorrer do tempo.

No capítulo 2, Uma visão sobre tendência, moda e pintura corporal, aborda-se, primeiramente, como esses universos desempenham um grande impacto na sociedade, sensibilizando o poder de decisão e exercendo um lugar importante e valoroso na vida cotidiana. Depois, discorre-se sobre a repercussão que as cores exerceram nesses universos com o passar dos séculos e como as crenças, valores e influências agregados a elas no passado acabam, muitas vezes, refletindo nas sociedades contemporâneas.

Dessa forma, fica colocado que, ao longo da história, o papel da cor teve vários propósitos, chegando, nos dias de hoje, a ser extremamente prestigiada. É uma característica que, tal como aquilo que designa, provoca, convida, desperta interesse e faz vender (FARINA, 1982).

No capítulo 3, A cor como forma de expressão, toma-se como base tanto o conteúdo dos capítulos anteriores como as contribuições deixadas por Michel Eugène Chevreul, com a Lei do Contraste Simultâneo (1987), as cores fisiológicas descritas por Johann Wolfgang 
von Goethe (2011), os contrastes cromáticos e o timbre subjetivo de Johannes Itten $(1961 ; 1970)$.

Assim, o somatório de todos esses conhecimentos são alicerces deste trabalho, pois ajudam a compreender a relação pessoal que cada indivíduo estabelece de percepção, sensação e consciência. Também embasaram esta pesquisa as harmonias objetivas e subjetivas, além das relações de contrastes de cor.

Como resultado, após ser produzida uma síntese de como os indivíduos atingem a consciência das cores, é possível propor a criação e o desenvolvimento de paletas que expressam as necessidades individuais. Trata-se de uma demonstração sucinta, devendo ser investigável durante um atendimento e percorrer um caminho seguro, sem generalizações, universalizações ou padronizações.

Por fim, apresentam-se as considerações finais. 


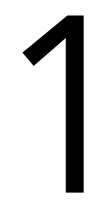

\section{REAÇÃO HUMANA}

\section{À COR}

"Ao projetar com cores, devemos sempre vê-las no contexto, e não aplicá-las por meio de generalidades. Embora possam funcionar em alguns casos, devemos analisar os casos individualmente para ver se as generalidades pertencem a uma situação particular”.

(MAHNKE, 1996, p. 43) 
É relativamente fácil perceber, conforme afirma Birren (1978), que a autoestima dos seres humanos pode ser alterada pelo ambiente, pelo nível de ruído, pela sensação térmica, pelo clima ensolarado ou chuvoso, pela harmonia do lugar, entre tantas outras condicionantes. As reações às cores disponíveis no ambiente em que se encontram presentes vão afetar a percepção humana, podendo elevar a consciência a algo inspirador e atraente ou deprimente e repulsivo (PEDROSA, 2009).

Da mesma forma, a autoestima também é alterada quando a pessoa tem um olhar de alegria para consigo, gosta e aceita a si própria e se encontra serena, tranquila e em paz (LÜSCHER, 1969). Quando em consonância com seu ser ou com o ambiente circundante, a maioria das pessoas pode encontrar suas disposições melhoradas e suas energias renovadas (BIRREN, 1961). Essas respostas provocadas são sutis e não seguem nenhuma lei universal. E com um espírito melhor, o sistema vascular, pulso, pressão arterial, tensão nervosa e muscular podem ser afetados e alterados (MAHNKE, 1996).

Para que a reação à cor aconteça, o estímulo primordial para desencadear atitudes nas pessoas é a luz e "ninguém pode duvidar hoje que o corpo humano responde à luz e à cor e, na verdade, também emite radiação por conta própria" (BIRREN, 1978, p. 45). Juntas, a luz e as cores são de extrema relevância para a existência da vida terrestre, pois são capazes de gerar um grande impacto nos seres vivos e desencadear reações fisiológicas e psicológicas.

A luz faz parte da onda eletromagnética que é composta por uma série de radiações, como, por exemplo, raio $\mathrm{X}$, raio gama, ultravioletas, infravermelhos e a parcela destinada às cores, ou seja, a radiação visível, que está compreendida na faixa de aproximadamente 400 a $700 \mathrm{~nm}$. Iniciando pelo menor comprimento de onda, em torno dos $400 \mathrm{~nm}$, estão as mais violáceas que seguem acompanhadas pelos azuis, cianos, verdes, amarelos, laranja até chegar aos vermelhos com aproximadamente $700 \mathrm{~nm}$. Essa porção luminosa destinada às cores ocupa uma parcela bem pequena se comparada com as outras faixas também presentes na onda eletromagnética.

Antes dessa faixa, estão os raios ultravioletas (UV) entre, aproximadamente, 100 a 400 $\mathrm{nm}$. Essa parcela não pode ser vista pelo órgão visual humano em condições normais porque esses raios causam tanto efeitos danosos como também benéficos à saúde. Pelo lado negativo, podem causar cegueira, desencadear alterações químicas e provocar vermelhidão na derme. Já o positivo é que são capazes de aumentar o bronzeamento, resultando na fixação de vitamina D.

$\mathrm{Na}$ outra ponta, com o comprimento maior que a luz visível, estão os raios infravermelhos entre, aproximadamente, 700 a $1000 \mathrm{~nm}$, que também não podem ser vistos 
pelo aparato visual humano em condições habituais. Todos os corpos aquecidos emitem esses raios que penetram pela derme, podendo provocar alguns sintomas, como o aquecimento cutâneo, a vasodilatação e alteração na temperatura do corpo. Ou seja, a pessoa pode sentir frio, calor e dor.

Dessa forma, vistas a importância e as múltiplas tarefas desenvolvidas pela fonte luminosa, fica mais fácil compreender como ela se apresenta de forma onipresente e pode causar uma aceleração da resposta nervosa ou um efeito de tranquilidade. Isso é essencial para uma vida saudável e equilibrada. Portanto, sendo a cor parte integrante da luz, logo "as reações à cor no homem seguem um padrão semelhante, onde a cor influencia o sistema endócrino e a cadeia de eventos que ocorre e varre o corpo" (BIRREN, 1961, p. 130).

Vale destacar que, para a experiência da cor acontecer, é preciso que o indivíduo esteja consciente e ciente dessa sensação. Segundo Mahnke (1996), são os fatores externos e internos, conscientes e inconscientes que influenciam esse processo, e a tentativa de sistematizar ou classificar pode ser reduzida a uma resposta equivocada e insuficiente. Mesmo assim, ele tenta propor, utilizando a forma de uma pirâmide, seis fatores que são importantes e determinantes na resposta individual à cor.

Essa pirâmide de Frank Mahnke (1996), junto com outras contribuições deixadas por outros mestres, estruturam a interpretação aqui proposta, pois, para que uma pessoa tenha sua reação à cor, alguns fatores são levados em consideração até chegar à conduta a esse estímulo. Junto a essa ordenação, os fatores psicológicos e emocionais também ancoram a elaboração desse trabalho para criação e desenvolvimento de paletas de cores voltadas para a expressão individual.

Todavia, o fato de os Tipos Psicológicos fazerem parte dessa proposta não significa que, quando for aplicada no indivíduo o que está sendo apresentado, haja necessidade de ser realizada uma análise psicológica que desbrave o inconsciente da pessoa. Essas categorias entram como guias, como dirigentes na abordagem dos aspectos gerais, indícios de aberturas e preferências individuais.

Para a realização da proposta que aqui se apresenta, foram desenvolvidos alguns gráficos utilizando o triângulo de cores do sistema sueco de notação cromático, Natural Colour System, NCS. A utilização do NCS tem o intuito de ilustrar cada uma das oito possibilidades propostas por Jung (1971) com a área de cores a que cada tipo e função poderia estar conectado e representado. É necessário ressaltar que essa conexão entre os perfis psicológicos com um espaço de cores NCS é a base desta pesquisa, mas é admitida a possibilidade de haver possíveis variações de interpretações. 
Vale colocar que esses ensaios entre caráter individual relacionado à área de correspondência de cor têm por objetivo trazer à tona alguns fatores psicológicos. Isso ajuda a estabelecer um elo entre os anseios do íntimo de cada um com as preferências por saturação e luminosidade. Geralmente, o que esse lado mais subjetivo do indivíduo pode revelar são traços de personalidade e aspectos individuais, não estando relacionados nem com fatores simbólicos e culturais das cores, nem com estudos de tendência e nem com a moda atual.

Observa-se ainda que, em paralelo aos ensinamentos propostos por Jung (1971) na área da psicologia, outros trabalhos foram desenvolvidos utilizando as cores como aliadas na criação de testes psicológicos para entendimento dos anseios individuais. Entre eles estão o de Rorschach Plates de 1921, de Faber Birren de 1940, de Max Lüscher de 1947, o de Pfister de 1950, entre outros. Tendo como ponto de partida a preferência por determinadas cores, esses estudos colaboram positivamente, cada qual a sua maneira, para ampliar o repertório e disponibilizar outras maneiras de entender os anseios humanos.

Ressalta-se que esses testes são uma ferramenta complementar que pode ser utilizada na tentativa de analisar os gostos, aceites, desgostos e recusas pelas cores, mas não são nem a base e nem parte integrante dessa abordagem que está sendo proposta.

Outros fatores que influenciam a reação à cor são os aspectos simbólicos e os aspectos culturais. Assim, ao longo da história, os fatores simbólicos e culturais tiveram seus valores modificados e alterados conforme os códigos estabelecidos pelas sociedades vigentes. Existiram momentos em que vestir-se com uma determinada tonalidade era um símbolo de status, pois informava a classe social a que o indivíduo pertencia, sendo as cores luminosas direito dos ricos e somente as cores opacas impostas aos mais pobres (HELLER, 2013).

Em outros momentos, usar cor se tornou algo repugnante, por isso um cidadão direito deveria fugir das suas amarras. Como afirma Pastoureau, a cor para muitos era (2016, p. 117):

(...) disfarce, luxo, artifício, ilusão. Ela é vã porque é matéria; perigosa porque distrai da verdade e do bem; condenável porque tenta seduzir e enganar; perturbadora porque impede um claro reconhecimento das formas e dos contornos.

Nesse sentido, as tonalidades de um vestido, de uma roupa de festa ou de ir à Igreja aos domingos não eram escolhidas por uma questão de gosto ou preferência, mas sim porque seguiam as regras ditadas por aquele momento. Conforme Eva Heller (2013, p. 61): 
Até a época da Revolução Francesa, existiam por toda parte códigos de vestimenta que determinavam quem deveria usar o quê. Existiam cores condizentes, tecidos condizentes e peças de vestuário para a alta e a baixa nobreza, o alto e o baixo clero, os burgueses ricos e os burgueses pobres, os fazendeiros ricos e os fazendeiros pobres, os servos e os escravos, as viúvas e os órfãos sem posses, até para os mendigos. Ninguém deveria usar roupas que fossem mais luxuosas a que o prestígio de sua condição fazia jus. Quem não se trajasse de maneira adequada poderia até ser preso e levado pela polícia.

Nessa direção, as tonalidades utilizadas no vestuário, dependendo da época histórica à qual se fazia referência, podiam determinar um caráter moralizante das pessoas ou até mesmo ressaltar a cultura a que elas pertenciam. De acordo com Fraser (2012, p. 10):

As associações com as cores variam entre culturas e indivíduos. Considere o azul, por exemplo. Você pode ter três pessoas sentadas na mesma sala, e para cada uma delas o azul pode significar algo profundamente diferente. Um piloto norte-americano pode associar o azul com as cores da sua força aérea. Para ele, as conotações dessa cor podem ser de extrema velocidade e poder. Um sikh pode usar um turbante azul para indicar que ele é um nihang, que segue uma doutrina muito diferente do código militar do piloto. E os heróis de um guitarrista de blues podem ter levado uma vida bastante diferente da vida dos modelos do sikh.

Entretanto, é o indivíduo que, mesmo sendo influenciado pelos valores culturais estabelecidos, ao aceitar uma determinada nuance, vai traçar uma concordância e identificação entre seu "eu" e o mundo ao seu redor. Dessa forma, a cor passa a ser vista como uma condição e, como tal, um fenômeno que vai abranger alguns fatores que integram conjuntamente todas as informações recebidas. Essas informações podem ser oriundas não só do mundo exterior, como as provenientes da luz, da cultura e da sociedade, mas também do mundo interior, como as advindas da fisiologia, da psicologia e da sensibilidade de cada ser. 


\subsection{A pirâmide de Frank Mahnke}

A percepção de cores, como afirma Frank Mahnke (1996), não se dá somente pelo par olho-cérebro, e sim por fatores psicológicos, emocionais, culturais, estéticos e associativos que compõem a vivência individual de cada um. Juntos, esses fatores vão aferir qualidade à informação luminosa que foi anteriormente captada, resultando na cor que é percebida. Essa informação pode ser quista e adorada, ou indesejada e rejeitada.

Mesmo sendo a cor uma temática que é praticamente impossível fazer entrar num plano estruturado, Mahnke utiliza o desenho de uma pirâmide e inter-relaciona seis aspectos importantes quanto à resposta humana à cor.

FIGURA 1: A pirâmide de Frank Mahnke.

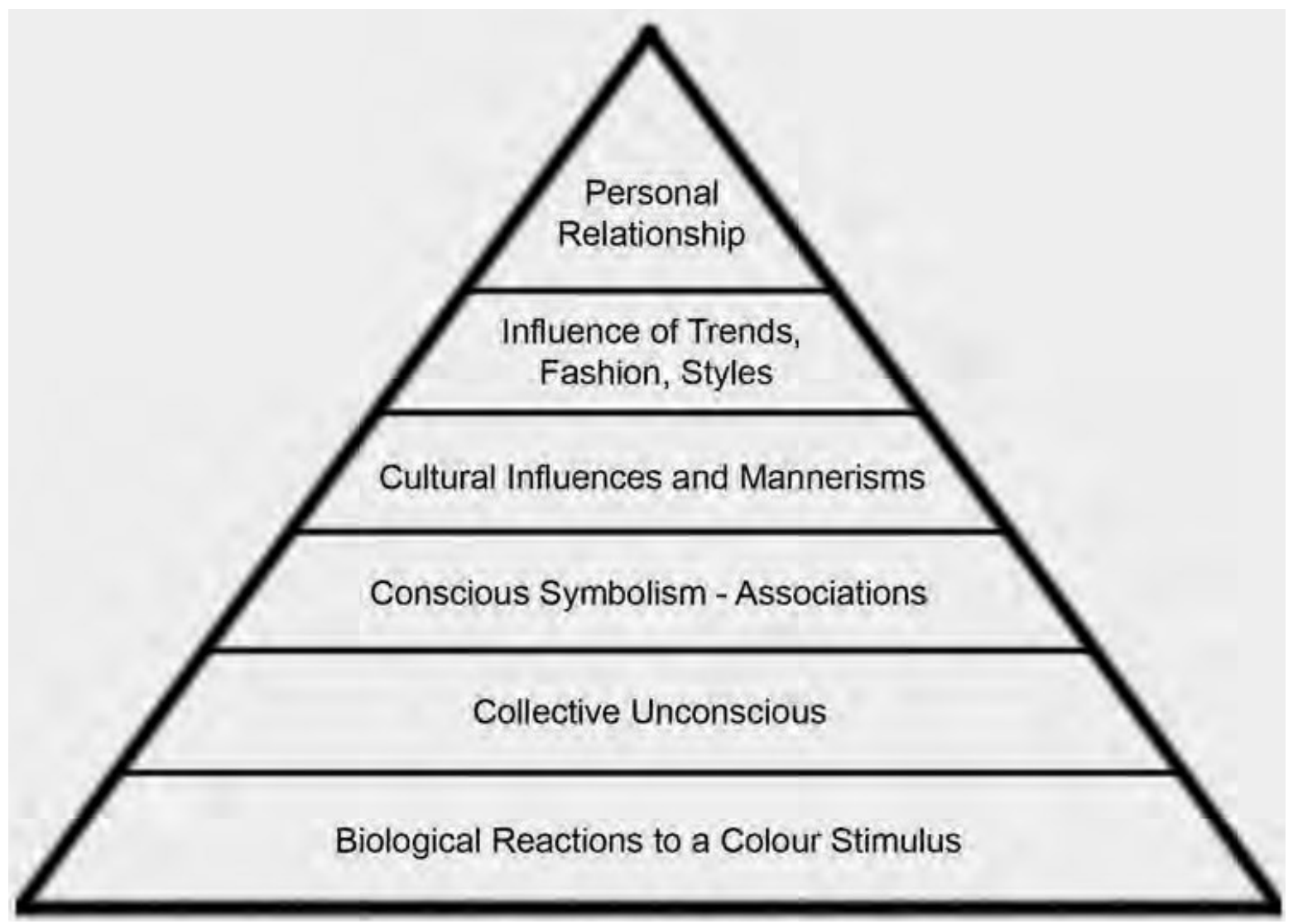

Fonte: MAHNKE, 1996, p. 11.

O primeiro degrau da pirâmide é composto pelas reações biológicas ao estímulo de cor. É nessa parte que toda a influência oriunda da luz solar irá desencadear uma série de 
reações metabólicas de extrema importância para a manutenção da existência. Isso porque ela não somente ilumina a vida, mas exerce uma poderosa força física ao penetrar o organismo humano.

A luz, ao transpor o aparato visual e a derme, faz dela uma parte importante dentro da existência. Ao atingir o olho e penetrar no organismo, nos músculos, tecidos subcutâneos e até nos órgãos centrais, ela realiza uma série de funções de extrema importância para o desempenho da vida. Com isso, a geração de células, a produção de anticorpos, a formação de pigmentos, a liberação de hormônios e o equilíbrio da pressão arterial são possíveis devido à presença da luz que contribui para tonificar, revigorar e manter saudável a estrutura fisiológica (MAHNKE, 1996).

Dessa forma, ao entrar em contato com o homem, a cor irá induzir uma série de reações biológicas e algumas partes são estimuladas pela via óptica até atingir a região cerebral conhecida como hipotálamo mesencéfalo. O hipotálamo, por sua vez, é uma parte do cérebro que possui centros nervosos autonômos e fibras que controlam funções como respiração, ação do coração e digestão. Além do mais, nessa região também estão alocadas as glândulas pineal e pituitária, que, juntas, formam o sistema endócrino e ativam a produção e a liberação de hormônios na corrente sanguínea (GUIMARÃES, 2004). Consequentemente, as reações que ocorrem a partir daí são essenciais para a manutenção da vida.

Quando afetados pela luz, os seres humanos respondem naturalmente de maneira favorável ou adversa, dependendo da necessidade, e ativam as células fotoelétricas embutidas no tecido cerebral. Isso significa que a luz é essencial para uma vida saudável e normal e que a natureza desenvolveu maneiras por meio das quais afeta o corpo através dos tecidos da pele, dos olhos e até do próprio cérebro.

Por meio da luz solar, todas as estruturas vivas - sejam elas plantas, animais ou seres humanos - rejeitam ou fazem uso daquilo que lhe é fundamental. A fração de luz visível está relacionada também com a manutenção do ciclo comportamental e fisiológico humano, pois controla, além das funções glandulares, as funções metabólicas e o sono. Ela faz com que o organismo desempenhe os seus ritmos, geralmente sincronizados pela luz solar, mantendo o funcionamento regulado pelo ciclo circadiano.

Sobre esse tema, Mahnke (1996, p. 107) esclarece que os

chromobiologistas encontraram uma série de fatos fascinantes sobre o nosso 'relógio interno'. Por exemplo, às oito da manhã a maioria dos 
hormônios sexuais são liberados (quando a maioria de nós está no caminho do trabalho), entre nove e dez temos maior disposição física; o cérebro está em sua fase mais ativa entre dez e meio-dia; uma da tarde uma maior quantidade de ácido gástrico é produzida, temos nós comido ou não; os sentidos do paladar, olfato e audição estão no seu mais agudo entre cinco e sete horas da noite; o fígado metaboliza o álcool entre as seis e oito horas; nesse mesmo momento, a pele é mais porosa, portanto, tornando-o mais suscetível aos ingredientes ativos como os cosméticos faciais.

Esses ritmos também afetam nosso desempenho de várias tarefas durante o dia. De dez horas até meio-dia a nossa memória imediata está no seu melhor, e é, portanto, um fator positivo para o desempenho de tarefas que exigem raciocínio, concentração e debate; as horas a partir das seis da tarde à meia-noite são favoráveis para estudar pois a nossa memória de longo prazo está no seu ápice. Trabalhadores do turno da noite são mais ineptos no desempenho de suas habilidades durante as horas de três às quatro da manhã.

Outra função da parte da luz visível está relacionada com algumas sensações experimentadas pelos seres humanos, como o desempenho físico e a fadiga. As relações cognitivas, comportamentais e emocionais também são influenciadas pela luz.

As reações à cor no homem seguem, pois, um padrão semelhante, influenciando o sistema endócrino e a cadeia de eventos que ocorrem e varrem o corpo. Isso evidencia a importância da luz e das cores como reguladora da vida, pois desempenham variações fisiológicas e bioquímicas no organismo. Sem luz, portanto, não há cor e sem ambas, não há vida.

O segundo degrau é composto pelas associações feitas pelo inconsciente coletivo "que não é controlado ou desencadeado por reações conscientes ou inconscientes experimentadas por cada indivíduo durante a vida" (MOCERI, 2016, p.29). São reações ou manifestações que acompanham os seres humanos enquanto espécie.

É nessa parte que Mahnke traz os arquétipos do psicólogo Carl Gustav Jung e como esses padrões influenciam as experiências e as respostas qua as pessoas dão às tonalidades. Tais respostas, mesmo sem uma razão consciente, "são arquétipos que foram formados através de imagens experimentadas no nosso desenvolvimento como espécie" (MOCERI, 2016, p.29).

Esses aspectos psicológicos não se limitam somente às reações biológicas, já que influenciam também outros níveis da pirâmide. No entanto, é nesse nível - posterior às reações biológicas - que os aspectos psicológicos são tidos como "reações que estão além do nosso controle, uma vez que estão no reino fisiológico que permanece fora do escopo de como nós, como indivíduos, pensamos ou sentimos sobre um determinado tom ou um grupo de cores" (MAHNKE, 1996, p. 13). 
Assim, o inconsciente coletivo de Jung é apontado como sendo o nível de reação que não é controlado ou desencadeado por situações conhecidas por cada indivíduo durante a vida. São cânones que foram formados por meio de imagens experimentadas no nosso desenvolvimento como espécie e "já era assim no simbolismo medieval das cores, e a consciência moderna reage do mesmo modo a esse velho padrão" (HELLER, 2013, p. 54).

O terceiro degrau é formado pelas associações provenientes de um simbolismo consciente. São associações em que se atribuem valores às cores, como, por exemplo, verde à natureza, amarelo ao sol, vermelho ao sangue, branco à paz e preto à morte. Esses simbolismos das cores não são naturais, mas sim aprendidos por todos desde pequenos, tornando os significados tão interiorizados que dão a impressão de serem instintivos.

Portanto, as associações formadas por um simbolismo consciente são aquelas relações entre cores e elementos ou acontecimentos feitos conscientemente. Como exemplo, na bandeira irlandesa, o verde representa a comunidade católica, enquanto laranja representa a comunidade protestante e o branco que os separam significa a paz que deve reinar entre eles (HELLER, 2013). Essas associações simbólicas ocorrem nas mais variadas áreas, como na publicidade, design de produto e gráfico, na moda, na arquitetura. As relações daí estabelecidas podem trazer diferentes significados, a saber: "amigável, inspirador, dinâmico, triste, sujo, frio, quente, áspero, caro, barato, distante entre outros aspectos" (MAHNKE, 1996, p. 16).

Essas associações conscientes são muito comuns e instantâneas no universo da moda. Tanto que no vestuário, determinada tonalidade ou combinação passa a ter rapidamente uma conotação, como, por exemplo, o branco estar associado ao campo da saúde ou a cerimônias e festas religiosas, como o candomblé. Já a combinação entre amarelo e verde faz referência à seleção brasileira de futebol, laranja e preto à seleção holandesa e o preto a movimentos punk ou góticos.

No quarto degrau, estão as influências culturais. É aqui, segundo Mahnke (1996), que são atribuídos valores culturais às cores e, dependendo de onde esse indivíduo esteja, pode atingir somente um nível local ou expandir, abrangendo uma maior universalidade.

Do ponto de vista cultural, as cores trazem em si valores simbólicos, associações e impressões com algum elemento de grande relevância. Pode ocorrer em nível pontual ou até mesmo de forma ampliada, extrapolando fronteiras e expandindo sua totalidade. Como exemplo, para os irlandeses, o verde, atrelado ao trevo de quatro folhas, representa a nação Irish. Para os japoneses, uma bola vermelha sob um fundo branco representa a nação japonesa e, para os hindus, a cor de Brahma é representada pela coloração azul. 
No quinto e penúltimo degrau, estão as influências ditadas pelas tendências, moda e estilo. É aqui que as escolhas de cores provenientes desses setores podem fazer sentido à vida da pessoa. Nesse caso, como colocado por Fraser (2012), vestir-se seguindo a moda é uma maneira de evitar a necessidade de explorar sozinho a forma e a cor. O inverso, porém, também pode ocorrer, o que pode gerar conflitos e apresentar dificuldade para aceitar as tonalidades eleitas.

Essas influências cromáticas precisam ser avaliadas, pois, dependendo de como essas cores são aplicadas, há a real utilidade de uma análise criteriosa preliminar sobre quais são as cores de tendência e se essas tonalidades satisfazem os aspectos objetivos e subjetivos, bem como as necessidades específicas individuais (MAHNKE, 1996). Somente aceitar as cores selecionadas como tendência e aplicá-las poderá resultar em uma escolha desastrosa. Isso porque tal prática pode desencadear, além de certos efeitos patológicos, como dores de cabeça, náuseas, falta de concentração, entre outros sintomas, uma falta de identificação entre o que foi proposto pelo criador e os desejos de quem usa.

Indo um pouco além, ao transportar essa ideia das cores selecionadas como tendência para ambientes arquitetônicos, por exemplo, faz-se necessário avaliar a função do local e se as cores selecionadas estão de acordo com suas características. Nesse sentido, um hospital, tem uma função diferente de um restaurante, uma casa de recreação não tem a mesma função de um posto de gasolina e uma loja infantil é diferente de uma loja de alta costura.

Essas condicionantes também vão ocorrer no universo da moda e, nesse caso, o ponto central que diferencia a moda da arquitetura é o tempo de duração e permanência, além do valor agregado. Na moda, muitas vezes o que se observa é que, ao lançar uma cor de tendência, o público em geral acata como sendo legítima essa informação. Como o tempo de uso é diferente em relação à arquitetura, pode não haver uma prévia análise do indivíduo, ficando ele oscilante perante seu próprio desejo e satisfação. É o que ocorre, por exemplo, com a duração de uma peça de roupa, de um artigo de maquiagem ou de um acessório. Outro fator é o custo para aquisição desse novo objeto, que é mais acessível se comparado com uma casa, por exemplo.

Isso não quer dizer que os trabalhos de tendência ou uma cor eleita e desfilada na moda não tenha a sua verdade e possa sim ser incorporada. O que Mahnke (1996) propõe é que o indivíduo, ciente da sua conduta tanto individual como social, ao ser influenciado pelas mídias sociais, pelas informações provenientes dos colegas de trabalho, família e amigos, entenda como e o que absorver dessas mensagens. A partir daí, ele terá condições 
de avaliar se cabe ou não, segundo sua particular interpretação e experiência, as tonalidades lançadas.

Por último, no sexto degrau e ápice dessa pirâmide, estão as relações pessoais. Segundo Mahnke (1996), cada indivíduo irá relacionar-se com os outros cinco níveis da pirâmide, estabelecendo, de alguma forma, seus caminhos e padrões.

Sendo assim, as escolhas pessoais para as cores, ou seja, o que cada um irá elencar como verdadeiro, passam por todos os outros níveis, uns com maior, outros com menor impacto, mas todos eles compõem, de forma objetiva e/ou subjetiva, o que ele chamou de gosto pessoal para a cor.

Isso significa dizer que, para uma pessoa, a cor vermelha pode despertar uma relação afetiva, pois, dentro dos limites culturais, o vermelho é visto como uma cor que estimula, expande e comunica algo ao seu íntimo de forma positiva. Nesse sentido, pelas associações simbólicas conscientes, a avó, durante a infância dessa pessoa, estava, por exemplo, sempre de batom vermelho, logo o carinho e afeto trazidos pela avó despertam nesse indivíduo algo com que ele está disposto e pronto para se relacionar.

\subsection{Fatores psicológicos e emocionais}

Lidar com a cor é, num primeiro momento, entender e aceitar que é um procedimento muito mais profundo e complexo. Um dos motivos se deve ao estímulo visual que, ao ser filtrado e conduzido através do nervo óptico até os hipocampos cerebrais, vai ser influenciado por alguns fatores que se justapõem para resultar na cor que é percebida. Por meio deles, estímulos psicológicos e emocionais irão impactar a sensibilidade humana e, como resultado, cada um irá traçar seus próprios artifícios quanto à reação pessoal que será estabelecida com cada nuance.

Para identificar uma tonalidade, são necessários tanto processos conscientes e mecânicos, de ordem fisiológica, como inconscientes e emocionais. Tais processos estabelecem uma correlação entre os fatores do ambiente externo com os fatores interiores, do íntimo de cada indivíduo. Isso porque muitas das respostas podem estar vinculadas tanto a experiências e vivências agradáveis como a traumas e aversões devido a algum acontecimento original (MAHNKE, 1996). 
Sendo assim, a luz, ao atingir o globo ocular, provocando uma excitação ou estímulo, desencadeia uma aceleração da resposta nervosa ou um efeito de tranquilidade (GUIMARÃES, 2004). Com isso, impressões de prazer ou desprazer podem estar menos associadas a qualidades espirituais e estéticas do que à reação do cérebro e, de fato, de todo o organismo (BIRREN, 1978).

Ao imprimir um estado psicológico e penetrar nas emoções de quem as observa, as cores podem despertar sensações de frio ou calor, aumento ou retração, conforto ou desconforto. Os volumes podem ser aumentados ou diminuídos, o peso alterado e a distância modificada conforme as tonalidades utilizadas, logo as cores são uma poderosa fonte de ação (PEDROSA, 2009). Isso justifica por que, por exemplo, na sociedade ocidental, atribuise às tonalidades escuras, geralmente o preto, um significado voltado ao emagrecimento, razão pela qual muitas pessoas fazem uso dela por sentir uma alteração da sensação do volume corporal, acreditando-se mais magras ou esbeltas (WRIGHT, 1999).

Vale frisar que, quando o sujeito está envolvido pela cor, ele não escolhe uma ou outra nuance apenas pelas orientações ditadas pela tendência e moda, que também influenciam na escolha cromática, mas também por outras influências. Ou seja, inicialmente, ele é envolvido pela propagação da onda eletromagnética, depois, essa onda, ao atingir o ser humano, desencadeia reações biológicas que resultam no estímulo visual e, como resultado desses dois fatores iniciais, surge a percepção sensorial que vai agregar, nesse momento, informações de ordem psicológica. Devido a todo esse percurso, fica claro que a cor não poderia ser tratada meramente como uma decoração ou um adorno, mas sim deve ser considerada um fenômeno complexo que envolve muitas condicionantes (MAHNKE, 1996).

Segundo Farina (1982), indo ao encontro da teoria exposta por Mahnke (1996), o primeiro fator tem um caráter mais objetivo e é independente da psique de quem é analisado. Esse primeiro fator pode ser dividido em duas categorias que propõem uma resposta à cor de forma mais abranguente e não está estritamente relacionada com a mente individual.

A primeira categoria diz que as cores despertam sensações estando diretamente relacionadas com o poder do impacto causado pela onda eletromagnética no sistema fisiológico, que irá desencadear uma impressão visual e mental. Assim, cores com maior comprimento de onda tendem a aumentar a pressão arterial e o ritmo cardíaco, e cores com menor comprimento de onda propõem o contrário.

Com isso, um vermelho saturado parece ser fisicamente estimulante e requer um ajuste no globo ocular, pois por ter o maior comprimento de onda pode parecer estar mais próximo 
do que realmente está. Essse é um dos motivos que é tão frequentemente usado quando o impacto visual é importante (GUIMARÃES, 2004). Para Birren (1962, p. 18):

\begin{abstract}
Boa parte da preferência de cores inatas é rastreável aos efeitos fisiológicos da cor. A luz vermelha e a cor aumentam a pressão sanguínea, a taxa de respiração e a tensão muscular. A luz e a cor azuis os retardarão. Haverá maior excitação do corpo inteiro, ativação cortical mais positiva (ondas cerebrais) para o vermelho do que para o azul. Isso significa que somos afetados pela cor, quer queiramos ou não. Todas as fusões estão mais à mercê do espectro do que podemos perceber ou apreciar.
\end{abstract}

Nesse sentido, cores "alegres" estimulam, independentemente da psique individual, não só o apetite como também o humor, ao passo que cores suaves tornam o entorno mais repousante. Assim, o vermelho, por ter o maior comprimento de onda, estimula o sistema nervoso, elevando a pressão arterial e alterando o ritmo cardíaco. Já o azul, com o comprimento de onda menor, é psicologicamente calmante (BIRREN, 1962).

É válido salientar que mensuráveis são somente as reações fisiológicas produzidas pelo organismo, como pulso, onda cerebral, frequência cardíaca, pressão arterial etc. Essas reações podem dar uma indicação da condição psicológica, no sentido da psicossomática, em que se deve considerar uma interação cujo impacto causado no corpo pode determinar a condição psicológica e vice-versa (MAHNKE, 2010).

Ademais, devido à fisiologia humana, a formação do cristalino que, no decorrer dos anos, se torna mais amarelado vai influenciar no impacto causado pelas cores. Dessa forma, uma criança absorve $10 \%$ da luz azul, enquanto um ancião absorve cerca de $57 \%$. Nos primeiros meses, a criança prefere igualmente o vermelho, o amarelo, o verde e, depois, o azul. Já os adultos e idosos preferem tonalidades escuras, azul, verde, acrescentando o vermelho como reminiscência do período infantil (FARINA, 1982).

Segundo Farina (1982, p. 107), o vermelho interage "diretamente sobre o ramo simpático do sistema neurovegetativo", já "o azul puro é psicologicamente calmante e atua principalmente através do ramo parassimpático do sistema neurovegetativo". Tanto que, para Lüscher (1969), o vermelho excita o sistema nervoso, por isso as pessoas que são colocadas diante dessa tonalidade por um determinado tempo apresentam uma elevação da pressão arterial e alteração do ritmo cardíaco.

Johannes Itten, professor da escola alemã Bauhaus, em 1928, desenvolveu uma série de exercícios com seus alunos, propondo combinações e harmonias cromáticas. Era desenvolvida uma série de atividades utilizando tonalidades para reconhecimento de 
situações como, por exemplo, representar combinações cromáticas das quatro estações do ano. Segundo Barros (2006, p. 83):

\begin{abstract}
Itten desenvolve um estudo sobre esse tema com a representação objetiva das cores das quatro estações do ano (primavera, verão, outono e inverno). $\mathrm{O}$ intuito desse exemplo era mostrar aos alunos que a cor deve ser aplicada de forma objetiva quando se faz necessária a transmissão de uma mensagem comum a todos os homens. Ele observa que nunca alguém se equivocou ao interpretar sua representação das quatro estações, pois cada paleta guiou-se pelo reconhecimento universal, e não pelo seu timbre subjetivo. Isso o levou a concluir que, acima de todos os gostos pessoais, se sustenta uma capacidade de julgamento mais elevada no homem, passível de ser comprovada e posicionada acima do sentimento individual.
\end{abstract}

A conclusão a que se chega dessa primeira categoria é que existem estímulos provocados pelas cores os quais desencadeiam reações fisiológicas responsáveis pela elevação da pressão arterial e do ritmo cardíaco. Isso despertará estados psicológicos nem sempre relacionados estritamente com o sujeito e com a psique individual, mas sim atreladas às relações mais universais.

Já com relação à segunda categoria, é preciso tomar cuidado, porque os resultados obtidos com os seres humanos e sua reação à cor podem ser, com frequência, reduzidas a simples preceitos mecanicistas. Segundo essa ótica, Mahnke (2010, p.47) postula que:

\footnotetext{
Uma descoberta recente em biologia molecular mostra uma diferença em um único aminoácido - a diferença genética mínima entre duas pessoas pode causar uma diferença na maneira como vemos a cor. As equipes de pesquisa da Universidade de Washington, em Seatle e da Universidade de John Hopkins, rastrearam a base genética dos fotopigmentos vermelhos e mostraram que o aminoácido recém-descoberto afeta a parte das células do cone onde começa a percepção da cor. Os estudos mostram que há um número infinito de maneiras de ver o vermelho sozinho. A variação de cada indivíduo em ver vermelho ligeiramente diferente de outro é, portanto, causada por diferenças sutis na composição genética. Isso é considerado uma explicação biológica para a subjetividade da resposta cromática.
}

Emtretanto, apesar de essa diferença biológica existir, fica evidente que, se a tentativa de impor uma padronização ao comportamento e à reação à cor é vaga, é também difícil de achar um significado para a diferença perceptiva entre um indivíduo e outro à oscilação biológica citada acima. Isso serve apenas para empurrar toda a questão para a área da relatividade, a qual, ainda de acordo com Mahnke (2010, p. 47): 
(...), pretende indicar que nossa reação à cor é uma questão que só pode ser compreendida dentro de certos limites e sujeita a pontos de vista individuais. Isso é verdade até certo ponto, talvez no que diz respeito à preferência pessoal por uma cor, mas nosso julgamento e reação à cor não são apenas uma questão de sentimentos, preconceitos e interesses pessoais; são influenciados por fatores conscientes e inconscientes.

Sendo assim, como colocado por essa segunda categoria, a percepção de cor não pode ser apenas atribuída ao campo da relatividade biológica. Nesse caso, devido a uma estrutura molecular causada por um aminoácido ou à formação dos cones na retina, passa a valer a argumentação segundo a qual a percepção de cor é fundamentalmente subjetiva. Mesmo tendo um indivíduo uma formação fisiológica diferente do outro, ainda prevalecerão os atributos de cor como saturação e luminosidade.

Isso significa que, ao ser impressa uma determinada frequência da luz, existem centenas de nuances que, embora sejam diferentes, a impressão ainda seria de um amarelado, alaranjado, esverdeado e assim por diante. A reprodução geral é importante, e um vermelho específico, seguindo o mesmo exemplo, ligeiramente alterado em sua posição de matiz, luminosidade e saturação, ainda é uma impressão vermelha e não uma sensação de um amarelo ou de um roxo. Sendo assim, é necessário entender a diferença entre a mecânica de "ver" e o ato de "perceber" uma determinada vibração cromática.

Por outro lado, o segundo fator apresentará um lado mais subjetivo que leva a mente do indivíduo em questão a interagir com todo seu repertório, crenças, memórias afetivas e conhecimentos. Por conseguinte, o efeito alcançado ou provocado pelo estímulo visual nem sempre é específico para nenhuma cor ou para certas tonalidades (MAHKNE, 2010).

É por esse motivo que cores com maior comprimento de onda, ou seja, vermelhos, amarelos e laranja, podem, ora acalmar ou relaxar uma pessoa, ora animar e excitar outras. Além disso, impulsos com menor comprimento de onda podem ser estimulantes para um e passivos para outro indivíduo. Sendo assim, Deutsch (apud Birren 1961, p.156) elenca quatro pontos. São eles:

1. A cor produz uma ação reflexa sobre o sistema vascular, mesmo que apenas através dos sentimentos e emoções.

2. O efeito alcançado não é específico para nenhum ou para certos matizes. Cores quentes podem acalmar uma pessoa e animar outra. Cores frias também podem ser estimulantes para uma pessoa e passivas para outra.

3. A irradiação com luz vermelha ou verde pode produzir uma elevação da pressão sanguínea e uma aceleração da pulsação. Ou o contrário pode ocorrer, dependendo da composição psíquica específica do indivíduo. 
4. "Um senso de cor orgânico, não óptico, não foi provado até agora". No entanto, a resposta que segue a exposição à cor pode ter um efeito orgânico.

Nessa direção, a irradiação da frequência que estimula o vermelho ou o azul pode produzir uma elevação da pressão sanguínea e uma aceleração da pulsação. Portanto, o vermelho pode levar uma pessoa ao relaxamento, dependendo da composição psíquica específica, que é pessoal, e das relações que ela estabeleceu com cada nuance durante a vida.

Para exemplificar essa relação, suponha-se que uma mulher foi apaixonada por um homem que se vestia com frequência de azul e que o rapaz não correspondeu às expectativas amorosas dela. É bem provável que, ao se apaixonar novamente por outra pessoa, e caso essa pessoa use com frequência as mesmas tonalidades do moço anterior, isso pode elevar o ritmo cardíaco e a pressão arterial, mesmo sendo o azul uma cor com menor comprimento de onda, ou seja, tido por muitos como sendo calmante e relaxante. Assim, as experiências e vivências são individuais, e os resultados alcançados por cada cor pode ser relativo.

Dito isso, ao considerar o fenômeno como um todo, quando a escolha está de acordo com a vontade e a identidade do ser, pode despertar no indivíduo sensações e sentimentos positivos de bem-estar, conforto e segurança. Consequentemente, como é o caso de toda percepção sensorial, vai desencadear uma série de reações psicológicas e emocionais, que sob algumas circunstâncias fisiológicas, pode tornar necessário recorrer aos aspectos científicos das disciplinas enraizadas na biologia e fisiologia, primeira camada da pirâmide, e da psicologia, segunda camada da pirâmide (MAHNKE, 1996).

Nessa perspectiva, a propagação luminosa, ao adentrar a fisiologia humana e posteriormente a psique, a priori, desperta duas dimensões opostas como resultado: simpatia de um lado ou antipatia de outro. Segundo Mahnke (1996), pode também causar uma terceira dimensão que vai além do julgamento dado como sendo positivo ou negativo e objetivo ou subjetivo. Pode-se designá-lo como "expectativa", talvez até "indiferença", no sentido de que nenhum julgamento ou emoções positivas e negativas imediatas são despertados inicialmente. Isso porque a cor, na maioria das vezes, corresponde às expectativas geradas de uma aparência, seja ela um objeto ou pertencente à natureza.

Sendo assim, somente quando a relação cor-objeto está fora das expectativas do que deveria ser, que parece fora do normal, do padrão, do convencional, como, por exemplo, uma banana ser apresentada na tonalidade azul ou mesmo o oceano ser exibido na cor rosa, pode-se falar imediatamente de uma reação positiva ou negativa dentro dessa terceira dimensão. Isso se deve pelo fato de que os seres humanos estão programados para que certas 
aparências devam possuir uma coloração específica e, quando isso não ocorre, há uma necessidade de negar ou avaliar um sinal de cor a que não estão acostumados. Além dos fatores relacionados à aceitação, à rejeição ou à necessidade de avaliação, existem outros dois que também vão interferir no resultado psicológico provocado pelo estímulo visual, conforme se vê no quadro 1.

QUADRO 1: Cisão esquemática relacionando os fatores psicológicos e emocionais.

\begin{tabular}{|c|c|c|c|}
\hline \multicolumn{4}{|c|}{ FATORES PSICOLÓGICOS E EMOCIONAIS } \\
\hline Fatores & Categorias & & ações \\
\hline \multirow{2}{*}{ Primeiro Fator } & \multirow{2}{*}{$\begin{array}{l}1^{\circ} \text { categoria } \\
2^{\circ} \text { categoria }\end{array}$} & \multicolumn{2}{|c|}{$\begin{array}{l}\text { relacionadas com o poder do impacto causado } \\
\text { pela onda eletromagnética }\end{array}$} \\
\hline & & \multicolumn{2}{|c|}{$\begin{array}{l}\text { a percepção de cor não pode ser apenas atribuída } \\
\text { ao campo da relatividade biológica e subjetividade }\end{array}$} \\
\hline Segundo Fator & única & \multicolumn{2}{|c|}{$\begin{array}{l}\text { a mente interage com todo seu repertório onde } \\
\text { uma cor pode ser calmante ou excitante } \\
\text { dependendo para quem - subjetividade }\end{array}$} \\
\hline \multirow[t]{2}{*}{ Consequências } & Dimensões & Reações & Resultados \\
\hline & $1^{\circ}$ & Simpatia & Aceitação \\
\hline \multirow[t]{2}{*}{$\begin{array}{l}\text { Percepção } \\
\text { Sensorial }\end{array}$} & $2^{\circ}$ & Antipatia & Rejeição \\
\hline & $3^{\circ}$ & Indiferença & $\begin{array}{l}\text { Necessidade } \\
\text { de avaliação }\end{array}$ \\
\hline
\end{tabular}

Fonte: a autora.

Dessa maneira, não surpreende que as ciências exatas tenham dificuldade em atribuir significado às cores e aceitar reações psicológicas fundamentais. Isso porque uma mesma tonalidade pode despertar sensações completamente diferentes, como um verde ser relaxante ou excitante, dependendo para quem. Por essa razão, os efeitos psicológicos da cor não podem ser compreendidos apenas através de pesquisas que investigam a reação entre estímulos e efeitos fisiológicos. Com isso, há uma necessidade de interpretação e uma análise da psique do indivíduo em questão. 
Isso justifica a existência de uma série de trabalhos que buscaram avaliar qual é a paleta de cor que mais reverberava em consonância com cada um onde Itten (1961) propôs também uma série de exercícios com seus alunos desenvolvendo, individualmente, combinações e harmonias cromáticas, como se observa na figura 2.

FIGURA 2: Timbre Subjetivo proposto por Johannes Itten.

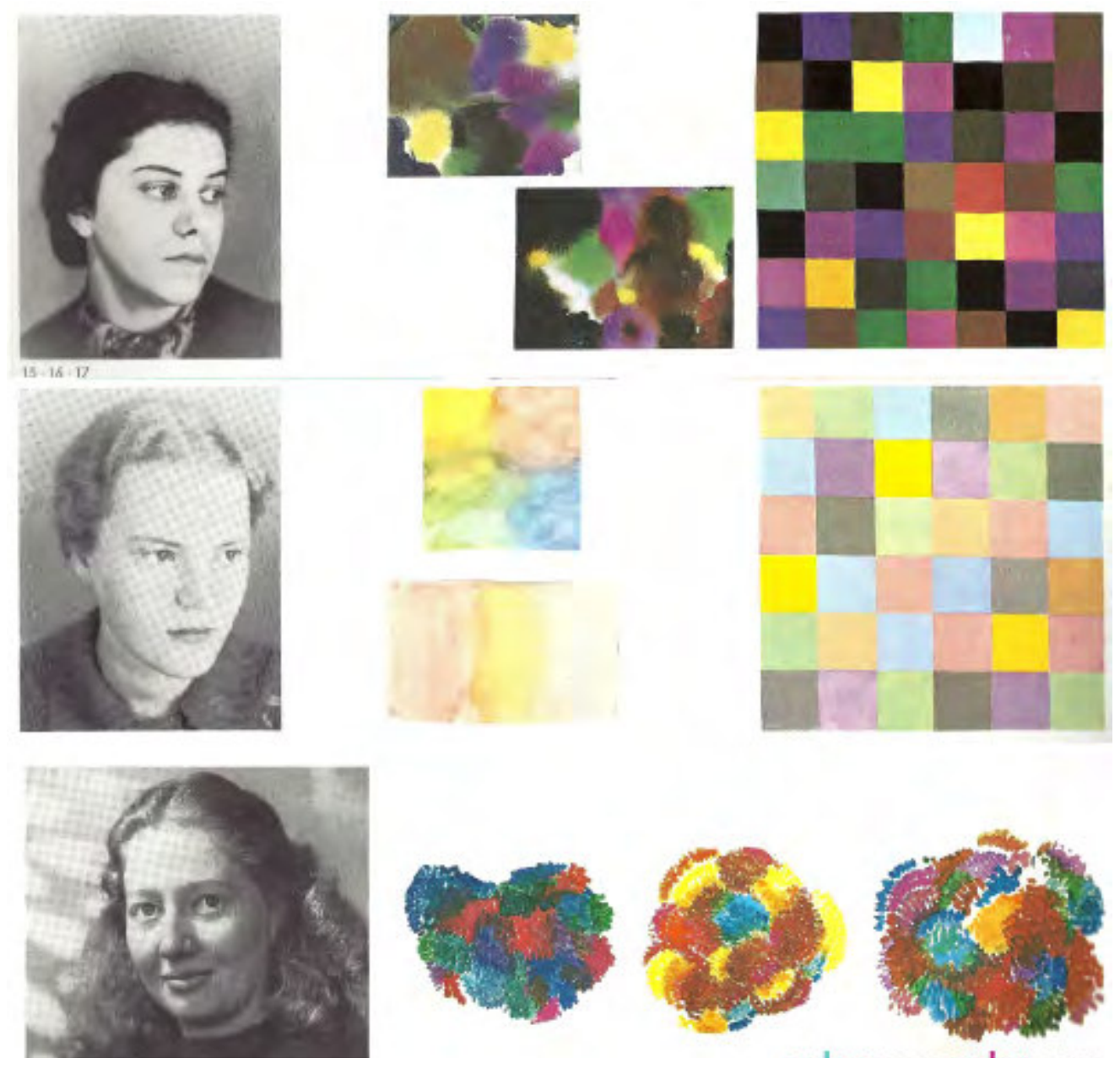

Fonte: ITTEN, 1961, p. 130-131.

Esses exercícios buscavam revelar o quanto as "cores devem ter uma capacidade mística de expressão espiritual, sem estarem vinculadas a objetos" (BIRREN apud ITTEN, p. 6, 1970). Para Itten (1970, p. 23, 24 e 26):

as combinações de cores construídas como harmoniosas por cada indivíduo aqui representam uma opinião subjetiva individual. Isso é cor subjetiva (...) combinações subjetivas de cores são uma chave para a identificação do modo natural de pensar, sentir e agir do indivíduo (...) onde o timbre subjetivo é significativo para o ser interior de uma pessoa, muito do seu modo de pensamento, sentimento e ação pode ser inferido a partir de suas 
combinações de cores. A constituição e as estruturas intrínsecas são refletidas nas cores, geradas pela dispersão e filtração da luz branca da vida e por vibrações eletromagnéticas no meio psicofisiológico do indivíduo.

Assim, a interpretação de combinações subjetivas de cores não deve ser baseada apenas nos matizes escolhidos, pois a relação de saturação e luminosidade exposta é de fundamental importância, ou seja, o timbre como um todo. Deve-se também levar em consideração "o posicionamento das cores entre si, suas direções, brilho, clareza ou turbidez, suas proporções, texturas e relações rítmicas" (ITTEN, 1970, p. 26).

Com isso, a paleta de cores que cada aluno desenvolvia dizia muito a respeito de si próprio, deixando evidente seus temperamentos e qualidades. Itten chamou-as de timbre subjetivo que "foi, sem dúvida, uma descoberta genuína desse mestre da Bauhaus" (BARROS, 2006, p.77).

Dessa forma, investigar e explorar o timbre subjetivo fazia parte dos trabalhos propostos por Itten com o propósito de descobrir as preferências cromáticas individuais. Ele desenvolvia uma prática mais direta ao investigar a relação entre cores, contrastes e formas elementares. Para tanto, utilizava formatos geométricos como o quadrado, o triângulo, o círculo, entre outros. A ideia era agregar tanto experiências obtidas a partir de esferas objetivas, como informações provenientes do timbre subjetivo. As figuras 3 e 4 ilustram o trabalho desenvolvido por Itten.

FIGURA 3: Associações entre cores e formas correspondentes propostas por Johannes Itten.

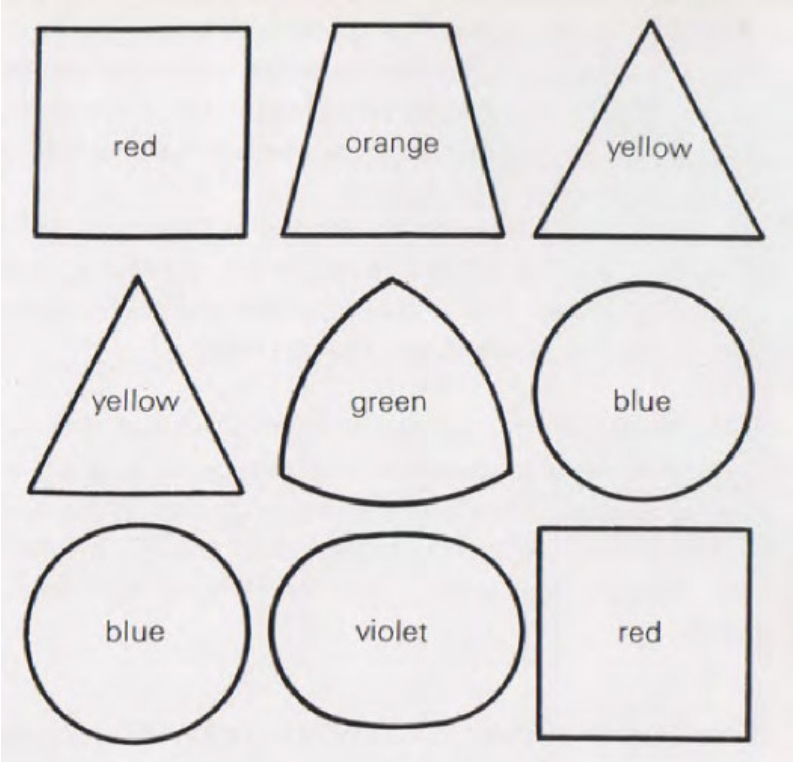

Fonte: ITTEN, 1970, p. 75. 
FIGURA 4: O berço feito por Peter Keler, em 1922, associando as cores e as formas fundamentais.

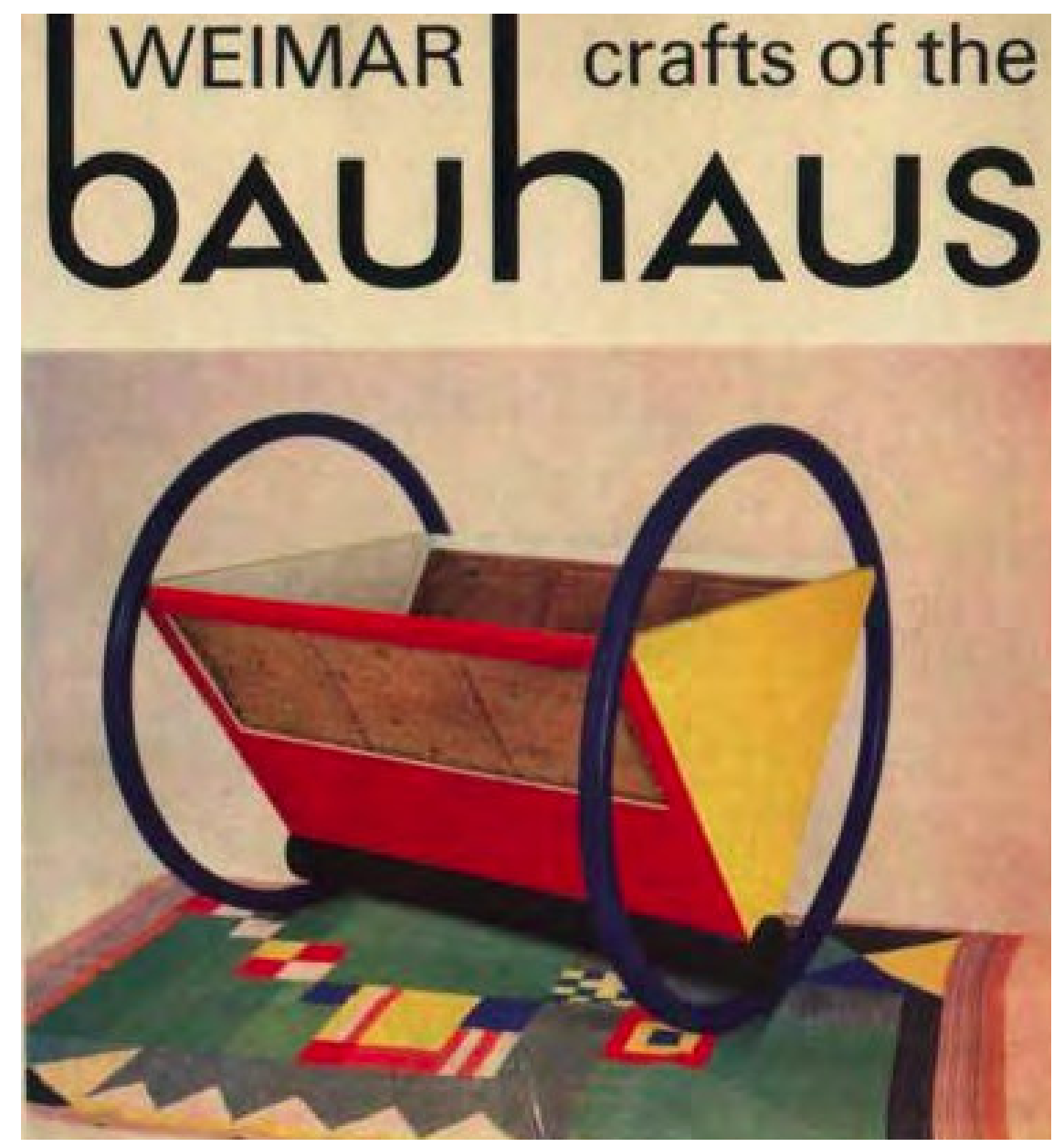

Fonte: PINTEREST, https://www.pinterest.at/pin/316518680034224818/

Com isso, fica evidente que, se por um lado, as cores produzem uma mensagem e comunicam informações psicológicas gerais; por outro, é algo intransferível vinculado à mente e à vivência de cada ser humano. Sendo assim, faz-se necessário adentrar o íntimo de cada um para evitar verdades e conceitos universalizantes.

Nessa perspectiva, os efeitos das cores têm que ser entendidos tanto por um viés objetivo, também fundamental para o conhecimento e avaliação correta, como por um ponto de vista dos fatores psicológicos e emocionais vinculados ao timbre subjetivo, conforme proposto por Itten (1961). Assim, fatores objetivos e subjetivos podem, através dos olhos de quem vê, revelar muito a respeito do modo individual de agir, pensar e sentir uma cor.

A partir desse entendimento, desde o começo do século XX, deu-se início a uma série de trabalhos relacionados à psicologia das cores. $\mathrm{O}$ que se passou nessa área foi a tentativa de estabelecer uma relação direta entre o estímulo produzido pela luz e interpretado pelo cérebro e a resposta humana quanto a preferências, posicionamentos e condutas provocadas 
por esse estímulo para, a partir desse ponto, propor uma interpretação das características de personalidade individuais.

Essa forma de categorização não agradou, todavia, a muitos e para dar à psicologia da cor seu verdadeiro valor, deve-se ir além dos dois extremos atribuídos a essa ciência. Por um lado, essa área foi vítima de um exagero excessivo de alguns, marcado por rígidas fórmulas ou receitas que não permitem desvios ou possíveis interpretações. Por outro lado, foi menosprezada por ser um campo misterioso e enigmático, considerada como sendo exotérica, sem a sanção de evidências científicas concretas.

É muito comum acontecer de, às vezes, muitas pessoas desejarem "ler sua verdade" posta através da psicologia das cores. O resultado pode ser tanto inconsistente e insuficientes, não representando, por meio das nuances selecionadas, os anseios e desejos pessoais. O contrário também é possível, uma vez que pode espelhar algumas verdades e pruduzir uma leitura a respeito da pessoa observada.

Quando isso ocorre, o indivíduo se sente confortado na busca do seu "eu" e consegue estabelecer um elo com as cores elencadas como sendo as mais pertinentes, refletindo sua verdade. Devido a isso, é constante verificar que o desejo de encontrar essa força interna tem muitos seguidores. Por essa razão, até hoje, as pessoas almejam explicações a respeito delas próprias, ou seja, buscam um fio condutor que desbrave ou até resolva questões mais profundas.

Assim, a psicologia das cores tem, entre alguns objetivos, provocar uma sensação por meio do estímulo causado pelas cores selecionadas: simpatia, ou seja, aceitação e aprovação; ou antipatia, isto é, rejeição e desaprovação para, a partir daí, buscar uma interpretação que desvende traços da personalidade. Entretanto, segundo Farina (1982, p.112), as cores

constituem estímulos psicológicos para a sensibilidade humana, influindo no indivíduo, para gostar ou não de algo, para negar ou afirmar, para se abster ou agir. Muitas preferências sobre as cores se baseiam em associações ou experiências agradáveis tidas no passado e, portanto, tornase difícil mudar a preferência sobre as mesmas, mas não revelar uma verdade científica e muito menos ser o enigma para o desbravamento do ser.

O relacionamento pessoal com a cor e seu possível significado, bem como a busca por respostas aos anseios individuais podem encontrar um acolhimento nos diagnósticos psicológicos. Eles exigem que os julgamentos de quais cores mais agradam, menos agradam ou até mesmo as que sejam indiferentes, sejam feitos espontaneamente, sem nenhuma 
associação direta vinculada a um objeto, como maquiagem, roupas, acessórios, móveis, materiais etc. Também não querem que os julgamentos estajam atrelados a experiências anteriores, buscando-se descartar, assim, qualquer base contextual.

Contudo, o trabalho proposto por esta tese não faz uso de nenhum teste psicológico, portanto, não desenvolve uma análise da psique individual para criação de paletas de cores. Todavia, como suporte ao método aqui proposto e adentrando o eixo central da construção piramidal proposto por Mahnke (1996) e o caminho percorrido por Farina (1982), consideraram-se os tipos psicológicos descritos por Carl Gustav Jung (1971) e como cada uma dessas classificações podem estar sobrepostas em um espaço de cor. Nesse sentido, há a possibilidade de uma correlação entre personalidade e estímulo cromático.

Não se trata, porém, de entender se o indivíduo aceita ou apresenta alguma rejeição a uma ou algumas nuances em específico, tampouco as razões que o levaram a tal sentimento ou emoção. O propósito é cercar as características e anseios primordiais, os impulsos principais e a possibilidade de proposição e aceite por parte dessa pessoa mediante a resposta ao estímulo referente à saturação e à luminosidade, como será colocado a seguir.

\subsubsection{Os tipos psicológicos de Carl Gustav Jung relacionados aos atributos de cor}

Carl Gustav Jung foi um psiquiatra e psicanalista suíço que viveu entre 1875-1961 e deixou inúmeras contribuições que extrapolaram o campo da psicologia e se fazem presentes em muitas áreas. Ele foi, inegavelmente, um dos autores que mais estudou a personalidade humana, interessado e preocupado com as relações do homem com o mundo externo, os aspectos interiores a cada indivíduo e a comunicação entre as pessoas, sendo conhecido como um dos maiores psicólogos do século XX.

Em 1921, ao escrever um de seus mais importantes trabalhos, os “Tipos Psicológicos", Jung afirmou que "Tipo é uma disposição geral observada nos indivíduos, caracterizando-os quanto a interesses, referências e habilidades. Por disposição deve-se entender o estado da psique preparada para agir ou reagir numa determinada situação" (JUNG, 1971, p. 51). Ainda profere Jung: "não creio de modo algum que minha classificação dos tipos seja a única verdadeira ou a única possível” (SILVEIRA, 1981, p. 43).

Jung distinguiu duas formas de disposição, ou seja, atitude das pessoas em relação ao objeto, e as dividiu entre extroversão e introversão. Cado tipo corresponde a uma preferência 
natural quanto ao modo de relacionar-se com o mundo ao redor, mesmo que de forma inconsciente. Para ele, as duas eram como condutas originais, distintas entre si, ou deslocamentos guiados para fora ou para dentro (JUNG, 1971).

Mesmo havendo esses dois tipos, vale pontuar que dois indivíduos com inclinações para a introversão, por exemplo, não necessariamente agem de forma parecida. Isso porque cada pessoa utiliza suas funções psíquicas e os processos mentais de forma individual.

Em contrapartida, pessoas com inclinação à extroversão estavam relacionadas a uma preferência segundo a qual o indivíduo dirigia sua atenção ao mundo externo de fatos, objetos e indivíduos. Desse modo, colocava atenção na ação, muitas vezes de forma impulsiva, com iniciativa e atitude prática, para comunicar-se e socializar-se. Esse tipo apresentava uma confiabilidade em relação à atitude, adaptando-se frente ao ambiente externo de forma natural e objetiva (SILVEIRA, 1981).

Já na introversão, o indivíduo dirigia sua conduta ao mundo interno de representações, emoções e impressões psíquicas, dando luz ao sujeito por meio da reflexão e por uma orientação subjetiva. Desse modo, sua postura é voltada para dentro, para o mundo interior, ponderando as atitudes antes de agir ou impulsionar uma ação. Acrescente-se ainda que esse tipo apresentava um comportamento e comunicação reservada, pois segurava as emoções e não disseminava seus pensamentos (SILVEIRA, 1981).

Apesar dessas duas inclinações, segundo Jung (1971), nenhum ser humano é exclusivamente extrovertido ou introvertido, visto que cada pessoa possui essas duas qualidades. O que diferencia um e outro é a forma de adaptação à qual o sujeito se moldou perante as condições existentes e "ambas as atitudes existem dentro dele, mas só uma delas foi desenvolvida como função de adaptação; logo podemos supor que a extroversão cochila no fundo do introvertido, como uma larva, e vice-versa" (JUNG, 1971, p. 48).

Os tipos psicológicos extrovertido e introvertido apresentam quatro funções psíquicas que a consciência usa para fazer o reconhecimento do mundo exterior e, a partir daí, buscar um caminho e uma orientação. As quatro funções são determinadas pelo ego e desempenham relações psicológicas, fornecendo ao sujeito habilidades, aptidões e tendências no relacionamento do indivíduo consigo mesmo e com o mundo ao redor.

Saliente-se que, embora todos os seres humanos tenham as quatro funções dentro de si, uma das quatro vai prevalecer e ser dominante em relação às outras. Uma segunda estabele uma conexão auxiliar, estando essas duas primeiras no nível da consciência. Já a terceira e a quarta função, de maneira geral, se apresentam de forma inconsciente, ficando no limbo entre o meio que o cerca e o inconsciente coletivo. 
A função dominante é, pois, a forma mais eficiente de expressão individual e tem por objetivo caracterizar o Tipo Psicológico do indivíduo. Cada um utiliza, preferencialmente, sua função principal, a fim de obter melhores resultados, expressando mais facilmente sua existência. Conforme escreveu Jung (1971, p. 43):

na luta pela existência e pela adaptação, cada qual emprega instintivamente sua função mais desenvolvida, que se torna, assim, o critério de seu hábito de reação.... Assim como o leão abate seu inimigo ou sua presa com a pata dianteira (e não com a cauda, como faz o crocodilo), também nosso hábito de reação se carateriza normalmente por nossa força, isto é, pelo emprego de nossa função mais confiável e mais eficiente, o que não impede que às vezes, também possamos reagir utilizando nossa fraqueza específica. Tentaremos criar e procurar situações condizentes e evitar outras para, assim, fazermos experiências especificamente nossas e diferentes das dos outros.

Já a função auxiliar está vinculada a um plano inferior e serve como apoio à função principal, não sendo contrária a esta. Essa função tem por objetivo trazer equilíbrio entre as partes extroversão e julgamento com introversão e percepção. Como exemplo, a função auxiliar dos extrovertidos traz acesso ao mundo interior e ao mundo das idéias, enquanto a auxiliar dos introvertidos traz o mundo das ações e formas de lidar com ele de maneira satisfatória.

A função terciária, por sua vez, apresenta desenvolvimento precário e oposto à função auxiliar na escala de preferências. Já a função inferior é menos desenvolvida e se contrapõe à função dominante. No entanto, essa função apresenta um grau acentuado de autonomia por não estar subordinada à autoridade da consciência, que é um lugar de enorme potencial, pois faz a ponte para o inconsciente.

Segundo Jung (1971, p. 50), a função inferior tende a aparecer quando uma pessoa se encontra sob pressão e/ou doente, tanto que

acontecimentos positivos ou negativos podem trazer a tona a função contrária inferior. Sobrevindo isso, manifesta-se a hipersensiblidade, sintoma da existência de uma inferioridade. Assim estabelecem-se as bases psicológicas da desunião e da incompreensão, não só entre duas pessoas, como também da cisão dentro de si mesmo... a natureza da função inferior é caraterizada pela autonomia; é independente, ela nos acomete, fascina e enleia, a ponto de deixarmos de ser donos de nós mesmos e não nos distinguirmos mais exatamente dos outros.

Nessa direção, junto com a extroversão e a introversão, os tipos psicológicos são definidos em quatro funções, sendo elas: Sensação, Intuição, Pensamento e Sentimento. 
Com isso, as pessoas utilizam uma das quatro como dominante, outra como auxiliar e outras duas como intermediária e inferior.

Dentro dessas quatro funções, existem duas maneiras por meio das quais os acontecimentos são percebidos. A primeira é formada pela dupla Sensação e Intuição. O ponto de partida é que essas duas formas ocorrem sem a presença de uma avaliação inicial, pois são funções irracionais, uma vez que a situação é apreendida diretamente, sem a intervenção de uma análise, julgamento ou deliberação. A segunda é composta pela dupla Pensamento e Sentimento, que são consideradas racionais por apresentarem uma origem julgadora e setenciosa e, devido a isso, serem determinadas pela tomada de decisões. Essas funções são também chamadas de funções de arbitragem porque são responsáveis pelos encaminhamentos acerca dos assuntos de que trata a consciência, conforme esquematiza o quadro 2 .

QUADRO 2: Cisão esquemática relacionando as funções psicológicas de Jung.

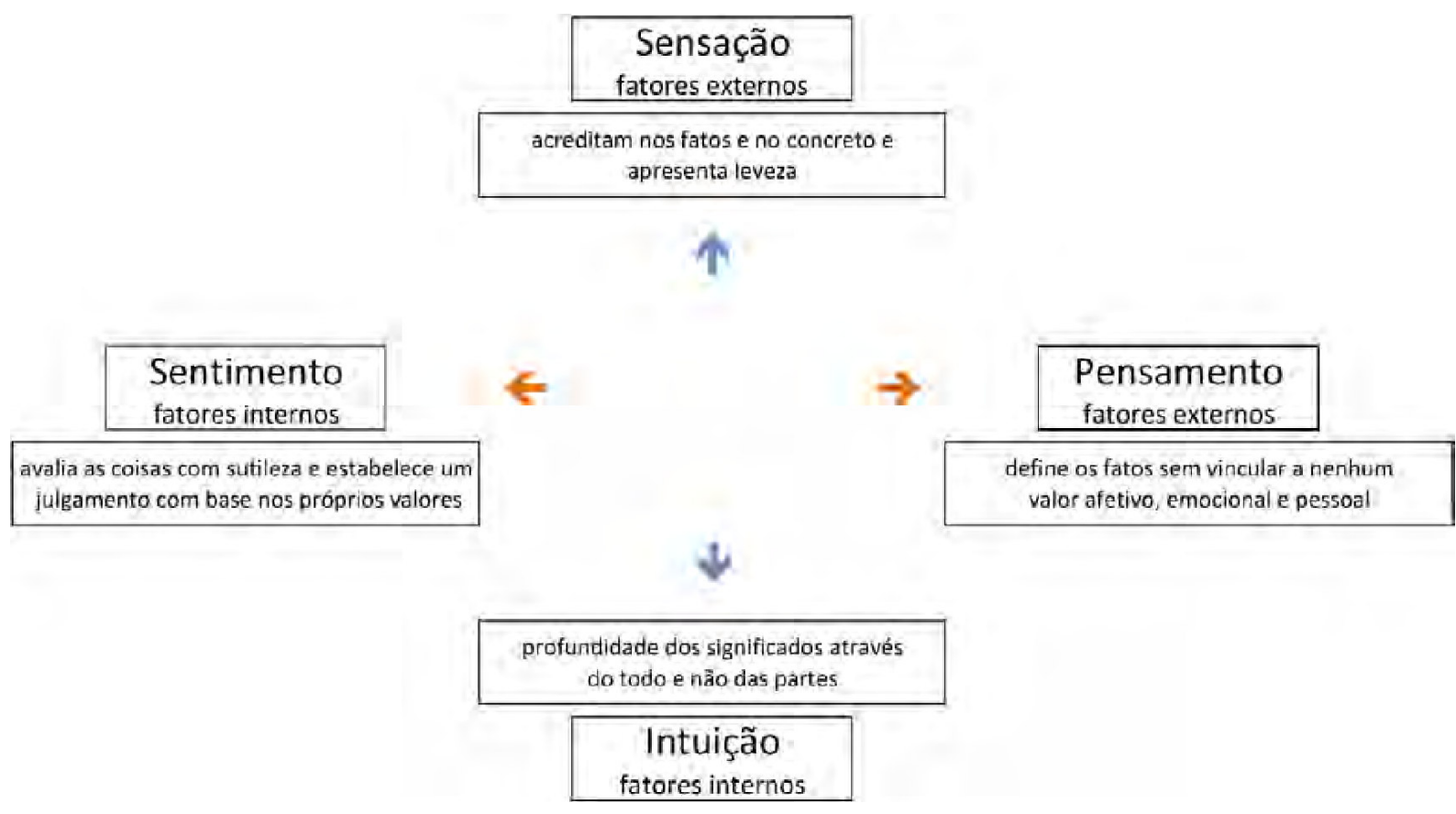

Fonte: a autora.

A função Sensação está conectada com a percepção de fatos externos responsáveis pelas informações que chegam até os sentidos, constatando o que realmente está presente. Esses indivíduos são práticos e realistas, gostam de conservar o funcionamento das coisas e 
vivem no tempo presente. Eles acreditam nos fatos, no real e no concreto e apresentam leveza para lembrar-se de tudo o que sucedeu.

Na função Intuição, a percepção se dá através do inconsciente e não mais dos sentidos, manisfetando-se por meio de premonições, instintos e feelings. Essa função procura a profundidade dos significados por meio do todo e não das partes, por isso costuma apresentar dificuldade na percepção de detalhes.

Pela função Pensamento, os indivíduos vinculam valor ao que realmente está presente através de um conceito e apresentam uma linha de conduta lógica e racional dos impactos que aconteceram. Através do julgamento, classificação e segregação, definem os fatos sem vincular a nenhum valor afetivo, emocional e pessoal. Como são movidos pela razão, geralmente são imparciais, não se vinculando a nenhuma situação, pois estabelecem padrões de conhecimento de forma intelectual. Consequentemente, a conclusão é gerada pela lógica.

Por último, existe a função Sentimento por meio da qual as pessoas avaliam as coisas com sutileza e estabelecem um julgamento com base nos próprios valores ou até mesmo nos valores dos outros, apresentando uma avaliação e não uma emoção. Mesmo que a tomada de decisão não apresente lógica aparente mediante a circunstância criada, esse grupo tende a ponderar os sentimentos, propondo uma harmonia e um equilíbrio.

Dessa forma, uma pessoa do gênero Sensação tende a não dar importância às suas intuições e o gênero Intuitivo ignora o que está a sua frente. Já a de função Pensamento tende a não dar importância ao seu sentimento e, por sua vez, a do gênero Sentimento expulsa pensamentos que lhe desagradam (JUNG, 1971).

Como consequência, depois de ter sido entendido cada tipo e cada uma das quatro funções, foi desenvolvida uma interpretação que, conforme colocado anteriormente, não é a única possível, sendo admitida a possibilidade de diferentes leituras e apreciações.

O objetivo da análise aqui proposta é cercar os tipos psicológicos dentro um espaço de cor e trazer ferramentas para esse trabalho, servindo como um guia, como um mapa de bolso, como um itinerário sem a pretensão de trazer uma verdade absoluta e única. Todavia, mesmo não se tratando de uma forma enrigecida de abordagem, utilizar esse conteúdo colabora para desenvolver paletas de cores individuais ao levar em consideração os anseios e as expectativas dirigidas pela Harmonia Subjetiva, como será tratado no capítulo 3.

Para tanto, faz-se necessário também esclarecer os conceitos relacionados aos atributos de cores, a saber: matiz, saturação e luminosidade. Sendo assim, entende-se como matiz a 
característica de cromaticidade identificada no espectro da luz solar. Este conceito está diretamente ligado ao comprimento de onda da radiação luminosa, normalmente dada pelos adjetivos: amarelo, alaranjado, vermelho, azul, verde etc. Deve-se acrescentar o púrpura, não presente no espectro, que faz a ligação entre o vermelho e o violeta (MOCERI apud MAZZILLI, 1993, p. 22).

A saturação "corresponde ao grau de pureza da cor, podendo ser obtido pela comparação da cor ao cinza neutro. Pode-se dizer que o grau de saturação diminui quando a cor se aproxima do cinza, perdendo sua 'força'" (MOCERI apud MAZZILLI, 1993, p. 22). Já a luminosidade, “corresponde ao grau de luminosidade da cor, podendo ser comparada a uma escala que vai do negro (cor de claridade mínima) ao branco (cor de claridade máxima)" (MOCERI apud MAZZILLI, 1993, p. 22).

Junto a isso, foi utilizado o sistema sueco de notação cromático, Natural Colour System, NCS, que, segundo Moceri (2016, p. 37),

é um mecanismo padronizado representado por amostras de cores, impressas ou digitais, que foram selecionadas em intervalos regulares e estruturadas a partir de coordenadas. Geralmente, esse tipo de sistema é estruturado por códigos, que, para serem decifrados, exigem que se entenda qual a sua origem, os conceitos envolvidos, a linguagem por meio de códigos e a base de sua formulação. Dessa forma, os sistemas não são estruturados a partir de tendências ou conceitos da moda vigente, o que faz com que sua possibilidade de utilização abranja as mais diversas áreas de pesquisa no campo das cores.

Esse sistema foi desenvolvido depois de décadas de pesquisa científica em um ambiente interdisciplinar que envolvia designers, engenheiros e psicólogos. Até que o Swedish Colour Centre, sob a direção do cientista Anders Hård, desenvolveu uma versão refinada dessa representação, publicado no ano de 1976, conforme se vê nas figuras 5, 6, 7 e 8 a seguir. 
FIGURA 5: Cores elementares NCS.
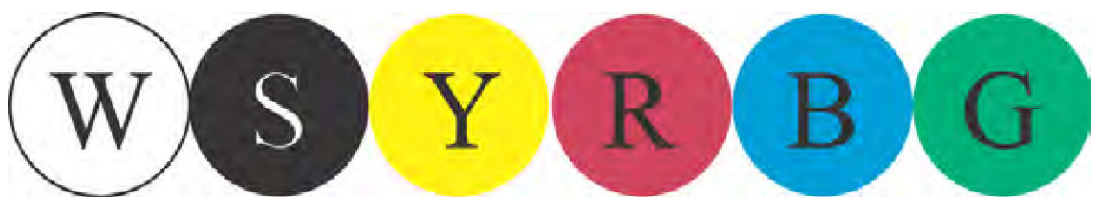

Fonte: NCS, 2020.

FIGURA 6: Espaço de cor NCS.

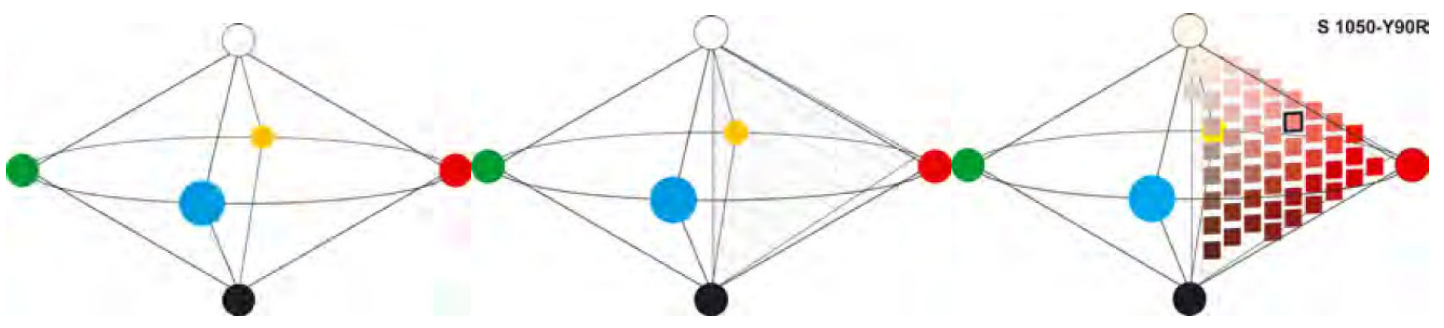

Fonte: NCS, 2020.

FIGURA 7: Círculo de cor NCS.

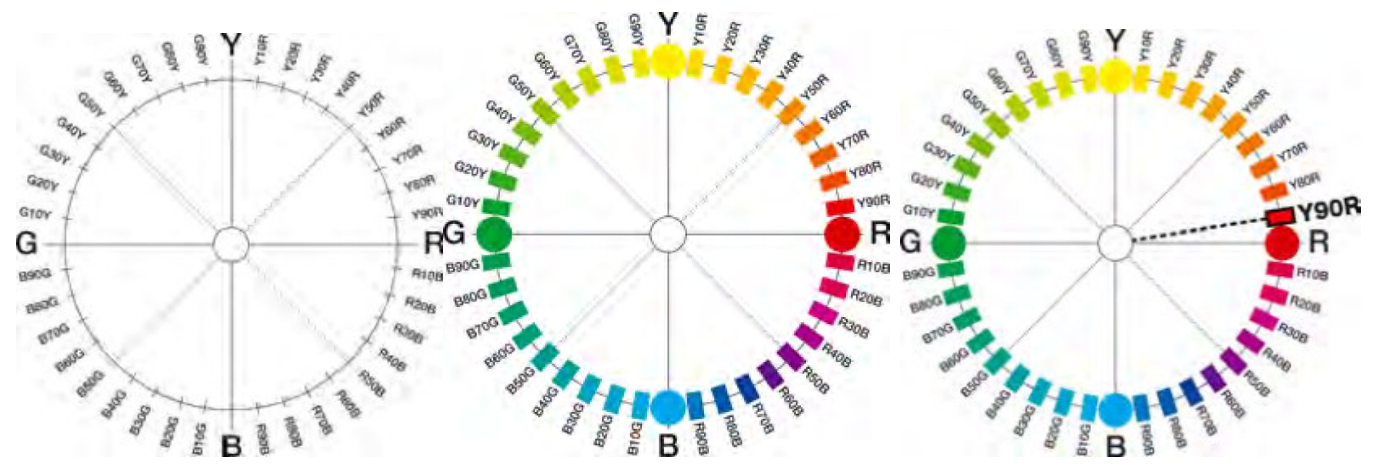

Fonte: NCS, 2020.

FIGURA 8: Triângulo de cor NCS.
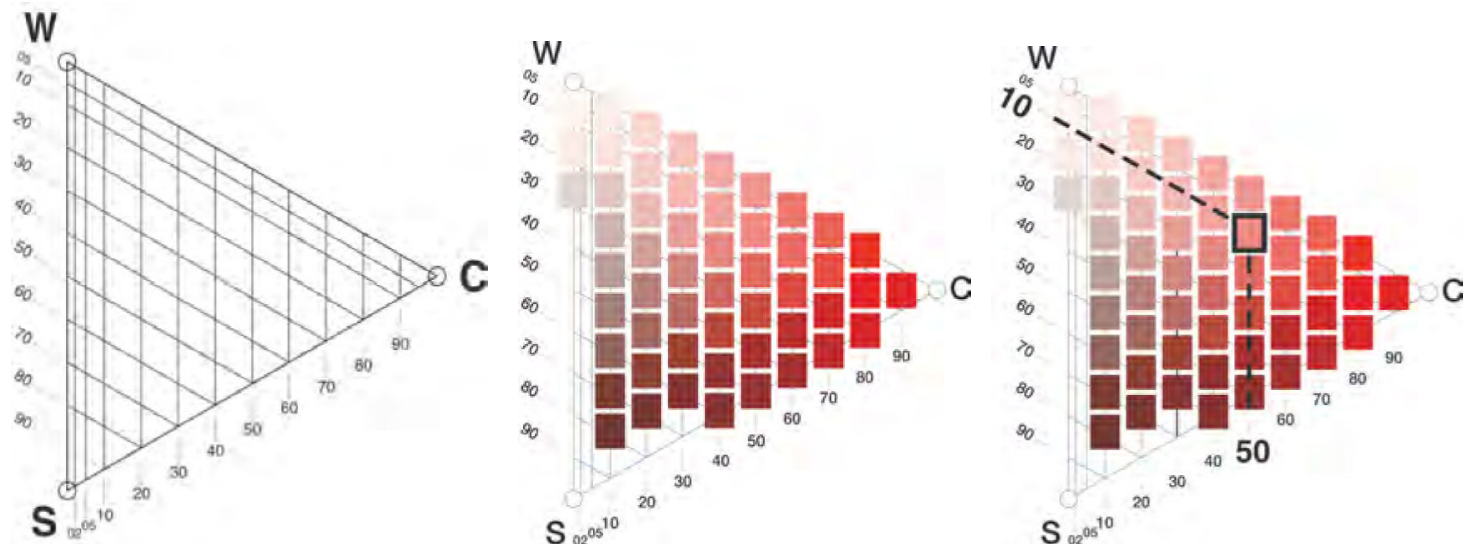

Fonte: NCS, 2020. 
Conforme seus preceitos, todos os seres humanos possuíam o NCS no cérebro e sua base de formulação foi desenvolvida obedecendo à mesma sequência lógica observada no aparato visual humano. Como os indivíduos possuem três tipos de cones responsáveis pela captação dos comprimentos de onda longo, médio e curto, cada tipo trabalha de maneira binária, produzindo a oponente ao cone que foi excitado. Existe ainda a participação do nervo óptico e, posteriormente, a interpretação do cérebro, resultando na sensação de identificação de milhares de cores possíveis pelo sistema visual humano (PEDROSA, 2009).

Pelo NCS, as amostras foram selecionadas em intervalos regulares, em princípio, a cada décimo de coordenada. Além disso, foram utilizadas em sua estrutura as nuances elementares compreendidas pelas tonalidades amarelo (Y), vermelho (R), azul (B) e verde (G), incluindo as acromáticas, o branco (W) e o preto (S) (Figura 5).

Por esse sistema, existem algumas formas de representações do espaço de cores. Uma delas é o formato tridimensional chamado Espaço de Cores NCS (Figura 6) no qual todas as cores de superfície podem ser representadas e, assim, ter a notação exata conforme os códigos propostos.

Outras formas de representação NCS são o círculo de cor (NCS Colour Circle, Figura 7) e o triângulo de cor (NCS Colour Triangle, Figura 8). O NCS Colour Circle é um corte no sentido horizontal no meio do espaço cromático onde as quatro cores elementares são colocadas como os pontos de uma bússola.

Já o NCS Colour Triangle "é um corte no sentido vertical através do espaço de cor. A base do triângulo é a escala de cinza que se inicia na parte branca (W) - na parte superior - e termina com o preto (S) - na parte inferior desse mesmo eixo” (MOCERI, 2016, p. 72).

Um matiz, apesar de ter um único comprimento de onda, pode receber diferentes "valores para blackness (S) ou chromaticness (C), ou seja, essa possibilidade existe pelo fato de esse matiz possuir diferentes nuances. Isso pode ser ilustrado na representação feita pelo triângulo de cores, em que as coordenadas variam conforme uma grandeza matemática de 0 a 100" (MOCERI, 2016, p. 72).

Ao observar as representações propostas pelo Triângulo de Cor NCS, contendo os três vértices, "W", "C" e "S", foi proposta uma analogia por parte dessa autora relacionando os tipos psicológicos de Jung com as características dos atributos de cor quanto à saturação e à luminosidade. Nessa classificação, não são levados em consideradação os matizes, mais sim uma preferência pelos outros dois atributos, como ilustra o quadro 3. 
QUADRO 3: Tipos Psicológicos de Jung sobrepostos ao espaço de cor NCS.

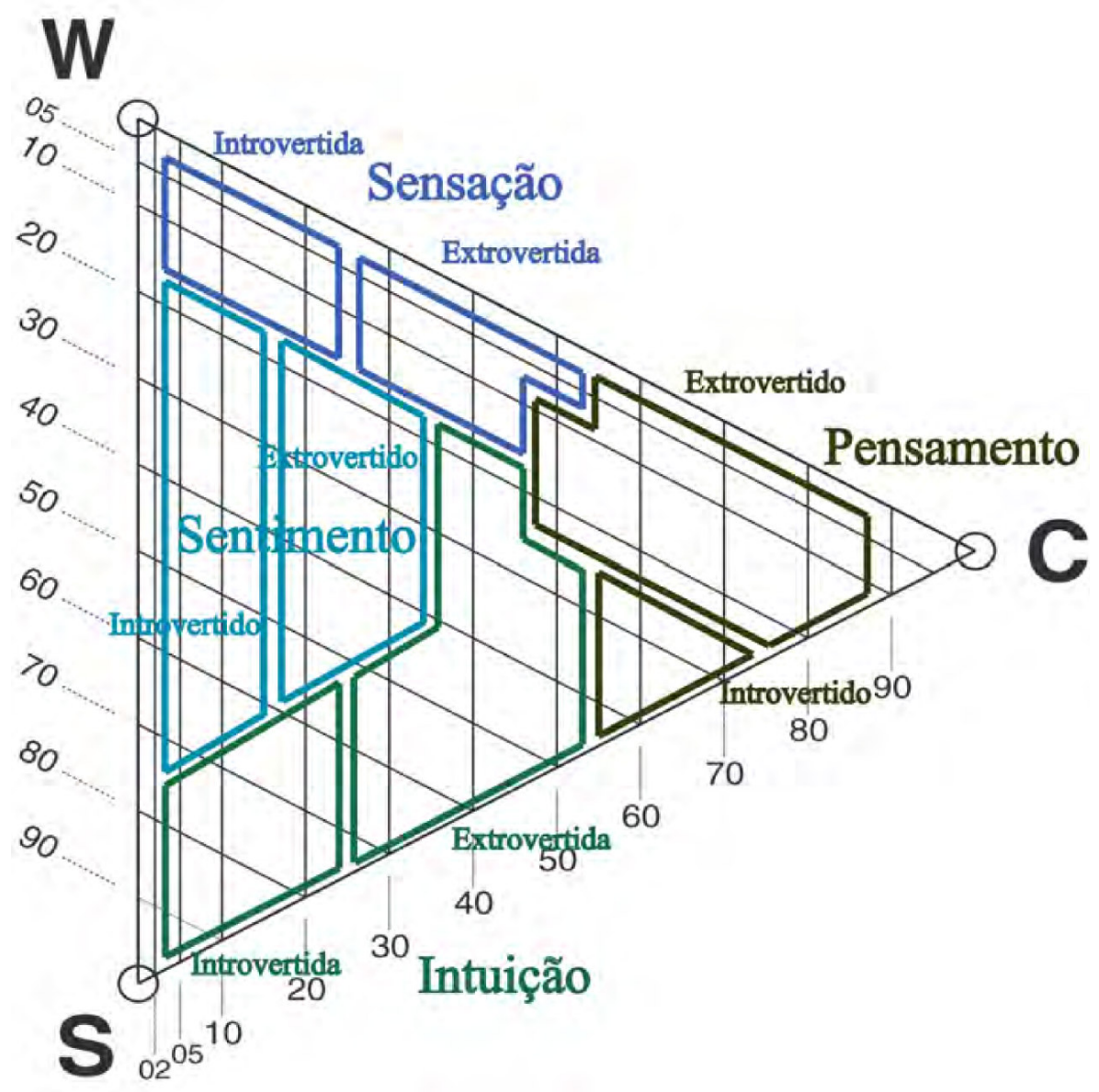

Fonte: a autora.

Com isso, na região superior do triângulo NCS "W”, estão as tonalidades mais claras, ou seja, com alta luminosidade. Já a saturação aumenta à medida que as nuances se deslocam para a direita no sentido do "C". Essa parte está relacionada ao tipo Sensação extrovertido e introvertido. É nessa região que a sensação de cor, conectada com a percepção dos fatos, já foi processada, iniciando, assim, a resposta ao estímulo visual.

Em contrapartida, na parte inferior mais acerca do "S" dessa representação NCS, estão as cores com menos luminosidade, as mais escuras. Já a saturação aumenta à medida que se aproxima do "C". É como se a luz tivesse se apagando, e a razão se desconectado para dar lugar ao mundo do inteligível, do intuitivo e do sobrenatural. Aqui está proposta uma conexão entre o tipo Intuição extrovertido e introvertido. Mais na ponta, à direita do triângulo "C", as nuances apresentam luminosidade média e maior saturação, sendo intensas e fortes. Nessa região, há uma proximidade entre o tipo Pensamento extrovertido e introvertido, que apresenta, de forma direta, as suas qualidades. Essa região propõe um valor 
exato do que realmente está presente, uma vez que apresenta uma linha de conduta lógica e racional.

Por último, na parte central dessa representação, as tonalidades têm uma luminosidade média e são mais dessaturadas, mais atenuadas e mais reservadas. Todavia, devido a isso, elas podem facilmente mudar de característica ao caminhar no sentido horizontal, indo em direção ao "C". Assim, o silêncio inicial é quebrado, prevalecendo um novo julgamento sobre as qualidades cromáticas. Aqui se encontra o tipo Sentimento extrovertido e introvertido.

Essa interpretação colabora com a investigação e entendimento ao cercar os indivíduos, relacionando-os com o espaço de cor NCS. Como consequência, nessa seção, é sugerido que as tonalidades elencadas devem ser colocadas na paleta de cor, pois vão ao encontro dos anseios e expectativas pessoais, como será abordado no capítulo 3.

Vale ressaltar que, assim como definido por Jung, para quem dois indivíduos com inclinações para a Intuição, por exemplo, não necessariamente agem de forma parecida, também não obrigatoriamente preferem as mesmas cores no que tange ao matiz. Pode ser que um se relacione bem com os tons amarelo, laranja e vermelho, por exemplo, e o outro não tem grandes aberturas para essas tonalidades. Isso porque cada pessoa utiliza suas funções psíquicas e os processos mentais de forma individual, logo o que define os aspectos cromáticos dos tipos são os atributos de saturação e luminosidade, não o matiz.

Como resultado, essa resposta individual ajuda na criação das paletas, não se tratando de ter que desenvolver uma análise clínica psicológica, pois esse não é o objetivo deste trabalho. Em vez disso, trata-se de elaborar um esquema como ferramenta para ajudar a entender os anseios e expectativas individuais e propor, de forma objetiva, uma paleta de cores.

Admite-se, ainda, que todos os seres carregam os tipos e as funções dentro de si, podendo relacionar-se com todas as cores existentes de forma natural e espontânea. No entanto, observa-se que há uma preferência por determinada região, sendo essa a principal, dominante ou auxilar, conforme propõe Jung. Existem também outras duas regiões que, no geral, quase não há muita afinidade aparente, sendo conhecidas como intermediária e inferior.

Assim, a preferência pelas cores também se apresenta dividida em principal, auxiliar, intermediária e inferior. Essa qualidade vai influenciar a maneira de interpretar e criar paletas de cores, como definido no capítulo 3 desta tese. 


\subsection{Fatores simbólicos e culturais}

Quando se fala de cor, é preciso ter em mente que nessa ideia está posta a História da humanidade, impressa e expressa por entre milhares de nuances. A cor exerceu grande fascínio, por isso desvendar seus significados é um desejo e um anseio que sempre existiu. Ela desperta no homem sensações, percepções, emoções e consciência a respeito da sua própria existência enquanto indivíduo e espécie. Ademais, é por meio das possibilidades delas que se pode investigar o passado, entender o presente e projetar o futuro.

Muito antes de pintar ou tingir, os humanos observavam as tonalidades na natureza. Eles primeiro as admiraram, depois as distinguiram e, finalmente, as identificaram (PIPER, 2008). Mais tarde, quando ainda eram nômades, antes mesmo de viverem em sociedade, naturalmente começaram a nomeá-las e a classificá-las.

Foi essa forma de classificar que estabeleceu as primeiras funções sociais da cor, as quais variaram amplamente ao longo dos séculos, períodos e sociedades. Tanto que, ao pegar como exemplo a época atual, a cor pode não ser percebida da mesma forma nos quatro cantos do mundo, havendo modificações quanto a sua simbologia e aos aspectos culturais a elas atribuídos. Isso se dá porque cada civilização a concebe e a define de acordo com seus próprios ambientes, histórias, conhecimentos e tradições, além de agregar valores simbólicos e culturais a todas as tonalidades.

Esse modo de interpretar as nuances e atribuir-lhes valor influencia o modo como os indivíduos se portaram em relação a elas, pois as questões de cor não eram apenas fisiológicas e psicológicas produzidas pela relação olho-cérebro, mas também sociais, simbólicas e culturais (PASTOUREAU, 2019). Não é à toa que as associações simbólicas e as influências culturais, as quais norteiam esta tese, estão presentes na terceira e na quarta camadas da pirâmide de Mahnke (1996) no sentido ascendente.

Os valores simbólicos e culturais levantados nesta pesquisa estão diretamente relacionados com a sociedade ocidental e, dependendo da época a que se referem, estão centrados no mundo europeu, pois foi ele que exerceu e determinou maior influência de tais valores no mundo ocidental. Mas também é preciso considerar que existe uma dificuldade em generalizar essas ações, pois esses preceitos passaram por muitas modificações e transformações dentro de uma mesma sociedade, ainda mais se comparado com círculos diferentes. Tanto que, segundo Pastoureau (2014, p. 202), para citar um exemplo: 
O que Kandinsky nos diz sobre as relações que as cores têm com a alma humana se aplica apenas ao próprio Kandinsky e não pode ser estabelecido como uma regra geral. E o que ele nos diz sobre cada cor está seriamente datado e não pode ser transferido como é para outros séculos e outras sociedades. Aqui estão alguns exemplos das "verdades" que ele apresenta: branco é um silêncio profundo e criativo; o preto é um nada sem possibilidade; cinza representa imobilidade desesperada; o vermelho é quente, agitado e possui um poder imenso; roxo é um vermelho resfriado; marrom é uma cor dura; laranja irradia tudo o que a rodeia; azul obedece a um movimento retrógrado, tanto que uma superfície toda azul parece se afastar de nós. Os europeus da primeira metade do século XX podiam aceitar parcialmente essas afirmações, sem dúvida, mas elas não podem ser estendida a todo o planeta.

É relevante destacar que as tonalidades utilizadas pela sociedade que regia os códigos sociais e de conduta sofreram alterações e reorganizações durante os vários períodos históricos devido à tecnologia e ao custo agregado à produção. Por muitas vezes, cores e ornamentos foram o termo da força e engenho. Em outras fases, um período mais enxuto e discreto se fez presente, tendo o branco, a escala de cinza e o preto sua importância e valor.

Séculos mais tarde, os ensinamentos da Bauhaus e, posteriormente, o movimento de Stijl deram prioridade à tríade azul-amarela-vermelha, combinada com preto e branco (DROSTE, 2006). Assim, o conhecimento, a sensibilidade e as "verdades" de hoje não foram as de ontem e, provavelmente, não serão as de amanhã.

De acordo com dados históricos, mesmo ocorrendo mutações nos valores cromáticos, durante boa parte da memória humana, o branco, o vermelho e o preto foram as tonalidades por excelência. Essa tríade tem um poder tão antigo e foram as primeiras paletas culturalmente usadas pelos homens que se apropriaram dessas tonalidades para aumentarem seus "poderes". Tanto que, desde as pinturas paleolíticas até os textos literários do período medieval, por exemplo, por diversas vezes, apareceram conotações em que predominaram o branco, o vermelho e o preto em vez de alusões a um cromatismo mais acentuado ou a outra escala de cores (PASTOUREAU, 2017).

Pastoureau (2011) esclarece, porém, que, no Ocidente, por volta do ano 1000, o branco e o preto não eram apresentados como um par de opostos, como é nos dias de hoje, pois a história conta que para o branco havia um segundo contrário, o vermelho, por vezes, mais "competitivo" que o preto nesse papel.

Colorações como o azul e o verde, no que lhe diz respeito, eram raras e referências a elas foram menos frequentes durante vários períodos históricos, não "porque não fossem vistas, mas porque desempenharam um papel menor nas ocupações humanas, nas relações sociais, na vida religiosa, no mundo dos símbolos e na imaginação da sociedade" 
(PASTOUREAU, 2014, p. 19). Uma cor "verdadeira" era, antes de tudo, uma cor manufaturada ou fabricada e tinham os tecidos e as roupas como os principais meios de referência, não uma cor presente por si mesma no mundo natural.

Segundo Pastoureau (2011), apesar da importância dessa tríade, na história ocidental da cor, houve três fases de mutações cruciais, à sombra das quais até hoje seus ensinamentos se fazem presentes. A primeira se deu na Idade Média Feudal, entre os séculos X-XII, que reduziu a importância dessa composição ternária. Foi nessa fase que se propôs uma nova ordem e novas formas de composições em que seis tonalidades, o branco, o preto, o vermelho, o azul, o verde e o amarelo passaram a ser as principais.

A segunda fase, que ocorreu por volta de 1450 e 1550, se deu em razão de dois acontecimentos nesse período. O primeiro foi o surgimento da imprensa, que alterou a velocidade da propagação da informação e mudou por completo o cenário até então existente e, $\log o$ a relação da sociedade com as cores circundantes. $O$ segundo acontecimento ocorreu devido à Reforma Protestante, que trouxe consigo novos conceitos morais, sociais e religiosos que propuseram novas diretriz de combinatória de cores, colocando as pessoas em contato com diferentes verdades cromáticas. Essa proposta religiosa não diz respeito somente à arte e às imagens, mas concerne igualmente às práticas sociais e à vida cotidiana.

A terceira e última fase foi marcada pela Revolução Industrial, por volta de 1750 e 1850, quando, pela primeira vez na sua história, "o homem europeu é finalmente capaz de fabricar, tanto no domínio da tinturaria como no da pintura, uma nuance precisa de cor previamente escolhida (anteriormente, apenas são possíveis aproximações)" (PASTOUREAU, 1997, p. 14). Surgem "uma multiplicação de tabelas, esquemas e escalas cromáticas que vêm demostrar as leis, os números e as normas a que a cor estava submetida. Aos olhos da ciência, esta surge ainda como mais ou menos dominada, perdendo por isso uma parte importante dos seus mistérios" (PASTOUREAU, 2016, p. 130).

Para tanto, é preciso levar em consideração que existiram vários avanços e acontecimentos que colaboraram para a mudança de percepção e postura. Tal mudança ocorreu mesmo havendo, desde o princípio, uma organização em torno da formação ternária das cores e, mais tarde, devido aos novos valores em decorrência das três fases de mutações que se sucederam ao longo da história. Em outras palavras, essa mudança está relacionada à química dos pigmentos, às técnicas de tingimento, aos códigos de conduta, às regras de vestimentas, ao lugar da cor na vida cotidiana, aos códigos morais da igreja, à criação 
artística e aos apontamentos científicos que afetaram todos os aspectos cromáticos colocados que as envolveram e definiram-nas.

É importante considerar também que o clima, a quantidade de luz do sol, a história, a religião, os regimes políticos ou os níveis de desenvolvimento econômico pareceram afetar, na maioria das vezes, as tonalidades que estavam em alta ou em desvantagem e os significados a elas atribuídos. Desse modo, o impacto que essas condicionantes exerceram e as possíveis simbologias que foram surgindo no decorrer da história modificaram os formatos e os valores que muitas vezes estavam associadas a cada nuance.

As alterações decorrentes dos fenômenos gramaticais e lexicais contribuíram também para essas modificações dos valores cromáticos. Os termos referentes à cor, que por muito tempo permaneceram como adjetivos, lentamente se tornaram definições, deixando de ser usados para expressar um significado figurativo ou metafórico. Devido a essas transformações, deram origem ao que se chama de "cores abstratas", ou seja, ao simbolismo das cores (PASTOUREAU, 2019).

O surgimento desses valores simbólicos foram ocorrendo gradualmente e, ao longo do século XII, encontraram uma maneira verdadeira e efetiva, já que deixaram de ser adjetivos e passaram a ser substantivos verdadeiros. Com isso, independentemente da técnica de produção ou do meio em que apareciam, houve uma desmaterialização de seus significados, pois uma definição como "o tecido vermelho é o mais belo" passou a assumir a seguinte sentença "vermelho é uma bela cor". Além dessa alteração de adjetivo para substantivo, todas as cores trouxeram uma ambivalência, apresentando cada uma aspectos positivos e negativos, virtudes e vícios (HELLER, 2013).

Devido às mutações dos aspectos simbólicos e culturais ao longo da história, novos valores foram surgindo. Com isso, as cores passaram a ser consideradas, ora como sendo fortes e necessárias, ora como superficiais, perigosas, triviais e fúteis, representando uma modificação de perspectiva extremamente importante e que sempre existiu (BATCHELOR, 2007).

Junto a essa oscilação, é fácil constatar que, quando alguma tonalidade se tornou aceita dentro de uma sociedade, é porque sua procedência vem de alguma necessidade por transformação e mudança. Essa nova configuração não é algo imposto ou forçado, e sim surgiu em decorrência dos acontecimentos que antecederam tal momento.

Além do mais, todos os valores simbólicos e culturais requerem um entendimento dos conceitos e das verdades atribuídas às tonalidades no momento em que se fala. Portanto, uma determinada nuance pode receber o status de sofisticada, glamorosa e requintada em um 
dado momento e, mais tarde, essa mesma cor cair em desuso ou simplesmente ter outros conceitos atribuídos. Sendo assim, para cada cultura e para cada fase da História da humanidade, existiu sua forma de construção e crença, segundo a qual, para muitos, a cor é um fenômeno simbólico e cultural que se define dependendo das sociedades e das civilizações na época em que se vive. Por esse motivo, houve uma dificuldade em sistematizar e generalizar seus conceitos e concepções (PASTOUREAU, 2011).

Para Pastoureau (2014), essas dificuldades podem ser agrupadas em três categorias. As primeiras são de natureza documental, a segunda é de ordem metodológica e a terceira de caráter epistemológico. Com relação à primeira categoria, os objetos, as imagens e as obras de arte e monumentos dos séculos passados não apresentam mais suas cores originais, mas o resultado visualizado foi o tempo que produziu. Muitas vezes, há uma diferença muito grande entre seu estado original e seu estado atual. Além disso, as condições de iluminação existente, atualmente fornecida pela eletricidade, são muito diferentes daquelas das sociedades anteriores em que a tocha, a lamparina a óleo, a vela e a luz a gás geravam outros resultados cromáticos. Além disso, durante muito tempo, pesquisadores tiveram o hábito de estudar o passado por gravuras e depois por fotografias por meio de reproduções em preto e branco. Daí por que foram influenciados a pensar e perceber o passado como um mundo em que a cor estava ausente.

As dificuldades da segunda categoria são metodológicas, já que existe uma grande dificuldade em tentar compreender e, consequentemente, interpretar a função de uma cor devido à diferença de materiais, técnicas e química de pigmentos utilizados. Já os problemas da terceira categoria são de ordem epistemológica, pois as definições, classificações e concepções de cor atuais certamente não são as mesmas do passado.

Isso significa que a maneira de ver as cores e os contrastes na Antiguidade ou no Período Medieval não é a mesma de hoje. Além disso, o espectro visual, a teoria das cores primárias e complementares, a distinção entre cores quentes e frias, a lei do contraste simultâneo e os efeitos fisiológicos e psicológicos não eram conhecidos até o final do século XVII. Nessa fase, a ciência apresentou uma verdade incontestável: as cores primárias e complementares modificam a forma aristotélica, conhecida há séculos, de classificá-las. Assim, foi alterado o modo como as nuances eram tidas, propondo-se a síntese aditiva e a subtrativa, as três primárias, as tonalidades complementares e excluiu o preto e o branco da ordem das cores (PASTOUREAU, 2011).

Com isso, definir o que poderia ter sido o universo cromático para as sociedades do passado exige levar em consideração os componentes de cada momento compreendido pelo 
léxico, pelos fenômenos da linguagem, pela química dos pigmentos, pelas técnicas de tingimento, pelos sistemas de vestimenta e pelos códigos que os acompanharam, o lugar da cor na vida cotidiana, as regras ditadas pelas autoridades, os padrões morais da igreja, as especulações científicas e as criações artísticas.

Durante muitas fases, as cores constituíam, além de uma harmonia, uma linguagem cujos significados estavam associados a vícios e virtudes, sentimentos e emoções, faixas etárias e categorias sociais, intenções morais e regras de vida. Todos esses conhecimentos e colaborações deixaram ensinamentos profundos e grandiosos nos valores e atribuições dadas às cores nos dias de hoje, nos códigos utilizados, nas concepções e definições, nas utilizações do vocabulário, nos rituais, na imaginação, na sensibilidade e na história. A forma de conhecer e interpretar seus caminhos e percursos devido aos valores simbólicos e culturais é parte integrante deste trabalho. 


\subsubsection{As acromáticas}

\subsubsection{Preto}

FIGURA 9: Pedaço de grafite natural constituído por folhas em camadas de anéis hexagonais de carbono. Imagem meramente ilustrativa para representar a cor preta.

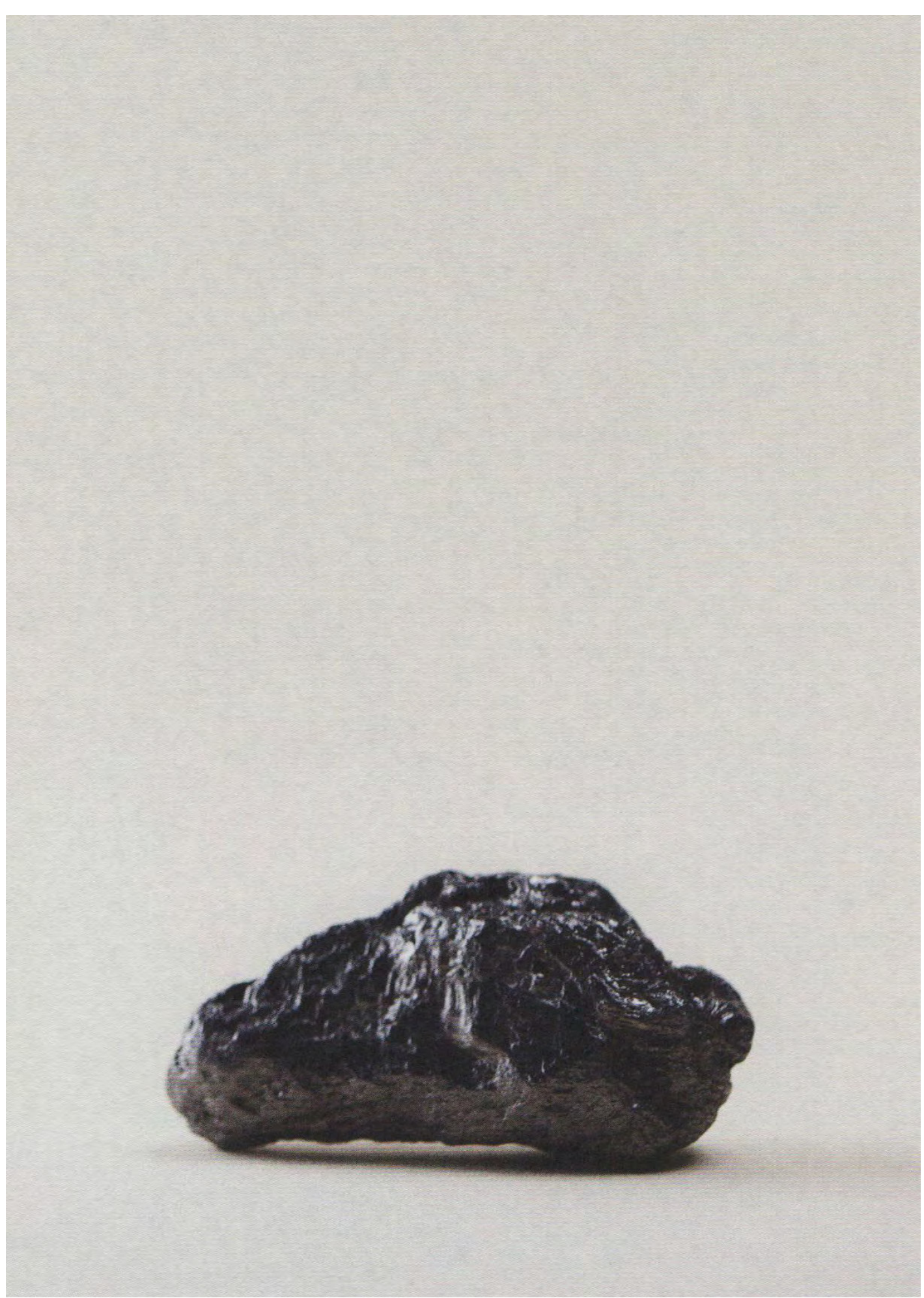

Fonte: THE HARVARD ART MUSEUMS' FORBES PIGMENT COLLECTION, 2017, p. 168. 
A palavra preto deriva do latim, niger, e quer dizer escuro, negro, obscuro (FARINA, 1982). É a cor mais sombria ou até mesmo representa a negação à própria cor, e emblematicamente traz a ideia de nada, da extinção, de vazio. Em contraposição ao branco, que representa a página inicial na qual a vida passará a existir, o preto revela, entre tantas outras coisas, a morte.

Simbolicamente, o lado positivo desse tom é que ele evidencia e fortalece qualquer tonalidade que estiver justaposta a ele (LÜSCHER, 1969). O lado negativo é que, ao salientar o outro, representa para a mentalidade ocidental a morte terrena e com ela a tristeza da ausência. O preto "transforma todos os significados positivos de todas as cores em seu oposto negativo (...) fazendo a diferença entre o bem e o mal, porque ele faz também a diferença entre o dia e a noite" (HELLER, 2013, p. 131).

Do lado positivo, estabeleceu-se uma dimensão erótica, sensual, nas roupas íntimas e no vestuário de maneira geral. É o símbolo maior da elegância e tornou-se a cor mais usada dentro desse universo particular. Do lado negativo, muitas superstições colocam o preto ao lado do azar, da falta de sorte, pois encontrar com algum bicho preto, como um gato, um corvo, uma galinha, pode trazer coisas ruins. É também a cor do misterioso, do enigmático, já que as capas pretas simbolizam esse valor. Foi por muito tempo a cor do luto e dos enlutados.

Psicologicamente, por absorver todos os comprimentos de onda e, portanto, representar a carência de luz, o preto está associado à escuridão, podendo ser ameaçador. Para muitas pessoas, é uma cor densa que fornece barreiras psicológicas, mas pode também proporcionar a sensação de proteção ou até mesmo coragem por ocultar os aspectos mais profundos (WRIGHT, 1999).

Em pesquisas de "cor preferida", o preto se destaca independentemente do sexo, idade, classe social e cultural dos interrogados (LÜSCHER, 1969). Ao serem colocadas seis cores de base, a saber: o amarelo, vermelho, azul, verde, branco e preto, o preto situa-se no meio da gama. Constatou-se que, para os jovens, esse tom pode conotar moda, sofisticação e glamour; para os mais velhos, pode estar associado à morte (HELLER, 2013).

Por muito tempo, acreditou-se que o preto era a ausência de todas as cores, por isso ele foi condecorado como sendo uma "não cor" na a escala dos tons de cinza neutros e o branco. Entretanto, não há como classificá-lo desse modo, uma vez que, atualmente, ele ganha o status de acromático devido a sua importância histórica.

Falar do preto, assim como falar do branco, é falar da História da humanidade. Nos primeiros versículos do Gênesis, o preto, usado como símbolo de escuridão, precedeu todas 
as outras cores. Por essa ótica, foi Deus quem, conforme descrito na Bíblia, ao criar o Universo, onde a terra estava disforme e vazia, dominada pelas trevas e pela escuridão, ordenou que existisse a luz, logo a luz se fez presente. Foi, somente a partir daí, que a vida passou a existir, conferindo ao preto, de acordo com essa interpretação, uma noção de impossibilidade de vida, assumindo, entre outros valores, a noção de algo mortal e letal (PASTOUREAU, 2011).

Nota-se, ainda segundo Pastoureau (2011), que não há na Bíblia muitas passagens falando sobre as cores, mas sim muitas associações mencionando a luz e as trevas. Nessas associações, as trevas, ou seja, o encontro com algo escuro e negro, tem uma natureza severa e punitiva. Neste caso, o preto é visto como uma cor má e impiedosa.

Outra teoria que também aborda o preto como sendo as trevas associado à imagem inicial é a teoria astrofísica do Big Bang (ACHENBACH, 2001). Tendo ou não o universo acontecido a partir de um momento primordial, essa hipótese faz uso da noção primeira de um sistema solar de escuridão dentro do qual uma "matéria que absorve toda a energia eletromagnética que ela poderia receber: um mundo perfeitamente negro, matricial por um lado e aterrador por outro; uma simbólica dupla que acompanhará a cor preta ao longo de toda a sua história" (PASTEUREAU, 2016, p. 18).

No entanto, tanto a Bíblia como teorias mais científicas não possuem o domínio de tal figura. Muitas mitologias também invocam essa mesma noção primordial, trazendo as trevas e a luz como o ponto de partida onde o mundo começou ou onde tudo termina. Tanto que Cronos, Deus do tempo, aparece de preto (WILKINSON, 2002).

$\mathrm{Na}$ Astrologia, a cor preta está diretamente ligada a Saturno, também conhecido também como o "planeta negro", atribuindo a esse tom o ideal de início e fim do mundo (HELLER, 2013).

Desde a Antiguidade até a alta Idade Média (aproximadamente de 4.000 a.C até 1.000 d.C), já eram atribuídas conotações a essa tonalidade, a qual possuía valores tanto bons como ruins. Desde lá, associações feitas à autoridade, devoção, humildade e hombridade colocavam o preto no lado bom, e associações que remetiam ao subterrâneo, aos mortos, ao castigo e à punição o direcionavam para o lado do mal.

Na Idade Média, dentro do período feudal (entre os séculos V à XV), o preto passou a assumir uma simbologia muito mais vinculada ao lado malvado devido a uma série de práticas que dominaram esse tempo. Ou seja, crescente número de moralistas e teólogos, amparados pelas práticas litúrgicas, pelas artes, pela heráldica e pelos costumes 
predominantes naquele período, contribuiu para atribuir ao preto uma representação funesta e perversa.

Sendo assim, por um lado, o preto possuía a simbologia do "pensamento mágico, "o igual pelo igual", para curar ou retirar: muitos adotavam o preto para afastar os demônios negros, para não serem apanhados por eles" (HELLER, 2013, p. 130). Por outro lado, essa tonalidade ficou filiada ao Diabo e seus discípulos, tornando-se, durante vários séculos, uma cor infernal. Tanto que o próprio Satã aparece nos textos constantemente representado por esse tom, e as práticas de feitiçaria e momentos de luto também são por vários momentos retratados por essa tonalidade, como se oberva na figura 10.

FIGURA 10: Representação de Satã elaborada na tonalidade preta.

O Julgamento Final, Fra Angelico, 1431-1432, Florença, Museu de São Marcos, têmpera em painel.

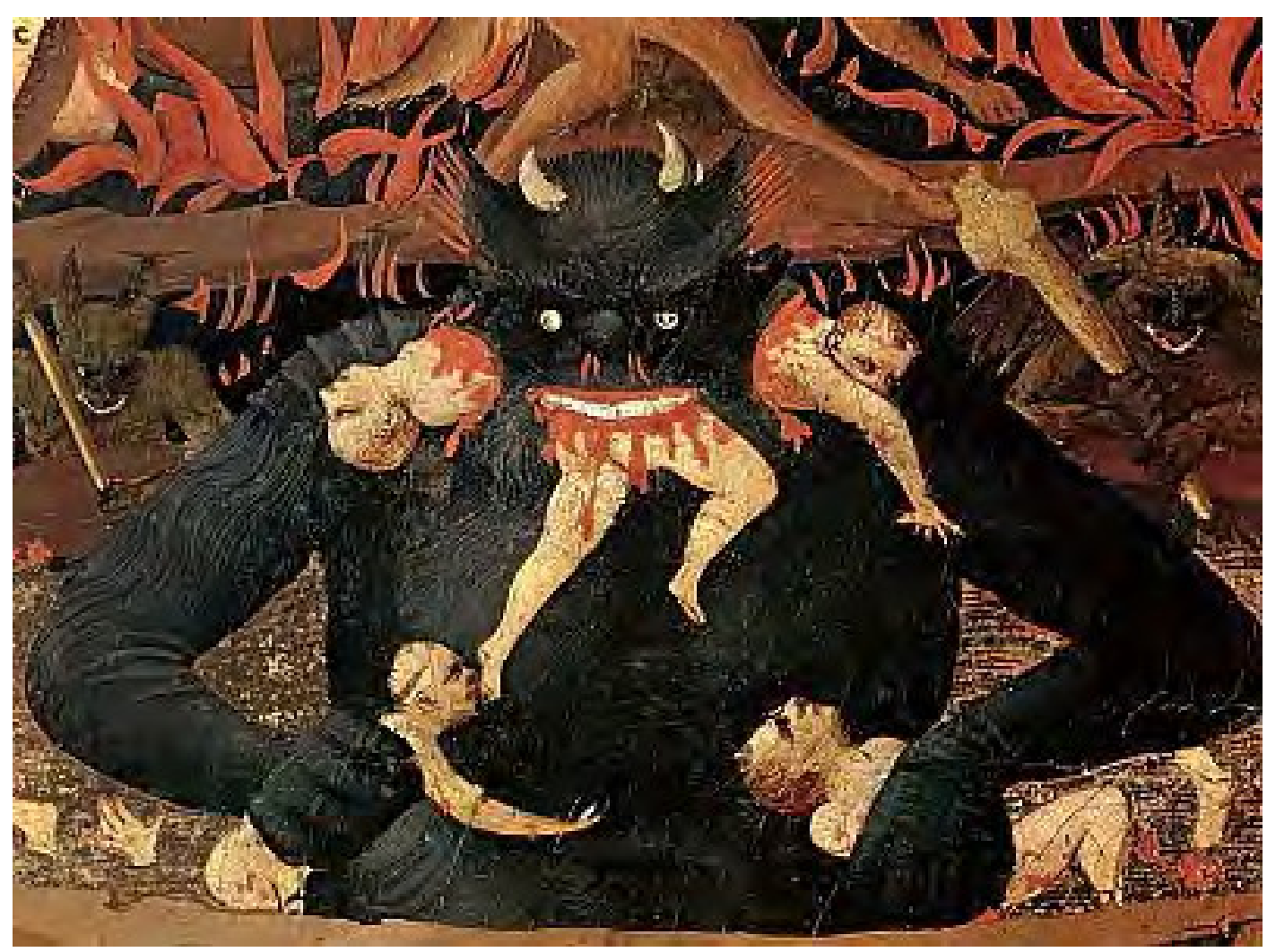

Fonte: PASTOUREAU, 2011, p. 46-47.

Entretanto, apesar dessa conotação com o Diabo, vai haver uma revalorização e uma apreciação dessa cor. Nesse sentido, até o final da Idade Média, ela se apresenta em forte progresso ao aparecer no contexto têxtil e de vestuário como possuidora de valores que a 
torna uma cor digna, uma cor na moda e até mesmo uma cor requintada. A partir desse ponto, o preto não apresenta mais um aspecto negativo, passando por um progresso considerável. Para Pastoureau (2016, p. 76):

Ao fazer o preto entrar na ordem das cores, e desembaraçando-o de seus aspectos sinistros e funestos, a heráldica havia preparado o terreno para tais promoções. Desde o final do século XIII, as práticas relativas ao vestuário do patriciado urbano e dos detentores de cargos ou funções assumem a substituição e tornam o peto uma cor digna e íntegra. No século seguinte, são as morais cívicas e as leis referentes ao luxo que acentuam a dimensão virtuosa dessa cor. Depois, quando a indústria da tinturaria faz progressos decisivos na gama das tonalidades pretas, principalmente sobre os tecidos de seda e de lã, são os príncipes que, dali em diante, mostram um gosto descomedido por uma cor da qual quase sempre tinham se afastado. $\mathrm{O}$ preto torna-se então uma cor paroquial, e até mesmo real, permanecendo assim até bem antes da época moderna, pelo menos até a metade do século XVII.

Desde essa época, o preto passou a ser apreciado com significado relacionado à autoridade pública, ao direito e à lei, motivo pelo qual os legistas, os juristas e os magistrados demonstravam uma certa atração por esse tom. Os religiosos e os monarcas também passaram a usar o preto, pois não agregavam a essa tonalidade uma conotação maldita e perversa, mas sim confiável e decente.

A partir do século XIV, todos aqueles que, de uma certa maneira, exerciam uma função ou um cargo a serviço do estado passaram a vestir-se de preto. Esses cidadãos, pouco a pouco, foram imitados por alguns professores universitários e depois por todos aqueles que detêm algum saber. Isso não quer dizer que o uso dessa tonalidade se fez obrigatório ou se tornou um uniforme, mas sim o uso de roupas pretas passou a possuir atributo distintivo, de respeito e de uma certa moral cívica.

O uso desse tom expandiu à medida que também dele se utilizaram os mercadores, os banqueiros e todas as pessoas relacionadas com as finanças. Isso porque os ricos deviam dar o exemplo de uma vida honesta e devota, e a vestimenta era o primeiro sinal exterior que visava à mais sobriedade e mais dignidade (PASTOUREAU, 2011).

Observa-se, porém, que o crescente uso desse tom ocorreu porque se fez também necessário como resposta às leis de segregação social. De acordo com essas leis, as pessoas que não eram nobres estavam proibidas de usar certas nuances, matérias corantes e pigmentos que, muitas vezes, eram os mais custosos, atraentes e admirados. Isso evidenciava uma divisão social claramente imposta dentro da sociedade. 
Nesse contexto, os patrícios detentores da riqueza e da fortuna, mas não pertencentes ao grupo dos nobres, encontraram refúgio nessa cor. Essa é razão pela qual vão procurar, junto com os tintureiros, desenvolver uma gama de pretos, até então, por muitas vezes, menosprezada porque desbotava com facilidade, perdendo sua intensidade e força.

Por esse motivo, essa parcela da sociedade, desde a afortunada burguesia até os patrícios, empenhara-se para que fosse produzida cor preta em sedas, lãs e peles, de forma duradoura, reluzente e primorosa. Como essa clientela rica e poderosa lhes pedia esse desenvolvimento, os tintureiros conseguiram fazer com que esse tom atingisse as expectativas. Por esse motivo, o preto tornou-se, desde a metade do século XIV até a metade do século XVII, uma cor de prestígio por grande parte da Europa (PASTOUREAU, 2011). Esse preto, agora muito mais vistoso e forte, passou a ser usado em grande proporção, por meio de uma combinação monocromática ou combinado com outra cor, geralmente o cinza, branco ou violeta, com grande destaque na moda.

Daí em diante, os séculos XVI e XVII colheram os frutos oriundos do aparecimento da imprensa e da imagem gravada no século XV, por volta dos anos 1450. A partir de então, passa-se a valorizar a tinta espessa preta sob um papel que, na maioria das vezes, era branco. Esse advento mudou por completo a forma de produzir imagens, pois as reproduções medievais, que eram policromáticas, passam a ser em branco e preto. Essa mudança revela "uma revolução cultural de uma amplitude considerável, não apenas no domínio dos conhecimentos, mas também no das sensibilidades" (PASTOUREAU, 2011, p. 112).

Ressalte-se que as morais sociais e religiosas também desempenharam um papel importante, principalmente as morais protestantes, atentas, de modo particular, às questões cromáticas, difundindo uma cultura e um imaginário "em preto e branco". Ocorre que, no século XVI, com a Reforma Protestante iniciada por Martin Lutero em 1517, "um preto moral se mantém e se reforça, o do hábito dos religiosos e das pessoas de manto longo" (PASTEUREAU, 2016, p. 101).

Lutero, Zuínglio, Calvino, Melanchton, líderes dessa seita religiosa, pregavam de preto, com uma batina completamente sem adornos. A justificativa é que eles acreditavam não haver distinção entre ricos e pobres, portanto essa era a cor que todos podiam usar, imprimindo também a ideia de responsabilidade individual. Ademais, para a moral protestante, o mais belo ornamento deveria ser a palavra de Deus, por isso os templos eram desprovidos de qualquer imagem e cor, como se vê nas figuras 11 e 12. 
FIGURA 11: Interior de um templo em Delft.

Interior de Oude Kerk, Delf, Emanuel de Witte, 1650, Nova York, MET, óleo sobre madeira.

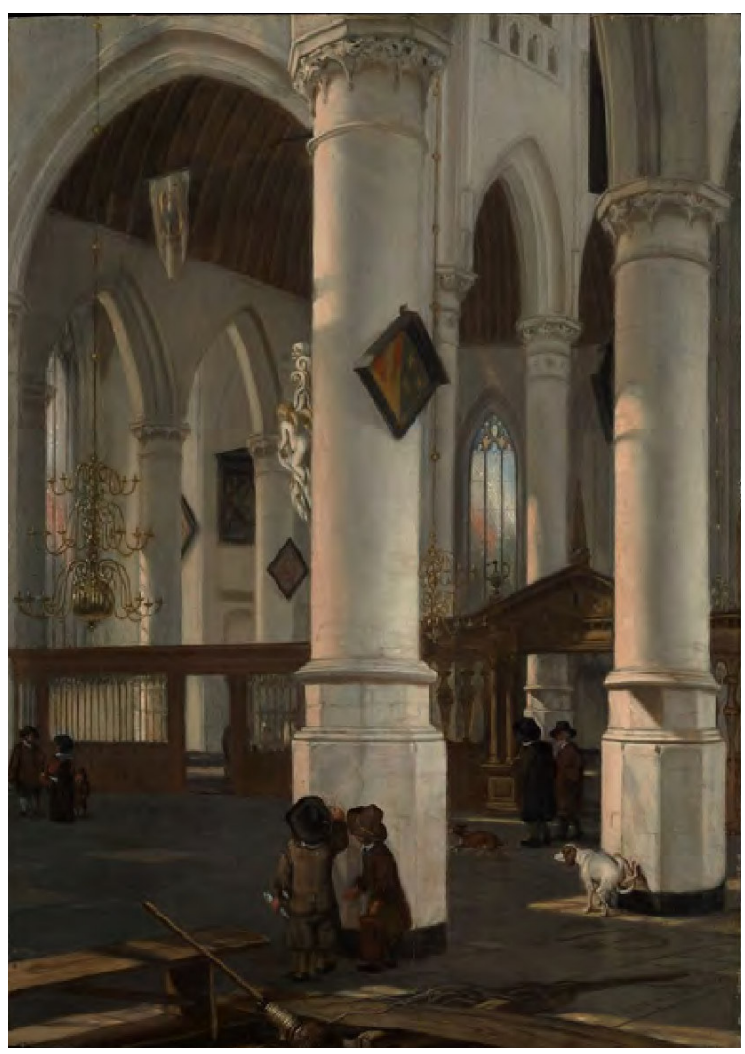

Fonte: THE METROPOLITAN MUSEUM OF ART

https://www.metmuseum.org/art/collection/search/438490

FIGURA 12: Templo calvinista.

Interior de Oude Kerk, Amsterdam, Emanuel de Witte, 1658, UK, Colchester and Ipwich Museums, óleo sobre tela.

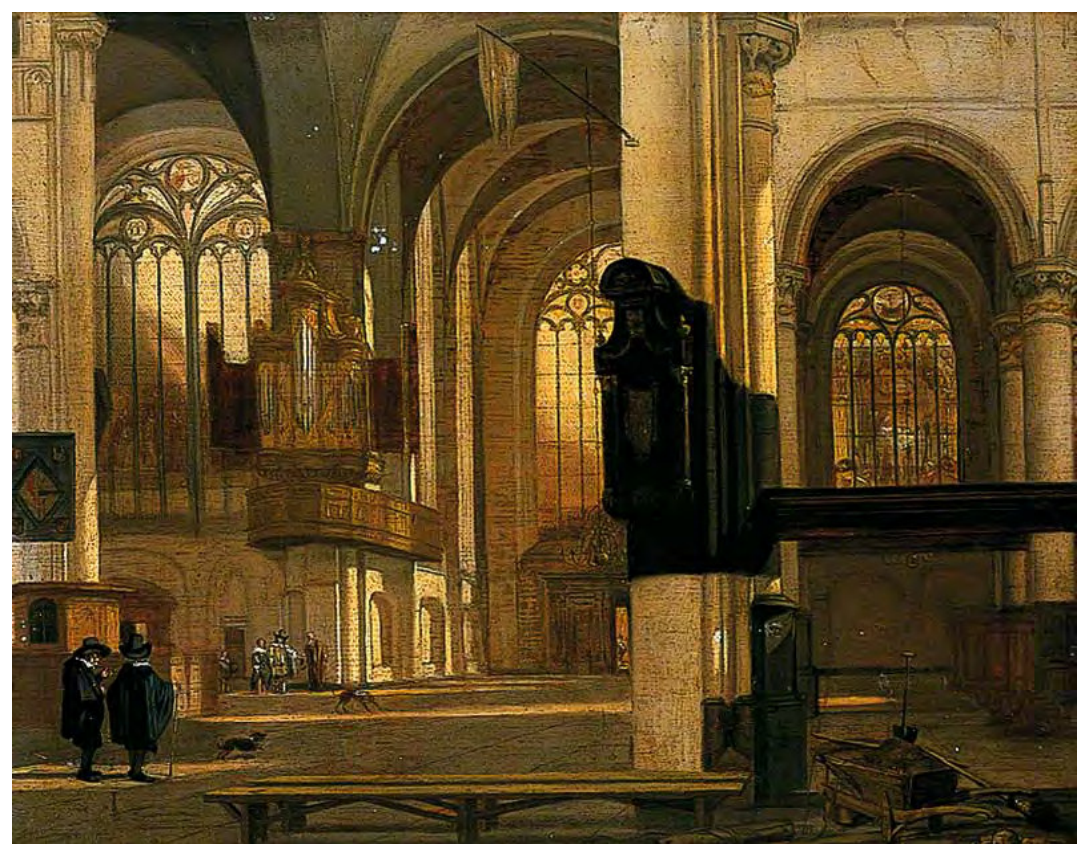

Fonte: https://artuk.org/discover/artworks/the-interior-of-the-oude-kerk-amsterdam-12160 
Com isso, tudo que cercava a vida religiosa e social, ou seja, o culto, a vestimenta, a arte, o ambiente e os "negócios", foi quase inteiramente construído em torno de um eixo de cor preto-cinza-branco.

A necessidade, muitas vezes observada, de excluir qualquer tonalidade aliada ao desejo de alguns de chegar a um grau mais acromático, foi mais enfática em relação às escalas litúrgicas. Isso de deu pois, segundo Pastoureau (2011, p. 123), até a Reforma era comum haver no ritual da missa, a cor desempenhando um papel primordial onde:

os objetos e as vestimentas não são somente codificados pelo sistema do calendário das cores, mas também estão plenamente associados aos conjuntos das fontes de luz e às decorações luminosas utilizadas em uma igreja, à policromia arquitetural e esculpida, às imagens pintadas nos livros santos e a todos os ornamentos preciosos, a fim de criar uma verdadeira teatralidade da cor.

A Reforma travou, portanto, uma batalha contra qualquer tipo de ornamento, não aceitando que gestos, sons e tons juntos compusessem o ritual católico, motivo por que os padres, por utilizarem adornos e cores, foram vistos como palhaços e até mesmo farsantes. Para Lutero, o templo deveria estar desprovido de qualquer vaidade humana, e a cor representava, naquele momento, uma violência e uma presunção (PASTOUREAU, 2011).

Nessa mesma linha, as artes visuais, principalmente a pintura, também vão sofrer as consequências cromofóbicas da Reforma, pois o uso de um cromatismo acentuado também não era tido como aceitável. Essa cromofobia se manisfestava em um discurso contínuo e explícito: qualquer nuance é dissimulação, luxo, artifício e ilusão. Tal discurso causou um grande impacto na sociedade, uma vez que passou a desempenhar uma função fundamental na transformação da sensibilidade ocidental às cores (BATCHELOR, 2007). A Reforma foi, portanto, propositora ao participar diretamente da mudança cultural e social que transformou o universo cromático, contribuindo para separar o preto e o branco da ordem das cores.

Mais tarde, com a Contrareforma, que se deu na segunda metade do século XVII, tanto na esfera pública como na vida privada, o clero adotou um posicionamento invasivo ao ver infração e pecado por toda parte. Era preciso se confessar, mortificar-se, vestir-se de preto em sinal de penitência. É o que os jesuítas e os jansenistas tanto recomendavam: divididos por suas disputas dogmáticas e disciplinares, concordam pelo menos num ponto, a cor do vestuário (PASTOUREAU, 2011).

Assim, o século XVII foi marcado pela escolha do preto ou de cores escuras, como o cinza ou marrom, devido às imposições religiosas existentes. Isso contribuiu para tornar esse 
tom a cor do luto, tanto pela aristocracia como por parte da burguesia, o qual passou a fazerse presente em quase toda a Europa ocidental. Ele ficou estigmado como sendo a cor da morte, e somente no século XIX, passou a fazer parte dos códigos sociais vigentes, abrindo espaço para outras conotações.

Faz-se mister destacar que, por mais que essas inversões de cromatismos pelas quais o branco e o preto, até então tão pertencentes ao mundo das cores, tenham passado, de forma lenta e gradual, a não mais terem um lugar, foi preparando o terreno para as experiências do físico inglês Isaac Newton. Por volta de 1665-1666, ao analisar a refração da luz pelo prisma, ele obtem uma nova forma espectral da luz, separando por completo as acromátricas das cromáticas.

Na primeira versão, ainda em 1665, Newton identificou cinco tonalidades no espectro visível compreendidas pelo vermelho, amarelo, verde, azul e violeta (PEDROSA, 2009). Entre 1671-1672, acrescentou duas outras, o laranja e o índigo, formando, assim, as sete cores, conforme se vê na figura 13.

FIGURA 13: Disco de Newton: concebido por cálculos matemáticos baseados nas misturas de cores e a porção que cada uma ocupava dentro do espectro.

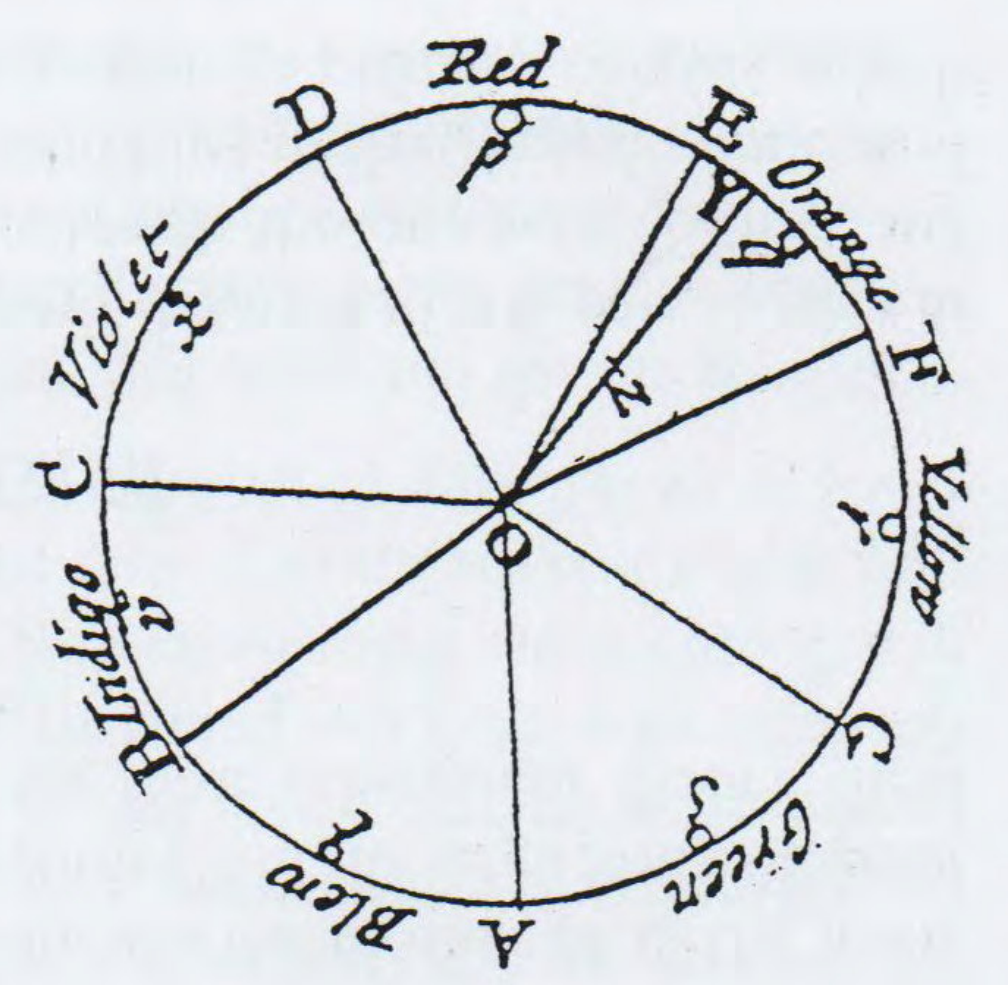

Fonte: GAGE, 1999, p. 136. 
Mais tarde, Newton reviu seu posicionamento do espectro com sete tons e reconsiderou que seria um contínuo colorido, havendo ali todas as cores possíveis. Sendo assim, no final do século XVII, a cor passa para uma nova fase de sua história (PEDROSA, 2009).

Como consequência, no Iluminismo, entre os séculos XVII a XIX, o preto, de forma geral, perdeu sua hegemonia para o território das cores. Nesse período, há uma inversão de alguns valores destinados a esse tom, por isso, nos espetáculos, o verde deixa de ser a tonalidade associada ao azar e passa a ser o preto. Segundo Pastoureau (2011, p. 160):

\begin{abstract}
No século XVIII, não é o verde de que traz azar aos espetáculos, é o preto. Em numerosos domínios, as pessoas parecem desviar-se dessa cor, que para a ciência não é nem mais verdadeiramente uma cor. Mesmo nas práticas de luto, que se estendem progressivamente ao conjunto da sociedade, o uso da cor preta torna-se mais discreto, em benefício das tonalidades apenas escuras, especialmente o violeta. Até mesmo nos pátios das fazendas, os vulgares porcos domésticos, em maior parte pretos na Europa desde milênios, tendem a tonar-se rosados, por cruzamento audacioso com raças de porcos asiáticos que se tornam mais gordos e alaram a sua pelagem. Essa passagem do preto ao rosa na pelagem dos porcos parece resumir por si só as mutações cromáticas do Século das Luzes.
\end{abstract}

No entanto, uma cor que ocupou o cenário central por quase quatro séculos não poderia cair em desuso, por isso, no final do século XVIII, o preto volta às cenas cotidianas. Isso se deu devido ao tráfico negreiro, com a descoberta das Américas, quando um homem de pele escura passou a ter muito valor por motivos, ao mesmo tempo, deprimentes e comerciais. Motivos esses aliados à Revolução Francesa, que foi a vitória da burguesia sobre a nobreza.

Daí por que esse tom prevaleceu como a principal nuance durante o Romantismo, conforme pontua Pastoureau (2014, p. 174):

Um pouco depois, era o preto, a cor da noite e da morte, que se tornou o emblema do segundo movimento romântico. $O$ amor deu lugar à melancolia, o sonho diurno ao pesadelo, o êxtase ao desespero. Doravante, não haverá mais flor azul vista em sonhos, mas alucinações macabras, violências, terrores mórbidos e frenéticos. Se a estatística fosse significativa e pudesse contar os termos de cor usados pelos poetas na geração 1820-1850, sem dúvida o adjetivo "preto" seria o mais comum e o mais significativo, na imagem do fascinante "Sol Negro da Melancolia" por Gérald de Nerval. 
Todas essas questões adentraram o século XIX e a Segunda Revolução Industrial, marcada pelas estradas de ferro e de asfalto, pelo carvão e alcatrão e, mais tarde, pelo aço e petróleo, o que contribuiu para tornar o horizonte preto, cinzento, marrom, escuro.

Dessa vez, esse cromatismo que dominou os cenários não foi imposto pela química dos corantes, como muitas vezes ocorreu, devido à dificuldade de imprimir determinadas tonalidades. Foi um cromatismo que se deu em decorrência da ética protestante cuja influência decisiva sobre o surgimento do capitalismo e das atividades econômicas se fez presente. Entre 1860 e 1920, grande parte dos objetos de consumo, desde aparelhos domésticos a câmeras fotográficas produzidos em escala, possuía uma gama que foi do branco ao preto, passando pelo cinza e por vezes pelos marrons.

A fotografia, que teve seu surgimento por volta de 1850, era reproduzida em branco e preto, também contribuiu, não só para a formação do imaginário das pessoas, mas também para o desenvolvimento da sensibilidade e da mentalidade delas. Isso porque passou a imprimir um mundo visto por essas tonalidades. Tanto que, durante várias décadas, a representação de objetos, seres e natureza foi legitimada por essas colorações em desfavor das reproduções coloridas introduzidas por volta de 1950, que por muitos foram desmerecidas (HELLER, 2013). As figuras 14 e 15 explificam esse fato.

FIGURA 14: Man Ray e a supremacia da fotografia em preto e branco.

Glass Tears, Man Ray, 1932, Los Angeles, Getty Museum, papel de gelatina e prata.

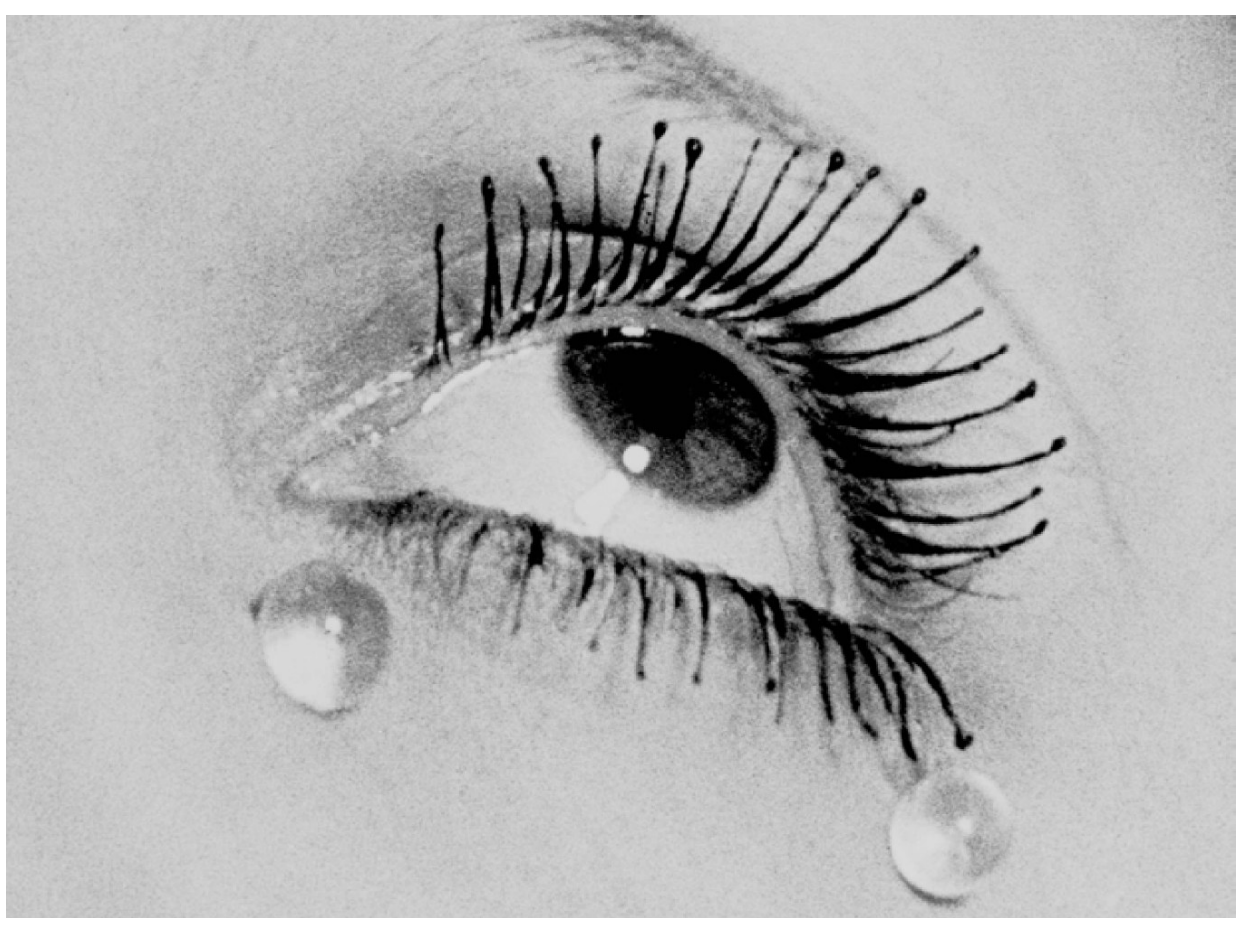

Fonte: WIKIART, https://www.wikiart.org/en/man-ray/larmes-tears 
FIGURA 15: Man Ray e a supremacia da fotografia em preto e branco.

Noire et blanche, Man Ray, 1926, Nova York, MOMA, papel de gelatina e prata.

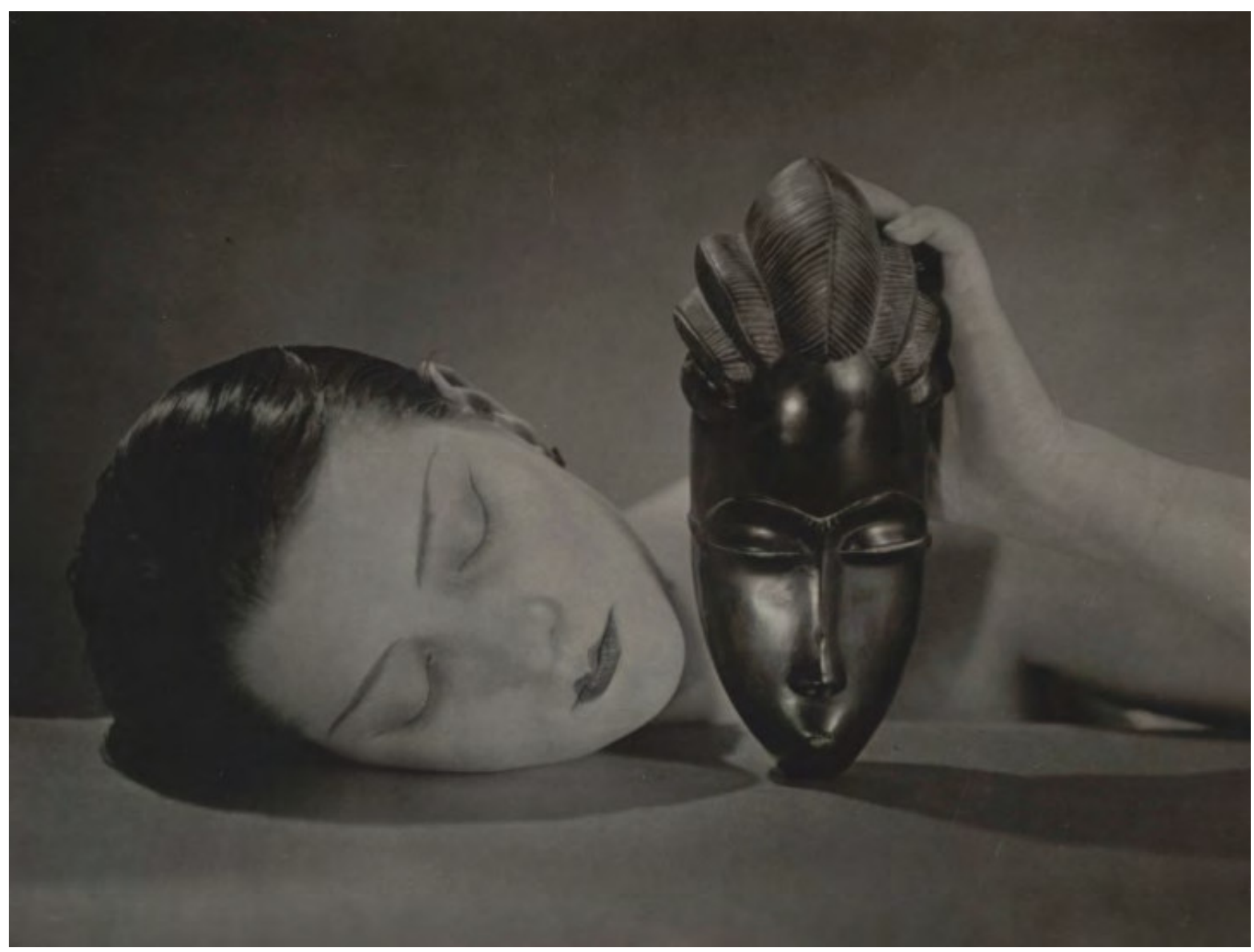

Fonte: MOMA, https://www.moma.org/collection/works/46738

Além disso, foram também os pintores, já no final do século XIX, que deixaram sua contribuição ao elegerem o preto como a cor suprema. Depois da primeira grande guerra, ao se voltarem para uma pintura mais abstrata e subjetiva, muitos fizeram do preto a cor por excelência e passaram a trazer em suas obras uma forte incidência dessa tonalidade (GAGE, 1999).

É importante ressaltar que, nesse momento histórico, apesar da nova relação com a luz e as cores propostas por Newton terem contribuído para uma mudança de postura e de mentalidade na sociedade, elas parecem ter sido abaladas. Isso porque se viram presentes, novamente, os efeitos da ética protestante que influenciou, de modo decisivo, o surgimento do capitalismo e das atividades econômicas.

Esse fato se fez bastante evidente nos produtos produzidos pela industrialização: aparelhos domésticos, objetos de uso pessoal, tecidos e roupas. Na maioria das vezes, essas mercadorias receberam uma paleta de cores que variou em uma gama que ia do preto, 
passando pelo cinzento, branco, marrons, até chegar aos azuis. Nesse momento, a química industrial dos corantes permitia a fabricação de objetos de cores variadas, mas esse século $\mathrm{XX}$ foi mais sombrio e escuro que o anterior. Corroboram o exposto as figuras 16 e 17.

FIGURA 16: O primeiro carro produzido em larga escala, o Ford T, na cor preta.

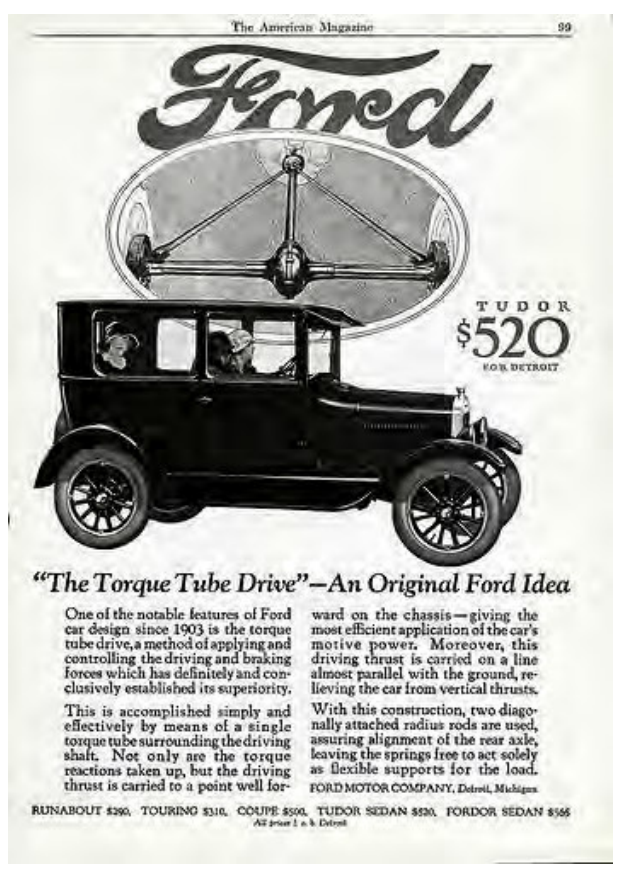

Fonte: PINTEREST, https://br.pinterest.com/pin/563161128408788269/

FIGURA 17: Henry Ford com o 1921 Modelo T na cor preta.

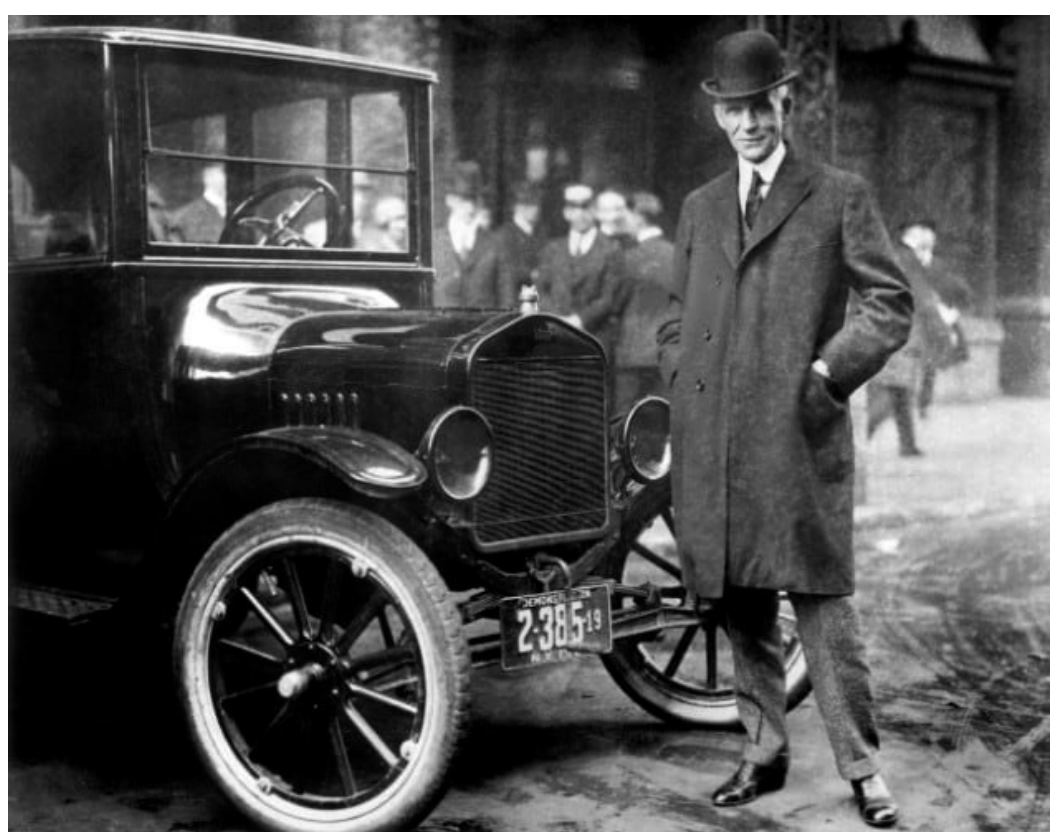

Fonte: https://media.ford.com/content/fordmedia/fsa/br/pt/news/2018/10/02/ford-modelo-t-primeiro-carro-popular-da-historia--comemora-110-.html 
Ao longo dos anos, permaneceu a simbologia atrelada ao preto de ser uma cor moderna, intelectual e, por vezes, até boêmia. Essa cor prevalece como sendo universal ou a cor por excelência dentro do métier não só da moda, mas também de muitos entre os quais a criatividade e poder de escolha se fazem presente (BLASZCZYK; WUBS, 2018). 


\subsubsection{Cinza}

FIGURA 18: Nitrato de Prata. Imagem meramente ilustrativa para representar a cor cinza.

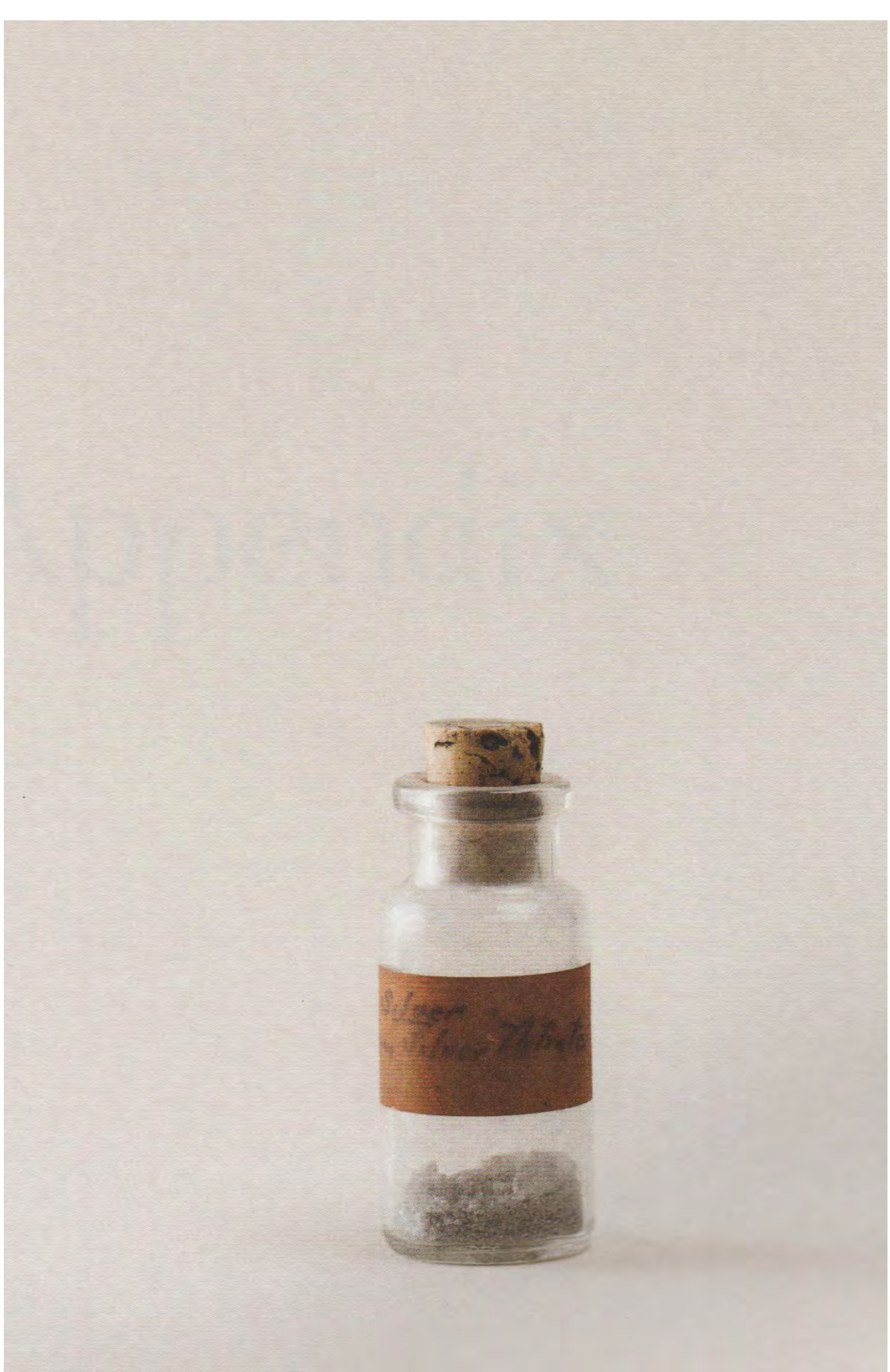

Fonte: THE HARVARD ART MUSEUMS' FORBES PIGMENT COLLECTION, 2017, p. 203. 
A palavra cinza deriva do latim, cinicia, ou do germânico, gris, e quer dizer cinzento, plúmbeo, simbolizando o posicionamento médio entre a luz e a sombra (FARINA, 1982). É a cor que, quando misturada na mesma proporção de claro e escuro, apresenta a menor interferência na percepção visual da coloração justaposta a ela sendo, dessa forma, a mais neutra em relação às cores. Dependendo das circunstâncias, um mesmo tom, colocado sob um fundo cinza, poderá ter sua percepção tanto com relação ao matiz como com relação à luminosidade alterada (ALBERS, 2009).

A pergunta que muitos se fazem é se o cinza é de fato uma cor. Sendo considerado, junto ao branco e ao preto, como sendo acromático, é visto como indiferente, não sendo nem sim e nem não, não exerce forças nem feminina e nem masculina, nem quente e nem fria, nem mental e nem material (LÜSCHER, 1969). Como diz Heller (2013, p. 270,): "Nada é decisivo no cinza, tudo nele é vago. O cinza é a cor sem caráter". É a cor mais apartidária de todas, pois nela o límpido branco está sujo e o poderoso preto perdeu sua valentia, tornandose uma cor regular, conformista e sem força. Não interfere em nada, não causa separação, rompimento ou intriga.

Simbolicamente, tudo o que é desfeito, inutilizado, termina no cinza. Tanto que o Carnaval, festa da exuberância máxima no que tange às cores, quando acaba, pela tristeza de seu fim, é celebrado pela quarta-feira de cinzas. Já os seres humanos, quando vão envelhecendo, ou seja, se aproximando do final da vida terrestre, tornam-se grisalhos, acinzentados. E quando morrem, viram cinzas. Conforme descrito por Heller (2013, p. 270):

Quatro "mulheres Cinzentas" visitam o velho Fausto, na tragédia de Goethe; Fausto já viveu de tudo, mas ainda assim não quer morrer. As quatro mulheres cinzentas tentam engajá-lo na morte - são elas: "Ansiedade", "Privação", "Culpa" e "Miséria".

Do ponto de vista psicológico, o cinza é a única cor totalmente neutra e não possui qualquer qualidade psíquica. Na maioria das vezes, é uma influência negativa, indicando falta de confiança e pode levar a estados psicológicos depressivos quando usado em demasia. Ela é o silêncio, indica baixa-estima e falta de confiança, ou até mesmo pode sinalizar a depressão (WRIGHT, 1999). Em contrapartida, há nela também a vontade de mudança e transformação, mas para que essa modificação aconteça, é preciso proteger-se da interferência e de todo o estímulo exterior.

Nesse sentido, uma reclusão se faz necessária para que tudo o que for do mundo exterior provavelmente aconteça de modo superficial, artificial e, por vezes, automático. 
Não há uma participação ativa e envolvida com o que está acontecendo, mas há uma vontade expressa por mudança, por um novo amanhã. Sendo assim, os opostos psicológicos ao cinza são as tonalidades amarelas e laranja por conotarem, no Ocidente e na sociedade atual, a felicidade de existir, a alegria da vida (HELLER, 2013).

Por estar praticamente isento de qualquer estímulo ou tendência psicológica, uma pessoa, ao citar o cinza como a tonalidade preferida ou o inverso, como a mais desgostosa, "não está pensando na cor propriamente dita, mas nos sentimentos que se relacionam a ela" (HELLER, 2013, p. 269). Não é indivíduo nem matéria, nem interno ou externo, nem inquietude ou descontração. Esse tom, segundo Lüscher (1969, p.55),

não é território ocupado, e sim uma fronteira: uma fronteira como "terra de ninguém", como zona desmilitarizada, uma região de separação que proporciona divisão entre áreas contrastantes. O cinza é um Muro de Berlim, uma Cortina de Ferro, tendo, em cada um dos seus lados, abordagem diferente.

Na natureza, os dias cinzentos para muitos são mais difíceis do que os dias de sol, quando a luz se faz presente e as cores são ressaltadas. Tanto que existe até uma expressão, “dias cinzentos", simbolizando, em sentido figurado, dias desagradáveis e contrários. No inverno, período de recolha, os dias costumam ser mais cinzentos e na simbologia moderna, cinza é a cor do tempo ruim, da oscilação do bom-humor, onde em dias chuvosos possuem o maior índice do uso de roupas nessa nuance (HELLER, 2013).

Essa tonalidade também podia causar a impressão de algo bruto e grosseiro absorvendo a sujeira e a "pobreza". Por muito tempo, como afirma Heller (2013, p. 281):

Eram cinzentas as roupas dos órfãos nos orfanatos. De cinza se vestiam os desamparados que eram acolhidos nos asilos. Até hoje o uniforme dos presidiários é cinza. As roupas cinzentas identificam a pobreza, em todas as nuances. No século XIX, a roupa de trabalho de modistas e costureiras de Paris eram vestidos cinzentos e simples; Paris era a metrópole mundial da moda e costureiras e modistas, naquela época, se contavam em centenas de milhares. Em função de suas roupas cinzentas, elas eram chamadas de grisettes. Era moças e mulheres das famílias mais pobres, que trabalhavam por um salário de miséria. As grisettes não tinham dinheiro para vestidos e nem tempo para se ocupar deles, e por isso usavam roupas confeccionadas com os tecidos mais baratos e na cor em que a sujeira menos se notava. Para o pensamento conservador daquela época, era inconcebível que uma mulher pudesse viver de seu trabalho, os vestidos cinzentos foram reinterpretados como próprios de mulheres imorais: grisette chegou a ser sinônimo das prostitutas mais baratas. 
Porém, como comunica a história, um fato que chamou a atenção na transição do século XIV para o XV foi o surgimento de um novo eixo de cores por conta das primeiras gravuras feitas em grisalha. Isso significa dizer que a maioria das imagens feitas nessa técnica não eram mais policromáticas, mas desenvolvidas exclusivamente nessas tonalidades. Essa tríade, agora composta pelo branco-cinza-preto, era nada óbvio ou evidente (PASTOUREAU, 2011). Nas artes, a técnica de grisalha colaborou com a ascensão do cinza como uma das cores principal, como ilustra a figura 19.

FIGURA 19: Arte em grisalha.

Peregrinos no monte São Miguel, salvos pela intervenção da Virgem, 1460-1465, Paris, Biblioteca Nacional Francesa.

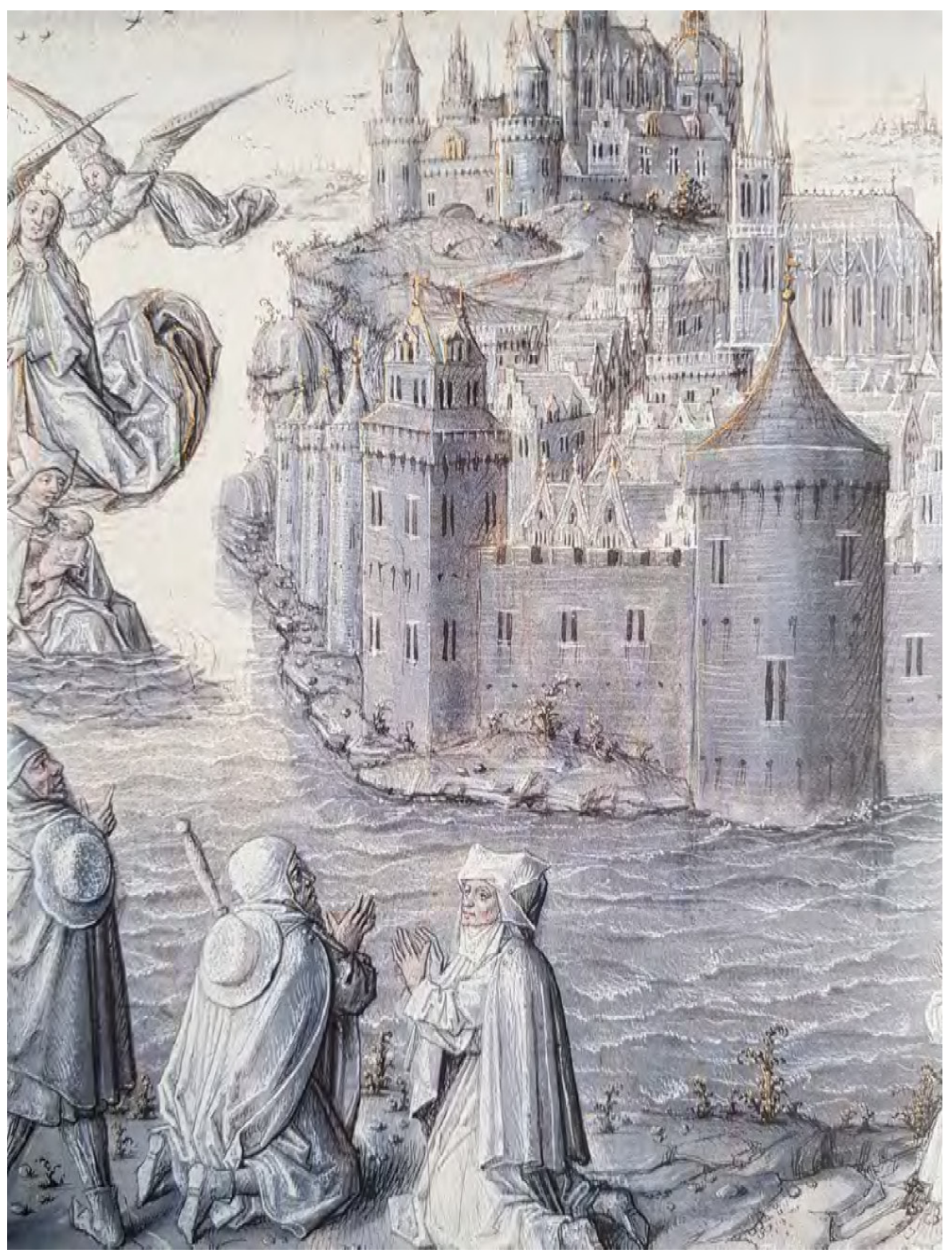

Fonte: PASTOUREAU, 2011, p.152. 
Assim, no século XV, ao lado do branco, a cor da ressurreição, e do preto, a cor do luto, o tom cinza simbolizava o juízo final na simbologia cromática cristã (HELLER, 2013). Com a crescente valorização dessa nuance, ele passou a ser, para muitas pessoas, uma cor contrária ao preto do luto, da aflição e do estigma, ao mal-apessoado marrom e ao infortúnio verde-escuro. Portanto, nesse período, o cinza foi considerado a cor da vida, da confiança e da felicidade (PASTOUREAU, 2011).

A valorização dessa tonalidade se fez sentir também em outras áreas, como na decoração, na fabricação de utensílios, e até mesmo na coloração da pelagem de certos animais. Essa é a razão por que, quando possuíam esse tom, passaram a ser mais desejados e com isso mais caros. Esse engrandecimento só foi possível por conta do estanho, material necessário para obter essa cor, o qual, ao ser aplicado, dava um resultado visual parecido com o tom da prata, um metal precioso, fino e valoroso naquela época.

Contudo, já nas primeiras décadas do século XVI, a apreciação do cinza sofreu uma queda até cair em desuso novamente, por completo, por volta de 1530 (PASTOUREAU, 2011). A partir desse momento, essa tonalidade regressa a sua conotação tida antes de ser reconhecida e volta para a simbologia da introversão, da reserva e da depressão. Com isso, as conotações atribuídas a essa cor ficou nesse lugar até final do século XVIII, quando retornou com novos significados.

Porém, essa coloração, cujo uso estava muito moderado desde o final da Idade Média, retorna no Século das Luzes, por volta de 1730, à vida cotidiana de forma considerada e definitiva. Todavia, nessa fase, não era mais nem um tom escuro, sujo e desbotado da Idade Média, nem um tom radiante, encantador e impressionante de dois séculos antes (PASTOUREAU, 2011).

O reaparecimento do cinza se deu devido a descoberta de Eugène Chevreul, publicada em 1839 e titulada A Lei do Contraste Simultâneo. De acordo com tal descoberta, as cores, ao serem justapostas uma à outra, são afetadas pelo colorido da vizinha (ALBERS, 2009). Essa lei, aceita até hoje como sendo legítima, dizia que uma cor tende a projetar na sua adjacente a complementar a ela própria (ITTEN, 1970). Tome-se como exemplo a figura 20. 
FIGURA 20: Fundo Reverso: como o cinza médio dos " $x$ ", tanto sob o lilás como sob o amarelo, muda de aparência conforme o fundo.

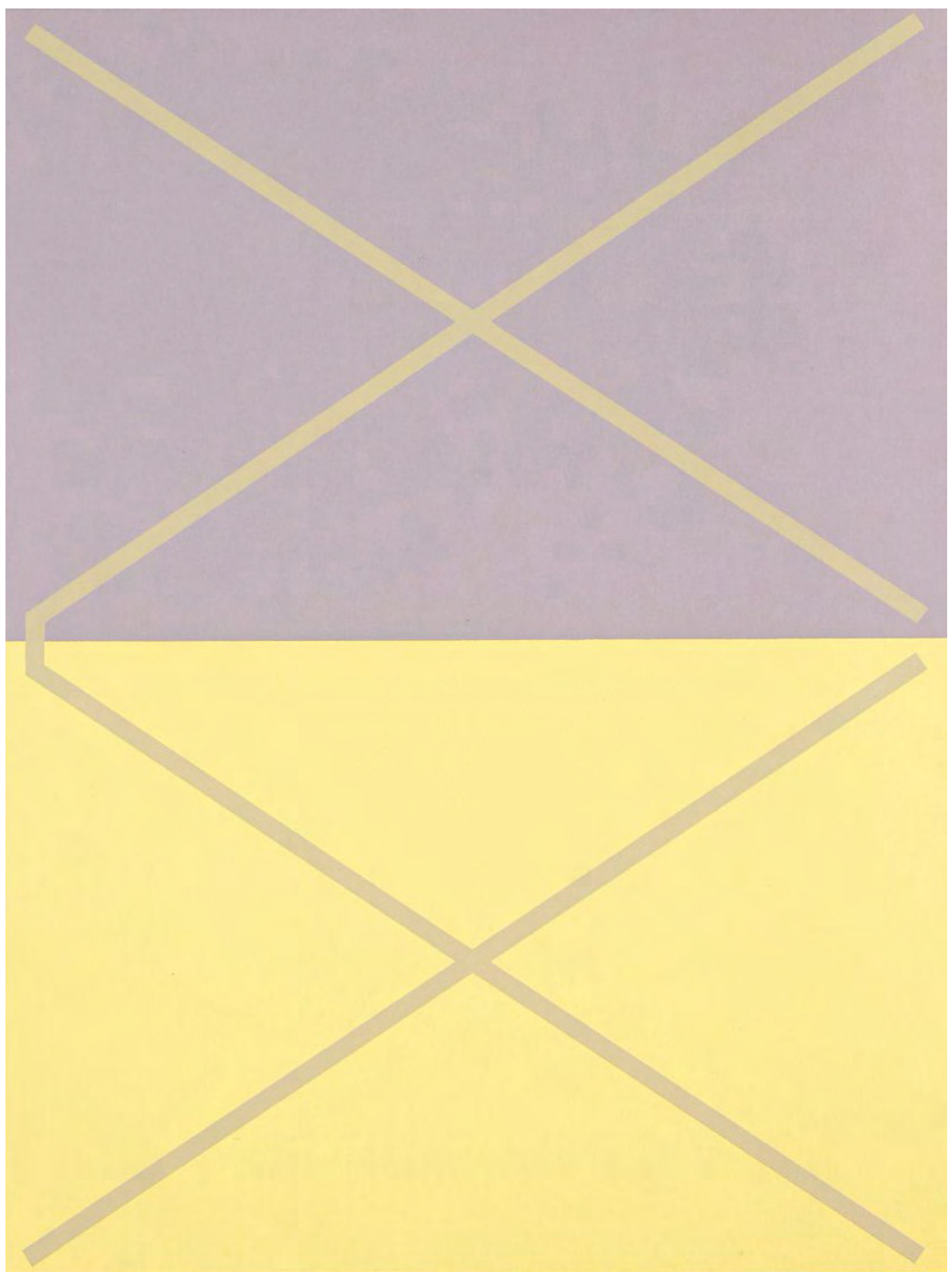

Fonte: ALBERS, 2009, p. 113. 
Ou seja, se um amarelo estiver ao lado de um lilás, esse amarelo vai "tingir" de lilás o próprio lilás, intensificando a tonalidade dele. Isso também acontecerá com o amarelo, que ficará com um aspecto mais intenso ao ser potencializado pela cor complementar a sua, ou seja, o lilás. Assim, em qualquer cor em contato com o cinza com média luminosidade, esse cinza perceptualmente aparentará a cor complementar na qual ele está inserido. Devido a isso, se tiver em meio a um amarelo, ele aparecerá lilás. Se estiver em meio a um azul, aparentará laranja, por exemplo.

Devido a esse grande poder de transformação dos tons cinzentos, ele volta às cenas com grande prestígio, pois, se por um lado, é o tom que mais pode sofrer metamorfoses, por outro, é o que mais ressalta a beleza das outras tonalidades. A seguir, as figuras 21 e 22 exemplificam as diferentes tonalidades da cor cinza.

FIGURA 21: Escala de cinza.

Josef Albers Greys Steps, Grey Scale, Grey Ladders, Nova York, David Zwirner Gallery, Exhibition view, 2016.

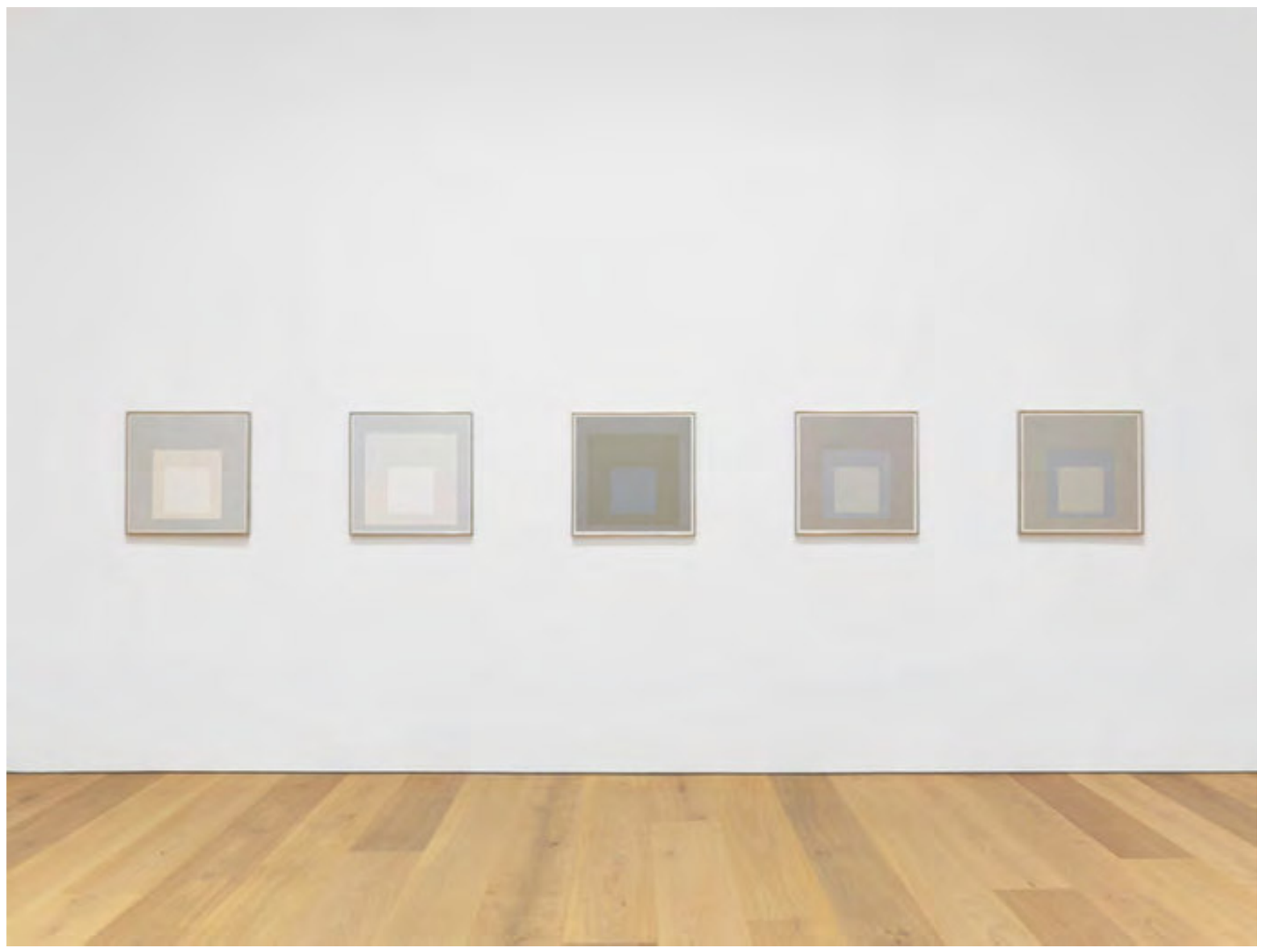

Fonte: https://wsimag.com/art/22518-josef-albers 
FIGURA 22: Escala de cinza.

Josef Albers Greys Steps, Grey Scale, Grey Ladders, Nova York, David Zwirner Gallery, Exhibition view, 2016.

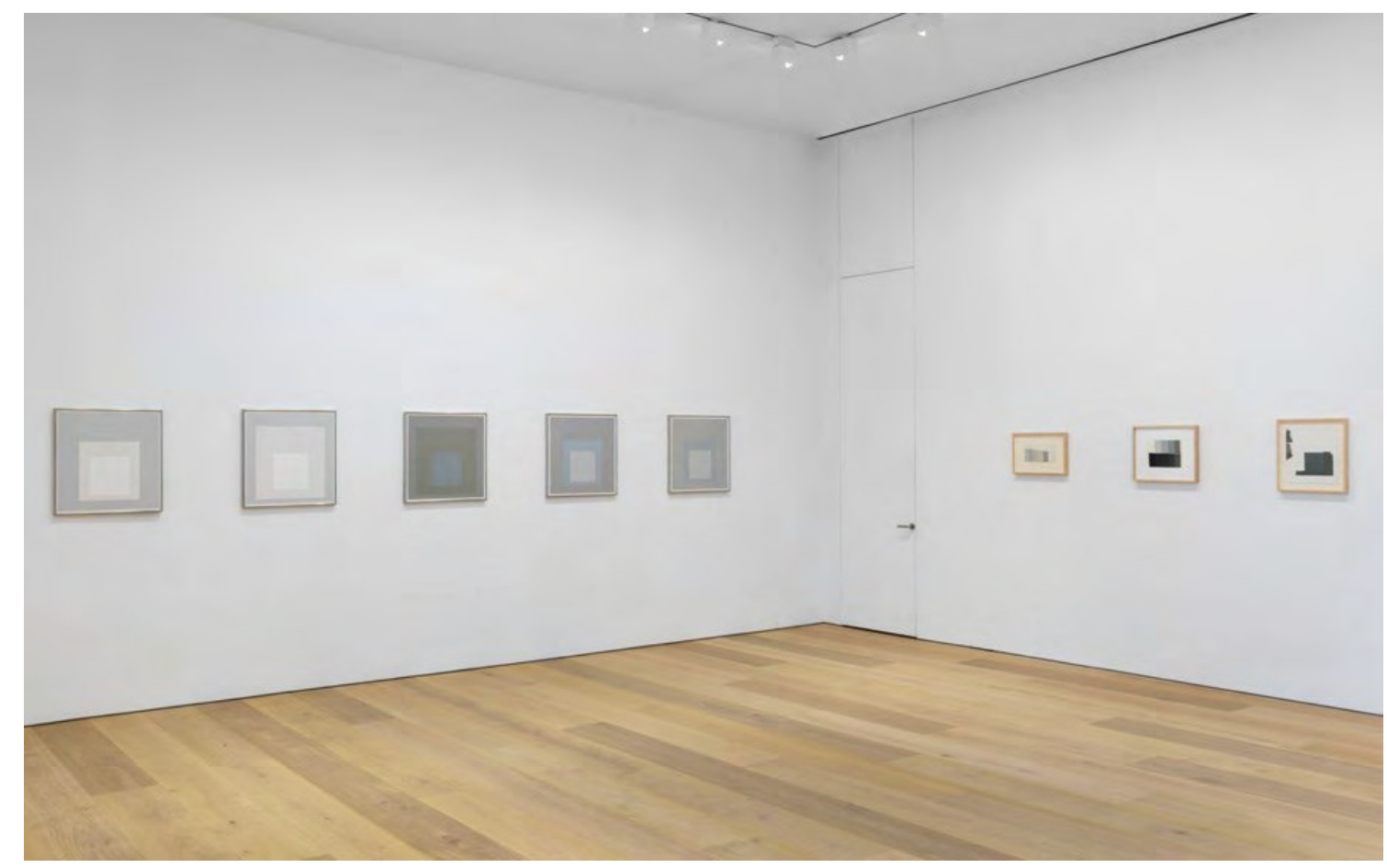

Fonte: https://wsimag.com/art/22518-josef-albers

No século XX, as qualidades atribuídas a esse tom percorreram caminhos diversos, mas, na maioria das vezes, ele foi tido como vazio, sem graça e depressivo. Por representar uma influência negativa, ora refletia a falta de segurança e confiança, ora indicava baixaestima ou até depressão (WRIGHT, 1999). Tanto que Guernica, de Pablo Picasso, datada de 1937, pintado em tons de cinza, retrata as vítimas da Guerra Civil espanhola.

Na virada do século XX para o XXI, porém, o cinza retorna com força, recebendo o lugar de ser uma cor chique, glamorosa, elegante, tornando-se aceito em amplos círculos devido a algum tipo de vontade autêntica. É visto como algo contemporâneo, que tem sua razão de ser, não por ser uma cor da moda, e sim uma cor moderna. Esse novo valor vai no sentido oposto à ideia atrelada a esse tom de ser a cor que absorve a sujeira, a cor da pobreza, do mofo, dos maus odores e da decomposição (HELLER, 2013).

Mesmo assim, essa tonalidade adquiriu um novo papel e, pela primeira vez na História da humanidade, é uma das cores mais aceitas, desejadas e consumidas por todas as classes econômicas e sociais ocidentais. Sua aparição se faz presente nas mais diversas áreas: pintura, arte, design, moda, carros automotivos, eletroeletrônicos e eletrodomésticos. Até o 
momento, é a cor que mais se destacou e cresceu em prestígio durante o século XXI, como se ilustra a figura 23.

FIGURA 23: O cinza metálico de Anish Kapoor.

Random Triangle Mirror, Anish Kapoor, 2016, aço inoxidável e resina.

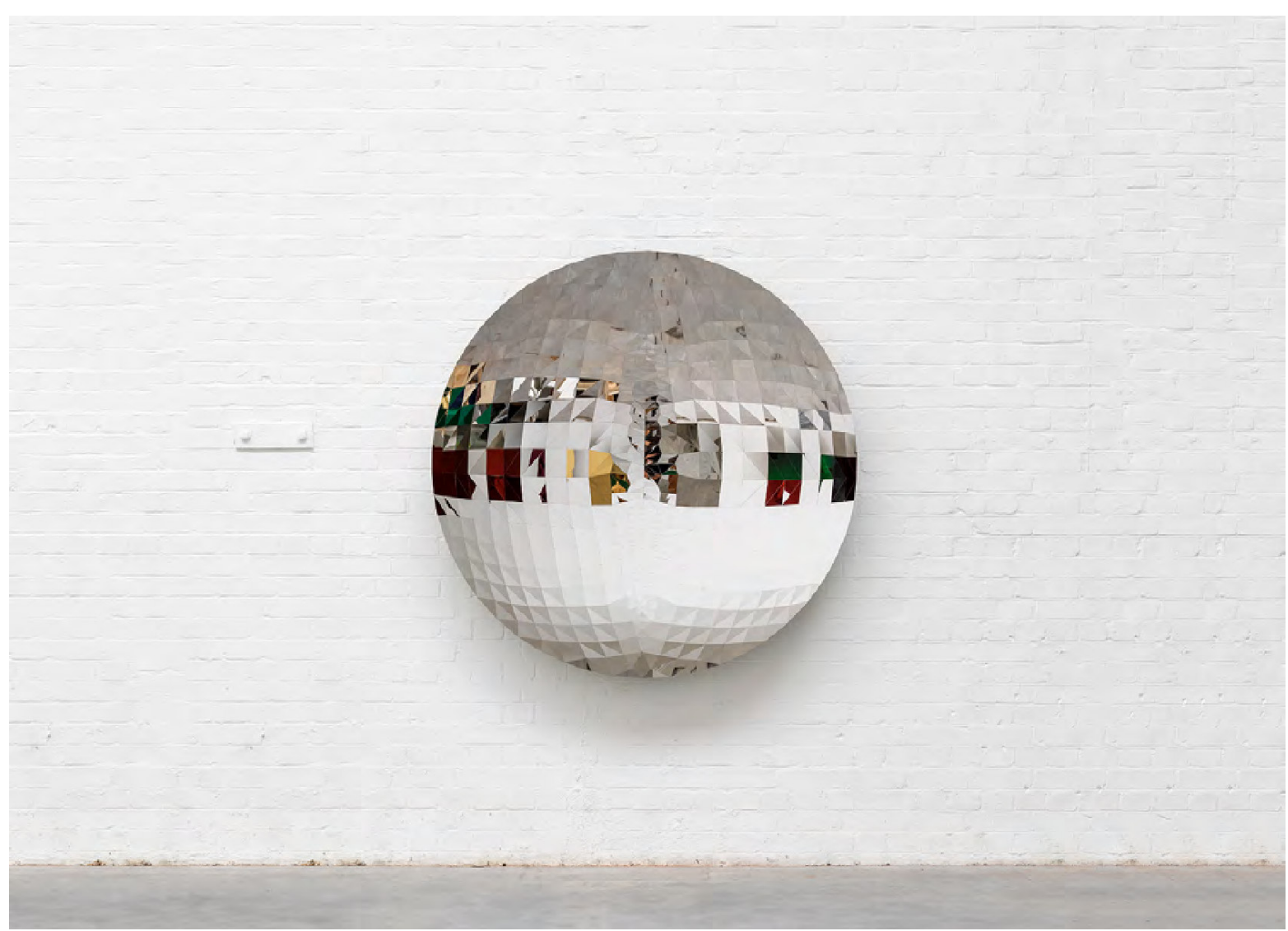

Fonte: https://anishkapoor.com/4965/random-triangle-mirror 
1.3.1.3 Branco

FIGURA 24: Lead White. Imagem meramente ilustrativa para representar a cor branca.

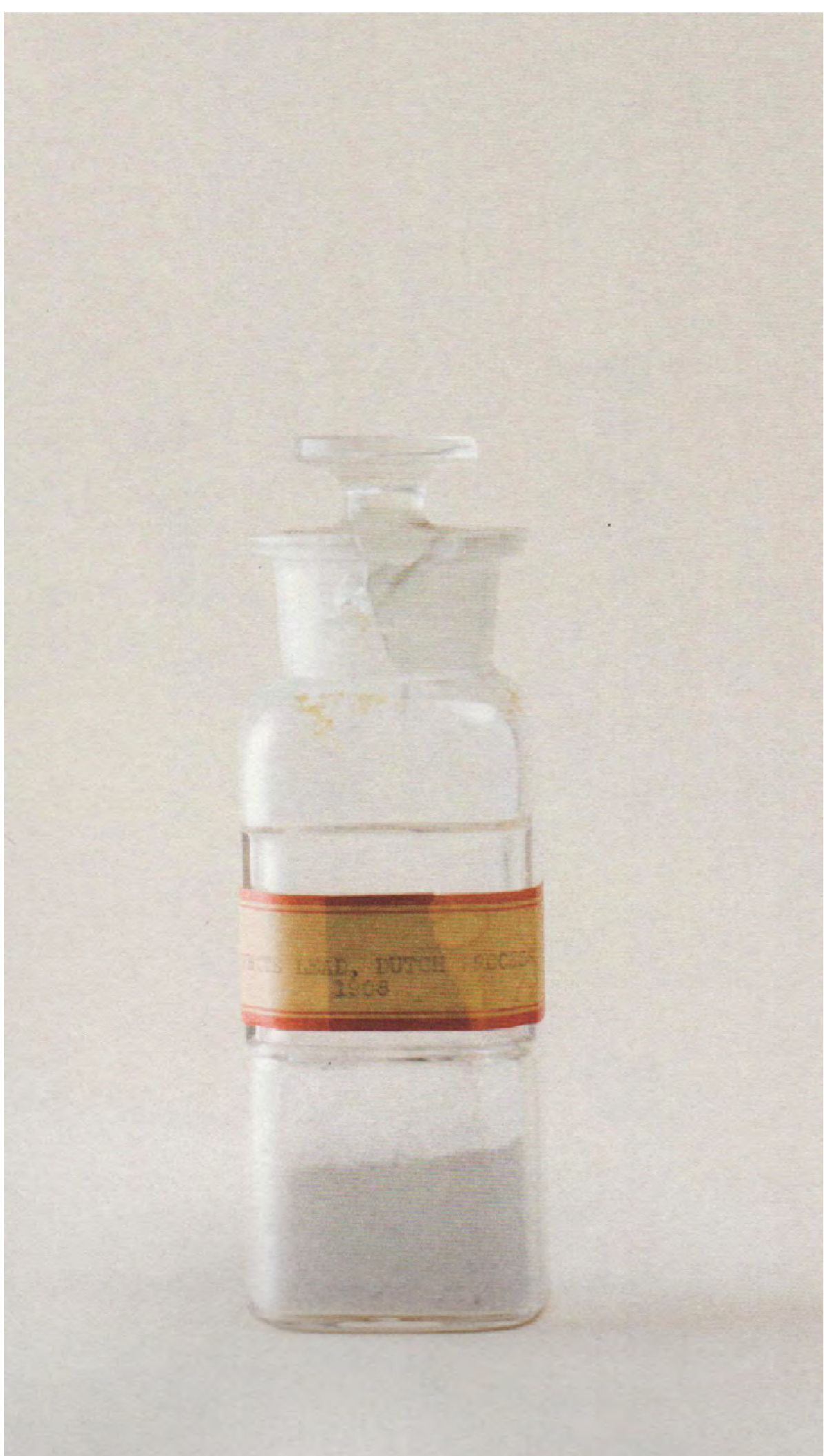

Fonte: THE HARVARD ART MUSEUMS' FORBES PIGMENT COLLECTION, 2017, p. 185. 
A palavra branco vem do germânico, blank, e simboliza algo brilhante, nascente de onde a luz provem (FARINA, 1982). Por muito tempo, acreditou-se que o branco era a somatória de todas as cores e todas as frequências quando, juntas, resultam na luz branca sendo ela a mais perfeita entre as cores. Tanto que a luz do sol tem sua verdadeira cor no branco. Essa luz que a estrela envia para a camada terrestre é composta de raios de cores diferentes que a atmosfera filtra, desvia ou reflete.

Por terem os comprimentos de onda mais curtos, o violeta e o azul, ao atravessarem as várias camadas da atmosfera, são mais dispersos e menos refletidos. Isso explica por que o céu é azul, sobretudo quando o sol está no máximo de intensidade. Quando está na posição zenital, a coloração dominante do espectro solar torna-se amarelo e alaranjado; quando ele nasce ou se põe, em tons de vermelhos e rosados (ROSSOTTI, 1983).

Necessário se faz destacar que, apesar de o branco conter em si a possibilidade de todas as cores, esse fato não o fez sair da posição que ocupa nos dias de hoje, pois permanece, ao lado do preto e do cinza neutro, como sendo uma tonalidade acromática.

Simbolicamente, o branco é o ícone maior da mensagem de paz dentro da cultura ocidental, conotando trégua e renúncia e, por consequência, a pomba branca e as bandeiras hasteadas receberam essa tonalidade (HELLER, 2013). Está associado à sensação de frio e frescor, pois a neve é "branquinha" e, quando está nevando, é porque a temperatura está abaixo de zero graus Celsius. Os drops de menta, que deixam o hálito fresco, também são na cor branca (PASTOUREAU, 1997).

Tendo em vista o aspecto psicológico dessa coloração, esse tom é exigente e pode ser muito severo, intransigente, salubre e clínico, possuindo muita força espectral. Como o preto, cria barreiras, mas de maneira diferente da absorção pretensiosa da cor menos luminosa - o branco é uma reflexão total e lança uma parede: "não me toque". Geralmente é usado apenas por pessoas que, grosso modo, não se sujam ou podem trocar de roupa com mais frequência do que a maioria, portanto não é exatamente um tipo de cor amigável e informal (WRIGHT, 1999).

Os primeiros cristãos, que acreditavam na vida após a morte, usavam branco nos funerais e em dias de luto, porque, para eles, a morte era a festa da ressurreição e, sendo assim, o Cristo ressuscitado aparece usando vestes brancas (PASTOUREAU, 2011). Por ser esse tom o sinônimo da renovação, da remissão dos pecados, a hóstia, símbolo desse novo nascimento, recebeu essa tonalidade (HELLER, 2013).

Outro exemplo é o ovo, ícone emblemático do início da criação, que também possuí essa mesma coloração. Conta a lenda que o mundo teve seu início a partir de um ovo, que 
era branco (PASTOUREAU, 2011). Não diferente, o primeiro alimento ingerido pelo homem ao nascer é o leite materno, que também possui um aspecto esbranquiçado.

Na cultura oriental chinesa do Yin-Yang, o Yin, por estar associado ao feminino, é representado pelo branco e pelo preto, ou seja, nobre e fraco (PASTOUREAU, 2011). Todavia, tanto na Bíblia como na cultura oriental chinesa do Yin-Yang, não há o domínio de tal tonalidade, aparecendo na astrologia e em muitas mitologias associado à Lua, outro símbolo feminino (WILKINSON, 2002). É a cor das personalidades passivas e tranquilas em que a calma e a paz prevalecem.

O branco também é associado ao divino, razão pela qual os anjos e as pessoas espiritualizadas são vinculados a esse tom, junto com a ideia de eternidade e paraíso. Por outro lado, os fantasmas e as aparições, ligados à morte, também se vestem nessa coloração (PASTOUREAU, 1997).

Na tríade organização funcional das cores, o branco, o preto e o vermelho são as cores por excelência. Essas tonalidades são regidas por várias sociedades antigas e medievais em suas crônicas e textos literários. Daí por que o branco aparece como sendo, em geral, a cor dos padres ou daqueles que rezam (PASTOUREAU, 2011).

Falar do branco, assim como do preto e do vermelho, é falar da História da humanidade. É a cor que, dentro da cultura ocidental, simboliza a vida e o bem, um novo início, a página inicial na qual uma nova etapa poderá ser escrita. "Quando Deus criou o mundo, seu primeiro comando foi: "faça-se luz!"” (HELLER, 2013, p. 156).

No relato da Criação, Noé, após quarenta dias de navegação, ao ver que o corvo não voltava depois de ordenar que ele fosse verificar se as águas recuaram, solta a pomba branca que, por duas vezes, volta à arca trazendo em seu bico um ramo de oliveira. Esse gesto simboliza a retirada das águas que lançam o branco como qualidade de íntegro e correto, sinônimo de vida, da paz e da conciliação (PASTOUREAU, 2011).

Alguns poucos versículos, após esse episódio, deixam confirmada a dualidade entre a luz e as trevas, ou seja, o branco e o preto. Assim, o brando se firma, tanto na Bíblia como para o cristianismo, desde seu início, como sendo algo positivo e o preto, negativo. A base disso está no Gênesis, simbolizada sempre por essa dualidade entre luz e trevas (PASTOUREAU, 2011). Tanto que, para a Igreja, a ideia do branco está atrelada à luz e ela participa naturalmente do divino, porque o filho de Deus foi consagrado como sendo o caminho, a verdade e a luz. Confirma o exposto a figura 25 , que mostra a luz como expressão máxima da presença divina. 
FIGURA 25: Capilla de las Capuchinas, Luis Barragán, Tlalpan, Cidade do México, 1925.

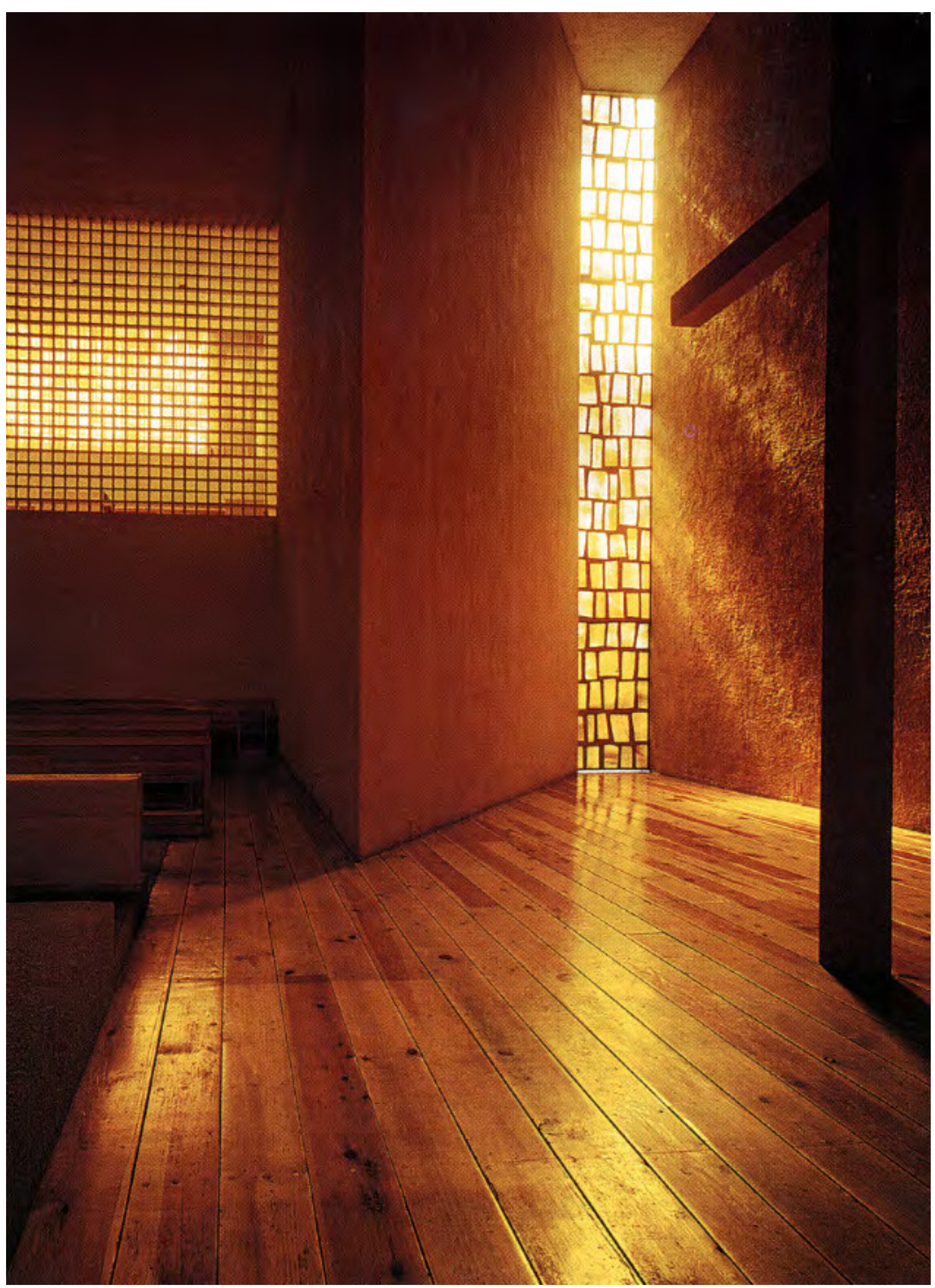

Fonte: PAULY, 2002, p. 219. 
Como se vê, a luz amplia-se no mundo terreno, o que, consequentemente, equivale a diminuir o lugar das trevas, e, portanto, a aumentar o lugar de Deus. Segundo Pastoureau (2011, p. 59):

\begin{abstract}
Nesses períodos, a associação feita a essa cor estava atrelada a luz, ao divino e ao sublime, onde os anjos e as pessoas espiritualizadas eram associadas a essa tonalidade junto com a ideia de eternidade e paraíso. Por toda parte, ou quase, as igrejas mantêm com a cor relações privilegiadas porque, como a luz, as cores afastam as trevas e, ao fazer isso, espalham aqui embaixo uma parcela do divino.
\end{abstract}

Durante toda a alta Idade Média, séculos VI a XI, nota-se que, entre aproximadamente 500 a 1000, havia uso de duas simbologias a partir das quais foram construídas e ancoradas as bases da simbologia das cores. A primeira foi influenciada pelo Gênesis, que desenvolveu um eixo oposto entre o branco e o preto. A segunda compreende a tríade primitiva entre o branco-vermelho-preto, em que os eixos branco-preto, branco-vermelho e vermelho-preto foram os opostos que cercaram muitas condições vividas pelo homem (PASTOUREAU, 2011).

Após o ano 1000, com o fim da alta Idade Média, iniciou-se uma outra fase e, junto a ela, uma nova maneira de pensar a cor, ou seja, deixam de existir não apenas a dualidade do branco com o preto, mas também teorias antigas sobre a natureza das cores.

Na virada do século XI para o XII, foi proposta uma nova teologia da luz. Algumas décadas mais tarde, já no século XIII, com a construção das primeiras catedrais góticas, a sensibilidade da época propôs novas questões de ótica e física da luz. Segundo Pastoureau (2011, p. 60):

Duas observações, no entanto, devem atenuar tal hipótese. Por um lado, a
cor preta parece ser a única atingida por essa nova concepção, a única a
sair da ordem das cores. O branco não a segue nesse caminho, sua sorte
não está ligada à do preto porque, nessa época, as duas cores não
constituem verdadeiramente um par.

Com o aparecimento da imprensa e da imagem gravada já no século XV, por volta de 1450, o branco do papel, um branco puro, alvejado, que surgiu na China no começo da nossa era e foi trazido para o Ocidente pelos árabes, ganhou um prestígio e um lugar de destaque. Ele aparece já no final do século XI e, quando Gutenberg inicia o processo das impressões, o papel já era usado em toda a Europa (PASTOUREAU, 2011; PASTOUREAU, 2019). 
Durante a Idade Média, quando as publicações eram feitas em pergaminho, esse material não era branco, tendendo a tonalidades mais amareladas, entre o cru e o bege, que escureciam com o passar dos anos. As primeiras impressões feitas em papel também não dispunham de um papel alvo. Todavia, no decorrer do tempo, a qualidade desse material vai sofrendo alterações à medida que se torna cada vez mais alvejado. Isso porque as técnicas utilizadas fizeram com que ele passasse do bege para uma tonalidade de branco acinzentado e, somente depois, para um branco mais lavado e limpo.

A partir desse ponto de extrema revolução para as sociedades de então, o branco do papel e o preto da tinta ficaram estritamente associados. Essa associação será mais uma vez firmada pelos experimentos de Newton realizados na segunda metade do século XVII. As ideias de Newton, publicadas em inglês em 1704, demonstraram uma nova lógica para a luz, que passa a ser concebida como uma mistura de todas as cores contidas no espectro visível. Ele desenvolveu uma nova classificação de base científica, já que propôs uma nova escala e retirou, por completo, o branco e o preto da ordem das cromáticas (PEDROSA, 2009).

Esse fato colocou essa tonalidade em outro patamar, mudando inteiramente a percepção da época. Mesmo assim, o branco permaneceu indiretamente relacionado com o espectro de cores. Isso porque ele continha todas elas, estabelecendo uma relação indireta com o universo cromático e impondo sua hegemonia. Para Pastoureau (2011, p.150):

\begin{abstract}
Mesmo sem efeito imediato sobre a vida cotidiana das pessoas comuns, as descobertas de Newton representam uma reviravolta essencial na história dos conhecimentos e dos usos da cor, talvez a mais importante depois do período Neolítico e das primeiras práticas de tintura. Ao demostrar que a cor se origina na transmissão e dispersão da luz, e que, como ela, pode ter medida, o sábio inglês fez com que a luz perdesse uma parte de seus mistérios. Dali em diante, produzida e reproduzida à vontade, controlável e mensurável pela ótica e pela física, a cor parece mais ou menos dominada.
\end{abstract}

Com todos esses acontecimentos, o século XVIII, o Século das Luzes, vai fazer uso dessa "luz" não só de forma espiritual, mas também na vida das pessoas. Tanto nos trajes como nos mobiliários, foram empregadas cores claras e contrastes mais suaves em alguns lugares da Europa como França, Inglaterra e Alemanha.

Essa procura por tons mais claros adentra e, em meados do século XX, a hegemonia do branco aparece de forma evidente e preponderante na Arquitetura, como esclarece Heller (2013, p. 165): 
Os arquitetos tentavam ressuscitar a Antiguidade. O estilo classicista de construções era concebido como uma fiel reprodução do estilo grego. Tudo era branco. A imagem típica do classicismo, de acordo com os antigos: filósofos vestidos de branco e disputando entre si caminhavam entre as colunas de mármore. Como enfeite das vestimentas somente suas pregas, como decoração arquitetônica apenas um relevo - a simplicidade branca é sublime.

Embasados nesse ideal, os pressupostos da arquitetura moderna fizeram dessa tonalidade a eleita por esse movimento. Interessados em construir linhas precisas, muitos arquitetos criam seus projetos, incorporando neles esse tom para com isso evidenciar a forma e a força arquitetônica, como se verifica na figura 26.

FIGURA 26: Casa Farnsworth, de Ludwig Mies van der Rohe, 1951, Illinois, Chicago, é um dos maiores ícones da arquitetura moderna e, junto com a forma, tem no branco o seu triunfo.

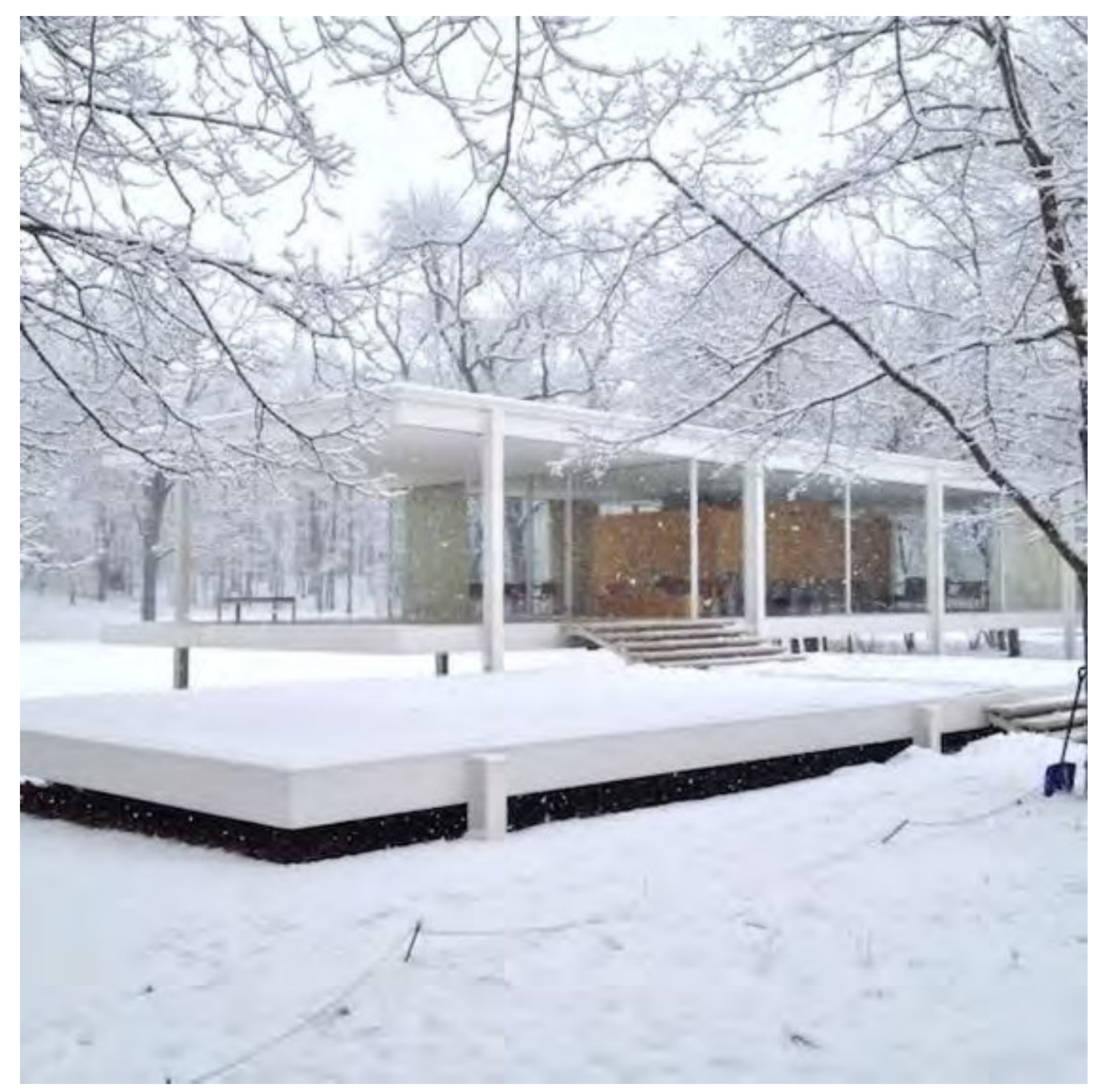

Fonte: PINTEREST, https://br.pinterest.com/pin/598767712938529729/ 
Nota-se, contudo, que a Antiguidade Clássica não foi pintada de branco, já que as estátuas, os templos e a vida cotidiana eram policromáticas (BATCHELOR, 2007).

Já no design de interiores, essa nuance imperou pela capacidade de criar distanciamento devido à alta de luminosidade, criando a ilusão de "aumentar" os espaços. Além disso, como a cor branca estava associada à ideia de higiene e salubridade, muitos lugares, como, por exemplo, hospitais, frigoríferos, cozinhas de restaurantes, por muito tempo, optaram (e muitos ainda optam) por essa tonalidade a fim de garantir seu ideal de conservação.

Acrescente-se, ainda, que o estilo minimalista conceituou os espaços ao reverenciar a ausência de adornos e ornamentos, sendo o branco o mais utilizado dentro dos espaços internos. Um ambiente absolutamente branco se tornou alvo de mobiliários, artigos e enfeites coloridos a fim de quebrar a esterilidade dessa tonalidade que pode ser hostil com a psique humana (WRIGHT, 1999). 


\subsubsection{As Cromáticas}

\subsubsection{Amarelo}

FIGURA 27: Ball of raw Indian yellow. Figura meramente ilustrativa para representar a cor amarela.

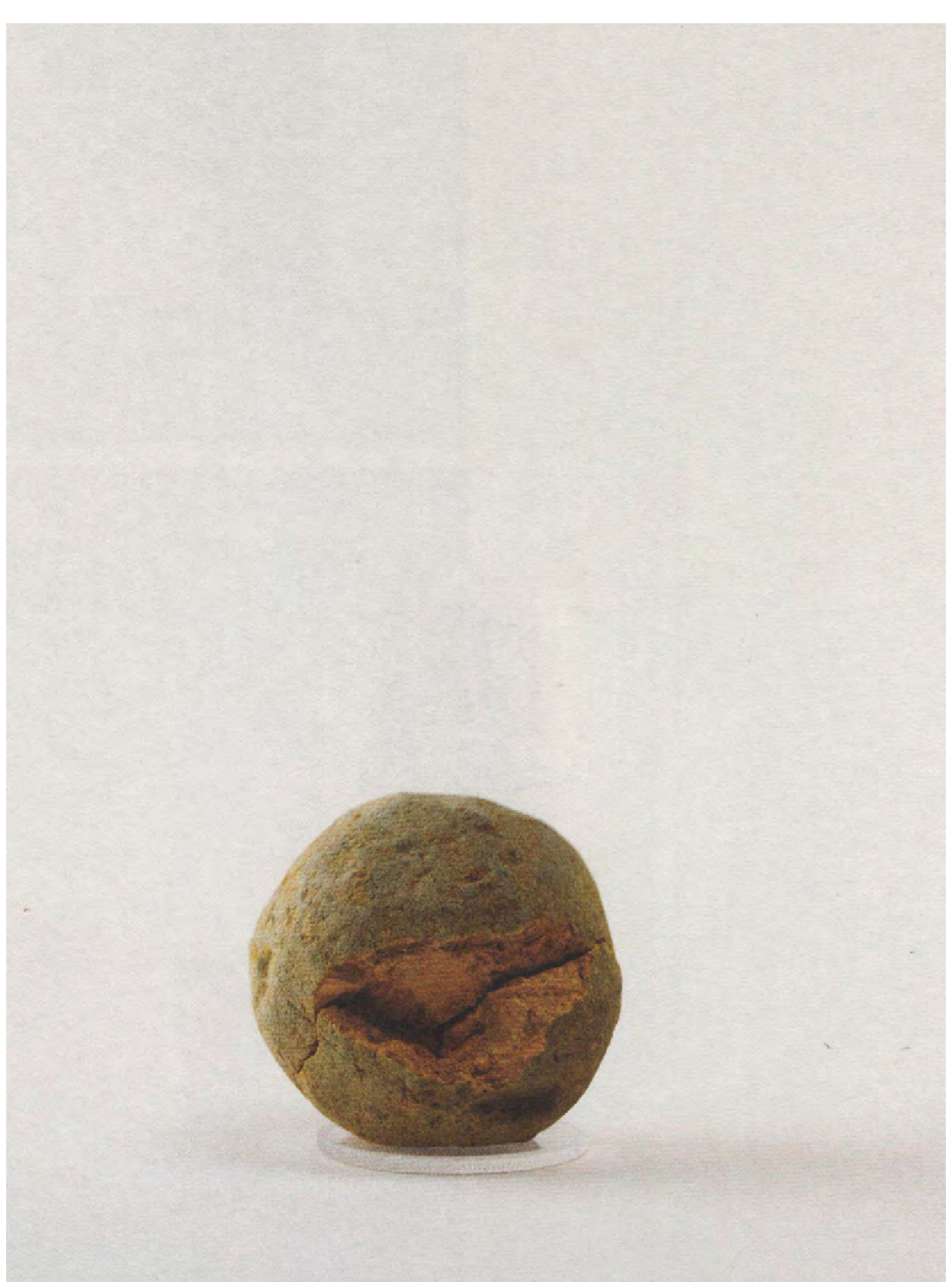

Fonte: THE HARVARD ART MUSEUMS' FORBES PIGMENT COLLECTION, 2017, p. 82. 
A palavra amarelo deriva do latim, amaryllis, e quer dizer a cor da luz irradiante, cintilante e que brilha (FARNIA, 1982). Ao lado do ciano e do magenta, é a cor da mistura subtrativa e não pode ser criada a partir da mistura de outras cores, sendo considerada uma tonalidade primária.

Simbolicamente, por dispor da maior quantidade de luz em sua formação, projeta muita energia e força, representa a parte favorável do espectro solar e traz consigo a alegria, o divertimento, a felicidade e o calor (PEDROSA, 2009). É considerada por muitos como sendo o tom do otimismo e da juventude, pois atua de maneira revigorante, irradiando uma energia amistosa e otimista, como uma expressão sorridente (HELLER, 2013). Por ser a mais luminosa dentre as cores, relaciona-se com o branco, conferindo a ideia de leveza e amizade.

Entretanto, tendo em vista o lado simbólico negativo, essa nuance esteve associada à loucura devido à alta carga emocional que ela poderia trazer. Esteve também conectada com a mentira e com a traição, por isso foi considerada a coloração dos maridos enganados e das pessoas traiçoeiras. Desde a Idade Média, foi a cor atrelada à imagem de Judas e, durante algumas passagens históricas, foi a coloração imposta aos Judeus para simbolizar sua identidade (PASTOUREAU, 2019).

À luz do lado psicológico, esse tom se concentra no ego, no otimismo e na autoestima, estimulando e projetando a mente para o exterior. Muito disso está relacionado com o fato de ser percebido como sendo a luz do sol e por isso é energético, empurrando a percepção de algo para frente. Pode indicar estados emocionais frágeis, disfarçando o fato de o amorpróprio não estar como desejado (WRIGHT, 1999).

No decorrer das estações do ano, essa nuance foi relacionada ao outono no hemisfério norte, onde a paisagem recebe uma coloração que contempla uma paleta dos tons de amarelo, laranja e vermelho com maior intensidade. É por isso que, por ser a estação que antecede o Inverno, quando as folhas caem e a paisagem se transforma, essa coloração também está associada ao declínio e à melancolia (HELLER, 2013).

Ao longo da história ocidental, essa cor foi menos presente se comparada com o branco, vermelho, preto, azul e o verde (PASTOUREAU, 2019). Entretanto, na maioria das vezes que apareceu, esteve associada ao astro solar, aos fenômenos meteorológicos, às plantas e minerais de todos os tipos, às águas enlameadas dos rios, ao mel, à cera, ao trigo, ao milho, à plumagem de alguns bichos e, mais tarde, ao ouro (PASTOUREAU, 2019). Esse metal, com seu aspecto dourado, trouxe consigo a junção entre a luz e a matéria, daí por que foi atrelado à figura divina, como está representado pela figura 28. 
FIGURA 28: Amarelo atralado a figura divina.

Midas Washing at the Source of the Pactolus, Nicolas Poussin, 1627, France, Musée des Beaux-Arts, óleo sobre tela.

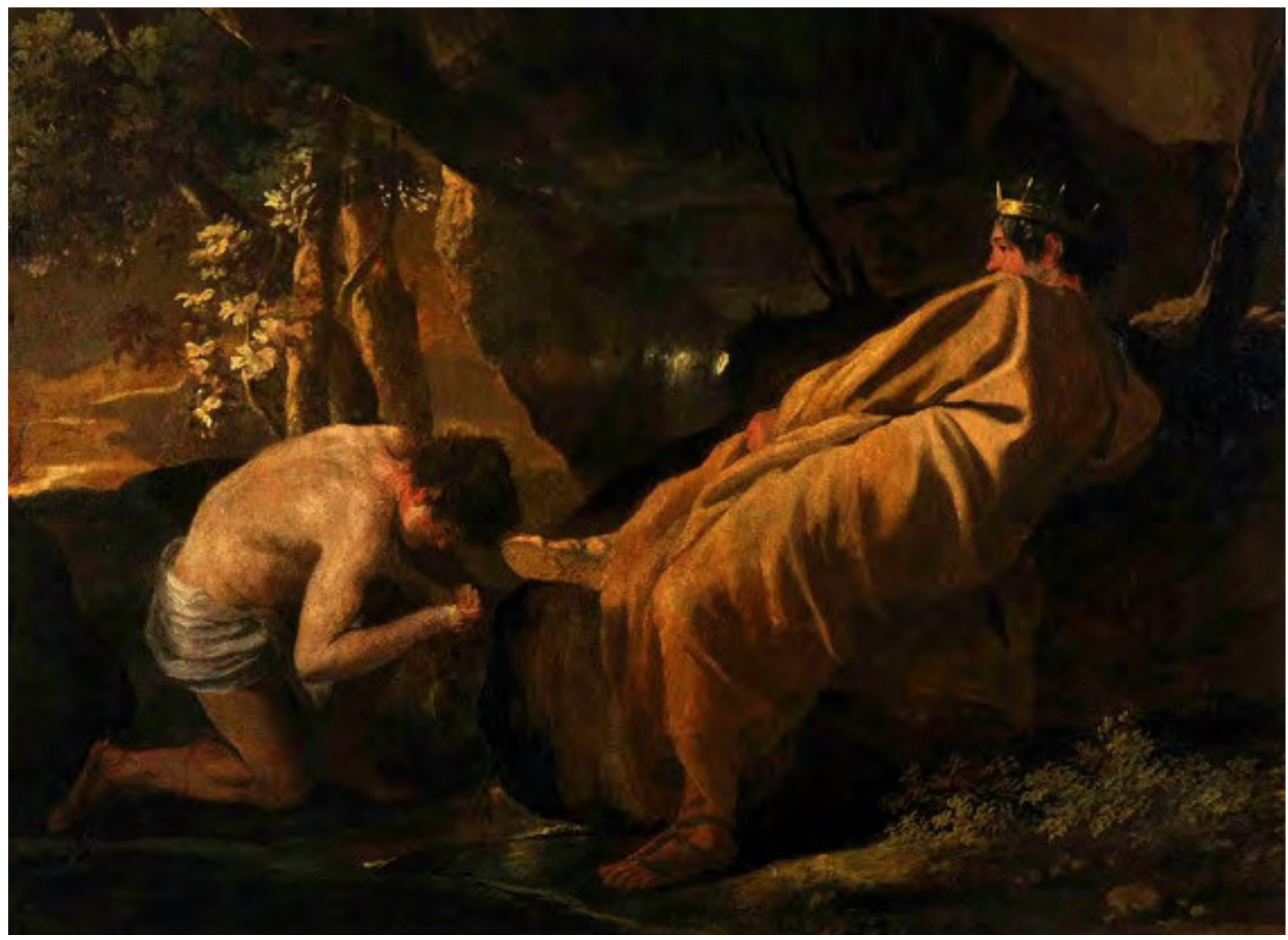

Fonte: PASTOUREAU, 2019, p. 36-37

Mesmo assim, é difícil afirmar ao certo que tipo de relações foram estabelecidas desde o princípio com a cor amarela. O que se sabe é que uma grande quantidade de objetos, desde o período Paleolítico, apresentava essa coloração (PASTOUREAU, 2019). Isso porque algumas ferramentas foram feitas a partir das pedras, ossos, barros, madeiras, couros e vimes, entre outros materiais existentes.

No período Neolítico, quando tecidos e roupas passaram a ser tingidos, sementes de plantas eram colhidas, principalmente algumas herbáceas muito usadas para tingir e que possuíam uma tonalidade mais amarelada. Também foi nesse período que o ouro começou a aparecer nos sepulcros e como oferenda aos deuses e às divindades (PASTOUREAU, 2019).

Dessa forma, houve uma ligação entre a história desse metal com a história da cor amarela, por isso tudo leva a crer que o prestígio do primeiro se refletiu no segundo. Para 
muitos povos, esse metal divino mantinha relações estreitas com o sol e era associado à luz, calor, poder, riqueza, beleza, perfeição e imortalidade (BRUSATIN, 1991).

Uma prática que, desde a Antiguidade, exerceu sua importância foi a agricultura que constituía o principal recurso e ocupava a maioria das populações, tanto no Egito como na Grécia e Roma antigas. O cultivo agrícola do trigo e do milho, ambos dispondo dessa coloração, trouxeram junto consigo a ideia de riqueza e prosperidade.

Com o passar do tempo, não só a prática agrícola emprestava sua tonalidade amarelada, mas também objetos de ouro começaram a ser cada vez mais numerosos e existentes na vida cotidiana. Como o ouro era muito fácil de manusear, começou a ser diferenciado dos outros metais (HELLER, 2013). Possuí-lo era, na verdade, um signo de grande poder, tanto que começou a ser acumulado em uma grande variedade de formas como lingotes, pratos, anéis, pepitas, joias, armas, pratos, relicários e objetos de trabalho.

Além de todas essas variedades de materiais produzidas por esse metal, as moedas, inventadas pelos gregos no século VII d.C., eram feitas dessa substância ou também de uma fusão de ouro e prata. Em decorrência da importância desse elemento na existência mundana, ele passou a ser inserido nos rituais fúnebres e nos sepultamentos, contribuindo para o prestígio do ouro já na Antiguidade clássica. Assim, além de todas essas interfases feitas a partir desse metal, tecidos e roupas foram enriquecidos com fios ou adornos dourados (PASTOUREAU, 2019).

Tamanha foi sua relevância que no Egito foram encontradas, nas tumbas de alguns faraós, paredes da sala do sarcófago pintadas de amarelo, além de roupas reais e objetos talhados em ouro, conforme se percebe na figura 29. 
FIGURA 29: Rosto de Tutankhamun.

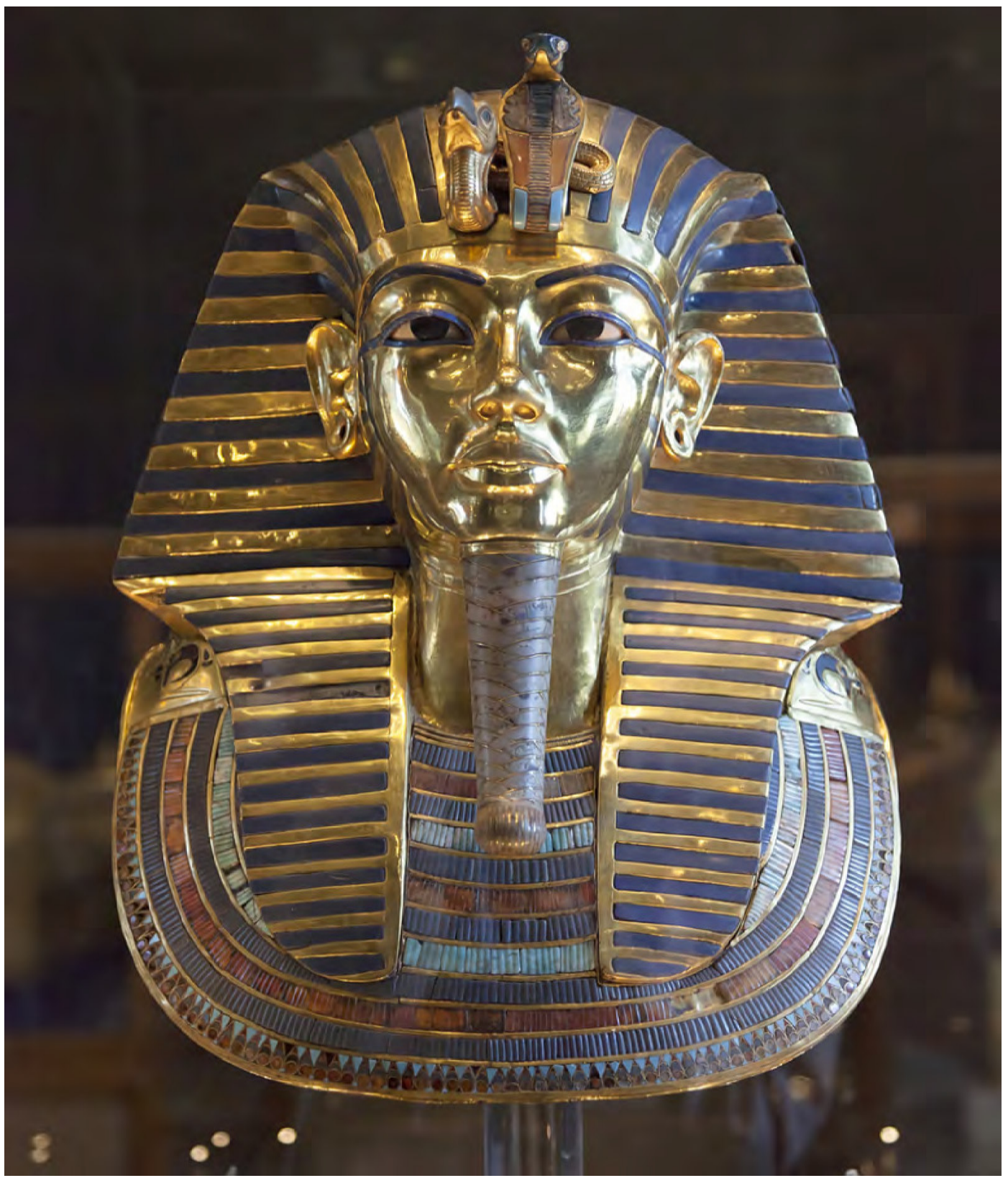

Fonte: https://www.tutankhamun-exhibition.co.uk/the-exhibition.

Essa tonalidade, parente da coloração dos papiros que eram sagrados para esse povo, trazia a ideia da imortalidade que, como afirma Heller: "no Antigo Egito, a cor do luto era o amarelo, pois o amarelo simbolizava a luz eterna" (HELLER, 2013, p. 130). O ouro, no Egito Antigo, esteve presente nas joias, colares, pulseiras, peitorais, moedas de ouro, vasos, espelhos, sarcófagos, máscaras funerárias e nas tumba.

Como se vê, esse metal parecia ser "luz materializada", e a ideia de Deus, semelhante à luz, fez com que sua presença fosse abundante tanto nos templos sagrados como no dia a 
dia. Assim, o metal amarelo manteve relações cada vez mais estreitas com o sagrado e o poderoso, passando a ser, não só armazenado e ofertado, como também exibido, transportado, oferecido, trocado, recebido, encoberto e até roubado (BIRREN, 1962).

Devido a toda essa energia que girou em torno desse material, nem sempre teve conotações somente positivas, trazendo consigo aspectos ruins, como a cobiça, ambição, agressividade, deslealdade e traição. Tanto que todos esses problemas de conduta, vício e crime estão retratados na Bíblia, e as mitologias grega, céltica, nórdica e germânica também apresentam esses aspectos quando é mencionado o ouro (PASTOUREAU, 2019).

Apesar dessas conotações negativas, o mito das quatro idades traz a Idade do Ouro relacionando os acontecimentos que se sucederam à cor amarela. A Idade da Prata foi relacionada à cor branca, a Idade da Bronze, à cor vermelha e a Idade do Ferro, à cor preta. Ao relatar uma passagem da mitologia grega, Pastoureau (2019, p. 31), assim a descreve:

A idade de ouro é a das delícias: os humanos vivendo intimamente com os deuses, puros de coração e despreocupados, isentos de dor, cansaço e velhice. Paz, amor e justiça reinam em todas as partes; a primavera é eterna, a guerra é desconhecida e a natureza é gentil. Os arbustos de baga produzem frutos abundantes e deliciosos, e a lã do dorso das ovelhas vem tingida em cores vivas e variadas, sem qualquer intervenção humana. A idade da prata começa quando Zeus sucede a seu pai, Cronos. Este é o período em que os humanos, que incomodaram Zeus, se tornam mortais; devem trabalhar para suprir suas necessidades, viver de acordo com o ritmo das estações, enfrentar o calor, o frio e a fome. Em seguida, vem a idade do bronze. Doravante os humanos têm o coração duro, eles experimentam violência, fazem guerra e devem lutar contra monstros e perigos de todos os tipos. Finalmente a idade do ferro chega, um tempo horrível e sem fim foi quando os vícios se tornaram supremos e os humanos não sabem mais nada além do medo, do sofrimento e da morte.

Nesse sentido, na mitologia grega, Apolo representa a luz solar e Hélios, deus dessa estrela. Independentemente da forma que recebe, era quase sempre representado, figurado ou descrito com amarelo (WILKINSON, 2002).

Para os egípcios, por exemplo, Rá, o mais antigo deus do sol, que todos os dias fazia sua viagem de barco, era considerado o criador do universo e o pai dos primeiros faraós. Assim, o rei das estrelas, fonte de calor, luz e fertilidade, inimigo das trevas e das forças do Mal, foi deificado desde muito cedo, dando origem a vários cultos no Velho e no Novo Mundo (WILKINSON, 2002).

Já Krishna, que é o maior deus da mitologia hindu, aparece vestindo uma peça de roupa nessa coloração (WILKINSON, 2002). Na cultura chinesa, na qual os imperadores 
eram considerados como filhos do sol, essa cor foi eleita como sendo a cor do Estado e da religião.

Na filosofia chinesa do Yin Yang, Yin é o feminino, representado pelas cores preto e branco. Preto simboliza o início, o começo e branco o fim, a morte (PASTOUREAU, 2011). Já Yang, força masculina, é representado pela cor amarela, vermelha e verde, pois, dentro dessa cultura, o lado masculino é o mais importante, por isso é representado por essas cores, sendo o amarelo a mais sublime (PASTOUREAU, 2019). Para Heller (2013, p. 98), "De acordo com o simbolismo chinês, o amarelo foi gerado do preto, assim como a terra amarela surgiu das obscuras águas primordiais".

Observa-se que muitas sociedades atribuíam ao amarelo esse lugar de excelência, pois viam no sol a base de toda a vida, o ancestral de seus deuses e, às vezes, de seus reis ou seu povo. Essa importância do amarelo dentro de várias mitologias e filosofias não ficou restrita a essa área, já que penetrou outros meios, como a arte figurada (PIPER, 2008).

Assim, os pintores egípcios tinham acesso a uma extensa paleta de amarelos, indo desde os ocres com suas várias tonalidades ao orpimento, que muitas vezes era usado para substituir o ouro devido ao seu brilho. Junto a eles, ao longo do primeiro milênio, surgiu um novo pigmento, o massicote, que possuía uma característica mais opaca e era utilizado principalmente para pintura de fundo (PASTOUREAU, 2019).

Já na tinturaria, o conhecimento provinha dos povos do Oriente, como os hebreus, egípcios e fenícios, ou dos germânicos e celtas, que influenciaram os romanos na gama dos amarelos. Como esses povos cultivavam um gosto por vestir-se de forma monocromática, uma mulher da boa sociedade romana geralmente se vestia de branco, bege ou amarelo. Esta última tonalidade era a cor do orgulho para os casados, sendo o próprio casamento a origem do costume (PASTOUREAU, 2019).

Durante o período da república romana, a cerimônia de casamento exigia que o casal entrasse junto em uma sala pintada ou decorada com a cor amarela, símbolo de alegria, felicidade, fertilidade e prosperidade. Esse ritual, posteriormente, diminuiu, deixando apenas a noiva vestida nesse tom (PASTOUREAU, 2019).

Dada a importância dessa cor, o corante mais prestigiado para tingir de amarelo era à base de açafrão (HELLER, 2013). Essa planta, depois de colhida, era seca e reduzida a pó, fornecendo um produto usado em tinturaria, perfumaria, medicina e culinária, como se observa nas figuras 30 e 31. 
FIGURA 30: O açafrão, apesar de seu aspecto mais alaranjado, foi muito utilizado para tingir de amarelo.

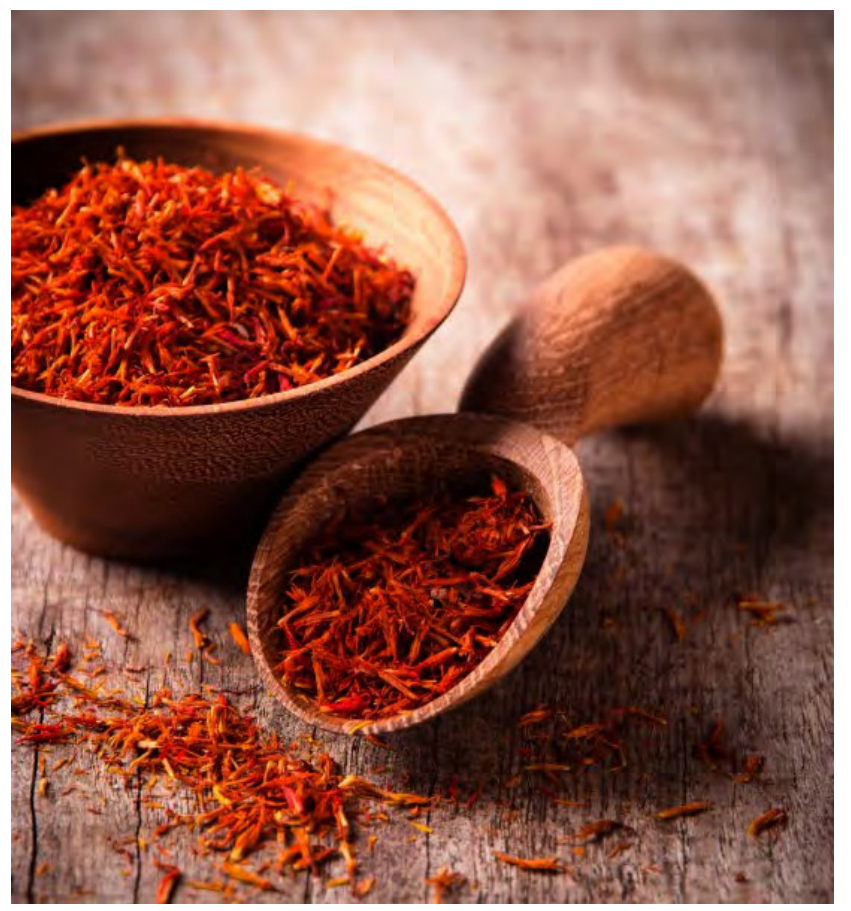

Fonte: https://br.depositphotos.com/stock-photos/a\%C3\%A7afr\%C3\%A3o.html

FIGURA 31: Tingimento em amarelo.

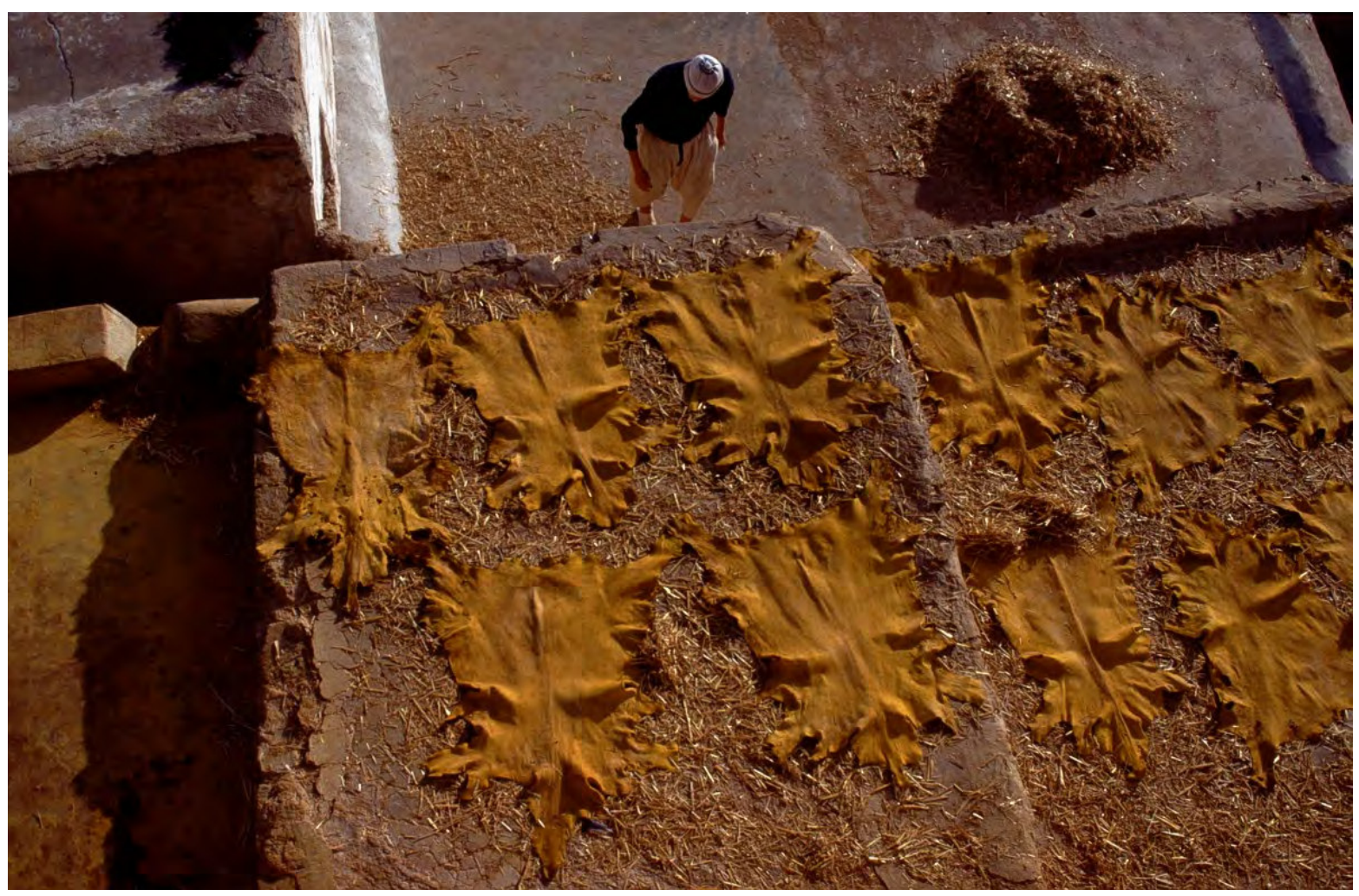

Fonte: https://pxhere.com/en/photo/1590775 
Como colorante, o açafrão oferecia tons esplêndidos de amarelo brilhante que ia em direção aos vermelhos, tendendo para o laranja ou para o rosa, não sendo nem muito estável e nem resistente à luz. Era usado especialmente para tecidos destinados a roupas femininas e o traje de certos padres. Havia outro corante também utilizado, a hena, cujas folhas secas e amassadas podiam ser usadas frias, produziam tons mais estáveis, principalmente na faixa dos vermelhos e marrons, mas também laranjas e às vezes até amarelos.

Já o lutum, por ser mais barato se comparado ao açafrão e por crescer em várias áreas podendo ser aproveitado inteiro, também foi utilizado em abundância. Com esse material, depois do procedimento realizado para obtenção do corante, era misturado um forte mordente, e a coloração resultante dava belos tons de amarelo, muito sólidos, mas menos brilhantes e menos laranja se comparado ao açafrão (PASTOUREAU, 2019).

Consequentemente, o amarelo deixou evidente como a sociedade estava circundada e, portanto, aceitava essa coloração. Isso em razão da grande diversidade de substratos que traziam os amarelos encontrados no ambiente quotidiano, devido às influências trazidas pelas plantas, minerais, elementos naturais, frutas, ceras, mel, grãos nutritivos, pedras e metais preciosos.

Ao que tudo indica, os amarelos eram mais próximos do laranja do que do verde, mas, gradualmente, abrangeu, na Roma do século I, tonalidades desde os amarelos esverdeados até os amarelos alaranjados (PASTOUREAU, 2019). Tanto que esse agrupamento de cores permaneceu unido conceitualmente em uma única categoria cromática, e todas essas possibilidades pertenciam a uma única família que expressava a mesma ideia, como, por exemplo, a feminilidade. Dessa forma, foi a cor mais usada tanto pelas matronas como, conforme afirma Pastoureau (2019, p. 56),

pelos homens afeminados, como os gregos, cuja moral havia chocado os romanos, ou mais repetidamente, os habitantes da Frígia (uma região da Ásia Menor onde o cidade de Tróia foi localizada); todos eles supostamente sentiam uma forte atração pelo amarelo e o usavam com frequência. Em Roma, eram determinados indivíduos que, por um motivo ou outro, geralmente político, eram caracterizados como efeminados (delicati) por seus inimigos ou por poetas que se deleitavam em fofocas e calúnias maldosas (Martial, por exemplo), não um tom específico de amarelo, mas todos amarelos: brilhante, vívido e saturado para os mais ricos, mais opaco e mais monótono para os outros.

Nota-se, pois, a existência de dois tipos de amarelos: o que imitava o ouro, mais luminoso, e o proveniente do açafrão, cujo aspecto era mais alaranjado e opaco (HELLER, 2013). Todavia, já no período medieval amarelo e ouro não eram a mesma coloração, pois 
cada um tinha seu próprio status e produzia seus próprios efeitos. Nesse sentido, o ouro evocava a luz divina, enquanto o amarelo era usado para pintar as vestes do anjo e a lã das ovelhas. Simbolicamente diferentes, o ouro e o amarelo também tinham de ser cromaticamente diferentes (WRIGHT, 1999).

A partir do século IX, apesar de as práticas variarem de uma diocese para outra, o ouro e as cores brilhantes e saturadas estavam presentes nos ricos tecidos e vestuários usados para o culto (HELLER, 2013). Entretanto, o amarelo quase não era citado e, portanto, a liturgia não o reconheceu como sendo uma cor forte. Por outro lado, o ouro foi onipresente e desempenhou o papel de cor na hora de completar a paleta litúrgica construída em torno do vermelho, violeta, branco, preto e verde (PASTOUREAU, 2019).

Em virtude da alta presença desse metal, o luxo e a ostentação nas grandes igrejas tornaram-se forte durante o século XII. Presente abundantemente em iluminuras e esmaltes, o ouro pareceu ancorar cores sob seu fundo dourado, encerrá-las através de molduras ou bordas e controlá-las e estabilizá-las para torná-las mais radiantes. Como o amarelo não estava na liturgia, foi o ouro que o substituiu. Assim, o ouro medieval era cor (PASTOUREAU, 2019).

Já em outros domínios nesse mesmo período, segundo Pastoureau (2019, p. 85):

\footnotetext{
O aparecimento de brasões ao longo do século XII constitui um ponto de inflexão essencial para a cor amarela, na verdade quase um segundo nascimento. Pela primeira vez na Europa, um sistema de sinais construído em grande parte na cor garantiu ao amarelo um lugar primário. O que a liturgia nunca conseguiu fazer, a heráldica conseguiu em poucas décadas: passando de três (branco, vermelho, preto) para seis cores básicas (branco, vermelho, preto, verde, amarelo, azul). Também pela primeira vez, o amarelo ganhou um significado simbólico próprio, independente de sua materialidade ou meio. Doravante existe "a (cor) amarela", uma abstração, não mais apenas alguns amarelos que variam de acordo com pigmentos, corantes, luz e técnica. Agora, depois de um longo atraso, essa cor pode rapidamente alcançar o vermelho, o branco e o preto na área de emblemas e símbolos. Ainda provisório no século XII, o simbolismo de amarelo cresceu mais rico nos séculos que se seguiram e, em seguida, se expandiu para domínios além da heráldica.
}

Em função disso, os romances de cavalaria trouxeram cada vez mais descrições dos personagens com seus cabelos dourados, repletos de uma qualidade luminosa e atraente desta tonalidade, como fios de ouro. A figura 32 confirma o exposto. 
FIGURA 32: O amarelo foi ganhando importância ao longo dos séculos e, no período feudal, apareceu em armas, brasões e desfiles de cavalaria.

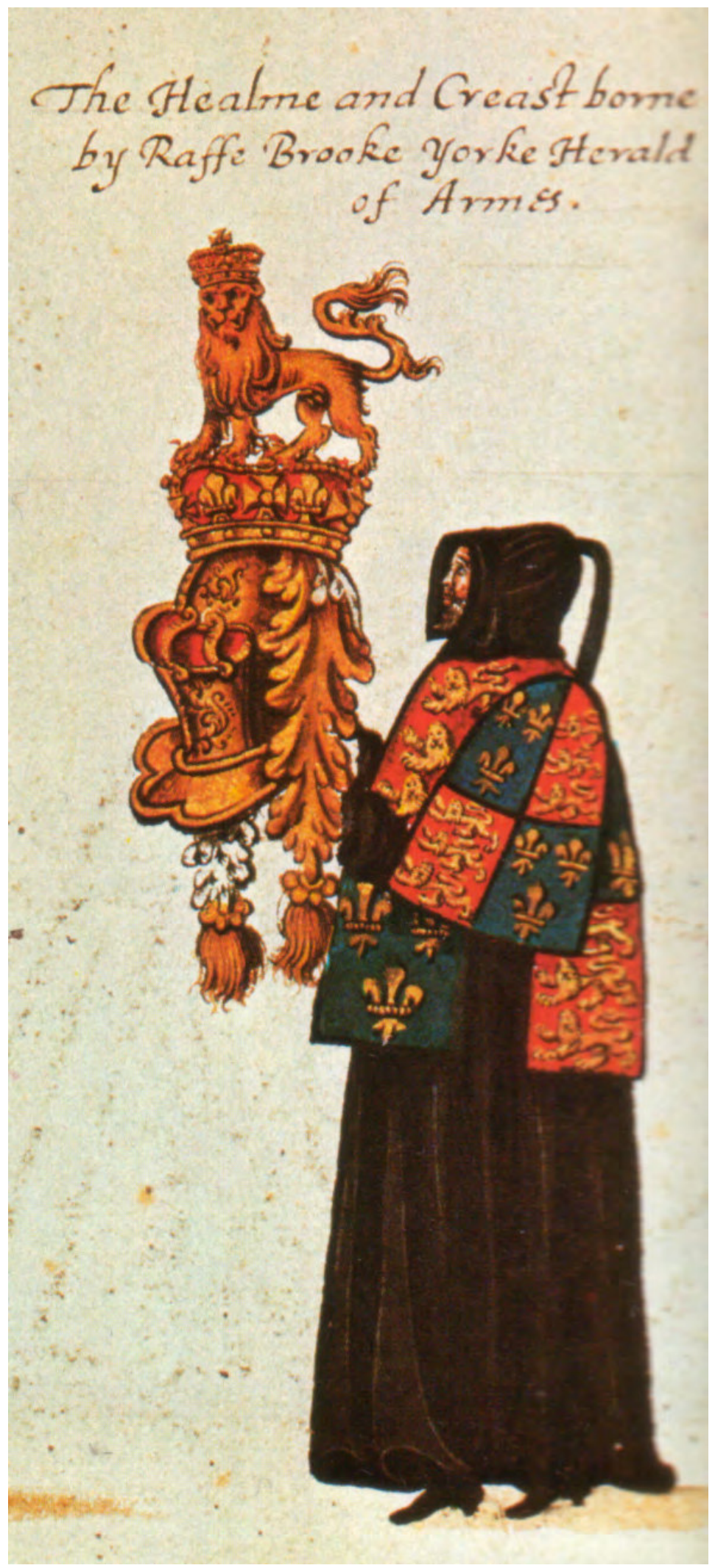

Fonte: WIKIMEDIA,

https://commons.wikimedia.org/wiki/File:Funeral_procession_of_Elizabeth_I_Ralph_Brooke_York_ Herald_1603.jpg 
Agregava a isso a ideia de juventude, sedução, nobreza e cortesia ao explorar a qualidade feminina e penetrar o universo masculino. Nesse sentido, cabelos loiros e brasões demostravam como o amarelo, apesar de não ter muita importância em alguns domínios, poderia ser considerado positivo no período feudal, presumindo não apenas o sol, o ouro e a beleza, mas também dignidade, orgulho, encanto, amizade e benevolência (HELLER, 2013).

No fim da Idade Média, já no final do século XIII, começaram a surgir outras conotações a essa tonalidade, e o número de vícios associados a esse tom era maior que suas virtudes. Somente quando era comparado ao ouro foi considerado positivo, e quando visto sozinho, era sempre negativo. Os vícios que estiveram conectado a essa cor eram a inveja, raiva, ciúme, desonra, engano, mentira, hipocrisia, traição e até mesmo a melancolia (HELLER, 2013).

Assim, esse tom foi considerado uma cor falsa e dúbia que não podia ser substituída, pois ele trapaceava, enganava, traia e causava um estado melancólico. Muito dessa simbologia negativa que o tirou do domínio da sedução e da cortesia se deu devido à noção de enfermidade, disfunção e infecção trazida da medicina por dois fluidos amarelados segregados pelo organismo: a bile e a urina (BIRREN, 1961).

Até esse momento, a medicina medieval e o domínio fisiológico não conheciam os verdadeiros valores da bile, pois consideravam-na apenas como um fluido orgânico produzido pelo fígado, espesso, amargo, viscoso e sujo. Quanto à urina, esta era um fluido ordinário, imundo e asqueroso, sendo somente o que o organismo descartava por não ter utilidade fisiológica, como ilustram as figuras 33 e 34. 
FIGURA 33: Modelo gráfico representando as cores da urina.

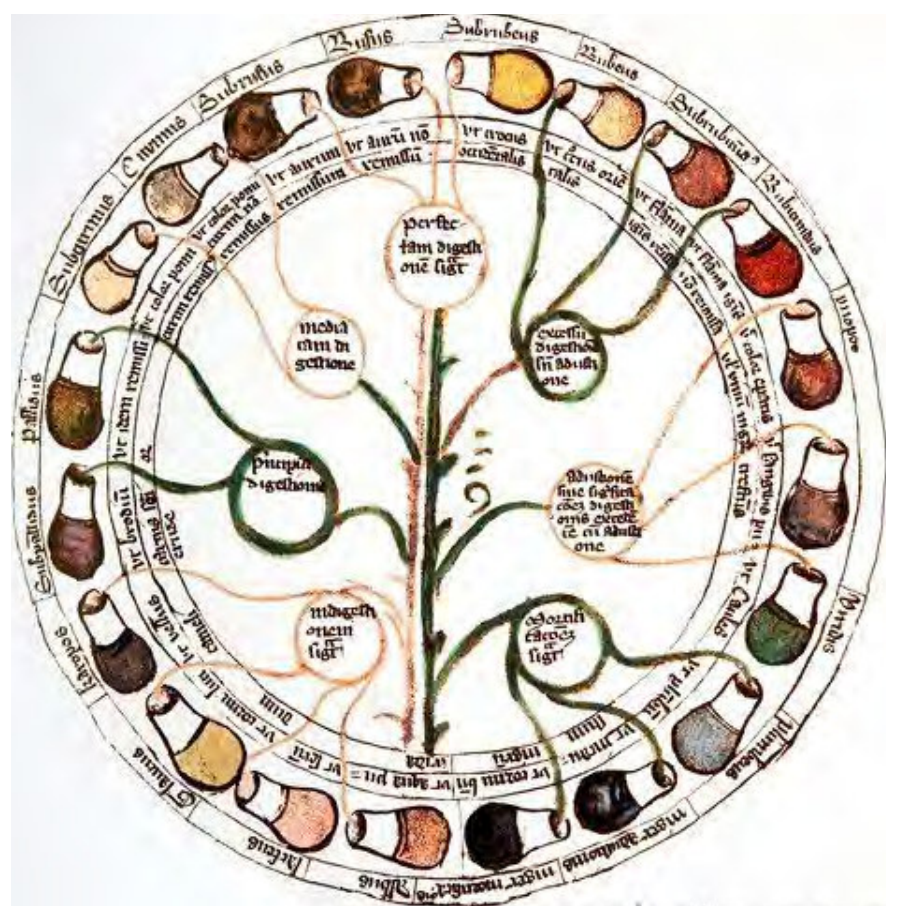

Fonte: PASTOUREAU, 2019, p. 107.

FIGURA 34: A coloração da urina sendo analisada.

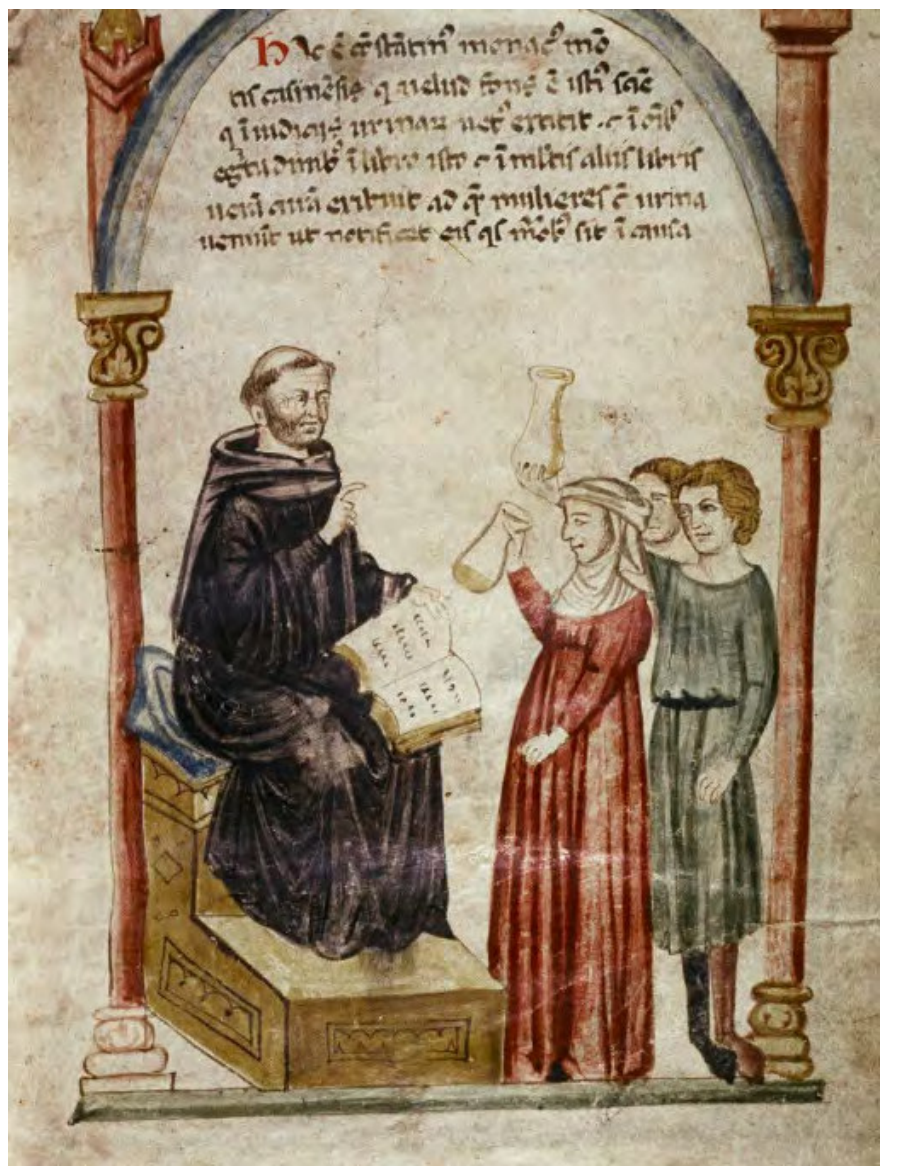

Fonte: WIKIPEDIA, https://en.wikipedia.org/wiki/Uroscopy 
Esses dois fluidos, bile e urina, contribuíram para o declínio do amarelo, pois, além de serem indicadores de sujeira e doença, estavam associados a um humor bastante negativo, a um temperamento colérico, violento, instável, rancoroso e hipócrita (BIRREN, 1961). Além disso, era excessivamente secretado não apenas por aqueles que eram irritados e raivosos, mas também por aqueles que eram mentirosos, ciumentos, invejosos e traidores.

Como a cor amarela estava conectada à mentira e à traição, no século XIII, Judas passou a ser representado por essa tonalidade, razão pela qual as sinagogas foram cobertas de amarelo. Em miniaturas e janelas de vitral do mesmo período, apesar de não ter havido práticas comuns a toda cristandade, os judeus eram frequentemente retratados vestindo roupas ou uma peça de roupa nessa coloração. Na vida cotidiana, as normas de vestimentas impostas obrigavam o uso de insígnias de pano, muitas vezes na cor amarela, para distinguilos dos cristãos (PASTOUREAU, 2019).

Século mais tarde, foi imposta uma estrela amarela aos Judeus, que deveriam usá-la para simbolizar a todos sua identidade (HELLER, 2013). Assim, para a cristandade, as imagens dele e a imagem da sinagoga, ambos de amarelo, desvalorizaram muito essa cor. Tanto que Pastoureau (2011, p. 87), ao relatar uma anedota que Jesus cometera, diz:

\footnotetext{
Jesus devia então cometer suas besteiras com outra gama de cores. Em lugar do preto, as versões do final da Idade Média escolhem então o amarelo, cor da mentira e da traição, de Judas e da sinagoga, para ser a tinta na tina em que a criança mergulha os tecidos, antes de fazer um milagre e dar a cada um a cor prevista. Naquela época, uma tina de amarelo era simbolicamente mais inquietante ou mais nefasta que uma tina de preto. Isso é uma novidade.
}

Por esse motivo, pessoas de má reputação, frequentemente, apareceram vestidos de amarelo na iconografia do final da Idade Média (HELLER, 2013). A casa dos traidores, dos cavaleiros desleais e dos impostores eram pintadas dessa coloração para sinalizar ao restante da população sua identidade.

Acrescente-se que, apesar de serem quimicamente estáveis, os tons de amarelo, em sua maioria, tanto no tingimento quanto na pintura, perdiam o brilho em certas luzes, sofriam a influência negativa dos tons vizinhos e eram rapidamente alterados até mesmo por uma mistura modesta (BIRREN, 1997).

Além disso, na época moderna, entre as cores básicas, o amarelo continuava sendo o primo pobre, o parente impopular, tanto no cotidiano como nos textos. Segundo Pastoureau (2019, p. 169): 


\begin{abstract}
Nas pinturas do século XVII e das primeiras décadas do século XVIII que nos mostram interiores, os amarelos não parecem realmente amarelos; são muito opacos e tendem mais para o bege, marrom ou dourado do que para o verde. Os tons que chamamos de "amarelo limão" ou "amarelo canário" são vistos apenas em naturezas mortas e usados apenas para pintar alguns tipos de frutas (marmelos, maçãs, peras). Essas sombras parecem ter estado ausentes nas roupas e nos móveis, pelo menos se formos acreditar nas pinturas, que - devemos sempre lembrar - não constituem de forma alguma "fotografia" da realidade colorida e nunca estão em seu estado original; seus pigmentos foram transformados com o tempo, e diferentes camadas de verniz foram cobertas ou totalmente alteradas.
\end{abstract}

No domínio da pintura, os manuais e coleções de receitas destinadas aos pintores impressos nos séculos XVII e XVIII, apesar de serem relativamente hostis e muito variados em seus objetivos, eram expansivos em cores, pigmentos e fórmulas. Por essa razão, os amarelos, geralmente, vinham atrás das demais, como se essa fosse uma cor marginal de pouco interesse para os pintores (PASTOUREAU, 2019).

Vale destacar que os pintores não foram os únicos a negligenciar a família dessa tonalidade. Em tratados e manuais de tingimentos, os tintureiros agiram de forma muito parecida, já que esse tom nunca aparecia entre os primeiros. Todavia, fora das fronteiras europeias, o amarelo tornou-se gradualmente a cor do imperador e do poder supremo, pois apenas a família imperial estava autorizada a usar roupas dessa cor (HELLER, 2013).

Essa tonalidade, quase ausente nas roupas e na vida cotidiana, uma cor cuja reputação negativa foi duradoura e mostrou-se difícil de refazer-se e melhorar seu valor. Para Pastoureau (2019, p. 188):

Na segunda metade do século XIX, o teatro, os editais, os desenhos animados políticos e as caricaturas tornaram o amarelo a cor tanto dos enganadores quanto dos enganados. Também representava os sindicatos de trabalhadores ligados a empregadores, bem como maridos traídos e cidadãos enganados por seus governantes eleitos e enganados por aqueles no poder.

Desde a Segunda Revolução Industrial até a Primeira Guerra Mundial, o lugar do amarelo não só confirmou o seu declínio. É provável que esse declínio tenha-se dado devido aos códigos morais e sociais vigentes, ou devido ao fato de que a maioria dos financistas e grandes industriais da revolução eram protestantes. Assim, foram os valores protestantes que se espalharam e o amarelo, junto ao vermelho, foram vítimas dessa moral, não tendo muito lugar na vida cotidiana. Quando apareciam, eram apenas pequenos toques na mobília e na 
decoração de interiores ou para sinalizar, junto com o vermelho, desde o século XIV, a prostituição (PASTOURAEU, 2017).

Isso se deu pelo fato de o amarelo ser uma cor que se vê, uma cor que se destaca e atrai os olhos, surpreendendo ou até mesmo sinalizando uma informação ao observador. $\mathrm{O}$ amarelo e o preto, juntos, passam a ser "sinais de alerta, pois eles sinalizam: "pense bem no que irá fazer, pois pode se machucar!" (HELLER, 2013, p. 131). Desse modo, faixas zebradas e placas de sinalizações possuem essa combinação. Já a propaganda evita essas cores, pois podem conotar algo de natureza perturbadora, perigosa ou repulsiva (FARINA, 1982).

Conforme Heller (2013, p. 91):

\begin{abstract}
No futebol fazem-se as advertências com "cartão amarelo"; esse é o termo que já entrou para o vocabulário de uso comum da língua, quando alguém "sinaliza alguém com cartão amarelo", ela o está ameaçando com feias consequências. Se uma bandeira amarela for erguida num navio, sinaliza a eclosão de uma epidemia, ninguém deve deixar o navio e ninguém deve ser admitido a bordo. Na linguagem das bandeiras, a amarela significa a letra "Q", de quarentena. Se fosse hasteada uma bandeira amarela numa aldeia da Idade média, significava que ali havia eclodido a peste.
\end{abstract}

Nos dias atuais, de forma mais mundana, a visibilidade do amarelo explica seu uso. Em certas cidades onde o inverno é muito rigoroso e os dias são curtos, quanto mais frio, mais o amarelo se apresenta no ambiente. Isso muito tem relação com o sol e, como na maioria das vezes, esse astro vem representado por esse tom, quanto mais amarelo no ambiente, mais a sensação de calor.

Portanto, a relação do amarelo com o dia e com a luz foi estabelecida desde os primórdios (PIPER, 2008). Luminoso, radiante, deslumbrante, esteve associado ao astro solar e é considerado um tom quente, sendo o sol a expressão máxima da sensação térmica de calor. Trazendo uma imagem referente às férias e ao tempo livre, essa nuance comunica essa mensagem presumindo a descontração e relaxamento.

Apareceu como uma cor benéfica criando circunstâncias em que é possível agir, que pode causar o aumento do índice metabólico e da secreção glandular, dando energia e induzindo a ocorrência de atividade, sem imposição (BIRREN, 1978). Amarelo, junto com outras cores com muita luz, como o laranja e o vermelho, é uma tonalidade que traz luminosidade para o dia a dia e ilumina a existência. 
1.3.2.2 Laranja

FIGURA 35: Kidney Haematite. Imagem meramente ilustrativa para representar a cor laranja.

Fonte: THE HARVARD ART MUSEUMS' FORBES PIGMENT COLLECTION, 2017, p. 66. 
A palavra laranja deriva do persa narang e do árabe naranja simbolizando o "flamejar do fogo" (FARINA, 1982). Provavelmente, a fruta laranja é originária das Índias e foi, na época das Cruzadas, entre os séculos IX a XIII, levada para as Arábias, onde ficou conhecida como sendo narang, a qual, por analogia, deu origem à cor laranja.

É a cor que representa, simbolicamente, a combinação da luz e do calor com o queimar do fogo, o lançar das chamas e o arder das labaredas. Seu ponto alto é associado ao divertimento, à descontração e ao jocoso, logo, quando há laranja em uma composição, há sempre a conotação de algo brincalhão e divertido. Segundo Heller (2013, p. 184):

Dionisio - os romanos chamam-no Baco - é o deus da fertilidade, da embriaguez e do vinho, em suma: o deus dos prazeres mundanos. A cor das vestes de Dionísio é laranja. No culto a Baco não existem sacerdotes, e sim sacerdotistas, as bacantes. Elas trajavam vestidos cor de laranja e coroas de folhas de cidreira, e celebravam, extasiadas pelo vinho, seu Deus.

Sob o ponto de vista psicológico, a cor laranja está associada à sensualidade, ao gozo físico e à paixão ardente. Instintos de sobrevivência secundários são evocados pelo laranja como calor, abrigo, comida, conforto físico e segurança. O tom laranja é o meio do caminho entre o luminoso amarelo e o potente vermelho (WRIGHT, 1999). Posto que essas duas cores são possuidoras de aspectos muito ambivalentes, é esse tom que vai unir os pontos favoráveis e os aspectos positivos de ambas, trazendo para si a força, a potência e o impulso.

Para Goethe (2011), era o tom com a mais alta vibração e, conforme também afirma Heller (2013), é comum que as "pessoas energéticas, saudáveis e primitivas apreciem tanto essa cor. Entre os selvagens notam-se essa mesma inclinação. E quando as crianças se põem a colorir, elas não economizarão no uso do cinábrio e do zarcão" (HELLER, 2013, p. 184).

Com relação ao negativo essa cor, no mundo ocidental, ela é vista de forma mais pragmática. Por ser uma tonalidade que se nota, destaca-se das outras e pode ser vista tanto à noite quanto no nevoeiro, é utilizada para sinalização, no mar com seus coletes, botes e bóias salva-vidas, bem como em locais considerados perigosos (PASTOUREAU, 1997). Por isso o laranja está presente em canteiros de obras, caixas de fusíveis, rótulos de produtos tóxicos, sinalizando perigo, aconselhando cautela.

Vale acrescentar que, desde a Idade Média até os dias atuais, a cor laranja, quando produzida artificialmente, é citada, ao lado do marrom, como uma das cores menos desejadas. Talvez esse fato tenha relação com a própria simbologia negativa da cor que traz consigo algo perigoso ou venenoso (PASTOUREAU, 1997). 
Ao longo da história, observa-se que o laranja nem sempre teve seu lugar, pelo menos não nas teorias e no discurso sobre a cor. Nem na Antiguidade e nem no período medieval, esse tom recebeu uma categoria cromática própria. Ademais, quase nenhuma palavra pode ser encontrada no léxico para marcar os tons de laranja encontrados na natureza (PASTOUREAU, 2019). Por muito tempo, foi necessário recorrer ao vocabulário de amarelos e vermelhos para nomear as flores e frutas. Tanto que as nuances castanha e marrom pareciam ser fruto de uma definição pejorativa que combinava o pior do amarelo e o pior do vermelho escurecidas (GOETHE, 2011).

Uma parte da população mostrou tanto apreço pela cor laranja que procurou um nome propício para ela. No final, eles pegaram emprestado o nome da própria fruta, então abundante nas mesas e nos pomares. A chegada desse alimento doce à Europa, substituindo a laranja amarga, a única conhecida até então, ajudou a aumentar o valor da fruta e, consequentemente, sua cor. Essa nova variedade cítrica, apreciada pela alta sociedade, gradualmente passou a ser uma referência de nobreza e riqueza, tornando-se a própria fruta símbolo da beleza, do amor, do prazer, da fecundidade e da prosperidade (HELLER, 2013).

Ao término da Idade Média, houve várias razões para os ganhos de importância da cor laranja. Com a descoberta do Novo Mundo e com ele o surgimento de madeiras tropicais possuidoras de propriedades de tingimento impressionantes, o laranja, que já vinha se distinguindo do castanho-avermelhado, começou mais ainda a iluminar-se e a afirmar-se como cor autônoma. Ao fazer isso, seu valor aumentou inegavelmente. Segundo Pastoureau (2019, p. 202):

Dos corantes, de uma calmaria na década de 1460, a laranja volta ao primeiro plano no início do século seguinte, quando os europeus descobrem no Novo Mundo outras espécies de madeiras tropicais da mesma Família das Índias e da Insulíndia, mas com ainda mais propriedades de tingimento impressionantes: madeira Campeche na América Central, madeira Pernambuco na América do Sul. A paixão por essa última foi tão grande que o país que o forneceu recebeu o nome de seu extrato corante: Brasil. O Brasil substituiu as Índias como principal exportador de corantes para a Europa. Apesar da longa e perigosa travessia do Atlântico, o custo do produto americano era na verdade inferior ao do asiático, porque para os colonos portugueses e espanhóis do Novo Mundo os escravos cortavam e preparavam a madeira.

Assim, no início do período moderno, esse tom adquiriu um status cada vez mais rico de símbolos conotando valores como riqueza, luz, saúde, beleza e fertilidade. Já na pintura 
dos séculos XVI e XVII, atestou-se a presença sutil dessa tonalidade nas práticas de vestir da alta sociedade, tanto para os homens quanto para as mulheres.

Isso se deu porque, às vezes, o tom laranja era acompanhado por uma dimensão política ou dinástica. Na segunda metade do século XVI, tornou-se a cor simbólica e militante dos príncipes da Casa de Orange, ardentes defensores da Reforma e da independência do norte da Holanda que lutaram contra a coroa espanhola.

Desde então, como o laranja é uma cor que pode ser vista e destaca-se das demais, foi muito utilizada na segunda metade do século passado, dentro de ambientes interiores, com o pretexto de "tornar a vida mais alegre", trazendo uma atmosfera divertida e original. As figuras 36 e 37 ilustram um trabalho proposto e o ateliê de Lena Meyer, no qual o tom de laranja foi utilizado, pois estava em evidência no começo do século XX.

FIGURA 36: Esboço realizado no ateliê de tecelagem da Bauhaus em 1928 por Lena Meyer-Bergner.

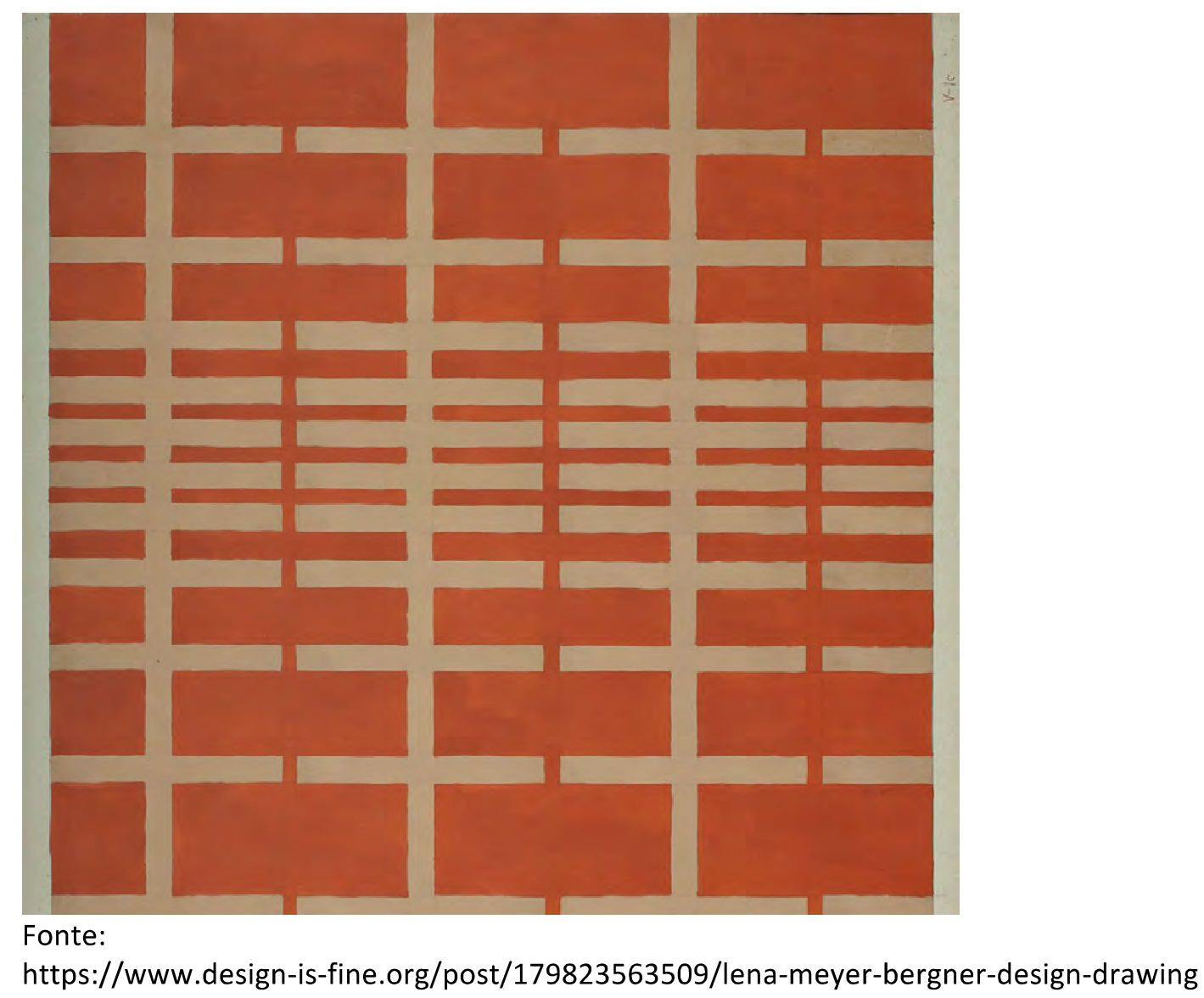


FIGURA 37: Lena Bergner trabalhando em seu ateliê.

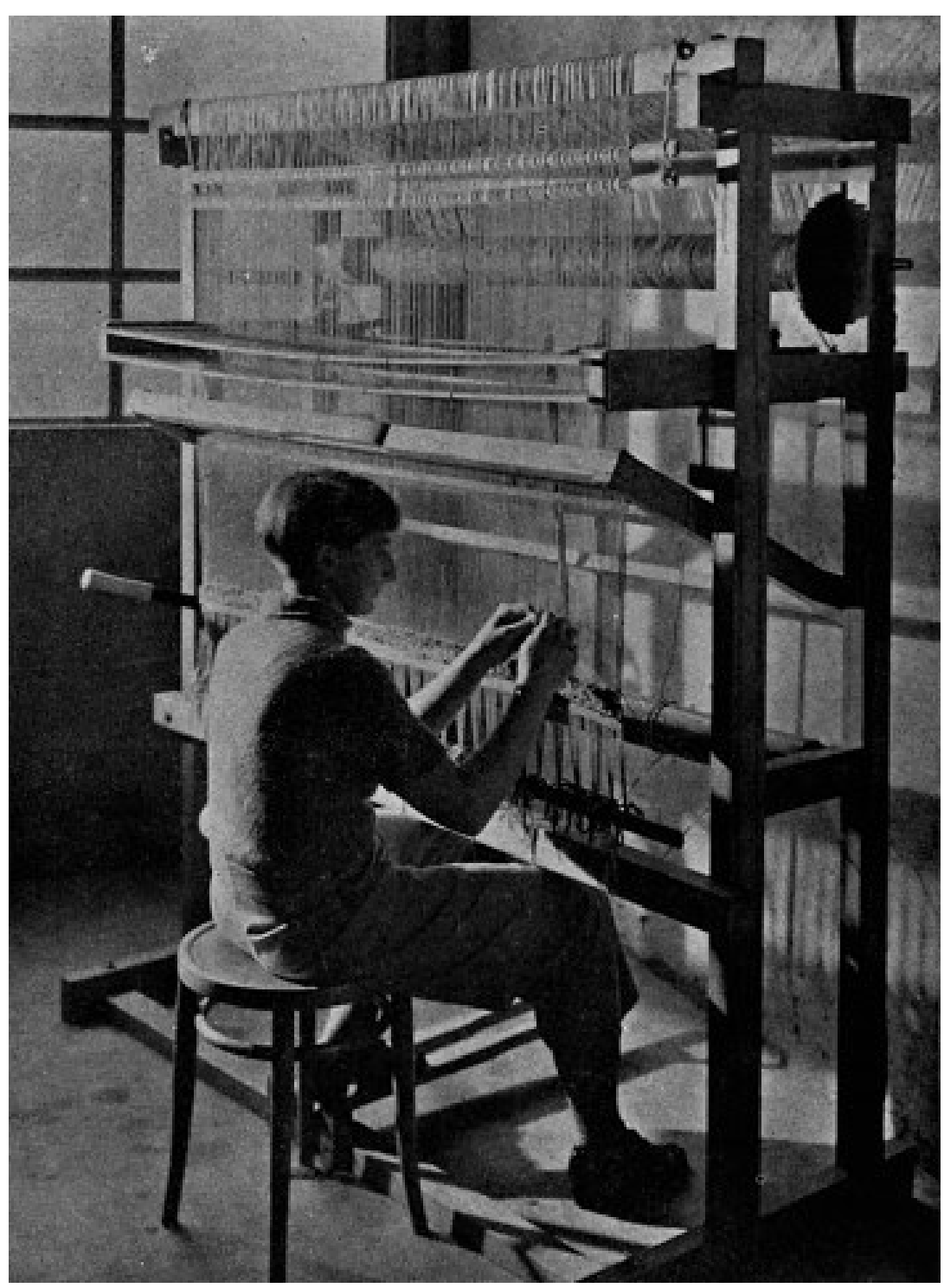

Fonte:

http://www.bauhaus-imaginista.org/articles/2485/lena-

bergner?0bbf55ceffc3073699d40c945ada9faf=0178aaeb1fde706b5e1082d95459995a

Como atrai o olhar, chama a atenção e é "alto demais", o tom laranja passou a ser usado com frequência na publicidade e em embalagens de produtos para saúde, sinalizando tônicos e todos os artigos ricos em vitamina $\mathrm{C}$ que melhoram a energia e o desempenho físico.

Além disso, na década de 70, o laranja era a cor referência dos tecidos e dos materiais sintéticos. Todavia, devido à discussão gerada em torno da sustentabilidade e da importância de não se produzir mais elementos em plásticos, pois não eram biodegradáveis, o laranja, associado a essas peças, passou a ser, muitas vezes, mesmo que inconsciente, uma cor não 
desejada na sociedade ocidental. Por essa razão, passou a ocupar um lugar de menor prestígio (HELLER, 2013).

Na sociedade oriental, a exemplo da Índia e Sudeste Asiático, como afirma Pastoureau (2019, p. 204), a cor laranja

desempenha um papel na vida cotidiana, e já faz isso há muito tempo. Não apenas é a cor sagrada do hinduísmo e do budismo, o símbolo da pureza, sabedoria e liberdade, mas também é, mais simplesmente, uma cor vivida para trazer boa sorte. É por isso que é vista em muitos tecidos e roupas, principalmente para mulheres, lado a lado com outras cores tão inusitadas em nossas latitudes. Isso é verdade a tal ponto que em nossa imaginação, quando pensamos em laranja, pensamos na espiritualidade hindu, monges tibetanos ou mesmo no manto açafrão de Buda, que as tradições afirmam ser originalmente uma simples mortalha.

Assim, o laranja, por estar associado tanto à luz quanto ao fogo, significa transformação, portanto traz consigo a ideia de espiritualidade e de sensualidade. E como espiritualidade e sensualidade não são necessariamente forças opostas, ele vem carregado do ideal de iluminação, podendo atingir o mais alto grau da perfeição. 


\subsubsection{Vermelho | Rosa}

FIGURA 38: Pigmento Vermelho da Persia. Figura meramente ilustrativa para representar a cor vermelha.

Fonte: THE HARVARD ART MUSEUMS' FORBES PIGMENT COLLECTION, 2017, p. 35. 
A palavra vermelho deriva do latim, vermiculus, e quer dizer verme, inseto (a cochonilha) ou do árabe girmezi, conotando uma coloração bem viva, escarlate (FARINA, 1982). É a última cor do espectro visível, com o maior comprimento de onda e é a mais invocada quando o assunto é cor, pois traz consigo um significado existencial.

Apesar das conotações coloridas serem raras nos textos, fábulas e contos literários, o vermelho, formando a tríade ao lado do branco e do preto, sempre aparece. Vermelho é a cor por excelência, a cor entre as cores, a primeira que se destaca, a cor arquetípica e foi a primeira cor com a qual o homem se relacionou. Trata-se da cor que, em muitas línguas, traz consigo o sinônimo de colorido, bonito e rico (PASTOUREAU, 2017).

Simbolicamente, o vermelho representa a força, o calor e a energia. Dentro da cultura cristã, enquanto o vermelho é a cor de Cristo, o azul é a cor de Maria (HELLER, 2013). É a cor simbólica da matéria e possui, também, um lado positivo e um negativo. Do lado positivo, o sangue e o fogo, qualquer que seja a cultura, possui uma razão existencial. $\mathrm{O}$ sangue é a conquista, o vermelho do salvador derramado na cruz para salvar a humanidade, a força guerreira, a masculinidade, o energético. O fogo corresponde ao temperamento ardente, à chama do Espírito Santo, de Pentecostes, que incendeia o espírito humano, que dá a vida, santifica, purifica (PASTOUREAU, 2017).

Do lado negativo, esse sangue é o símbolo do pecado, da imoralidade, da sujeira e da brutalidade. Tem sua origem não só em todas as passagens sobre muitos crimes contidos na Bíblia por discípulos revoltados, sem fé perante seu Deus e sem amor para com seus semelhantes, mas também no pecado original, pois alguns teólogos viram na menstruação das mulheres a continuação de um castigo imposto por Deus a Eva (HELLER, 2013).

Instigada pela serpente, Eva pegou o fruto proibido e deu a Adão. Para eles, Deus castigou-a e condenou todas as mulheres a serem manchadas de vermelho a cada mês em memória desse pecado, que representa a sujeira do corpo feminino. Em algumas representações e imagens, o anjo que expulsou Adão e Eva do Paraíso depois de terem desobedecido ao Senhor e comido do fruto proibido é um anjo vermelho, um membro da justiça angelical (PASTOUREAU, 2017).

Quanto ao lado negativo do fogo, este se manisfesta nas chamas do Inferno, que queimam, agridem, machucam. Tem um lado satânico e traidor, como a cabeleira de Judas. É um vermelho proveniente do descontrole humano, da marca, do ódio, da raiva e da morte.

Mesmo que o lugar do vermelho na vida cotidiana tenha diminuído se comparado com o lugar que ocupou na Antiguidade greco-romana e na Idade Média, ele ainda permanece 
como a cor mais forte, mais notável e a mais rica em possibilidades simbólicas (GUIMARÃES, 2004).

Do ponto de vista psicológico, o vermelho parece ser fisicamente estimulante, uma vez que cria uma impressão de força física e até mesmo de agressão, um lugar de confronto ou uma batalha. Ao optar por esse tom, a pessoa pode estar sentindo-se um pouco abaixo do normal no nível físico e sabe que o vermelho lhe dará um impulso. Ou inversamente, o indivíduo pode estar cheio de energia e feliz, por isso deseja que o mundo saiba disso. Pode também haver um desejo de autoafirmação, pois sabe que essa tonalidade causa o máximo impacto visual como um desejo de minimizar a feminilidade, independentemente do gênero, por ser esse tom representado pelo lado masculino (WRIGHT, 1999).

Está relacionado a tudo que traz a sensação de calor, pelo paralelo instantâneo traçado com as fogueiras, ou a tudo que é barulhento. Devido a sua natureza circular que se projeta e faz "sair do lugar", é um dos motivos que, do ponto de vista psicológico, causa impressão de aproximar as coisas ou diminuir os espaços (LÜSCHER, 1969).

Portanto, falar do vermelho é falar do encontro, desde tempos imemoriais, do sangue e do fogo, sendo esses dois elementos naturalmente associados ao vermelho, independentemente da cultura ou da época. No entanto, se o vínculo entre vermelho e sangue é óbvio, a associação entre vermelho e fogo não é. Na realidade, uma chama raramente é vermelha, podendo ser amarelada, azulada, alaranjada, às vezes branca, e daí por diante.

O fato de o homem sempre ter associado vermelho ao fogo deve ser pela possibilidade que essa cor trouxe: ser condecorada como um elemento tão vital quanto o sangue (PASTOUREAU, 2017). Sua domesticação pelos seres humanos constitui um dos eventos mais importantes na História da humanidade, um fato que mudou completamente as condições de existência e formou a base para o que pode ser chamado de "civilização" (PIPER, 2008).

No princípio, o homem primitivo, como conta a história, ou estava caçando e atacando ou estava sendo atacado e defendendo-se. Ora conquistava ou adquiria, ora preservava a própria existência, por isso a ações de combate e conquista estavam inteiramente representadas pela cor vermelha, e as ações de manutenção da vida, pelo seu complementar, o verde (PASTOUREAU, 2017). Dessa forma, a primazia simbólica do vermelho nas sociedades antigas é, portanto, um fato firmemente estabelecido, que existe há muito tempo, conforme exemplificam as figuras 39 e 40. 
FIGURA 39: Grande bisão vermelho de Altamira, norte da Espanha, descoberto em 1879, que data, aproximadamente, entre $15.500-13.500$ a.C.

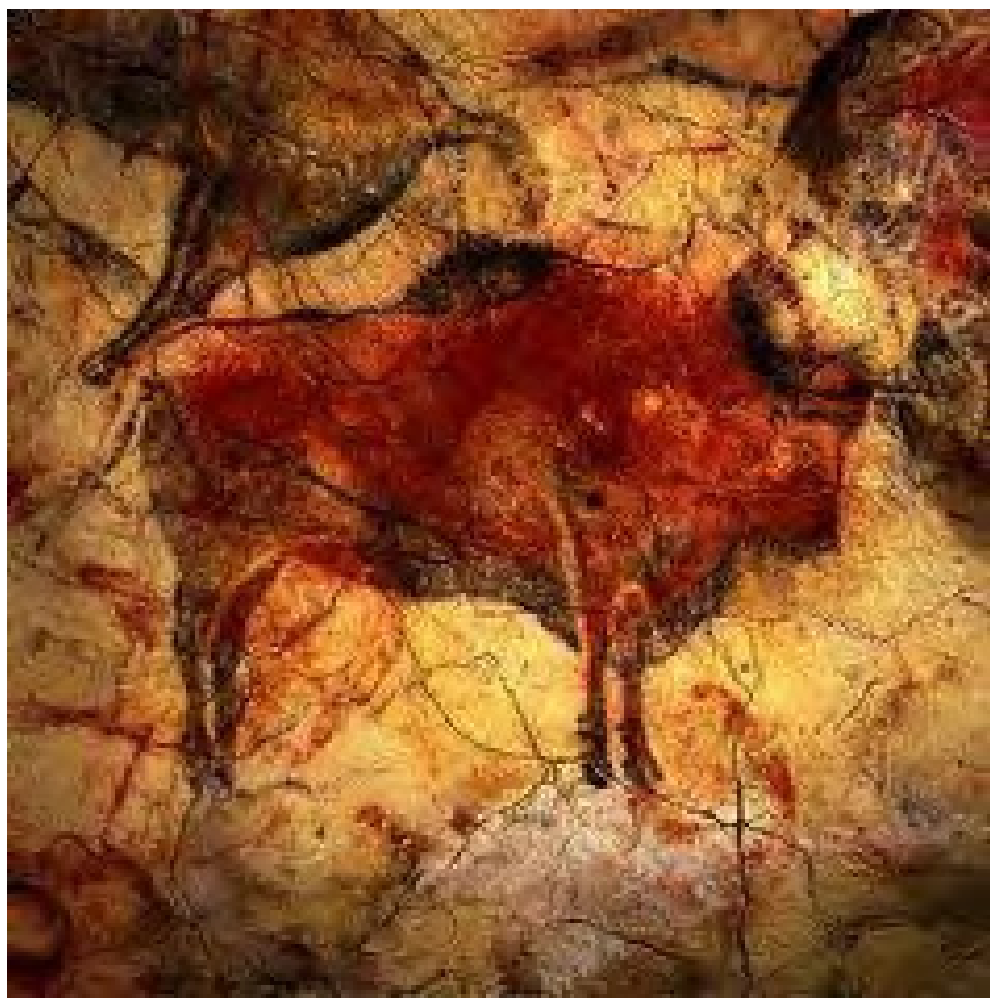

Fonte: PASTOREAU, 2017, p. 12.

FIGURA 40: Grande bisão vermelho de Altamira, norte da Espanha, descoberto em 1879 que data, aproximadamente, entre $15.500-13.500$ a.C.

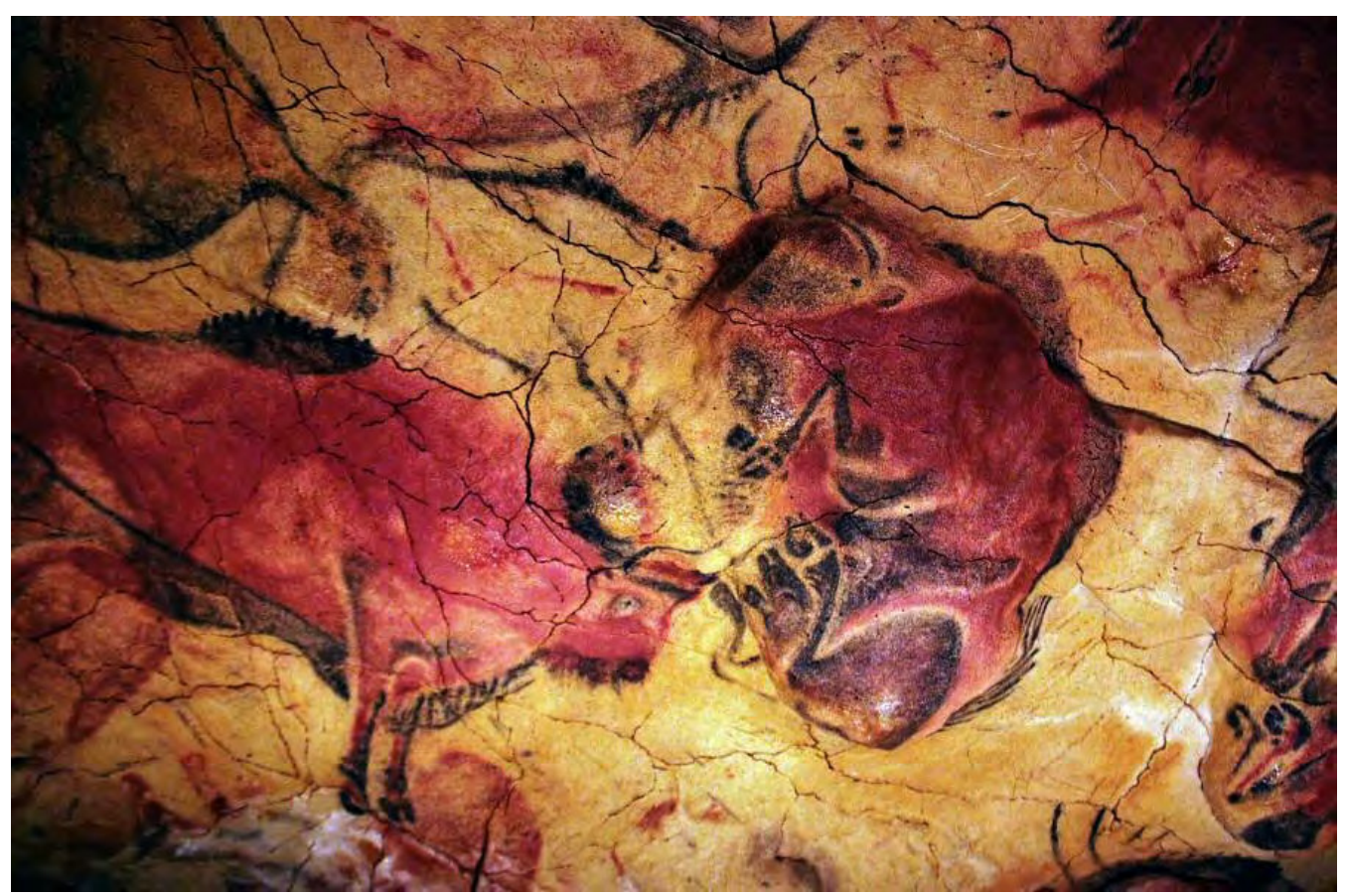

Fonte: PASTOREAU, 2017, p. 12. 
Como o vermelho propõem sempre dois lados muito fortes, o bem e o mal, simbolicamente é mais forte do que qualquer outra cor. Tanto que, por ser o vermelho essa potência, foram encontrados, em tumbas e locais de sepultamento, objetos na faixa dessa coloração. Isso porque, segundo Pastoureau (2017, p. 16),

\begin{abstract}
se pensava que essa cor tinha propriedades protetoras ou mágicas (...) Os vermelhos usados nos corpos em tempos pré-históricos cumpriam três funções: deidética, profilática e estética. Naqueles tempos remotos, homens e mulheres já estavam chamando a atenção para se protegerem e se enfeitarem de vermelho. Eles continuariam fazendo isso por um longo tempo - muito tempo.
\end{abstract}

Na cultura antiga egípcia, o lado positivo dessa cor trazia uma associação com o poder, a proteção e a glória, por isso o amuleto de jaspe vermelha, simbolizado pelas lágrimas ou sangue de Ísis, era uma proteção. Já o lado negativo estava atrelado à pele dos homens que moravam no deserto, os inimigos do povo. Ou seja, como a pele deles era avermelhada, simbolizava a agressão, crueldade e violência. Tanto que o deus Seth era associado à brutalidade, maldade e violência (WILKINSON, 2002).

$\mathrm{Na}$ cultura oriental chinesa do Yin-Yang, essa tonalidade aparece do lado Yang, força masculina, relacionado ao amarelo e ao verde, cores da potência e do poder (PASTOUREAU, 2019). Vale salientar que, nos dias de hoje, o vermelho está muito mais assossiado ao feminino do que ao masculino para muitas culturas (ELDRIDGE, 2015).

Já na cultura cristã, ele parecia tornar-se uma religião que cultuava o vermelho e o sangue. A principal razão para isso foi a representação cada vez mais frequente do Cristo crucificado e a exaltação de sua paixão com a obra do sangue sagrado se desenvolvendo como consequência. Para Pastoureau, (2017, p. 64):

\footnotetext{
Para os vários teólogos, o sangue de Jesus não era como nenhum outro. Embora o filho de Deus tenha sido feito homem, seu sangue não podia ser idêntico ao dos meros mortais. Era sangue redentor e salvador, derramado como resgate pelos pecados da humanidade. Alguns autores o descreveram como um vermelho mais claro que o sangue de homens e mulheres, necessariamente contaminado por seus pecados.
}

Desde a Antiguidade até meados do século VIII, com a fundação de Roma, aproximadamente, tingir um tecido, na maioria das vezes, consistia em substituir a cor de origem por outra situada na gama dos vermelhos. Tais iam desde os terracotas e os rosas mais pálidos até os tons de púrpura mais intensos (PASTOUREAU, 2017). A garança, que 
foi provavelmente a tintura mais antiga, mas também outros vegetais, como o quermes e certos moluscos, penetravam com facilidade e profundamente nas fibras têxteis e resistiam melhor do que as outras tinturas aos efeitos do sol, da água, das lavagens e da luz (PIPER, 2008).

Assim, tingir com essas matérias-primas permitiam também jogos de matizes e de luminosidade mais ricos do que as matérias que servem para tingir de outras cores. Por vários milênios, o tingimento dos tecidos é, sobretudo, um tingimento de vermelho. Durante o Império Carolíngio, séculos VIII a X, o imperador Carlos Magno parecia mais dedicado ao vermelho que o papa. Tanto que o seu palácio e a catedral de Aachen eram pintados nesse tom, sinalizando a todos e a Igreja quais eram os pertences do Imperador e, consequentemente, seu poder (HELLER, 2013).

Em sua coroação, no ano 800 d.C., Carlos Magno apresenta-se ao Papa Leão III vestido totalmente de vermelho (PASTOUREAU, 2017). É por isso que o manto vermelho tornou-se a representação do poder imperial para todos os seus sucessores até o final do século XVIII, herança do prestígio do roxo antigo. Essa moda de usar vermelho foi incorporada por muitos, desde os representantes dos imperadores e reis até os duques, condes, barões e senhores menores, como se observa na figura 41. 
FIGURA 41: O homem de turbante vermelho.

Portrait of a Man, Jan Van Eyck, 1433, London, National Gallery, pintura a óleo.

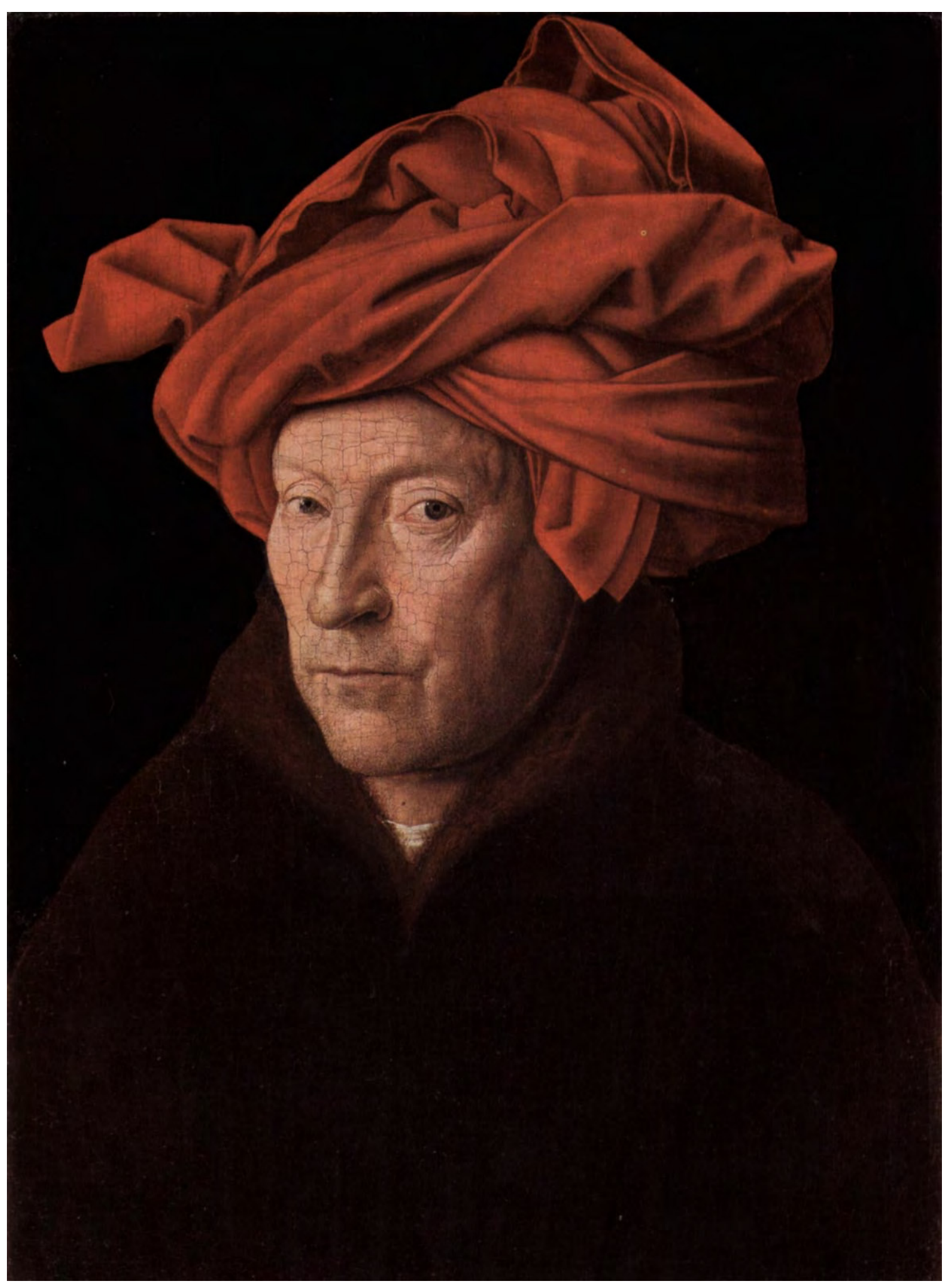

Fonte: NATIONAL GALLERY, https://www.nationalgallery.org.uk/artists/jan-van-eyck 
Trata-se de uma época em que até mesmo funcionários e cidadãos comuns apareciam vestindo roupas vermelhas. Alguns até exigiam de seus vassalos ou camponeses que produzissem desde tecidos até vitrais utilizando sementes de cochonilha, frutas e bagas nesse tom.

Isso explica por que versões da fábula Chapeuzinho Vermelho, segundo Pastoureau (2017), originalmente datando dos anos 1000, tiveram suas versões reinterpretadas em 1697 por Charles Perrault e, em1812, pelos Irmãos Grimm. Algumas interpretações podem ser traçadas a partir daí. Uma delas é que a menina, ao usar um capuz na cor vermelha, simbolicamente, antecede o fim dramático que ocorreria depois.

Do ponto de vista histórico, Chapeuzinho Vermelho aparece vestida nessa tonalidade, pois, além de o vermelho ser a cor por excelência, era costume vestir as crianças nesse tom porque podiam ser visualizadas a grandes distâncias. Do ponto de vista litúrgico, como o conto se passa no dia em que ela nasceu, em dia de Pentecostes, daí o uso dessa coloração. Pela psicanálise, apesar de a interpretação ser contraditória, pois não é certo que o vermelho na Idade Média estivesse relacionado a sentimentos amorosos ou carnais, o uso da capa, supostamente, tinha conotações sexuais, já que a menina desejava se deitar com o lobo. Já pela semiótica, o vermelho da menina, o preto do lobo e branco da manteiga compõem a tríade de cores tradicionais (PASTOUREAU, 2017). Essas interpretações, sejam no âmbito simbólico, histórico, litúrgico, psicanalítico ou semiótico, caminharam ao lado do fato de que a menina, ao visitar a avó, foi vestida com sua roupa mais bonita, como se vê na figura 42. 
FIGURA 42: Chapeuzinho Vermelho: ilustração datada de 1875, feita por Walter Crane, representando o vermelho da roupa, o preto do lobo e o branco da manteiga que ela levava para a vovó.

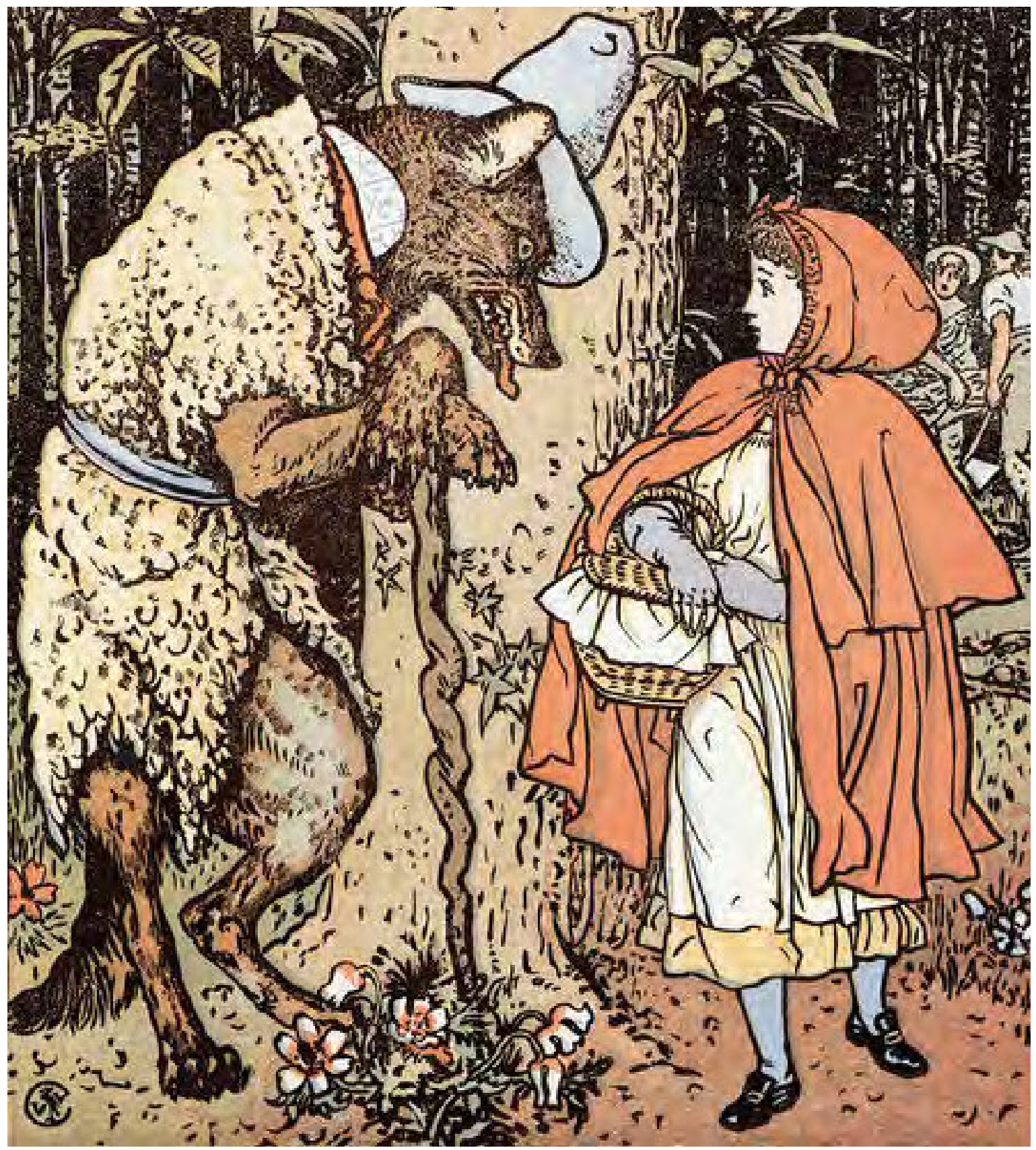

Fonte: PASTOUREAU, 2017, p. 136.

De modo geral, um traje vermelho nunca era neutro e quase sempre estava associado ao amor, a paixão, os rituais e as festas. Tanto que a figura do Papai Noel, associado e herdeiro de São Nicolau, protetor das crianças, também usava trajes nessa tonalidade (PASTOUREAU, 2017). A ideia do Papai Noel provém de São Nicolau, bispo de Myra, na Anatólia, que executou inúmeros milagres e era considerado protetor das crianças, a quem, 
no dia 6 de dezembro, distribuía presentes. Desde a Idade Média, ele é representado vestido de vermelho, conforme se verifica na figura 43 .

FIGURA 43: Papai Noel veste vermelho a exemplo de São Nicolau.

Poster americano de John D. Kelley publicado na revista St. Nicholas, 1825, Nova York.

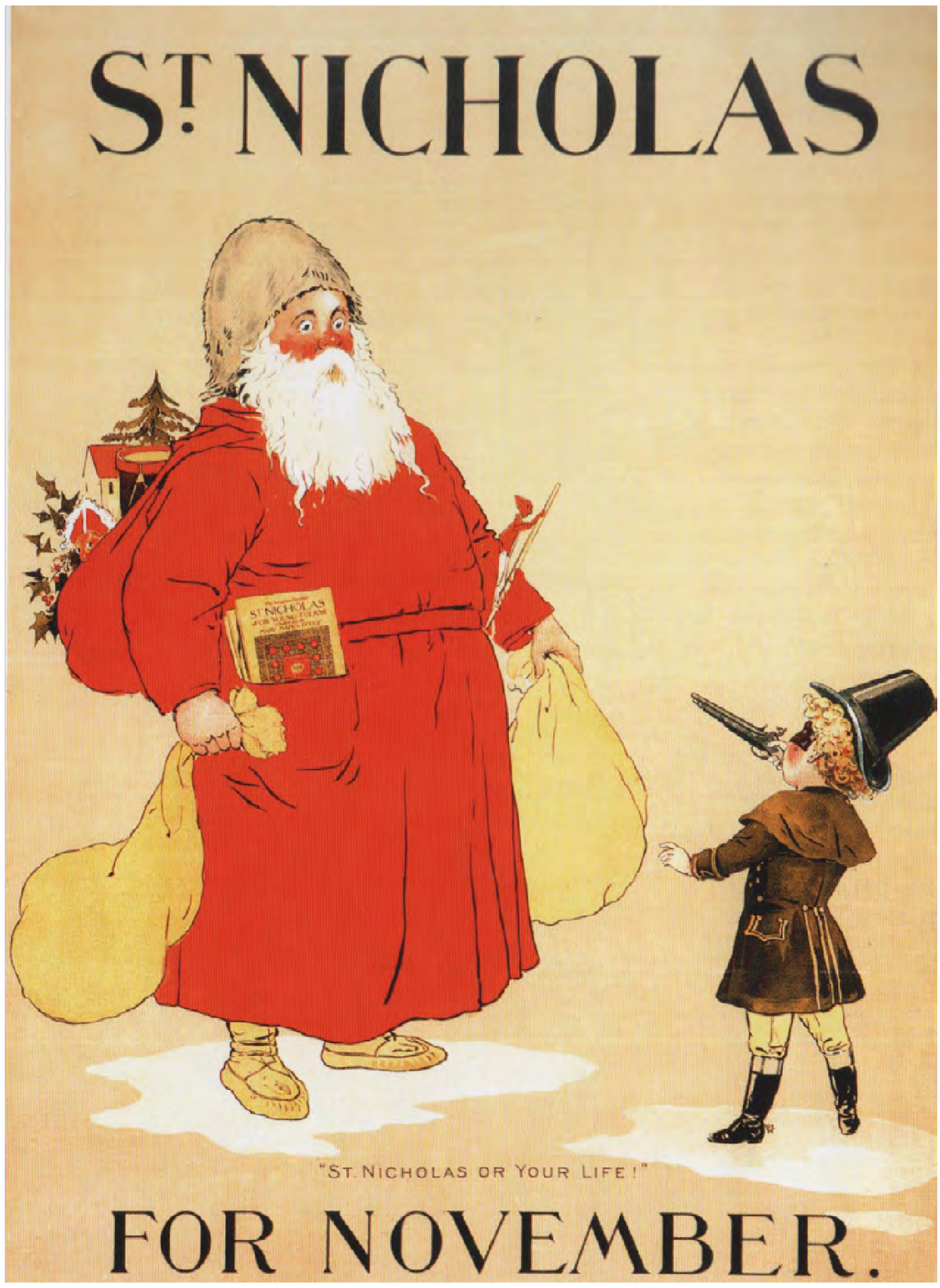

Fonte: PASTOUREAU, 2017, p. 183. 
De maneira mais geral, a Idade Média atribuiu maior poder simbólico ao vermelho do que a qualquer outra cor e prestou atenção a todas as circunstâncias em que ele entrou em cena (PASTOUREAU, 2017). Sendo assim, quando alguém manifestava seu poder, seja ao proibir, comandar ou até mesmo julgar, lá estava o vermelho como um atributo. É o caso, por exemplo, dos juízes, que estavam inevitavelmente vestidos dessa coloração para fazer valer a sua função de declarar as leis e os julgamentos. Com isso, esse tom se tornou a cor simbólica da justiça.

Até mesmo a bandeira do Sacro Império Romano Germânico, no início lisa, passou a ser, a partir do século XII, vermelha com uma cruz branca, e os brasões também receberam essa tonalidade. A prática das touradas adotadas nesse período usava o lenço vermelho com o intuito de conotar a dominação e o poder do homem sobre o animal (PIPER, 2008).

Na virada do século XII para o XIII, o sangue de Cristo que era ofertado na comunhão foi representado pelo vinho tinto. E mesmo essa bebida sendo misturada com água no cálice, simbolicamente, era vermelho figurando a imagem de ser o sangue de Cristo ofertado aos homens. Nesse mesmo século, os cardeais, que propagavam a fé em nome da Igreja, tiveram o apoio do Papa Inocêncio IV, em 1245, com o Primeiro Concílio de Lyon. Para esses cardeais, foi destinado o uso específico de um chapéu da cor vermelha para distingui-los dos outros abades. Mais tarde, além do chapéu, eles passaram a usar, também, durante os principais feriados da Igreja, manto também vermelho, reafirmando, assim, sua condição perante a sociedade (PASTOUREAU, 2017).

O grande triunfo do vermelho medieval foi ter representado tanto o lado masculino como o lado feminino. Se essa tonalidade foi eleita pelos guerreiros, caçadores, juízes, reis, príncipes, teólogos e pela aristocracia de modo geral, foi também a cor das damas e das senhoras aristocratas (ELDRIDGE, 2015). Era a cor símbolo do amor, místico ou carnal, associado tanto à paixão por Cristo quanto ao amor entre os humanos e as paixões mais devassadoras.

O vermelho era a cor símbolo da magnificência, da suntuosidade, da formosura, da beleza, da graça e da grandiosidade. Uma mulher bonita tinha que ter, pelos conceitos da época medieval, uma pele clara e os lábios e as bochechas avermelhadas. Tanto que vermelho e branco foram a combinação de cores mais potente para a sensibilidade medieval (ELDRIDGE, 2015), como se oberva nas figuras 44 e 45. 
FIGURA 44: Retrato de Susanna Lunden: vermelho destacando a beleza feminina. Portrait of Susanna Lunden, Peter Paul Rubens, 1625, London, National Gallery.

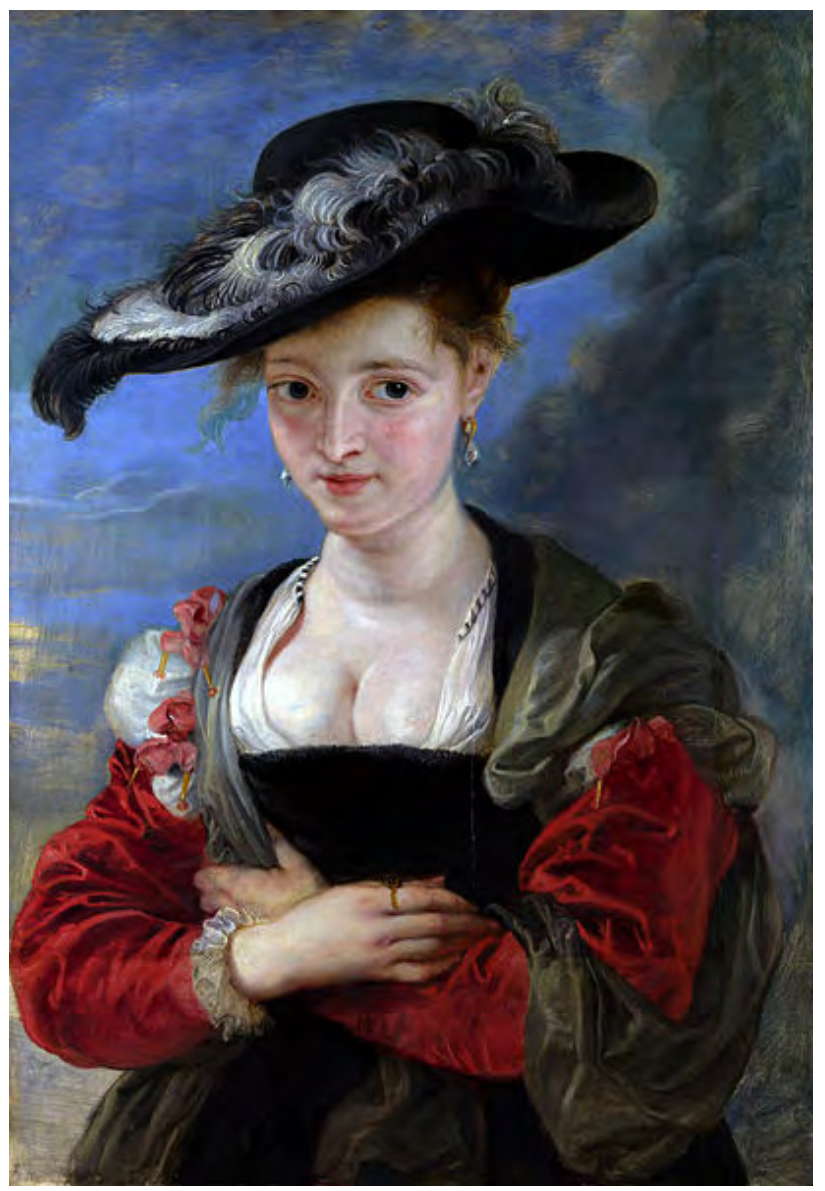

Fonte: NATIONAL GALLERY, https://www.nationalgallery.org.uk/paintings/peter-paul-rubensportrait-of-susanna-lunden-le-chapeau-de-paille.

FIGURA 45: Close dado no rosto de Susanna Lunden para exaltar o rubor da face.

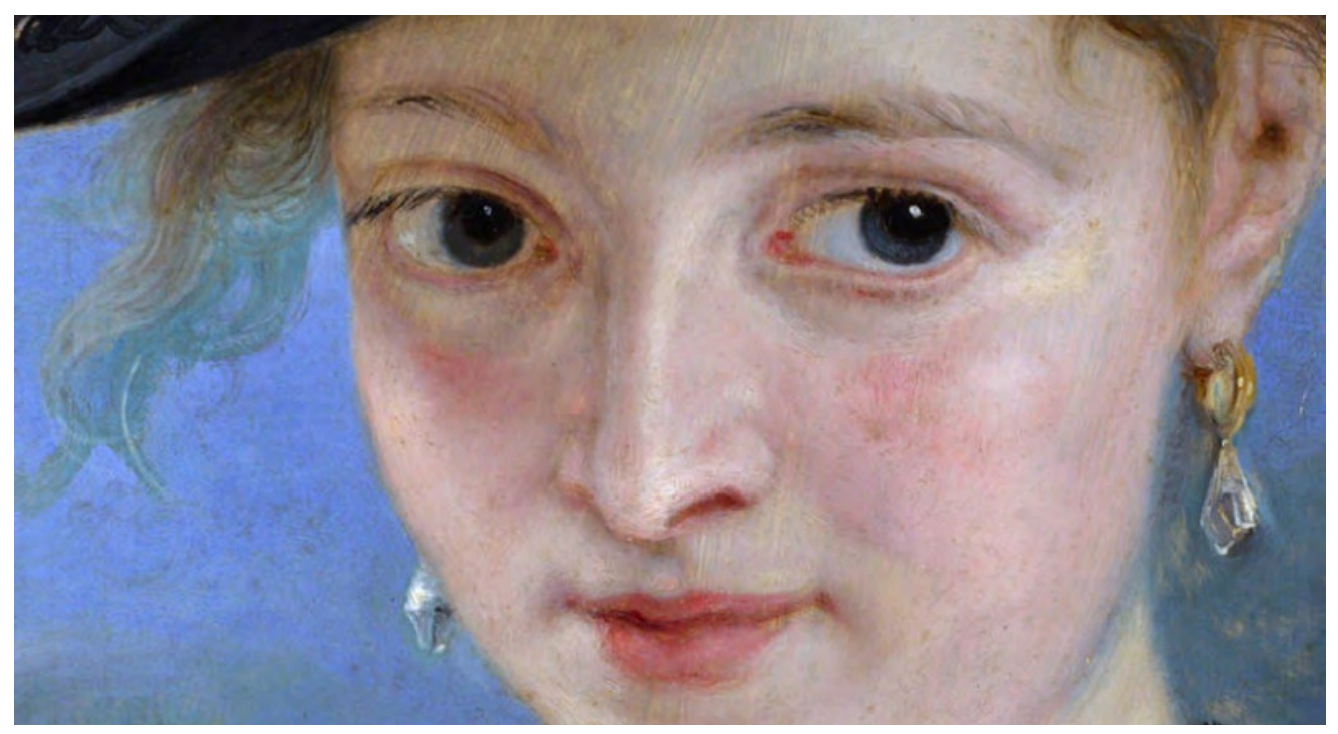

Fonte: NATIONAL GALLERY, https://www.nationalgallery.org.uk/paintings/peter-paul-rubensportrait-of-susanna-lunden-le-chapeau-de-paille 
Convém destacar, porém, que esse uso foi condenado pelos teólogos e moralizadores porque eles acreditavam que tal comportamento feminino ia contra à beleza natural feita por Deus, e os lábios pintados conotavam, para eles, uma bruxa ou uma prostituta.

Todo o prestígio do vermelho, que foi a cor mais adorada e celebrada por anos, começou ao longo do século XII, a ser confrontada por uma nova tonalidade que surgiu, o azul (HELLER, 2013). Apesar do aumento de tons de azul em roupas reais e principescas ao longo do século XIII, o gosto por belos tecidos vermelhos não desapareceu. Com isso, a competição entre as duas cores estimulou a demanda e a produção.

Entretanto, pouco a pouco, fatos que ocorrem na sociedade contribuíram para o declínio do vermelho ainda nesse século. Foi a partir desse momento que apareceu, em textos e imagens, a figura de Judas, que passou a ser gradativamente representada com cabelos e barba ruivas. Dois séculos depois, no início do período moderno, o semblante ruivo de Judas havia-se tornado sua característica mais comum, pois era associado à mentira e à traição (PASTOUREAU, 2017).

Ao longo do século XIII, a Igreja, ao formular a lista dos sete pecados capitais, associou o vermelho a quatro deles: orgulho, ira, luxúria e gula. Avareza ficou com o verde e a inveja com o amarelo. A preguiça, dependendo do autor, oscilou entre vermelho e o amarelo, mas nunca nenhum deles foi associado ao azul. Ademais, o vermelho era mais comumente associado a tudo o que evocava violência, devassidão e assassinato (PASTOUREAU, 2017).

No final da Idade Média, contudo, o vermelho perdeu sua posição de cor preferida e entrou em declínio, já que começou a ser contestado pela sociedade. Essa queda não se deu pela mudança de sensibilidade da época, e sim porque, no período feudal, outras tonalidades e nuances, ao entrarem na vida das pessoas, roubaram a cena e deixaram o vermelho para segundo plano.

No simbolismo e na hierarquia das cores, essa cor constituía uma fonte rica para identificar os sistemas de valores subjacentes aos códigos cromáticos do final da Idade Média. Dentro da heráldica, o vermelho foi o mais dominante nos séculos XIV e XV. Por essa razão, essa tonalidade geralmente ocupou o primeiro lugar entre as cores por ser um sinal de nobreza, beleza e coragem. O vermelho do poder, o vermelho do pecado, o vermelho do castigo e o vermelho do sangue derramado passou a ser encontrado simbolicamente até o período moderno (PASTOUREAU, 2017), como se observa nas figuras 46 e 47. 
FIGURA 46: Onipresença do vermelho na heráldica nos trajes dos cavaleiros.

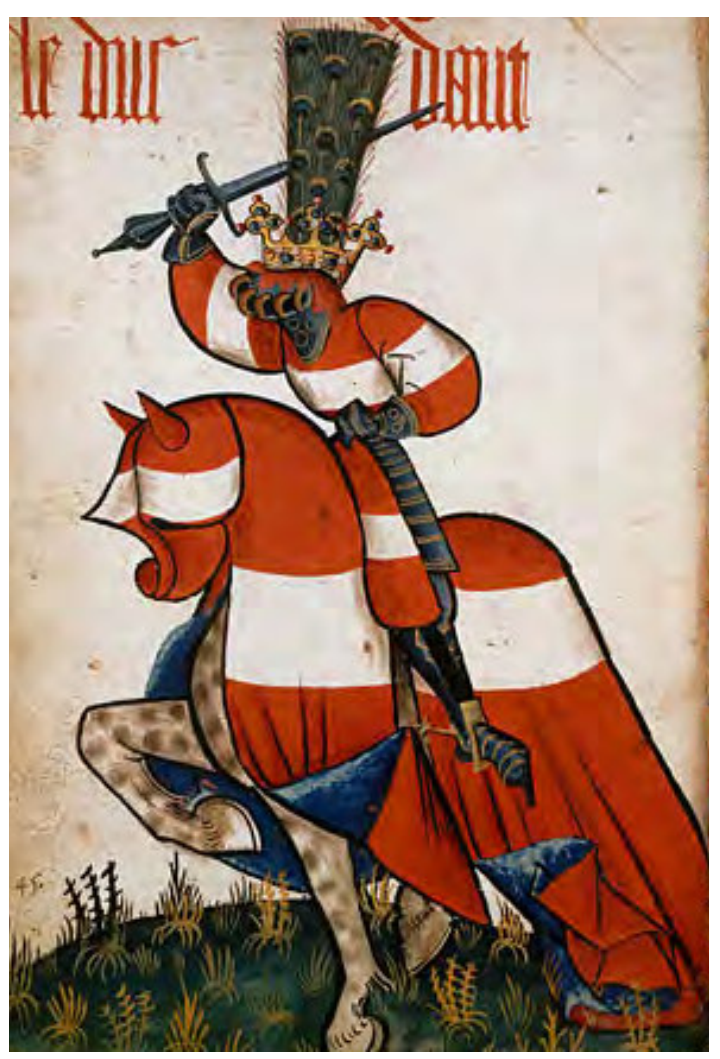

Fonte: BIBLIOTHÈQUE DE L'ARSENAL, https://www.bnf.fr/en/arsenal

FIGURA 47: O vermelho presente nos brasões.

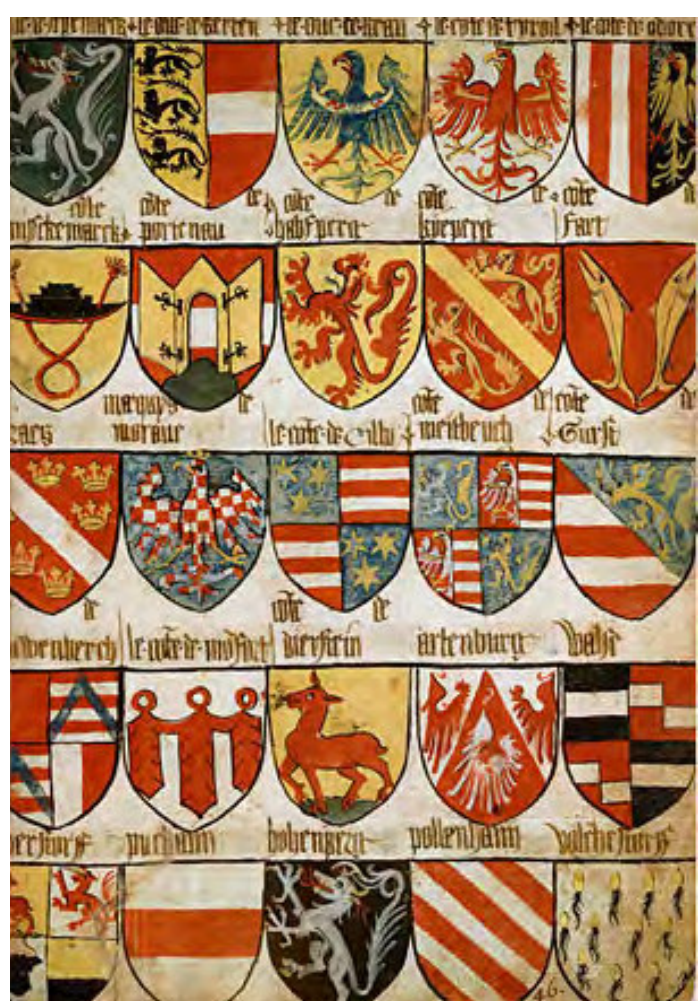

Fonte: BIBLIOTHĖQUE DE L'ARSENAL, https://www.bnf.fr/en/arsenal 
Dessa forma, essa nuance predominou na Idade Média como a cor do poder, símbolo de uma atitude destemida e gloriosa e se estendeu até o período moderno. Até o final do século XV, era tida como a mais nobre, protegida por leis sumptuárias e permitida para uma parcela restrita da população que fazia parte da aristocracia, pois havia preços elevados aos corantes vermelhos (HELLER, 2013).

Por ser a cor favorita, houve uma predominância por coisas nesse tom, como tecidos, roupas, artigos de luxo, artigos de decoração, jóias, acessórios, pedras preciosas, flores, mobiliário, emblemas e brasões. A proliferação de artigos nesse tom, com o descobrimento da América no final do século XV, era possível também obter essa nuance proveniente das cochonilhas americanas (HELLER, 2013). A partir desse momento, os espanhóis importavam os cactos existentes no México e obtinham essa matéria corante com seu vermelho intenso, vivo, saturado. De acordo com Pastoureau (2017, p.79,):

\begin{abstract}
Até muito tarde, às vezes muito além da Idade Média, o vermelho continuava sendo a cor favorita da aristocracia no Ocidente. Isso foi assim não apenas entre as mulheres nobres, que encontraram nela a cor da beleza e do amor, mas também entre os homens, porque simbolizava simultaneamente coragem, poder e glória. Como uma cor eminentemente feminina em muitas áreas, o vermelho também era uma cor masculina, usada na guerra, em torneios, para a caça: três terrenos onde era necessário fazer uma aparição, ser visto, reconhecido, temido e admirado. Qual a melhor maneira de conseguir isso do que vestir de vermelho? De fato, a longo prazo, essa cor - já a cor do deus Marte dos romanos - vestia muitos soldados (...).
\end{abstract}

Assim, até o final da Idade Média, vários eram os setores que faziam uso do vermelho, tanto que os cardeais e o papa também estavam trajados com esse tom, por vezes associado ao branco. Representava o sangue de Cristo e foi para a Igreja Universal, com uma faixa vermelha e uma cruz branca, o seu emblema. Todavia, nos séculos XVI e XVII, pinturas e gravuras já representam o papa de branco e somente a capa permaneceu vermelha.

Esse branco papal veio ao encontro dos preceitos defendidos pela Reforma Protestante e posteriormente pela Contrarreforma, que declararam guerra às cores (PASTOUREAU, 2011). Devido a isso, a principal opção cromática não era mais a vermelha, considerada uma tonalidade muito voluptuosa, obscena e indigna. Gradualmente, em todos os domínios, a Reforma deu prioridade ao eixo acromático, considerado mais digno do que as cores implantadas pela Igreja e utilizadas nos rituais.

A cromofobia protestante impôs restrições tanto às vestimentas como ao uso de cores no templo. Isso porque, para os grandes reformadores, isso era excessivo e deveria ser 
reduzido ou até mesmo suprimido, pois denunciava muita riqueza. Eles equiparavam os templos e os palácios a teatros e circos, argumentando que o excesso de cromatismo falsificava o culto (PASTOUREAU, 2011). Por esse motivo, o vermelho foi alvo das maiores críticas por ser considerada a representação máxima do luxo, do pecado e da imposição humana perante a palavra de Deus.

O diabo, em muitos domínios, também manteve laços obrigatórios com essa tonalidade (assim como com o preto), por isso, pouco a pouco, o Papa, que, em épocas anteriores, estava trajado predominantemente desse tom, passou a adotar o branco como a tonalidade mais adequada. Além disso, as leis sumptuárias colaboraram para esse declínio, já que era caro, custoso e até mesmo ostensivo estar trajado com essa coloração.

Até o final do século XVI, o ódio pelo vermelho parece ter atingido seu ápice, pois, naquele período, passou-se a valorizar as cores da natureza, ou seja, as que foram feitas pelo Criador. Assim, tons de azul que remetiam ao céu e os tons de verde que dirigiam as plantas passaram a ser consideradas as tonalidades mais belas (PASTOUREAU, 2017).

Outro fato que colaborou para a debilidade dessa coloração foram as descobertas de Isaac Newton, que tirou o vermelho da posição central e colocou-o no final do espectro (PEDROSA, 2009). Assim, ao ser considerado uma cor marginal, essa tonalidade perdeu seu lugar central ocupado durante toda Idade Média.

Ao longo dos séculos XVI e XVII, as novas classificações provenientes do universo químico e físico, que às vezes faziam do vermelho uma cor principal e outras vezes um tom marginal, também estiveram presentes no âmbito social. No plano simbólico, manteve seu lugar de prestígio com todo seu poder. Assim, brilho, amor, glória e beleza ainda estavam associados a essa tonalidade.

Com as transformações que ocorreram na sociedade no século XVIII, devido às Guerras Napoleônicas e a Revolução Francesa, o simbolismo do vermelho ganhou um novo significado. Ou seja, esse tom passou a ser uma cor política, assumindo, no século XIX, uma dimensão internacional. Nesse período, muitos uniformes militares eram vermelhos, como explicita Pastoureau (2017, p. 163):

Em muitas áreas, a palavra "vermelho" se tornou uma espécie de sinônimo de adjetivos como "socialista", "comunista", "extremista" e "revolucionário". Nunca, no curso da história, uma cor incorporou um movimento ideológico, nem mesmo na Roma imperial ou no Bizâncio medieval, quando o azul e o verde simbolizavam duas facções políticas particularmente barulhentas. 
Já no vestuário papal, desde meados do século XIX, essa cor, praticamente, despareceu, ficando relegada quase somente aos calçados. Todavia, foi a cor das cerimônias oficiais presente no antigo Senado Romano, na Cúria papal no final da Idade Média e durante o Império Napoleônico, que buscaram nesse tom uma espécie de majestade (PASTOUREAU, 2017). Tanto que, em cerimônias de nomeação ou inauguração, ao receber chefes de estado, por exemplo, corta-se uma fita vermelha ou lança-se um tapete vermelho.

Adentrando o século XX, no universo do marketing e na publicidade, essa tonalidade é usada para chamar a atenção, pois simboliza a cor do dinamismo da propaganda (GUIMARÃES, 2004). O vermelho é a cor veloz, que atrai a atenção e é usado para acentuar e destacar. Também é o tom usado para agradar ou encantar, porque permaneceu como sendo a representação da sedução, associada ao prazer, especialmente ao prazer sensual (LÜSCHER, 1969).

É uma cor dinâmica, que sai do lugar, que se mexe e não se contém "em si”, aguça, propõe novos desafios. É fácil de ser recordada, pois, como apresenta o maior comprimento de onda, é retratada levemente pelas lentes do olho, cujo foco está atrás da retina. Isso obriga o cristalino a uma maior curvatura e, ao se tornar mais convexo, consegue focar melhor a cor. Esse movimento, ao "empurrar a cor para frente", provoca uma visualização com maior impacto visual e emocional, o que acentua melhor a forma (GUIMARÃES, 2004).

Sendo assim, por exigir tal ajuste nos olhos, o vermelho parece estar mais próximo do que é, por isso é tão frequentemente usado quando o impacto visual é importante. As sinalizações são os exemplos mais óbvio de que o vermelho chama atenção. É o caso dos semáforos, que possuem essa tonalidade comunicando "pare", ou os faróis dos carros, os quais, quando brecam, acendem essa coloração mostrando essa mensagem para quem vem atrás.

Com o vermelho os professores sinalizam os erros nas provas ao corrigi-las para chamar a atenção do aluno. Já os medicamentos que contém a tarja vermelha indicam que a dosagem seja respeitada, assim como as bandeiras vermelhas apontam perigo e orientam as multidões a saírem daquele lugar. Nos laços e nas fitas, a cor vermelha é a tonalidade usada para embrulhos e para os presentes, portanto, nos dias de hoje, é uma cor que permeia vários universos e comunica muitas mensagens. 


\subsubsection{Violeta | Púrpura}

FIGURA 48: Concha contendo o pigmento púrpura. Imagem meramente ilustrativa para representar a cor púrpura.

Fonte: THE HARVARD ART MUSEUMS' FORBES PIGMENT COLLECTION, 2017, p. 140. 
A palavra violeta é, em latim, o diminutivo de viula e conota uma pequena flor. Já a origem da palavra púrpura também provém do latim, purpùra, e simboliza a dignidade real, principal, soberana (FARINA, 1982). Na Antiguidade, foi eleita a cor dos regentes e da autoridade. Segundo Heller (2013, p. 193):

É digno de nota observar a proximidade entre os termos "violeta" e
"violência". Em italiano, o nome da flor é "viola" - contudo, "violenza" é
"violência" e "violare" corresponde ao verbo violar. Tanto na Inglaterra
como na França, "violência" se diz "violence", e em ambas temos também
"violation", "violação". É historicamente plausível que essa ligação tenha
surgido em virtude do púrpura, pois o violeta púrpura era na Antiguidade a
cor dos governantes. Assim, essa cor, no tom púrpura, tornou-se a cor do
poder. E o nome da violeta transformou-se no nome da violência.

Essa tonalidade é a primeira cor do espectro visível, com o menor comprimento de onda, e por isso traz consigo a passividade e a tolerância. É a cor que antecede os raios ultravioletas, que não são visíveis ao olho humano em condições normais, marcando a fronteira entre o visível e o invisível.

Para formar esse tom, é preciso misturar proporções de azul com vermelho e, apesar de o resultado dessa mistura ser uma outra nuance, independentemente das suas origens, consegue concentrar em si os aspectos de ambos. Metaforicamente, o violeta apresenta o encontro de forças opostas: com o feminino, delicado e espiritual, representado pelo azul, e com o masculino, impulsivo e sensual, representado pelo vermelho, ou seja, da passividade com a atividade, do concêntrico com o excêntrico (HELLER, 2013).

Violeta é a cor dos sentimentos ambíguos, por isso, ou as pessoas apresentam afinidades com essa coloração estabelecendo com ela relações positivas, ou a recusam e não apresentam quase nenhuma empatia por ela (LÜSCHER, 1969).

Simbolicamente é a cor da mutação entre "os mundos", da magia, do fascínio, do deslumbre e do oculto. Tanto que, por ser dependente da luz e dos reflexos por ela produzidos, muitos acreditavam que era a cor símbolo da eternidade. Para Lüscher (1969, p. 67):

De certo modo, isto é encantamento, sonho tornado realidade, estado mágico, feérico, onde os desejos se realizam - de forma que a pessoa que prefere o violeta quer alcançar uma relação "mágica". Não apenas ela quer envolver-se de atração, mas, ao mesmo tempo, quer encantar e deleitar os outros, exercer fascinação sobre eles, porque, embora se trate de identificação mágica, ainda existe a distinção entre sujeito e objeto. 
Pela simbologia negativa, a cor violeta foi, durante muito tempo, atrelada à "tristeza, à renúncia, aos maus presságios e até mesmo à traição, daí ser considerada a cor de Canelão, o traidor da Chanson de Roland" (PASTOUREAU, 2011, p. 104). Ademais, por ser, junto com o lilás, as cores mais raras da natureza, muitas pessoas associam esse tom a uma "cor artificial", pois quase nada em sua forma originária é dessa tonalidade.

Do ponto de vista psicológico, essa tonalidade traz uma conjunção mística e um alto grau de sensibilidade e encantamento que leva a uma parte específica da psique humana. Isso complementa a integração entre sujeito e objeto (WRIGHT, 1999). Essa cor relacionase com a mente superior e com o espírito. Por esse motivo, no Oriente, o violeta é frequentemente atrelado ao sétimo chakra - o nível mais alto de evolução espiritual que está conectado à glândula pineal também conhecida como o local da alma (HELLER, 2013).

$\mathrm{O}$ violeta é uma cor ligada à introversão e geralmente indica que quem a usa prefere ficar sozinho, em contemplação pacífica. Ele fornece uma espécie de barreira que protestará contra demandas insensíveis ou impensadas (BIRREN, 1961).

Conta a lenda que essa nuance foi descoberta por marinheiros fenícios que, ao tentar realizar suas refeições extraindo um molusco de sua concha, o murex, notaram que seus dedos ficavam tingidos de tons de vermelho vivo e intenso (PIPER, 2008). Assim, por volta do século XVI a.C., os fenícios descobriram como realizar tingimentos com a cor púrpura (PASTOUREAU, 2017).

A partir daí, esses moluscos começaram a ser apanhados para serem extraídos deles um muco incolor que eles secretavam. Entretanto, as condições de colheita eram difíceis, pois na primavera, período reprodutivo, o suco perdia seu poder de coloração e, no verão, os moluscos se escondiam em águas profundas, areia ou debaixo de rochas para fugir do calor. Por esse motivo, a pesca só podia ocorrer no período entre outono e inverno.

Colhidos no mar, perto da costa nas rochas submersas, os moluscos precisavam ser capturados e mantidos vivos, porque, quando morriam, liberavam seu suco. O suco era produzido por uma pequena glândula que tinha que ser cuidadosamente extraída da casca sem danificá-la. Uma vez coletado, esse sumo passava por vários procedimentos, motivo pelo qual o custo para obtenção dessa tonalidade era tão alto (PIPER, 2008).

Inicialmente, os moluscos eram macerados com sal e ficavam em repouso para produzirem mais muco. Depois iam para a fervura e lá permaneciam por dias no cozimento. Devido a isso, o odor que liberavam nesse procedimento era incômodo para quem tivesse por perto. Finalizada a fervura, eles iam para uma etapa conhecida como redutina, que 
reduzia o volume inicial em $80 \%$ a menos. Em seguida, iam para a filtragem onde se extraíam o líquido que seria usado como corante (PASTOUREAU, 2017).

Esse líquido final tinha uma coloração amarelada. Os tecidos eram tingidos com esse suco e, ao secar ao sol com o passar dos dias, ia pouco a pouco aparecendo a cor violácea. Mas os resultados obtidos também diferiram amplamente de acordo com a natureza do marisco, sendo que "do caramujo Morex Trunculus obtinha-se um violeta avermelhado; do Morex brandaris, o púrpura mais caro, o púrpura violeta escuro" (HELLER, 2013, p. 195). A figura 49 ilustra alguns tipos de moluscos e as cores que surgem como resultado de cada tipo.

FIGURA 49: Tecidos tingindos de diferentes espécies de moluscos.

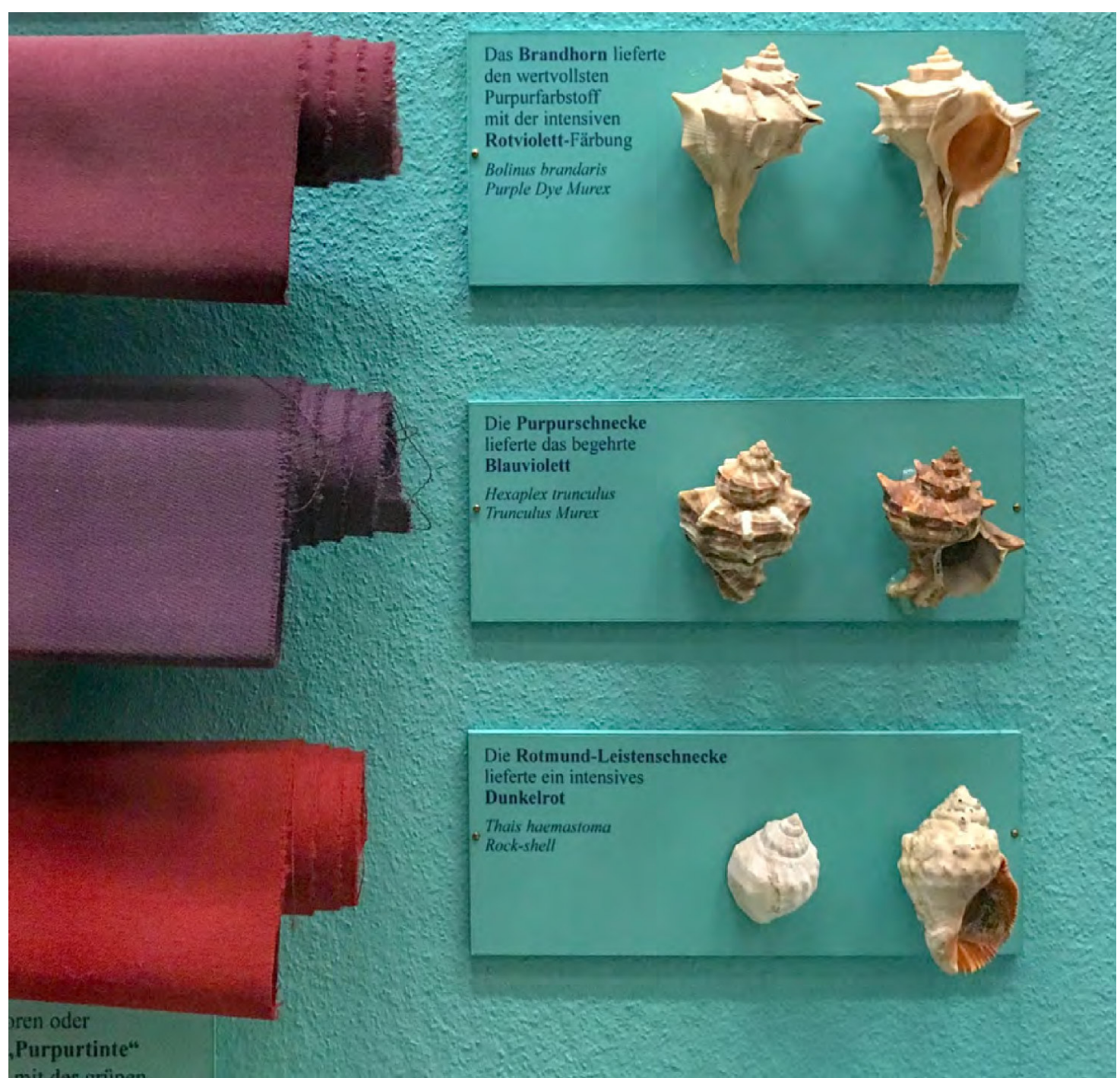

Fonte: WIKIPEDIA,

https://en.wikipedia.org/wiki/Tyrian_purple\#/media/File:Purple_Purpur_(retouched).jpg 
Outros fatores que interferiam no resultado era "o tempo da colheita, a possível mistura de sucos, a exposição à luz, a experiência dos tintureiros, a natureza dos têxteis e a natureza dos mordentes utilizados" (PASTOUREAU, 2017, p. 84). Os resultados também dependiam dos tons e efeitos de cores desejados que variavam entre vermelho, rosa, malva, roxo e preto.

Com o passar do tempo, os fenícios permanecem produzindo e usando essa coloração, mas os romanos, pouco a pouco, alteraram seus gostos e valores. Muito disso está atrelado ao alto custo para a obtenção desse tom e, também, porque começavam a ter resultados muito interessantes com o tingimento em vermelho provenientes de outros materiais (HELLER, 2013).

Séculos se passarm e atualmente, tons de violeta aparecem no design e na moda com mais frequência se comparado aos períodos anteriores. Todavia, seu uso ainda encontra barreiras, pois para muitos, quando fabricados pelo homem, podem chegar a ser desagradáveis e forçados. Como esse tom é raro na natureza, quem quer chamar a atenção deve usar essa tonalidade (GOETHE, 2011). 


\subsubsection{Azul}

FIGURA 50: Lapiz Lazuli. Encontrado somente no Afeganistão, o azul é extraído para produzir ultramarino. Figura meramente ilustrativa para representar a cor azul.

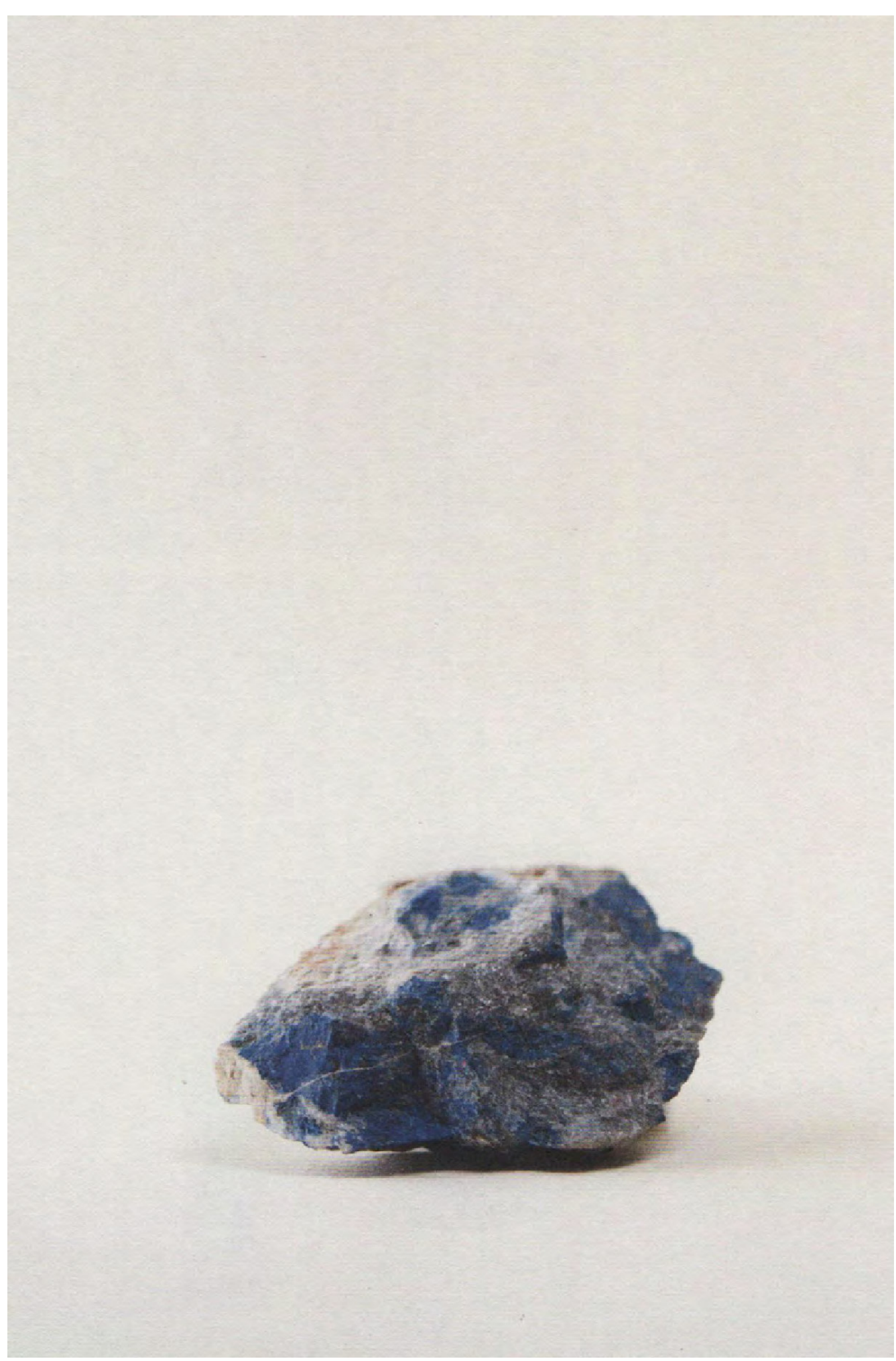

Fonte: THE HARVARD ART MUSEUMS' FORBES PIGMENT COLLECTION, 2017, p. 116. 
A palavra azul deriva do árabe e do persa, lázúrd, lazaward, e conota uma sensação de um movimento para o infinito, para o imensurável, para o incalculado (FARINA, 1982). É uma das primeiras cores do espectro visível, com menor comprimento de onda, e traz consigo a tranquilidade, o contentamento, a harmonia e o acordo. Essa tonalidade é, nos dias de hoje, eleita no ocidente como a preferida quando o assunto é cor (HELLER, 2013).

Enquanto simbologia, o azul representa a profundidade de sentimentos, os laços com os quais a pessoa se conecta, a unificação pacífica do ser. Essa tonalidade, como sensibilidade tranquila, é um requisito prévio para a empatia, para a experiência estética e o caminho para a consciência meditativa (LÜSCHER, 1969).

Metaforicamente, a cor azul representa o infinito da eternidade, a percepção da liberdade que propõem a calma e a tradição dos valores duradouros. Ele evoca atualmente o céu, o mar, a tranquilidade e o infinito. É leve, faz sonhar e é menos sublinhado durante a história em relação a outras cores. Esse tom desperta a concordância e a conformidade, não sendo forte, impetuoso e transgressor. É a cor que apazigua, gera conforto, acalma e estimula a amizade, por isso foi a cor eleita por algumas organizações mundiais como a ONU e a UNESCO, por ser considerada uma cor apartidária que remete à paz e à proximidade (PASTOUREAU, 1997).

A simbologia negativa frequentemente atribuída a essa tonalidade reside no fato de ela representar o sentimentalismo, a sensibilidade e até melancolia. Daí por que o blues, estrutura musical de origem afro-americano, recebeu essa denominação por interpretar estados de espíritos mais nostálgicos e saudosos. Segundo Fraser (2012, p. 24):

Dizem que o azul - cor do céu e do mar, vastas extensões que oferecem uma percepção de liberdade e perspectiva - acalma as pessoas. Contudo, também se diz que é uma cor "fria" e mesmo solitária. A experiência "mais azul" seria estar em um barquinho no meio do mar contemplando o céu. Liberdade ou serenidade ou fria solidão? Tudo depende.

Psicologicamente, é a cor do intelecto e é considerado o redutor da pressão arterial, por isso é tido como um calmante que estimula a reflexão. A natureza usa-o com abundância - no céu e no mar - mas isso é em um sentido reflexivo, já que nem o céu nem a água contêm qualquer cor. Tons mais claros indicam um humor ponderado e um desejo por gentileza, enquanto tons mais escuros de azul trazem a eficiência e a confiabilidade (WRIGHT, 1999).

Na psicologia, ele representa a vontade por serenidade emocional e a necessidade de paz. Quando isso não ocorre, pode desencadear aspectos perturbadores ligados à ternura, ao 
amor e ao afeto íntimo nos relacionamentos. Fisiologicamente, está conectado à vontade de repouso e de recuperação. Para Lüscher (1969, p. 58):

\begin{abstract}
Quando se escolhe o azul para a primeira posição, há uma necessidade de tranquilidade emocional, de paz, de harmonia e contentamento ou há necessidade fisiológica de descanso, de repouso e de oportunidade para recuperação. Quem quer que favoreça o azul deseja um ambiente calmo e organizado, livre de agitações e perturbações, onde os acontecimentos se desenrolam e desenvolvem suavemente, dentro de padrões mais ou menos tradicionais.
\end{abstract}

Em algumas mitologias, o azul representa a Mãe Terra, Gea, por ser a verdade, a segurança, o cuidado e a tenacidade (WILKINSON, 2002). É a concretização fortuita dos mais altos ideais de unidade, de estar em harmonia, de ter consistência e resistência.

Na História da humanidade, desde tempos mais remotos até a alta Idade Média feudal, o azul quase não teve lugar, apesar de estar tão presente na Natureza, devido à interface com a abóboda celeste, mesmo que de forma cognitiva (PEDROSA, 2009). No Paleolítico, com as primeiras pinturas murais, esse tom quase não esteve presente. E mesmo milênios depois, no Neolítico, com o surgimento das primeiras técnicas de tinturaria, essa tonalidade também não se fez presente de forma considerável (PASTOUREAU, 2016).

Com o passar do tempo, já na Grécia antiga, o azul também não foi valorizado, servindo somente de plano de fundo para a arquitetura e a escultura policromas. Da mesma forma, na Roma antiga, os romanos atribuem ao azul uma conotação ameaçadora e oriental. Para eles, essa era a cor dos bárbaros, dos celtas e dos germânicos que representavam uma ameaça. Devido a isso, para gregos e romanos, sua utilização foi quase imperceptível e a sua valorização quase inexistente, já que nem no arco-íris, tão aclamado por essas sociedades, havia azul (PASTOUREAU, 2016).

Tanto que, durante a República e o início do Império Romano, por volta de IV a.C até II d.C, trajar-se com essa tonalidade era algo depreciado ou estapafúrdio, quando não um sinal de luto. Somente nos mosaicos bizantinos, na arte decorativa e na sua forma de esculpir, provenientes do Oriente, o azul e mesmo o verde se fizeram presentes como se observa a onipresença do azul na figura 51. No mais, esse tom, de modo geral, não era uma opção (HELLER, 2013). 
FIGURA 51: Detalhes da Mesquita Azul, Istambul, Turquia, em tons azulados.

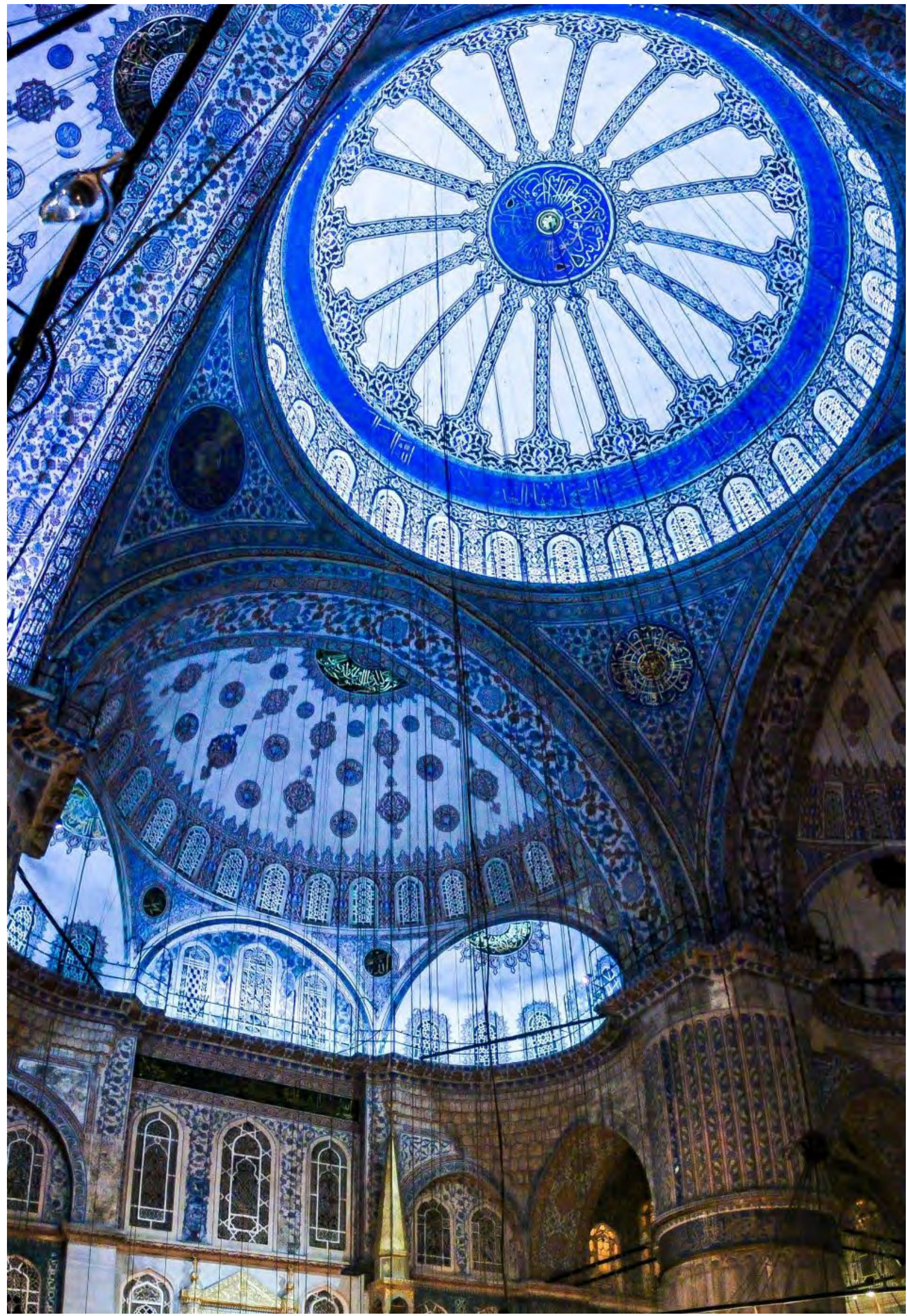

Fonte: http://www.bluemosque.co/architecture.html 
Assim, da Antiguidade até a Idade Média, o azul foi menosprezado, desdenhado e pouco empregado em várias áreas, desde as artes visuais até a tinturaria aplicada em tecidos e usadas no vestuário. Entretanto, na Alta Idade Média, por volta dos anos 476 aos anos 1000, essa coloração apareceu na vida cotidiana de forma recatada, mas não totalmente ausente. Por esse motivo, ele não esteve presente nos círculos da corte, que deram preferência ao vermelho, um tom aceito e usado somente pelos camponeses e pelas classes com menos poder aquisitivo (HELLER, 2013). Essa parcela da sociedade utilizava nos seus tingimentos o pastel-dos-tintureiros que, por ser desprezado pela alta sociedade, era mais barato e, consequentemente, de fácil alcance.

Com isso, dentro dos sistemas de cores e os códigos existentes, o azul não despertava sensações e sentimentos, bem como não surpreendia, ao contrário, causava memórias poderosas e profundas. Não esteve em lugar de prestígio em códigos ou sistemas e, hierarquicamente, foi desprezado a um nível mais baixo, em toda classificação ou comunicação de cor. Isso se deu devido à falta de importância representativa associada a essa tonalidade considerada, pela sociedade de outrora, fraca e inferior para ter conceito, ser importante e, consequentemente, propagar princípios e ideais (PASTOUREAU, 2016).

Por conta disso, durante muito tempo, esse tom foi relegado a uma cor de segundo plano, não aparecendo de modo impactante em nenhuma circunstância. É claro que podia ser visto aqui e ali, especialmente nos tecidos, mas não foi uma tonalidade com um valor significativo, nem nos níveis sociais e artísticos, nem nos religiosos e simbólicos. Por conseguinte, não exerceu alguma importância na vida social, não esteve presente nos círculos da corte, na criação artística, no plano simbólico e na vida religiosa até meados da época feudal (PASTOUREAU, 2014).

Somente quando a Igreja, uma das percursoras da inserção do azul na sociedade, em meados do século XII, começou a introduzir essa coloração no fundo dos vitrais, esse tom principia seu surgimento e notoriedade (HELLER, 2013). Isso porque era uma cor que destacava as "formas, o que contribui para que sejam lembradas, mas oferece baixas condições de visibilidade, portanto poucas condições para fixá-las na memória se levarmos em conta a cor, abstraindo a forma" (FARINA, 1982, p. 197).

Depois disso, a transformação do azul começa de maneira até que acelerada à medida que aparece em vários setores, como nas pinturas, nos vitrais, nos tecidos, nos vestuários deixando de ser renegado como foi desde então. Em algumas cortes, essa tonalidade se tornou a preferida, rivalizando com o vermelho favorito e aristocrático (PASTOUREAU, 2016). 
Com isso, essa "surpreendente e súbita promoção resulta de uma reorganização total da hierarquia das cores nos códigos sociais, nos sistemas de pensamentos e nos modos de sentir" (PASTOUREAU, 2016, p.53), que já havia sido começada no final do século XI e que vai atingir todas as cores. Contudo, foi esse tom que passou a obter outro posicionamento social e assim mudou, de forma decisiva, a sociedade de então.

A entrada no azul simbolizou uma grande agitação no plano simbólico como no plano social. No plano simbólico, não é mais com o azul, e sim com o preto que Jesus cometeu tolices, mergulhando os tecidos que deveriam ser tingidos numa tina com tinta preta (PASTOUREAU, 2011). No plano social, os tintureiros, tão acostumados a tingir de vermelho, foram perdendo prestígio. A figura 52 ilustra o avanço do azul na tinturaria.

FIGURA 52: A ascensão do azul na tinturaria devido à crescente demanda por essa tonalidade.

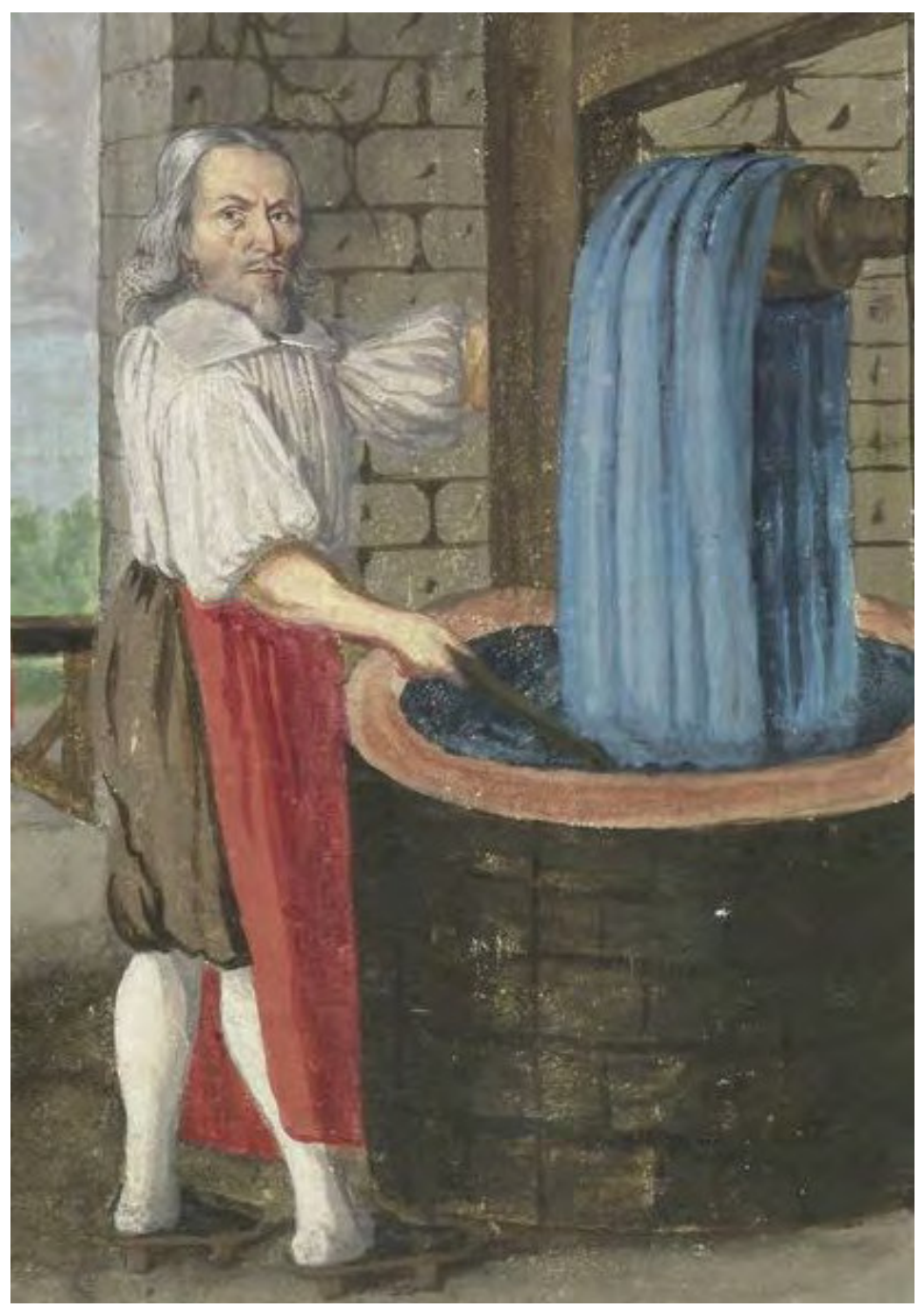

Fonte: THE HISTORICAL DYER, https://www.thehistoricaldyer.com/about_dyes.php 
O progresso dessa tonalidade foi tão significante tanto que, segundo Pastoureau (2016, p. 83):

\begin{abstract}
No que diz respeito apenas às tinturas, é surpreende verificar que, até ao fim do século XIV, as recolhas dedicam três quartos das suas receitas à cor vermelha, ao passo que depois dessa data as receitas relativas ao azul se tornam cada vez mais numerosas - a ponto de, no início do século XVIII, nos manuais de tinturaria, as segundas acabarem por ultrapassar as primeiras. Encontramos uma evolução idêntica nos receituários e nos tratados destinados aos pintores: as receitas de vermelhos dominam largamente até ao Renascimento; depois, os azuis vêm fazer-lhe concorrência, acabando mesmo por ultrapassá-los. Esta rivalidade entre o vermelho e o azul nada tem de anedótico; pelo contrário, constitui um aspecto importante da sensibilidade às cores nas sociedades ocidentais a partir dos séculos XII-XIII.
\end{abstract}

Sendo assim, a presença do azul de forma tão decisiva vai desfazendo a ordem ternária das cores, com seus dois eixos cromáticos e três cores de base, cuja origem se deu na Antiguidade e foi até então vigente. Isso vai resultar numa profunda alteração que engloba o agrupamento das cores e as relações que elas condicionavam umas com as outras.

Na virada do século XII para o XIII, contudo, a ausência desse tom nos códigos litúrgicos e nas marcas discriminatórias revelou um significado expressivo da falta de relevância que essa tonalidade possuía pelos símbolos sociais e pelos sistemas de valores. Em contrapartida, por não ter uma simbologia forte, já que seu uso era autônomo e independente, foi um fator determinante que auxiliou uma condição moral. Isso justifica por que sua utilização foi tornando-se cada vez mais presente.

Uma mudança de sentido começa a surgir no começo da época moderna, já no início do século $\mathrm{XV}$, quando esse tom passou a ser associado pela primeira vez à água e, sobretudo, à inusitada sensação térmica de frio (PASTOUREAU, 2016). Contudo, no imaginário e na vida cotidiana, ainda muito tempo terá de passar até que a água se torne azul, e o azul, frio.

A partir desse momento, ao se tornar a mais desejada e ilustre tonalidade, passou a receber o valor simbólico de ser a cor da ternura, afeto, felicidade, harmonia, tomando, gradativamente, o lugar do vermelho (HELLER, 2013). Depois, já no final do século XVI, ele passou, definitivamente, a integrar o lote das cores honradas e honestas, sendo seu uso permitido para grande parte da população. Com isso, ele é retirado do lugar que ocupou nos antigos sistemas, tanto na Antiguidade, na Idade Média e no Renascimento, e passou a ocupar uma posição prestigiada nas classificações cromáticas (PASTOUREAU, 2016). 
E no século XVII, nota-se que essa tonalidade passou a ser considerada uma cor quente, por vezes, a mais quente de todas as cores (GOETHE, 2011). Devido à revolução newtoniana, à valorização do espectro e à nova teoria das cores primárias e complementares, o azul passou a ser o primeiro entre as cores. Tanto que, para Pastoureau (2016, p.133),

é no século XVIII que esse triunfo verdadeiramente se concretiza: primeiro, com a utilização em larga escala de um corante natural, há muito conhecido mas cujo uso não era livre (o índigo); depois, com a descoberta de um novo pigmento artificial que permitia a obtenção, tanto em pintura como em tinturaria, de novos tons (o azul-da-prússia); finalmente, com a construção de uma simbologia renovada das cores, que concede ao azul o primeiro lugar, convertendo-o, em definitivo, na cor do progresso, das luzes, dos sonhos e das liberdades. Nestes domínios, foi essencial o papel desempenhado pelo movimento romântico e pelas revoluções americana e francesa.

Esse prestígio do azul foi tão importante e significativo que, para a mentalidade do Século das Luzes, as pessoas pertencentes à aristocracia e à alta sociedade deveriam ter a pele uniforme e mais clara possível. Isso se deu porque não era desejo ser identificado com a pequena nobreza ou com os camponeses. Esses últimos, por estarem ao ar livre e expostos à radiação solar, tinham uma pele muito avermelhada e, por vezes, muito manchada. Dessa forma, para não ser confundido com essa parcela da sociedade, ser bem-nascido significava ter "o sangue azul", ou seja, ter a pele tão pálida e translúcida que deixava transparecer as veias da tez (HELLER 2013).

No entanto, essa forma de identificação sofreu alteração, e o importante passou a se distinguir não mais do camponês, e sim do operário. Este, por sua vez, trabalhava dentro ou debaixo da terra, possuindo a cútis bem pálida, uma vez que não estava exposto às radiações. Com isso, os valores dessa sociedade mudaram novamente, pois ter "o sangue azul" deixou de ser um sinal de prestígio.

Com a chegada do XIX, uma nova mudança ocorreu na ordem das cores, já que, progressivamente, esse tom vai deixando de ser uma cor quente e ganha o seu verdadeiro sentido de cor fria. Goethe, que inevitavelmente contribuiu com a primazia do azul, ainda tinha nessa tonalidade uma cor quente ao fazer dele e do amarelo os dois polos essenciais do seu sistema (GOETHE, 2011) como se observa na figura 53. Todavia, de "um ponto de vista simbólico, enquanto o amarelo constitui um polo negativo (cor passiva, fraca, fria), o azul, sempre conotando algo favoravelmente, representa o polo positivo (cor ativa, quente, luminosa)" (PASTOUREAU, 2016, p.151). 
FIGURA 53: Diagrama de Goethe apresentando as duas cores prismáticas: amarelo e azul.

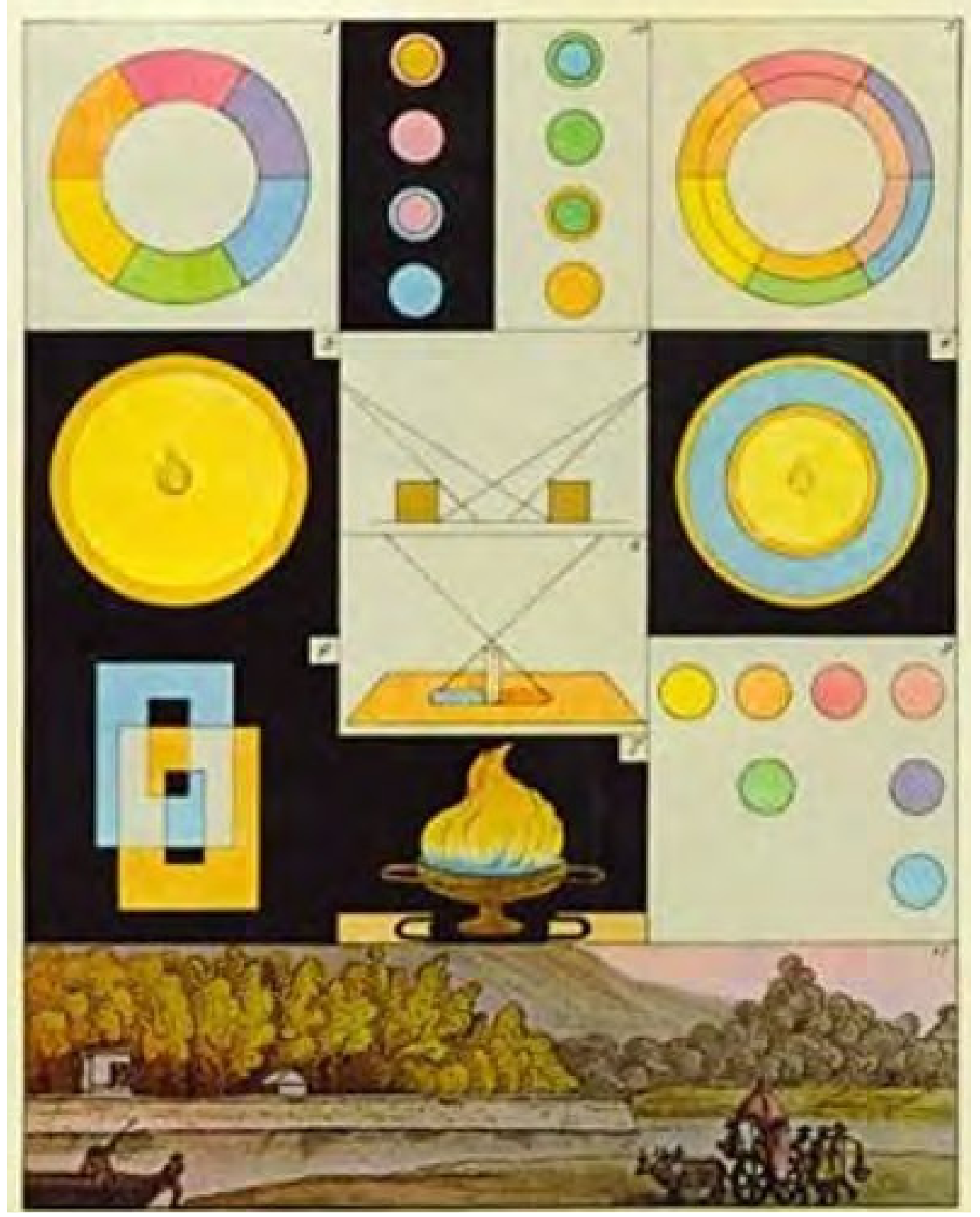

Fonte: BARROS, 2006, p. 298.

Já no século XX, desde a Segunda Guerra Mundial, esse tom é o mais citado quando o assunto é preferência, pois traz consigo a calma e a paz de espírito (LÜSCHER, 1969). É por isso que remédios da categoria dos calmantes possuem essa coloração (FARINA, 1982). Em muitos lugares, os quartos de hospital tinham suas superfícies pintadas dessa tonalidade com o objetivo de descansar e serenar o paciente conforme está colocado na figura 54 representando um quarto destinado a ambinente de saúde. 
FIGURA 54: Campanha publicitária desenvolvida por um fabricante de tintas para uso terapêutico da cor em ambientes de saúde onde observa-se o emprego do tom de azul no teto.

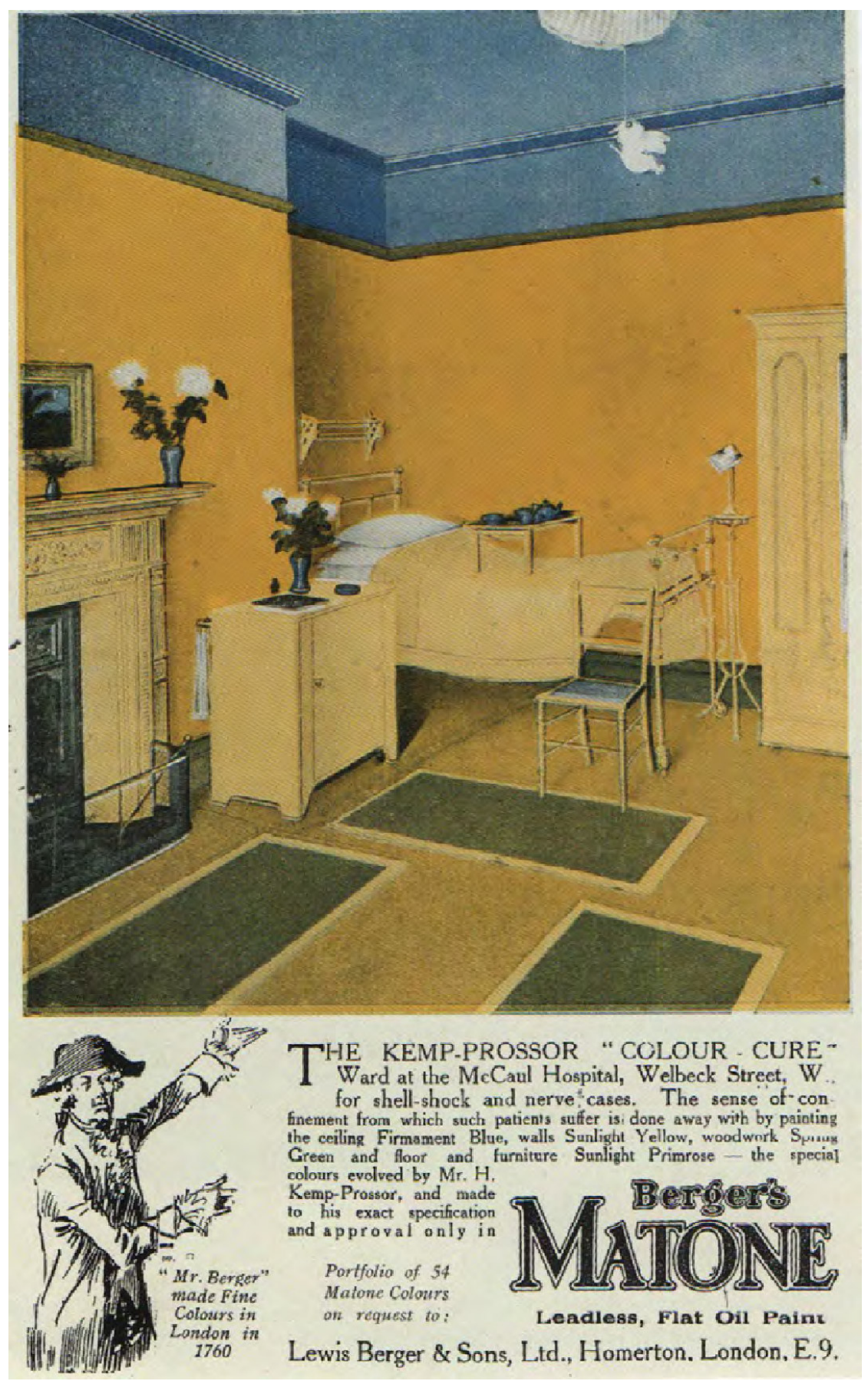

Fonte: GAGE, 1999, p. 208.

Isso vai ao encontro do que, conforme aponta Farina (1982, p. 107):

recomenda-se não pintar de branco o teto de um quarto onde o doente tenha de permanecer por muito tempo. Como o branco reflete intensamente a luz, pode ocorrer o fenômeno de ofuscamento, que tem a propriedade de 
ocasionar no doente uma sensação de cansaço e de peso na cabeça, considerando-se o fato de ele, na maior parte das vezes, ser obrigado a repousar de costas e, inevitavelmente fixar os olhos no teto. O cansaço que parecia ilógico para um indivíduo em repouso encontra assim uma explicação. $\mathrm{O}$ uso do azul no forro, em substituição ao branco, e que confere ao paciente uma sensação de calma, tranquilidade e bem-estar, vem corroborar a opinião de Lüscher sobre as reações corporais do indivíduo a determinadas cores, e a de Léger, que já dizia: “(...) o hospital policromo, a cura pelas cores, um domínio desconhecido que começa a apaixonar os jovens médicos. Salas repousantes, verdes e azuis para os nervos, outras vermelhas e amarelas para os deprimidos e anêmicos. (...) e a influência da luz-cor agiu sobre eles".

Assim, o azul passou ao longo da História a ter o seu lugar se tornando uma cor presente, relevante e dominante independentemente do contexto em que está aplicado sendo, por muitos, como a cor predileta (LÜSCHER, 1969). 


\subsubsection{Verde}

FIGURA 55: Byaku Roku. Imagem meramente ilustrativa para representar a cor verde.

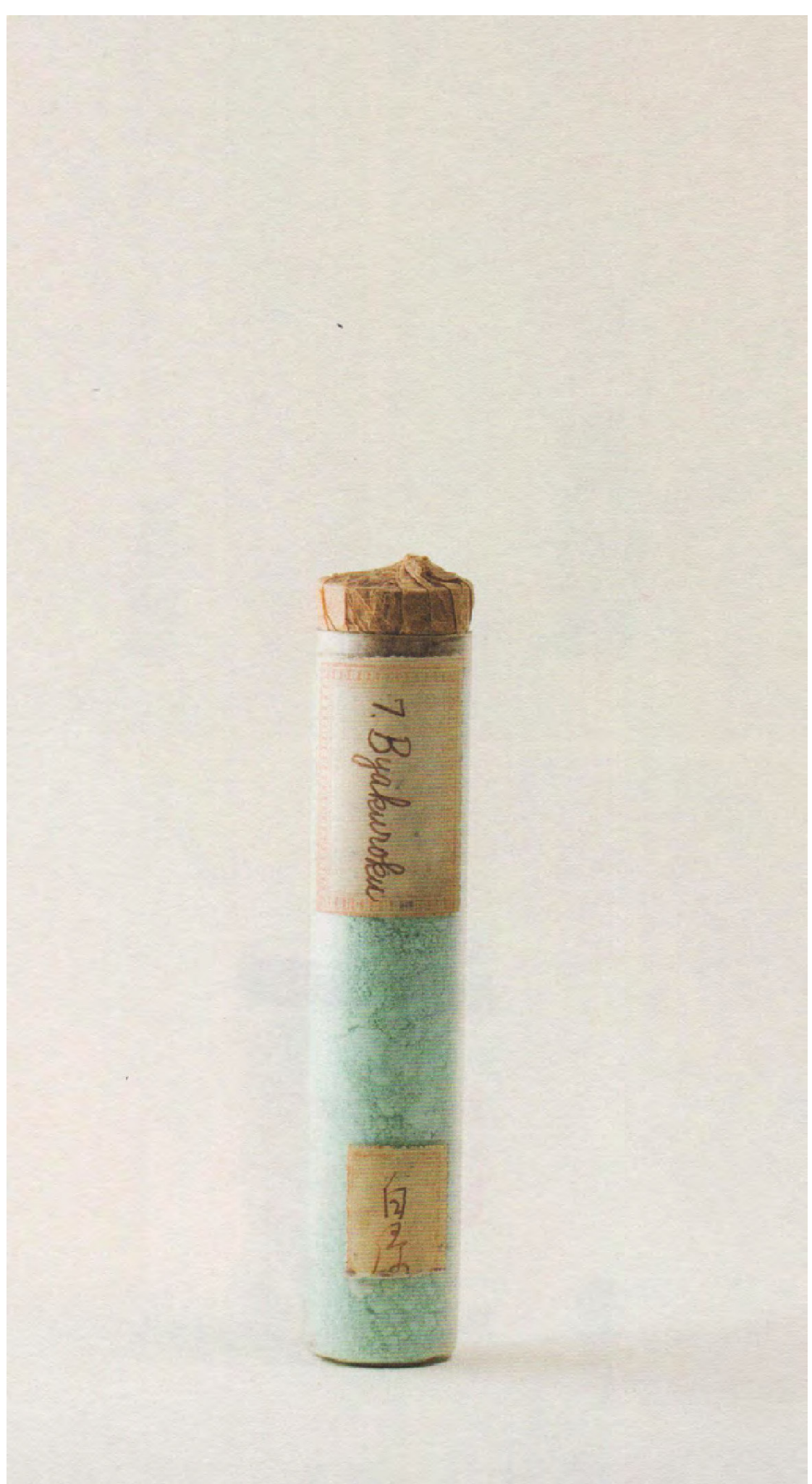

Fonte: THE HARVARD ART MUSEUMS' FORBES PIGMENT COLLECTION, 2017, p. 93. 
A palavra verde deriva do latim, viridis, e representa o meio do caminho entre o amarelo do sol e o azul do céu (FARINA, 1982). É considerada uma cor discreta e cautelosa que possibilita o equilíbrio e o sossego tranquilizador. Essa tonalidade, apesar de renegada durante boa parte da sua história, é considerada, nos dias de hoje, a "salvadora do mundo" pelos valores de sustentabilidade, preservação, ecologia e natureza a ela atribuídos (PASTOUREAU, 2014).

Onipresente no mundo das plantas, o verde foi a cor que os humanos reproduziram, criaram e dominaram tardiamente, com dificuldade. Talvez isso explique por que, no Ocidente, ele permaneceu por muito tempo como uma cor secundária, praticamente não desempenhando um papel importante na vida social, nos rituais religiosos ou na criação artística.

Simbolicamente, esse tom é o mais ambivalente de todos, uma cor, simultaneamente, atraente e incômoda, pois, por um lado, é a cor da fortuna, por outro, é o tom do infortúnio. Ora simboliza o destino, ora a infelicidade. Às vezes, remete à ideia de ventura e de sorte, às vezes, à ideia de desventura e de azar. Assim, possui uma ligação com circunstâncias e rituais em que intervêm o acaso e o inesperado.

Isso é tão verdade que as superfícies onde se "joga o destino", ou seja, as mesas de jogos, desde roletas e carteados até campos de futebol e mesas de pingue pongue possuem essa coloração. "Com o verde, os dados estão lançados, e estes dados têm, por vezes, consequências importantes" (PASTOUREAU, 1997, p. 157).

Essa simbologia contraditória e paradoxal pode ter sua explicação na instabilidade e na mudança daquilo que se deseja ardentemente, mas que se revela aleatório ou efêmero: a juventude, o jogo, o amor, a esperança e mesmo o dinheiro. Isso justifica por que é a cor mais mutável de todas, a que mais se modifica com a luz tanto natural como artificial, não sendo nem boa, nem ruim.

O verde é o meio do caminho entre o vermelho, que traz em si a noção de temperatura agradável, a relação de proximidade, o masculino e a matéria, e o azul, que, por sua vez, transmite a ideia de distanciamento, de feminino e de espiritual. Apesar de ser a cor complementar do vermelho, é também o azul que mais contrastes faz com esse tom, ficando o verde em segundo plano (HELLER, 2013). Tanto que Goethe (2011), ao se referir a essa coloração em sua Doutrina das Cores, considera-o como a tonalidade mais equilibrada e recomendável para o repouso do corpo e a paz da alma (GOETHE, 2011).

Psicologicamente, essa tonalidade está no centro do espectro e representa o equilíbrio perfeito. Ele atinge o olho no ponto que não requer ajuste, portanto não apresenta tensão. $\mathrm{O}$ 
pigmento que reflete esse tom, a clorofila, é vital para a vida e, cercadas por essa coloração, as pessoas ficam tranquilas e serenas (WRIGHT, 1999).

Essa tonalidade propõe um estado psicológico diferente da tranquilidade calmante colocada pelo azul. Quando a opção é pelo verde, provavelmente o indivíduo deseja relaxamento, está em paz consigo mesmo e com o mundo, sentindo-se positivamente equilibrado. Isso porque é a cor de cura mais eficaz, da estabilidade e do amor universal (LÜSCHER, 1969).

No início do Gênesis, o verde apareceu como sendo uma cor fecunda, abençoada e benfeitora, prescrita, decretada e constituída por Deus (PASTOUREAU, 2014). Tanto que, segundo essa ótica, o Jardim do Éden é descrito como uma coleção e um conjunto de variados símbolos e possibilidades. Para Pastoureau (2014, p. 64):

na Bíblia, o Cântico dos Cânticos retoma esse simbolismo ao tornar a noiva Sulamita (a quem a Idade Média cristã comparou à Virgem) "um lírio dos vales", "um jardim trancado", "uma fonte selada", "uma bacia de água doce", "um cedro do Líbano". Da mesma forma, no Novo Testamento, o tema de Cristo jardineiro, caro à iconografia do final da Idade Média, parecia legitimar tudo o que foi encontrado ou aconteceu no Jardim. Pouco depois da Ressurreição, Maria Madalena chora no jardim das oliveiras perto do túmulo vazio; vendo um homem parado perto dela, ela não o reconhece e o toma pelo jardineiro (em algumas imagens posteriores ele usa um chapéu de palha e segura uma pá) e pergunta a ele para onde levou o corpo de Jesus. O Senhor se revela e, quando Maria Madalena se joga a seus pés, manda que ela não o toque (Noli me tangere).

Apesar do apreço quase sagrado que é atribuído ao verde em algumas passagens bíblicas, a ausência dessa coloração na vida cotidiana poderia ter sido o resultado da natureza material, técnica, biológica, mesmo ideológica e simbólica dessa tonalidade. Tanto que nas pinturas Paleotíticas, ou no período Neolítico, quando surgiram as primeiras práticas de tingimento, essa cor não esteve presente de forma considerável. Como se tornaram sedentários, os humanos tingiam em tons de vermelho e amarelo muito antes de tingir em verdes ou azuis (PASTOUREAU, 2014).

Assim, desde os primórdios, verifica-se que, como estava tão presente na vegetação e dominava em relação as outras cores, talvez por essa razão esse tom esteve ausente nas primeiras paletas que os humanos conceberam e produziram.

Essa inexistência do verde nas atividades humanas levaram muitos estudiosos "do final do século XIX a se perguntar se os homens e mulheres da antiguidade clássica eram 
cegos para o verde ou se pelo menos o viam de forma diferente de como foi visto mais tarde" (PASTOUREAU, 2014, p. 13).

Ao contrário dessa crença, o que se sabe é que alguns métodos pictóricos atestaram seu uso na Grécia, desde os tempos antigos, assim como de uma ampla gama de pigmentos que traziam essa família de cor. Ao que parece, pode ter sido mencionado diariamente na fala, mas raramente na escrita. Assim, os antigos gregos, certamente, viam o verde muito bem, mas suas oportunidades de nomear essa cor por escrito eram provavelmente limitadas ou não particularmente dignas de nota (PASTOUREAU, 2014).

Do período Neolítico ao início da Idade Média, devido ao baixo papel material e ideológico que o verde desempenhou, por muitos milhares de anos, na maioria das sociedades europeias, ele não representava um lugar importante na vida cotidiana, nos rituais cívicos e religiosos ou nas ocasiões mais festivas e solenes (HELLER, 2013). Em alguns meios, como as cerâmicas de vidro, porém, receberam magníficos tons de verde e azul, o que os tornou cada vez mais leves e translúcidos ao longo dos séculos.

Vestígios da tradição islâmica encontrados no século VII revelam que o profeta Maomé tinha preferência por essa cor durante um longo período de sua vida. Segundo reza a lenda, ele gostava de usar turbante verde e de estar rodeado por tecidos nesse tom, embora geralmente se vestisse de branco. Após sua morte em 632, o verde tornou-se uma cor dinástica de sua família e daqueles que afirmavam ser seus descendentes diretos (HELLER, 2013).

No entanto, somente a partir do século XII, esse tom parece ter-se tornado definitivamente a cor religiosa e emblemática do Islã. Depois disso, no mundo islâmico, o verde foi considerado bom e benfeitor ao ser associado ao paraíso, à felicidade, às riquezas, à água, ao céu e à esperança, e, com isso, tornou-se uma cor sagrada (HELLER, 2013), como revela a figura 56. 
FIGURA 56: A presença do verde na Mesquita de Herat, Afeganistão.

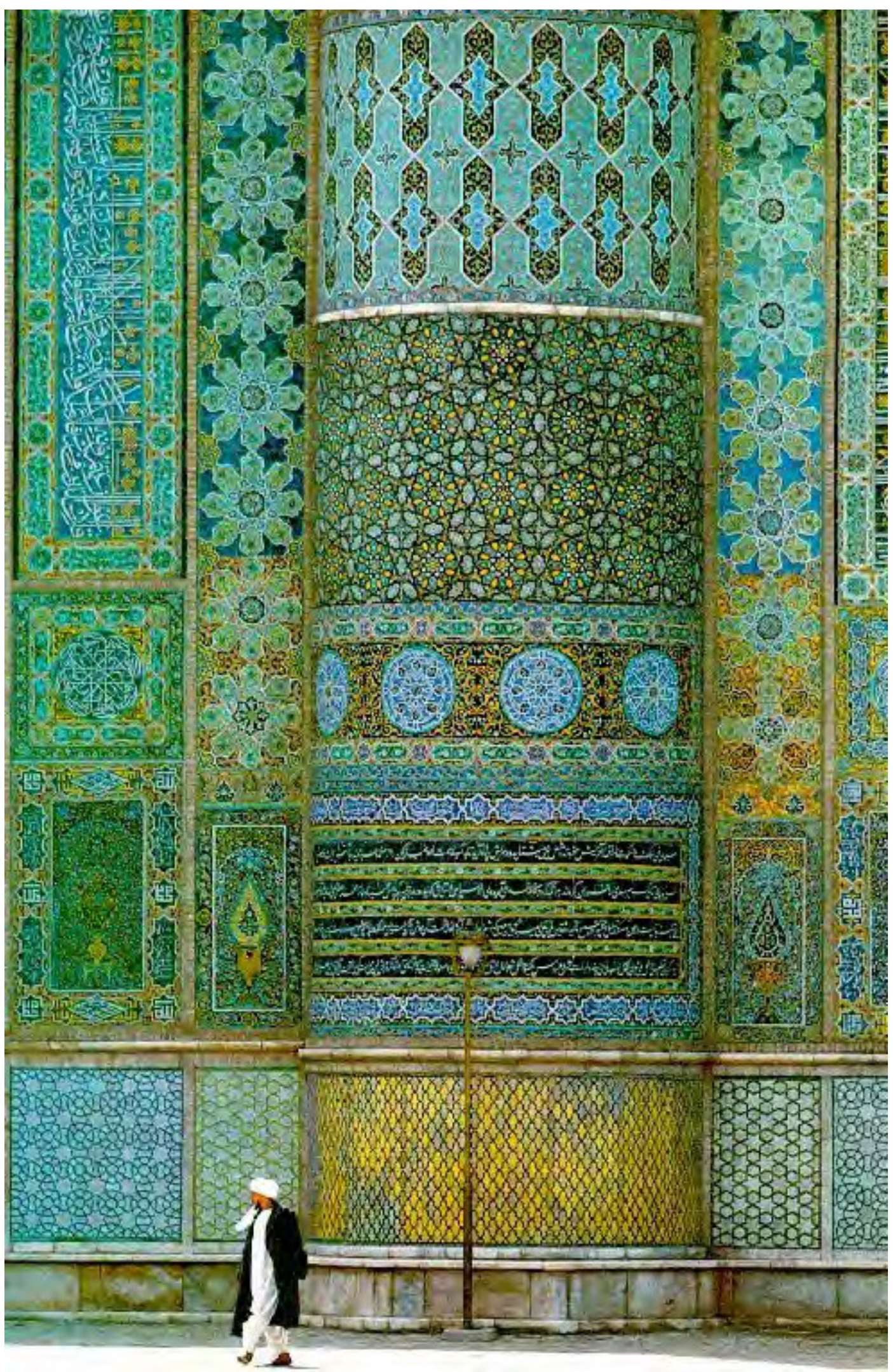

Fonte: PINTEREST, https://br.pinterest.com/pin/26247610311439476/ 
O tom verde também foi apreciado pelos egípcios, que o consideravam benéfico, motivo por que foi muito procurado para proteção e segurança. Tanto que animais verdes eram acreditados sagrados e móveis funerários eram revestidos com um esmalte que lhes conferia um aspecto vítreo bonito, afastando os poderes do mal e protegendo os mortos no mundo além.

Na cristandade, por volta do ano 1000, observa-se uma certa unidade aos códigos de vestimenta litúrgicos nos quais o verde se revelou o mais original. Ele se tornou a cor da esperança e da vida eterna, a quarta cor colocada no meio do sistema composto pela tríade branco, vermelho e preto (PASTOUREAU, 2014).

Foi escolhido para os feriados e os dias em que nem o branco, nem o vermelho e nem o preto eram adequados, porque, segundo essa ótica, era uma cor intermediária entre esses tons. A partir desse momento, com essa nova posição que passou a ocupar, deixou de ser uma cor imperceptível e tornou-se essencial para o funcionamento do todo.

No início do século XII, os vitrais, esmaltes e as miniaturas despertaram interesse, e o verde passou a ser usado geralmente combinado com o azul, com o amarelo ou com o branco. Assim, nesse período, ele ocupou um lugar importante, tanto que a literatura fez dessa coloração não só a cor emblemática do mundo vegetal, mas também a cor da juventude e do amor. Já a cavalaria reservava para ele um lugar novo nos caminhos da aventura e nos campos do torneio (PASTOUREAU, 2014).

Por outro lado, devido a sua ambivalência, que trazia também conotações diabólicas junto com o preto e com o vermelho, gradualmente foram aparecendo os primeiros demônios verdes. Por volta de meados do século XII, eles foram surgindo, primeiramente em vitrais, depois em iluminuras, murais e, por fim, na arte. Dessa forma, os animais encarnados pelo Satanás eram, na maioria, de coloração escura. É o caso, por exemplo, do urso, lobo, javali, cabra, gato, coruja, corvo que traziam a simbologia do preto. Já o dragão, sepente, crocodilo, hidra, sapo, sirene e gafanhoto eram verdes (PASTOUREAU, 2014).

Surgiu também nessa época a relação entre esse tom e os fantasmas. Teoricamente, essas assombrações não tinham nem forma nem cor, mas passaram, por vezes, a ser esverdeadas ou sem cor determinada na Idade Média (PASTOUREAU, 2014).

Junto a eles, as bruxas, que traziam consigo um valor assustador e medonho, tinham olhos e dentes verdes e se trajavam com essa coloração. Os elementos a elas associados, como as poções, receberam essa tonalidade, e os animais que na maioria das vezes as acompanhavam, ou eram verdes como as serpentes, os dragões, os gafanhotos, as rãs, ou eram negros como os gatos, cães, cabras, lobos e corvos. 
Em decorrência disso, a partir do século XIII, os tratados sobre a fisionomia humana não foram tão gentis com os olhos verdes, pois, nessa fase, revelavam mau caráter, espírito falso, mentira e uma vida depravada. Tanto que as representações que traziam Judas e os traidores, as prostitutas e as bruxas os retrataram com olhos nesse tom (PASTOUREAU, 2014).

Por outro lado, não foram somente seres terríveis e assustadores que ganharam representatividade atrelada ao verde. Como era também considerada uma cor suave e aprazível, as ninfas, os elfos e os espíritos das folhas, já no século XII adentrando o século XIII e o período moderno, eram representados por essa coloração. Como explica Patoureau (2014, p. 165):

\begin{abstract}
Menos frequentemente do que vermelho, branco ou preto, o verde era a cor dos seres sobrenaturais, principalmente das fadas. Na era moderna, em muitas partes da Europa, eram chamadas de "damas verdes" (die grünen Damen). As razões eram várias: às vezes, suas roupas ou sapatos eram verdes; às vezes eles tinham olhos ou cabelos verdes (como bruxas); às vezes eles viviam em ambientes verdes que evocavam seus laços primários com os ciclos das plantas, adoração da água, árvores e florestas. No norte da Europa, quando as fadas se vestiam de verde, elas não ficavam muito felizes se simples mortais fizessem o mesmo. Se alguém quisesse ganhar seu favor, era melhor não emprestar essa cor deles nem usar as plantas das quais tiraram um pouco de seus poderes mágicos: espinheiro, árvore servisse, avelã e alguns outros. Verde era a cor das fadas. Bem, fosse ela avós ou amante, anjo da guarda ou espírito maligno, uma fada costumava ser caprichosa e, como a própria cor, podia mudar repentinamente de humor, aparência ou significado. Ela deveria ser temida e respeitada.
\end{abstract}

Assim, no período feudal, tanto a literatura como os costumes da corte deram ao verde sua importância. Ao trazer desde elementos fantasiosos até elementos existentes na natureza por meio das árvores, plantas, gramíneas e flores, contribuíram para a presença e, consecutivamente, a permanência desse tom e todos os sentimentos a ele associados.

De acordo com essa mentalidade, a natureza, ícone máximo do esplendor divino, certamente fazia parte dessa ação que envolvia todos os seres vivos existentes. Segundo essa ótica, tudo que pertencia ao divino era formado pelos quatro elementos básicos, e cada um desses elementos tinha suas próprias cores. Com isso, o ar foi associado ao branco, a terra ao preto, o fogo ao vermelho e a água ao verde (PASTOUREAU, 2011).

Em virtude de o verde ter sido conectado à cor das águas, mais uma vez reafirmou a noção de que as criaturas amedrontadoras e até mesmo fantásticas que ali viviam eram 
frequentemente representadas nessa coloração, como o dragão, o crocodilo, a sereia, a víbora e o sapo.

$\mathrm{Na}$ vida cotidiana, elementos verdes ficavam ao lado das pessoas para descansar os olhos. Essa é razão pela qual o comprimento de onda que produz a sensação de verde é o ponto mais alto da sensibilidade do olho humano, como se observa na figura 57.

FIGURA 57: O comprimento de onda que produz a sensação de verde é o ponto mais alto da sensibilidade do olho humano.

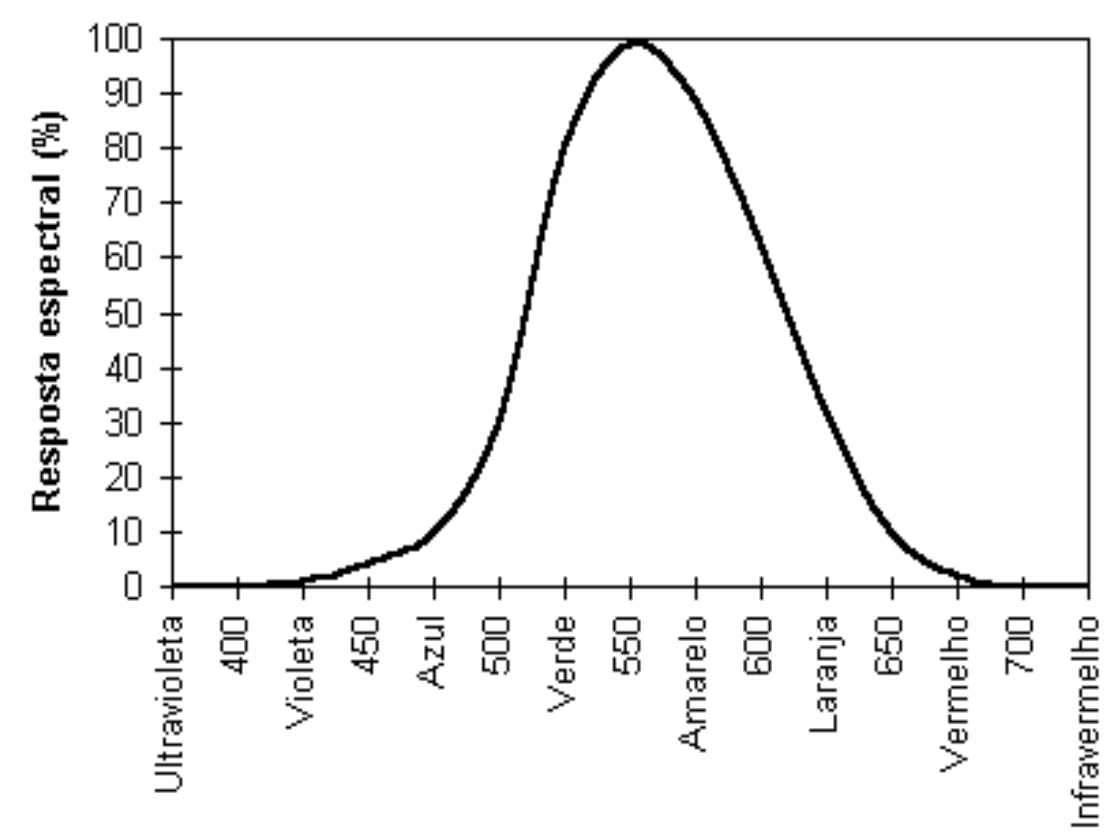

Comprimento de onda (nm)

Fonte: PEDROSA, 2009, p. 77.

Tanto que os quadros para escrever, feitos de cera, antes brancos ou pretos, foram substituídos por esse tom, e objetos verdes ou até mesmo esmeraldas também compunham os espaços com o objetivo de tranquilizar e relaxar.

Assim, por despertar esses sentimentos, naturalmente a cor verde foi associada à saúde e aos elementos a ela conectados, como os medicamentos e, em algumas cidades, as farmácias. Essa ligação, que já existia desde tempo mais antigos, continuou ao longo dos séculos, provavelmente porque a maioria dos remédios tinha uma base vegetal na sua elaboração. Com isso, aos poucos, esse tom se tornaria a cor emblemática da medicina e da farmácia por ser calmante, higiênico e médico (FRASER, 2007), como se observa na figura 58. 
FIGURA 58: Guia de plantas e ervas voltado para as propriedades medicinais, culinárias e de tingimento desenvolvido no final da Idade Média.

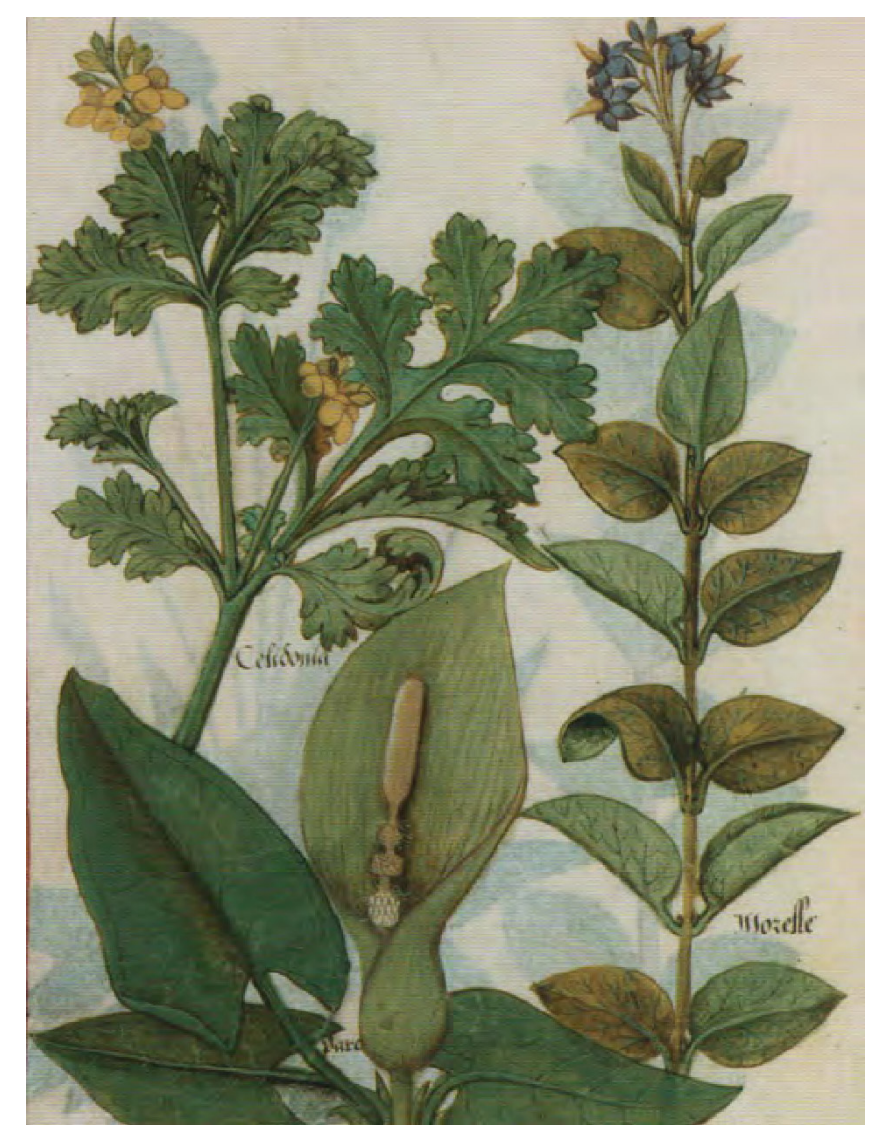

Fonte: PASTOUREAU, 2014, p. 112.

Com isso, essa tonalidade que dominava os jardins, as planícies e as florestas, estava extremamente presente na vida cotidiana, atraía os olhos devido não só a sua abundante presença, mas também a sua beleza, despertando um sentimento tranquilizante e calmante aos sentidos. Essa cor predominante nos pomares passou a ter a estação da primavera como sua aliada.

Assim, esse verde agradável, arejado, jovial e alegre apresentou-se para a sensibilidade medieval, pois estava associado a tudo a ele referenciado, ou seja, à juventude, à alegria, à festividade, à música e, acima de tudo, ao amor. A relação com a junventude se deu porque, assim como a vegetação nascente era nova e fresca, a juventude também o era. A primavera não marcava apenas o despertar da natureza, mas também testemunhava o avivar das paixões românticas. A seiva foi a metáfora encontrada que unia o transbordar dos corações apaixonados e extravasava das árvores e plantas durante essa estação (PASTOUREAU, 2014). 
No que diz respeito ao amor, outras cores também foram associadas a esse sentimento, conforme afirma Pastoureau (2014, p. 71):

na Idade Média, o amor possuía uma ampla paleta. O verde dos amores incertos da juventude contrastava com o azul do amor leal e fiel, o cinza dos amores infelizes, o vermelho do amor e da caridade cristãos. Poderíamos até adicionar a essa lista o amarelo do amor ciumento, o negro do desespero causado pela perda do amado e o roxo dos amores incestuosos ou proibidos. O próprio vermelho poderia ser dividido: de um lado, o vermelho cristológico, derramado por e para Cristo; por outro lado e o extremo oposto, vermelho erótico, o vermelho dos casos carnais, luxo, libertinagem e prostituição. Do ponto de vista simbólico, absolutamente não se tratava do mesmo vermelho. Nem da perspectiva artística: os pintores nunca usaram o mesmo pigmento para representar o vermelho do amor divino e o vermelho do amor carnal, mesmo que o efeito de cor produzido no painel ou na pintura parecesse o mesmo.

Então, a Idade Média, entre meados dos séculos XII e XIII, foi um período de ascensão inegável para essa cor cuja presença cresceu na vida cotidiana, na cultura material, no mundo das imagens e através dos símbolos, ganhando um lugar que nunca teve. Essa é razão por que se fez presente nas roupas e nos objetos do cotidiano, refletindo uma vontade da sociedade de estar em harmonia com a natureza.

Nesse mesmo período, com a unificação litúrgica, o verde impactou a vida cotidiana, por isso foi eleita uma cor relevante pela cristandade romana. Apesar de ser menos importante que o branco, o vermelho ou o preto, adquiriu um certo prestígio, vindo antes do amarelo, do azul, do roxo e de todas as outras cores (PEDROSA, 2009).

Essa notoriedade se deu porque, na virada do século XII para o XIII, os apontamentos deixados por Aristóteles foi gradualmente sendo redescobertos e levados em consideração. Segundo ele, o verde estava no centro de um eixo formado pelo branco, amarelo, vermelho, em uma extremidade e azul, roxo e preto na outra ponta (PASTOUREAU, 2014).

Como a própria sequência proposta por Aristóteles representava, essa cor mediana raramente era obtida pela mistura do azul e do amarelo. Para os homens da Idade Média, que ignoravam tudo sobre o espectro e a classificação espectral das cores, o azul e o amarelo eram dois tons com valores diferentes que, quando situados num mesmo eixo, ficavam muito afastados um do outro.

Foram as descobertas realizadas no plano científico, realizadas por Newton e que já haviam sendo propostas por outros pesquisadores anos antes, que deram lugar a novas classificações das cores, como se observa nas figuras 59 e 60. 
FIGURA 59: Diagramas desenvolvidos durante o século XVII por diferentes pesquisadores na tentativa de propor a ordem das cores.

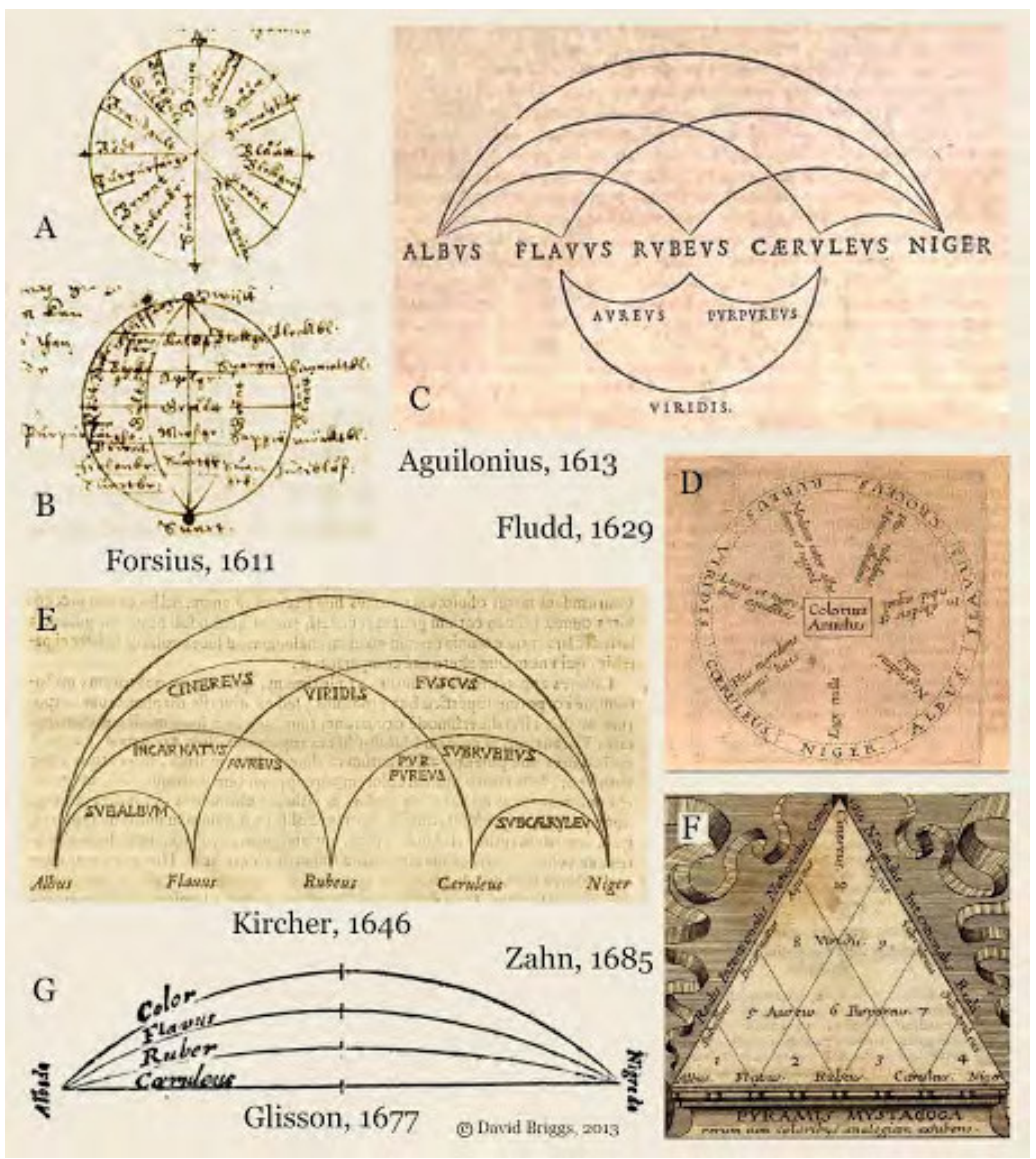

Fonte: http://www.huevaluechroma.com/071.php

FIGURA 60: Pela genealogia da cor proposta, em 1613, por François d'Aguilon, o verde era o resultado da combinação do amarelo com o azul.

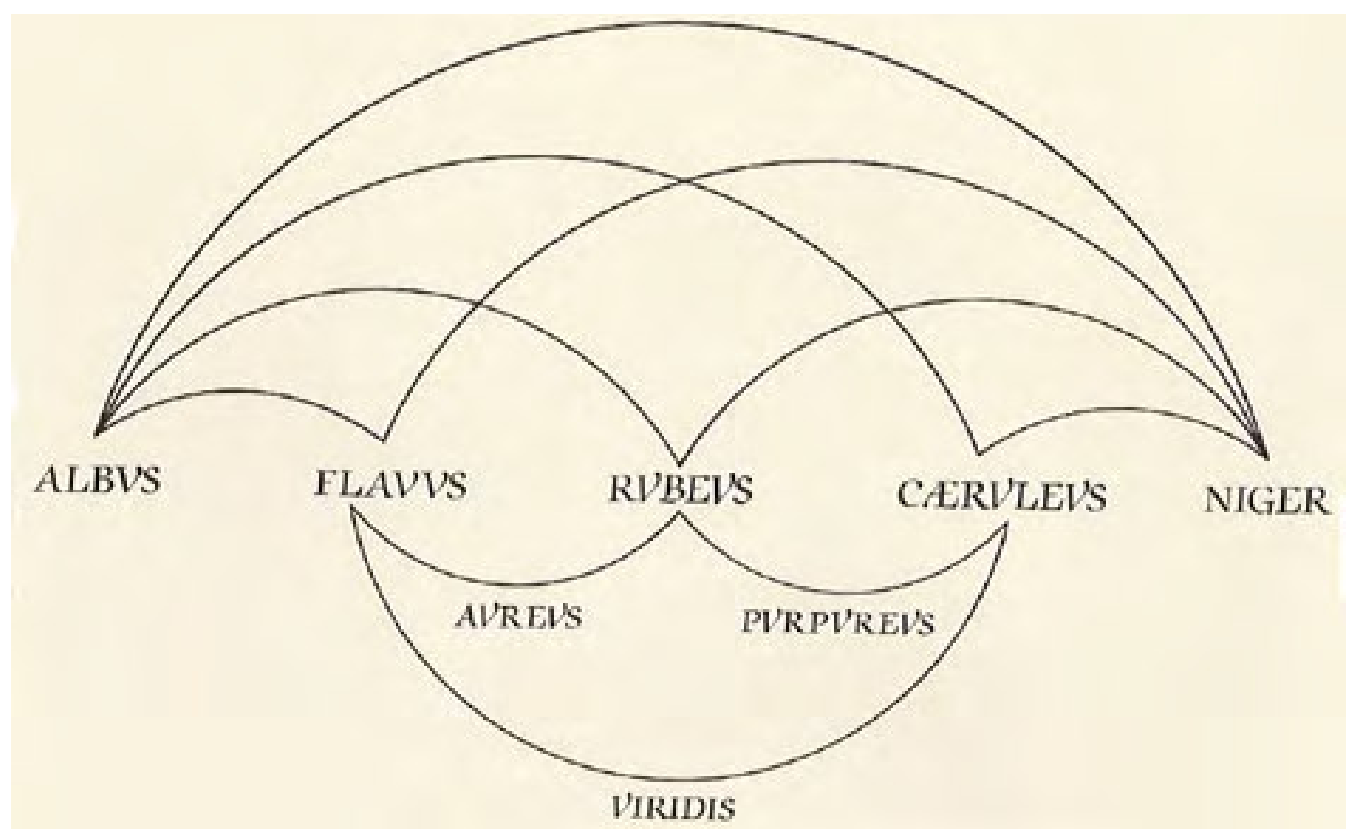

Fonte: WIKIPEDIA, https://commons.wikimedia.org/Franciscus_Aguilonius_color_scheme.png. 
Até então, para o homem da Antiguidade ou da Idade Média, isso não tinha sentido. Em nenhum sistema antigo ou medieval, o verde estava entre o amarelo e o azul. Essas duas últimas cores não ocupavam lugar nas mesmas escalas nem nos mesmos eixos não podendo, portanto, ter um patamar intermediário composto pelo verde. Ele até podia ter relações estreitas com o azul, mas não tinha relação com o amarelo para essa mentalidade. Conforme afirma Pastoureau (2011, p. 14):

\begin{abstract}
Em nenhum sistema antigo ou medieval o verde se situa entre o amarelo e o azul. Essas duas últimas cores não ocupam lugar nas mesmas escalas nem nos mesmos eixos: não podem, portanto, ter um patamar intermediário, um "meio", que seria o verde. O verde entretém relações estreitas com o azul, mas não tem nenhuma com o amarelo. De mais a mais, quer em pintura ou em tintura, nenhuma receita antes do século XV nos ensina que é preciso misturar o amarelo com o azul para obter o verde. Pintores e tintureiros sabem fabricar a cor verde, mais para fazê-la não misturam essas duas cores. Da mesma forma que não misturam o azul e o vermelho para obter o violeta: eles misturam o azul e o preto. Tanto o violeta antigo como o medieval são considerados subpreto, e durante longo tempo ficou restrito à liturgia católica ou às práticas relativas ao vestuário do luto.
\end{abstract}

Dessa forma, devido a essa dificuldade de trabalhar e aplicar esse tom tanto no tingimentos quanto na pintura, reafirmou-se a simbologia associada a tudo o que era mutável ou caprichoso, como a juventude, o amor, a fortuna e o destino (HELLER, 2013). Isso porque o verde tendia a ter uma personalidade dividida, uma cor ambígua, perturbadora e até perigosa identificada com o mofo e a putrefação (BIRREN, 1962).

Junto a esse infortúnio, dentro do sistema dos sete pecados capitais, a avareza foi designada como sendo verde e permaneceu nesse lugar por muito tempo. Observou-se que, em decorrência disso, desde o final da Idade Média adentrando o período moderno, quando o verde se referia às finanças, era associado às dívidas e aos jogos de azar (PASTOUREAU, 2014).

A depreciação desse tom, já muito concreta e legitimada pela sociedade no final da Idade Média, continuou na Era Moderna (PASTOUREAU, 2014). Em primeiro lugar, devido aos aspectos moral e religioso. Isso porque os decretos relacionados a vestimentas, determinados pelas autoridades civis e pelos reformadores, contribuíram para o declínio e para a imoralidade, por isso o verde deveria ser evitado.

Em segundo lugar, no plano artístico, independente da temática relacionada à pintura, ele foi desprezado, ficando, quando muito, destinada à paisagem de gênero. Tanto que os verdes da natureza eram permitidos, pois as representações, geralmente associadas com a 
água, eram desse tom ou poderiam ter qualquer cor, embora, do ponto de vista simbólico, fossem associadas ao verde. Nas imagens e nas mais antigas cartas geográficas, os mares, lagos e rios eram quase sempre representados por essa tonalidade. Só a partir dos fins do século XV, esse verde passou a ser usado para representar as florestas, lugar que, progressivamente, o azul lhe cedeu (PASTOUREAU, 2016).

Em terceiro e por último, de mais a mais, quer em pintura ou em tintura, nenhuma receita, antes do século XV, dizia que era preciso misturar o amarelo com o azul para obter o verde. Pintores e tintureiros sabiam fabricar essa cor, mas, para fazê-la, não misturavam essas duas nuances. Como dito acima, foi com as experiências de Newton e a classificação espectral das cores que o verde se tornou, incontestavelmente, um tom que se situava entre o amarelo e o azul, não sendo mais uma cor básica. A partir desse momento, era secundária, produzida pela mistura de duas outras cores, produto do azul e do amarelo (PEDROSA. 2009).

Todos esses fatos colaboraram para aumentar a má reputação do verde, adentrando outras áreas como os teatros e os códigos navais, por exemplo. No teatro, a ideia de que o verde trazia infortúnio parecia já estar bem estabelecida. Os atores não só se recusavam a vestir-se de verde, como também não queriam sua presença no palco, seja em tecidos, móveis ou objetos. Supostamente trazia má sorte para a apresentação e para o corpo artístico (HELLER, 2013). Já nos códigos navais, era indesejável, pois, ao que parecia, atraia trovões e relâmpagos. Essa evidência explica a falta desse tom no código internacional de sinais marítimos, o que se faz presente até os dias de hoje (PASTOUREAU, 2014).

Todavia, devido a mais uma ambivalência do verde, às vezes azarado, às vezes benéfico, prevaleceu em certos lugares a reputação oposta de afastar as forças do mal, por isso foi aplicado em portas de estábulos para proteger o gado de raios, bruxas e infortúnios. Além desses seres imagináveis, séculos mais tarde, no final do século XIX, surgiram também as criaturas extraterrestres que viviam em Marte, os "marcianos", complementando a fama sobrenatural atrelada a esse tom.

Mesmo possuindo um lado positivo atrelado a essa cor, o verde não era particularmente emblemático para a criação romântica, pois o espetáculo da natureza não se limitava à vegetação. A água, o mar, o céu, a lua e a noite tiveram um papel pelo menos igual a ele e, consequentemente, a paleta da alma romântica não se limitava apenas à cor verde.

Por enquanto, em meados do XVIII, ele permanecia negligenciado, imperceptível e popular. No entanto, nos últimos anos desse século, houve uma atração renovada pela 
natureza como um lugar de paz e contemplação, longe dos círculos da moda e do agito das cidades (GOETHE, 2011).

Com a chegada do Romantismo, quando os gostos mudaram e a natureza voltou a ser atraente, essa cor recuperou uma certa respeitabilidade e virtude. A melancolia, o aborrecimento e o pesar, temas recorrente nessa época, tornaram-se um atributo de qualidade, por isso as almas sofredoras se acolheram nos verde e nos cenários esverdeados para buscarem a tão desejada serenidade.

Junto a esse novo gosto, os avanços em relação à gama dos azuis, como o azul da Prússia e ao índigo americano, que, com o uso de novos pigmentos e corantes, tornou-se possível, com mais facilidade, a criação de lindos tons dentro dessa família (HELLER, 2013). A partir daí, expandiu-se a gama de verdes escuros. Mesmo assim, isso não foi suficiente para estabelecer ou restabelecer o gosto por essa cor.

Nesse período, a mistura mecânica de azul e amarelo, apesar de sofrer com as regulamentações profissionais referentes aos tingimentos que ainda eram severas e tensas, teve sua ascensão no começo desse século. Ao fim definitivo do tabu sobre as misturas dali em diante, nem os pintores e nem os tintureiros se privariam de misturar o amarelo com o azul para obter o verde.

Além disso, a utilização do azul da Prússia e do índigo beneficiou tanto a gama dos esverdeados como a dos azulados, que se tornaram mais claros e diversos ao longo de todo o século. Tanto que, conforme Pastoureau (2011, p. 157):

\footnotetext{
a partir dos anos 1750 , as pessoas começam a pintar os aposentos em que dormem dessa cor, moda que se torna quase sistemática no final do século. Goethe faz eco a isso no seu tratado das cores, onde apresenta o verde como a tonalidade mais equilibrada e recomendável para o repouso do corpo e a paz da alma.
}

Assim, no final do século XVIII, o verde experimentou seu primeiro renascimento entre as cores "da moda", primeiramente no mobiliário e depois no vestuário. Isso porque era o tom que trazia a sensação de ser reconfortante e protetor, uma fonte de inspiração e uma cor divina.

Esse novo gosto andou de mãos dadas com a ideia cristã da esperança, que vinha desde a Idade Média, e com os movimentos de liberdade que floresciam. Isso porque, por ser quimicamente instável, era, do ponto de vista simbólico, libertário, autônomo e emancipativo (HELLER, 2013). 
Ademais, devido às teorias de cores que também surgiram nesse período, apesar de já no século XVII ter recebido a condição de uma cor "primitiva", o verde se tornou o oposto do vermelho, o que o reduziu um ponto na genealogia cromática. Hierarquicamente, foi colocado no mesmo nível do laranja e do roxo, "complementares" do azul e do amarelo, respectivamente.

O vermelho, tão consagrado durante a História continha em si o status da censura e impedimento, o que naturalmente contribuíu para o seu oposto - o verde - tornar-se o tom da aprovação e do consentimento. Essa foi a razão pela qual essas duas cores se fizeram presentes, tornando-se, no sistema de tráfego, a cor do "pare" e a cor do "pode avançar".

Outro fator que contribuíu para o declínio do verde foram as observações e princípios de Chevreul, confirmando a física óptica o que a química há muito deixara claro. Com isso, esse tom não precisava mais ser produzido pela mistura de pigmentos, bastando a mistura óptica, ou seja, a justaposição de azul com amarelo, uma combinação feita por um estímulo cerebral cuja materialidade não existia.

Em decorrência dessa não existência material, alguns teóricos da cor, como os professores da escola alemã Bauhaus, Kandinsky, Itten e Albers, deram a ele um papel menor na criação artística. Isso porque o consideraram uma cor secundária, desprezível e inútil. Em contrapartida, priorizaram as três cores primárias até então: vermelho, amarelo e azul (PASTOUREAU, 2014). Esse fato se refletiu nos objetos do dia a dia, artigos de decoração e no mobiliário de maneira geral, e, apesar de não estar totalmente ausente na vida cotidiana, seu lugar era discreto e moderado. Nã obstante o pouco prestígio do verde por ter sido considerado uma cor secundária, algumas obras, como representado pelas figuras 61 e 62 trazem esse tom. 
FIGURA 61: Wald Bau, Paul Klee, Jucker Collection, 1919, gesso sobre tela transferido para papel.

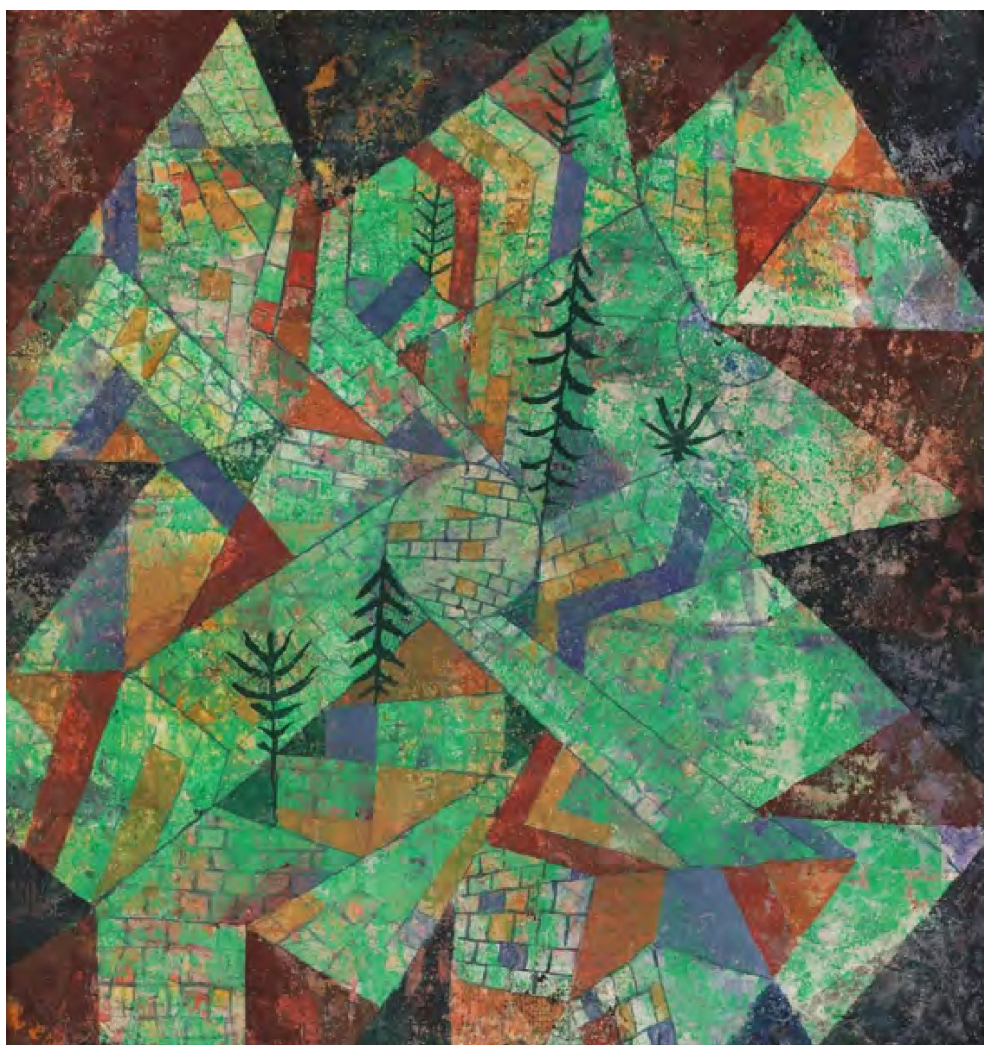

Fonte: https://artsandculture.google.com/asset/wald-bau-paul-klee/FQGzzQvfdf-jpg

FIGURA 62: Homage to the Square, Josef Albers, Collection SFMOMA, 1969, óleo sobre masonita.

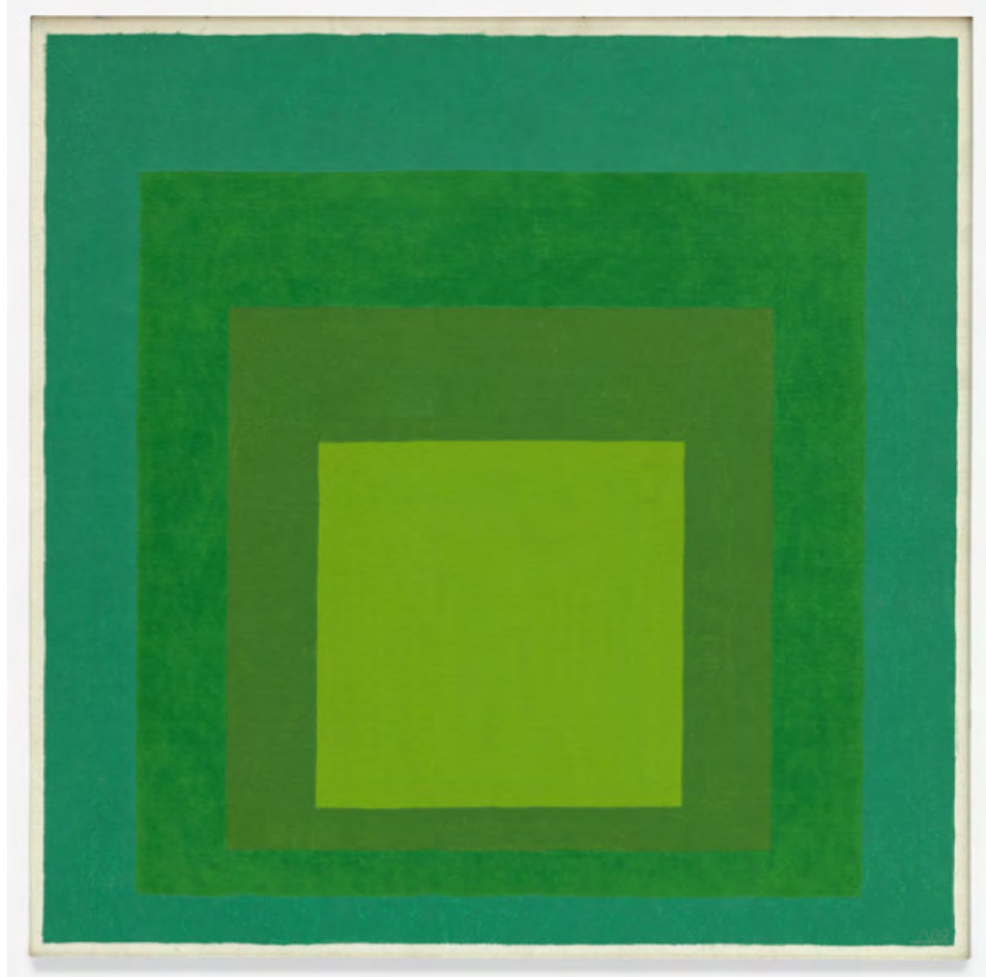

Fonte: SFMOMA, https://www.sfmoma.org/artwork/79.124/ 
E, junto a essa falta de prestígio dessa nuance, as duas grandes guerras ocorridas no século XX trouxeram uma tonalidade esverdeada, em algum lugar entre marrom, amarelo, cinza e verde. Isso porque os uniformes militares, em seus tons de verde cáqui, que não desbotavam e não ficavam sujos, eram baseados na paisagem e permitiam camuflagem. Esse fato marcou uma ruptura acentuada e uma nova forma de travar uma guerra.

Essa tonalidade dos uniformes apareceu tanto nas paredes quanto nos móveis dos escritórios, em estações de trem, nos correios e até em empresas privadas, fazendo-se presente em várias partes. Monótono e triste, era para ser neutro, "padrão" e funcional, tornando-se, assim, a cor emblemática da burocracia.

Dessa forma, nesse século XX, a existência do verde se fez presente em duas outras áreas. A primeira foi na saúde, pois um entorno rodeado por essa coloração contribuía beneficamente para o equilíbrio tanto físico como psíquico. A segunda foi no lazer, que, devido a cada vez mais crescente industrialização das cidades, buscou refugio na natureza em contrapartida aos cenários urbanos crescentemente mais efervescentes e agitados. Por isso, começaram, nesse período, novas políticas para conservação e implementação de espaços verdes, ou seja, parques e praças públicas a fim de se manter o bem-estar dos habitantes. Assim, ele foi ganhando espaço ao ser associado à saúde, à higiene, à limpeza, à salubridade e à purificação. Tanto que, em alguns lugares, as latas, os caminhões e os sacos de lixo e qualquer material que garanta a saúde pública são verdes, pois ele limpa, refresca e purifica (PASTOUREAU, 1997).

Ainda com referência à natureza como fonte de revitalização, restauração e renovação, o verde se faz presente nos centros urbanos e subúrbios para quebrar o domínio esmagador das tonalidades predominantes. Por essa razão, férias, atividades ao ar livre e a busca por espaços verdes, aulas verdes, divertimentos verdes, alimentos verdes, energias verdes, revoluções verdes passaram a ser a nova atratividade e até mesmo responsabilidade cívica, conforme pontua Pastoureau (2014, p. 181):

Mais recentemente, as virtudes atribuídas ao verde alcançaram novos patamares e assumiram uma dimensão ética. Agora tudo deve ser verde, a cor que acalma e salva. Em muitos países, o adjetivo tornou-se um substantivo usado para designar um movimento político ou partido que faz da defesa do meio ambiente uma das formas de suas campanhas. A ligação entre "verde" e ecologia política tornou-se tão forte que imediatamente adquiriu conotações políticas. O verde não é mais tanto uma cor quanto uma ideologia. 
No campo esportivo, tanto os destinados a ambientes externos com seus campos com grama verde, como os internos, como tênis de mesa e bilhar são jogados em uma mesa ou em um feltro dessa tonalidade, sendo onipresente no mundo dos esportes. No campo ideológico, embora difiram em muitos aspectos, os movimentos se reconhecem sob a cor verde, à imagem do Greenpeace, uma organização não governamental que, em todo o mundo, luta contra as ameaças ao meio ambiente. Com isso, busca promover uma atitude e uma educação verde, sendo a cor da agricultura orgânica, assim como é a cor da política ambiental.

Dessa forma, a história desse tom é de altos e baixos. Às vezes na moda, às vezes menos, às vezes admirado, muitas vezes desprezado, o verde teve de esperar que os tempos mais recentes realmente se manifestassem para ele assumir um lugar definidamente de prestígio. Isso porque ocupou um lugar modesto no cotidiano e na criação artística pelos seguintes motivos: até o século passado, foi muito desacreditado por estudiosos que o viam apenas como uma cor "complementar" ou de segunda categoria; negligenciado por pintores que reclamavam de sua instabilidade e da má qualidade dos pigmentos necessários para obtê-lo; rejeitado por mulheres da moda que o culpavam por não ser lisonjeiro bastante; suspeitado pelo corriqueiro de quem continuava a acreditar que trazia azar; superado em quase todas as áreas pelo azul, vermelho, preto e mesmo branco ou amarelo.

Hoje, apesar de haver alguns simbolismos negativos atrelado a essa coloração, como veneno, feitiços malignos, inveja, avareza, ciúme, esse tom traz consigo aspectos positivos, como a calma, frescor, juventude, harmonia, simpatia, natureza, amizade e confiança. Cor agitada, instável e muitas vezes transgressiva no passado, o verde parece ter se abrandado e pacificado bastante. 


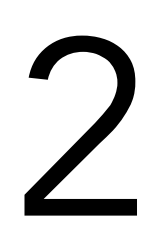

\section{UMA VISÃO SOBRE TENDÊNCIA, MODA E PINTURA CORPORAL}

"É discutível quando a "moda" se tornou um fenômeno econômico e social importante. Evidentemente, assim que surgiu a civilização humana, as roupas e o estilo começaram a ter importância como identificadores sociais".

(BLASZCZYK; WUBS, 2018, p. 9) 
Nos dias de hoje, ainda é comum haver uma percepção errônea generalizada de que a tendência, moda e pintura corporal são "supérfluas", que a antecipação das mudanças de estilo depende muito da intuição ou de um "sexto sentido" (BLASZCZYK; WUBS, 2018). Nessa perspectiva, para muitas pessoas, falar sobre tendência, moda e pintura corporal está atrelado a uma ideia de um consumismo exagerado que pode haver e com ele uma vontade de ter coisas sem necessidade.

Em primeiro lugar, é preciso diferenciar consumo de consumismo. O consumo implica o ato de consumir algo, o que é natural e existe desde sempre. Todos os dias são usufruídos diversos artigos como vestuário, alimento, cultura, entretenimento, informação por todos de uma forma ou de outra (CALDAS, 2015). Já o consumismo está relacionado ao gasto em artigos sem utilidade imediata, os quais são considerados, a priori, supérfluos.

Junto ao consumo ou consumismo, ocorre que, muitas vezes, um indivíduo, ao utilizar um artigo, na maioria das vezes, deseja comprar sua própria identidade e com isso comunicar uma informação a respeito de si próprio a outros indivíduos, posicionando-se perante a sociedade.

Em segundo lugar, é importante colocar que a previsão de moda não é uma invenção francesa nem americana, como muitos acreditam ser. Seu aparecimento se deu por causa da lógica econômica, cultural e social da Segunda Revolução Industrial que ocorreu em várias localidades geográficas com o objetivo de gerenciar e reduzir o risco. Mesmo assim, é discutível quando a "moda" se tornou um fenômeno econômico e social importante impactando consideravelmente a vida dos indivíduos (BLASZCZYK; WUBS, 2018).

Não à toa, essa relação que as pessoas estabelecem com a tendência e a moda é o quinto degrau da pirâmide de Frank Mahnke (1996) e parte integrante na decisão ou rejeição a uma determinada cor. É aqui que, segundo Mahnke (1996), reside o impacto mais importante a ser analisado e ponderado. Isso se dá porque os indivíduos, ao serem constantemente bombardeados pela mídia e pelos muitos veículos de comunicação existentes, aceitam as informações que lhes são passadas sem, na maioria das vezes, averiguar, apurar e examinar se essas ideias lhes servem ou não.

De acordo com Mahnke (1996), nessa falta de investigação, pode residir uma das causas da ausência de identidade cujos efeitos gerados podem ser desastrosos. Segundo ele, para que isso não ocorra, é preciso considerar todas as etapas propostas pelos degraus abaixo dessa pirâmide e confrontar com as mensagens provenientes desse nível para, somente depois, traçar as relações pessoais que cada um irá estabelecer com as cores (MAHNKE, 1996). 
Devido a isso, entender os inputs e os processos oriundos da tendência, moda e pintura corporal são peças fundamentais para a construção da metodologia aqui proposta. Isso porque a força de persuasão dessas vertentes são enormes e simplesmente aceitar e validar ou negar e dispensar poderia não ser o melhor a se fazer, por isso é necessário entender, ponderar e avaliar as informações lançadas.

Para tanto, as contribuições deixadas pela Hierarquia das Necessidades de Abraham Maslow (MASLOW apud VEJLGAARD, 2008), A Curva de Difusão da Inovação de Everett Rogers (ROGERS apud SANTOS, 2013) e Modelo de Tendência em Forma de Diamante de Henrik Vejlgaard (2008), assim como os outros tópicos tratados no capítulo anterior fazem parte do método proposto por esta tese. Dessa forma, entender as aberturas e os aceites que as tendências despertam nas pessoas e como elas se portam perante tais informações contribuem para a criação das paletas de cores voltadas para a imagem pessoal.

Portanto, tanto como nos outros níveis propostos por Mahnke (1996), nesse também as tonalidades vão desempenhar um papel preponderante, uma vez que ditam, muitas vezes, as opções de maior impacto a um determinado período em específico. Em virtude disso, geralmente, essa escolha cromática se submete a ritmos cíclicos e a movimentos pendulares. Esses ritmos e movimentos apresentam intervalos longos entrecortados por fases mais curtas e sistemas de valores que podem se alterar de um meio social para outro (VEJLGAARD, 2008).

Com isso, é preciso conceituar tendência e moda, pois elas não têm a mesma função e suas bases de formulação são bem diferentes. Ainda hoje é muito comum encontrar pessoas que acreditam nas tendências como fenômenos misteriosos ou inexplicáveis e que ninguém realmente entende. Com relação a tendência, na verdade, elas são mais previsíveis do que a maioria dos indivíduos acreditam ser. Sua previsibilidade decorre do fato de serem processos sociológicos que envolvem seres humanos, e o comportamento humano em conjunto pode, às vezes, ser bastante previsível (CALDAS, 2015).

Conforme afirma Janiene Santos (2013), uma tendência começa de forma branda e como resultado propõe uma mudança de comportamento dos consumidores. Elas frequentemente surgem como reações a um estilo ou gosto existente, geralmente apresentam longa duração, sendo capazes de chegar a 20 anos, e podem causar um grande impacto na vida das pessoas.

A principal característica da história de uma tendência é, naturalmente, se haverá ou não uma predisposição para os criadores desse movimento decidirem o que se tornará uma inclinação e uma propensão. Isso não significa, contudo, que as decisões desses autores 
vingarão ou serão aceitas. Em muitos casos, o que eles abraçam pode tornar-se uma moda passageira ou apenas uma ondulação. Também pode acontecer de, por motivos múltiplos e diversos, nem todos os novos produtos, designs ou inovações de estilo prosperarem e serem aceitos (VEJLGAARD, 2008).

Com relação à moda, é discutível quando ela se tornou um fenômeno econômico e social importante. Segundo Blaszczyk e Wubs (2018, p.9):

Evidentemente, assim que surgiu a civilização humana, as roupas e o estilo começaram a ter importância como identificadores sociais. No entanto, a maioria dos historiadores da moda datam o surgimento do sistema da moda moderno na segunda metade do século XIV, seguindo assim a tese de Werner Sombart de que era a demanda por luxos, proveniente da classe crescente de comerciantes e banqueiros em cidades como Florença e Veneza e mais tarde em Amsterdã e Londres, que transformaram o verdadeiro sistema socioeconômico da Europa do feudalismo para o capitalismo. A razão do crescimento extravagante do luxo naquela época foi o surgimento da "burguesia" que vivia na sociedade hierárquica. O cidadão burguês teve que se distinguir das classes inferiores consumindo um grau mais alto de luxo. Isso aumentou ainda mais a demanda por luxo, o que resultou na criação de novos mercados. Portanto, para Sombart, a ascensão do luxo, incluindo a moda, estava intimamente ligada à ascensão do capitalismo e da modernidade. Aliás, as palavras alemã e francesa "mode" e italiana "moda" têm origem na palavra latina "modus", que significa modos, mas também estão ligadas aos conceitos "moderno" e "modernidade" e, portanto, à ascensão do capitalismo.

Com isso, ao contrário da tendência, a moda é utilizada de modo consciente, mas não altera o comportamento dos usuários e geralmente não dura muito tempo (SANTOS, 2013). De acordo com Blaszczyk e Wubs (2018, p. 4):

Os sociólogos Patrik Aspers e Frédéric Godart definem a moda "como um processo não planejado de mudança atual em um cenário de ordem na esfera pública”. Eles distinguem esses conceitos em quatro categorias: moda passageira, inovação, estilo e tendência. As modas estão relacionadas aos modismos passados, aparecem e desaparecem repentinamente. Inovação e moda estão intimamente relacionadas à mudança, escrevem Aspers e Godart, mas inovação tem um impacto social mais profundo e sempre se refere à melhoria, enquanto este não é o caso da moda. O estilo pode ter um impacto cultural duradouro e pode transcender o tempo, como mostra o look punk que está conosco desde os anos 1970, mas o estilo em si não é moda. Uma tendência é "a direção que a moda pode tomar".

Essa direção que a moda foi tomando teve a contribuição do inglês Charles Frederick Worth que, em meados do século XIX, se estabeleceu em Paris. Em 1845, conseguiu um 
emprego com Gagelin e Opigez, na loja de tecidos mais elegante da cidade, onde trabalhou por 12 anos, primeiro como balconista e depois como costureiro.

Worth, ao longo desse processo, foi desenvolvendo sua própria maneira de fazer os vestidos a ponto de não mais perguntar às clientes o que elas queriam. Ele analisava o tecido e a pessoa que usaria o traje na tentativa de entender as reais necessidades de suas clientes. Em 1858, o inglês abriu sua própria alfaiataria, e o reconhecimento se tornou evidente quando a esposa do então embaixador austríaco, ao usar um vestido feito por ele, recebeu elogios da imperatriz Eugénie, frequentadora da corte de Napoleão III.

Esse fato tornou Worth o costureiro da corte imperial, e sua maneira de costurar abriu caminho para um jeito nunca tido antes. Assim, no início do século XX, não foram mais os clientes que decidiram como as roupas deveriam ser, mas sim os designers que desenvolviam os modelos. Desde então, inaugurou-se uma nova fase na qual se estabeleceu uma distinção entre um alfaiate tradicional e um designer de moda. A diferença principal era que um alfaiate seguia as vontades dos clientes, enquanto um designer criava seus próprios modelos. A partir desse momento, as roupas passaram a ser produzidas e comercializadas de forma diferente, não havendo mais tanta distinção no modo de se apresentar entre um e outro.

No entanto, como a sociedade conceitua os indivíduos por sua aparência, a moda é uma das grandes responsáveis por esse julgamento, exigindo, muitas vezes, desembaraço, arrojo e certo desprendimento ou até mesmo distanciamento das opiniões alheias. Aliado a isso, é muito comum encontrar situações em que, junto a tendência e a moda, a cor desempenha um papel importante, aparecendo, com frequência, da seguinte forma: "a cor do ano de 2021 é o azul naval" ou até mesmo "o pretinho básico é a opção mais elegante do momento".

Os trabalhos que tornaram a cor o foco central tiveram seu início no final do século XIX com a empresa francesa J. Claude Frères \& cie, seguido pelos americanos, que fundaram, em 1914, a Textile Color Card Associtation, TCCA. Em 1930, os britânicos criaram a British Colour Council Ltd, BCC, desenvolvendo paleta de cores para a indústria têxtil (BLASZCZYK; WUBS, 2018).

Essa forma de impulsionar as nuances pode determinar as tomadas de decisões, sendo os indivíduos influenciados não só por essas empresas como também pela propaganda do momento. Com essa atitude, além de muitas vezes não considerarem seus próprios anseios, desconsideram também algumas relações importantes. A primeira delas é a física das cores, 
uma vez que determinados comprimentos de onda são capazes de absorver mais o calor e outros refletirem mais facilmente a radiação.

Assim, por uma razão física, o uso de tonalidades claras pode ser mais indicado para dias quentes, ao passo que as tonalidades mais escuras, que absorvem mais as radiações, seriam mais adequadas para dias frios. Esse seria o fundamento, caso houvesse, quando o assunto era a cor.

Essa questão física da cor não é restrita a essa prática, podendo ser facilmente observada em outras áreas, como nas artes plásticas e na publicidade. É muito comum, e não uma regra, artistas plásticos expressarem suas cores em conformidade com a zona territorial em que estão conectados (GAGE, 1999). No caso, por exemplo, de um artista da zona equatorial, devido à grande incidência de luz solar, expressar sua arte com um cromatismo mais intenso do que um artista que vive mais próximo aos pólos.

Já na publicidade, ao se lançar um produto ou buscar evidenciar alguma mercadoria, é comum como estratégia a marca desenvolver uma análise do público que majoritariamente a consome. Nesse caso, "a cor adquire condições de atingir o indivíduo naquilo que ele tem de mais profundo: suas raízes nativas" (FARINA, 1982, p. 32).

A segunda relação importante a ser observada está conectada à estrutura fisiológica humana em que a faixa etária predominante deve ser considerada ao lançar uma cor de tendência. Isso se dá porque estudos evidenciam que o cristalino do olho humano, a partir da passagem pelo tempo, vai tornando-se mais amarelado, modificando, assim, suas características de visibilidade ao longo da vida (FARINA, 1982).

Dessa forma, uma criança é capaz de absorver $10 \%$ da luz azul contra os $57 \%$ de um ancião (FARINA, 1982). Isso prova que as pessoas com mais idade conseguem absorver o comprimento de onda azul com mais facilidade, por isso é bem provável que haja mais aceite a essa frequência cromática. Como afirma Farina (1982, p. 106):

Se observarmos os adultos quando efetuam compras para a família, notaremos que os mais idosos preferem comprar produtos contidos em embalagens em que predomina o azul. A preferência, nesse caso, leva vantagem em cerca de $50 \%$ na venda em relação a produto com outras cores. Está comprovado que o indivíduo mais jovem prefere cores fortes, o vermelho, por exemplo, e com uma vantagem de $50 \%$ nas vendas em relação a outras cores.

É importante salientar que essa relação não fica restrita à publicidade, podendo a moda, as artes plásticas, o design entre tantas outras áreas, fazerem uso dessa informação. 
Ademais, deve-se levar em conta também a sensação que determinada frequência de cor pode causar e as características de personalidade individuais que não estão atrelados à idade cronológica. Além disso, é importante considerar os sistemas de valores que cada tonalidade recebe, como preocupações morais e questões artísticas.

Junto a essas relações colocadas pelas cores de tendências atreladas a física da cor e a fisiologia humana, uma outra questão deve ser levada em consideração e está conectada a sensibilidade medieval às cores que influência como a sociedade atual se posiciona quanto aos conceitos relacionados as tonalidades. Se for observado, já no século XII, São Bernardo condenava o uso de trajes coloridos e foram criados leis e decretos relativos ao vestuário. Como afirma Pastoureau (2011, p. 94), três motivos se fizeram evidentes:

Em primeiro lugar, uma necessidade econômica: limitar em todas as classes da sociedade as despesas relativas ao vestuário e seus acessórios, porque são investimentos improdutivos. Na segunda metade do século XIV, esse tipo de despesas atinge, nos meios nobres e patrícios, um exagero que por vezes beira a loucura. Trata-se, portanto, de colocar um freio nessas despesas ruinosas, no endividamento permanente e no luxo ostentatório. Trata-se igualmente de prevenir a alta dos preços, de reorientar a economia, de estimular a produção local, de frear as importações de produtos de luxo vindo de longe, algumas vezes das profundezas do Oriente. Em seguida vêm as preocupações morais; renunciar o excesso no cuidado com a aparência e manter a tradição cristã de moderação e virtude. Nesse sentido, essas leis, decretos e regulamentos estão em relação com uma vasta corrente moralizadora que atravessa todo o final da Idade Média e da qual a reforma Protestante se tornará herdeira. Por essa razão, a maior parte dessas leis parecem reacionárias: são hostis às mudanças e as inovações, que perturbam a ordem estabelecida e transgridem os bons costumes; e com frequência dirigem-se contra os jovens e contra as mulheres duas categorias sociais que buscam demasiado o prazer da novidade. Finalmente, e sobretudo, por razões ideológicas: instaurar uma segregação por meio do vestuário, pois cada um deve usar o adequado a seu sexo, idade, condição, dignidade ou status. É preciso manter sólidas barreiras, evitar as passagens de uma classe para outra, para que o vestuário permaneça como o sinal patente das classificações sociais. Romper essas barreiras significa romper uma ordem estabelecida não somente pelas autoridades, mas também por Deus, como proclamam alguns textos normativos (grifo nosso).

Evidencia-se que, além desses fatores, existiram também os inimigos da cor, independentemente se aplicada no vestuário ou em outro meio, que a condenavam, priorizando o desenho. Para eles, ela era menos elevada e digna, vinculada aos sentidos e sendo apenas um produto do pigmento e da matéria. Já o desenho era o ato mais nobre da criação, vinculado ao intelecto, à concepção e à representação da imagem (LICHTENSTEIN, 2008). Dessa forma, a cor era tida como uma maquiagem, um engodo, 
uma mentira e não deveria ser prioriza no lugar das formas em nenhum meio a que estivesse vinculada (BACTHELOR, 2007).

Não é à toa que, os séculos que se sucederam, XIV e XV, viram a permissão do uso de tonalidades nos vestuários serem impostas por leis, decretos e regulamentos. Essas determinações eram, muitas vezes, moralizadoras, reacionárias e segregacionistas. Isso porque proibiam para algumas categorias sociais o uso de determinadas nuances e contrastes da mesma forma que, para outras, era permitido e aceito (PASTOUREAU, 2019).

Esse fato, ao que parece, teve suas razões baseadas em alguns fatores cuja finalidade era cumprir mais uma vez uma tripla função: econômica, moral e social. Para Pastoureau (2017, p. 108):

Primeiro, eles visavam combater gastos de luxo e investimentos improdutivos. Segundo, procuraram combater novas modas consideradas frívolas, escandalosas ou indecentes. Por fim, e mais importante, comprometeram-se a reforçar as barreiras entre as diferentes classes sociais e garantir que cada uma, na aparência e no estilo de vida, seja refeita em seu lugar.

Assim, o primeiro fator é de ordem financeira onde só os bem-nascidos e pessoas mais afortunadas tinham o direito de fazer uso de determinadas tonalidades obtidas mediante tinturas mais custosas. Nesses casos, a moral não visava à coloração ou aos contrastes, mas sim à natureza do produto utilizado para conseguir tais tons (HELLER, 2013).

Além desse fator econômico, o segundo fator, de ordem moral, impôs proibições de cores saturadas ou vivas para as pessoas que deviam guardar uma aparência digna e reservada, como os membros da igreja, os promovedores da justiça e as viúvas. De uma maneira geral, para essa parcela da população, eram proibidos não só o uso das cores como também de contrastes fortes e roupas estampadas com riscas, xadrezes e poás. Segundo Pastoureau (2011, p. 96):

No que se refere aos tecidos e vestuários, portanto, tudo é regulamentado segundo o nascimento, a riqueza, a faixa etária, as atividades: a natureza e o tamanho do guarda-roupa que se pode ter, as peças que o compõem, os tecidos com os quais as peças são feitas, as cores com que são tingidas, as peles, os adornos, as joias e todos os acessórios da indumentária. $\mathrm{Na}$ verdade, essas leis suntuárias também dizem respeito a outros domínios da propriedade (louças, prataria, alimento, mobiliário, imóveis, carruagens e até animais), mas a vestimenta é a principal implicação, porque constitui o primeiro suporte de sinais em uma sociedade que, na época, está em plena transformação e na qual a aparência desempenha um papel cada vez maior. 
Já o terceiro fator, de ordem social, visava criar um obstáculo entre as diferentes classes sociais com a intenção de preservar a hierarquia existente. Isso explica por que um documento feito na Toscana, intitulado Prammatica del vestire, entre 1343 a 1345, apontou uma espécie de inventário geral dos guarda-roupas das mulheres florentinas pertencentes às classes mais altas (PASTOUREAU, 2011).

No que diz respeito ao vestuário, esse documento também tinha como objetivo combater posturas consideradas vergonhosas e indecorosas que faziam valer vestidos de cores vivas, decotes e modelos justos. Dessa forma, por esse documento cada um deveria vestir-se de acordo com sua posição e condição a fim de manter a segregação social, a ordem estabelecida, zelar pelos bons costumes, seguir as tradições, evitar confundir gente honesta com aqueles cujo status os diferenciava ou os situava à margem.

Ele era uma espécie de alistamento realizado por muitos advogados para implementar as recentes leis suntuárias e para tributar todos os que deviam ser cobrados. Desse modo, reduziram-se os gastos com o que era considerado luxuoso ou investimentos improdutivos como, por exemplo, com os tecidos, joias, louças e móveis (ELDRIDGE, 2015).

Por essa razão, todas as mulheres da alta sociedade tiveram que apresentar seus enxovais perante uma autoridade. Essa autoridade tentava fornecer o máximo de detalhes possível para cada vestimenta, como tipo de tecido, estilo, corte, dimensões, decorações, forros, acessórios e cores. Para as cores, como afirma Pastoureau (2019, p. 128):

os tons vermelhos dominaram ( $67 \%$ de todos os itens inventariados), mas o
amarelo ficou em segundo lugar $(41 \%)$. Além disso, essas duas cores
costumavam ser combinadas como listras, quadrados, pontos ou metades
vérticas. Verdes ( $27 \%)$ e azuis $(19 \%)$ eram mais raros, e marrons, cinzas e
brancos ainda mais raros. Quanto ao grande gosto pelo negro, então
emergente em Milão, só chegaria à Toscana no final do século.

Tempos mais tarde, com a Reforma Protestante iniciada no século XVI, deu-se a continuação de todas as ideias já desenvolvidas por São Bernardo, quando o vestuário deveria ser o mais discreto possível, por isso condenava-se o uso de maquiagens ou qualquer outro ornamento que desviasse a atenção para o mundano e superficial. Assim, a cor foi censurada porque, segundo a ideia antiga, era perigosa, incontrolável e rebelde, sendo necessário dispensá-la sempre que possível.

Com o caminhar dos séculos, no Século das Luzes, as pessoas voltaram a se vestir de forma colorida, representando um oásis em cores para esse segmento. As luzes, a partir desse momento, passam a não ser somente a do espírito, mas também a da vida cotidiana. 
Assim, "por quase toda parte as tonalidades de marrom, violeta ou carmesim perdem terreno, bem como as tonalidades escuras e saturadas, os contrastes violentos usados no século precedente" (PASTOUTEAU, 2011, p. 153).

Porém, no momento seguinte, essa forma mais colorida de se vestir não se fez tão presente e a Revolução Industrial (1760 a 1840) colaborou para mudar a maneira como homens e mulheres viviam e trabalhavam, além de todo reconhecimento das necessidades materiais das pessoas produzidas em larga escala. A vivência urbana e suburbana, os desenvolvimentos na educação e alfabetização em massa e o nascimento da mídia impactaram significativamente a vida das pessoas.

Na sequência, durante a Primeira Guerra Mundial (1914 a 1918), com os homens indo para a guerra, as mulheres passaram a assumir alguns lugares profissionais nunca antes vistos. Devido a esse fato, muitas tiveram que vestir uniformes, e, como não havia uma distinção de estilo e gosto pessoal, elas eram padronizadas pelos trajes (ELDRIDGE, 2015). Essa realidade não permaneceu ao longo da segunda metade desse século XX e muito menos adentrou o século XXI onde, muitas vezes, a distinção se deu também através das cores usadas nas vestimentas.

Portanto, o que se observa é que ao longo da História, essas idas e vindas de como as sociedades se comportaram, aceitaram, usaram e se posicionaram perante as cores se fazem presentes até hoje em dia, como será tratado adiante.

\subsection{As Influências ditadas pela tendência}

Quando se fala de tendência, a primeira tarefa que se faz necessária é entender o que é tendência, quais são seus objetivos e os percursos e impactos causados por ela. Como explica Dario Caldas, tendência é um termo que provém do latim, tendentia, e possui o seguinte significado (CALDAS, 2015, p.72):

(...) "tender para", inclinar-se para" ou ser "atraído por". Desde o berço, portanto, a palavra vem carregada dos sentidos de alteridade - a medida que ela só pode existir em função de uma atração exercida por um outro objeto -, de movimento (a imagem da inclinação decorrente dessa atração) e de abrangência (o verbo tender também significa "extender" e "desdobrar', além da acepção mais literal de "levantar uma tenda" ou "acampar"). 
Os significados que essa palavra traz foi mais comumente empregado no começo do século passado, em um círculo restrito constituído de estatísticos e economistas. Tanto que, originalmente, como afirma Henrik Vejlgaard (2008, p.6):

\begin{abstract}
Nas estatísticas, tendência significa a direção de uma curva. Frequentemente, um estatístico usa a palavra tendência quando a direção de uma curva não é tão evidente. Por exemplo, se houver apenas uma ligeira alteração na curva, um estatístico cuidadoso falará de uma tendência positiva ou negativa na curva, em vez de dizer que a curva está subindo ou descendo (a direção pode ser positiva ou negativa, dependendo sobre o que a curva está representando).
\end{abstract}

No entanto, por volta do final da década de 30 do século XX, essa palavra começou a ser empregada em outros setores, e seus significados obtiveram maior alcance, tornando-se mais comum e conhecido. Desde então, observa-se, com muita frequência, o emprego desse termo cuja presença é muito forte na indústria da moda e da maquiagem. Isso se deu porque, em 1936, a Design and Industries Association publicou uma revista cujo nome era Trend, que trazia aos seus leitores os mais novos artigos, produtos, gêneros e design recém-criados. As figuras 63 e 64 evidenciam a tendência no universo da moda nos anos 30 .

FIGURA 63: Imagem publicada em uma revista de moda da década de 30 sugerindo as tendências que estavam em alta.

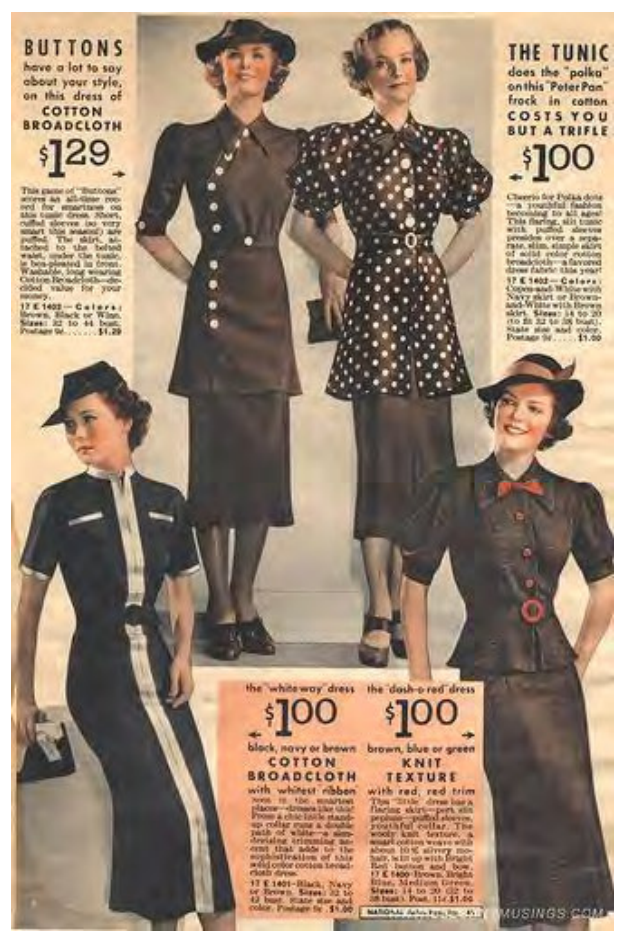

Fonte: PINTEREST, https://br.pinterest.com/pin/430304939372427611/ 
FIGURA 64: Coleção de outono-inverno 1937-1938.

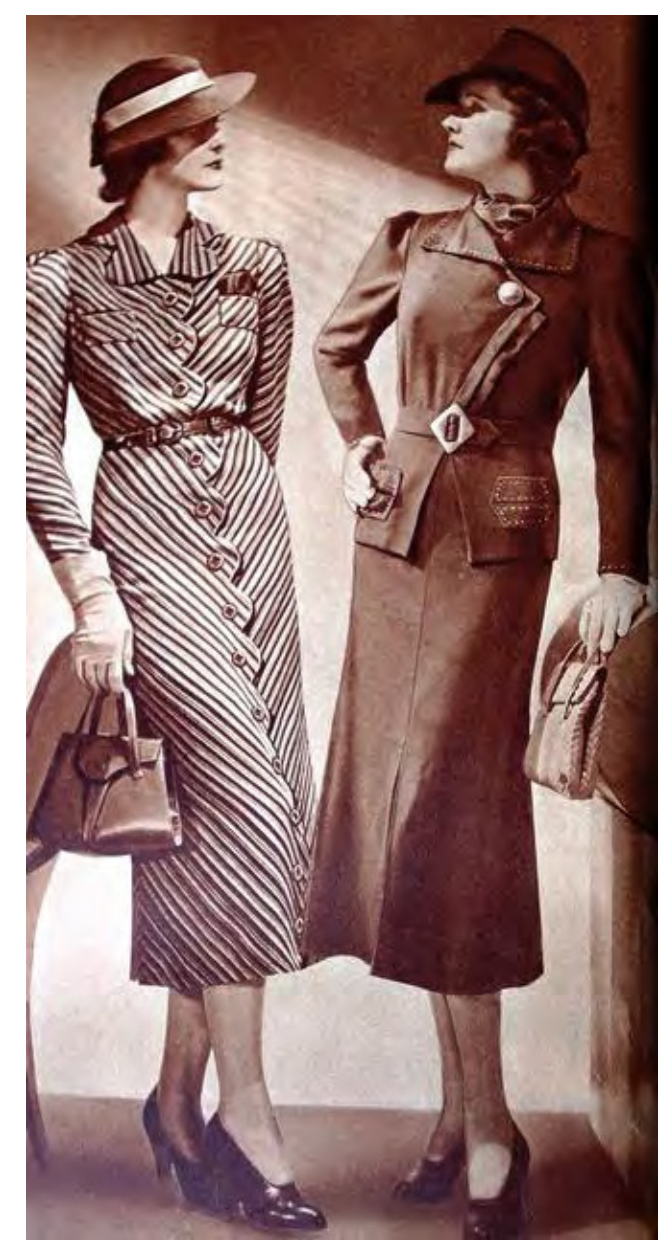

Fonte: PINTEREST, https://br.pinterest.com/pin/118289927683491428/

Vale destacar que o uso da palavra tendência vai muito além desse setor, pois é empregada em outros ramos como na automobilística, gastronomia, lifestyle, cultura, economia, política e tecnologia, por exemplo. Cada área tem suas próprias características, mas não necessariamente seguem o mesmo processo observado no design e no estilo.

Tanto que para setores como cultura, política e tecnologia, por exemplo, de forma geral, as mudanças ou as transformações ocorrem durante períodos mais longos e são mais profundas e múltiplas. Isso se dá porque, se essas alterações ocorressem na mesma velocidade ou da mesma forma que ocorrem no design e no estilo, tenderiam para verdadeiras modificações ou até mesmo revoluções, dependendo de como e do que está sendo proposto.

Com isso, por não se tratar necessariamente do mesmo processo, alguns pesquisadores, como o americano John Naisbitt, "usam a palavra megatendência para 
discutir mudanças culturais, econômicas, políticas ou tecnológicas que estão prestes a acontecer, com a implicação de que essas megatendências afetarão todas ou quase todas as camadas da sociedade" (NAISBITT apud VEJLGAARD, 2008, p.20).

Sendo assim, as megatendências pressupõem pilares e caminhos diferentes da tendência porque, além de reverberarem por mais tempo, nem sempre seus rumos são previsíveis ou imagináveis. Além do mais, o impacto gerado por uma megatendência dura mais, afetam muitos aspectos diferentes da vida cotidiana e envolvem processos complexos.

Quanto ao impacto causado pela tendência, segundo Martin Raymond, teria que ser considerado, (2018, p. 6)

\begin{abstract}
cuidadosamente um conjunto de evidências e linhas de possibilidade colocadas, uma contra a outra, com o objetivo de determinar o possível, plausível e provável e resultados preferíveis - os quatro P's, como às vezes os chamamos. Essas quatro estradas divergentes, ao longo das quais existem muitas oportunidades - e ao longo das quais muitas outras foram destruídas devido à falta de preparação. A previsão, na sua forma mais básica, ajuda a reajustar o equilíbrio e a refazer as probabilidades e oportunidades mais uma vez a seu favor. Portanto, permita que essas palavras - possível, plausível, provável e preferível - sejam seus guias, guardiões e agregadores sobre o que é realmente a previsão: não o futuro, mas uma gama de futuros no plural. Futuros que serão solicitados a selecionar o mais útil e acionável para o seu cliente ou a considerar futuros que possam ver o seu cliente totalmente fora de cena, a menos que eles ajustem sua trajetória atual.
\end{abstract}

Sendo assim, se por um lado, um estudo de tendência não significa uma previsão de futuro ou algo premeditado que traz consigo o enigmático, o oculto e o inexplicável, como um acontecimento completamente imprevisível e aleatório, por outro lado, também não se refere a algo que surgiu no momento em que se fala, sendo alguma coisa nova, recente e atual. Nesse sentido, a tendência é um prognóstico, uma antecipação de algo que acontecerá e reverberará de alguma maneira dentro de camadas da sociedade a qual está conectada e relacionada (RAYMOND, 2018).

É preciso mencionar que a tendência pode ocorrer de algumas formas e percorrer direções diferentes, sendo preciso entender qual é o objetivo e o objeto no qual há necessidade de colocar atenção e foco. Isso porque, dependendo de como e do que, seus caminhos podem ser diferentes e precisam ser entendidos. Assim, por exemplo, se o ponto central for o lançamento de algum produto que acabou de ser criado e será disponibilizado no mercado, exige um caminho. Agora, se o que se pretende evidenciar é o aperfeiçoamento de produtos que já existem, mas podem ter algo a ser "melhorado" ou "otimizado", tais 
produtos necessitam de outros recursos para que se tornem tendência e para que possam ser visualizados.

Por fim, o mais abrangente e que muitas vezes requer um tempo maior de ação é o início de um processo de mudança de olhar e de posicionamento em que se faz necessária a construção de todo um caminho, desde os criadores de algo novo até integrar a quem será destinado.

Nessa situação, convém ponderar algumas condicionantes que podem aparecer nesse processo mais abrangente. A primeira seria uma postura conservadora do público a quem essa novidade está destinada, não querendo aderir a uma nova orientação. Já a segunda seria a probabilidade de as pessoas serem capazes de registrar que algo diferente está acontecendo simplesmente por observar uns aos outros e querer aderir a esse novo movimento. Com isso, observar e atentar são ações necessárias para que se possa mapear uma nova tendência.

Todo esse procedimento de mudança pode afetar uma cadeia de pessoas, por isso deve ser pensado e elaborado como parte integrante do processo. Sendo assim, segundo Vejlgaard (2008), há, na maioria das vezes três pistas que são observadas e dizem respeito a esse procedimento.

A primeira pista, que pode ser dividida em dois pontos, é considerar que, em primeiro lugar, esse sistema não tem seu início no nada, mas evidências apontam para seu cerne que comprova esse novo foco. Em segundo lugar, leva tempo e empenho para que um novo estilo ou gosto possa ser alterado ou aderido por uma parcela da população.

A segunda pista evidencia que um mesmo estilo ou gosto pode ser incorporado e legitimado em diferentes categorias. Isso quer dizer que, por exemplo, o estilo boho, que teve seu surgimento no início do século XXI entre Londres e Manhatan, foi incorporado tanto na decoração de interiores, já que muitas casas passaram e ser decoradas conforme seus preceitos, como na moda, pois roupas e acessórios foram desenvolvidos seguindo essa nova tendência.

Por fim, a terceira pista diz que a observação do que está acontecendo no estilo convencional que se torna, pelos olhos de muitos, popular e comum, poderá levar os formadores de opinião a reagirem a esse convencionalismo, mudando a estratégia para algo novo ou até mesmo completamente diferente do que estava sendo visto e usado. Isso se faz necessário para que o estilo não se torne generalizado ou que essa generalização seja o ponto de partida para a criação de uma nova tendência.

É sempre oportuno colocar que as pessoas, sejam elas pertencentes a qualquer categoria ou parcela da sociedade, antes de aderirem a qualquer tendência, precisam atender 
ao que o psicólogo americano Abraham Maslow chamou de Hierarquia das Necessidades (MASLOW apud VEJLGAARD, 2008).

Com isso, o ponto de partida de Maslow (MASLOW apud VEJLGAARD, 2008) de extrema significância é que os seres humanos tenham suas necessidades básicas e essenciais, alocadas na base dessa hierarquia, atendidas em primeira instância. Segundo ele, as relações afetivas, os laços familiares, as necessidades primordiais de comida e abrigo são exemplos do que ele chama de exigências fundamentais.

Somente a partir daí, outras questões passariam a ser eloquentes e pertinentes. Tais questões vêm à tona quando as pessoas estão confortadas e são atendidas nas primeiras faixas dessa estrutura, como se gosta ou não do estilo boho, ou se há necessidade de mudar de carro e incorporar um novo padrão.

Entretanto, somente manter o sustento físico e afetivo não é algo desejado pela maioria das pessoas, já que, muitas vezes elas vão buscar realizar outras necessidades para que se sintam preenchidas. Maslow (MASLOW apud VEJLGAARD, 2008) elenca 5 aspectos que são importantes e que devem ser levados em conta, conforme se vê na figura 65 .

FIGURA 65: Hierarquia das Necessidades de Abraham Maslow.

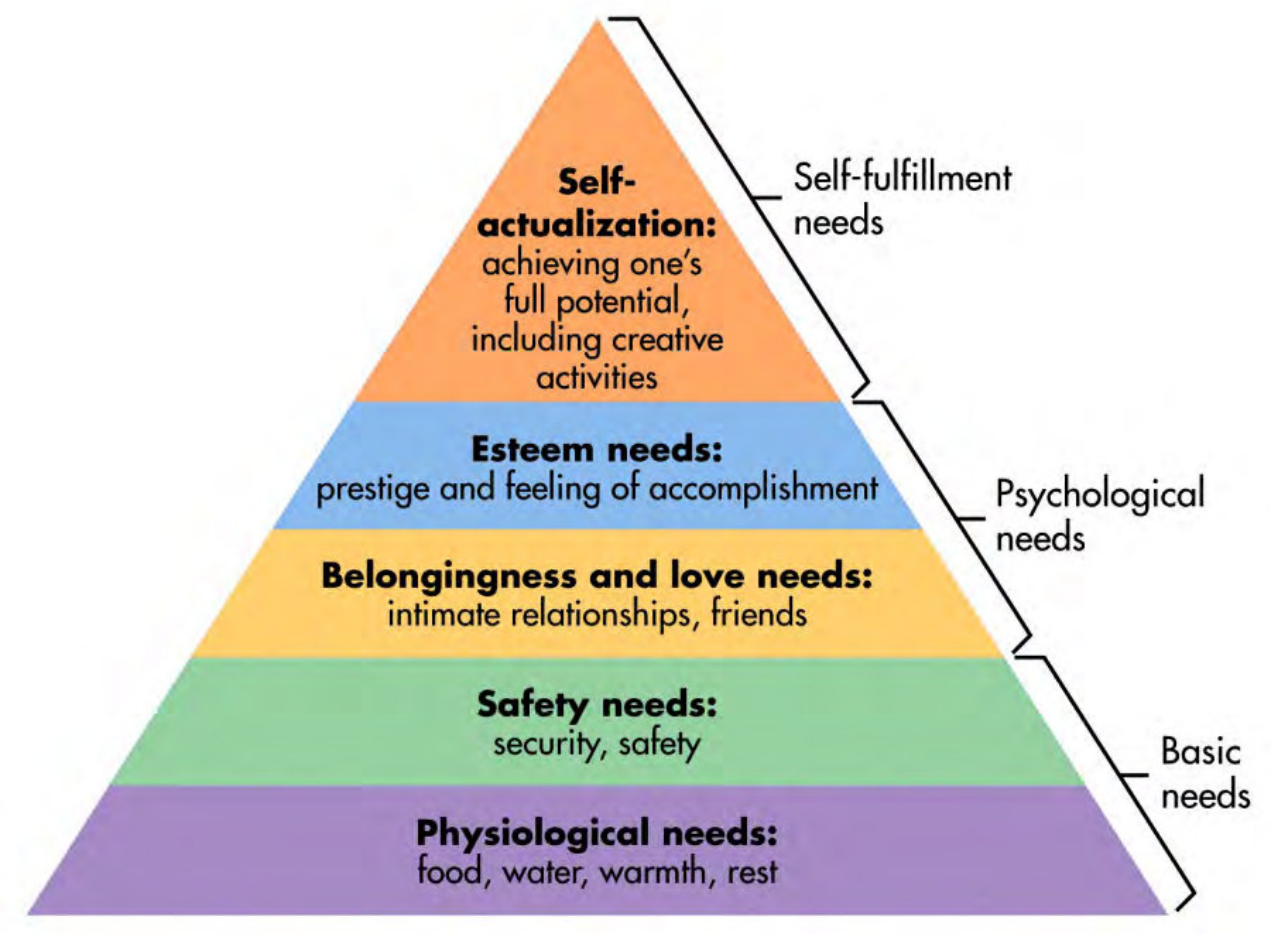

Fonte: WIKIPEDIA, https://en.wikipedia.org/wiki/File:Maslow's_Hierarchy_of_Needs2.svg 
O primeiro aspecto são as necessidades fisiológicas, uma vez que comer e beber é de fundamental importância para que o corpo humano realize as funções metabólicas vitais. Além do mais, somente com um organismo sadio se pode estabelecer elos com os outros aspectos.

Quanto ao segundo aspecto, este diz respeito às necessidades de segurança. É nesse setor que as casas, sejam elas do tamanho e formato que são, trazem a segurança e o conforto. Isso tanto é verdade que, desde os primórdios, os homens se abrigaram nas cavernas com o intuito de se refugiarem e se acolherem.

$\mathrm{O}$ terceiro aspecto são o pertencimento e necessidade de amor. É nesse lugar que os laços afetivos, a compaixão e a vontade de se relacionar, desejos esses tão humanos, têm o seu lugar.

Com relação ao quarto aspecto, trata-se das necessidades de estima. É aqui que aparece uma vontade de envolvimento social, de amizade, afeição, estima e carinho para com os outros.

Por fim, o quinto e último aspecto diz respeito à necessidade de autorrealização e autoatualização. Aqui são desempenhadas tarefas mentais e intelectuais que envolvem os seres humanos em suas práticas de trabalhos, ofícios, empregos das mais diversas ordens. Ocupar a cabeça e produzir algo faz parte do dia a dia, por isso, para muitos, quando não há alguma ocupação, pode haver uma perda da estabilidade emocional.

Somente quando esses fatores elencados por ele são atendidos, as necessidades estéticas surgem e necessitam também ser solucionadas. É importante salientar que, muitas vezes, as pessoas se enganam ao atribuírem a esses valores pormenores relacionados à futilidade e à falta do que fazer. Todavia, é sabido como a História da humanidade demostrou que questões de estilo e bom gosto sempre foram uma vontade humana. Pintar o rosto, pintar o corpo, pintar as paredes, "enfeitar a alma" é mais importante do que muitos acreditam ser (PIPE, 2008).

Entretanto, verifica-se que os consumidores estão mais ligados com estilo e bom gosto “quando estão bem, porque estão no topo da Hierarquia das Necessidades. Essa preocupação com estilo e gosto provavelmente não mudará, a menos que a economia ou o sistema político mude radicalmente" (VEJLGAARD, 2008, p. 24). Nesse sentido, pessoas mais abastadas provavelmente vivem suas vidas no topo da Hierarquia das Necessidades de Maslow, podendo dar maior foco no lado estético da vida do que outras classes econômicas. Como consequência, são elas que, por não estarem separadas do resto da sociedade, podem ter maior poder de disseminação de uma nova tendência. 
Assim, a necessidade de autorrealização, ou seja, para que os humanos se sintam completos e preenchidos, é preciso percorrer, de alguma maneira, os outros caminhos listados anteriormente, não precisando necessariamente ocorrer de forma linear, podendo ser o percurso aleatório. Sentir-se autorrealizado diz muito a respeito do indivíduo de quem se fala ou convive e demonstra que as outras etapas foram supridas.

Com isso, todas as camadas que compõem, segundo Vejlgaard (2008), essa ordenação pode ser uma previsão qualificada para uma demanda crescente por parte da sociedade. Claro que detectar uma tendência significa que não é preciso reagir à informação e muito menos de forma imediata, havendo a possibilidade de ter certeza antes de começar a mudar os procedimentos. Por outro lado, caso haja necessidade e a vontade de querer reagir imediatamente e enfrentar o novo mercado, existe também abertura para essa possibilidade.

Outra teoria que complementa os caminhos que são percorridos, conforme proposto por Maslow, é a Teoria da Difusão de Inovações de Everett Rogers (ROGERS apud SANTOS, 2013). Por essa visão, é preciso entender o perfil de indivíduo que se pretende impactar e propagar a nova tendência. Segundo Santos (2013), ao discutir tendências socioculturais, torna-se importante considerar os cinco perfis, conforme apresentados a seguir.

Nessa teoria da Difusão de Inovações, um processo de disseminação geralmente ocorre dentro de um grupo muito semelhante. É o caso, por exemplo, das mães de recémnascidos, pesquisadores ou esportistas, que compartilham uma característica ou vivência em particular. Portanto, um discurso ou artigo direcionado para uma lactante vai afetar quem se encontra nessa mesma condição e dificilmente se espalha ou é interessante para o público que não está vivendo esse momento. As figuras 66 e 67 exemplificam como se dá a Curva de Difusão da Inovação de Everett Rogers. 
FIGURA 66: Os grupos que formam A Curva de Difusão da Inovação de Everett Rogers.

\section{Early Majority}

\section{Late Majority}

\section{Early adopters}

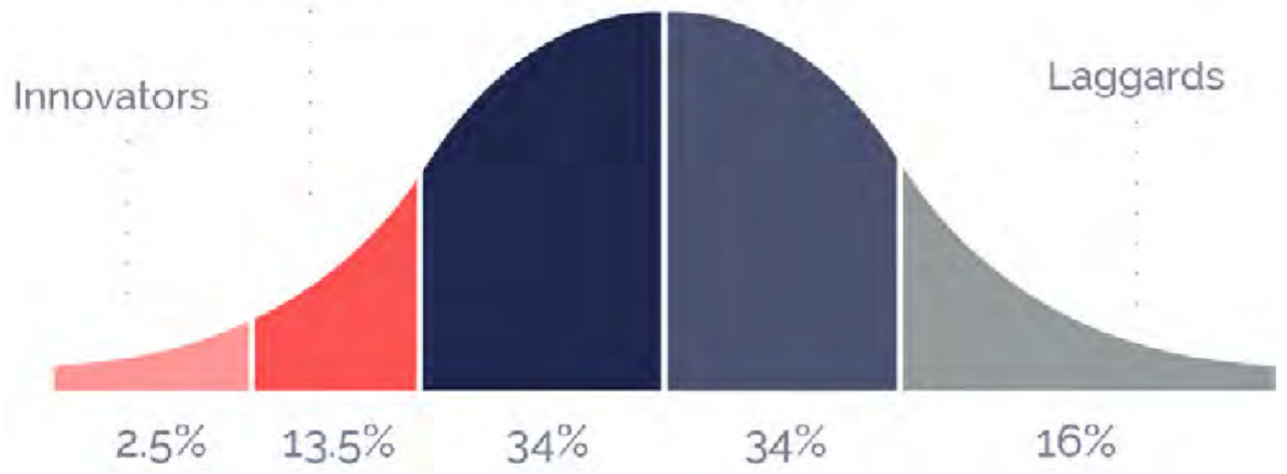

Fonte: WIKIPEDIA, https://en.wikipedia.org/wiki/Diffusion_of_innovations

FIGURA 67: Relação entre os grupos e a quantidade de participantes que formam A Curva de Difusão da Inovação de Everett Rogers.

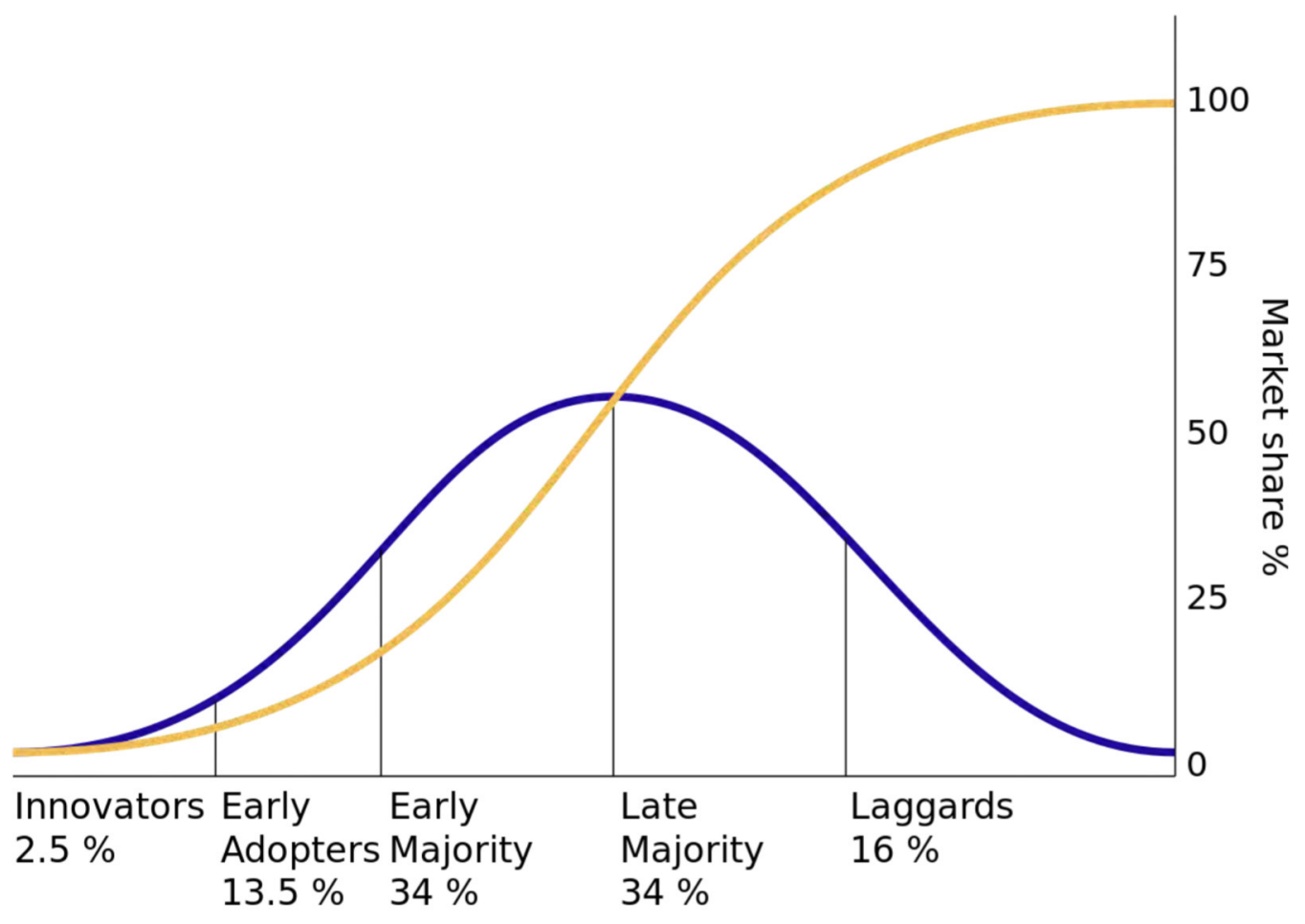

Fonte: WIKIPEDIA, https://en.wikipedia.org/wiki/Diffusion_of_innovations 
Segundo essa teoria, o primeiro grupo é formado pelos Inovadores (innovators), que, por ser um nicho seleto de pessoas, adotam novas tecnologias e comportamentos ainda em fase inicial. Eles são também os formadores de opinião e os que lançam tendências. Contudo, os Inovadores não são quem pensam novas ideias, criam novos conhecimentos ou desenvolvem novos métodos, e sim os primeiros a adotar o que outras pessoas estão propondo. Portanto, não são como criadores de tendências, ou seja, os que realmente criam novas tendências à medida que difundem mudanças de estilo e gosto.

O segundo grupo é formado pelos Primeiros Adotantes (early adopters), que compreende um grupo pequeno, porém maior em número do que o grupo acima. Eles aceitam bem e buscam as inovações, mas não assumem os mesmos riscos que os Inovadores.

Quanto ao terceiro grupo, este é formado pela Maioria Inicial (early majority) que, ao contrário dos outros dois citados acima, é um grupo grande. Quando uma certa inovação é adotada por esse grupo, é um sinal de que ela será bem aceita pelo restante do público-alvo.

Já o quarto grupo é formado pela Maioria Tardia (late majority), que, assim como o grupo de cima, também é um grupo grande. Porém, a diferença é que são muito mais resistentes às novidades do que a Maioria Inicial. Esses só irão adotar uma inovação depois que estão convencidos de que esta possui muitas vantagens.

Por fim, o quinto e último grupo é formado pelos Retardatários (laggards), que são os últimos a aderir a uma inovação. Eles só conseguem incorporar o novo quando este se encontra bem experimentado e estabelecido.

Junto a esses grupos elencados por Everett Rogers (ROGERS apud SANTOS, 2013), é importante dizer que existem algumas formas de difundir uma nova tendência para a sociedade. Isso pode ocorrer, segundo Santos (2013), pelas teorias conhecidas como Trickledown (gotejamento) e Bubbling-up (borbulhamento). Pelo gotejamento, as tendências surgem de cima para baixo, ou seja, são adotadas pelas camadas economicamente mais altas da sociedade e depois descem para as camadas mais baixas. Por essa razão, é comum as camadas mais baixas almejarem a condição das classes acima delas. Já o borbulhamento se dá quando as classes mais baixas são as que irão difundir e impactar as classes mais altas da sociedade.

Seja pelo movimento descendente ou ascendente, são os formadores de opinião que, junto a essas direções, ao observarem e incorporarem novos conceitos, são capazes de determinar e disseminar uma tendência, impactando, de alguma forma, os cinco grupos elencados por Rogers (ROGERS apud SANTOS, 2013). Assim, quando os formadores de 
opinião perdem o interesse em um produto, uma nova versão deve estar disponível para recuperar a valia e manter esse processo em andamento. Isso mantém o fluxo de tendências ativo e permite que outros grupos se tornem parte desse processo.

Hoje em dia, existe uma superprodução de novos estilos e gostos que até os mais fervorosos disseminadores de tendências e formadores de opinião não conseguem absorver. Observa-se que, além da grande quantidade existentes, também algumas inovações acabam sendo extremas demais para encontrar um mercado, mesmo entre os disseminadores de tendências. E se, por qualquer motivo, não puder ser copiado, isso poderá impedir que se torne um movimento.

Esse processo, como afirma Henrik Vejlgaard (2008), possui um padrão que pode ser mais bem visualizado através de um modelo gráfico denominado por ele como sendo Modelo de Tendência em Forma de Diamante. Esse padrão, segundo Henrik (2008), é um esquema simplificado de representação de um processo extremamente complexo, conforme se vê na figura 68. 
FIGURA 68: Modelo de Tendência em Forma de Diamante de Henrik Vejlgaard.

\section{TREND CREATORS}

\section{TRENDSETTERS}

\section{TREND FOLLOWERS}

EARLY MAINSTREAMERS

MAINSTREAMERS

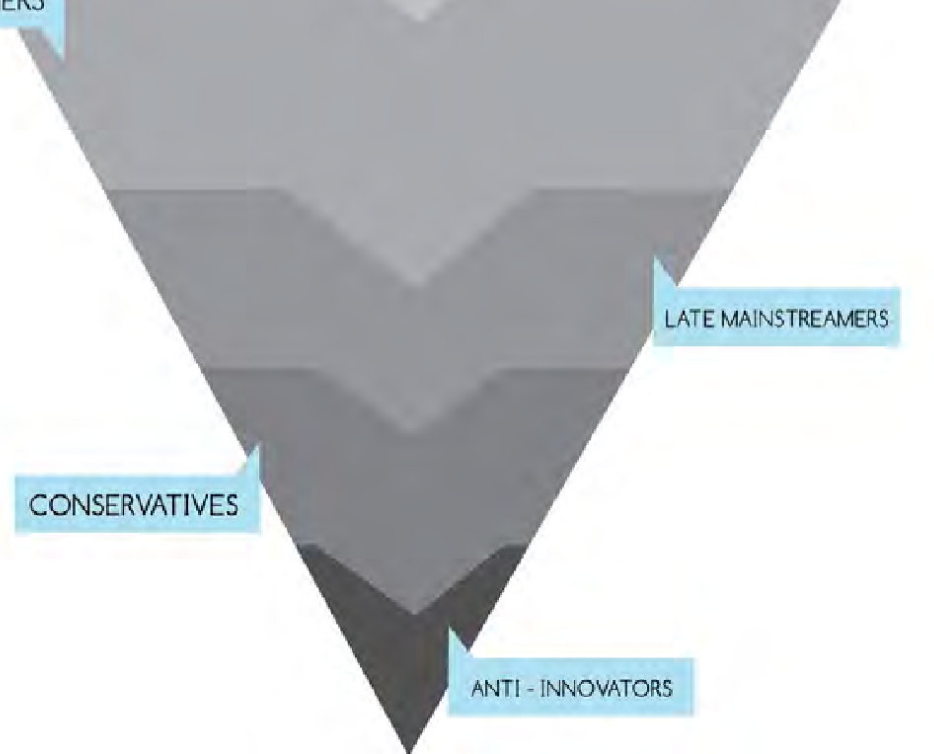

Fonte: RESEARCH GATE, https://www.researchgate.net/figure/Figura-1-Modelo-de-Tendencias-emForma-de-Diamante-Fonte-Adaptado-de-VEJLGAARD-2007_fig1_311462383

Através dessa representação, são os Criadores de Tendência (trend creators) que começam a usar, a manipular e a divulgar uma ideia, contribuindo com a difusão e comercialização de novos produtos ou serviços. Com isso, são eles que pensaram, elaboraram, desenvolveram e lançaram tais conceitos.

Esse grupo geralmente é muito pequeno, mas desempenha um papel fundamental nesse processo, porque são eles que criam os novos estilos e gostos. Embora os Criadores de Tendências não sejam um grupo homogêneo e não se possa dizer que representam um 
mercado, eles são colocados no topo do modelo, porque são responsáveis por propor ou fazer algo que possa tornar-se uma tendência.

Depois deles, são os Formadores de Opinião (trendsetters) que os seguem. Por serem indivíduos mais ligados ao novo e abertos em relação ao estilo e ao gosto, aceitam a ideia de o fluxo ter sempre um movimento, atribuindo um valor positivo a isso. Geralmente, junto com os Criadores, são os primeiros a adotarem o novo estilo antes de este ser autenticado e legitimado por outras pessoas.

No entanto, o que atrai a atenção dos Formadores de Opinião e, consequentemente, o que eles adotam varia. Apesar disso, eles geralmente se concentram em alguns fatores: estilos e gostos completamente novos e nunca antes vistos; estilos e gostos que estão fora do padrão; estilos ou produtos em constante desenvolvimento; algo que ainda não foi visualizado pela mídia como uma tendência (VEJLGAARD, 2008).

Observa-se também que os Formadores de Opinião provavelmente requerem um forte senso de individualismo e uma necessidade de ser diferente. Essa a razão por que desempenham um papel na motivação, aceitam o novo e incorporam-no como autêntico e verdadeiro para propagar o novo estilo.

Na sequência, vêm os Seguidores de Tendência (trend followers). Ao contrário dos trendsetters, que buscam e incorporam o novo de maneira natural e espontânea, os Seguidores de Tendência necessitam que outras pessoas primeiramente legitimem esse novo estilo para que depois eles o incorporem.

Já as Pessoas Menos Convencionais (early mainstreamers) são indivíduos que preferem uma tendência já incorporada, mas que têm facilidade em aceitar novos estilos pouco antes da maioria. Isso quer dizer que eles conseguem relacionar-se ativamente com uma tendência antes que ela tenha caído no senso coletivo.

Sendo assim, a diferença básica entre os Seguidores de Tendência das Pessoas Menos Convencionais é que estas precisam ter visto várias pessoas usando o estilo antes de adotálo, enquanto aqueles precisam ter visto apenas algumas comprarem ou usarem um estilo inovador.

Na sequência, vêm as Pessoas Convencionais (mainstreamers), que só vão adotar algo novo se a maioria das pessoas já incorporaram e fazem uso daquilo. Dessa forma, são pessoas que não têm por objetivo estar tão na moda como os outros grupos citados acima, mas também não querem ser vistas como conservadoras.

Depois vêm as Pessoas Mais Convencionais (late mainstreamers), que não apresentam em si abertura para lidar com o novo, desconsiderando, muitas vezes, as mudanças de estilo 
e gosto. Apesar de tais indivíduos aceitarem o fato de que as tendências existem e que muitas vezes o novo faz parte e com o qual é necessário saber lidar, elas geralmente se mantêm na maneira e no estilo que estão acostumadas. Isso faz com elas se destaquem em relação aos outros, justo por permanecerem nesse lugar.

Por último, estão os Conservadores (conservatives), que não gostam de muitas mudanças e preferem manter-se fiéis aos velhos costumes e tendências. Para esse grupo, só haverá a aceitação e incorporação de algo novo se não acharem mais os artigos que preferem e usam por anos.

Dessa forma, o início de uma tendência é um processo social único e complexo que, de fato, não ocorre com muita frequência. Mas quando isso acontece, vários fatores entram em ação. Seja um processo rápido de absorção ou muito mais lento, seja promovido por pessoas abertas e receptivas ao novo ou por pessoas mais conservadoras. O fato é que uma tendência se espalha quando vários grupos incorporam e fazem uso das suas informações.

Além disso, a mídia colabora para que a tendência possa ser visualizada com maior impulso e propagação. Os bureaus de tendência com seus cool hunters, como são conhecidos os profissionais que trabalham nesse mercado, também contribuem para a difusão de uma tendência. Esses profissionais, espalhados pelo mundo, não apenas monitoraram tendências de moda, mas também comportamentos, cultura, economia, política etc. Atualmente, a maioria desses escritórios são online, e o cliente faz uma assinatura para utilizar o serviço.

O trabalho desses escritórios é traduzir as informações das principais tendências de comportamento e o nicho de mercado para seus clientes. Para tanto, trabalham com alguns movimentos socioculturais e tiram disso cartela de cores, ideias de estamparia, novidades do mercado têxtil, forma para modelagem etc. Segundo Caldas (2015, p. 92):

Foi criado em 1955, na França, o Comitê de Coordenação das Indústrias de Moda (CIM), cuja principal missão era fornecer aos diversos elos da cadeia têxtil, das fiações à imprensa, indicações precisas e coerentes sobre as tendências. O CIM serviu de modelo aos birôs de estilo, que durante as décadas de 1960 e 1970 exerceram um papel fundamental por meio dos "cadernos de tendências", verdadeiros guias contendo todas as informações para o desenvolvimento de uma coleção.

A reinvenção da indústria da moda francesa em torno do pronto-a-vestir, de 1960 em diante, criou novas oportunidades empresariais que levaram à liderança francesa no negócio internacional de previsão de moda. Segundo Blaszczyk e Wubs (2018, p. 17): 


\begin{abstract}
A Promostyl levou sua fórmula de sucesso para o exterior. Ao longo do início dos anos 1970, licenciou a marca Promostyl no Japão; colaborou com o designer nova-iorquino Halston para adaptar um novo tecido de uretano ao pronto-a-vestir; e uniu forças com uma fábrica de roupas na Índia para projetar roupas para lojas de departamentos americanas, como R. H. Macy \& Company e Bloomingdale's. Em 1976, a Promostyl tinha um escritório em Time Square, próximo ao movimentado distrito de roupas da Sétima Avenida, para atender melhor a esses e outros clientes americanos. Depois de atuar como diretora da CIM de 1975 a 1985, Nelly Rodi partiu para se dedicar ao desenvolvimento de sua própria agência de tendências. Ela foi uma das primeiras previsões de moda a ampliar o escopo da previsão da moda para incluir automóveis, beleza, comida e decoração de casa. Em 1986, sua colega holandesa Lidewij 'Li" Edelkoort - as duas mulheres trabalharam juntas na CIM - fundou uma agência independente especializada em previsão de tendências, a Trend Union. Hoje, a equipe de Edelkoort publica previsões de tendências semestrais, que são vendidas em mais de vinte países. Ela aconselhou marcas globais como Coca-Cola, L'Oreal e Siemens, mostrando que as previsões de tendências podem ter um impacto muito além da indústria da moda. Como David Wolfe e Leigh Rudd, Rodi e Edelkoort acreditam que a intuição é o cerne de sua metodologia.
\end{abstract}

À medida que o negócio de previsão de moda continuou a se expandir no final do século XX, novas plataformas digitais foram desenvolvidas para a divulgação de tendências. Em Londres, a Worth Global Style Network, WGSN, fundada como uma plataforma de previsão de tendências online pelos irmãos Julian e Marc Worth, em 1998, obteve um sucesso excepcional. Isso mostra que, além de Paris e Nova York, novas práticas de tendências poderiam surgir para atender aos clientes que produzem mercadorias para diferentes mercados ao redor do mundo.

Esses escritórios colaboram ao fornecerem informações dos padrões de uma tendência para prever necessidades futuras. Contudo, é igualmente importante estar ciente de que o elemento-chave nesse processo é a observação realizada no comportamento humano, seja tomando distância da mídia ou através dela (BLASZCZYK; WUBS, 2018).

Para tanto, é preciso considerar os anseios e as expectativas dos indivíduos que são impactados pelas opiniões de celebridades e influenciadores, como também por pessoas comuns, do dia a dia, com quem elas podem se relacionar. Esses levantamentos são uma das maneiras mais importantes por meio das quais as pessoas adotam novos estilos.

Convém destacar que incorporar um novo padrão pode levar tempo para se firmar não acontecendo, na maioria das vezes, de forma rápida e instantânea. Um dos motivos é porque a disseminação e, consequentemente, a aceitação de um estilo novo e inovador pode ser um processo muito complexo. Outro motivo é pelo fato de as pessoas viverem, em sua maioria, 
em grupos sociais restritos, não circulando por diferentes tribos e, portanto, permanecendo dentro de certos esquemas e protótipos (VEJLGAARD, 2008).

Vale frisar que dependendo da categoria de produto, a velocidade do processo de tendência pode variar consideravelmente. Por exemplo, ao lançar uma nova música ou um cantor, é possível difundi-lo por meio de vários meios como o rádio, a televisão, os filmes e a internet. Essa pluralidade de veículos facilita que se espalhem mais rápido e se tornem tendência em um curto período de tempo. Já produtos de algum nicho específico que não possui vários meios de propagação demoram mais tempo para se disseminar.

Outro fator importante a ser considerado é que o processo geralmente é mais rápido em categorias de preço mais baixo, provavelmente porque os consumidores podem comprar produtos nessas categorias com mais frequência. Além disso, caso não se adaptem, o valor financeiro investido é mais fácil de recuperar.

Para finalizar, quando se fala de uma nova tendência, alguns fatores, como esses listados por Vejlgaard (2008, p. 190), devem ser observados:

1. Nem tudo o que é novo, diferente, inovador ou chamado de moda pela mídia se tornará ou é de fato uma tendência;

2. Às vezes, o novo pode ser extremo demais para se tornar uma tendência, ou será apenas uma moda passageira;

3. Observar o que a maioria dos criadores de tendências estão adotando, porque é isso que os outros grupos de tendências têm maior probabilidade de observar;

4. Procurar pistas para uma tendência em categorias que apelam a diferentes sentidos (roupas, música e comida, por exemplo);

5. Os criadores de tendências geralmente não são criadores de tendências em todas as categorias. Portanto, nem tudo o que um criador de tendências indica necessariamente é uma nova tendência;

6. Quanto mais imitável for um novo estilo, maior será a probabilidade de se tornar uma tendência;

7. A tecnologia definitivamente precisa ser levada em consideração ao discutir o futuro das tendências, e uma aposta certa é que as tecnologias existentes mudarão no futuro. Em outras palavras, a internet mudou não apenas a velocidade do processo, mas o processo em si. 
Sendo assim, a tendência sinaliza os primeiros sinais de mudança. É o caso, por exemplo, de uma alteração ou modificação de interesse pelo público que participa daquele setor quando são atraídos para um novo tipo de olhar.

A tendência prepara para o futuro, para o que virá, considerando que a probabilidade de surgir uma nova inclinação a cada estação é mínima, sendo muito mais lenta e pode durar até 20 anos para ser legitimada. Portanto, o aparecimento de uma nova predisposição depende de diversas mudanças na sociedade como um todo, desde crises econômicas a sanitárias e de pessoas ativas em fazer a mudança acontecer.

\subsection{A cor como influenciadora da moda e da pintura corporal}

A cor é, em essência, um fenômeno natural, fisiológico, psíquico e um acontecimento social (MOCERI, 2015). Ao ser emitida pelo espectro solar e legitimada pelo ser humano, ela vai ao encontro tanto da psique individual de cada ser como da convivência social que dita muito do que se pensa, sente e vive. Isso colabora para uma construção cultural complexa, rebelde de qualquer universalização e de qualquer categorização, envolvendo muitos e complexos dilemas (MAHNKE, 1996).

Dessa forma, falar da cor como influenciadora da moda, tendência e pintura corporal é falar de um fato que engloba em si aspectos natural, físico, fisiológico, cultural, econômico, psicológico e social. Nesse sentido, discorrer sobre cor exige, muitas vezes, percorrer alguns caminhos traçados pela História tanto das cores como do vestuário e da pintura corporal (PASTOUREAU, 2011).

Além de todos esses aspectos, a sociedade tem um papel importante, pois ela, com suas verdades e crenças, colabora e legitima à medida que dá suas definições e seus sentidos, constrói suas verdades, seus códigos e seus valores, gera suas aplicações e práticas ao uso de determinadas tonalidades (PASTOUREAU, 2019). Todavia, mesmo havendo influências decisivas que vão impactar nas escolhas e conceitos dados a cada cor, não há uma verdade transcultural em nenhum momento tanto histórico como relativo a todos os seres (PASTOUREAU, 2011).

Pode-se afirmar, portanto, que há vários acontecimentos ao longo da passagem pelo tempo que contam como as tonalidades surgiram e tornaram-se referência e padrão. Tais acontecimentos também revelam como as cores foram sendo rejeitadas ou até mesmo 
proibidas devido à dificuldade de obtenção, reprodução, ao custo e à imposição dos códigos sociais vigentes (PIPER, 2008).

Uma dificuldade que se observa é que as cores, no decorrer da história, foram poucas vezes citadas e, quando aparecem, é devido a algum episódio exclusivo e específico. Já as listas de artigos de vestuário, a essência de tecidos, a estrutura dos acessórios e as formas e cortes das peças aparecem com muito mais frequência (PASTOUREAU, 2011).

Ao lado desse fato, as nuances presentes na moda e na pintura corporal, por sua vez, se submetem a pulsações periódicas e a movimentos oscilantes, ou seja, a ciclos longos descontinuados por ciclos mais curtos. Assim, seus mecanismos possuem valores que se alteram de uma classe econômica para outra, de um período histórico para outro, de um meio social para outro, não tendo em si, a priori, durabilidade, estabilidade e conservação.

Seja como for, desde os primórdios, as pessoas sempre manifestaram uma vontade de estar na cor, de vestir-se, pintar-se, expressar-se, comunicar-se e, portanto, colorirem-se. Foi através de pinturas, tinturarias e maquiagens que muitas dessas vontades foram atendidas e permitidas, por isso facilmente se observa que o percurso humano foi um caminho trilhado, essencialmente, ao lado das cores.

Tanto que, para os povos da Antiguidade, o ato de pintar não era restrito somente à face. Essa policromia também esteve presente nas estátuas e em boa parte da arquitetura, com suas casas, templos, edifícios e espaços públicos que eram pintados, decorados e adornados. Eles também usavam em suas vidas diárias tecidos tingidos e enfatizavam as expressões de seus rostos com cores vivas e atraentes, com contrastes fortes nos quais a policromia se fazia presente cotidianamente (PIPER, 2008).

Mesmo havendo essa policromia nas mais diversas áreas, houve na História da humanidade a tríade consagrada pelo branco-vermelho-preto, cores que lideraram boa parte dos acontecimentos que se sucederam (PASTOUREAU, 2017). Essas são as cores por excelência, pois seus reflexos se fizeram presentes não só na moda e na pintura corporal, mas também na vida social, determinando muito dos conceitos e das verdades existentes.

De maneira geral, por mais que houvesse relações com as cores e que as tendências de beleza aristocrática existissem, dificilmente eram visíveis fora da área a qual pertenciam. Ainda que os retratos reais fossem pendurados nos palácios, criando um microcósmico de moda e maquiagem, essas informações ficavam mais restritas a esses limites. E quando extrapolavam as fronteiras, a velocidade de propagação dessas informações era muito diferente da que se observa nos dias de hoje. 
Acrescente-se que, por mais que o mais antigo sistema de impressão conhecido tenha sido inventado na China, por volta de 1041 d.C., foi a invenção da prensa com caracteres móveis por Johannes Gutenberg, em 1450, que mudou por completo a forma de comunicação existente. Antes do seu surgimento, os conceitos de "modelo de beleza" difundidos e até padronizados pelos exemplares não existiam, exceto pelo falar e escrever. Assim, muitas pessoas não tinham ideia de como alguém fora de sua cidade ou vila poderia parecer (PASTOUREAU, 2011; PASTOUREAU, 2019).

A invenção do modelo impresso trouxe uma mudança radical na troca de informações e no sistema de comunicações. Esse advento possibilitou a inclusão de conhecimentos sobre o que e como as pessoas se vestiam, além da produção e uso de cosméticos. Até então, os "segredos" e receitas de beleza teriam sido passados pelas mulheres de uma mesma família ou mantidos pela mulher sábia da região (ELDRIDGE, 2015).

$\mathrm{Na}$ maioria das vezes, esses produtos eram feitos à mão, com ingredientes produzidos e cultivados localmente. Com a invenção da imprensa, porém, esses conhecimentos, até então restritos aos territórios, passaram a serem difundidos, espalhando-se por diferentes lugares. Essa forma de comunicar esses conhecimentos eclodiu já no século XVIII, com o surgimento de revistas e periódicos direcionados, na maioria das vezes, para as classes mais alta da sociedade, que também tinham por objetivo difundir bons modos e costumes, além de entreter. Isso se expandiu para o século XIX e, entre 1880 a 1900, havia mais de uma dezena de periódicos disponíveis na Europa. O objetivo dessas revistas era servir como guias de etiqueta (para os quais surgiu um forte mercado), instruindo as mulheres sobre como se vestir, maquiar e agir (ELDRIDGE, 2015).

Isso explica por que uma das primeiras revistas europeias, a francesa Les Modes, fundada em 1901, apresentava imagens de mulheres da sociedade usando vários designers, muitas vezes, com maquiagem notável. Em várias edições de Les Modes, desse mesmo ano, as modelos apresentadas e mulheres de classe alta exibiam a cor das roupas combinadas com as cores da maquiagem. Assim, alguns exemplares sugeriram que a moda e a maquiagem estavam realmente começando a fundir, sendo cada vez mais difundida para uma parcela grande da população (ELDRIDGE, 2015).

Essa nova possibilidade de contrastes e paletas de cores utilizadas teve como influência o trabalho do químico francês da indústria de tinturaria, Eugène Chevreul. Foi ele quem publicou um pouco antes, em 1864, uma obra propondo modelos de harmonia cromática e de como combinar cores que impactaram as mais diversas áreas, entre elas, a moda e pintura corporal (ITTEN, 1970). Com isso, surgiu, pela primeira vez, uma 
diferenciação entre cores primárias e complementares, indo ao encontro de uma mentalidade mais cromática que se deu tempos anteriores, com a dispersão da luz branca, de acordo com as leis do espectro proposto por Isaac Newton.

Junto a essas descobertas no campo das cores, a Revolução Industrial (1760 a 1840) mudou a maneira como homens e mulheres viviam e trabalhavam, além de todo reconhecimento das necessidades materiais das pessoas produzidas em grande escala.

Na sequência, durante a Primeira Guerra Mundial (1914 a 1918), as mulheres passaram a vestir uniformes, e, como não havia uma distinção de estilo e gosto pessoal, elas eram padronizadas pelos trajes. Essa nova realidade despertou uma necessidade das pessoas em cuidarem da aparência, por isso alguns anúncios oriundos da publicidade diziam que deveriam manter-se bonitas e cuidadas (ELDRIDGE, 2015).

Esse novo posicionamento das mulheres nos ambientes de trabalho teve um papel preponderante em alguns setores, pois a ciência provava que elas eram menos propensas a serem daltônicas do que os homens. Por essa razão, acreditava-se que elas tinham maior sensibilidade às qualidades emocionais das cores (PEDROSA, 2009).

Essa nova realidade impactou a sociedade, pois o lado feminino passou a ter mais autonomia financeira, política e sexual. Dois grandes marcos, o direito de votar e a introdução da pílula anticoncepcional, contribuíram para alterar a forma de comportamento da sociedade. Isso possibilitou o surgimento de uma indústria sofisticada, glamorosa e global voltada para diferentes públicos, razão pela qual houve, gradativamente, uma diminuição das restrições de gênero e classe social.

Por esse motivo, a mulher passou a possuir muito mais roupa do que as mulheres mais ricas dos séculos anteriores (PASTOUREAU, 2011). O setor da moda soube aproveitar bem essa oportunidade ao lançar, a cada primavera, verão, outono e inverno, coleções que continham novos comprimentos de barra, novos cortes e novas propostas cromáticas (BLASZCZYK; WUBS, 2018).

Nesse período, que teve seu início em 1914 e seguiu até 1940, uma nova abordagem para a criação de paletas de cores se cristalizou nos Estados Unidos. Contudo, apesar de os americanos não terem "inventado a previsão de cores, eles tomaram emprestadas as práticas francesas e as aumentaram, aplicando os princípios da administração científica às práticas de previsão" (BLASZCZYK; WUBS, 2018, p. 13).

Essa forma de anteceder as possibilidades cromáticas teve início no final do século XIX com a empresa francesa J. Claude Frères \& cie. Foi ela que, durante décadas, desenvolveu as tendências cromáticas, as quais foram disseminadas no mercado por meio da 
cartela de cores. Durante a Primeira Guerra Mundial, os americanos fundaram, em 1914, a Textile Color Card Associtation, TCCA. Em 1930, os britânicos incorporaram a British Colour Council Ltd, BCC, em que tanto a TCCA como a BCC desenvolviam sua própria paleta sazonal para a indústria têxtil com objetivos semelhantes. As figuras 69 e 70 ilustarm essas paletas de cores.

FIGURA 69: Modelo desenvolvido pela Textile Color Card Association propondo não somente as cores de tendência, mas como combiná-las.
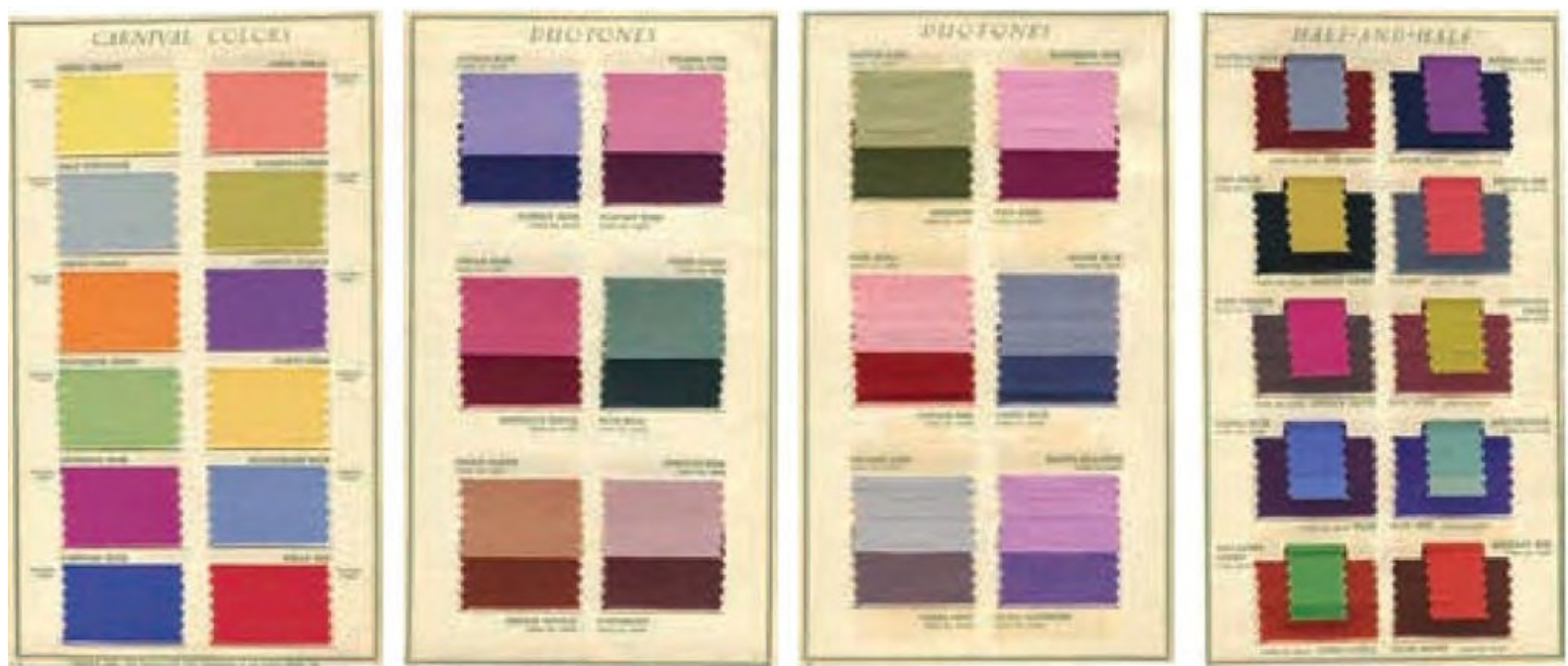

Fonte: BLASZCZYK; WUBS, 2018, p. 41.

FIGURA 70: Modelo desenvolvido pela British Colour Council trazendo a previsões de cores sazonais muito semelhante do que era proposto pelo Textile Color Card Association.

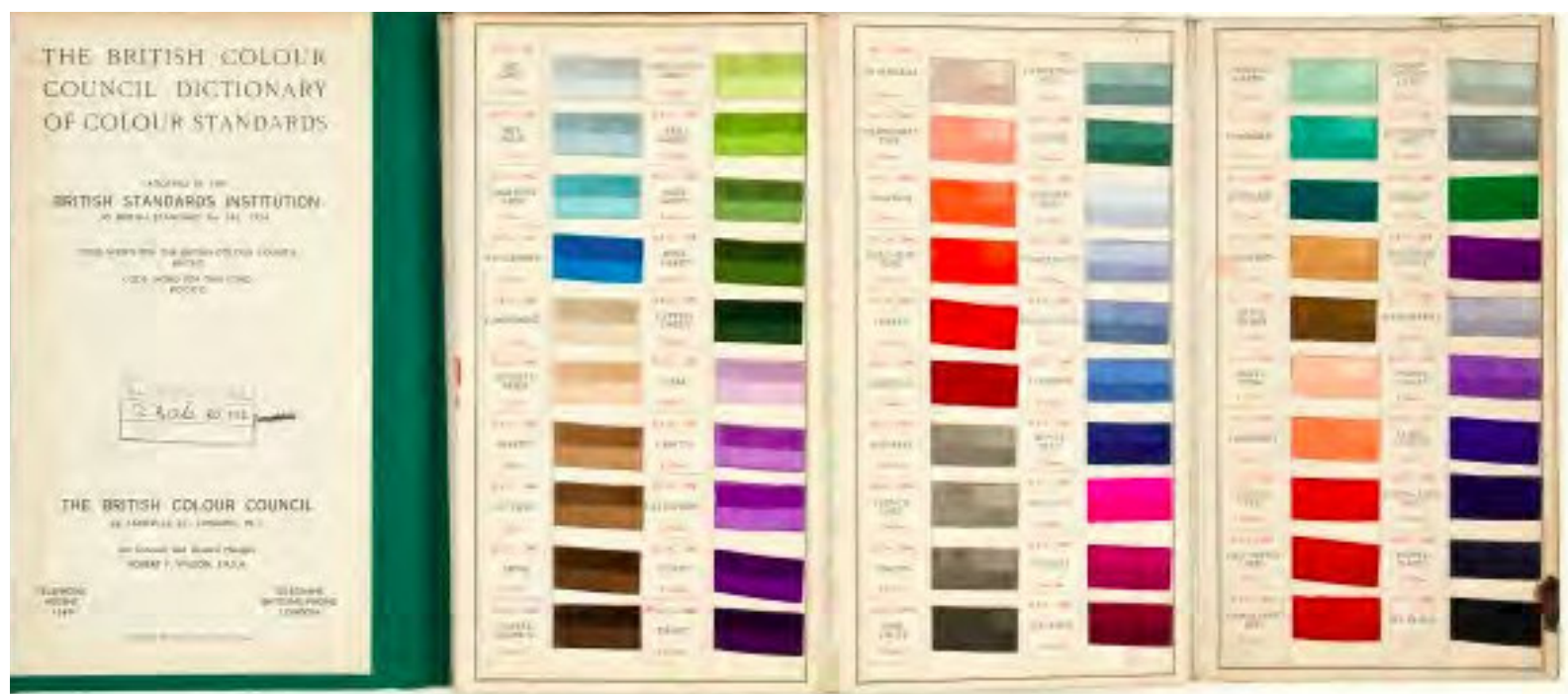

Fonte: BLASZCZYK; WUBS, 2018, p. 54. 
A proposta era fornecer uma ferramenta importante que precisava de informações de ponta sobre as cores que provavelmente estariam em evidência na próxima estação. Assim, o objetivo era reduzir os riscos associados aos erros de julgamento das tendências de cores e eliminar o desperdício que resultou da produção cromática que não vendia.

Tanto que elas forneciam uma cartela e chips de tonalidades sazonais que se adaptavam ao cenário da moda em rápida mudança. O kit de ferramentas de cores TCCA foi transformado em um sistema de gerenciamento que incluía padrões, previsões sazonais e relatórios de tendências cromáticas ocasionais. Esse sistema era especialmente adequado à crescente demanda por moda cotidiana e aos gostos do mercado de massa multicultural.

Essas primeiras agências de previsão abordaram o gerenciamento de cores e desenvolveram o conceito de negócios de que a cor poderia ser "domesticada, embalada e divulgada para o benefício do comércio, uma ideia que incorporava o Zeitgeist do momento modernista na cultura de negócios ocidental” (BLASZCZYK; WUBS, 2018, p. 37).

Isso porque havia um conceito que pairava na sociedade segundo o qual as roupas da estação anterior ficavam obsoletas, por isso pessoas bem-vestidas deveriam usar um traje diferente a cada dia (ELDRIDGE, 2015). Além disso, encontrar outra pessoa usando o mesmo modelo era visto como se, com isso, quem o estivesse usando perdia sua individualidade, como se a individualidade se fizesse representar apenas pelo vestuário (BLASZCZYK; WUBS, 2018).

Contudo, mesmo havendo essa forma de encarar as situações, as pessoas consumiam os artigos que estavam disponíveis, pois vestir-se convencionalmente e seguir os padrões eram maneiras de evitar a necessidade de explorar sozinho a forma e a cor. Tanto que, "quando a pessoa ainda não pode definir sua posição social pela profissão e pelas posses, o símbolo de sua individualidade é a roupa" (HELLER, 2013, p. 142).

Com a chegada da internet nos anos 90, a plataforma digital Worth Global Style Network, WGSN, ganhou prestígio ao desenvolver a previsão de moda para atender à demanda de seus clientes. Assim, esse fato impulsionou esses segmentos que criaram padrões para diagnosticar como os comportamentos influenciam, entre muitas coisas, o valor atribuído às cores.

Dessa forma, é inegável o valor que as vestimentas exercem nas pessoas, independentemente da posição social. Isso porque, nos dias de hoje, elas estão cercadas de informações advindas de várias fontes: livros, revistas, televisão, aparelhos eletrônicos, internet, ou simplesmente andando pelas ruas, onde as imagens e as influências estão por toda parte, logo impossíveis de ser evitadas. 
Nesse mesmo contexto exercido pelos trajes e pelas vestimentas, rímel, blush, batom, esmalte de unha são tão onipresentes que para muitos é difícil imaginar um tempo sem eles. Vale destacar que esses artigos, tão comuns e frequentes no momento atual, foram desenvolvidos e comercializados em larga escala apenas no século passado, quando a pintura facial se tornou popular e comum. Porém, como o ato de pintar o corpo e a face remonta a História da humanidade, esses produtos de maquiagem anteriormente eram elaborados com pigmentos feitos à mão e com pastéis caseiros que, para muitos, se chocavam com algumas curas e amuletos (BIRREN, 1997).

$\mathrm{A}$ ascensão dos cosméticos em meados do século $\mathrm{XX}$ tornou a maquiagem acessível às massas e, por conseguinte, houve o crescimento expressivo da indústria da beleza e do uso de cores inovadoras. Com isso, é inegável que a escolha e a oferta estão cada dia mais presentes e atuantes no mercado, por isso a proliferação da expressão através das tonalidades pode necessitar cautela e auxílio.

\title{
2.2.1 A cor na moda
}

Como conta a Bíblia, Adão e Eva viveram nus no paraíso até infringirem as regras e ordens de Deus, e, ao serem expulsos, recebem roupas para encobrirem sua nudez. Dessa forma, as vestes utilizadas por eles eram o símbolo máximo de seus pecados e sua função foi também lembrar o homem dessa penitência. Sendo assim, desde o princípio, o uso de artigos de vestuário já veio como um fardo carregado de peso, responsabilidade, ressentimento e culpa (PASTOUREAU, 2011).

Nessa direção, Pastoureau, citando Platão (2019, p. 47), pondera:

\begin{abstract}
A beleza é simples, pura, sem mistura, muito distante da perversão das cores e de todas as vaidades humanas. Procurar embelezar-se com as roupas é uma coisa má, hipócrita, vil e servil; o aliciamento engana não apenas por meio das formas, mas também por meio de tecidos, cores, cosméticos e artifícios de todos os tipos.
\end{abstract}

Assim, se for desenvolvida uma análise etimológica da palavra cor, notar-se-á que ela provém do latim e faz parte da família do verbo celare, cujo significado está associado com “ocultar", "esconder”, “envolver”. Essa mesma noção também está presente no grego em que a palavra khrõma deriva da palavra khrõs, que significa a pele ou qualquer superfície 
corporal. Nas línguas germânicas, o termo farbe significa película, envelope, filme (PASTOUREAU, 2019).

Por essa razão, a cor foi considerada um material, uma superfície que vestia, escondia e cobria outra superfície. Portanto, as roupas não apenas identificavam o status, a classe social, o gênero e a idade de uma pessoa, mas também revelavam seu nível de riqueza, cargo, posição e profissão através de seus materiais, tons e estilo. Às vezes, evocava-se um feriado ou ocasião formal que exigia o uso de certas roupas em vez de outras. Por outras vezes, a função das vestimentas foi social e sistemática antes de ser prática e estética.

Durante muitos séculos, os tecidos para fabricação das roupas eram tingidos. Os primeiros traços de tingimento apareceram depois de 3000 a.C., em um período em que os seres humanos já eram sedentários, praticavam a agricultura e viviam em sociedades organizadas (PASTOUREAU, 2019). Os tintureiros foram seus primeiros artesões, e o conhecimento da tinturaria chegou para os romanos através do Oriente Próximo e Médio com povos como os hebreus, egípcios e fenícios, por exemplo, ou pelos germânicos e celtas.

Apesar de a policromia ter sido adotada em muitos segmentos, inclusive nos vestuários, as cores utilizadas pelas sociedades são difíceis se ser generalizadas. Muito cedo, os tintureiros romanos formaram uma guilda especializada de acordo com a cor e o corante. Junto a essa proliferação cromática, como afirma Pastoureau (2019, p. 48):

No final da república, regulamentos profissionais detalhados, a constitutio tinctorum, distinguiam onze categorias de artesãos. Havia cinco para os tons de vermelho: os sandicinii (que produziam tintos à base de garança); os coccinarii (tintos à base de quermes); os purpurarii (tintos luxuosos à base de murex); os rucellarii (tintos comuns, à base de orceína ou líquen); e os spadicarii (vermelhos escuros e acastanhados de várias bases de madeira). Três para laranjas e amarelos: os flammarii (laranjas à base de cartamina); os crocotarii (amarelos à base de açafrão); os luteolarii (amarelos à base de solda). E três para pretos e pardos: os nucitarii (tons escuros da casca ou raízes das nogueiras); os castanearii (marrons das raízes dos castanheiros); os atramentarii (pretos com tinta ou base relacionada à tinta). Não há menção a brancos, azuis ou verdes.

Entretanto, a chegada de novas ondas provenientes de outras regiões da Europa diversificou a paleta de cores na moda. Isso justifica por que os tons como verde, azul e violeta, que eram considerados indecentes e ridículos, tornaram-se muito populares.

Porém, a entrada dessas novas cores não tão comum para aquele período não foi apreciada por uma parcela da sociedade. Moralistas e defensores da tradição se opuseram à medida que defenderam as colorações mais tradicionais, contidas, dignas e monocromáticas, 
cujo uso antigo e a tradição foram responsáveis, entre outras condicionantes, pela grandeza de Roma.

Uma das cores mais importantes foi o púrpura e havia duas razões principais para o prestígio dos tecidos nessa coloração. Primeiro, a luminescência excepcional; segundo, sua solidez e resistência à luz. Diferentemente das outras tonalidades, que desapareciam, o componente de coloração da cor púrpura se fortalecia ao longo do tempo e era aprimorado pelos efeitos da luz tanto solar como da lua e das chamas. Os tecidos não perdiam suas características cromáticas, pois esmaeciam e assumiam novas tonalidades por vezes até cintilantes que não tinham inicialmente.

Sendo assim, bem antes do domínio romano sobre todo o Mediterrâneo, na vitória contra Cartago nas Guerras Púnicas (264-146 a.C.), os tecidos tingidos dessa coloração já eram os mais prestigiados e os mais onerosos. Como esse tom sinalizava riqueza e poder, eram considerados tesouros, por isso tanto os membros da Igreja como os imperadores vestiam-se com essa coloração (PASTOUREAU, 2017).

Além disso, durante todo o tempo do Império Romano, aproximadamente 27 a.C. a 395 d.C., o direito de usar peças de vestuário púrpura era restrito aos mais altos cargos militares ou civis liderados pelos sacerdotes, magistrados e comandantes. Vestir-se inteiramente desse tom era um privilégio de poucos, simbolizando a autoridade absoluta do imperador e sua essência divina, como pode ser observado na figura 71. 
FIGURA 71: O triunfo romano celebrado por Júlio Cesar que cavalga usando uma toga púrpura.

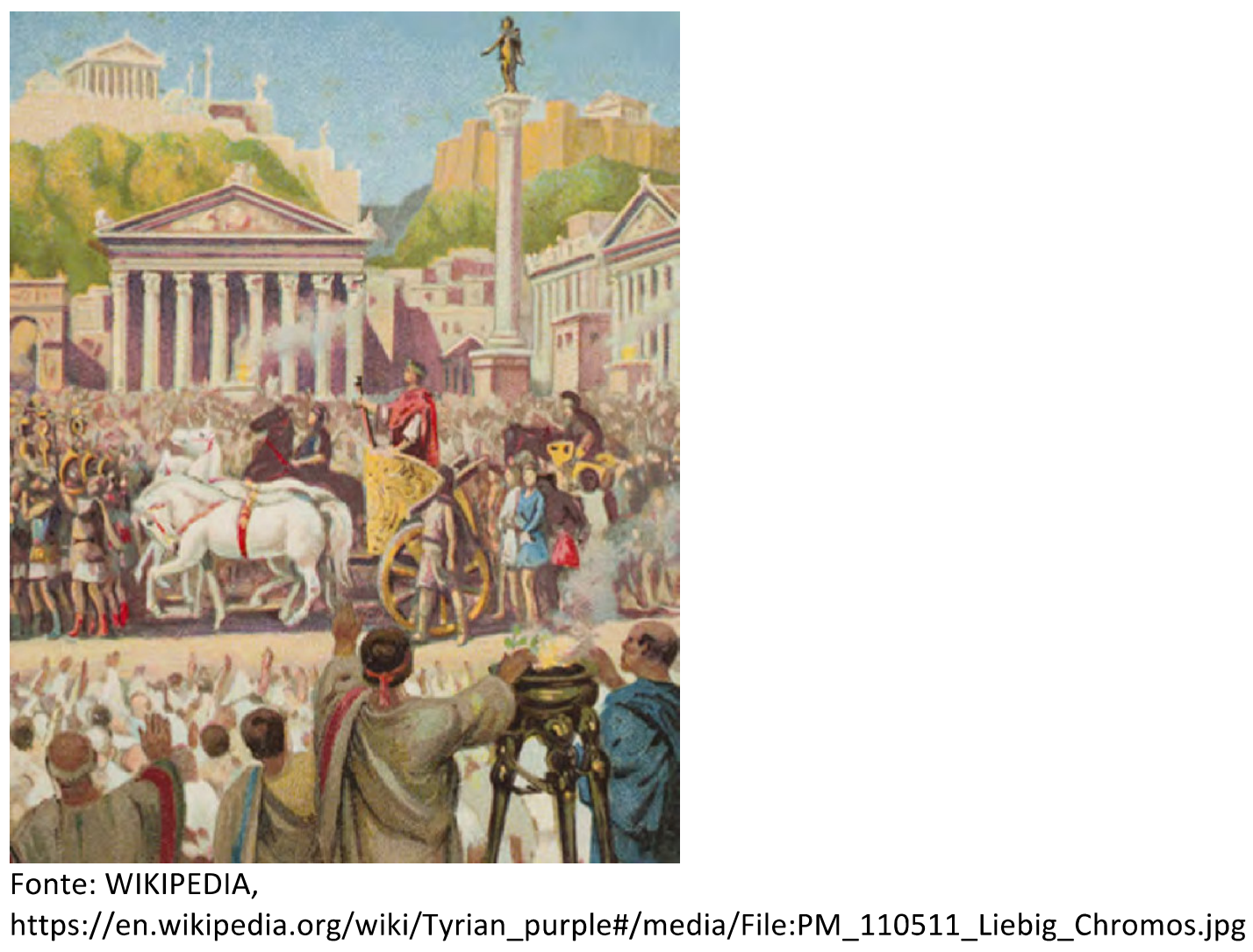

Além do púrpura, desde o começo do Império Romanao, apesar de quase não haver menção ao verde, no século I d.C., os tintureiros, que até então tinham grande dificuldade com os corantes nesse tom, começaram a desenvolver essa tonalidade de forma mais vistosa e elegante ao introduzirem essa coloração nas vestimentas femininas (PASTOUREAU, 2014). Provavelmente, sua influência veio da moda oriental graças aos tintureiros de origem germânica que se instalaram em Roma, especialistas na faixa de azuis e verdes.

Assim, sua presença cresceu e pode ser que isso se deu, pois, segundo Pastoureau (2019, p. 29)

Os historiadores romanos falaram longamente sobre Nero. Graças a eles, conhecemos algumas de suas preferências em questões de cor; sua cor favorita era verde. Gostava de se vestir de verde, colecionava esmeraldas, sustentava o estábulo verde nas corridas de carruagem e, quando se tratava de cozinhar, saboreava alho-poró. A pátina verde na moeda, devido à oxidação do bronze, parece ecoar os gostos do imperador.

Apesar da preferência de Nero pelo verde, os tons de branco e vermelho permaneceram por mais tempo, ao passo que o amarelo era mais comum nas vestimentas do 
público feminino. O verde apareceu nas togas masculinas depois do século IV, mas, mesmo assim, permaneceu uma exceção (PASTOUREAU, 2019).

Mas esse gosto de Nero contribuíu para que esse tom reverberasse pelos séculos II e III, quando as mulheres aristocráticas, caprichosas e versáteis nas questões do vestuário, recorreram a ele. A estola feminina, um vestido longo plissado, franzido na cintura, e a palla, uma espécie de grande xale retangular com drapeado frouxo, antes branca, vermelha ou amarela, começou a apresentar uma paleta cada vez mais variada que incluíu essa coloração (PASTOUREAU, 2014).

Durante o Império, as matronas romanas, sob a influência das modas orientais e "bárbaras", introduziram uma paleta de cores cada vez mais variadas em seus guardaroupas. Segundo Pastoureau (2017, p. 45):

Sob Nero, alguns patrícios e o próprio imperador criaram um escândalo vestindo roupas verdes. Mas foram especialmente as matronas romanas que romperam com a tradição e a necessária tríade branco-vermelho-preto. No final do primeiro século, eles estavam vestidos de azul, violeta e verde, e, como os celtas e os alemães, usavam túnicas (túnicas), mantos (estolas) e capas (palas) com listras, xadrezes e padrões de cores vivas.

Em geral, as novas cores passaram a desempenhar, na vida cotidiana, um papel ao trazerem o verde, púrpura, rosa, laranja e até o azul. Tanto que, no século III, apareceram as togas amarelas, vermelhas e marrons, além das togas com padrões de duas ou três cores, as quais não foram mais consideradas espalhafatosas e excêntricas (PASTOUREAU, 2019).

Entretanto, esse cromatismo não foi bem recebido por todos os moralistas e defensores da tradição, que denunciaram a chegada dos colores floridi como frívolos, falsos e vulgares. Isso porque eram muito vívidos ou muito decorativos, raramente usados sozinhos, mas em combinação para produzir fortes contrastes e paletas ruidosas e chamativas. Eles se opunham aos colores austeri (branco, vermelho, amarelo, preto), contidos, dignos e monocromáticos, cujo uso antigo foi responsável pela grandeza de Roma (PASTOUREAU, 2019).

Assim, para as roupas que todo mundo via, existia uma gama de cores disponíveis junto à tríade branco-vermelho-preto. As tonalidades das roupas eram utilizadas segundo uma ordenação: à tríade cromática acrescentavam-se amarelos e suas variações, atingindo até a gama dos tons de laranja, que foram reservados para as mulheres (PASTOUREAU, 2019). A tríade mais com destaque para o preto, também com suas variações indo dos tons 
cinza aos marrons devido à falta de estabilidade dos corantes, era destinada a certos magistrados e aos enlutados (PASTOUREAU, 2011).

Quanto às roupas de baixo, ou seja, as roupas e tecidos que tocavam a pele, essas eram mais comuns serem encontradas na coloração branca ou não eram tingidas. Isso se deu tanto por motivos higiênicos e materiais, uma vez que as roupas eram fervidas, e, portanto, desbotavam. Outro motivo era, sobretudo, moral, pois as cores vivas podiam ser consideradas impuras e desonestas (HELLER, 2013).

Todavia, o fato de somente as mulheres aristocráticas incorporarem as influências "bárbaras" não foi suficiente para expandir o papel das cores no vestuário. Porém, dois fatores contribuíram para a expansão das cores nessa área. Segundo Pastoureau (2017), o primeiro está relacionado às invasões germânicas no século $\mathrm{V}$, quando os alemães trouxeram novos métodos tradicionais e costumes de vestuário, e as paletas diferiam amplamente. Nessa altura, branco, vermelho, preto, monocromático ficaram de um lado, ao passo que azul, verde, amarelo, combinações de cores vivas e distintas, do outro.

O segundo fator está relacionado ao texto bíblico que, como foi ficando mais rico em notações coloridas ao longo dos séculos devido a suas versões e traduções, começou-se a construir um sistema simbólico de cores dificilmente existente na Antiguidade. Esse sistema exerceu forte influência na vida religiosa, nas práticas sociais, nas roupas, nos brasões, nas insígnias e cerimônias, até mesmo na criação artística.

No século XI, de acordo com Pastoureau (2011), como também havia desde então toda uma estrutura cromática evidente na sociedade, a Igreja elaborou uma classificação das cores litúrgicas e os usos permitidos nas roupas para as datas comemorativas. Assim, o branco, símbolo de pureza, era utilizado para as festas como o Natal, Quarta-feira Santa, domingo de Páscoa, Ascensão de Cristo e Dia de Todos os Santos.

$\mathrm{O}$ vermelho, ainda associado ao sangue derramado por e em nome de Cristo, foi destinado para a festa dos apóstolos e dos mártires, para a Santa Cruz e para o Pentecostes. O preto e o violeta, ligados ao luto e à penitência, tiveram seu lugar na missa dos defuntos, durante o Advento da festa dos Santos Inocentes e toda a Quaresma. Por fim, o verde, que por vezes podia ser substituído pelo amarelo, foi destinado aos dias em que nem o branco, nem o vermelho, nem o preto eram apropriados (PASTOUREAU, 2011).

Foi durante esse período também que outro acontecimento, que se deu por ocasião do IV Concílio de Latrão (1215), determinou o uso de insígnias cromáticas para os não-cristãos. Essa atitude visava a identificar essas pessoas com o intuito de evitar o casamento entre 
cristãos e não cristãos. Com essa determinação, veio uma longa lista de todos os que deveriam fazer uso dessas prescrições cromáticas, como afirma Pastoureau (2016, p. 99):

\begin{abstract}
os homens e as mulheres que exercem atividade perigosa, desonesta ou simplesmente suspeita: médicos e cirurgiões, carrascos, prostitutas, usuários, jograis, músicos, mendigos, vagabundos e miseráveis de toda a espécie. A seguir, aqueles que, por uma ou por outra razão, foram condenados, desde os simples bêbados que causavam desordem na via pública até as falsas testemunhas, aos perjuros, ladrões e blasfemadores. Depois, diferentes categorias de enfermos; no sistema de valores medievais, a enfermidade (física ou mental) é sempre sinal de um grande pecado: coxos, estropiados, agotes, leprosos, "pobres de corpo", "cretinos e simples de cabeça". E por fim, os não cristãos, judeus e muçulmanos, cujas comunidades são numerosas em várias cidades e regiões, sobretudo na Europa Meridional.
\end{abstract}

Nota-se que o branco e o preto, quer sozinhos, quer associados, diziam respeito aos miseráveis e aos enfermos, especialmente os leprosos. $\mathrm{O}$ vermelho, aos tiranos e às prostitutas. O amarelo, aos falsários, aos hereges e aos judeus e o verde, quer sozinho, quer associado ao amarelo, aos músicos, aos jograis, aos bobos e aos loucos (PASTOUREAU, 2016).

Também se oberva que, embora essa medida tenha ocorrido, é impossível generalizar, pois não houve nenhum sistema de cores designadoras das diferentes categorias de excluídos que seja comum a todas as sociedades. Ao contrário, os costumes variam enormemente de uma região para outra, de uma cidade a outra e, no interior de uma mesma cidade, de uma época a outra, havendo numerosas exceções.

É o caso das prostitutas que, ao fazerem uso de um símbolo discriminatório realizando a função tanto fiscal como moral, esse distintivo era, na maioria das vezes, sinalizado por um tom de vermelho. Já a peça de vestuário podia variar entre um vestido, uma corrente, um casaco ou uma capa.

Além do mais, desde o final do século XI, o sistema com três pólos e dois eixos, ou seja, os três pólos compreendidos pelo branco-vermelho-preto e os dois eixos formados pelo branco-vermelho e branco-preto, começou a entrar em declínio e o azul, o amarelo e o verde, até então quase sem um espaço, do ponto de vista simbólico, começaram a ascender socialmente. Assim, pouco a pouco, o azul, o amarelo e o verde, apesar de não terem um desempenho e aceite com a mesma força e função da tríade cromática por excelência, passaram a existir e eram presentes na vida material e cotidiana (PASTOUREAU, 2019), como exemplificam am figuras 72 e 73 . 
FIGURA 72: A ascensão de tons como azul, amarelo e verde presentes na vida cotidiana desde o vestuário até em objetos de decoração.

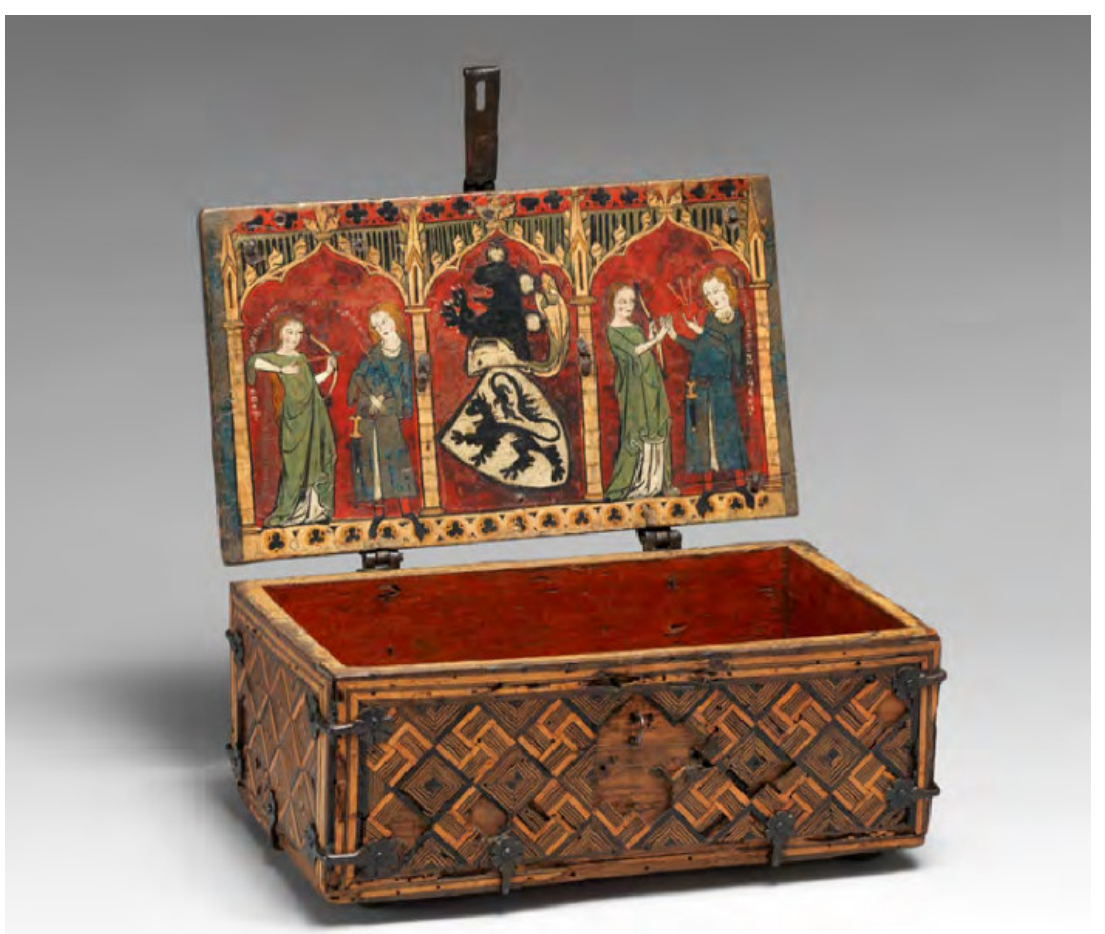

Fonte: PINTEREST, https://br.pinterest.com/anplica/sca-caskets/

FIGURA 73: Imagem aplicada da figura 72 para evidenciar os trajes em tons de azul e verde.

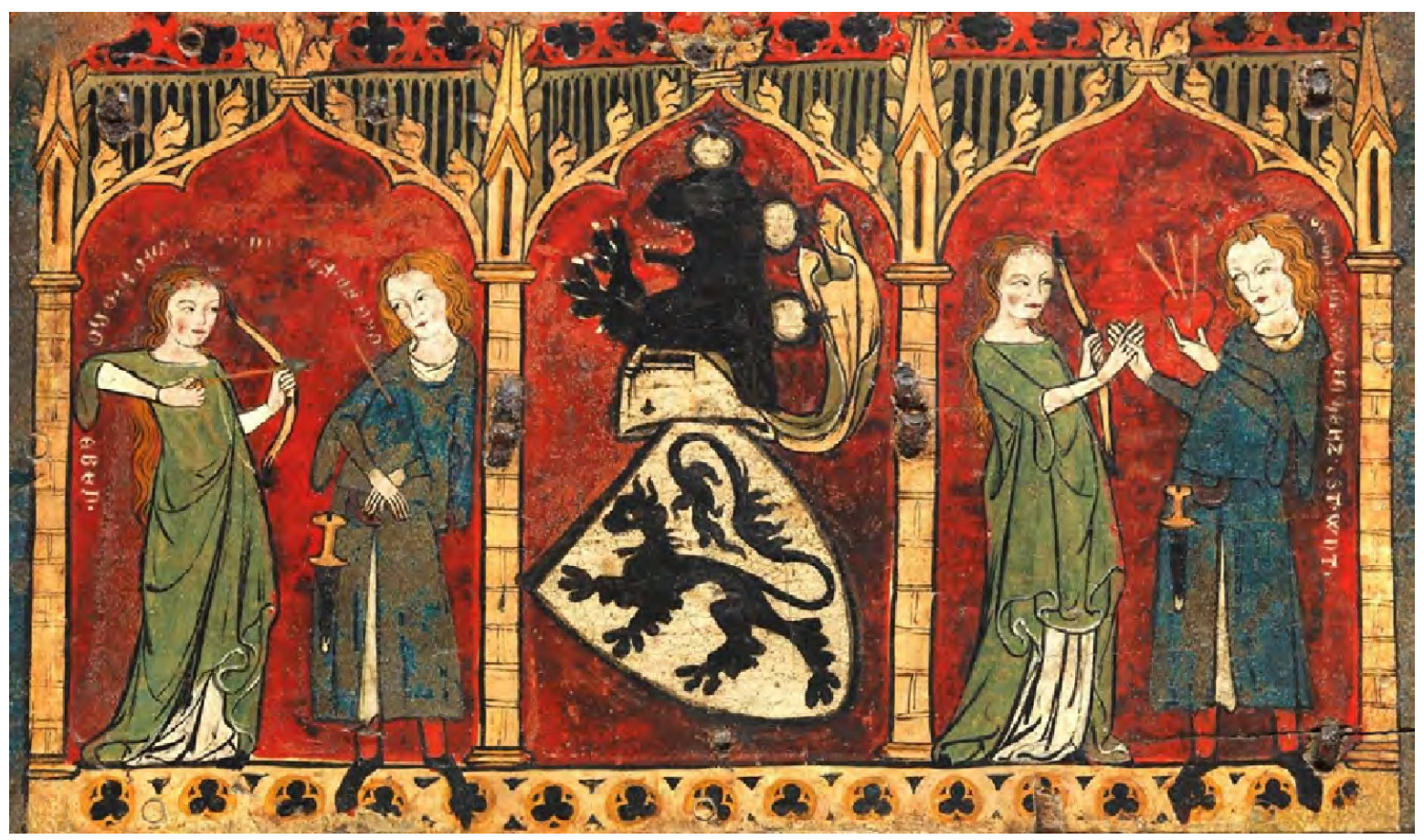

Fonte: PINTEREST, https://br.pinterest.com/anplica/sca-caskets/ 
Com isso, a cultura ocidental foi abrindo espaço e, em apenas algumas décadas, o sistema cromático, que era dividido em três cores básicas, passou para um sistema com seis cores compreendido por essas tonalidades. Esse novo status social e simbólico gerou uma mudança de postura ideológica e, consequentemente, promoveu a ascensão e a permanência dessas cores que, em certa medida, existem como as seis cores fundamentais ou elementares até hoje (PEDROSA, 2009).

Então, entre meados do século XII e as primeiras décadas do século XIII, observou-se que os tons utilizados começaram a vivenciar um notável desenvolvimento, principalmente o azul. Essa cor, que até então era muito tímida e quase prescindível, foi mudando de status e significado, transformando-se em uma cor da moda, primeiro na arte e nas imagens, depois no vestuário. Gradualmente, tornou-se valorizado, começando a rivalizar com o vermelho, a primeira entre as cores e a mais nobre e bela até então (HELLER, 2013).

O fato é que, durante séculos, foi na faixa dos vermelhos que os tintureiros europeus passaram a ter tons puros, densos e luminosos que penetravam profundamente nas fibras do tecido e desempenhavam resultados mais belos e vistosos (HELLER, 2013). Agora, devido à ascensão dessas três tonalidades (azul, verde e amarelo), houve uma valorização dessas "novas" nuances, sendo com tons de azul que obtiveram resultados mais esplêndidos e valorosos, como coloca Pastoureau (2017, p.86):

Após um exame cuidadoso, parece que as apostas teológicas e ideológicas precederam mudanças químicas e econômicas. O exemplo da Virgem, a primeira "pessoa" no Ocidente a aparecer frequentemente vestida de azul em imagens, constitui evidência importante. Até o século XI, Maria podia estar vestida de qualquer cor, mas era quase sempre um tom escuro: preto, cinza, marrom, roxo, azul escuro ou verde. A ideia principal era que deveria ser uma cor de aflição, uma cor de luto, apropriada para a Virgem em luto por seu filho, morto na cruz. Mas depois do ano 1000, essa paleta encolheu, e somente o azul tendia a preencher o papel de atributo do luto. Além disso, ficou mais leve e mais atraente; do opaco e escuro, tornou-se mais puro, mais luminoso e mais saturado.

Nesse sentido, a Virgem, com seu manto nessa coloração, contribuiu significativamente para o avanço dessa cor (GAGE, 1999). A figura 74 exemplifica o tom de azul usado por Maria. 
FIGURA 74: $O$ manto azul da Virgem.

Ghent Altarpiece, Jan Van Eyck, 1432, Belgium, Ghent, St. Bavo's Cathedral, Ghent, óleo sobre madeira.

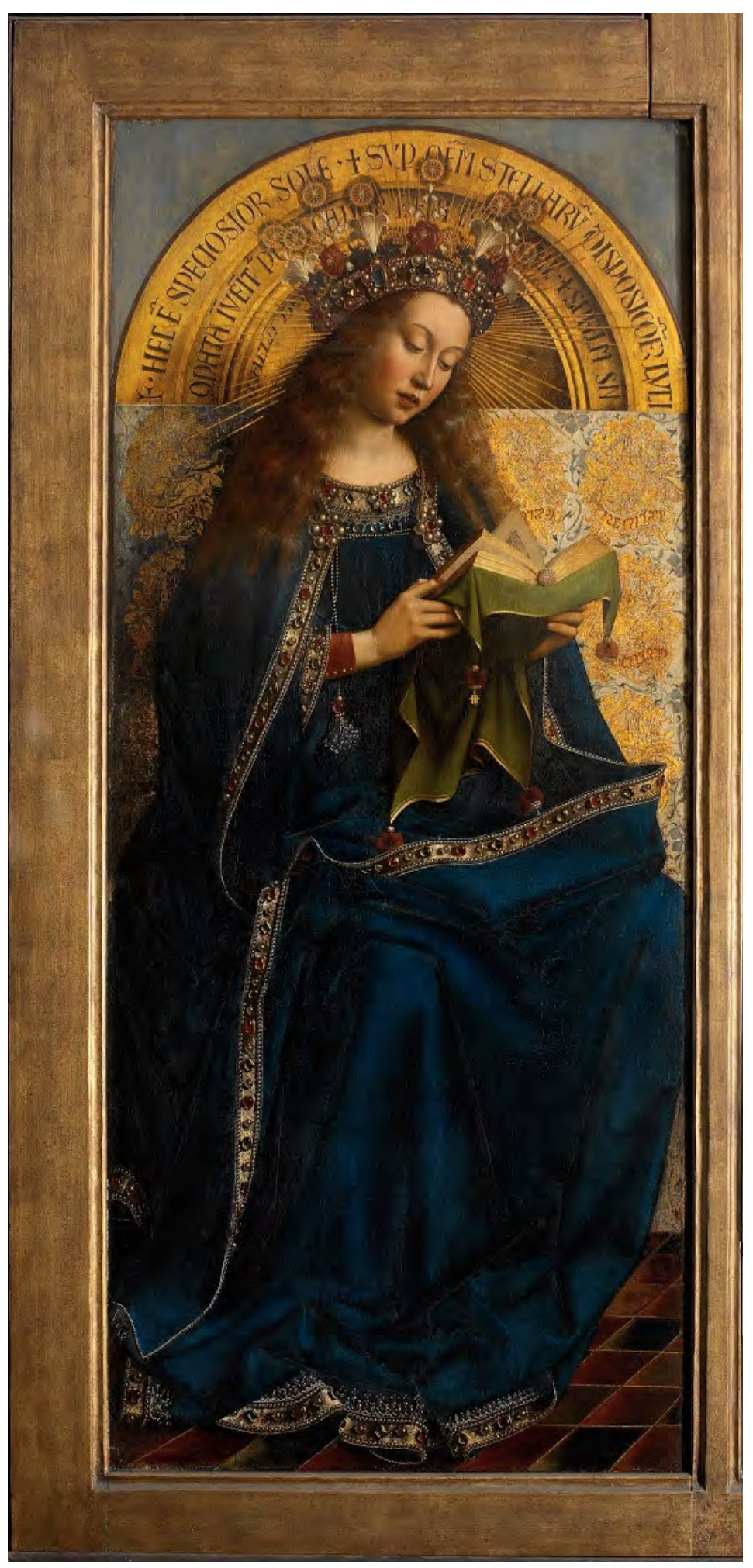

Fonte: GAGE, 1999, p. 60. 
Essa proliferação dessa coloração, devido a uma mudança de gosto e atitude por parte da sociedade, fez com que, já no século XII e XIII, duas guildas comerciais pudessem ser distinguidas, tornando-se competidoras e até mesmo rivais. As oficinas foram divididas: de um lado, estavam os "tintureiros de vermelho" com seus kermes, ruiva-dos-tintureiros, garança, carmesim e cochinilha, que também tingiam de amarelo, com o lírio dos tintureiros e de brancos; de outro, as oficinas dos "tintureiros de azul" com seus pastel-dos-tintureiros, índigo e lagostins, que também tingiam de preto e verde (PASTOUREAU, 2017).

Outro fator que contribuiu para a ascensão do azul no vestuário foi de ordem prática, devido à própria fixação da cor nos tecidos com estimulantes, ou seja, com a utilização de uma substância intermediária que podia ser feito com tártaro, alúmen, vinagre, urina, cal, entre outras substâncias. Esses estimulantes ajudavam a matéria corante a penetrar nas fibras do tecido e fixar-se, garantindo, assim, que a cor dos corantes e pigmentos penetrassem de maneira mais profunda cujo resultado era maior durabilidade e maior exuberância da cor.

Em contrapartida, houve também uma desvantagem tanto dos tons de vermelhos, com a garança, como dos tons de amarelos, com o lírio dos tintureiros, pois, para permitirem belas cores, essas tonalidades exigiam um estimulante forte. Assim, num primeiro banho, deviam ferver em conjunto o mordente, a tintura e o tecido, o que significava um processo mais lento, mais custoso e muitas vezes até mais tóxico (HELLER, 2013).

Esse mesmo processo de acrescentar um forte estimulante, no caso dos tons de azul, com o pastel-dos-tintureiros e, mais tarde, do índigo com suas possíveis tonalidades de verde, cinza e até preto, não se fazia necessário (HELLER, 2013). Ou, quando indispensável, necessitavam que essa etapa de fixar a cor através de um catalisador fosse feito de forma mais curta, até mesmo menos tóxica e, em certos casos, podiam ser tingindo a frio (PASTOUREAU, 2016).

Desse modo, as etapas para tingimento dos tecidos também contribuíram para a segregação entre as duas tinas, ou seja, a tina de vermelho e a tina de azul, que não podiam estar nos mesmos ateliês. Com isso, naquele período, a profissão de tintureiro foi ficando cada vez mais compartimentada e regulamentada. Passou a ser regida com rigor não só pelas colorações que eram permitidas, como também devido à "localização do ateliê na cidade, os direitos e as obrigações dos tecelões e dos tintureiros, assim como a lista dos corantes lícitos ou ilícitos que era muito bem estruturado, organizado e regulamentado" (PASTOUREAU, 2017, p. 88).

Essa forma de segregar as duas cores por tinturarias distintas contribuiu para que a dualidade entre o vermelho e o azul passasse a ter uma grande relevância. Esse fato abriu 
novos caminhos para que o vermelho, até então rival ao branco, passasse a ter, naquele momento, um segundo contrário, ou seja, o azul. Com isso, desde o século XIII, essas duas cores passaram a ser opostas e permanecem assim até os dias de hoje (HELLER, 2013).

Em meados século XV, a crescente procura dessa nuance pela sociedade desencadeou transformações nos procedimentos, por isso os tintureiros passaram aos poucos a produzir essa coloração com maestria. O azul tornou-se tanto uma cor da moda como uma cor real e passou a ser usado nas representações iconográficas no manto da Virgem, como ilustrou a figura 74, sendo, devido a isso, o tom eleito por grande parte da aristocracia (HELLER, 2013), revelado pela figura 75 .

FIGURA 75: Retrato de Luis XVI, rei da França, trajado de azul. Louis XVI of France, Joseph-Siffrein Duplessis, 1775.

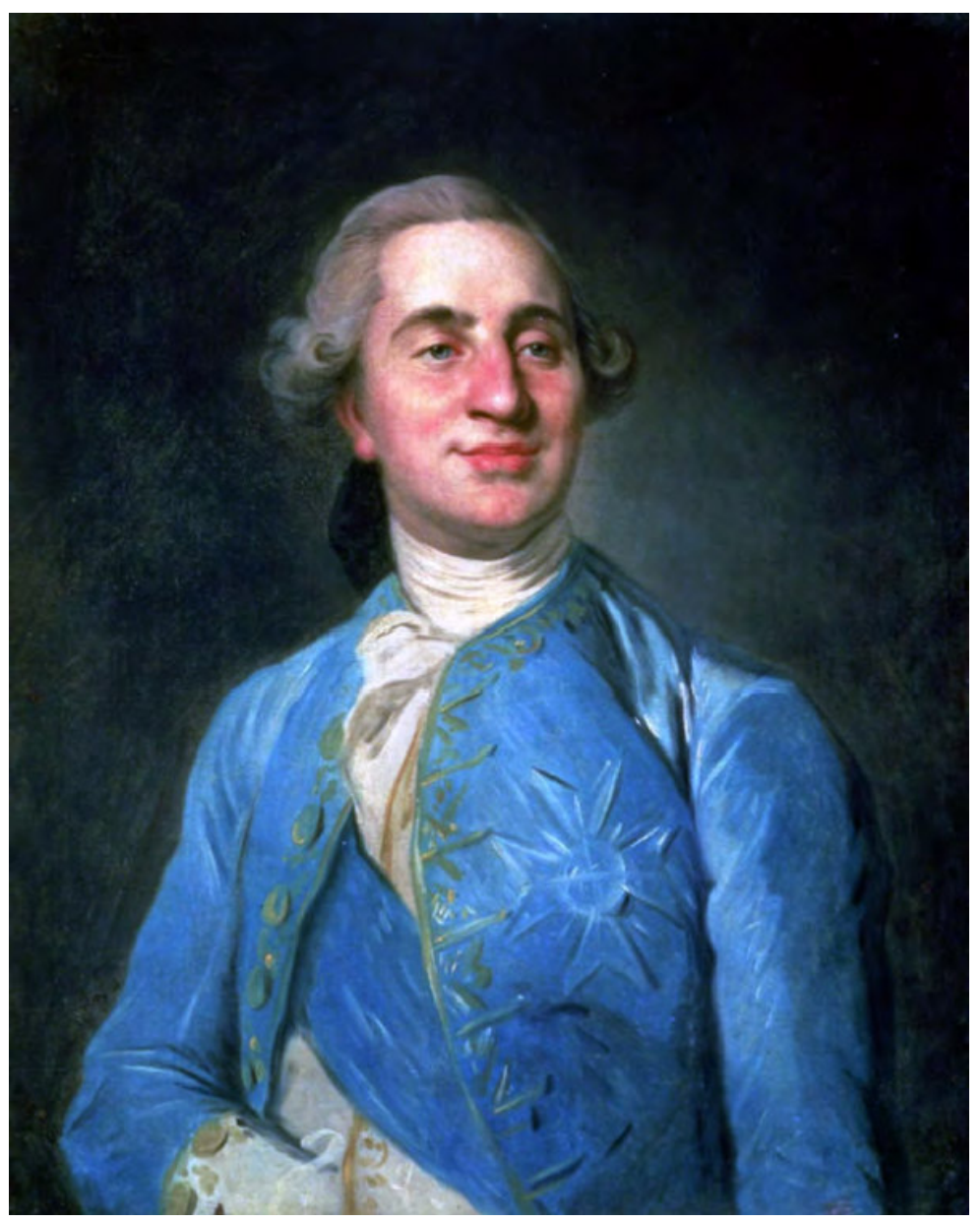

Fonte: PINTEREST, https://br.pinterest.com/pin/415034921907788978/ 
É válido ressaltar que, mesmo com os avanços obtidos no tingimento de azuis, até a Peste Negra que se sucedeu entre 1346 a 1353 e devastou três quartos da população europeia, as tonalidades de vermelhos ainda obtinham o maior prestígio. Para essa nuance, as estampas eram compostas com amarelos, verdes, às vezes brancos em listras, xadrezes e poás, mas raramente azuis ou pretos devido às imposições por parte das legislações vigentes.

Nessa época, uma outra cor, o verde, que até então foi pouco empregado, apresentou uma notoriedade nas vestimentas. Apesar de ser quimicamente instável e pelo fato de os tintureiros não misturarem azul com amarelo na produção dessa tonalidade, contribuindo para a compartimentação profissional em que os tintureiros de azul não tinham permissão para terem tinas de amarelo em seus atelies e vice-versa, sendo materialmente impossível misturar essas duas cores (PASTOUREAU, 2019). Quer no domínio da tintura, quer no da pintura, a obtenção do verde era de outra forma, seja a partir de pigmentos e de corantes naturalmente verdes, seja submetendo corantes azuis ou pretos a uma série de tratamentos que não estavam da ordem da mistura.

Entretanto, o verde teve sua fase de inegável ascensão entre meados dos séculos XII e XIII. Ele se fez presente nas roupas e nos objetos do cotidiano, refletindo uma vontade da sociedade de estar em harmonia com a natureza, ou seja, ambas estariam trajadas de verde (PASTOUREAU, 2014).

Nessa mesma época, as práticas esportivas que traziam consigo valores emblemáticos, simbólicos e estéticos desempenharam um papel importante, por isso essa cor se fez onipresente, pois geralmente os torneios aconteciam em um espaço aberto como uma floresta ou um campo. Dessa forma, a vegetação configurava o cenário de pano de fundo, e muitas das pessoas que ali estavam abundavam em tecidos e em roupas verdes, conforme se vê nas figuras 76 e 77 . 
FIGURA 76: Nesse período, os caçadores foram frequentemente retratados de verde, havendo uma aproximação entre as cores do vestuário com as cores da natureza.

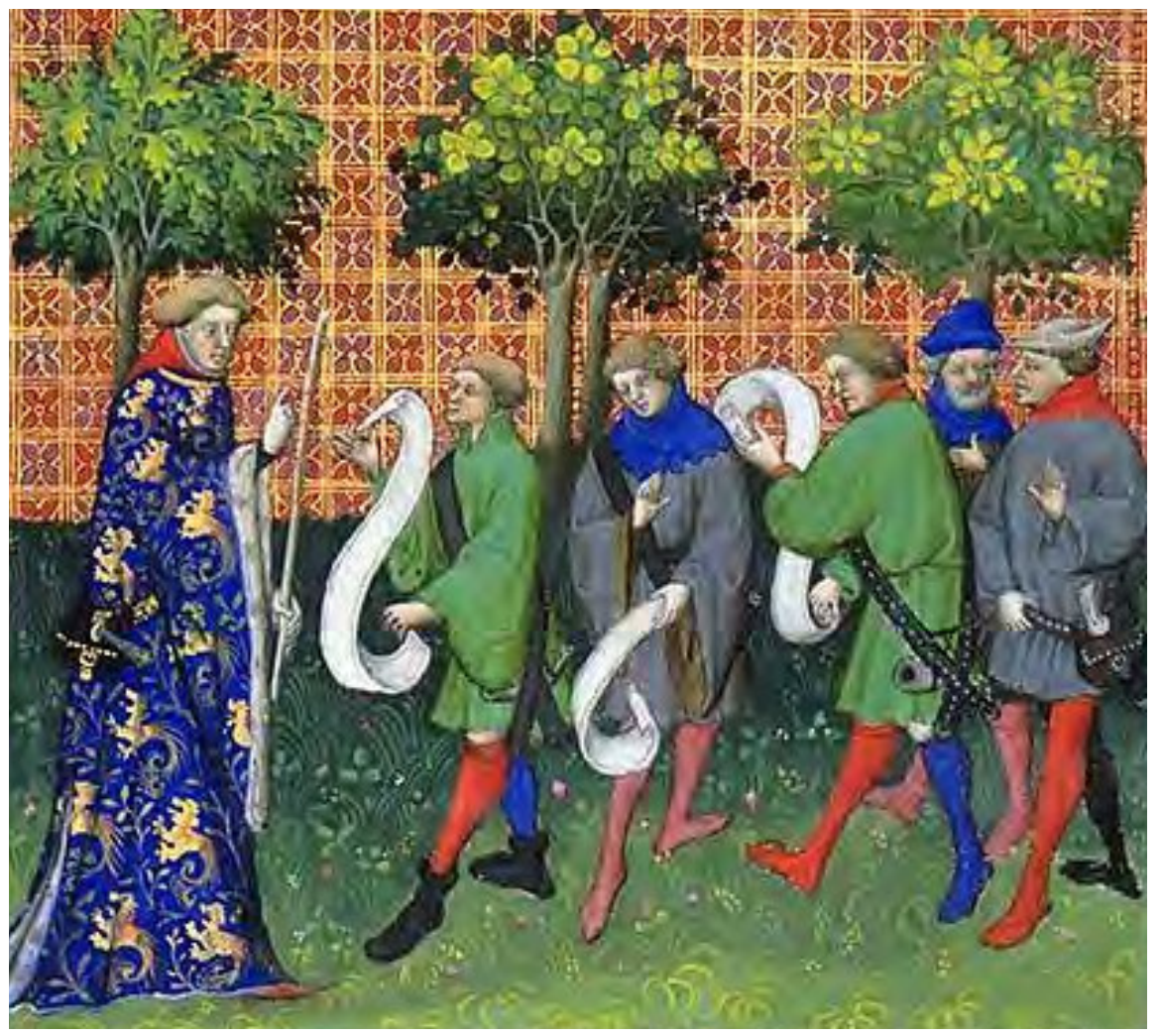

Fonte: PINTEREST, https://www.pinterest.fr/pin/511721576383964168/.

FIGURA 77: As fadas foram frequentemente retratadas de verde, aproximando suas qualidades as da natureza.

Green Summer, Edward Coley Burne Jones, 1868, coleção particular, óleo sobre tela.

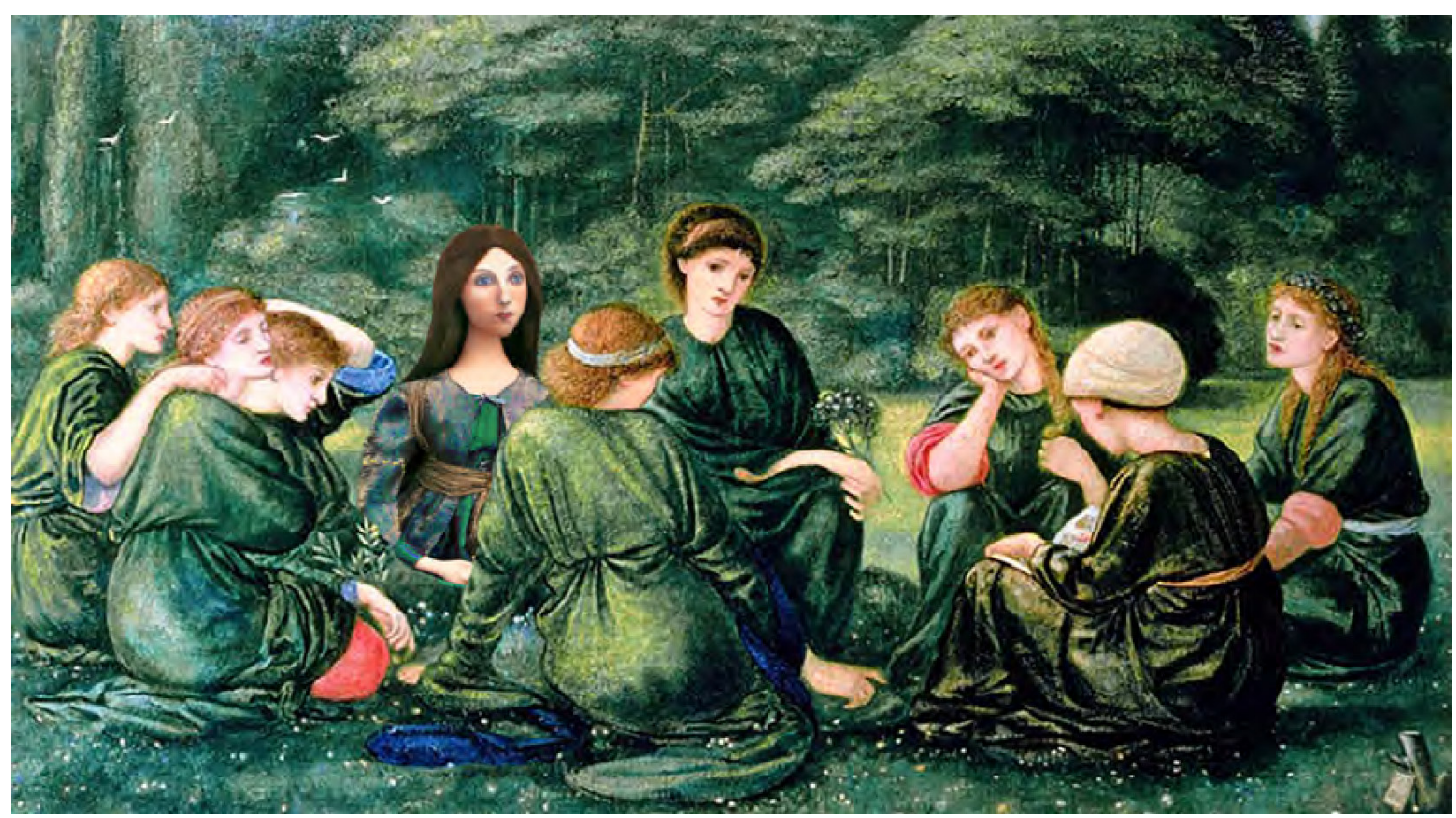

Fonte: WIKIMEDIA, https://commons.wikimedia.org/wiki/File:Edward_BurneJones_Green_Summer_(1868).jpg 
Assim, mesmo sendo admirado nesse período, época da cavalaria e da cortesia, o verde começou a perder prestígio por ainda ser materialmente oscilante em algumas regiões. Tanto que, até séculos mais tarde, tingir de verde não era um exercício fácil, pois a cor não penetrava profundamente no tecido e dava-lhe uma aparência desbotada, ou dificilmente resistia aos efeitos do claro, do sol e da lavagem ficando amarelo, marrom ou cinza. Para Pastoureau (2019, p.116):

\begin{abstract}
o verde era ainda mais difícil de produzir e consertar. Em tecidos e roupas, os tons de verde costumavam ser desbotados e não resistentes à lavagem e à luz. Fazer com que as cores penetrassem profundamente nas fibras dos tecidos, tornando-as puras e luminosas, e evitando que descolorissem rapidamente, foi uma tarefa difícil por muito tempo na Europa. Para a maioria dos tingimentos comuns, produtos vegetais eram usados: verdes como samambaias, urtigas ou banana-da-terra, flores como dedaleira, galhos como vassoura, folhas como as do freixo ou do vidoeiro, casca como a do amieiro. Mas nenhum desses produtos vegetais forneceu um verde puro, rico e estável. O verde mal pegou, se dissipou e até desapareceu em alguns tecidos. Além disso, a necessidade de um mordente poderoso tendia a matar a cor, que muitas vezes era desbotada, nunca viva. É por isso que o verde foi reservado para roupas comuns e para as pessoas comuns. Às vezes, em ocasiões especiais (um feriado ou torneio), eram usados corantes minerais à base de cobre (verdete) e tons mais fortes, mas, como na pintura, esses materiais eram corrosivos, tóxicos e não produziam uma tintura duradoura. Seguindo esse processo, que o teatro continuou a usar até o século XVII, os tecidos eram mais pintados do que tingidos.
\end{abstract}

Nesse mesmo momento, por volta dos séculos XIII e XIV, ao lado da inconstância do verde, o amarelo também sofreu um desprestígio, pois estava atrelado à mentira e à traição, às vestes de Judas e aos judeus, os quais eram frequentemente retratados vestindo roupas ou uma peça de roupa nesta coloração. Devido a isso, frequentemente, pessoas de má reputação apareceram vestidos de amarelo na iconografia do final da Idade Média. Dessa forma, no final desse período e início do período moderno, foi uma cor usada principalmente no guarda-roupa feminino, apesar de aparecer com menos frequência nos vestuários do que no período feudal. Mesmo assim, a maioria das classes sociais ainda se vestiam com essa tonalidade (PASTOURAEU, 2019), como evidencia a figura 78. 
FIGURA 78: O amarelo, quando usado, era majoritariamente uma cor feminina.

Portrait of a Lady in Yellow, Alesso Baldovinetti, 1465, Londres, National Gallery, têmpera em painel.

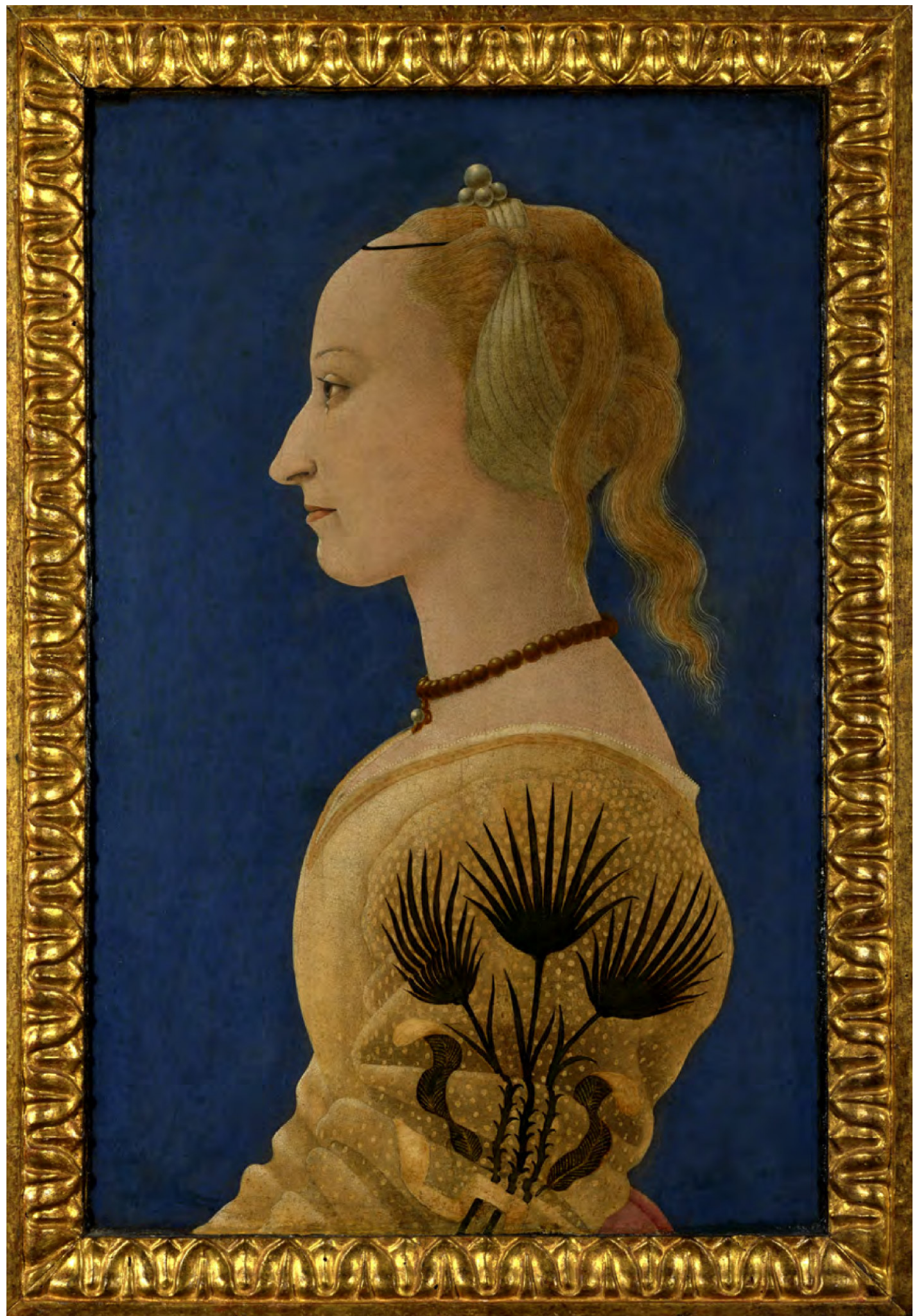

Fonte: NATIONAL GALLERY, https://www.nationalgallery.org.uk/paintings/alesso-baldovinettiportrait-of-a-lady 
E devido as associações que o amarelo recebeu nessa época, é provavelmente por isso que, no que diz respeito às roupas, ele tornou-se uma cor impopular no período moderno, relegado aos camponeses, artesãos e domésticos.

Por outro lado, outras tonalidades ascendiam nesse período e já no final da Idade Média, no século XIV, os tintureiros notaram que certas espécies de árvores produziam corantes melhores do que as que eles vinham usando habitualmente. Decidiram, então, fazer uso dessa madeira que trazia uma coloração semelhante ao vermelho da brasa. Esse corante dela extraído trazia tons brilhantes e saturados e, dependendo do mordente utilizado, o resultado cromático era rosa para os mordentes alcalinos e laranja para os mordentes ácidos (PASTOUREAU, 2019).

Essas duas cores, rosa e laranja, antes negligenciadas por serem muito opacas e monótonas, tornaram-se moda em 1400 e assim permaneceram por algumas décadas, pelo menos por uma parte da sociedade.

No campo do laranja, a promoção da fruta que estava em alta na sociedade europeia, beneficiou a cor, amplamente utilizada para tecidos e roupas com a chegada de novos corantes. Com isso, no século XV, nasceu o laranja, pelo menos no que diz respeito ao tingimento, à moda e ao léxico (PASTOUREAU, 2011). Isso pode ser observado na figura 79 que apresenta uma enorme quantidade da cor laranja em sua composição devido ao apreço que esse tom recebeu nesse período. 
FIGURA 79: Essa cor ocupa grande parte dessa obra devido o prestígio que essa cor recebeu nessa época.

Fresco of Madonna, Lippo di Dalmasio, século XV, St. Stephen Churches, Bologna.

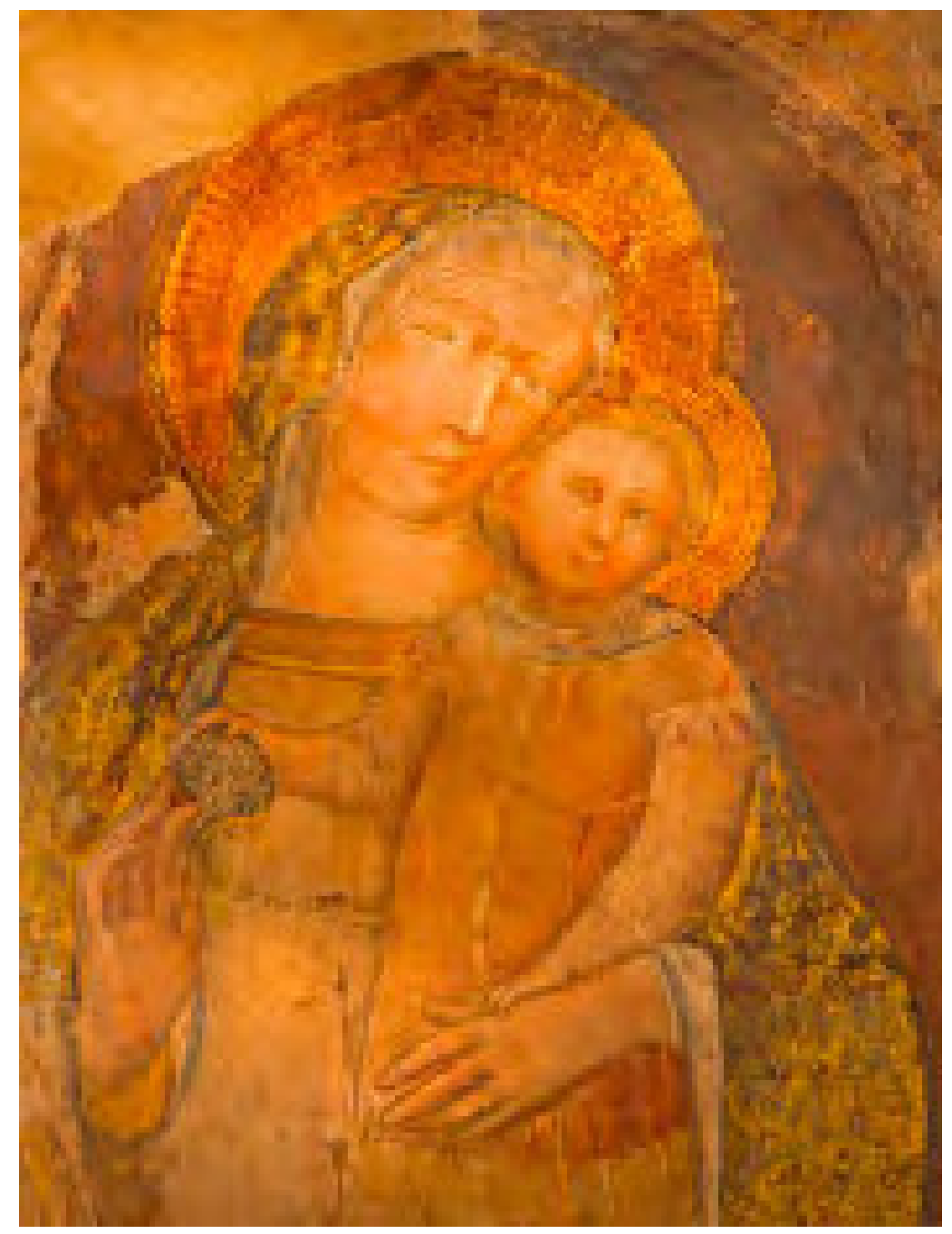

Fonte: https://www.alamy.com/stock-photo/lippo-di-dalmasio.html.

Nesse mesmo momento observa-se que, o violeta, que desempenhou uma considerável importância nos tempos de outrora, não foi impedido, mas ficou, durante longo tempo, restrito à liturgia católica ou às práticas relativas ao vestuário do luto. Já no final da Idade Média, a ascensão da cor preta na sociedade beneficiou o gosto tanto dos cinzas como dos violetas, que são próximas ao preto tanto no plano relativo à tinturaria como no plano simbólico. Para Pastoureau, a cor violeta (2011, p. 104):

rara no vestuário europeu antes do século $\mathrm{XV}$, era até então uma cor essencialmente litúrgica, um substituto do preto para os tempos de aflição e penitência. Como dizia muito claramente seu nome latino (subniger), o violeta era uma espécie de "subpreto", obtido não como se faz hoje, por 
uma mistura de azul e vermelho, mas sim de azul e preto; ou ainda, pela ação sucessiva sobre o tecido a ser tingindo de um banho de azul seguido de um banho de preto. Ora, nos anos 1400, esse violeta tradicional quase desapareceu, pelo menos no mundo da tinturaria. Uma nova cor violeta aparece, ou melhor, tonalidades de violeta, que dali em diante tendem mais para o vermelho. As tonalidades mais claras e brilhantes são obtidas a partir de uma matéria corante recentemente importada do Ceilão, Java e das florestas tropicais na Índia: o pau-brasil (brasileum), que serve igualmente para reproduzir tonalidades rosa muito belas e até mesmo algumas alaranjadas. Os violetas mais escuros e duráveis são fabricados de maneira diferente, não com o pau-brasil mas mergulhando o tecido num banho de pastel-dos-tintureiros e em seguida em outro de ruiva-dostintureiros.

Acrescenta ainda Pastoureau (2011, p. 104):

Para fazer isso, os tintureiros que tingem de vermelho começam a infringir os regulamentos que regem a profissão há vários séculos: escondem em seus ateliês tinas com pastel-dos-tintureiros, que utilizam para dar aos tecidos que serão tingidos um sólido pié de azul. Ao mergulhar em seguida esse tecido (...) em uma tina de vermelho (ruiva-dos-tintureiros, urzela), conseguem as tonalidades do violeta-escuro. O mundo dos príncipes é seduzido por esses novos violetas, dali em diante mais vermelhos que azuis.

Isso vai implicar em dois tipos de violetas. Por um lado, esses tons tendiam mais a ser avermelhados do que azulados. Por outro, os tintureiros misturavam o azul e o preto, o que fez o violeta ser considerado um subpreto.

Faz-se mister destacar que essa forma de obter uma coloração por mistura dessas substâncias não existia nem em pintura nem em tinturaria. Até esse momento, nenhum receituário antes desse período mencionava que, para obter o violeta, era preciso misturar o azul com o vermelho.

No mais, pelo menos até o século XVI, os tintureiros enfrentavam dificuldades, pois as autoridades proibiam o uso dos tons de violeta provenientes da mistura de pastel-dostintureiros e de garança, ou seja, de azul com vermelho. O que eles conseguiam fazer, quando não infringiam as leis, era misturar um mordente específico na garança e com essa técnica obter tons de violeta mais avermelhados (PASTOUREAU, 2017).

Daí em diante, desde o início do período moderno, e os séculos que se seguiram, esse tom se afirmou como uma cor difícil de encontrar nos círculos aristocráticos. Com isso, deixou de ser uma cor da moda e, no caminhar dos tempos, não se tornou mais uma tonalidade tão desejada quando, novamente, caiu em desuso. 
Contudo, no início do período moderno, em meados do século XV, a exemplo do que ocorreu em 1215 com o IV Concílio de Latrão mencionado anteriormente, proliferaram, como muitos outras vezes ao longo da História, leis e decretos de vestimenta emitidos por autoridades civis. As cores das roupas foram de grande importância, pois ou foram proibidas para certas classes sociais, ou foram obrigatórias para outras em que o vermelho foi a coloração que mais sofreu imposições. Nos dois casos, ele apareceu no topo da lista. Tanto que as prostitutas deveriam usar algo chamativo, no caso, o vermelho geralmente combinado com outra tonalidade, ou uma peça de roupa berrante a fim de serem diferenciadas das mulheres dignas. De acordo com Pastoureau (2017, p. 83):

\footnotetext{
Esse elo entre a cor vermelha e a prostituição encontra suas raízes na Bíblia. No décimo sétimo capítulo de Apocalipse, um anjo mostra a São João, a grande prostituta da Babilônia. Ela está "vestida de púrpura e escarlate", sentada nas águas e segurando um espelho (a imagem da luxúria); depois, ela monta um "peito vermelho monstruoso" com sete cabeças (o dragão). Os artistas medievais frequentemente representavam a visão de São João e davam à grande prostituta um vestido vermelho, assim como muitas vezes vestiam Maria Madalena de vermelho, uma mulher santa, é claro - e até a primeira a quem o Cristo ressuscitado pode ter aparecido - mas uma ex-cortesã, com longos cabelos ruivos e um rosto pintado.
}

Além dessa categoria da sociedade, outras profissões e classes sociais também foram afetadas por essas medidas e exigidas a se identificarem por meio de uma insígnia vermelha. Foram o caso dos leprosos, bêbados, pobres e vários tipos de condenados, como os judeus e os muçulmanos.

Com a queda dos vermelhos brilhantes e luminosos na área do vestuário, no século $\mathrm{XV}$, os tons mais escuros, como o carmesim, e os que tendiam ao azul, como os roxos, tiveram sua escalada e ganharam a preferência (PASTOUREAU, 2016). Em contrapartida, certas tonalidades "vermelhas tendendo ao amarelo ou ao marrom foram rejeitadas e associadas a tudo o que evocava as chamas do pecado original do inferno e todo um desfile de vícios importantes, entre eles orgulho, falsidade e luxúria" (PASTOUREAU, 2017, p.90).

Já uma outra cor, desde um pouco antes do período moderno, em meados do século XIII, início do XIV, o branco, apresentou avanço no tingimento. Até então, tingir um tecido de um branco bem branco era uma tarefa difícil, pois a brancura pascal foi muitas vezes um horizonte teórico. Quando possível, fazia-se visível somente para o linho e, mesmo assim, era complexo. Para outros tecidos, como a lã, por exemplo, o branco obtido não era verdadeiramente alvo ao fim de algum tempo, tornando-se pardo, amarelo, cru ou até 
mesmo com reflexos acinzentados, esverdeados ou azulados, dependendo da matéria corante que era empregada (PASTOUREAU, 2011).

Contudo, a partir desse momento, foi obtido um branco mais reluzente e que fixava mais facilmente, por um período de tempo maior, em diferentes tipos de tecidos. Esse avanço no tingimento do branco, tão significativo no culto católico, foi importante, pois garantiu que a simbologia atrelada a essa coloração fosse utilizada de forma mais esplêndida.

Junto com o branco, em meados do século XIV, o preto viu crescer seu prestígio. Mas dessa vez não no plano simbólico, e sim com a prática da tinturaria se fazendo presente como uma cor da moda. Como nesse momento estavam em evidência as leis e os regulamentos sobre o vestuário, os patrícios e os comerciantes, por não pertencerem ao topo da hierarquia social, não tinham o direito por lei de fazer uso dos vermelhos mais esplendorosos e pomposos "como os célebres escarlates de Veneza, scarlatti veneziani di grana, ou dos azuis demasiado intensos como os famosos azuis "pavonados" de Florença, panni pavonacei" (PASTOUREAU, 2016, p. 103).

Assim, a ascensão do preto passou a ser usado pelos comerciantes e patrícios que, por sua vez, requisitaram aos fabricantes de tecidos e aos alfaiates que lhes fornecessem novos tons negros, mais consistentes, fortes e sedutores. Estimulados por essa nova procura, os fabricantes pressionam os tintureiros, pedindo-lhes um esforço que lhes permitissem satisfazer a tão endinheirada freguesia. Os tintureiros passaram a usar, por exemplo, a noz de galha, que permitiu obter tonalidades uniformes, como ilustra a figura 80. 
FIGURA 80: O tingimento de preto se fez possível devido ao emprego da noz de galha, que permitiu obter tonalidades uniformes, por penetrar profundamente nas fibras.

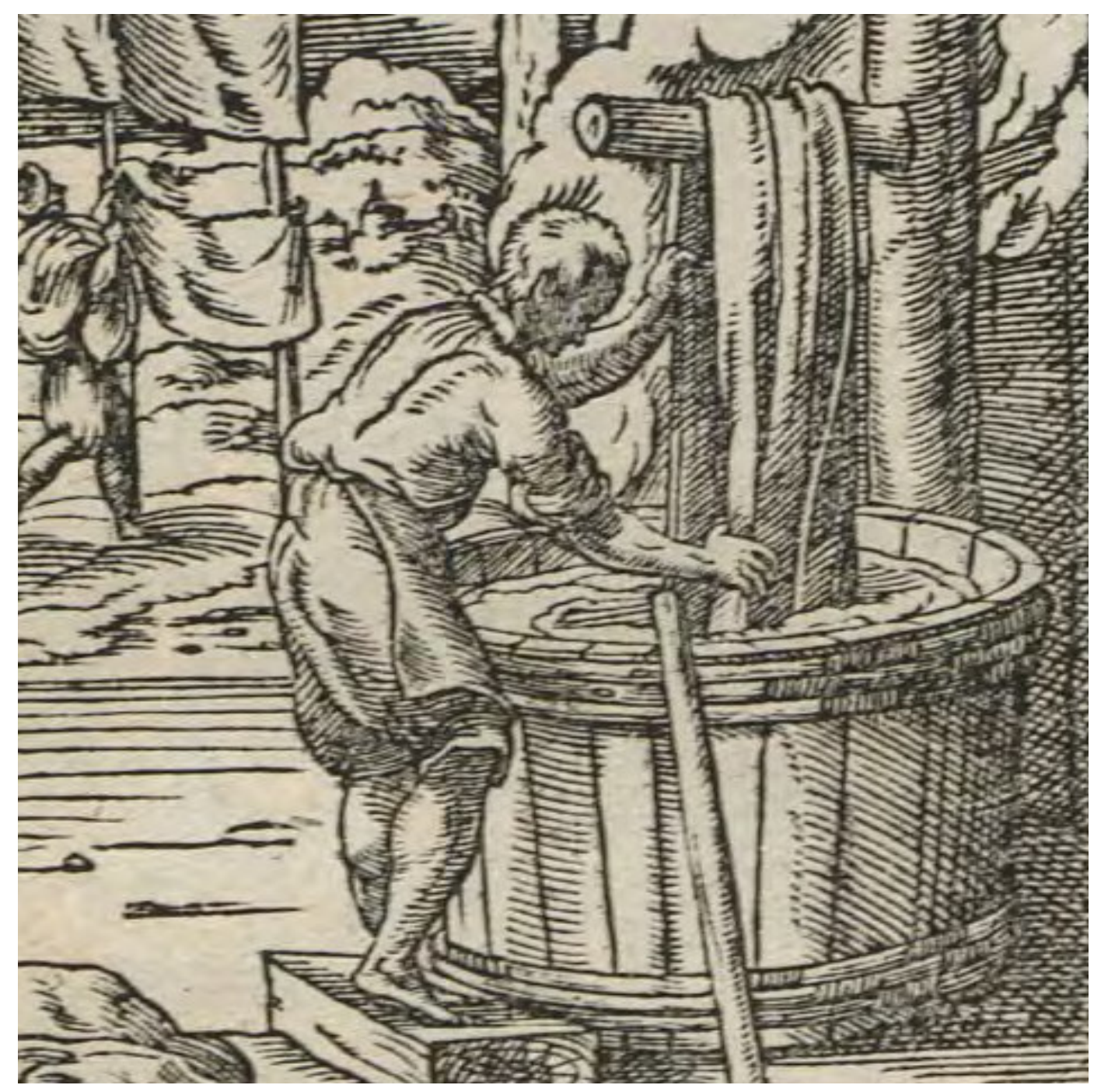

Fonte: WIKIMEDIA,

https://commons.wikimedia.org/wiki/File:Fotothek_df_tg_0008092_St\%C3\%A4ndebuch_\%5E_Han dwerk_\%5E_Schwarzf\%C3\%A4rber_\%5E_F\%C3\%A4rber.jpg

Em pouco tempo, ainda no século XIV, os tintureiros, que até então nunca haviam conseguido obter através da tinturaria uma tonalidade preta bela e vistosa, começaram a obterem maiores êxitos. Assim, um tecido tingido desse tom passou a ser mais nobre e digno das mais belas vestes (PASTOUREAU, 2011).

Para tingir de preto, os materiais corantes mais comuns eram extraídos de algumas cascas, raízes ou frutos de diferentes árvores, como o amieiro, a nogueira, a castanheira e certos carvalhos (HELLER, 2013). Outra técnica usada para garantir a estabilidade do preto obtido através dessas matérias orgânicas era dar ao tecido primeiro um banho de azul. Antes 
de mergulhar o tecido num banho de nogueira, amieiro ou castanha, davam vários banhos de pastel-dos-tintureiros, até então a matéria corante vegetal mais comum para tingir de azul que proporcionava à peça de tecido uma cor de fundo durável e um aspecto mais ou menos escuro (PASTOUREAU, 2016).

Com toda a firmeza e solidez dessa coloração, uma vez que além de certos tons de vermelhos, por exemplo, e certas peles que eram direito reservados aos príncipes, a moda de preto foi apresentada e impulsionada para a sociedade. Isso permitia aos patrícios ostentarem suas vestem em tons belos e estáveis, desde que obedecessem aos decretos existentes. Como consequência, as altas classes, ao se depararem com o triunfo obtido através desse tingimento, começam a fazer uso do preto, contribuindo definitivamente para o prestígio de vestes dessa tonalidade em todo o Ocidente (PASTOUREAU, 2011).

Em decorrência disso, nesse mesmo século XV, na moda e no vestuário, apareceu uma outra cor, o cinza. Essa cor, pela primeira vez na História da indumentária ocidental, deixava de ser uma cor vinculada às roupas de trabalho e passou a ser adorada por boa parte da sociedade de então (PASTOUREAU, 2011).

Naquela época, como a burguesia e o patriciado não podiam usar certas tonalidades conforme os códigos sociais existentes, foram eles os grandes incentivadores dos tintureiros a criarem tonalidades autênticas, vistosas e estáveis. Por essa razão, junto com o preto, o cinza passou a ter uma nova cromaticidade e intensidade. De acordo com Pastoureau (2011, p.107):

\footnotetext{
Para obter essas novas tonalidades de cinza, aplicam substâncias mordentes nos banhos de casca de amieiro ou de bétula, acrescentando sulfatos de ferro e por vezes um pouco de noz de galha. O cinza tende a escurecer mais torna mais uniforme, durável, brilhante. A partir dos anos 1420-1430, algumas cidades fabricantes de tecidos (Rouen e Louviers, por exemplo) especializam-se na produção de tecidos cinzentos de qualidade, tão grande é a demanda. Isso teria sido impensável um século mais cedo.
}

Com a ascensão dos tons de cinza, porém, tanto no plano simbólico como através das imagens, os tintureiros começaram a produzir tingimentos também em tecidos, pois a procura aumentou consideravelmente. Para obter essas novas tonalidades, alguns mordentes eram aplicados, e o resultado era uma cor uniforme, durável e brilhante que atendia aos anseios e expectativas da população. Segundo Pastoureau (2011, p. 107): 
vermelho (João, duque de Berry), ao preto (Filipe, o Bom, no final de sua vida), ao branco (René de Anjou).

Com isso, essa cor sem nenhum prestígio e estigmatizada viu sua ascensão, como confirma a figura 81 .

FIGURA 81: O surgimento do cinza como uma cor de prestígio formando uma nova tríade junto com o branco e o preto.

Portrait of a Young Woman in a Pinned Hat, Rogier Van der Weyden, 1435, Berlim, óleo sobre painel.

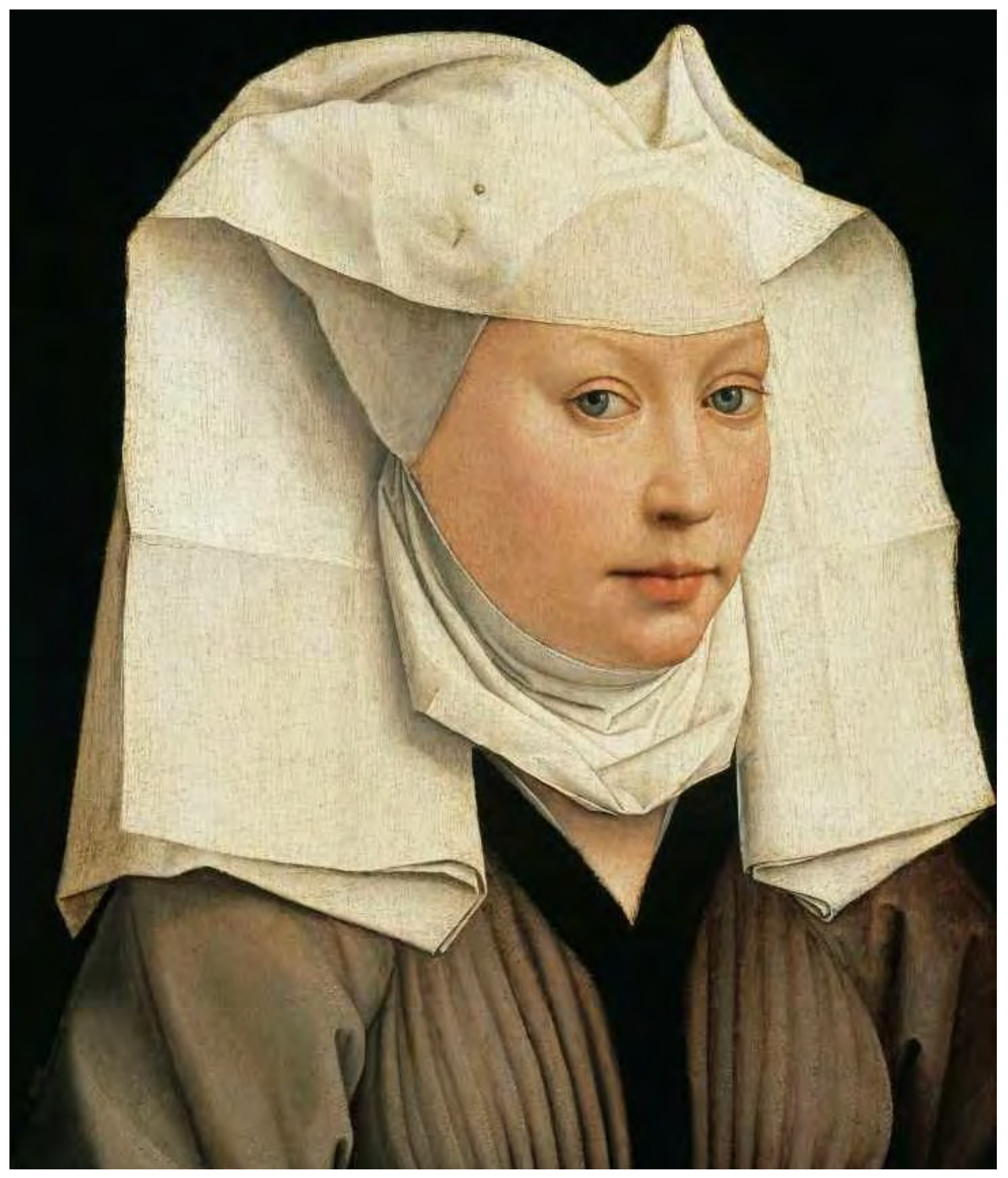

Fonte: PASTOUREAU, 2011, p. 107.

Junto com o preto, o cinza ganhou o status de ser sedutora e atraente, fascinando os olhos desse período. Por outro lado, houve quem acreditasse que o cinza era o oposto do preto quando atribuíam a essa última tonalidade a simbologia do luto ou da melancolia ao darem ao tom de gris uma conotação de esperança e de alegria. 
Assim, no século $\mathrm{XV}$, essa nova tríade formada pelo branco-cinza-preto foi considerada a mais sedutora, mas o preto dominou o cenário se fazendo presente em muitos guarda-roupas, tanto reais como cotidianos. Quer usado de forma monocromática, ou seja, uma veste somente em tom de preto, quer associado ao branco ou ao cinza, esse trio se destacou e adentrou o século seguinte com grande prestígio (PASTOUREAU, 2011).

Dessa forma, o século XVI continuou duplamente fiel a essa cor negra. Isso porque ela se apresentou tanto como uma cor destinada a ser real e reservada às altas classes da sociedade, mas também voltada para membros da igreja como uma tonalidade moral e de princípios, conforme exemplifica a figura 82.

FIGURA 82: Felipe, o Bom, lança a moda do preto na corte de Borgonha.

Portrait de Philippe le Bom, Rogier Van der Weyden, 1445, Chatêau d'Ambras, Innsbruck, óleo sobre madeira.

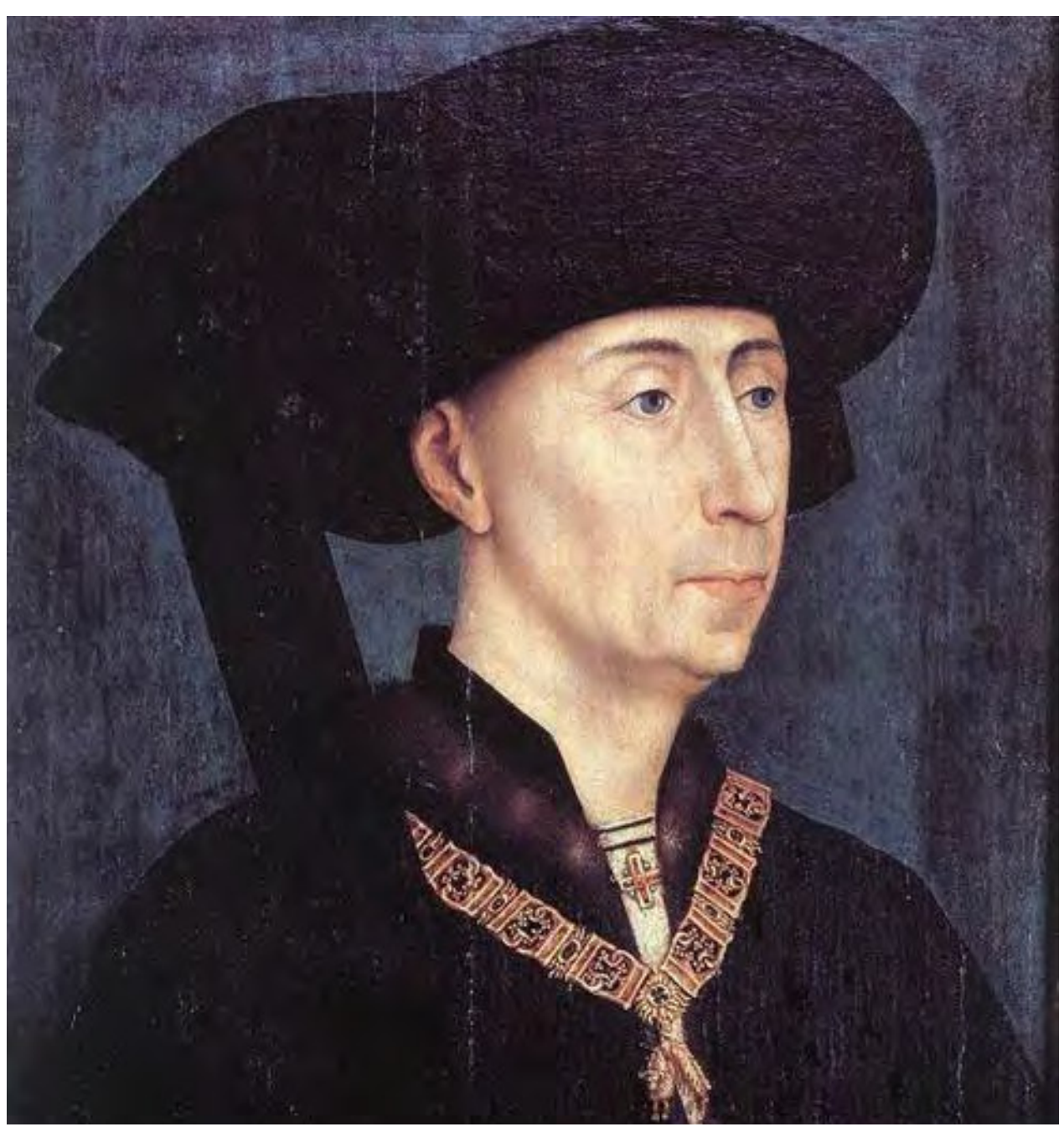

Fonte: PASTOUREAU, 2011, p. 98. 
É relevante ressaltar que a Reforma Protestante considerou esse preto a cor mais grandiosa, digna e que representava a moral cristã. Gradualmente, aproximou dele o azul, uma cor honesta e sóbria, a cor do céu e do espírito (HELLER, 2013).

Um fato chama atenção: foi por meio das vestimentas que a cromofobia protestante exerceu sua ação mais marcada, excessiva e duradoura. Não houve quase divergências quanto ao discurso no que tange ao vestuário cujas roupas deveriam ser pretas e sem nenhum ornamento. Isso porque, para a Reforma, os trajes eram sempre sinal de vergonha, pecado e estava ligado, segundo esses princípios, à Queda, ou seja, à expulsão de Adão e Eva do paraíso. A vaidade demonstrada por meio das vestes tinha como uma das principais funções lembrar ao homem seu declínio e sua decadência (PASTOUREAU, 2011).

Dessa forma, o vestuário deveria não ter ostentação, ao contrário, deveria ser sinal de humildade e pesar, logo deveria ser sóbrio, simples e discreto, indo na contramão do luxo, da ostentação e da vaidade. Em função disso, uma das consequências observadas foi uma grande austeridade na forma que as pessoas se expressavam através da aparência, por isso viram-se obrigadas a usar trajes mais simples, sem cores chamativas e acessórios extravagantes. O mesmo aconteceu no uso de maquiagem, que foi negada porque poderia ser artificial e mascarar a verdade da alma (ELDRIDGE, 2015).

As vestes se tornaram escuras, sóbrias e extremamente discretas. Como esclarece Pastoureau (2011, p. 130):

Essa busca da simplicidade e severidade traduz-se por uma paleta relativa
ao vestuário da qual estão ausentes todas as cores vivas, julgadas
desonestas: o vermelho e o amarelo, em primeiro lugar, mas também as
tonalidades rosas, as alaranjadas, a maior parte dos verdes e até mesmo os
violetas. Em compensação, são utilizadas abundantemente as cores escuras,
entre as quais encontramos em primeiro lugar as cores pretas, os cinzas e
os marrons. O branco, uma cor pura, é recomendado para as vestes das
crianças e por vezes das mulheres. O azul é tolerado na medida em que
permaneça discreto. Aquilo que se destaca pela variedade de cores, que
veste "tanto os homens como os pavões" - essa expressão é utilizada por
Melanchaton em um célebre sermão de 1527 - é severamente condenado.
Como na decoração do templo e na liturgia, a Reforma repete seu ódio pela
policromia.

Ao pregar o uso de roupas escuras, a Reforma elevou o preto ao status de cor mais empregada e correta para ser usada. Com isso, deu continuidade à enorme prática que teve em seu início, um século antes, quando elegia esse tom que desfavorecia a moda com suas transformações e originalidades. 
Nota-se que o uso do preto no vestuário não se fez presente da mesma forma durante os vários períodos como, por exemplo, na Antiguidade ou na Idade Média. Todavia, todos os decretos relativos aos vestuários, os textos normativos e legislativos recomendavam ou impunham cores escuras e sóbrias devido, não apenas à coloração como também à saturação (PASTOUREAU, 2011).

Isso se deu porque as matérias corantes eram demasiado ricas e densas, pois tingiam os tecidos com cores que, apesar de dignas, eram muito concentradas. Todavia, entre os séculos XV a XVIII, o preto tornou-se a cor mais utilizada no vestuário, apesar de ser comum as pessoas vestirem-se de cores escuras como cinza, marrom e, mais tarde, azulmarinho, além do preto. Essa medida mudou a forma geral de se portar perante roupas coloridas, sendo mais usadas em algumas condições, como rituais ou festas comemorativas (HELLER, 2013).

Entretanto, vale dizer que o preto possuía dupla personalidade. De um lado, esteve presente em todos os guarda-roupas reais e da alta sociedade, conotando seu luxo e sofisticação. Por outro, conotava humildade, controle e abstinência imposto pela Reforma que dividiu o espectro em duas metades: vaidade e extravagancia quando tinha cores; discrição e sobriedade quando não as tinha (PASTOUREAU, 2011), como exemplifica a figura 83 . 
FIGURA 83: A cor ícone da moral protestante.

Portrait of Girolamo Savonarola, Moretto da Brescia, 1524, Verona, Museu Castelvecchio, óleo sobre tela.

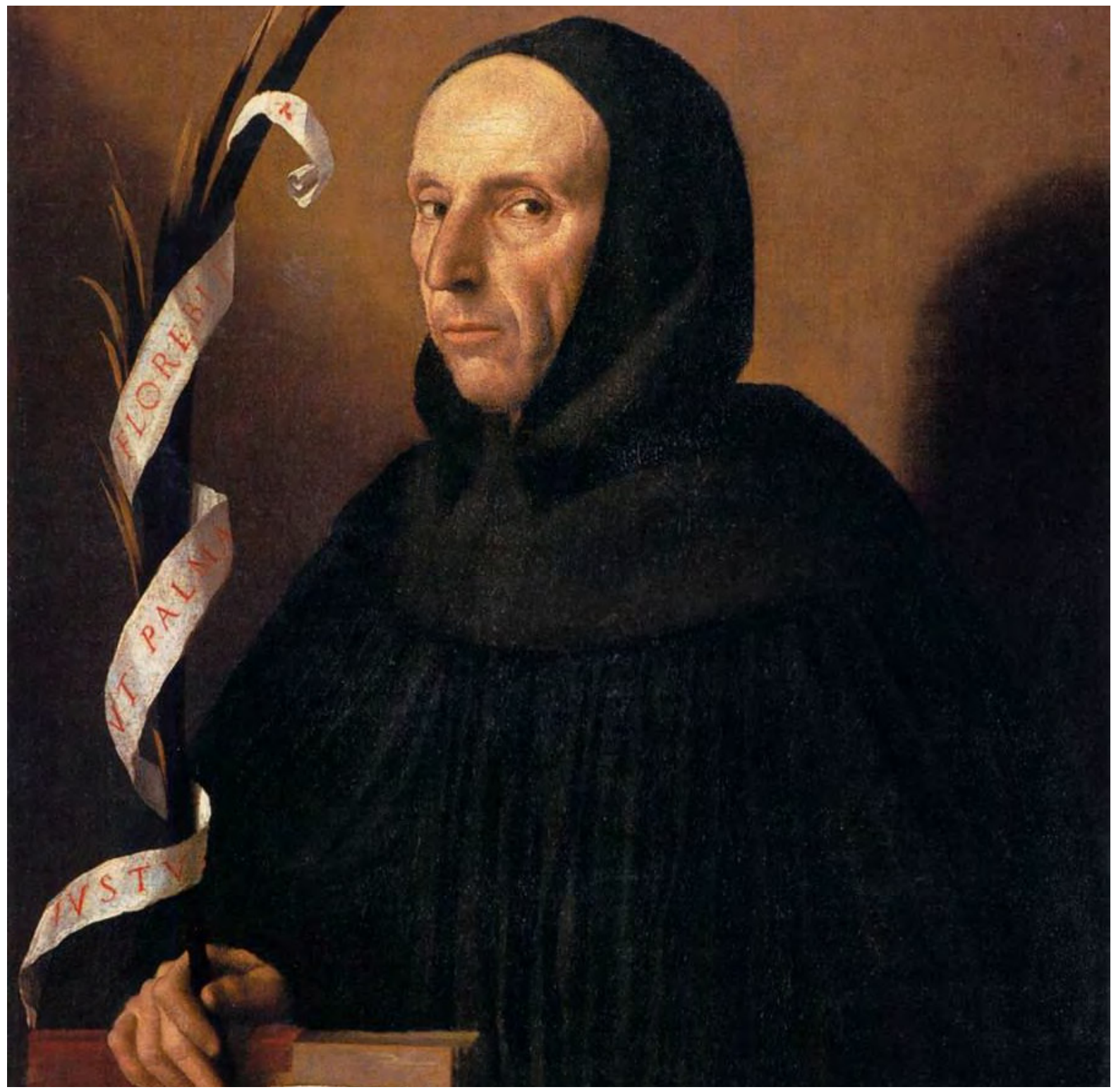

Fonte: PASTOUREAU, 2011, p. 128.

Assim, marcou-se essa divisão entre mundos: de um lado pela tríade recém-formulada um século antes, composto pelo preto-cinzento-branco; do outro, pelo restante das cores existentes, as quais, gradativamente, alteraram e implementaram uma nova sensibilidade cromática na vida cotidiana, cultural e moral.

Isso foi firmado no século XVII, talvez o mais sombrio de todos para a população europeia, que trouxe consigo o despotismo, a miséria, os horrores da guerra, os conflitos religiosos, a sobrevivência das pestes e epidemias, o retorno do medo e da fome. Em outras 
palavras, o século que trouxe o reverso do Grand Siécle, século de Luis XIV e de Versailles, das festas e pompa da corte. Não à toa, o preto foi a sua cor junto com a escala dos tons de cinza e de marrom ao lado de uma policromia também existente (PASTOUREAU, 2011).

Apesar de a arte barroca ter feito resplandecer os dourados e a policromia, o hábito de vestir-se de preto prevaleceu, pois era evitado o uso de cores vivas, de maquiagem e de adornos. Isso pode ser facilmente observado nos inventários feitos depois da morte de alguém, em que se destacava uma predominância de tecidos e vestimentas escuras, desde o final do século XVI até os primeiros decênios do século XVIII. Segundo Pastoureau (2011, p. 132):

\footnotetext{
Em Paris, por exemplo, por volta de 1700, 33\% do vestuário dos nobres homens e mulheres considerados conjuntamente - é de cor preta, $27 \%$ é marrom e $5 \%$ é cinza. Entre os funcionários públicos, a proporção de vestimentas escuras é maior ainda: $44 \%$ pretas, $13 \%$ cinza e $10 \%$ marrom; e entre os empregados domésticos, mostra-se ainda mais elevada: $29 \%$ pretas, $23 \%$ marrons e $20 \%$ cinza.
}

Foi nessa época também que as práticas generalizadas de luto sob a forma de tecidos e vestuário, que não existiam até então, passaram a existir e eram reservadas às classes mais favorecidas. Elas tiveram, sobretudo no preto, a cor propícia, apesar do cinza, o azul-escuro e o violeta também serem permitidos para vestir as pessoas próximas ao defunto com vestuário específico.

Contudo, a partir do século XVII, essas colorações cedem lugar para a supremacia do preto como a cor do luto entre a aristocracia, o patriciado e uma parte da burguesia. Mas somente no século XIX, esse tom tornou-se a cor da morte de forma geral, além, claro, de ser a tonalidade eleita que revelava bons hábitos, a forma adequada de viver em sociedade e aos acordos de boas maneiras (HELLER, 2013).

Apesar desse gosto pelo preto, o século XVIII, também conhecido como o Século das Luzes, mudou a relação da cor na vida cotidiana de acordo com as atividades e as classes sociais. Isso porque as tonalidades estabeleceram uma relação com o mundo urbano e as camadas superiores da sociedade. A partir desse momento, elas aparecem no vestuário com nuances claras e luminosas, com cores alegres, com tonalidades "pastel", principalmente na gama dos tons de azul, de rosa, dos amarelos e dos acinzentados (PASTOUREAU, 2016).

Esse período incorporou o laranja que já havia sido notado desde o final do século $\mathrm{XIV}$, e nessa fase, podia ser dividido em vários tons. Esses tons iam dos amarelos com tendência para o laranja, tons não tão vívidos e saturados, tons sutis e discretos até, muitas 
vezes, aos tons de rosa. Acrescentem-se ainda os tons escuros de laranja também tenderam para o marrom, para o castanho e para o terracota avermelhado. Essa tonalidade se beneficiou muito pelos avanços da química em relação aos corantes (PASTOUREAU, 2019).

Já o amarelo, que havia sofrido uma queda desde os séculos XIII e XIV, em meados do século XVIII, continuou com esse retrocesso, permanecendo o que era anteriormente, não sendo ausente, mas longe de ser a cor mais listada, especialmente porque era mais comum entre as classes menos influentes do que as mais ricas. Eles perderam seus aspectos dourados ou castanhos, pois passaram a ser mais leves e claros permanecendo de forma branda na moda (PASTOUREAU, 2019).

O azul, mais discreto anteriormente, diversifica-se ao mesmo tempo que os tintureiros conseguiram obter novos efeitos com uma gama de azul-claros e luminosos nunca antes vista (PASTOUREAU, 2016). Até o cinza reaparece - depois de uma fase mais discreta desde o final do século XV - e reaparece de forma deslumbrante no tingimento de tecidos, sem desbotar com facilidade e muito diferente da austeridade vista antes pelos uniformes e pelos mantos (PASTOUREAU, 2011).

Já o verde deve seu avanço com o fim do tabu sobre as misturas de cores. Isso porque os tintureiros, em vez de somente utilizar uma matéria corante com uma determinada cor, conseguiram, a partir de então, reproduzir uma tonalidade, no caso o verde, pela mistura de amarelo com o azul (PASTOUREAU, 2016).

Nesse momento o vermelho teve uma grande expressão nos rostos, principalmente nos círculos da corte, sendo utilizado nas maquiagens de forma até excessiva (ELDRDGE, 2015). Com essa colocaração, na História da tinturaria ocidental, até o século XVIII, foram obtidos os melhores resultados, as cores mais vivas, mais estáveis e mais diversificadas. Tanto que era comum, em dia de casamento, as noivas e até mesmo as convidadas vestirem seus vestidos mais bonitos, geralmente nesse tom, porque os tintureiros obtinham tonalidades mais vistosas com essa cor, apesar de não ter nenhuma regra quanto a nuance a ser usada. Somente no final do século XIX, as noivas passaram a usar o branco como símbolo do vestido de noiva (HELLER, 2013) como será mencionado a seguir.

Essas colorações aparecem geralmente associadas contendo alta luminosidade como, como se observa na figura 84. 
FIGURA 84: O aparecimento de tons mais claros ganha espaço na moda no século XVIII. La Pastorella, Jean-Honoré Fragonard, 1750-52, Milwaukee Art Museum, óleo sobre tela.

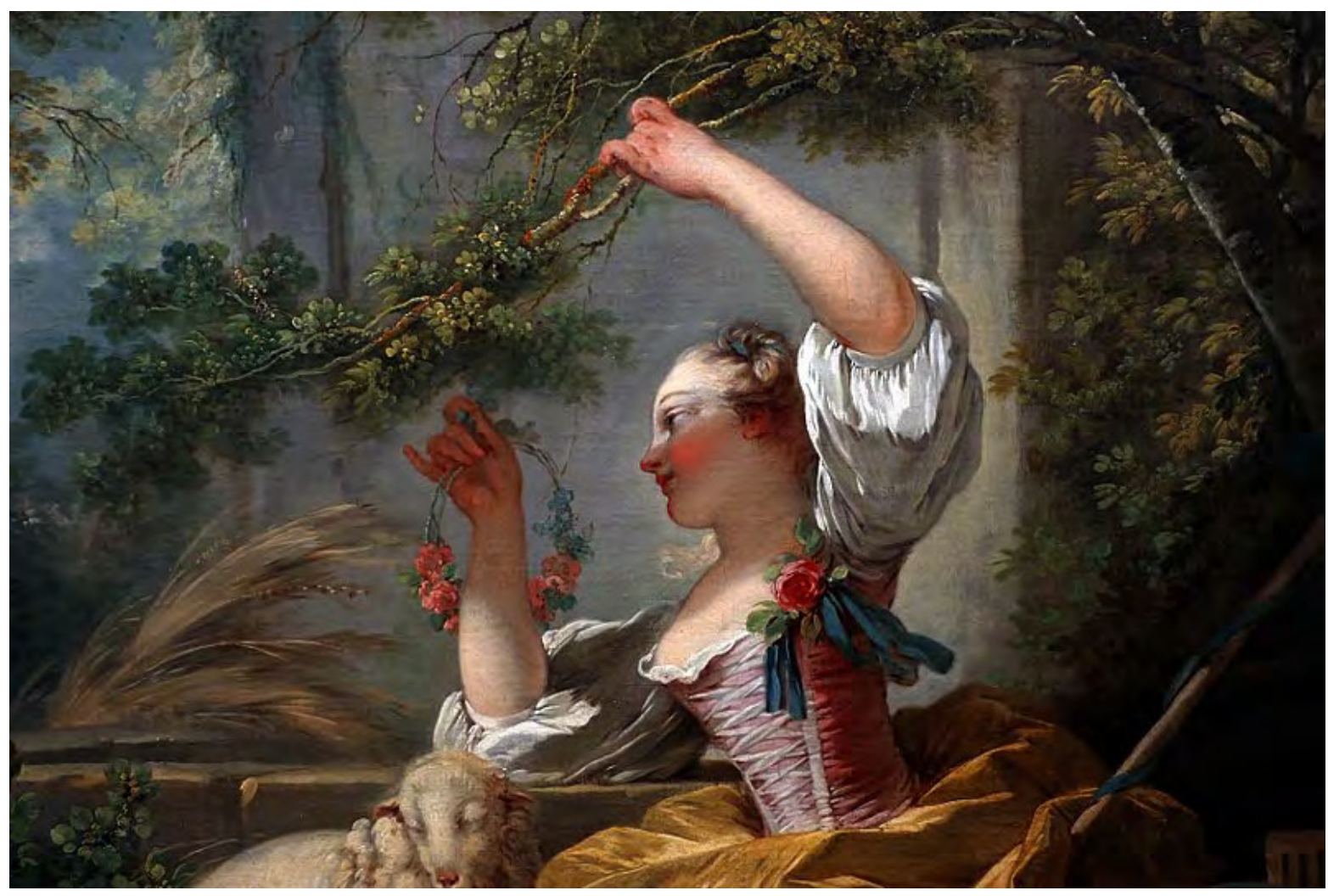

Fonte: WIKIPEDIA, https://commons.wikimedia.org/wiki/File:Jeanhonor\%C3\%A9_fragonard,_la_pastorella,_1750-52_ca._02.jpg

O resultado dessa mudança de postura e comportamento foi que a reprodução de cores nos vestuários passou a estar completamente em foco, facilitada pelo progresso definitivo devido à química dos corantes e à disponibilidade dos pigmentos. Essas mudanças beneficiaram as indústrias de tingimento e têxtil, desde a classe média até as parcelas mais altas da sociedade, que viram surgir e tiveram acesso a cores fortes, vivas, claras, cinza e pastel com maior durabilidade nos tecidos. Como consequência, tons escuros e sombrios, como marrons, azuis escuros e roxos, entraram em declínio.

Assim, muito do impacto causado, já no final do século XVIII, devido à Revolução Francesa, fez transformar a sociedade, a mentalidade da época, trazendo com isso uma transição e uma mudança extremamente sensível e definitiva na moda. Ao invés do desconforto causado "pelas cinturas apertadas, panturrilhas acolchoadas, o cabelo escondido debaixo de perucas e o rosto coberto de branco" (HELLER, 2013, p. 165) da moda rococó, a nova moda, que tinha os valores da burguesia de liberdade, igualdade e fraternidade, buscavam, "em lugar de corpetes, um aspecto natural" (HELLER, 2013, p. 165). 
Surgiu um estilo mais simples: as damas, tanto aristocratas quanto burguesas, passaram a vestir vestidos mais singelos, sem tanto ornamento ou enfeites e, de preferência, na cor branca. Esse tom conotava a simplicidade de ser, o livre viver em oposição ao estilo rococó do século anterior: o século da corte de Louis XIV e da construção de Versailles, marcado por uma moda que trouxe o preto aliado a uma policromia e foi a mais dispendiosa de todos os tempos.

$\mathrm{O}$ que se pretendia era passar uma imagem mais natural e verdadeira que fosse ao encontro dos novos valores consagrados com a revolução de liberdade, igualdade e fraternidade. A burguesia, a partir desse momento, passou a ter uma maior participação na sociedade e ansiava pela vontade de pertencimento, desejando demonstrar sua força econômica e sua grandeza espiritual. Com isso, o branco entra em moda, por isso se faz presente tanto nos vestuários femininos como nos trajes masculinos, ou seja, tanto nas rendas quanto nos tecidos de forma geral.

Conforme mencionado por Heller (2013, p.165):

\begin{abstract}
Napoleão favoreceu na França o estilo imperial, que no resto da Europa correspondia ao estilo do classicismo. Goethe escreveu em sua Teoria das Cores a moda de 1800: "As mulheres andam agora quase inteiramente vestidas de branco, e os homens de preto". Os trajes pretos eram, fazia tempo, costumeiros para os dias de festa - os brancos, contudo, eram novidade. Essa moda feminina branca converteu-se em moda mundial, pois expressava o ideal do classicismo - era clássico-grega.
\end{abstract}

Porém, a tentativa de imitar uma moda em estilo clássico grego, que contava com tecidos leves e com sandálias de couro imitando o costume gladiador, não durou muito tempo devido à imposição climática e à falta de privacidade causada pela transparência dos tecidos. Contudo, a cor branca perdurou durante o século XVIII na moda, sendo considerada a cor mais elegante da época. Tanto que, segundo Heller, citando Goethe (2013, p.166):

\footnotetext{
Inspirado pela Antiguidade branca, Goethe escreveu: "Os homens cultivados têm certa aversão pelas cores". Quanto mais cores, mais bárbaro o gosto, nisso Goethe e seus contemporâneos estavam de acordo: "Os homens em estado de natureza, as pessoas rudes e as crianças sentem uma grande atração pelas cores altamente energéticas... eles têm também uma inclinação por tudo que é colorido"”.
}

Verifica-se que, com a ascensão da burguesia nesse período, havia uma vontade por parte dessa camada da sociedade de impor o status social e econômico. Para desempenhar esse papel, recorreu-se ao uso da cor branca. Vale salientar que, como essa coloração 
evidenciava a sujeira, para ter a roupas limpas, era preciso ter funcionários para limpar. Esse fato conferiu um valor econômico que estava por trás da escolha dessa tonalidade.

No início do século XIX, com a aparição do primeiro tear mecânico em 1808, e, posteriormente, com o surgimento da máquina de costura em 1830, o custo dos tecidos ficaram mais acessíveis, colaborando, mais uma vez, para a transformação da moda na sociedade (HELLER, 2013).

A partir do século XIX, os vestidos, inclusive os de noiva, junto com o véu e a grinalda, passaram a ser brancos eleitos pela burguesia como a cor que espelhava seus valores. Segundo Heller (2013) as noivas, antes desse período, usavam nas cerimônias de casamento o seu melhor vestido, e não existia, até então, a mentalidade de se ter um padrão de vestimenta para essa festa. Heller descreve que (2013, p. 173):

\footnotetext{
Na peça Romeu e Julieta, de Shakespeare (1597), a condessa Júlia Capuleto deveria se casar, conforme o desejo de seus pais, com o conde Paris. Júlia tinha então quatorze anos, que era, em sua época, uma idade apropriada para se casar. Estava tudo preparado, fazia tempo, para uma grande festa; já estavam contratados os vinte melhores cozinheiros do país... porém, na noite anterior à boda, a mãe de Julieta pergunta que vestido irá trajar a noiva. Julieta examina com sua criada os baús e escolhe um vestido, que não é descrito. A questão está resolvida. A condessa Júlia não vestiria nenhuma roupa nova - isso não fazia parte dos costumes daquela época.
}

Muito desse costume de não ter um traje específico para essa cerimônia foi ditado pela Igreja, que condenava o intuito desse desperdício de fazer um vestido para ser usado uma única vez. Dessa forma, cada classe social casava-se à sua maneira, ou seja, as damas da corte usavam as roupas com as quais iam aos bailes, as da burguesia preferiam trajar-se de seda preta e as camponesas com as roupas de domingo (PASTOUREAU, 2011).

Essa relação é alterada em 1840, com a rainha Victoria usando um vestido de seda na cor branca, passando essa tonalidade a ser a mais apropriada para cerimônias de casamento. Como consequência, elegeu-se o branco como sendo a cor oficial dessa celebração no Ocidente, como se obeserva na figura 85. 
FIGURA 85: Branco cerimonial usado pela rainha Victoria criando tendência dos vestidos de noiva.

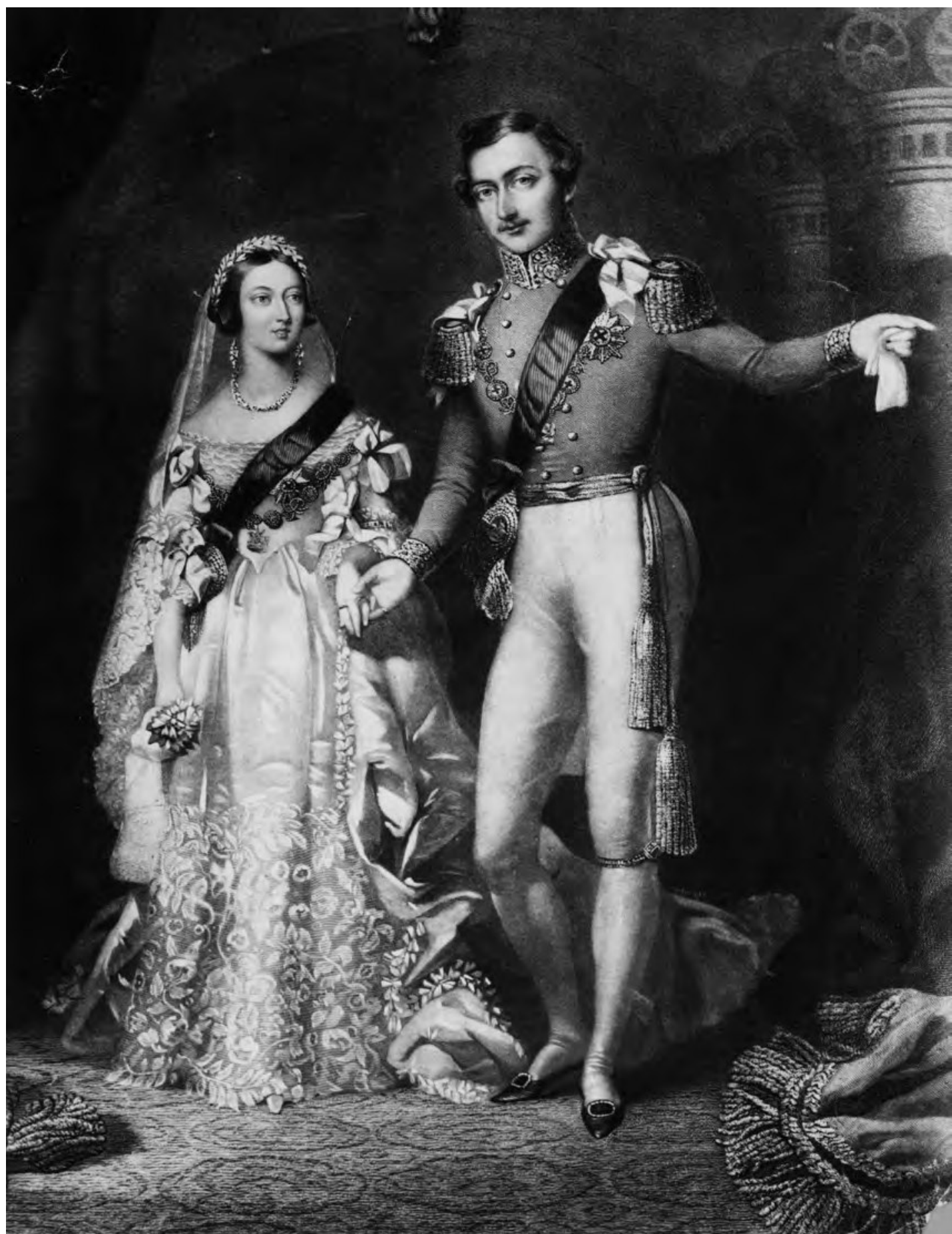

Fonte: VICTORIA AND ALBERT MUSEUM, https://www.vam.ac.uk/articles/wedding-colour

Já as peças íntimas como roupas de baixo, lenços, lençóis e roupas de banho que, ao longo da História, receberam a coloração branca, pois eram alvejadas e lavadas com maior frequência, na virada do século XIX para o XX, passaram, progressivamente, a ser coloridas (HELLER, 2013). Assim, essas peças claras foram dando lugar para peças em tonalidades 
pastel ou para listradas, por isso era possível encontrar na moda "um saiote azul, uma camisa verde, roupa íntima cor-de-rosa, enxugar-se com um guardanapo vermelho ou deitar-se sobre lençóis listrados" (PASTOUREAU, 2011, p. 190).

Nessa mesma época, uma outra cor volta a exercer um grande impacto no final do século XIX e início do século XX, o azul, proveniente do jeans. Apesar de originalmente não serem azuis, passaram, a partir de 1860 e 1865, a ser confeccionados com um tecido diferente da sarja, o denim, feito de algodão, mais maleável e tingido com índigo (PASTOUREAU, 2016). Assim, em uma vasta gama de azuis, o jeans, além de ter confrontado diretamente o preto tão prestigiado, atingiu várias classes econômicas, contribuindo para elevar os tons azulados sobre todas as outras cores no vestuário ocidental (PASTOUREAU, 2016).

O fenômeno do azul acentuou-se a partir da década de 1920, principalmente nas cidades grandes, com a recente e gloriosa moda dos tecidos disponíveis nessa coloração. Mas esses tecidos azuis passaram a ser comercializados não só para jeans ou até mesmo para uniformes, onde muitas pessoas substituíram os tons de seus trajes, casacos ou calças anteriormente pretas para adaptar aos trajes azul.

Algumas peças tiveram maior impacto, mas foi no "blazer, e continua a ser, o sinal mais evidente desta revolução que, seguramente, ficará para a história como um dos grandes acontecimentos da moda do século XX: a transformação do preto em azul-marinho" (PASTOUREAU, 2016, p.180). Deste modo, em um período entre as duas grandes guerras mundiais, o azul viu crescer, cada vez mais, seu prestígio e afeição ao ser utilizado por todas as classes sociais.

Nos dias de hoje, observa-se que essa coloração é dominante, independentemente do sexo, cultura, origem, profissão e até de relação econômica, sendo uma das nuances mais usadas na moda (HELLER, 2013). Isso muito se deve ao fato de ser considerada uma cor democrática nas sociedades contemporâneas em que os jeans se tornaram direito de todas as classes. Da alta costura aos trajes do dia a dia, das passarelas à moda das ruas, o uso do azul tem o seu aceite e destaque.

Todavia, o uso constante do preto no vestuário continuou. Isso foi possível aliado ao trabalho dos estilistas, designers, alfaiates e costureiros que, desde o final do século XIX e ao longo de quase todo o século $\mathrm{XX}$, fizeram uso desse tom, reafirmando o seu poder. Segundo Pastoureau (2011, p. 187): 
O preto do design não é o preto principesco e luxuoso dos séculos precedentes, nem o preto sujo e miserável das grandes cidades industriais; é um preto ao mesmo tempo sóbrio e refinado, elegante e funcional, alegre e luminoso; em suma, é um preto moderno. Ainda que a história das relações entre o design e as cores tenha sido quase sempre constituída de encontros fracassados (pensamos nas feias tonalidades pastel dos anos 1950 ou nas vulgaridades cromáticas dos anos 1970), a relação do design com o preto foi perfeitamente bem-sucedida. Para muitos criadores e para uma boa parte do público, o preto tornou-se mesmo, com o passar dos decênios, a cor emblemática do design e da modernidade.

Assim, a chegada do século XX, com a Primeira Guerra Mundial, o preto regia o mundo do trabalho e visava a garantir respeitabilidade e austeridade. Dessa forma, para quem trabalhava em bancos, nos gabinetes ministeriais e de função pública, em escritórios administrativos e locais comerciais, o preto foi a cor mais emblemática, sendo evitadas cores vivas ou muito chamativas.

O prestídio da coloração cresceu tanto que, em 1926, Gabrielle "Coco" Chanel, criou o icônico "tubinho preto" cujo emblema que o simboliza existe até hoje de forma sensível e ao mesmo tempo irreverente (HELLER, 2013).

Outro fato que colaborou para a hegemonia do preto foi a grande procura por parte dos consumidores. Por ser a cor mais cobiçada e desejada, o mercado se curvou a essa procura, por isso em quase toda coleção houve (e ainda há) artigos nesse tom, atendendo, assim, aos anseios e expectativas dos clientes. Segundo Fraser (2007), mais de dois terços das roupas vendidas no Reino Unido e nos Estados Unidos em 2003 eram pretas.

Esse tom também se faz presente com grande impacto nas profissões que faziam uso de uniformes, como policiais, guardas, bombeiros, carteiros e marinheiros, os quais, até as primeiras décadas do século XX, usaram essa cor. Porém, com o passar dos anos, o azulmarinho ou o cinza, menos severos e impositivos, substituíram essa tonalidade negra (PASTOUREAU, 2016).

Contudo, mesmo tendo observado a ascensão do azul causado pelo jeans e pelo azulmarinho, para a sociedade atual, o preto pode representar a elegância, a modernidade e a moda. Dessa forma, essa opção cromática é uma tendência que quase não mostra sinais de enfraquecimento. Essa questão adentrou o século XXI, por isso esse tom impera quando o assunto é moda nos trajes, indo desde o rebelde e transgressivo ao luxuoso e moderno (BLASZCZYK; WUBS, 2018). Por um lado, conferiu identidade, delimitando grupos que querem destacar-se, como os beatniks, os roqueiros, os góticos e os punks. Por outro lado, desde o século XX, fraques, gravatas borboletas, smoking e o célebre "pretinho básico" são sinônimos da sofisticação e do refinamento (HELLER, 2013). 
Essa cor ainda é usada em grande proporção se comparada a qualquer outra nos dias de hoje, quando, mesmo nem sempre sendo tendência, se tornou uma opção segura e confortável, por isso perdura na moda. Devido a isso, é comum ouvir depoimentos de pessoas dizendo que vestem preto porque é mais fácil de combinar com as outras peças disponíveis no próprio guarda-roupa ou mesmo encontrar peças no mercado para compor o visual (CAYGILL, 1980).

Um dos motivos que garantem a soberania dessa tonalidade dentro desse universo é que, segundo Heller (2013, p. 143),

Cada vez mais mulheres clamavam por cores que resistissem ao tempo - e
nenhuma cor resiste mais ao tempo do que o preto. O mercado da moda
teve que se curvar aos desejos de suas clientes: desde 1980, o preto tem
prevalecido nas coleções de todos os grandes desenhistas da moda. Aliás,
modelos em outras cores também são lançados, mas não é segredo para
ninguém: os que vendem mesmo são os pretos. (...) Assim o preto, como
cor de fato, não depende da moda, se tornou também a principal cor... do
que está na moda.

Já a moda destinada ao público infantil, ainda no século $\mathrm{XX}$, ganhou cores que se tornaram acessíveis às mais diversas camadas sociais. Um dos motivos foi não ser mais necessário nem ferver, nem alvejar os tecidos para ficarem limpos. Com isso, o Ocidente viu surgir um conceito nunca antes visto na História do vestuário: o rosa passou a ser a cor destinada ao sexo feminino, ao passo que azul-claro a cor mais adequada ao sexo masculino. Segundo Heller (2013, p.216):

E foi só com a moda colorida para os bebês que o rosa se tornou uma cor feminina. Para essa transformação existem duas causas: quando todos os vermelhos desapareceram dos uniformes militares, após a Primeira Guerra Mundial, o vermelho desapareceu também da moda masculina civil - e com isso também passou a parecer ilógico usar o cor-de-rosa para meninos. Nessa época se produziu uma verdadeira revolução na moda: a chamada "moda reformista" liberou as mulheres dos corpetes e criou uma moda específica para as crianças. Antes, os meninos vestiam cópias em miniatura dos trajes dos adultos. Agora, tanto meninos quanto meninas passariam a vestir roupas confortáveis e os vestidos de marinheiro - tingidos com um índigo artificial, a nova tinta, a melhor de todas. Dos trajes de marinheiro se derivou, com uma lógica quase que forçosa, o fato de que o azul-claro, ou o azul em geral, se convertesse em cor dos meninos. Como cor tradicionalmente contrária, o rosa passou a ser então a cor das meninas.

Pouco a pouco, os velhos códigos de vestuário, que se fizeram presentes desde os primórdios, também libertaram os corpos de todas as restrições e tabus, incluindo os 
cromáticos. Segundo Heller, "por volta de 1950, iniciou-se um processo que alterou a moda de maneira fundamental: com o advento das fibras sintéticas, das cores sintéticas e da produção industrial em massa, as roupas foram tornando-se cada vez mais baratas". (HELLER, 2013, p. 143).

Hoje, qualquer pessoa pode vestir-se de vermelho, preto, cinza, violeta etc, independentemente da idade, classe econômica, profissão ou círculo social. Observa-se que, somente em algumas circunstâncias muito particulares, como festas tradicionais e comemorativas, pode ser evitado usar alguma cor.

Contudo, quanto à busca pela identidade e personalidade relacionada às cores, faz-se necessário se perguntar, no entanto, se a pessoa, ao usar qualquer cor, por exemplo, está "vestindo" a nuance de forma consciente, confortável e feliz, ou simplesmente está carimbando um conceito pré-estabelecido por medo de errar ou por insegurança.

\subsubsection{A cor na maquiagem}

Pintar o rosto e o corpo é uma prática existente em muitas sociedades por várias maneiras e por milhares de anos. As primeiras pinturas faciais e corporais teriam sido uma forma de proteção usadas como camuflagem antes de as pessoas irem para a batalha ou poderiam ser parte de um rito tribal. Desde povos aborígenes até as primeiras civilizações da Mesopotâmia e Egito Antigo, eram usados ingredientes naturais para adornar e embelezar, sugerindo que se pintar fazia parte da natureza humana tanto quanto a necessidade de oxigênio, água, alimento e repouso (PIPER, 2008).

Os estudos do antropólogo Andrew Strathern, como descreveu Lisa Eldridge (STRATHERN apud ELDRIDGE, 2015) demonstram como essa forma de expressão pode ser um exercício sério e uma fonte de linguagem e comunicação. Tais estudos versaram sobre a mentalidade tribal e a necessidade de pertencimento, mostrando rituais incríveis que elaboram pinturms faciais e corporais de vários grupos. Seus desenhos marcam o status masculino em comparação com o feminino, além do embelezamento superficial, o adorno, a forma, a atração sexual e a identidade de grupo.

Essa necessidade de identidade e pertencimento a uma tribo fica evidente no uso de maquiagem. Ademais, esse instinto de ter a melhor aparência pode ser impulsionado pelos 
instintos primários de reprodução (PIPER, 20008). Nesse sentido, como afirma Pastoureau (2019, p. 18):

\begin{abstract}
o amarelo foi uma das primeiras cores que o homem produziu para pintar, primeiro no próprio corpo; em seguida, tons, pedras e vários objetos pessoais; e finalmente na parede das cavernas. Não sabemos nada sobre as primeiras pinturas corporais. No máximo podemos arriscar a hipótese de que tinham base de solo argiloso e serviam de proteção contra o sol, doenças, insetos e até forças do mal. Mas, sem dúvida, eles também tinham uma função taxonômica: distinguir grupos ou clãs, estabelecer hierarquias, marcar pontos no tempo ou rituais, e diferenciar gênero (ocre vermelho para homens, cor amarela para mulheres?), grupos de idade. No entanto, isso tudo é conjectura.
\end{abstract}

Com o passar do tempo, a pintura corporal foi deixando de se fazer tão presente, permanecendo a facial decorativa. Assim, a tendência predominante foi pintar o rosto passando o branco proveniente do giz e ceruse, as maçãs do rosto e os lábios obtido através da cochonilha, garança, ocre e cinabre e nos cílios e ao redor dos olhos, com o preto que era proveniente das cinzas, carvões e pó de antimônio (ELDRIDGE, 2015). Isso evidencia que branquear a pele, avermelhar as maçãs e lábios do rosto e escurecer o contorno do olhar, desde os muitos períodos históricos que se sucederam, enfatizou a tríade cromática por excelência composta pelo branco-vermelho-preto.

Junto a essa tríade, os egípcios, cujas pinturas faciais e cosméticos datam de 6.000 a.C. aproximadamente, tinham por costume usar a malaquita para dar às suas pálpebras um brilho verde iridescente, mas esses primeiros exemplos não continuaram. Assim, uma sombra de olho colorida saiu de moda por quase dois mil anos, permanecendo o contorno nos cílios e ao redor dos olhos (CHASE, 1979).

Nessa civilização, as mulheres foram as primeiras a usar maquiagem, sendo também uma das mais experimentais como se observa na figura 86, que traz o ideal de beleza, representado por Nefertiti, com as bochechas marcadas, os olhos acentuados, as sobrancelhas arqueadas e a boca realçada. 
FIGURA 86: Nefertiti, aproximadamente 1340 a.C.

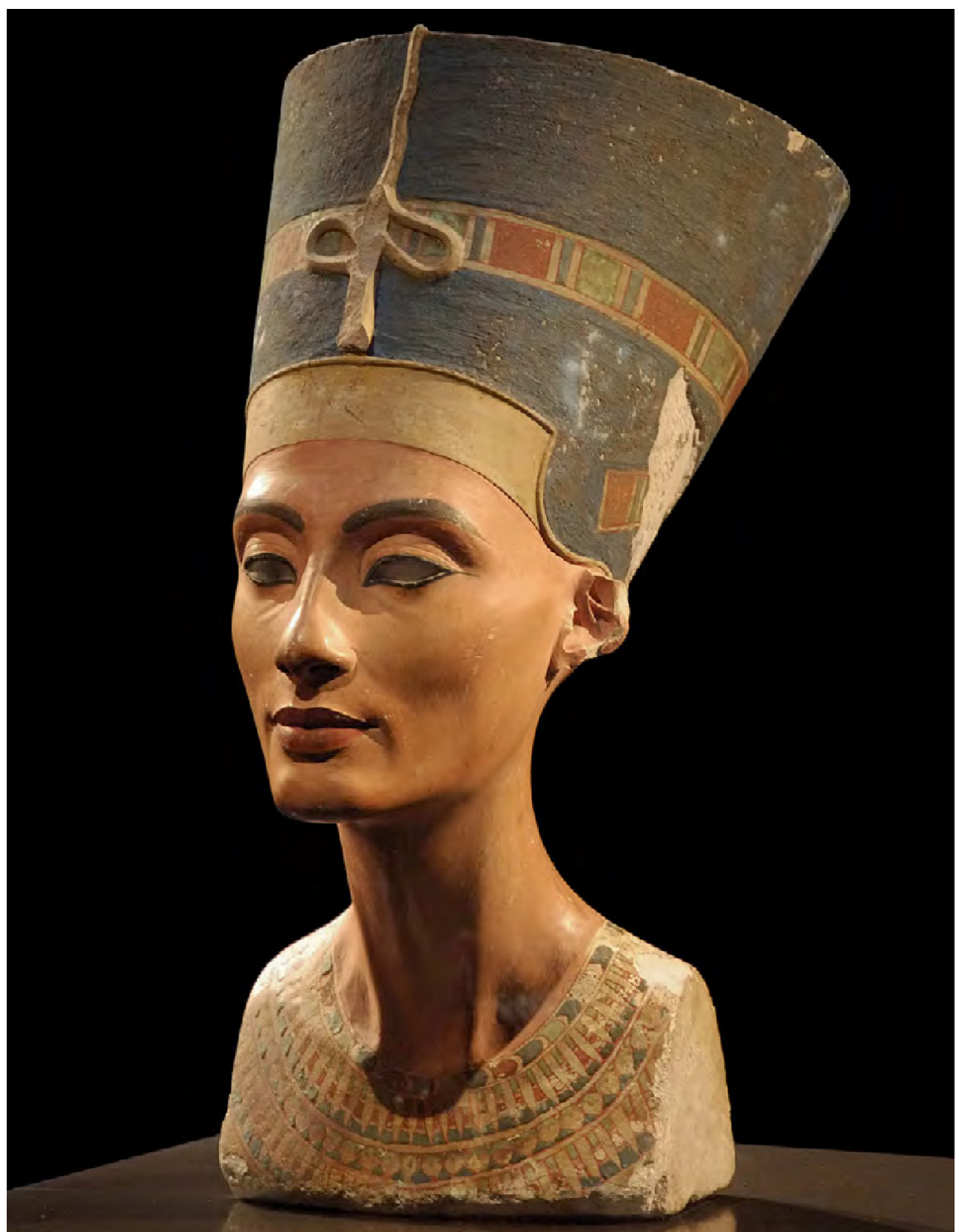

Fonte: WIKIPEDIA, https://pt.wikipedia.org/wiki/Busto_de_Nefertiti.

Esse fato não permaneceu o mesmo para as sociedades posteriores, que não se mostraram tão abertas quanto ao uso desses adornos, embora o que é considerado belo varie entre uma cultura e outra e entre diferentes períodos de tempo (PASTOUREAU, 2011).

De maneira geral, os egípcios eram excelentes químicos e adoravam maquiagem. Eles misturavam alguns ingredientes para preparar cosméticos, desde hidratantes, kohl, rouge para lábios e bochechas até cores para as unhas. Essas misturas eram feitas de uma variedade de substâncias naturais e eram preparadas em uma tijela, prato ou colher, 
acrescentando algum óleo animal ou vegetal para transformar a textura e permanecer firme e duradora (PIPER, 2008). Eles davam tanto valor a esses ornamentos faciais que as descobertas arqueológicas encontraram, entre os primeiros enterros, objetos que se assemelham a paletas de maquiagem, moedores e aplicadores, sugerindo que não eram apenas essenciais à vida diária, mas também valorizados na vida após a morte (ELDRIDGE, 2015).

Juntamente com as descobertas arqueológicas, as referências às práticas de maquiagem na arte e na literatura permitiram reunir uma boa compreensão de tais práticas ao longo da história. Ou seja, evidencia-se quais cores de pintura estavam disponíveis e eram populares, como eram feitas e, principalmente, o que foi pensado e dito sobre as pessoas que se pintavam (JACKSON, 1984).

Já para os romanos, apesar da frequente desconfiança e censura aos cosméticos, eles continuaram a fazer parte da vida diária e estavam amplamente disponíveis. Havia uma enorme variedade de recipientes, alguns feitos com embalagens básicas e baratas, como madeira e vidro, destinadas às classes mais baixas, até recipientes mais ornamentados, feitos de metais preciosos, que teriam pertencido às classes ricas e nobres. Esse fato sugere que a maquiagem não era um luxo e foi usada por muitos, ricos ou pobres (PASTOUREAU, 2017).

A quantidade de anedotas e representações da maquiagem na literatura, arte e escultura romanas também proporciona uma visão da vida diária e dos papéis sociais das mulheres nessa sociedade. No entanto, observa-se que, assim como na Grécia antiga, as atitudes masculinas em relação à maquiagem, diferente da sociedade egípcia, parecem ter sido contrárias a essa, pois eram vistas como algo para criticar ou satirizar. Ao lado disso, as mulheres romanas que usavam rouge para colorir o rosto e, em menor medida, os lábios o fizeram de forma moderada (ELDRIDGE, 2015).

Devido a esse fato, os primeiros escritos cristãos criaram uma associação poderosa entre maquiagem e engano desde os primeiros tempos, a que São Cipriano, no século III, era adepto. Para ele, o ato de pintar o rosto e "manchar" as bochechas era "para expulsar toda a verdade, tanto do rosto quanto da cabeça, mas o ataque de sua própria corrupção" (ELDRIDGE, 2015, p. 23).

Nota-se que, entre as idas e vindas da relação que as sociedades foram estabelecendo com o uso de maquiagem, nem sempre sua aplicação foi criticada ou mal vista. Tanto que no século XII, uma coletânea de três livros, o Trotula, foi criada e enfocou a pintura facial e o tema da medicina feminina. Nessa coleção havia uma parte intitulada "Sobre Cosméticos 
Femininos" que salientava como preservar e realçar a beleza, além de uma ampla visão das tradições locais da época, como se nota nas figuras 87, 88 e 89 (ELDRIDGE, 2015).

FIGURA 87, FIGURA 88 e FIGURA 89: Trotula: coletânea de três livros com o foco voltado para maquiagem e em como preservar e aumentar a beleza.
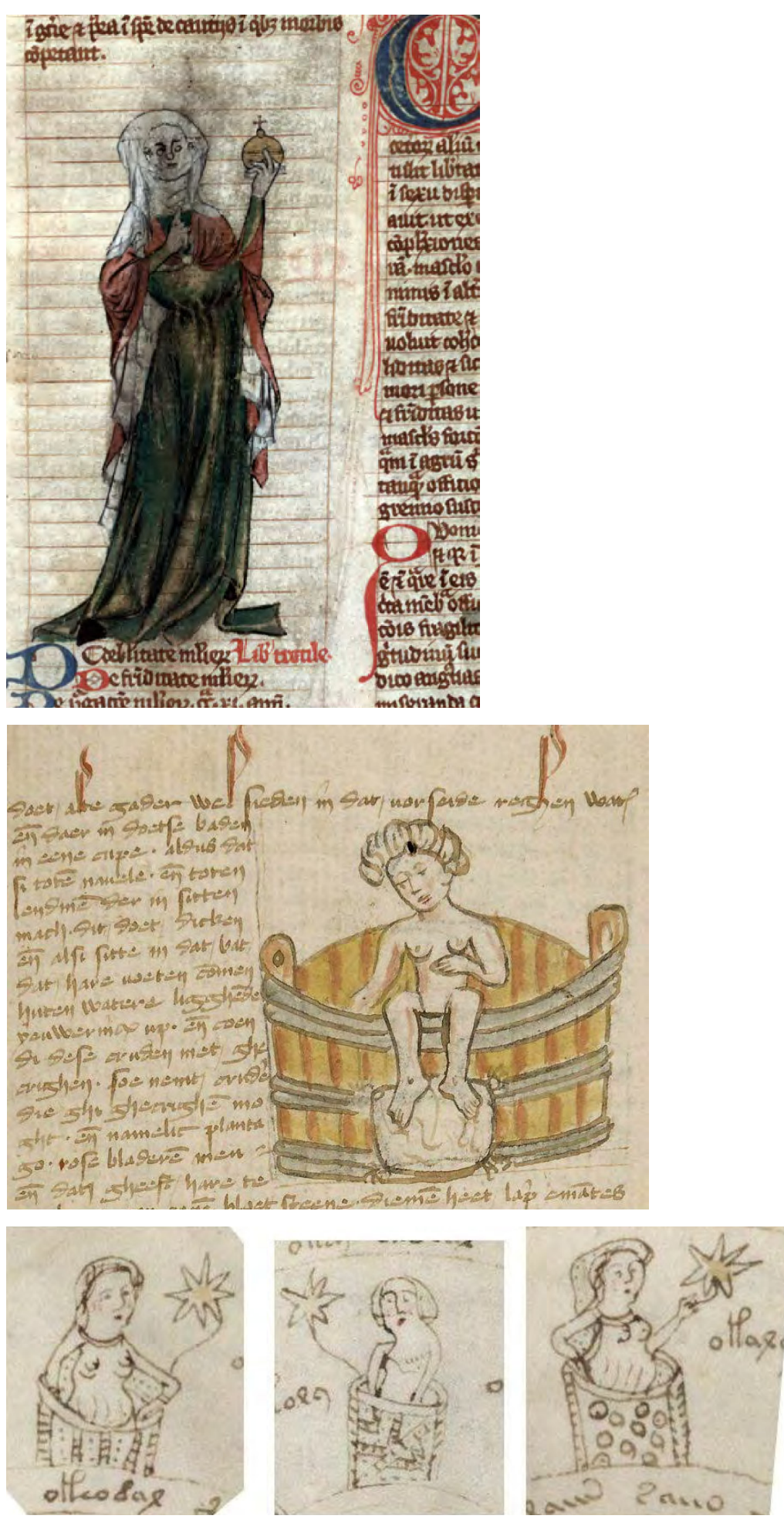

Fonte: WIKIPEDIA, https://en.wikipedia.org/wiki/Trotula 
Entretanto, como quase todos os aspectos da vida das mulheres foram monitorados e avaliados durante a História da humanidade, não é surpresa que para o uso de maquiagem tenha acontecido o mesmo. Houve períodos em que quem estava autorizada a usar maquiagem eram as hereges. Em outros momentos, o uso da maquiagem esteve associado às cortesãs, amantes profissionais e prostitutas, um padrão que se repetiu ao longo dos tempos (JACKSON, 1984).

Durante a Renascença (XIV-XVI), veio a difusão da ideia de que, ao usarem esses adornos, as pessoas criavam uma "falsa cara" (PASTOUREAU, 2017). Essa mesma mensagem pode ser vista nos escritos de Shakespeare, quando Hamlet diz a Ofélia: "Também ouvi falar de sua pintura, muito bem; Deus te deu uma face e vocês se fizeram outra" (ELDRIDGE, 2015, p. 30).

Não é surpreendente que, na sequência, devido à Reforma Protestante no século XVI, o uso de pintura facial tornou-se mais discreto, moderado e, por vezes, proibido. Essas medidas continuaram no século XVII, devido às posturas religiosas e moralistas, pronunciada nas palavras de São Cipriano para quem a pintura facial revelava uma falsidade, uma alteração da autenticidade (ELDRIDGE, 2015).

Nesse mesmo período, porém, viu-se emergir, em direção contrária aos ataques feitos ao uso desse cosmético pela Reforma Protestante, a "cultura da beleza", como afirma Eldridge (2015, p. 94):

houve uma onda de impressão de mulheres em que os cosméticos foram fortemente defendidos. Na Inglaterra, ao lado de The Gentlewoman's Companion (1673), houve também A Discourse of Auxilitary Beauty (1656), que argumentou que: "Nem é o rosto mais para ser considerado, ou negligenciado, do que outras partes do corpo". Da mesma forma, The Ladies Dictionary (1694) argumentou que a maquiagem não tinha como objetivo enganar ou disfarçar, mas servir a um propósito útil. A utilidade foi posteriormente debatida em Várias Cartas Entre Duas Senhoras, em que a Legalidade e a Ilegalidade da Beleza Artificial no Ponto de Consciência São Bem Debatidas (1701). Com a mudança das artes religiosas e moralistas, e uma audiência pronta, a cosmética começou a se afastar da noção de "um assalto à obra divina, uma distorção da verdade", nas palavras de São Cipriano. O que surgiu imediatamente, em grande parte da Europa, foi uma cultura da beleza.

Tanto que, no reinado de Louis XVI, na França (1774-1792), maquiagem e cosméticos foram usados com excesso. Homens e mulheres cobriam o rosto com chumbo branco e acentuavam os lábios e maçãs da face com produtos vermelhos à base de cinábrio. Essa prática tornou o uso de maquiagem cada vez mais associado ao embelezamento, status social 
e preservação da juventude. Um fato importante foi que, nessa fase, por volta do século XVIII, ela começou a ser intimamente associada à moda e não mais à distinção de classes (PASTOUREAU, 2017).

Esse fato veio ao encontro da distinção de raças, trabalho publicado também nesse século XVIII, pelo médico e antropólogo alemão Johann Friedrich Blumenbach (17521840), como conta Pastoureau (2019), autor de vários tratados sobre anatomia e história natural. Blumenbach formulou uma obra sobre a humanidade e a diversidade das "raças", publicada em 1795. Segundo Pastoureau (2019, p. 184):

\begin{abstract}
Mesmo enquanto proclamava firmemente a unidade da espécie humana, Blumenbach distinguiu cinco raças (variedades) de acordo com a cor da pele: Etíope (preta), Caucasiana (branca), Mongol (amarela), Malaia (marrom) e Amerindian (vermelha). No entanto, ele reconheceu que essas diferentes cores de pele formavam um continuum cromático e que existiam numerosos tons intermediários, difíceis de classificar. Além disso, ele não postulou nenhuma teoria racista ou racial, no sentido em que entendemos essas palavras hoje. A ideia da superioridade da raça sobre uma ou muitas outras era estranha para ele, e a explicação que ele propôs para entender as diferenças na cor da pele e no tipo físico era de natureza geográfica e climática: quanto mais se vivia em um país com clima quente e seco, quanto mais escura era a pele. Nada muito novo, pois tais explicações já podem ser encontradas entre autores da antiguidade e da Idade Média. Sua originalidade consistia apenas em tornar a cor da pele uma característica sujeita a mudanças. Blumenbach lembrou com propriedade que, na Grécia antiga, a palavra que designava cor, khrõma, tinha sua origem etimológica na ideia de pele. Caso contrário, Blumenbach apoiou a teoria da monogênese (todos os humanos descendem de um único ancestral) e enfatizou a existência de uma fronteira absolutamente impermeável entre a espécie humana e os animais, mesmo aqueles considerados "superiores".
\end{abstract}

Assim, na primeira metade do século XIX, muitas línguas começaram a usar as expressões "raça branca", "raça negra" e "raça amarela" com bastante frequência. No entanto, as teorias raciais surgiram daí em diante e mancharam essas palavras com conotações mais ou menos pejorativas. Mas vale dizer que, o racismo, que é fruto do colonialismo e do capitalismo, é anterior aos conceitos proposto por Blumenbach.

Com as novas ordens sociais e políticas colocadas pela Revolução Francesa (1789 1799), um novo estilo mais sutil se fez presente, diferente do que estava acontecendo antes. Tanto que os homens passaram a não usar mais maquiagem e assim permaneceu nos séculos que se seguiram. Foi a partir desse momento que o mercado de cosméticos se concentrou prioritariamente nas consumidoras femininas (ELDRIDGE, 2015). 
Dessa forma, os cosméticos começaram a ser comercializados, no século XVIII, numa proporção bem mais ampla do que havia sido feito até então mais direcionados para o público feminino. Em muitos aspectos, a maquiagem tornou-se um dos itens mais democráticos entre todos os bens de "luxo", já que era possível produzir e vender a baixo custo, ao contrário de outros artigos (ELDRIDGE, 2015).

No entanto, a chegada do século XIX marcou mais uma mudança nas atitudes em relação à pintura facial. A declaração da rainha Victoria da Inglaterra, que reinou de 1837 1901, ao condenar o uso excessivo de maquiagem, atribuindo a ela uma qualidade de vulgarizar quem dela fizesse uso, significou a preferência por um visual pálido e virtuoso como sendo o preferido e o mais adequado (HELLER, 2013).

Isso contribuiu para que o uso excessivo de maquiagem fosse desaparecendo gradativamente e deu lugar a práticas "mais sutis e restritas, de acordo com a nova iluminação e os novos códigos sociais. Somente aquelas mulheres que fizeram uma profissão de devassidão ou desejaram criar uma cena continuaram pintando seus rostos e usando demais de vermelho" (PASTOUREAU, 2017, p.157).

À medida que o século XIX chegava ao fim, começaram a surgir no mundo da maquiagem algumas transformações. Nesse período, os cosméticos nos Estados Unidos e no resto da Europa, apesar de estarem sendo comercializados em maior proporção, ainda não eram produzidos em escala. Porém, um grupo de figuras-chave surgiu dentro desse universo, sendo eles os pioneiros a criarem a moderna indústria de cosméticos como é conhecida hoje.

Durante a Primeira Guerra Mundial, as mulheres começaram a ganhar seu próprio dinheiro e, com isso, tinham renda disponível para comprar seus produtos de beleza (KNAPP, R; DORR, D, 1985). "Democratizadas e empoderadas, as jovens usavam maquiagem para se expressar e se diferenciar de sua mãe e avó, para quem a maquiagem era rejeitada” (ELDRIDGE, 2015, p. 122).

Nesse mesmo período, a recém-criada indústria cinematográfica de Hollywood ajudou a alavancar a comercialização de cosméticos. O teatro e o ballet também desempenharam um papel importante na introdução da ideia dos olhos coloridos, embora a fotografia, filmes, revistas de cinema e anúncios fossem principalmente feitos em branco e preto até o final da década de 20, o que retardou a adesão às sombras coloridas.

Outro fator que colaborou para o fascínio pelos rostos pintados foi a descoberta, em 1923, da tumba de Tutancâmon, que suscitou o encantamento por todas as coisas antigas e exóticas. Nesse momento, as mulheres estavam começando a se sentir confortáveis à medida 
que usavam mais maquiagem e mais cores, sem ter que lidar com a desaprovação social. Segundo Eldridge (2015, p. 101):

Em 1929, a Vogue francesa estava anunciando o batom "Rouge Camelon",
e na Vogue norte-americana, Helena Rubisntein estava aplaudindo a
"mágica que reside na maquiagem" e anunciando seu Batom Cubista e
Vermelho Raspberry Rouge. (Rubinstein começou a anunciar rouge e
batom nos Estados Unidos no início de 1923, muito mais cedo do que no
Reino Unido, onde os anúncios de sua empresa ainda eram fortemente anti-
cosméticos). "A Defense of Rouge", o primeiro filme de maquiagem
profissional da Vogue do Reino Unido, não apareceu até julho de 1924 .

Depois da Segunda Guerra Mundial, esse mercado se fortaleceu ainda mais. O nascimento da TV entre 1936 e 1941 forneceu uma plataforma nova e empolgante para a publicidade da beleza, introduzindo novos produtos diretamente em milhões de lares. $\mathrm{O}$ mercado global nesse setor estava crescendo, atingindo seu apogeu na década de 1950. No entanto, nos anos 60 e 70, as revoluções feministas que se sucederam alteraram e por vezes até mesmo lançaram um novo olhar sobre o papel da mulher e sua necessidade de beleza (BLASZCZYK; WUBS, 2018).

Essa nova conduta, porém, não fez com que esse mercado parasse de prosperar, por isso, desde então, a tecnologia por trás desses cosméticos se desenvolveu, o que melhorou e aumentou consideravelmente a qualidade, durabilidade e oferta de cores. Como afirma Eldridge (2015, p. 227):

Nos dias de hoje, usar cor na maquiagem pode ser visto como uma opção onde "a maquiagem não pode mais ser vista como um extra opcional, mas sim como um processo central de identificação que pode oferecer significados como prazer e expressão criativa". O fato de termos opções parece uma visão mais realista, como resume Slater: "maquiagem é o que você faz dela. É uma escolha”.

A infinidade de produtos à disposição de todos os gostos e poder aquisitivo impulsionou a indústria de produtos de beleza, tornando-a multibilionária. Faz-se mister ressaltar que esse mercado propôs uma inversão de valores. Isso porque, no passado, as tendências de maquiagem teriam impulsionado o desenvolvimento de novas tecnologias. Hoje em dia, porém, as tendências são conduzidas em grande parte pela tecnologia, além de uma grande quantidade de dinheiro que é gasta para investir em novos caminhos (BLASZCZYK; WUBS, 2018). 


\subsubsection{1 $O$ ato de branquear a pele e as idas e vindas do bronzeamento}

$\mathrm{O}$ ato de iluminar a tez, mesmo entre culturas distintas e sem o menor conhecimento de uma sobre a outra, como a grega e a chinesa, por exemplo, era obter uma pele pálida, clara. Tanto que, por muito tempo, colocar uma sanguessuga atrás da orelha a fim de sugar o sangue e deixar a pessoa desvanecida foi uma prática que existiu dentro de muitas sociedades, como conta a História (PIPER, 2008). Para tanto, uma forma mais comum de atingir esse ideal amplo e transcultural de beleza era usando ingredientes à base de chumbo nos cosméticos, o que servia para clareamento da pele.

A pele pálida e translúcida podia ser obtida por meio de uma variedade de cremes, pomadas e cosméticos destinados a iluminar e uniformizar a aparência, embora fosse um método muito perigoso, agredindo tanto a cútis como a saúde em geral. Eles também eram altamente tóxicos, pois o ceruse era feito combinando chumbo e vinagre forte, que era deixado para macerar até formar uma película. Esse procedimento era repetido inúmeras vezes para que o chumbo se transformasse em pó, e esse pó aplicado na cútis (PASTOUREAU, 2014).

Ao longo do tempo, contudo, essa substância fazia com que a pele parecesse envelhecida e murcha, provocando o efeito oposto ao desejado. Mesmo apresentando todos esses fatores que não beneficiavam a longo prazo a qualidade da pele, as pessoas continuavam usando esses produtos, pois ter a tez alva era considerado um sinal de excelente saúde e boa educação. Especificamente para as mulheres, era um indício de juventude, fertilidade e virtude, como representado pela figura 90. 
FIGURA 90: Pele pálida e translúcida era desejada por muitas mulheres, pois conotava o sentido da juventude, fertilidade e virtude.

Portrait of a Lady, Rogier Van der Weyden, 1460, Washington, National Gallery of Arts, óleo sobre madeira.

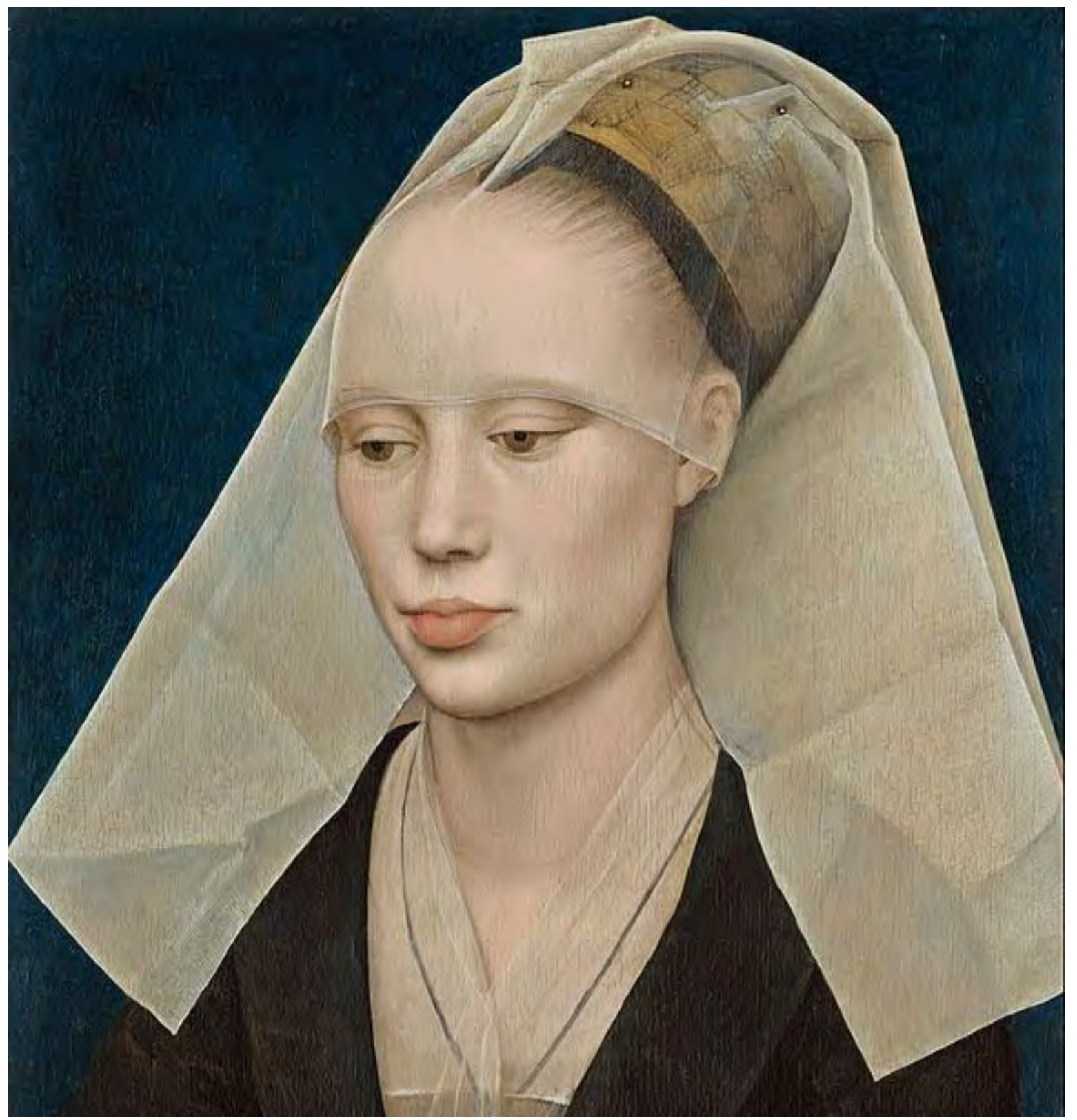

Fonte: ELDRIDGE, 2015, p. 39. 
Outra forma menos prejudicial à saúde de obter a pele pálida era por meio do pó de arroz ou do pó de pérolas, datado aproximadamente de 320 d.C. Esses métodos foram encontrados no Leste Asiático, China e Japão, que foram uma das primeiras civilizações a se esforçar para realçar a palidez. O uso "dos primeiros clareadores de pele registrados foi o pó de arroz, uma substância inofensiva feita pela moagem fina do grão em farelo de arroz e usado cosmeticamente pelos chineses e japoneses". (ELDRIDGE, 2015, p. 45)

Já o pó de pérola era feito a partir de pérolas esmagadas. Originalmente, seu uso era destinado ao tratamento de uma variedade de doenças pela medicina oriental chinesa. Depois passou a ser usado antes como um branqueador de pele e empregado de forma embelezadora.

Com o passar do tempo, quando o Império Romano se tornou oficialmente cristão no século IV, em 380 d.C., com o decreto do imperador bizantino Teodósio I, uma nova moralidade se espalhou por todos os aspectos da vida diária. A partir de então, o branqueamento passou a ser considerado algo extravagante e vulgar. Ademais, a percepção da cor durante esse período era outro, em um mundo onde a fonte de luz artificial também era distinta (PASTOUREAU, 2011).

Desse modo, durante a Idade Média (séculos V a XV), a pele branqueada passou a ser considerada desagradável pela simples razão de que usar maquiagem sugeria que a criação de Deus não era boa o suficiente em seu estado original e que a vaidade desejava melhorá-la (ELDRIDGE, 2015).

Entretanto, embora os médicos alertassem as mulheres sobre o perigo de alguns ingredientes, e a Igreja considerasse os cosméticos como sendo uma obra do diabo, as mulheres continuaram a aspirar ao branco virginal. Aplicavam ceruse letal como base para o rosto e decote, com alguns efeitos colaterais bastante desagradáveis (ELDRIDGE, 2015).

Sendo assim, mesmo sendo vista por uma parte da sociedade como algo inapropriado, o esforço para manter a pele clara continuou durante a Idade Média por uma boa parcela da sociedade. Nesse sentido, embora o uso de outros cosméticos fosse moderado durante esse tempo, continuava a ser desejável ter uma pele sem manchas e protegida do sol. Portanto, por toda a Europa, da Idade das Trevas (Idade Média) à Idade do Ouro (Renascimento), a pele branca como a neve continuou a ser o epítome da harmonia e da perfeição (PASTOUREAU, 2011).

Durante o Renascimento (século XIV a XVI), as ideias sobre beleza eram rígidas, e o uso de cosméticos eram ainda menos flexíveis. Por esse motivo, pintar o rosto foi considerado uma atitude quase inaceitável, mas, caso fosse feito, deveria ser indiscernível, já 
que as pessoas não tinham a opção de se expressar por meio dessa prática. No entanto, como a noção de algo etéreo estava em alta, os renascentistas experimentavam várias misturas para dar à pele a luminosidade desejável associada à beleza virginal (PASTOUREAU, 2011).

Outro fato que se pode observar é que, segundo Lisa Eldridge (2015, p. 54):

\begin{abstract}
as mulheres que usam ceruse como se tornando rapidamente "murchas e com cabelos grisalhos". Não é uma aparência desejável ou pretendida. E pode ter havido outros efeitos colaterais: a moda das testas altas nessa época poderia muito bem ser devido ao fato de que a tinta com chumbo causava queda de cabelo e manchas. As mulheres podem ter sido forçadas a arrancar as manchas desagradáveis restantes, fazendo com que a linha do cabelo se mova gradualmente para trás. Apesar de numerosas desvantagens, por volta de 1685, a maioria das mulheres (e homens) européias aristocráticas estavam fazendo camadas na pintura facial de branco.
\end{abstract}

Em parte, a razão para isso era que, novamente, palidez ainda era sinônimo de status social elevado, enquanto pele castigada pelo tempo ou bronzeada significava alguém que era forçado a trabalhar ao ar livre e, portanto, pertencente às classes mais baixas.

Tanto que a busca pelo "sangue azul" almejado pela aristocracia era para distinguir-se dos camponeses e da pequena nobreza rural, assumindo uma aparência lunar, com veias aparecendo na testa e nas têmporas. Naquele período, a pele com uma palidez azulada deixava evidência de pureza racial e nobreza antiga, o que parece ter atingido seu auge por volta de 1750 (PASTOUREAU, 2016). Assim, uma espessa camada de ceruse era aplicada para esconder todas as imperfeições da pele e pecados do envelhecimento (PASTOUREAU, 2011).

A toxicidade do chumbo branco em ceruse estava começando a ser reconhecida naquele momento, mas a preocupação com as aparências superava os riscos. Era aplicado como creme ou pó com o objetivo de ter o rosto e pescoço mais claro possível para não ser confundido com um camponês, cuja pele estava necessariamente bronzeada ou avermelhada.

Para esse ideal de rosto lunar, muitas vezes foi aplicado ceruse à base de arsênico que, embora ainda muito tóxico, o arsênico em doses baixas tinha o poder de clarear a pele a ponto de aparecerem as veias acentuando esse ideal de superioridade (HELLER, 2013). Outro recurso também utilizado foi a maquiagem azul clara para enfatizar as veias visíveis através da pele na testa e nas têmporas.

Nada foi mais enobrecedor ou melhorador de status na segunda metade do século XVII, com a Revolução Inglesa (1642-1651) e, no século XVIII, com a Revolução Francesa 
(1789-1799), do que o uso de chumbo branco e pastilhas de arsênico (ELDRIDGE, 2015). Essa foi uma prática frequente, mesmo as pessoas correndo o risco de enfrentar alguns problemas de saúde como resultado do uso dessas substâncias.

Já no início do século XIX, a tez pintada como porcelana foi finalmente atenuada. No entanto, continuou a ser o objetivo final da beleza, por motivos de classe e posição social, pois esperava-se que mulheres castas e respeitáveis protegessem sua pele fina dos raios solares.

Naquele momento, como estavam em alta maquiagens mais discretas e até indetectáveis, as mulheres procuravam ter uma pele perfeita quando produtos tópicos para clarear a pele e pastilhas ingeríveis se tornaram populares. Os clareadores de pele foram substituídos por pó de óxido de zinco branco que dava a brancura necessária e parecia mais natural.

Outra substância usada foram os produtos à base de lavanda e tingidos de azul, que também se tornaram populares para uso noturno. Esses, por sua vez, conferiam ao rosto uma palidez incandescente e neutralizavam o brilho amarelo da luz de velas e lamparinas (CHASE, 1979).

Já no período vitoriano, apesar de a Rainha Victoria (1819-1901) condenar o uso de substâncias prejudiciais à saúde, o uso de branqueadores de pele e outros cosméticos estava tornando-se popular entre as mulheres de todas as classes. Do lado positivo, foram descobertos produtos menos danosos para obter uma pele clara (HELLER, 2013). Com isso, o aumento das revistas femininas fez com que as mulheres compartilhassem suas descobertas, tornando-se mais experientes sobre branqueadores prejudiciais, como chumbo e arsênico. A partir daí, começaram a usar o giz francês e o pó de magnésio alcançando um acabamento mais natural que, dificilmente, envenenaria o usuário (ELDRIDGE, 2015). No final do século XIX, como as atitudes estavam mudando rapidamente por parte da sociedade, a fabricação de cosméticos começou a ser um grande negócio (BLASZCZYK; WUBS, 2018).

Ademais, surgiram outros valores e comparações no que se refere à brancura da tez com algumas classes sociais nas quais, nessa época, o bronzeamento ganhou seu prestígio e pode ser separado em três períodos como relata a seguir Pastoureau (PASTOUREAU, 2011).

No primeiro período, compreendido pela primeira metade do século XIX, as pessoas pertencentes à aristocracia ou à "boa sociedade" deveriam ter a pele mais clara e a mais uniforme possível para não ser confundida com os camponeses. Estes últimos, que 
trabalhavam ao ar livre e sob o sol, tinham, com efeito, uma tez acobreada, a pele do rosto muito avermelhada, por vezes, pontilhada com manchas escuras. Ser bem-nascido significava, então, ter "o sangue azul", quer dizer, ter a pele tão pálida e translúcida que deixava perceber as veias.

Mas tudo isso muda na segunda metade do século XIX, ou seja, no segundo período, quando o essencial não era mais distinguir-se do camponês, e sim do operário, que trabalhava dentro ou debaixo da terra e tinha sua pele alva e pálida devido à falta de exposição aos raios solares. Com isso, mudaram-se os valores de uma parcela da sociedade, atingindo até a classe média com uma situação financeira favorável, que passaram a procurar, então, o sol, pois não queriam ser confundidos com os operários. Assim, o ideal de beleza passou a ser uma pele bronzeada como novo status social.

Essa pele bronzeada entra em declínio no terceiro período, ou seja, depois da Segunda Guerra Mundial, quando as férias na praia e na montanha, pouco a pouco, se democratizam por volta dos anos 1960-1970. Devido a isso, uma boa parte da sociedade começou a não desejar mais o bronzeamento, pois estar ao ar livre estava ao alcance de muitos. Além do mais, a multiplicação dos cânceres de pele e das doenças devidas à exposição voluntária ao sol.

Entretanto, mesmo havendo momentos em que a busca pela pele na cor bronze foi algo desejado tanto como ideal de beleza, como também devido à distinção de classes, a vontade de branquear a pele, como afirma Eldridge (2015, p. 57);

ainda é vista e sentida nos dias de hoje, percorrendo universos distantes, milhões de mulheres (e alguns homens) em toda a África, Oriente Médio e partes da Ásia estão mais uma vez usando produtos químicos prejudiciais para clarear a cor de sua pele, encorajando o clareamento cosmético da pele a atingir seu status antigo mais uma vez - um pensamento sóbrio.

Apesar de a cor da pele estar ligada à raça ou origem, como dito anteriormente, cada um com o seu tom, isso também está ligado ao gênero. Segundo Eldridge (2015, p. 40):

O tom da pele também é um significante de fertilidade, uma observação que a psicóloga evolucionista Nancy Etcoff ressalta, observando que a diferença no tom da pele entre meninos e meninas só na puberdade e que "depois disso as mulheres ficam mais claras durante a ovulação do que durante os dias inférteis do ciclo". Ela também observa que "o cabelo e a pele de uma mulher tendem a ficar permanentemente escurecidos após a primeira gravidez, mudando para sempre a tez feminina da juventude". A pele clara (mais clara) é, portanto, um símbolo da juventude e um significante do fato de que uma mulher não teve um filho, o que, por mais 
antiquado que possa parecer agora, é algo que foi tradicionalmente valorizado no passado.

Assim, independentemente da etnia, as mulheres, por questões fisiológicas e pela presença de certos hormônios, tendem a ser mais pálidas que os homens. Isso porque elas têm menos hemoglobina, que é o pigmento vermelho presente no sangue, e melanina, que é o pigmento marrom na pele e no cabelo em seu corpo (WRIGHT, 1999).

\subsubsection{O toque de cor vermelho}

Continuando com as cores da tríade cromática, como conta a história, rouge, como é conhecido, é o item de maquiagem mais antigo, eclético e curinga, usado para colorir lábios e bochechas há milhares de anos (ELDRIDGE, 2015). Embora o grau de uso do rouge varie ao longo da história, por vezes, usado de forma excessiva, com o vermelho para ornar a face em demasia e outras cores usadas de forma mais discreta, essas variações dependem da moda e da percepção social durante a época observada. De qualquer forma, o poder e a força do vermelho raramente diminuíram ou se alteraram na maquiagem (CAYGILL, 1980).

Um dos objetivos ao aplicar esse tom adicionando cor à pele era trazer a coloração do sangue e dar um toque de vida e da energia vital. Vale a pena observar que o fato de ter sido usado o vermelho, e não outra cor, se deu por dois motivos como relata Pastoureau (PASTOUREAU, 2017). O primeiro é que ele apresenta o maior comprimento de onda dentro do espectro visível, ou seja, é a frequência que chega primeiro para os seres humanos, com mais força e intensidade. Isso causa maior impacto e estimula uma resposta humana tanto em nível consciente como em nível subconsciente.

O segundo motivo é que essa coloração é a cor que recobre áreas como os lábios, os mamilos, os órgãos genitais, estimulando os sinais sexuais, a vontade e o desejo de procriação da espécie. Assim, por atrair a atenção do outro, comunica uma informação e desperta desejo, cumprindo, portanto, um papel evolutivo. Dessa forma, avermelhar as bochechas e os lábios contribuem para o aumento dessa energia, dessa potência e desse vigor.

Tanto que na Grécia antiga, no século IV a.C., as mulheres adotavam o rouge para adicionar um rubor juvenil aos lábios e bochechas, aplicando-o nas maçãs do rosto de 
maneira semelhante à maneira como se aplica o blush atualmente. Esse vermelho era obtido pela mistura à base de cochonilha, garança, ocre e cinabre. Segunda Eldridge (2015, p. 23):

\begin{abstract}
O rouge usado pelos gregos era feito de uma série de substâncias naturais, incluindo algas marinhas e paederos, uma raiz semelhante ao alkanet, cultivada em extraída com óleos e álcool de vinho. Mais tarde, um pigmento vermelho chamado vermelhão, criado a partir do mineral em pó cinabre, derivado do sulfeto de mercúrio vermelho, foi usado para criar um rubor, mas como com qualquer mercúrio um longo período. Embora a maquiagem fosse usada, qualquer coisa óbvia era amplamente desaprovada, especialmente pela elite masculina que acreditava que o principal papel da mulher na vida era ser virtuosa e ficar em casa e supervisionar seu funcionamento.
\end{abstract}

Nos primórdios, essa coloração era obtida através de um pigmento natural vermelho ocre misturado com óxido de ferro e algum tipo de gordura vegetal ou animal. Também poderia se feito misturando os pigmentos dessa coloração com cera e resina, dando às bochechas um brilho vermelho laqueado (PIPER, 2008).

É interessante notar que, durante os períodos mais longos da História, o uso leve e moderado de vermelho foi o padrão, enquanto durante outros períodos mais curtos, a aplicação excessiva e exagerada esteve em evidência. O oposto do uso delicado e contido desse rubor é a abordagem durante o século XVII, na Europa, quando a maquiagem pesada foi comum para uma parcela da sociedade, contrariando ao valores colocados pelos ideiais Renascentistas e pela Reforma Protestante. Ao que parece, nessa época, o uso de pintura facial excessiva se deu pelo desejo de mascarar quaisquer efeitos negativos que uma dama poderia ter.

Isso também se observa em meados do século XVIII que foi conhecido por ser um período em que a sobrecarga de rouge era comum. O ideal de beleza sugerido pelos retratos da época era a pele pálida com bochechas rosadas, semelhantes às do século XVI, e sobrancelhas escuras e definidas. A maneira extravagante com que o vermelho era usado era tão evidente que não havia como parecer natural (ELDRIDGE, 2015).

O que se sucedeu depois foi que, no Século das Luzes, até aproximadamente 1790, o vermelho era muito usado na maquiagem tanto por homens como por mulheres (PASTOUREAU, 2017). Eles cobriam o rosto com chumbo branco, assemelhando-se a estátuas de mármore antigas, e coloriam as bochechas e os lábios com produtos rubros. A moda da sociedade exigia que lábios e bochechas nunca fossem exibidos, por isso o artifício de usar vermelho foi a forma como as pessoas conseguiram se expressar. O objetivo era ter o rosto e o pescoço, também colo e ombros para as mulheres, mais pálidos possíveis. Isso se 
deu também pela necessidade de distinção social, já que as pessoas não queriam ser confundidas com um camponês que, por viver mais exposto ao sol, tinha a pele bronzeada ou avermelhada (ELDRIDGE, 2015).

Assim, nessa época, os homens aristocráticos assim como as crianças também usavam rouge (PASTOUREAU, 2017). Tratava-se de um tom que podia ser manipulado tanto de forma caseira e artesanalmente como comprado em certos estabelecimentos. Era usado tanto pela classe média, de forma mais moderada, e pela aristocracia, de forma mais exagerada. Como no final do século XVIII, havia um grande número de variedades disponível, os rouges vegetais tornaram-se mais procurados. Em meados do século XIX, o produto vermelho estava disponível de várias formas, como em pó, pomada, creme ou infusão líquida (ELDRIDGE, 2015). A figura 91 é exemplo do uso do rouge no século XIX.

FIGURA 91: Retrato de Madame Pompadour acrescentando à face um toque de rouge. Marquise de Pompadour at the Toilet, François Boucher, 1758, Harvard, Fogg Museum, óleo sobre tela.

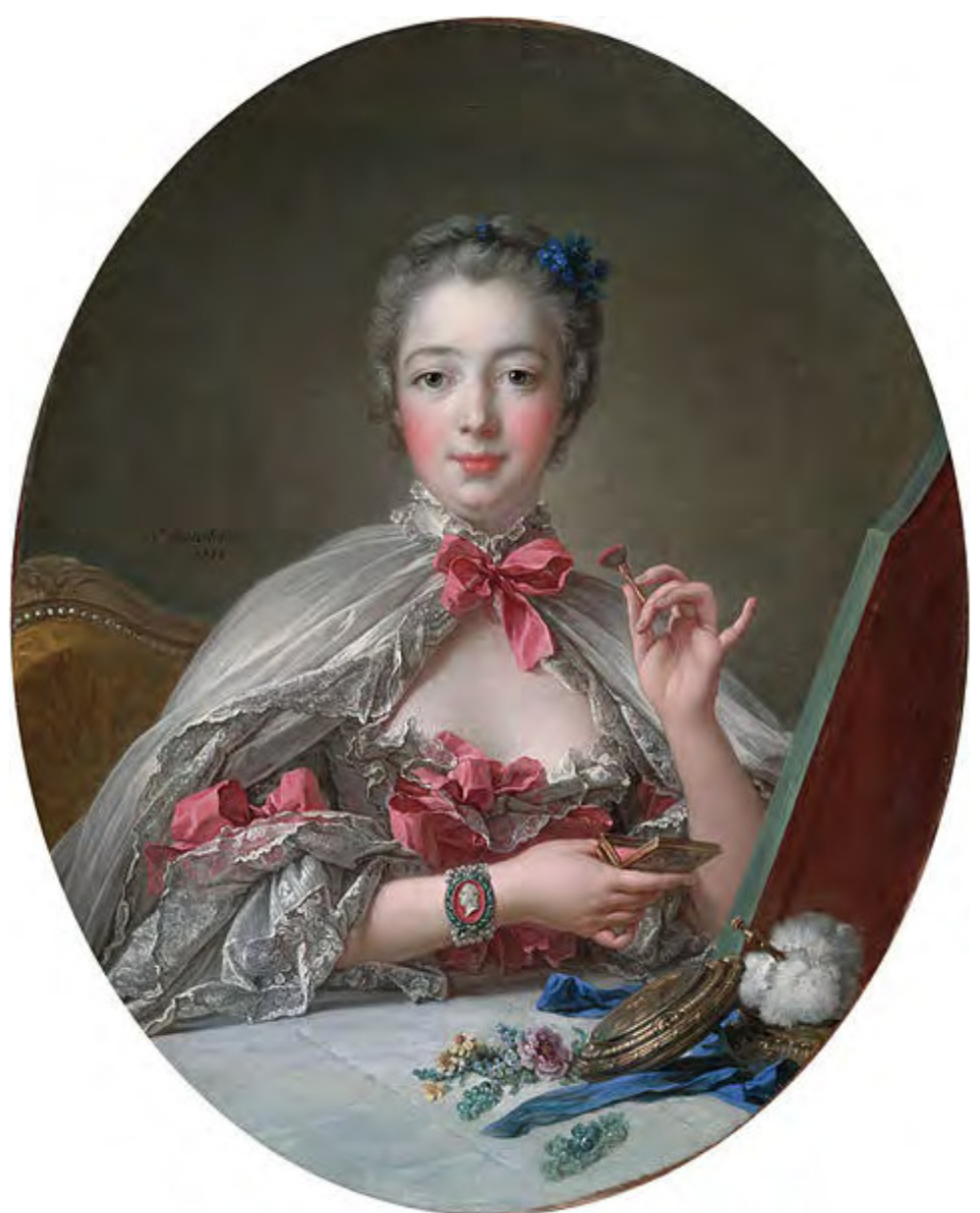

Fonte: HARVARD ART MUSEUM, https://www.harvardartmuseums.org/art/30356 
As várias possibilidades existentes para esse produto, tanto pelas cores, como pelos acabamentos e a forma que podia ser acondicionado, impulsionaram a democratização da beleza, pois, nesse momento, havia rouge disponível para as várias classes econômicas e sociais. "Em 1830, em uma boutique na rue Saint-Martin, Paris, os potes de rouge variavam de cinco a oitenta e cinco francos, e os pequenos potes de rouge em pó de Bourjois iriam além de suas origens teatrais antes exclusivas" (ELDRIDGE, 2015, p. 176).

Assim, já em 1850, a produção de cosméticos tornou-se cada vez mais impulsionada, marcando o início desse produto comercialmente disponível em uma escala nunca antes vista (KNAPP; DORR, 1985). Na virada do século XVIII para o XIX, esse artigo estava disponível em várias tonalidades e texturas, passando a ser tratado com menos desdém e pouco caso. Outro fator que colaborou para isso foi a aproximação do Rei Edward VII, filho e sucessor da Rainha Victoria, com algumas das atrizes de teatro mais famosas da época, o que tornou os cosméticos mais admissíveis (ELDRIDGE, 2015).

Todavia, como a Rainha Victoria condenava o uso excessivo de maquiagem, por ser vista como algo vulgar e até desprezível, nessa fase, as pessoas recorriam ao artifício de beliscar suas bochechas e morder os lábios para estimular um rubor natural. Ademais, quando recorriam ao artifício de usarem maquiagem, faziam-no de forma moderada e cautelosa (JACKSON, 1984).

Em contrapartida, para as mulheres do início do século $\mathrm{XX}$, usar batom ainda podia ser moralmente questionável e pairava a noção de que usá-lo pertencia ao reino das prostitutas e atrizes. Mais do que isso, esse período sinalizou também a liberdade feminina, ou seja, surgiu o "movimento de direito das mulheres, com as mulheres fazendo campanha pelo direito de votar em uma marcha em Nova York em 1912, pintando desafiadoramente suas bocas de um vermelho vivo" (ELDRIDGE, 2015, p. 175).

Na Segunda Guerra Mundial, as mulheres foram ativamente encorajadas a pintar os lábios de um vermelho brilhante com o intuito de manter a moral, uma vez que o "batom vermelho era um sinal de patriotismo e mostrava vontade de vencer (...). Em 1942, o US War Production Board mudou de tom e anunciou que os cosméticos eram "necessários e vitais" (ELDRIDGE, 2015, p. 175).

Nos últimos anos, constata-se que muitas mulheres, por motivos e impulsos diferentes, fazem uso do vermelho na maquiagem, tom que ainda causa um grande impacto 


\title{
2.2.2.3 0 ponto focal preto e as sombras coloridas
}

Independentemente da cultura ou do período histórico, os olhos são sempre citados como sendo as "janelas da alma" e a importância deles, maquiados ou não, permanece uma constante (JACKSON, 1984). Junto com o vermelho, o preto é uma das cores mais antigas que foram usadas nas pinturas rupestres desde o Paleolítico e Neolítico, na forma de carbono e óxido de manganês (PIPER, 2008). Mundialmente, a maquiagem preta é amplamente usada para realçar a região ocular.

Para o Egito antigo, os olhos delineados pelo preto kohl eram usados não somente pelos ricos e poderosos como pelas pessoas de maneira geral, por isso paletas de maquiagem foram encontradas nas mais remotas sepulturas e tumbas de ambos os sexos. Tanto que a arte e a escultura sempre retrataram figuras com olhos fortemente definidos e sobrancelhas marcadas, como foi representado por Nefertiti na figura 86.

Para esse povo, maquiar a região ocular com preto ia muito além do embelezamento e da vaidade. Delinear os olhos, a que tudo indica, poderia ser por duas razões, como afirma Lisa Eldridge (2015, p. 70):

\begin{abstract}
A primeira e cada vez mais popular teoria é que a maquiagem usada era medicinal e protegia os olhos contra infecções e fortes raios solares. Se você considerar que a maioria dos antigos egípcios vivia em desertos áridos e cheios de poeira ou pântanos ao redor do Nilo, então é claro que a necessidade de proteger sua pele - e especialmente a pele delicada ao redor dos olhos - teria sido ótima. Vários textos médicos que foram descobertos contêm prescrições para a cura de doenças oculares, como tracoma e conjuntivite, que eram prevalentes no Egito e em outros países áridos, como a Pérsia. Também trazem receitas detalhadas de remédios para pálpebras, íris e córnea. (...) Infecções oculares bacterianas eram (e ainda são) um problema sério nas áreas pantanosas ao redor do Nilo durante as enchentes, e os cientistas acreditam que os antigos egípcios podem ter usado deliberadamente cosméticos à base de chumbo para ajudar a prevenir o tratamento de doenças oculares.
\end{abstract}

E com relação à segunda razão, continua Eldridge (2015, p. 70):

$\mathrm{Na}$ segunda teoria, Kohl é considerado um símbolo de status e de significado espiritual e ritualístico. Historiadores e antropólogos têm repetidamente relacionado os olhos enegrecidos de Kohl vistos na arte egípcia a Hórus, um deus antigo com muitas associações, mas na maioria das vezes descrito como um falcão. O Olho de Hórus - conhecido como wedjat - era usado como um símbolo de proteção. O símbolo do olho está bem delineado, então é fácil ver por que a conexão foi feita. Outra 
associação espiritual na ligação entre a deusa Hathor e malaquita; talvez, para as mulheres egípcias, aplicar o poder aos olhos fosse compartilhar algo da essência da própria Hathor.

Entretanto, independentemente da razão exata para o uso do kohl, o que se sucedeu foi a vontade decorativa e de embelezamento que não havia no momento inicial. A partir desse momento, esse povo passou a adotar cor nas pálpebras como uma forma de expressão. No princípio, a combinação mais comum era a sombra verde-esmeralda e kohl para definição dos olhos e sobrancelhas. Mais tarde, o preto tornou-se a cor preferida para ser usado nessa região (PIPER, 2008).

Essa mesma tendência de enfatizar os olhos e preencher as sobrancelhas também foram vivenciadas pelas gregas e pelas romanas, que utilizaram fuligem, chumbo, pó de carvão, cortiça queimada, cinzas e suco de sabugueiro para escurecer cílios ao longo da história (ELDRIDGE, 2015).

Porém, a prática de enfatizarem o olhar com essas substâncias nem sempre foi bemvista pela sociedade, por isso, por muitas vezes, foram julgadas de má reputação mulheres que assim se pintavam. Isso porque estabelecer contato direto através dos olhos com os homens estava explicitamente ligado ao erotismo e à sexualidade (PASTOUREAU, 2011).

Com o passar dos séculos, o uso da maquiagem teve idas e vindas. Aqui também, devido a descoberta da tumba de Tutancâmon, em 1923, teve um papel importante no retorno do eyeliner e o amor pela tinta preta se manteve constante. Além disso, Hollywood, sem dúvida, desempenhou um papel na crescente popularidade dos produtos para os olhos, com os olhos maquiados incentivando o uso do delineado (ELDRIDGE, 2015).

Apesar disso, observa-se que, assim como a sombra colorida, os olhos fortemente maquiados ou esfumados não foram imediatamente adotados. O estigma associado ao uso de cosméticos visíveis demoraria um pouco para ser superado. Era uma prática muito ligada ao palco e à tela, espaços em que era comum pelas atrizes e performers.

Pouco a pouco, esse item passou a ser um produto considerado básico para os apreciadores de maquiagem, uma mistura pré-embalada e transportável de pó de carvão e vaselina. O rímel, quando surgiu, por ser bastante instável, viu sua popularidade se espalhar rapidamente, já que muitas mulheres passaram a usá-lo de forma embelezadora. As figuras 92 e 93 mostram que Brigitte Bardot, um ícone da beleza do século XX, foi uma das personalidades que mais usaram os olhos delineados de preto. 
FIGURA 92: Brigitte Bardot com os olhos pintados com rímel

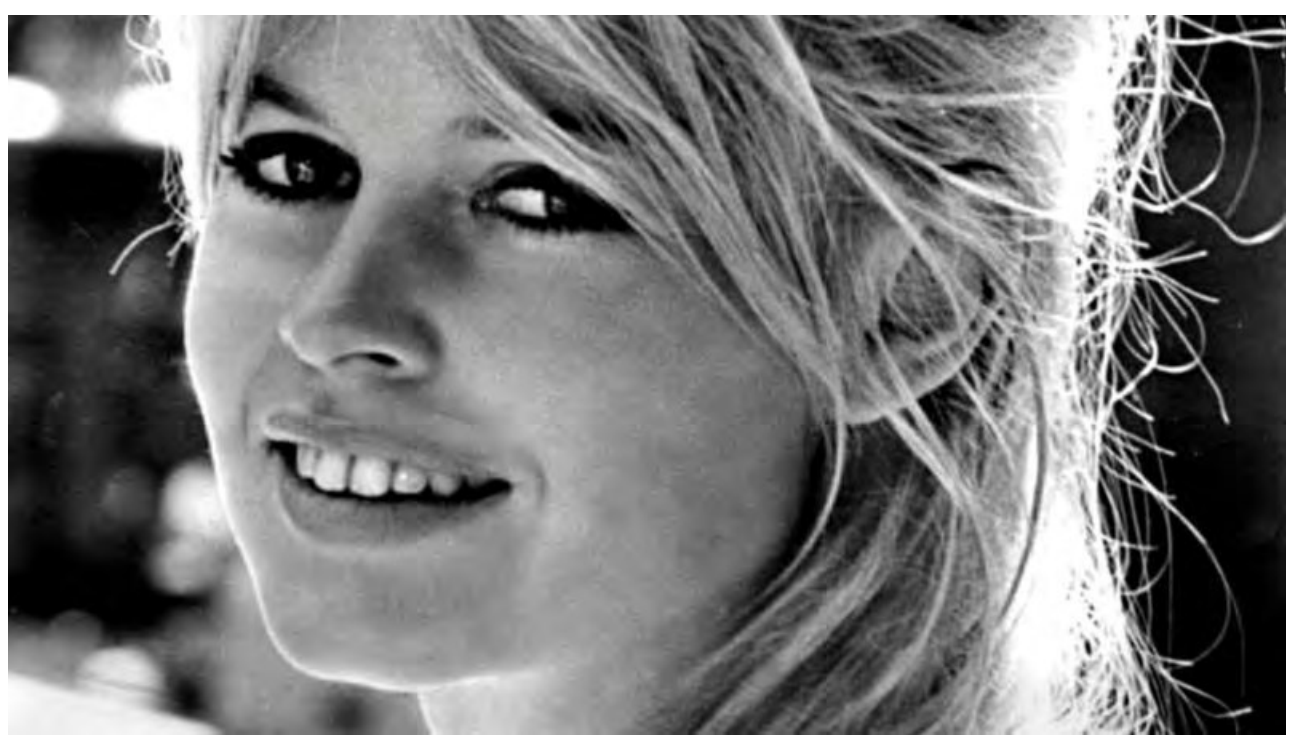

Fonte: WIKIPEDIA, htttps://en.wikipedia.org/wiki/Brigitte_Bardot

FIGURA 93: A intensidade do preto nos olhos delineados de Bardot.

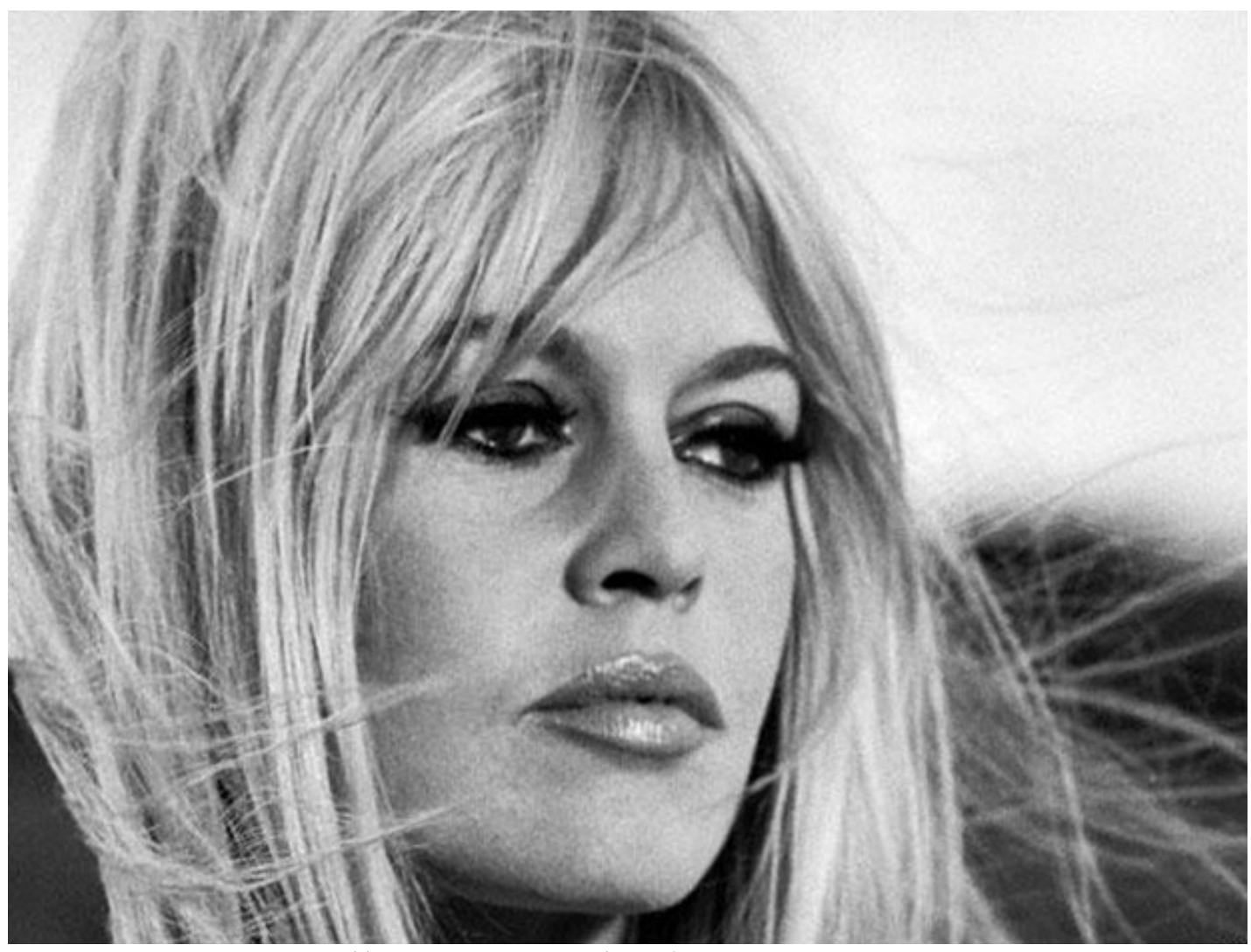

Fonte: WIKIPEDIA, https://en.wikipedia.org/wiki/Brigitte_Bardot 
Além desse produto, as sombras de olhos coloridas, vinculadas aos anúncios publicitários desenvolvidos pela Maybelline de 1930, começaram e cair no aceite popular. Para facilitar as combinações, Lisa Eldridge diz que a empresa lançou a seguinte campanha (2015, p. 168):

\begin{abstract}
dos quatro tons oferecidos, "o azul deve ser usado em todos os tons de olhos azuis e cinza; castanhos para olhos castanhos e amendoados; preto para olhos castanhos escuros e violetas. Verde pode ser usado para olhos de todas as cores e é especialmente afetivo para roupas de noite". Como isso deixa claro, a maneira como a sombra dos olhos era usada era incrivelmente prescritiva e não muito sofisticada - era tudo uma questão de combinar com seus olhos, seu cabelo ou suas roupas.
\end{abstract}

Após a Segunda Guerra Mundial, com todo o incentivo dado à necessidade colocada nesse período de autocuidado, houve um grande avanço tecnológico possibilitado pela introdução da pérola artificial nos cosméticos. Em meados da década de 1960, com a Revolução Feminista, à medida que as mulheres se tornavam mais donas de si e as velhas regras passavam a ser menos relevantes, a maquiagem dos olhos coloridos ganhou espaço. Essa possibilidade encorajava as consumidoras a se divertirem, serem criativas e fazer suas próprias regras, apesar do tão utilizado delineado preto (WRIGHT, 1999).

Os anos setenta em diante viram o lançamento de uma grande variedade de cores e texturas disponíveis, por isso os sofisticados olhos daquela década exibiam cores terrosas, escuras e pastel, além de acabamentos foscos, metálicos, cintilantes e perolados (RICHMOND, 2008).

Junto a essa oferta de produtos, o trabalho dos maquiadores e a publicidade que aconteceu nesse setor ajudaram a impulsionar a maquiagem de olhos "vale tudo" dos anos oitenta. Desde então, os artigos para os olhos tornaram-se extremamente sofisticados, logo maquiar a região ocular tem muito a ver com realçar, sombrear, esculpir, quanto definir com cor. 


\section{A COR COMO FORMA} DE EXPRESSÃO

"Goldstein escreve sobre uma mulher com doença cerebral que tinha tendência a cair inesperadamente e caminhar com um andar instável. Quando ela usava um vestido vermelho, esses sintomas eram mais pronunciados. As roupas verdes e azuis tiveram um efeito oposto e restauraram seu equilíbrio quase ao normal".

(GOLDSTEIN apud BIRREN, 1978, p. 48) 
Na convenção das cores, no início da Idade Média, cor significava poder (PEDROSA, 2009). A nobreza reservava para si o direito às cores mais luminosas e saturadas, e as classes menos abastadas usavam somente tonalidades com menor saturação (HELLER, 2013). Quando a burguesia começou sua ascensão devido ao poder econômico que possuía, ela passou a não tolerar mais que os nobres ditassem sua maneira de se vestir. Dessa forma, as cores permitidas para essa parcela da sociedade foram alteradas, passando a incorporar outras tonalidades com significados maiores (PASTOUREAU, 2019).

Nos dias de hoje, porém, algumas convenções tão comuns para outros períodos quase não existem, portanto, na maioria das sociedades, as pessoas têm livre arbítrio para escolher a tonalidade que querem vestir ou preferem usar. Essa vontade de estar com cores que legitimam sua essência, não apenas pela posição material e econômica, mas também pelo fator emocional, vem ao encontro do fato de que uma pessoa, quando se identifica positivamente com sua própria imagem, pode se beneficiar de forma terapêutica ou até mesmo ter sua autoestima aumentada (WRIGHT, 1999). Isso contribui, consequentemente, para uma conduta mais positiva em relação à vida, conforme defendido pelas autoras Sherlock e Spillane (1995).

Esse, entre outros fatos, colaborou para impulsionar, nas últimas décadas, a tecnologia incorporada ao desenvolvimento de novos materiais e pigmentos tanto na moda como na maquiagem que se desenvolveu consideravelmente. Isso possibilitou um aumento significativo na criação de novos padrões e tendências, com cores mais saturadas e paletas mais diversificadas, com diferentes texturas e acabamentos.

Entretanto, mesmo havendo uma grande oferta de produtos com cores cada vez mais variadas, os indivíduos, ao se relacionarem com essa crescente quantidade, precisam percorrer alguns caminhos seguros que são intrínsecos à natureza humana. Para tanto, as camadas da pirâmide de Mahnke (1996), os fatores psicológicos e emocionais, conforme proposto por Modesto Farina (1982), bem como os Tipos Psicológicos de Jung (1971) ajudam a propor uma seleção de cores que vai ao encontro da existência de cada um e do objetivo da metodologia que está sendo proposta nesta tese.

Os traços de personalidade e comportamento são de extrema importância nas escolhas cromáticas, não apenas o produto gerado por uma opção unicamente estética ou ditada pela moda. Nesse sentido, ao usar uma peça de roupa, por exemplo, devido à reverberação causada no organismo pelo contato direto com a frequência luminosa, pode tanto despertar sentimentos de conforto e tranquilidade como também de excitação e ansiedade. Outro fato que deve ser levado em consideração é que, ao longo da vida bem como do desenvolvimento 
e consciência humana, os indivíduos foram adquirindo outras maneiras de sentirem sua própria existência e podem eleger relações e predileções cromáticas diferentes (BIRREN, 1978).

Assim, as preferências por determinadas tonalidades eleitas hoje podem ser cambiantes, dependendo das condicionantes em que o mesmo está inserido, das vontades, desejos e dos acontecimentos vividos. Dessa forma, não há como dimensionar por quanto tempo essa pessoa consegue relacionar-se favoravelmente com as tonalidades eleitas e nem se algum dia passará a não aceitar a legitimidade dessas mesmas cores.

Para ilustrar essa questão, por exemplo, é muito comum uma pessoa que passou por um trauma durante a vida e não conseguiu superá-lo ter preferência pelos tons com baixa luminosidade ou até mesmo ter maior predilação pelo preto (BIRREN, 1961). Muito provavelmente essas pessoas poderiam ter maior resistência em aceitá-los ou sentirem-se bem com outras tonalidades. Esse fato pode permacecer ao longo da vida ou até mesmo, caso ela consiga criar outras condicionantes psíquicas e dissolver esse choque, conseguir ter mais abertura e se relacionar tanto com seus problemas de modo diferente, como apresentar maior aceite para com as nuances.

É importante ressaltar que, quando isso não ocorre, ou seja, se há alguma rejeição ou dificuldade no desprendimento de alguma preferência cromática, o mais indicado a ser feito é que essa condicionante deve ser respeitada, incorporada e aceita. Em outras palavras, não se deve insistir com propostas que, por mais que sejam sob determinada ótica as mais adequadas, não são as mais desejadas quando vistas por outra perspectiva.

Isso porque a sensação de cor, conforme defendido por Fernanda Moceri (2016, p.12):

é um procedimento muito mais profundo e complexo, influenciado por alguns fatores que se justapõem para resultar na cor que é percebida. Para se identificar uma cor, tanto processos conscientes e mecânicos como inconscientes e emocionais são necessários. Por meio deles, é estabelecida uma correlação entre os fatores do ambiente externo com os fatores interiores, do íntimo de cada indivíduo.

Dessa forma, Moceri diz que (2016, p. 24):

A cor percebida é o resultado da ativação mecânica de células sensoriais do córtex cerebral, o que proporciona a percepção óptica e fisiológica desses estímulos por meio da influência de aspectos emocionais - que cada indivíduo emprega na cor que é experimentada. Sendo assim, aspectos fisiológicos, em conjunto com outros aspectos - simbólicos, culturais, 
associativos, emocionais, psicológicos, entre outros - vão influenciar na cor que será experimentada, podendo essa mesma cor receber conotações e atribuições diferentes de acordo com cada indivíduo.

Apesar disso, observa-se que, muitas vezes, a personalização visível e a estéril padronização também podem ocorrer por simplesmente só se seguir diretrizes da tendência e moda ao invés de detectar as variações entre temperamentos e subjetividades individuais. Isso não quer dizer que os critérios definidos para esses universos não deveriam ter relevância, mais sim que é preciso ponderar e analisar tais conceitos para, somente depois, validá-los ou recusá-los (MAHNKE, 1996).

Todavia, o que se faz indiscutível, segundo Abraham Maslow, com seu trabalho proposto pela Hierarquia das Necessidades, é que o desejo estético faz parte da vontade humana de se relacionar com a vida e torna-se primordial quando as outras etapas propostas por ele já foram atendidas. Isso valida a razão pela qual os indivíduos se relacionam com as ideais colocadas pela tendência, moda e estilo, uma vez que fazem parte da experiência individual (MASLOWapud VEJLGAARD, 2008).

Para tanto, os trabalhos propostos por Everett Rogers, com a Curva de Difusão da Inovação (ROGERS apud SANTOS, 2013), e por Henrik Vejlgaard, com o Modelo de Tendência em Forma de Diamante (VEJLGAARD, 2008) colaboram para entender como as pessoas se relacionam com esses prognósticos. Ou seja, se apresentam uma postura conservadora ou mais facilmente aceitam e incorporam novas tendências cromáticas.

Apesar de tudo isso influenciar as opções e escolhas de cores, sendo uns mais impactados pelos estímulos externos e outros menos, é necessário também levar em consideração a natureza das cores. Isso porque pode haver uma diferença perceptiva entre a cor previamente escolhida e o resultado cromático obtido depois de utilizada. Esse fato ocorre por alguns motivos. O primeiro deles é causado pela estrutura visual humana, por ser capaz de produzir cores, o que Goethe, em sua Doutrina das Cores, nomeou como sendo as cores fisiológicas (GOETHE, 2011).

O segundo deles é causado pela própria natureza cromática gerada por aquilo que Chevreul denominou como sendo o contraste simultâneo em que os tons interagem uns com os outros, podendo alterar perceptivamente a escolha cromática inicial (CHEVREUL, 1987). Com isso, as tonalidades de pele, olhos e cabelos vão relacionar-se com a cor usada, e o resultado perceptivo será dado pela interação entre esses componentes. Assim, alguns aspectos devem ser considerados para a realização dessa metodologia, pois, para que a 
paleta de cores seja a mais assertiva possível, faz-se necessário percorrer um caminho seguro e efetivo.

Apesar dessa proposta não ter sido testada nos indivíduos, alguns aspectos são importantes, logo devem ser considerados. O primeiro aspecto é que essa metodologia objetiva que seja realizada com o indivíduo pessoalmente, uma vez que se faz necessário fazer uma análise das colorações da face e, dessa forma, não teria como ser feita por foto ou câmera via alguma plataforma digital. Além disso, o tempo dessa investigação de cores é de aproximadamente uma hora e meia feito à luz do dia, sem interferência de nenhuma fonte artificial.

O segundo aspecto é que todo o material pensado e produzido para ser usado foi feito por mistura subtrativa, ou seja, por pigmentos, sendo utilizados tecidos e material impresso. Isso porque não é recomendado o uso de cores provenientes da mistura aditiva projetada por algum dispositivo eletrônico. Outro ponto importante é que as amostras de cores selecionadas foram classificadas pelo sistema sueco de notação cromático, Natural Colour System, estando todas as tonalidades especificadas por códigos e não por nomes de cores.

O terceiro aspecto que também deve ser considerado é a formação do indivíduo enquanto estrutura de personalidade e posicionamento do eu. Com isso, aqui foi levado em consideração que essa proposta não deve ser aplicada nem em bebês, nem em crianças, pois como eles estão em fase de entendimento em relação às características dos tipos psicológicos, não estão prontos para se posicionarem frente aos aspectos subjetivos.

Isso porque, somente por volta da idade do jardim da infância, conforme defendeu Jung (1971), as crianças começam a desenvolver sua função principal e, dessa forma, demostram suas preferências por alguma ocupação ou pela forma de relacionamento com seus colegas. Essa característica vai sendo desenvolvida com o avanço do tempo e de acordo com o meio em que está inserida, que colabora para reforçá-la, verificando, portanto, o aumento do desenvolvimento da função superior e a diminuição da função inferior (SILVEIRA, 1981).

Esse fato também se reflete nas escolhas cromáticas, pois as crianças, ainda em fase de formação da personalidade, possuem aberturas diferentes da fase adulta, o que mais uma vez dificulta uma análise cromática que leve em consideração aspectos subjetivos. Devido a isso, as preferências por determinadas tonalidades nesse início de vida podem ser facilmente cambiantes.

O quarto aspecto a ser considerado é que, independentemente da faixa etária em que o método se faz aplicável, desde que sejam adultos, como colocado anteriormente, se é uma 
pessoa de 20 anos ou uma outra de 65 anos, é inegável que a forma como cada um se relaciona com as cores pode não permanecer a mesma com o passar do tempo. Isso porque são vários os fatores que vão interferir nessas escolhas e não há como mensurar o tempo de permanência e relevância de uma paleta de cor na vida do indivíduo e nem se haverá ou não uma alteração na forma como essa pessoa sente e se relaciona com as cores.

Com isso, pode ser que um indivíduo permaneça com as mesmas cores por toda a vida, assim como pode ser que determinada pessoa se relacione por 20 anos, ou ainda que outra encontre um tempo de identificação relativamente curto. Portanto, assim como a criação da paleta de cores e a relação delas com o indivíduo são pessoais e intransferíveis, o tempo de permanência e atuação também o é.

Além disso, é relevante considerar que, à medida que as pessoas envelhecem, o tom de pele, olhos e cabelos, pode ser suavizado ou perder a intensidade. Assim, mais tarde, segundo Sherlock e Spillane (1995), algumas pessoas podem passar a preferir outros tons, e esses fatores fisiológicos também podem influenciar o tempo de duração da cartela.

Acrescentem-se ainda a dieta, o estilo de vida e o estado de saúde, que geralmente podem afetar também as colorações condicionadas pelos fatores fisiológicos. Isso porque alguns suplementos terapêuticos, sejam orgânicos ou artificiais, e dietas podem criar tonalidades nocivas ao corpo, afetando a cor da pele, assim como a saúde (BIRREN, 1978). O estilo de vida também é capaz de "criar" cores. Se a pessoa leva uma vida agitada e hiperativa, com um nível de stress alto, seu coração pode bombear demasiadamente o sangue, levando essa pessoa a ter um aspecto ruborizado mais constante na pele devido à pressão alta ou uma taxa de pulso elevada (BIRREN, 1978). Já, quando está calmo e descansado, seu aspecto pode parecer muito diferente, sendo menos "rosado". Da mesma forma, quando está cansado ou sem praticar atividade física devido a um estilo de vida sedentário, acarretando uma má circulação sanguínea, pode parecer mais pálido do que seria se estivesse mais ativo. Assim, essas formas de conduta vão influenciar a leitura da parte destinada à Harmonia Objetiva e pode ser que seja necessária uma nova interpretação.

O quinto aspecto a ser considerado é que essa proposta independe do sexo ou da opção sexual adotada. A única diferença que tem que ser feita diz respeito à estrutura fisiológica, pois a produção e a liberação de hormônios na corrente sanguínea não é a mesma para ambos os sexos, podendo acarretar uma diferenciação devido às cores que biologicamente são produzidas (BIRREN, 1978).

E também, a liberação de hormônios não é a mesma dentro de um mesmo sexo com idades diferentes. Isso porque, como exemplo o sexo feminino, depois que as mulheres 
passam pela menopausa e experimentam estrógeno em seu sistema, é comum apresentarem uma mudança em sua coloração se comparadas a quando eram mais jovens (WRIGHT, 1999).

O sexto aspecto a ser apontado é que esse trabalho não classifica os seres humanos por temperatura de cores quente e fria, pois considera, assim como Johannes Itten, o contraste de temperatura o mais relativo entre os sete apresentados por ele (ITTEN, 1970). Por essa razão, dentro desta proposta, considera-se que a espécie humana, conforme o estudo desenvolvido pela Pantone (figuras 95 e 96) possui tonalidades predominantemente alocadas no primeiro quadrante do espaço de cores NCS, ou seja, compreendido pelas tonalidades amareladas, alaranjadas e avermelhadas (figuras 97 e 98).

Por essa ração, foram adotadas as classificações propostas por Lilian Barros em um curso dado no Universo da Cor, “A Cor na estética Pessoal”, em 2011. Segundo a referida autora, as tonalidades foram divididas em três categorias: Harmonia Ouro, com predominância de tons mais dourados; Harmonia Prata, com predominância de tons mais rosados; e Harmonia Mista, quando há tanto tons dourados como também rosados entre os aspectos cromáticos dos indivíduos.

Vale destacar que, por mais que as pessoas possam vir a terem características que as levem a ocupar algum dos outros três quadrantes do círculo cromático, como veias, marcas, manchas, olheiras ou qualquer outra característica, mesmo assim, majoritariamente, as predominâncias de tonalidades da raça humana se concentram no primeiro quadrante do espaço de cores.

O último e sétimo aspecto a ser considerado é que os indivíduos em estado psíquico em equilíbrio podem relacionar-se com todas as cores existentes, não havendo nenhuma contraindicação de ordem patológica cientificamente comprovada. Isso porque o homem é uma extensão da natureza, e a natureza é essencialmente cor.

Entretanto, o motivo de ser proposta a elaboração de uma paleta de cores é porque cada pessoa apresenta consigo vontades, anseios, características, qualidades, traços de personalidade, história de vida, relação afetiva que contam a sua história e essa história está diretamente relacionada com as cores.

Outro fator importante é que não é possível afirmar que existe uma resposta humana padronizada às cores (BIRREN, 1961). Isso significa que indivíduos diferentes podem reagir de diferentes maneiras a um mesmo estímulo cromático. Tudo vai depender das várias condicionantes envolvidas, levando em consideração que a psique é capaz de propor novos parâmetros e relações, conferindo significados diferentes. Para tanto, o espaço de cores 
Natural Colour System, dentro deste trabalho, foi dividido em quatro partes e foram nomeados da seguinte forma: Leveza, Sutileza, Profundidade e Impacto.

Ao definir as cores que serão utilizadas em um projeto ou em uma paleta voltada para a expressão individual, deve-se sempre analisar e levar em consideração o contexto em que essas nuances serão inseridas, ao invés de aplicá-las seguindo modelos ou regras prédefinidas por modas e conceitos generalizantes. Embora possam funcionar em alguns casos, é preciso analisar cada caso individualmente, levando em consideração as particularidades de tais personalidades e estilos de vida.

Entendido isso, esse método de espeficicação cromática foi criado para ser realizado em três fases e serve como um guia, uma bússula, um norteador de como poderia ser realizado nos indivíduos e obter reasultados satisfatórios.

Sendo assim, a primeira fase é composta pela Estratégia Inicial, que abrange desde as orientações de quais são os objetivos deste trabalho e como seria aconselhável a pessoa comparecer no dia da análise. Seu início é marcado por uma conversa com perguntas que foram desenvolvidas baseadas tanto nas camadas da pirâmide de Frank Mahnke (1996), quanto nos estudos de tendência desenvolvido por Everett Rogers (ROGERS apud SANTOS, 2013) e Henrik Vejlgaard (2008), entre outras perguntas que também fazem parte e ajudam na elaboração desse método. Essa primeira fase foi dividida em duas etapas.

Na primeira etapa, após a pessoa sinalizar o interesse em realizar sua leitura cromática, devem ser enviadas por email algumas recomendações. Na segunda etapa, que seguiria de forma presencial, inicia-se um trabalho de investigação que percorre as camadas da pirâmide de Mahnke, passando por elas, nível por nível, mediante um bate-papo. Além disso, será observado como esse indivíduo se relaciona com a Curva de Difusão da Inovação (ROGERS apud SANTOS, 2013) e com o Modelo de Tendência em Forma de Diamante (VEJLGAARD, 2008). Para essa etapa, foi desenvolvido um quadro-questionário, com perguntas direcionadas $\mathrm{e}$ as respostas anotadas, sempre observando as reações e comportamentos que contribuem para a construção do resultado final.

A segunda fase, Levantamento das Harmonias e Contrastes, foi dividida em três etapas. Na primeira etapa, deve ser realizada uma análise das harmonias objetivas ditadas pelas cores da pele, olhos e cabelos. É aqui que serão levados em consideração os trabalhos de Goethe (2011), com a cores fisiológicas, de Chevreul (1987), com a Lei do Contraste Simultâneo e de Itten (1961;1970), com o contraste de temperatura de cor. Na segunda etapa, inicia-se uma análise dos contrastes que o indivíduo apresenta entre tons de pele, olhos e cabelos. Essa análise foi dividida nos contrastes baixo, médio e alto. Na terceira e 
última etapa dessa fase, seria feita uma análise das harmonias subjetivas, conforme proposto por Itten $(1961 ; 1970)$ com o timbre subjetivo e os Tipos Psicológicos de Jung (1971). É aqui também que é utilizado o triângulo de cores do sistema Natural Colour System e proposta uma relação entre os tipos psicológicos e os atributos de cor de saturação e luminosidade.

$\mathrm{Na}$ terceira fase, Processo de Criação de Paletas de Cores, após analisados e considerados todos os percursos percorridos nas etapas anteriores, pode ser desenvolvida a paleta de forma individual e tanto as cores disponíveis como a forma de montagem constituirão o resultado final e o objetivo da metodologia aqui proposta. Para tanto, foi desenvolvido o quadro abaixo que contém as etapas necessárias para realização desse projeto.

QUADRO 4: Processo criativo proposto pela metodologia de criação de paletas de cores.

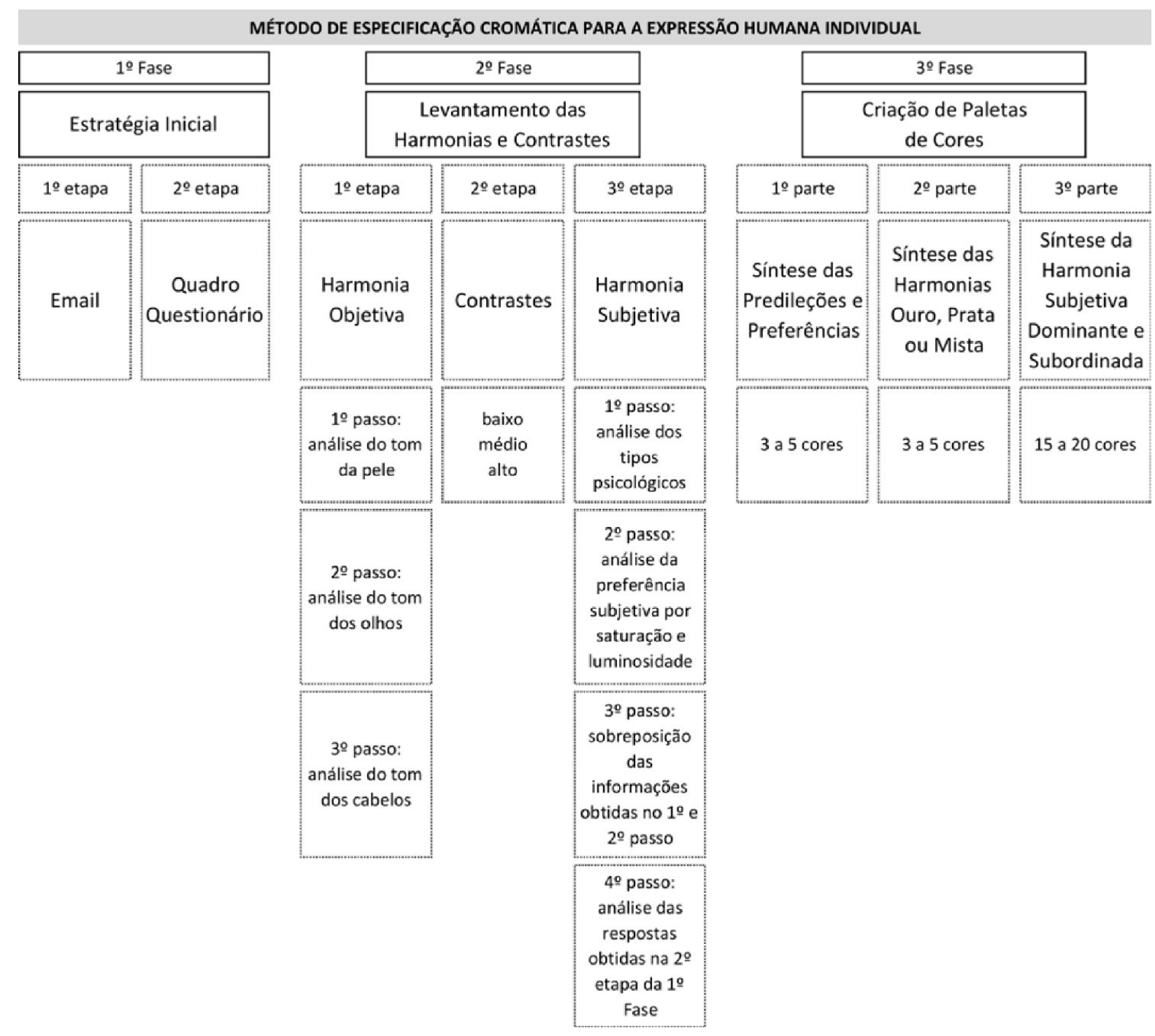

Fonte: A autora. 
Com isso, um dos objetivos desse método seria propor uma possibilidade de identificação do indivíduo com as cores, mas, de forma alguma, eliminar ou ir contra a maneira como cada um se relaciona com determinadas tonalidades. Isso quer dizer que, caso um indivíduo tenha, independentemente do motivo que o levou a isso, afinidade com algum tom específico, essa relação será considerada e respeitada na construção das paletas de cores $\left(3^{\mathrm{o}}\right.$ Fase, $1^{\mathrm{o}}$ Parte).

Assim, essa tese vai ao encontro de uma série de trabalhos desenvolvidos no século passado, ancorados nos ensinamentos deixados pelos grandes mestres que buscavam entender quais eram as tonalidades que mais beneficiavam as pessoas, quais eram as harmonias objetivas ditadas pelos tons da pele, olhos e cabelos. A partir desse ponto, propor-se-á uma cartela de cores condizente com os anseios individuais de cada um.

\subsection{Estratégia Inicial}

Esse método conta com a Estratégia Inicial. Ela é a primeira fase desse trabalho e foi dividida em duas etapas. Na primeira etapa, após ter sido sinalizada a vontade de realizar a análise proposta, conforme as diretrizes estabelecidas por essa metodologia, sugere-se enviar um pdf por email contendo uma série de recomendações e informações, de forma breve e sucinta, para que o indivíduo se familiarize tanto com os objetivos pretendidos como em como comparecer no dia agendado.

Abaixo segue uma sugestão de como isso poderia ser feito:

\footnotetext{
"encaminho-lhe algumas orientações para que sua leitura cromática seja realizada corretamente:

- venha, se possível, sem maquiagem (caso não haja essa opção que sua maquiagem possa ser removida para que eu consiga ver as suas cores sem interferências);

- se possível, venha com roupas leves, sem estampas e com tons acromáticos (preto, cinza e branco);

- se você estiver com alguma blusa fechada, de manga comprida ou casaco, traga uma regata, pois preciso analisar a cor do seu colo e ombros em relação à cor do seu rosto;
} 
- caso queira trazer algum referência de cor ou alguma peça de roupa que te agrade, fique à vontade (só não vale trazer por foto);

- caso queira trazer alguma referência de alguém que admira fique à vontade (essa pode ser por foto);

- caso você esteja bronzeado, mas essa não seja a sua característica na maior parte do tempo, é recomendado que espere até sua coloração ser a predominante;

- caso esteja fazendo algum tipo de tratamento de saúde, avise-se para que isso possa ser considerado;

- venha tranquilo, tente não estar bloqueado ao novo, pois muitas vezes as nossas preferências por determinadas tonalidades podem ser as que, por algum motivo, estamos acostumados a usar;

- sua análise de cores é realizada de forma individual, dura aproximadamente 1 h e $30 \mathrm{~min}$, feita à luz do dia;

- no final, será desenvolvida uma paleta de cores e entregue a você como resultado dessa investigação;

- por último, gostaria que refletisse qual é o seu objetivo em realizar sua análise de cores, pois irei lhe perguntar.

Ao receber essas orientações, o indivíduo fica consciente de que existem alguns procedimentos a serem seguidos e que são necessários para que a leitura seja realizada de forma precisa.

Feito isso, inicia-se a segunda etapa da primeira fase. É nesse momento que a pessoa tem que se dirigir até o lugar onde será realizado esse trabalho, após ter agendado um dia e horário. Para essa etapa, foi sugerida também uma relação de perguntas baseadas no percurso percorrido e disponibilizadas no quadro 5, que são os eixos e alicerces desta tese e foram trabalhadas nos capítulos anteriores. 
QUADRO 5: Relação de perguntas sugeridas para a segunda etapa da primeira fase.

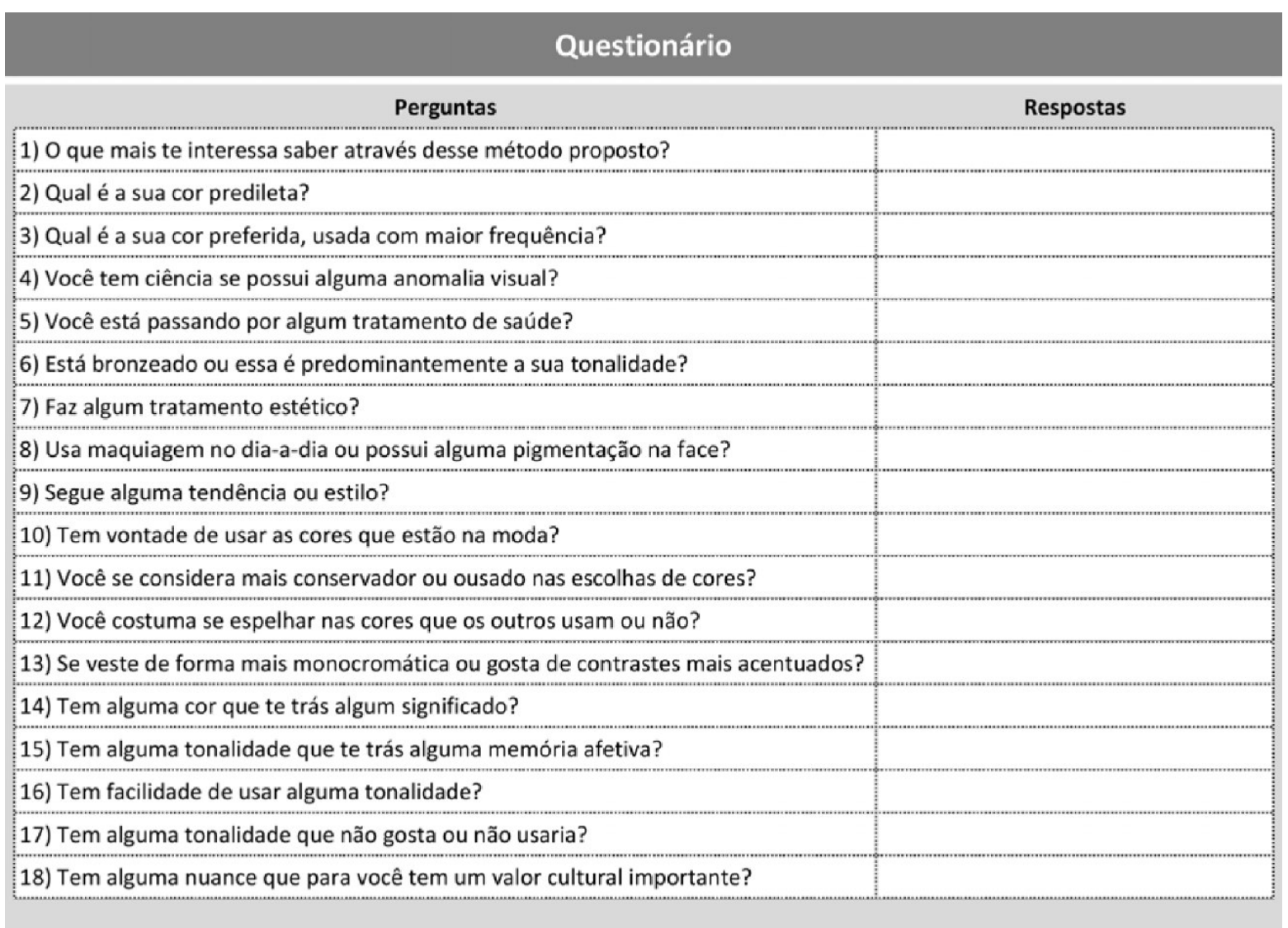

Fonte: a autora.

Conforme as perguntas listadas no quadro 5, a primeira que dá início e comunicada no email contendo as orientações, é entender o que mais motiva a pessoa nesse tipo de trabalho. Aqui, entende-se que as respostas podem ser inúmeras, de natureza variada, o que ajudaria nos encaminhamentos que devem ser dados no resultado final.

Para exemplificar essa parte inicial, pode ser que o intuito da pessoa, ao estar em contato com as cores que mais vão ao encontro de si própria, seja para ajudar a recuperar a autoestima depois do tratamento de alguma doença. A de outra pode ser para deixar de gastar dinheiro com cores com as quais depois ela não consegue se relacionar. E ainda a resposta poderia ser para ajudar a sair do luto devido ao falecimento de algum parente querido, evento que a fez usar preto desde então. Todas as respostas são válidas e podem conduzir o encaminhamento dado rumo ao objetivo final.

A segunda e a terceira perguntas trazem uma diferenciação entre cor predileta e preferida. É importante colocar que a noção de cor predileta pode ser, em si mesma, uma noção extremamente vaga (HELLER, 2013). Quando se refere ao vermelho, por exemplo, 
isso não significa que essa preferência diz respeito a todas as práticas e a todos os valores, tanto ao habitat e à simbologia quanto aos instrumentos da vida cotidiana, aos sonhos e às inspirações artísticas.

Todavia, a resposta a essa pergunta que, em certos aspectos, pode parecer muito superficial, tem o desejo de abrir uma reflexão sobre os anseios individuais, buscando encontrar resultados relativos à cultura e à psicologia, e não somente verdades de sensibilidade gerais e abrangentes. Isso porque é indiscutível que "as crenças, os pensamentos, as admirações, as rejeições passam sempre pelo olhar e pelo julgamento dos outros pelo simples fato de que o homem não vive só, mas vive em sociedade, e a simbologia e a cultura são fortes aliadas nessa construção" (PASTOUREAU, 2016, p. 192).

Em paralelo às condicionantes colocadas pela coletividade, engana-se quem acredita que a cor predileta de uma pessoa tem de ser também a cor considerada por ela a expressão da beleza. Isso porque, na maioria das vezes, a predileção por determianadas tonalidades não atinge vários segmentos, entre eles a moda, a maquiagem, a publicidade, as artes visuais e os bens de consumo. No geral, as pessoas não pensam nem agem de maneira unilateral, sendo seus critérios regidos pela interação de inúmeros fatores e o resultado pode não ser aplicado de forma singular. Para Heller (2013, p. 234):

\footnotetext{
As preferências concretas relativas às cores são, em sua maioria independentes da cor predileta. A cor predileta é apenas um critério, enquanto que a funcionalidade ou a adequação de uma cor têm, quase sempre, um papel mais importante. Quem escolhe uma cor para a beleza não pensa obrigatoriamente na cor de um automóvel ou de uma roupa pensa numa atmosfera em que certas cores dominam claramente.
}

Diferente da cor predileta, a cor preferível geralmente anuncia indivíduos com mais ou menos abertura a estímulos exteriores. Tanto que, por muito tempo, um dos temas tratados nos sermões era a vaidade, e, segundo essa ótica, entregar-se às alegrias mundanas significava distanciar-se de Deus (PASTOUREAU, 2011). E, como era por meio das vestimentas que as pessoas manifestavam mais claramente seus desejos, ímpetos e impulsos, era comum também encontrar o preto predominando nos trajes a fim de "esconder" ou camuflar tais anseios.

Dessa forma, a nuance preferível pode ser um produto da sociedade e, junto com seus valores simbólicos e culturais, estão aqueles que fazem as cores, ditam as regras e orientam o comportamento das pessoas por um período de tempo. Além disso, as influências provenientes da tendência, moda e estilo também vão agregar informações, e os indivíduos, 
ao fazerem sua opção cromática, mesmo que de forma inconsciente, pode ser que sejam impactados por essas condicionantes.

Apesar disso, as pesquisas de opinião relacionadas a essa área específica, na sua maior parte, tentam não ressaltar nem a cor preferível nem a setorização dos campos do saber, buscando não dividir por substratos ou meios de aplicação (BIRREN, 1961). Pelo contrário, procuram posicionar-se no absoluto, nos anseios subjetivos. Buscando uma ética global, chegam a considerar que, para serem válidos, as pessoas interrogadas sobre a sua cor devem responder "espontaneamente", isto é, em menos de cinco segundos, sem raciocinar ou criar estratégias enganadoras (LÜSCHER, 1969).

Para esse tipo de proposta, é comum que, mesmo num primeiro momento, as respostas surjam por impulso e, num segundo momento, sejam conectadas a algum meio específico. Se forem analisados os jovens, por exemplo, nesse segundo momento, eles, no geral, farão conexão com a coloração de suas roupas. Isso porque são as roupas que irão definir sua posição social, pois eles ainda não possuem uma profissão e seu patrimônio, caso haja, tem que ser autorizado por um responsável legal, o que contribui para que o símbolo de sua individualidade sejam suas vestimentas (HELLER, 2013). Já uma pessoa na fase adulta, nesse segundo momento, é mais cambiante, podendo tanto relacionar ao vestuário como a qualquer outro meio específico.

Verifica-se que, muitas vezes, há de fato uma fácil aceitação da cor eleita, fazendo naturalmente uma ponte entre essa nuance e o vestuário. Além disso, o que precisa ser fixado é qual a saturação e luminosidade desse tom que vai guiar os próximos passos. Caso a pessoa diga que, apesar da predileção por tal tonalidade, é incapaz de usar uma peça que tenha essa coloração, isso também precisa ser considerado e recolocado na parte destinada à investigação da Harmonia Subjetiva (Etapa 3 da Fase 2).

Todavia, vale dizer que essa diferenciação observada entre a noção de cor predileta e cor preferida abre passagem para o entendimento de como os indivíduos se relacionam com as cores, investigando as aberturas e os aceites. Entendido isso, considera-se que seria ideal apresentar para essa pessoa uma série de amostras de cores, todas em tecido de algodão, codificadas e classificadas segundo o sistema Natural Colour System. A figura 94 exemplifica esse conjunto de modelos. 
FIGURA 94: Opções de cores apresentadas para que a pessoa aponte qual é sua cor predileta e preferida.

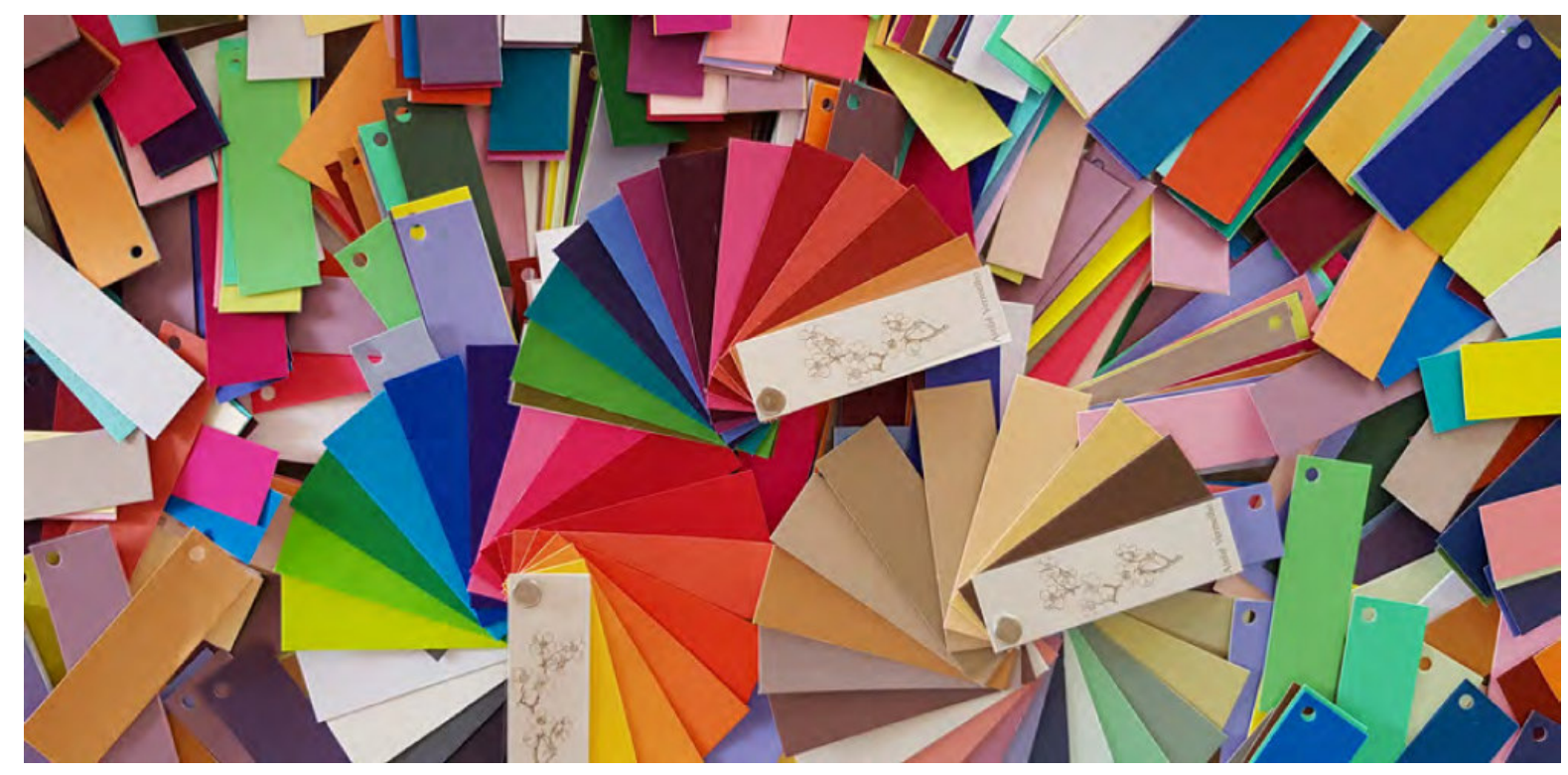

Fonte: a autora.

Assim, ao observar a pluralidade de amostras de cores, seria indicado que a pessoa aponte a cor imaginada e dita como predileta e preferível, com vistas a sair do plano da imaginação e do inteligível e direcionar para o plano do concreto e do real. Isso porque é impossível entender se a forma, os valores e a linguagem que uma pessoa atribui ao designar um roxo, por exemplo, é a mesma forma que outra também atribui.

É importante ressaltar que, por mais que um computador possa disponibilizar mais de dezesseis milhões de nuances, só existem apenas onze termos básicos de cores em vários idiomas. Essas cores são, segundo Angela Wright (1999): preto, branco, vermelho, laranja, amarelo, verde, azul, rosa, violeta, marrom e cinza. Confusamente, o que é feito é emprestar termos de muitas esferas da vida como da natureza, da gastronomia e do universo lúdico e assim por diante, para descrever tonalidades como azul pavão, areia, pêssego, creme, entre tantas outras possibilidades (WITTGENSTEIN, 2009).

Além disso, onze é o número máximo de termos de cores básicas em qualquer uma das noventa e oito línguas estudadas pelos antropólogos Berlin e Kay na década de 1960. Eles conduziram pesquisas entre tribos primitivas em partes remotas do mundo e fizeram descobertas surpreendentes sobre a unanimidade da nomenclatura de cores (BERLIN; KAY apud WRIGHT, 1999) 
Devido a essa inexistência de termos suficientes para nomear todas as cores disponíveis, nos sistemas de notação cromáticos, as cores que constam nos mostruários são nomeadas por códigos específicos. O fato de apresentarem códigos em vez de palavras tem razões muito claras. Uma delas é porque, se dentro de um sistema, uma cor chama-se verdeesmeralda, por exemplo, só poderia supor que essa coloração contém verde em sua composição.

Contudo, não seria possível compreender em que posição do círculo cromático esse verde estaria e qual a sua relação com os outros verdes presentes no círculo (se é mais para um verde amarelado ou para um verde azulado). Outra razão é o fato de a nomenclatura não informar qual é sua escala de luminosidade e saturação, uma vez que a tonalidade verdeesmeralda pode variar - e muito - entre o entendimento cromático do indivíduo que aplicou essa designação e a compreensão imaginativa da pessoa que recebeu essa informação.

Isso vai ao encontro do que disse Ludwing Wittengeist (2009, p. 51):

\begin{abstract}
À pergunta 'O que significa as palavras 'vermelho', 'azul', 'preto' e 'branco' (?') podemos decerto apontar para coisas assim coloreadas - mas não vai além nossa capacidade de esclarecer estas palavras! De resto, acerca de seu emprego, nós não fazemos qualquer representação ou apenas uma de todo grosseira e em parte falsa.
\end{abstract}

Por essa razão, todos os sistemas apresentam códigos em vez de palavras, por isso é recomendado que as amostras selecionadas sejam classificadas, não sendo necessário o uso de termos para nomear as cores. Como descrito por David Batchelor (2007, p. 97):

A ideia de que a cor está além da linguagem, ou de alguma outra forma no limite dela, tem sido expressa de diversas maneiras por inúmeros autores. No início de Color and Culture, John Gage menciona rapidamente 'a sensação de que a linguagem verbal é incapaz de definir a experiência da cor'. Em Color Codes, Charles A. Riley observa que 'a cor se recusa a submeter-se a sistemas verbais e esquemáticos'. Para Stephen Melville, a cor 'pode [...] parecer terrivelmente refratária à nomeação e absolutamente atrelada à própria especificidade [...]'. Dave Hickey nota que 'quando a cor significa alguma coisa, sempre significa também uma suspensão temporária da linguagem e da história'. E ele reconhece o paradoxo: 'Eu já sabia, claro, que a suscetibilidade ao arrebatamento da cor decerto era o meu principal defeito como escritor, já que, para um escritor, a cor é menos um atributo da linguagem do que uma cura para ela'. Leonard Shalin, em seu estudo sobre arte e física, escreve: 'A cor precede a linguagem e antedata a civilização, conectada que está aos lençóis aquíferos subterrâneos do arcaico sistema límbico', e ele cita a habilidade dos bebes 
de 'reagir a objetos de cores vivas muito antes de aprenderem a falar [...]'. E Julia Kristeva, ao refletir sobre os afrescos da Capela Arena de Pádua, inicia sua instigante discussão sobe o uso da cor em Giotto em a afirmação de que, embora 'as abordagens semiológicas considerem a pintura uma linguagem', elas são limitadas na medida em que 'não sugerem um equivalente para a cor entre os elementos da linguagem identificados como linguística'. Kristeve conclui que, 'se é que um dia serviu para alguma coisa, a analogia linguagem/pintura, quando afrontada com o problema da cor, torna-se indefensável.

As respostas que poderiam ser obtidas da quarta a sétima perguntas devem ser consideradas na parte destinada à análise da Harmonia Objetiva. A quarta indagação, "Você tem ciência se possui alguma anomalia visual", é feita para entender quais são as condições fisiológicas que a pessoa apresenta para a captação da visão colorida. Se não há nenhum distúrbio dessa natureza, segue para a próxima pergunta. Se há algum, precisaria ser ponderado e entendido qual o espectro de cores a pessoa consegue absorver.

Isso não quer dizer que, mesmo a pessoa apresentando alguma anomalia visual para os vermelhos, por exemplo, deve-se excluir tal tonalidade da sua cartela. Isso porque as cores produzem efeitos tanto conscientes como insconscientes, tanto causado pela via ótica ao adentrar o aparato visual humano e ser decodificada pela mente, como também pela energia que dela provém, causando efeitos orgânicos desencadeados pelo contato com a pele (BIRREN, 1978).

Já a quinta, "Você está passando por algum tratamento de saúde", está relacionada com as condições de bem-estar do indivíduo. Uma vez que está sendo medicado ou está fazendo algum tipo de tratamento, como, por exemplo, quimioterapia, as características cromáticas da pele e as cores dos cabelos podem apresentar algumas modificações, fato que tem de ser levado em consideração. Caso já tenha finalizado o tratamento, também é preciso considerar se houve uma alteração de permanência com relação às tonalidades ou se há uma tendência de ser dissipada com o passar do tempo. Como conta a história, observar as tonalidades de tez foi uma prática que, conforme afirma Pastoureau (2011, p. 77),

na maior parte das sociedades antigas, na Idade Média cristã presta-se uma atenção cuidadosa às cores do corpo, principalmente da pele, mais ainda do que às dos olhos e dos cabelos. Os textos e as imagens oferecem nesse domínio uma informação abundante e instrutiva, que evolui com o passar dos séculos e difere segundo a geografia e os meios a que se referem. 
A sexta pergunta, "Está bronzeado ou essa é predominantemente a sua tonalidade", sugere que, geralmente, "a cor da pele dos indivíduos muda segundo o tempo de exposição às irradiações solares (...)" (FARINA, 1982, p. 32). Um indivíduo bronzeado apresenta um aspecto mais saudável e pode ter maior abertura para aceitar contrastes maiores entre seus tons e as cores de suas roupas. Aqui, se a pessoa permanece a maior parte do ano bronzeada, ou porque mora na praia ou porque tem o hábito constante de tomar sol, essa dinâmica é levada em consideração e aceita como legítima, pois pertence ao universo desse indivíduo. Mas caso seja momentâneo, é recomendado esperar e analisar as cores originais.

A sétima, "Faz algum tratamento estético?", propõe entender se foi realizado algum procedimento estético como peeling ou algum tratamento com ácido. Isso porque normalmente esses tipos costumam deixar a pele avermelhada por um certo período de tempo, mas assim que seu efeito passa, essa vermelhidão tende a sumir. Outro tipo de tratamento estético seria para olheiras, situação em que se deve considerar não o estado atual, mas sim a pele sem aquela interferência de cor. Nesse caso, assim como no anterior, o mais recomendado seria esperar tais procedimentos finalizarem para ser realizado esse trabalho.

A oitava pergunta, "Usa maquiagem no dia a dia ou possui alguma pigmentação na face?", está relacionada à prática de pintura facial. Caso a pessoa coloque que se maquia com frequência, isso pode diminuir os contrastes provocados entre as cores contidas na harmonização pessoal com as cores eleitas para o vestuário. Por exemplo, caso a pessoa apresente rosácea na pele, mas tem o hábito de usar maquiagem, esse artificio irá disfarçar tal característica de modo que, quando ela estiver utilizando um traje verde, devido ao contraste simultâneo de cor, essa rosácea não ficaria ainda mais em evidência. Mas caso não exista o hábito de passar maquiagem, nessa mesma situação, usando roupas esverdeadas, devido ao contraste simultâneo, acentuaria as manchas avermelhadas (CHEVREUL, 1987).

As perguntas nove, dez, onze, doze e treze estão relacionas com as aberturas e os aceites para o mundo exterior e colaboram para traçar um entendimento da etapa seguinte, composta pela décima quarta a décima oitava perguntas, que estão diretamente relacionadas à Harmonia Subjetiva.

A nona e a décima, "Segue alguma tendência ou estilo?" e "Tem vontade de usar as cores que estão na moda?", procuram entender se a pessoa é aberta e adepta a seguir as orientações provenientes do mundo exterior: se gosta, aceita e incorpora com facilidade cores lançadas pela tendência e pela moda. 
A décima primeira e segunda, "Você se considera mais conservador ou ousado nas escolhas de cores?" e "Você costuma se espelhar nas cores que os outros usam ou não?", procuram investigar as aberturas e os aceites para o mundo exterior ou o contrário disso também. A décima terceira, "Se veste de forma mais monocromática ou gosta de contrastes mais acentuados?", ajuda na sugestão de combinações depois de elaborada a cartela.

A perguntas quatorze, quinze, dezesseis, dezessete e dezoito, vão levar para uma investigação do mundo interior de cada indivíduo, o que pode despertar nele alguns sentimentos tanto positivos como negativos. É o caso das perguntas quatorze a dezessete, “Tem alguma cor que te trás algum significado?", “Tem alguma tonalidade que te trás alguma memória afetiva?", “Tem facilidade de usar alguma tonalidade?”, “Tem alguma tonalidade que não gosta ou não usaria?", que estão diretamente relacionadas com a psique individual. Pretende-se entender se há algum bloqueio que faz com que a pessoa não consiga se imaginar vestindo alguma ou algumas tonalidades. Caso haja, pode ser solicitado para que ela aponte ou selecione a coloração que não possui facilidade em manter uma relação harmônica e pode ser perguntado se ela tem consciência do porquê.

Pode ocorrer de as respostas, muitas vezes, girarem em torno da falta de contraste entre a cor da pele e as tonalidades apontadas "empalidecendo" e isso causar um sentimento ruim. Outras vezes, elas poderão estar relacionadas a alguma memória desagradável. Outras, ainda, poderão estar relacionadas à própria natureza da cor cujas características de saturação e luminosidade não correspondam ao perfil do indivíduo.

Aqui também o objetivo dessas perguntas selecionadas não seria fazer uma avaliação psicológica, mas sim observar as respostas dadas que fazem um link com a segunda fase. Outro fator a ser considerado é que as possibilidades de respostas podem ser inúmeras, por isso sugere-se anotar e avaliar as reações.

Já a última pergunta "Tem alguma nuance que para você tem um valor cultural importante?" é realizada, pois é comum as pessoas terem preferências por algumas tonalidades por esses tons remeterem às próprias vivências e experiências. Para tanto, foi desenvolvido a quadro 6 para auxiliar na síntese das respostas dadas para essa primeira fase. 
QUADRO 6: Síntese das respostas obtidas na primeira fase.

\begin{tabular}{|c|c|c|c|}
\hline \multicolumn{4}{|c|}{ ANÁLISE DA 19 FASE ESTRATÉGIA INICIAL } \\
\hline FASE & ETAPAS & RESULTADOS & OBSERVAÇÕES \\
\hline \multirow{2}{*}{$\begin{array}{c}19 \text { Fase: } \\
\text { Estratégia Inicial }\end{array}$} & $\begin{array}{l}\text { 19 etapa: } \\
\text { Email }\end{array}$ & Informações relevantes: & \\
\hline & $\begin{array}{c}\text { 20 etapa: } \\
\text { Questionário }\end{array}$ & Preferências: & \\
\hline
\end{tabular}

Fonte: a autora.

Feito isso, devem ser analisadas todas as respostas para as perguntas sugeridas. Terminada essa etapa, inicia-se a segunda fase desse processo.

\subsection{Levantamento das Harmonias e Contrastes}

Desde os tempos mais antigos, o homem manifesta sua vontade de querer organizar, sistematizar e criar uma forma de manipular as cores, por isso já existem vários estudos que tentaram metodizar as tonalidades (PEDROSA, 2009). Um dos mais conhecidos é o Litúrgico, que baseou seus conceitos na questão simbólica das cores (PASTOUREAU, 2011).

Para da Vinci, a essência da harmonia estava no "contraste entre luzes e sombras, ou seja, entre claro e escuro. À medida que se alteram os contrastes, altera-se o nível de beleza. Daí pode-se concluir que a beleza da cor é sempre relativa" (PEDROSA, 2009, p. 54).

As descobertas de da Vinci levaram à relatividade da aparência da cor, que teve grande importância nas artes visuais, pois revelava o fenômeno da simultaneidade do contraste cromático. Pedrosa $(2009$, p. 54) afirma que "esta descoberta revela a essência da beleza do colorido, oriunda da ação das cores uma sobre as outras, ao mesmo tempo que mostra a relatividade da aparência da cor".

Isso levou, anos mais tarde, Johann Wolfang von Goethe (2011), Michel Eugène Chevreul (1987) e Johannes Itten $(1961 ; 1970)$ a entenderem, a proposta de da Vinci e formular suas teorias baseadas nesses ensinamentos. Goethe, em sua Doutrina das Cores, defendeu que as tonalidades poderiam ser um produto gerado pela ação da luz, que, ao entrar 
em contato com o aparato visual, produzia cores. Assim, essas teriam muito mais um caráter fisiológico e psicológico do que o caráter físico defendido por Newton um século antes (PEDROSA, 2009).

Partindo do ponto de vista de que uma "análise cromática deveria ser tida sempre como a análise de um processo da mente, em que se torna fundamental observar o comportamento do olho durante o processo perceptivo" (MAZZILLI, 1991, p. 17) fez "avançar a caracterização da cor como sensação que se transforma em percepção" (PEDROSA, 2009, p. 65).

Isso levou Chevreul (1987) a formular sua teoria baseada nessa relatividade, conhecida como A Lei do Contraste Simultâneo. Como consequência, as escalas cromáticas de Chevreul foram influenciadas a ponto de ele observar que a falta de consistência nas cores dos corantes não era uma questão química, mas sim óptica, por isso concentrou sua atenção na exploração da mistura óptica. Ele publicou suas descobertas nas quais discutiu o conceito de contraste simultâneo (as cores de dois objetos diferentes afetam um ao outro), contraste sucessivo (um efeito negativo de pós-imagem) e contraste misto.

Por essa lei, Chevreul (1987) tirou vários ensinamentos que podem ser verificados por observação e concluiu que as cores justapostas se exaltam simultaneamente. Isso significa que, se tiver um vermelho próximo a um verde, esse vermelho, por mistura óptica, recebe o "fantasma" da cor complementar ao verde, ou seja, o próprio vermelho torna-se mais vermelho, intensificando seu cromatismo. Já o verde, também por mistura óptica, recebe o "fantasma" da cor complementar ao vermelho, ou seja, o próprio verde, ficando esse verde mais intenso visualmente.

Existe outro fenômeno cromático responsável pela geração de um contraste parecido com o contraste complementar e com o contraste simultâneo, que também desencadeia na coloração complementar. Porém, esse fenômeno, chamado de pós-imagem, é diferente em essência, pois ocorre num instante depois e permanece por alguns segundos na retina humana. Isso acontece porque, depois que os cones ficam expostos e são saturados a uma determinada informação cromática, eles geram a cor complementar à que foi visualizada pelo observador. Segundo Luciano Guimarães (2004, p. 39):

Inicialmente, os cones, em áreas próximas as áreas saturadas, manifestam a tendência de inibição e provocam, no objeto percebido, auréolas na cor complementar. Se a área monocromática saturada tiver como fundo uma superfície acromática, o efeito é mais perceptível e o fundo assumirá tons que tendem a cor complementar. Se o campo visual, no entanto, for 
constituídos de áreas monocromáticas diversas, a saturação provocará influências recíprocas nos limites entre as cores. O segundo efeito é a necessidade que o olho sente de se desviar do objeto cuja cor foi saturada e buscar a cor complementar para recuperar o equilíbrio. Uma vista saturada pelo amarelo, por exemplo, solicita a presença do violeta. Com esses recursos, também é possível contribuir no direcionamento na "leitura" de uma página impressa. A predominância de determinada cor atrairá o olhar para a cor complementar. Por fim, caso o olhar não encontre novos objetos com a cor complementar, provocará por si mesmo a manifestação conhecida como 'pós-imagem negativa', em fundos neutros.

Os estudos de Chevreul (1987) tornaram-se um dos manuais mais amplamente utilizados e influentes do século XIX, com um impacto significativo e duradouro nas artes finas e industriais. Ele desenvolveu também um modelo contendo 72 tonalidades e propôs uma exploração de harmonias relacionadas às preferências pessoais às cores.

Essa é razão pela qual, como parte de seus estudos, Chevreul definiu possíveis aplicações para uniformes militares masculinos e roupas femininas. Para tanto, considerou a integração entre as tonalidades das vestimentas com a cor da pele, olhos e cabelos e desenvolveu uma longa lista de tonalidades relacionando os efeitos de cada uma delas com as peles claras e escuras (CHEVREUL, 1987).

Uma revista americana, Godey's Lady's Book Magazine, voltada para o público feminino, focada em moda, padrões de costura, mobiliário e economia doméstica, ouviu falar dos ensinamentos de Chevreul sobre análise de cores e sua teoria de contraste simultâneo, por isso a revista, na edição de abril de 1855, decidiu apresentar essas ideias de seleção de cores conforme a aparência.

Anos mais tarde, Johannes Itten, professor da escola alemã Bauhaus, entre 1919 e 1923, elencou sete principais contrastes, considerando os estudos desenvolvidos anos antes por Goethe, Bezold, Chevreul e Holzel (BARROS, 2006). Para Itten (1970, p. 32), cada um dos contrastes "é único em seu caráter e valor artístico, com efeito visual, expressivo e simbólico. E, juntos, constituem o recurso fundamental do projeto da cor". Os contrastes gerados podiam interferir completamente no resultado final, modificando - às vezes por completo - as cores que foram previamente especificadas.

Essa leitura se faz importante, pois qualquer nuance pode ser cansativa e irritante quando inserida num jogo específico de contrastes, ou quando não expressam a essência e personalidade individual de cada um. O inverso também é válido, sendo que, neste caso, pode-se chegar a uma nuance convidativa e prazerosa, como afirma Lilian Barros (2006, p. 45): 
O efeito da percepção das cores se dá através de uma rede de relações nos cenários em que as percebemos. As formas, estilos, texturas e associações culturais interagem com as cores para dar sentido a elas. Assim, a interpretação da cena visual é o resultado intrincado de todas essas relações.

Quando as cores estão justapostas umas às outras, ou quando a retina é saturada com uma informação cromática constante, é possível que ocorra uma modificação na informação cromática que está sendo transmitida. Tanto a justaposição de cores quanto a saturação da retina por uma determinada informação luminosa provocam a formação de contrastes de cores. Os contrastes cromáticos são de grande importância para o entendimento do fenômeno cor.

A base fundamental dos ensinamentos apresentados por Itten (1961) foi a teoria geral dos contrastes. De acordo com essa teoria, "os alunos tinham que estudar os contrastes de três formas: experimentá-los sensivelmente, objetivá-los racionalmente, compreendê-los sinteticamente" (ITTEN, 1961 apud BARROS, 2006, p. 70). Os contrastes cromáticos propostos por Itten foram sete. Lilian Barros (ITTEN, 1961 apud BARROS, 2006, p. 97-100 apud MOCERI, 2016, p. 32) os apresenta da seguinte forma:

1. Contraste de cores puras: é quando as cores puras do círculo cromático, ou seja, as cores vivas e saturadas contrastam uma com as outras, destacando-se a participação do branco e do preto na composição das cores.

2. Contraste de luminosidade: esse contraste envolve a relação de claro-escuro e o valor tonal das cores. Pela relação claro-escuro, qualquer cor pode ser clareada com o branco ou escurecida com o preto. Pelo valor tonal das cores, as cores puras possuem qualidades tonais diferentes, sendo um amarelo vivo uma cor mais clara se comparada a um azul vivo.

3. Contraste de quente-frio: atinge o seu efeito mais vigoroso quando o contraste se dá entre as cores laranja-vermelho e azul-verde. Esse contraste é relativo, pois, se for colocado um verde amarelado perto de uma composição feita com amarelos e laranjas, esse verde amarelado será uma cor fria. Porém, se essa mesma cor for colocada perto de uma composição de azul e verde, esse verde amarelado parecerá quente.

4. Contraste de complementar: ocorre quando é feita uma composição com dois matizes diametralmente opostos no círculo cromático. Do ponto de vista químico, um dos efeitos que surge quando se aproximam duas cores complementares é que elas se anulam, resultando no cinza. Do ponto de vista fisiológico, duas cores complementares justapostas intensificam-se ao máximo. Esse conceito está relacionado com o conceito de contraste simultâneo, descrito a seguir. 
5. Contraste simultâneo: também conhecido como ilusão de ótica ou indução cromática, complementa o conceito de contraste de complementares. Isso significa que, se forem colocadas duas cores complementares justapostas, um amarelo junto com um roxo, por exemplo, o amarelo "joga" no roxo a cor complementar ao amarelo, ou seja, o próprio roxo, e este "joga" no amarelo o próprio amarelo, intensificando o cromatismo dessa composição. Porém, esse contraste não se refere somente a cores complementares, acontecendo com todas as cores existentes no círculo cromático. O contraste simultâneo ocorre "quando áreas com colorações diversas interferem simultaneamente na percepção cromática: um mesmo verde, por exemplo, parecerá mais azulado quando estiver ao lado de um vermelho e mais amarelo ao lado de um violeta" (GUIMARÃES, 2004, p. 45).

6. Contraste de saturação (qualidade da cor): é o contraste existente entre as cores vivas e puras com cores acinzentadas e dessaturadas. Uma cor está dessaturada quando, em sua mistura, haver uma boa quantidade de sua cor complementar.

7. Contraste de quantidade/extensão: esse contraste refere-se à quantidade de cores que deve haver em uma composição, considerando que apresentam intensidades diferentes, devendo dimensioná-las conforme essa regra. Itten vai resgatar os estudos desenvolvidos por Goethe em que ele considerava que uma cor pode ser naturalmente mais clara e luminosa e a outra ser naturalmente mais escura e tênue. A primeira razão, apresentada abaixo, foi estabelecida para uma composição contendo as três cores primárias; a segunda razão foi estabelecida para uma outra composição contendo as três cores secundárias. Como resultado, temos a seguinte razão:

$$
\begin{aligned}
& \text { amarelo : vermelho }: \text { azul }=3: 6: 8 \\
& \text { laranja }: \text { violeta }: \text { verde }=4: 8: 6
\end{aligned}
$$

Se for desenvolvida uma composição com duas cores complementares, como laranja e azul, obedecendo ao contraste de quantidade, deverá haver, nessa composição, quatro partes de laranja para oito partes de azul. Ou seja, $4: 8=1: 2$, o que significa que a composição deve conter o dobro de azul em relação ao laranja.

Todos os sete contrastes elencados por Itten (1961) são relavantes dentro dessa metodologia proposta, mas o contraste de temperatura de cor chama especial atenção. Isso porque, além de ser relativo conforme a composição observada, admiti-se que os seres humanos são seres sanguíneos e, portanto, as características de tonalidade de pele estão majoritariamente no primeiro quadrante do círculo cromático NCS, composto pelos tons de amarelo, laranja e vermelho. 
Sendo assim, é difícil falar em uma divisão entre os seres humanos por temperatura de cor quente e fria, pois, conceitualmente e predominantemente, são "seres quentes". Dessa forma, os indivíduos não são classificados em quente ou frio. Se assim fosse, dividir-se-ia mecanicamente o círculo cromático ao meio de modo e entender-se-ia que uma metade dele estaria relacionado às cores quentes e a outra metade às cores frias.

Realizada essa etapa, recomenda-se avançar para a terceira etapa da segunda fase na qual se sugere o desenvolvimento de uma análise da harmonia subjetiva com vistas a realizar uma sobreposição entre as características dos Tipos Psicológicos (JUNG, 1971) com as escolhas pessoais das cores no que tange à saturação e à luminosidade.

Aqui se admite que as pessoas apresentem predileções, independentemente de uma razão estética ou de embelezamento, tendo ou não aberturas a determinadas frequências de cores devido às suas próprias vivências, história e traços de personalidade. Todavia, muitas vezes, poderia ocorrer que, apesar de ser admitido que um indivíduo possa ter preferência por determinadas vibrações cromáticas, isso pode não significar que a pessoa consegue se trajar com essas cores.

Isso vai refletir-se na etapa seguinte destinada à criação das paletas de cores e é indispensável que seja entendido todo o percurso e levado em consideração a preferência por determinadas nuances e não somente a predileção. Assim, é necessário realizar uma síntese de todos os resultados coletados ao longo do processo sugerido.

\subsubsection{Análise da Harmonia Objetiva}

A primeira etapa da segunda fase conta com a Análise da Harmonia Objetiva. Realizada a primeira fase, em que as perguntas já foram feitas, as respostas já foram dadas e a pessoa já teve a oportunidade de entrar em contato tanto com as amostras de cores quanto com seu universo interior. É aqui que deve ser desenvolvida uma leitura das características existentes entre tonalidades de pele, olhos e cabelos.

Para que essa análise seja feita, recomenda-se que se tenha disponíveis alguns elementos. O primeiro deles é uma quantidade suficiente de luz natural, pois não é aconselhável o uso de nenhuma fonte de luz artificial. Isso porque além da luz natural reproduzir melhor e mais fielmente as cores, é gratuita e acessível a todos. 
Outro ponto recomendável é não estar sob influência das cores que estão na roupa com a qual a pessoa pode estar vestida, pois "é extremamente perturbador para o olho julgar uma cor enquanto outra cor compete por atenção" (JACKSON, 1984, p.56). Para que isso não ocorra, é aconselhável orientar a pessoa a utilizar um tom acromático, como descrito no email enviado na fase inicial, ou pode ser colocado um tecido com uma coloração neutra, ou seja, cinza com média luminosidade.

Para que essa leitura seja a mais adequada possível, além de a pessoa estar sem maquiagem, é oportuno também que as tonalidades do colo e pescoço sejam verificadas. Isso porque é muito comum haver uma diferença de tonalidade entre essas partes do corpo, logo é prudente que essa relação seja observada. Além do mais, todas as cores observadas foram traduzidas para os códigos NCS como colocado no quadro 7.

Essa etapa foi dividida em três passos. O primeiro passo seria analisar o tom da pele. Em 2011, um estudo produzido pela Pantone buscou medir cientificamente, por meio de aparelhos capazes de desempenhar tais leituras, milhares de tons da pele com o intuito de entender quais eram as tonalidades das raças humanas em relação ao espectro visível (PANTONE, 2011).

Esse estudo da Pantone foi feito com o objetivo de formular um guia pensado para ser a representação física mais próxima das cores da tez. Como resultado, foi elaborado um catálogo contendo 110 tonalidades e que foi comercializado pela marca como apresentado nas figuras 95 e 96. Ele é uma referência visual abrangente de tons cutâneos para uso em qualquer mercado em que esse tipo de informação seja relevante. 
FIGURA 95: Análise da coloração da pele desenvolvida pela Pantone.

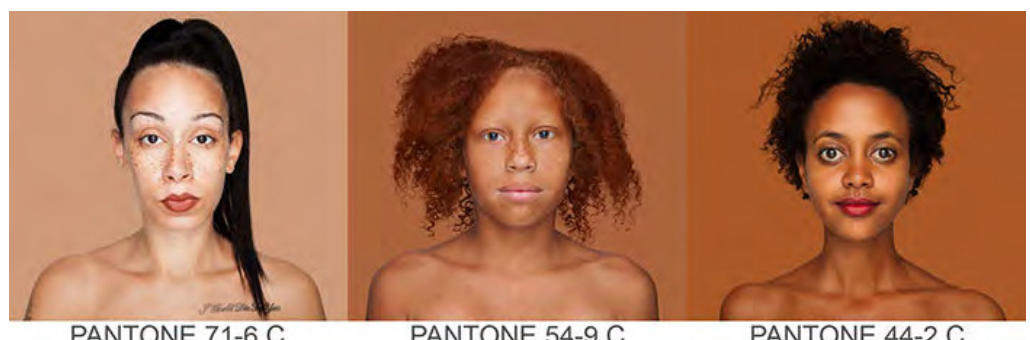

PANTONE 71-6 C

PANTONE 54-9 C

PANTONE 44-2 C

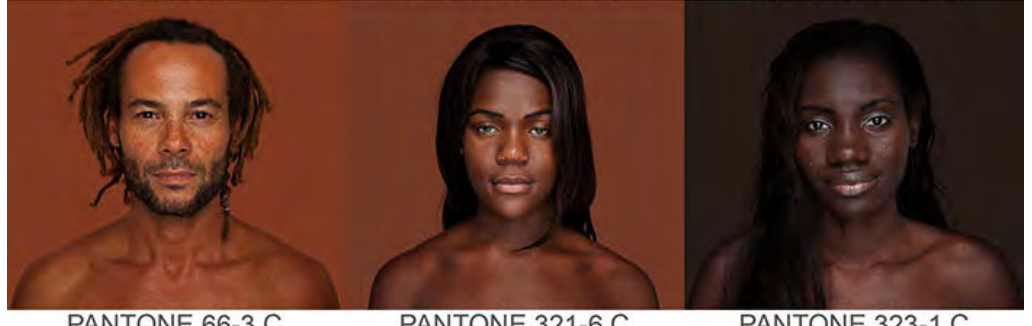

PANTONE 66-3 C PANTONE 321-6 C PANTONE 323-1 C

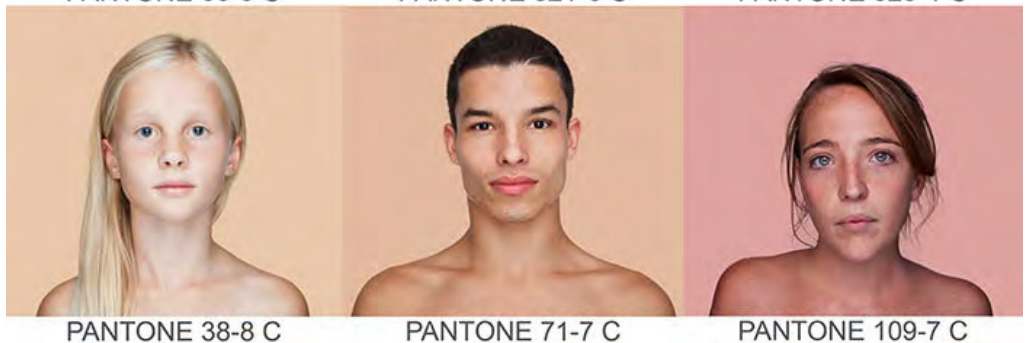

Fonte: PANTONE, https://www.pantone.com/pantone-skintone-guide.

FIGURA 96: Leque de cores, Skin Tone Guide, desenvolvido pela Pantone trazendo as tonalidades de pele.

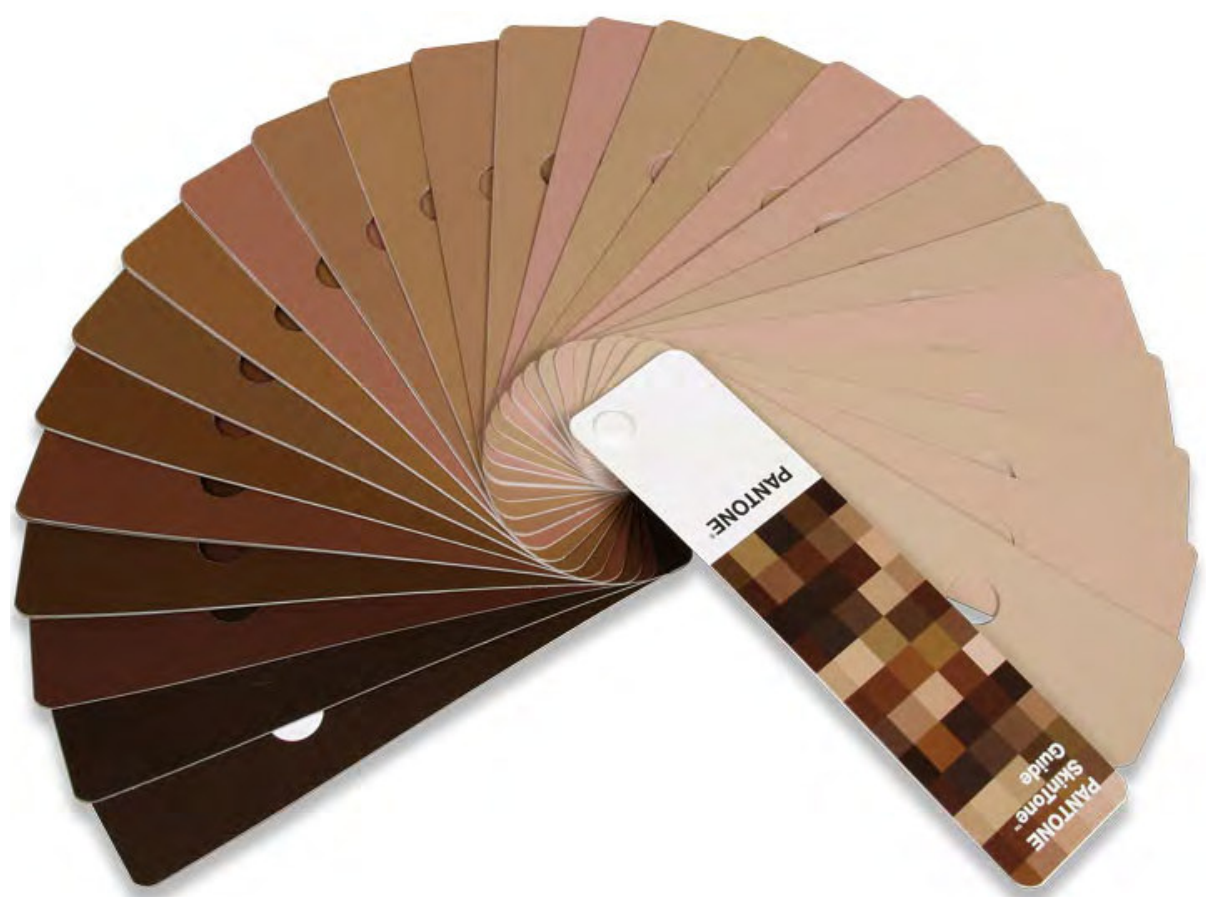

Fonte: PANTONE, https://www.pantone.com/pantone-skintone-guide 
Nas páginas iniciais desse mostruário, conforme apresentado nas figuras 97 e 98, existe uma representação da porção dentro do espaço de cores em que essas tonalidades estão conectadas em uma relação de luminosidade, saturação e matiz. Essas cores estão disponibilizadas entre os amarelos ("Y"), passando pelos laranjas ("YR") indo ao encontro dos vermelhos ("R").

FIGURA 97: Representações esquemáticas dos tons de pele desenvolvida pela Pantone.

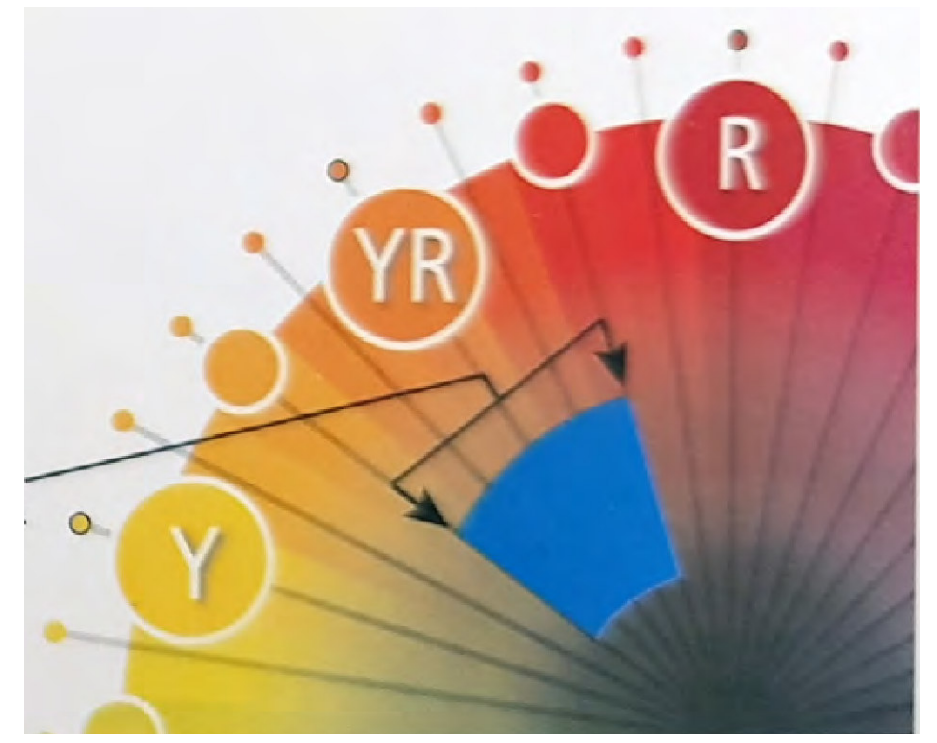

Fonte: SkinTone Guide, Pantone.

FIGURA 98: Representações esquemáticas colocadas no espaço tridimensional dos tons de pele desenvolvida pela Pantone.

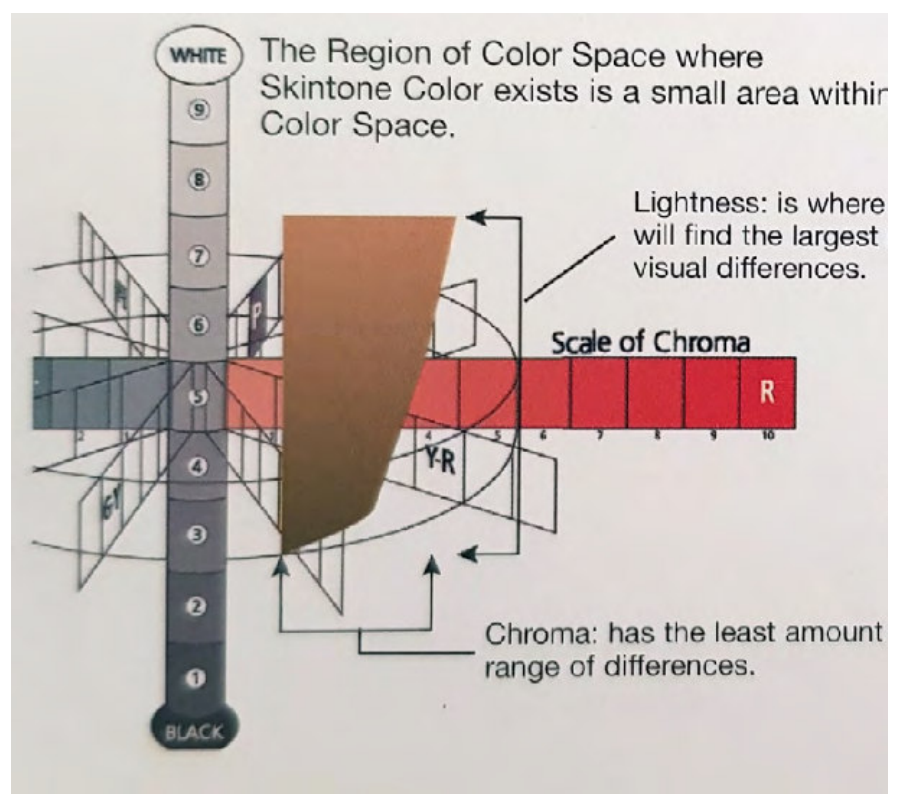

Fonte: SkinTone Guide, Pantone. 
Dessa forma, pelo estudo realizado pela Pantone (2011), os tons de pele pertencentes à raça humana estão, em sua maioria, no primeiro quadrante do espaço cromático, compreendidos pelos tons de amarelo, laranja e vermelho, que seriam predominantemente “quentes”. Todavia, conforme proposto por Itten (1961) é importante dizer mais uma vez que a noção de temperatura de cor é algo relativo, já que sua característica depende do contexto em que as cores estão inseridas. Além do mais, não há como afirmar que um tom vermelho, se comparado a um tom amarelo, torna-se mais frio. Como afirma Pastoureau (2014, p. 200):

\begin{abstract}
Em pura teoria, é óbvio que não existem cores quentes e cores frias. Tratase de uma mera questão de convenções - e as convenções variam com o tempo e com o espaço. Na Europa, na idade Média e no Renascimento, o azul passa assim por ser uma cor quente, por vezes mesmo por ser a mais quente de todas as cores. É só a partir do século XVII que ele vai progressivamente arrefecendo, e só no século XIX ganha o seu verdadeiro estatuto de cor fria (para Goethe, como vimos, é ainda em parte uma cor quente). Neste domínio, o anacronismo espreita o historiador em cada recanto do documento. Um historiador de arte, por exemplo, que num quadro no fim da Idade Média ou do Renascimento estudasse o modo como o pintor distribuiu as cores quentes e frias e tomar o azul pela cor fria que hoje é, enganar-se-ia redondamente.
\end{abstract}

Além disso, o que leva uma pessoa a ter predileção por cores mais "quentes" ou "frias" não se dá unicamente por uma motivação estética. É de fundamental importância que sejam considerados também os impulsos subjetivos que ajudam a determinar como os indivíduos se envolvem com as nuances e apresentam relação de predileções e preferências, como se vê na terceira etapa dessa segunda fase.

Ainda que sejam predominantemente "quentes", admite-se que, muitas vezes, algumas caraterísticas individuais, como alguma veia mais ressaltada ou olheiras, no que tange às suas colorações, por exemplo, podem estar em uma outra região do espaço de cores. Essa é uma leitura que deve ser feita, pois ela interfere na percepção visual e no resultado final.

É válido saliantar que, apesar de haver essas características como subtom de pele, não é aconselhável que sejam interpretadas, classificando o indivíduo como sendo "frios". Aqui é preciso analisar essas particularidades cromáticas, pois é dentro do subtom que tonalidades de pele podem se "deslocar" no círculo cromático, indo para a outra metade, ou seja, aparentando serem mais "frios".

Assim, poder-se-ia levar a conclusões que admitem temperaturas de peles mais frias que outras e que as veias existentes na face podem ter aspectos mais arroxeados, azulados ou 
esverdeados. Isso sim acarretaria um "esfriamento do aspecto visível da pele". Caso a pessoa tenha olheiras evidentes tendendo para essas tonalidades, isso também causaria esse "esfriamento". Outro aspecto que poderia contribuir para essa percepção visual seria o acinzentamento dos cabelos.

Mesmo havendo essas possibilidades causadas por subtons com características mais frias, como também cabelos com traços mais grisalhos, eles não podem ser considerados, quando se analisa cromaticamente o todo, frios, dividindo mecanicamente o espaço de cor. Isso porque a natureza cromática humana não é estática, mas sim completamente dinâmica e, predominantemente, os indivíduos se concentram no primeiro quadrante cromático. Nesse sentido, o que prevalece é a coloração geral da pele, e essa coloração tende, na maioria das vezes, para o "quente".

Ocorre que, não raro, esses aspectos, por mais que em termos de área, geralmente, são bem menores do que o resto da coloração do corpo, saltam aos olhos, chamando mais atenção se comparados com outras qualidades. Quando isso acontece, é preciso entender se a pessoa tem o hábito de usar maquiagem. Se sim, essas qualidades são atenuadas. Se não, é preciso orientar o indivíduo em como minimizar, caso haja essa vontade, tais condições.

Essas situações irão implicar nos estudos de Goethe (2011) e Chevreul (1987), isto é, nas cores fisiológicas produzidas pelo aparato visual humano e no contraste simultâneo de cor. Assim, uma pessoa com tons de pele mais avermelhados, em contato com tons mais distantes dessa parcela do círculo cromático, ou seja, mais diametralmente opostos, como os tons mais esverdeados ou azulados, só iriam ficar ainda mais com aspectos avermelhados e não o contrário. Dessa forma, se a intenção é deixar esse indivíduo com o aspecto "menos vermelho", ele deveria usar tons "mais quentes": vermelho, laranja e amarelo.

Para tanto, acredita-se que a forma mais adequada de realizar essa análise é tanto por comparação, utilizando o leque da Pantone Skin Tone Guide ao ser justaposto à face do indivíduo, como através do scanner de cores da NCS. Aqui, caso seja utilizado o material da Pantone, todas as tonalidades disponibilizadas no Skin Tone Guide foram traduzidas para os códigos NCS por serem a base desta tese, conforme está apresentado no quadro 7. 
QUADRO 7: Parte dos códigos do leque Skin Tone Guide traduzidos para o sistema NCS.

\begin{tabular}{|c|c|}
\hline Códigos Pantone SkinTone Guide & Códigos Natural Colour System \\
\hline $1 Y 01 \mathrm{SP}$ & 3010 Y50R \\
\hline $1 Y 02 \mathrm{SP}$ & 3010 Y50R \\
\hline $1 Y 03 \mathrm{SP}$ & 3010 Y50R \\
\hline $1 Y 04 \mathrm{SP}$ & 3010 Y50R \\
\hline $1 Y 05 \mathrm{SP}$ & 3010 Y40R \\
\hline $1 Y 06 \mathrm{SP}$ & 3020 Y $60 R$ \\
\hline $1 Y 07 \mathrm{SP}$ & 3020 Y $60 R$ \\
\hline $1 Y 08 \mathrm{SP}$ & 3020 Y $60 R$ \\
\hline $1 Y 09 \mathrm{SP}$ & 4020 Y50R \\
\hline $1 Y 10 \mathrm{SP}$ & 4020 Y50R \\
\hline $1 \mathrm{Y} 11 \mathrm{SP}$ & 5020 Y40R \\
\hline $1 \mathrm{Y} 12 \mathrm{SP}$ & 5020 Y40R \\
\hline $1 Y 13 \mathrm{SP}$ & 6020 Y30R \\
\hline $1 Y 14 \mathrm{SP}$ & 6020 Y70R \\
\hline $2 \mathrm{YO} 01 \mathrm{SP}$ & 3010 Y50R \\
\hline $2 \mathrm{YO} 2 \mathrm{SP}$ & 3010 Y50R \\
\hline $2 \mathrm{YO} 03 \mathrm{SP}$ & 3010 Y50R \\
\hline $2 \mathrm{YO} 4 \mathrm{SP}$ & 3010 Y50R \\
\hline $2 \mathrm{YO} 05 \mathrm{SP}$ & 3010 Y40R \\
\hline $2 \mathrm{YO} 06 \mathrm{SP}$ & 3020 Y70R \\
\hline $2 \mathrm{YO} 07 \mathrm{SP}$ & 3020 Y $60 R$ \\
\hline $2 \mathrm{YO} 08 \mathrm{SP}$ & 4020 Y50R \\
\hline $2 Y 09 \mathrm{SP}$ & 4020 Y50R \\
\hline $2 \mathrm{Y} 10 \mathrm{SP}$ & 4020 Y50R \\
\hline $2 \mathrm{Y} 11 \mathrm{SP}$ & 5020 Y $40 R$ \\
\hline $2 \mathrm{Y} 12 \mathrm{SP}$ & 5020 Y50R \\
\hline $2 Y 13 \mathrm{SP}$ & 6020 Y30R \\
\hline $3 Y 01 \mathrm{SP}$ & 3010 Y50R \\
\hline $3 \mathrm{YO} 2 \mathrm{SP}$ & 3010 Y50R \\
\hline $3 Y 03 \mathrm{SP}$ & 3010 Y50R \\
\hline $3 Y 04 \mathrm{SP}$ & 3010 Y50R \\
\hline $3 \mathrm{YO} 05 \mathrm{SP}$ & 3010 Y $40 R$ \\
\hline $3 \mathrm{Y} 06 \mathrm{SP}$ & 3010 Y40R \\
\hline $3 \mathrm{YO} 07 \mathrm{SP}$ & 3020 Y40R \\
\hline $3 Y 08 \mathrm{SP}$ & 4020 Y40R \\
\hline $3 Y 09 \mathrm{SP}$ & 4020 Y40R \\
\hline $3 Y 10 \mathrm{SP}$ & 5010 Y30R \\
\hline $3 Y 11 \mathrm{SP}$ & 5020 Y50R \\
\hline $3 Y 12 S P$ & 5020 Y30R \\
\hline $4 \mathrm{Y} 01 \mathrm{SP}$ & 2010 Y40R \\
\hline $4 \mathrm{YO} 2 \mathrm{SP}$ & 3010 Y30R \\
\hline $4 Y 03 \mathrm{SP}$ & 3010 Y50R \\
\hline
\end{tabular}

Fonte: a autora. 
Faz-se mister ressaltar que, como as tonalidades da pele não são uniformes, já que existe uma pluralidade de informações cromáticas contidas na face, se for comparado ou medido um único ponto ou região, pode ser insuficiente. Nessa etapa, é aconselhável que sejam analisadas algumas partes e confrontados os resultados.

O segundo passo seria analisar as tonalidades dos olhos. Aqui também a cor revelada é anotada e serve como guia. É indicado que as nuances sejam observadas através de uma lupa de aumento. Isso porque existem íris que possuem uma gama de cores complexa e observar através desse instrumento pode ajudar na compreensão. Além disso, é tênue a diferença entre o azul e o verde, por exemplo, ou até mesmo entre o verde e o castanho, portanto, ao ser ampliado, facilitaria a leitura. Mas no caso dos olhos não é indicado tentar medir com algum aparelho, como o scanner de cor, pois pode machucar o globo ocular. A figura 99 ilustra como poderia ser desenvolvida essa leitura da íris. 
FIGURA 99: Análise da coloração dos olhos.

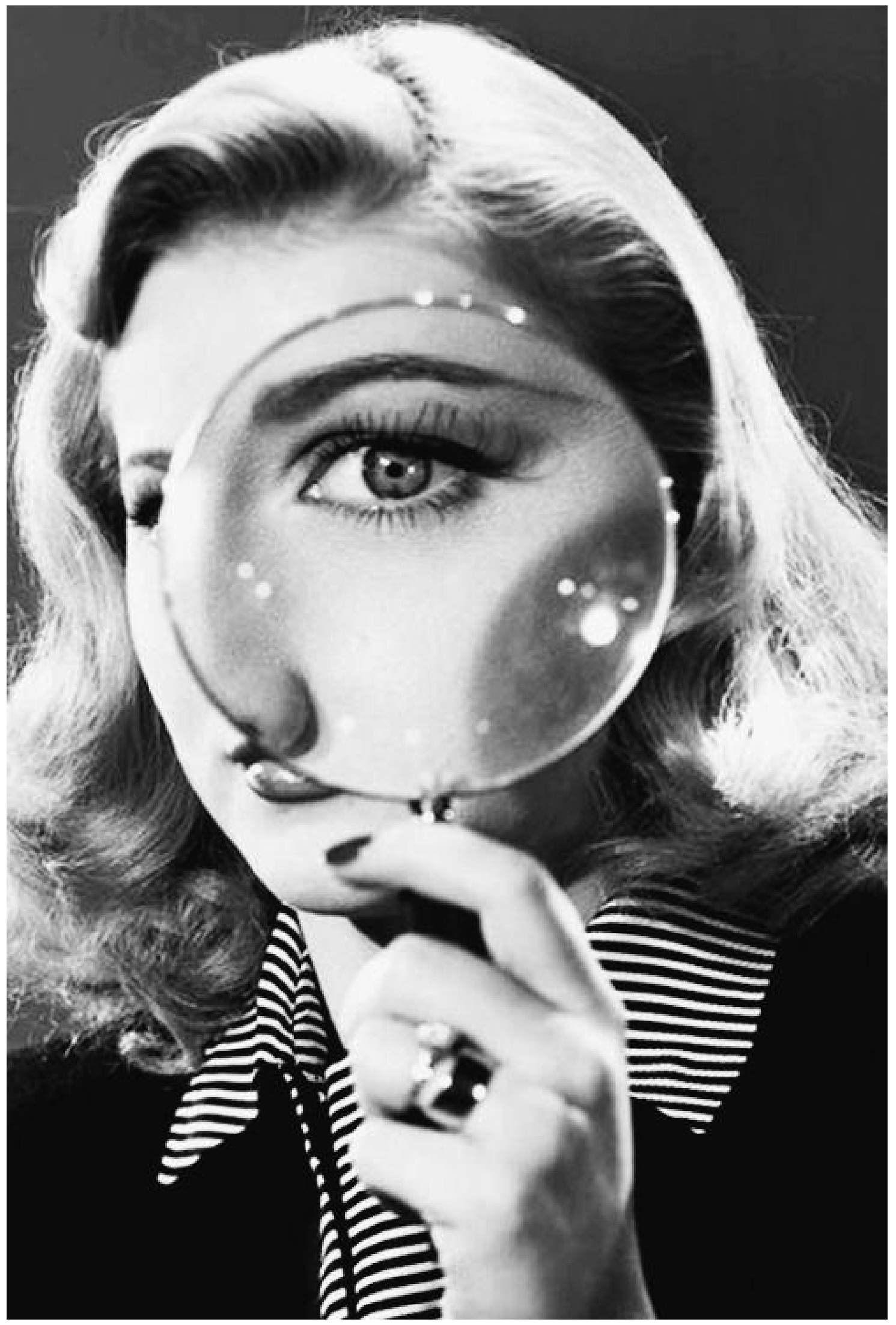

Fonte: PINTEREST, https://www.pinterest.com/pin/515732594827856452/ 
O terceiro passo é dedicado à coloração dos cabelos. Aqui, mesmo podendo haver cabelos com luzes ou reflexos os quais contêm mais de uma tonalidade, geralmente as pessoas possuem uma, duas ou três cores predominantes, o que deixa a cor dos cabelos mais uniforme se comparada ao tom da pele. Nessa parte, é recomendável que seja feita por comparação.

Para isso, dentro dessa metodologia, utilizou-se o catálogo da DiColore para ajudar nessa leitura, como está representado na figura 100.

FIGURA 100: Paleta de cores de cabelo DiColore desenvolvida para realização da leitura das tonalidades dos cabelos feita por comparação.

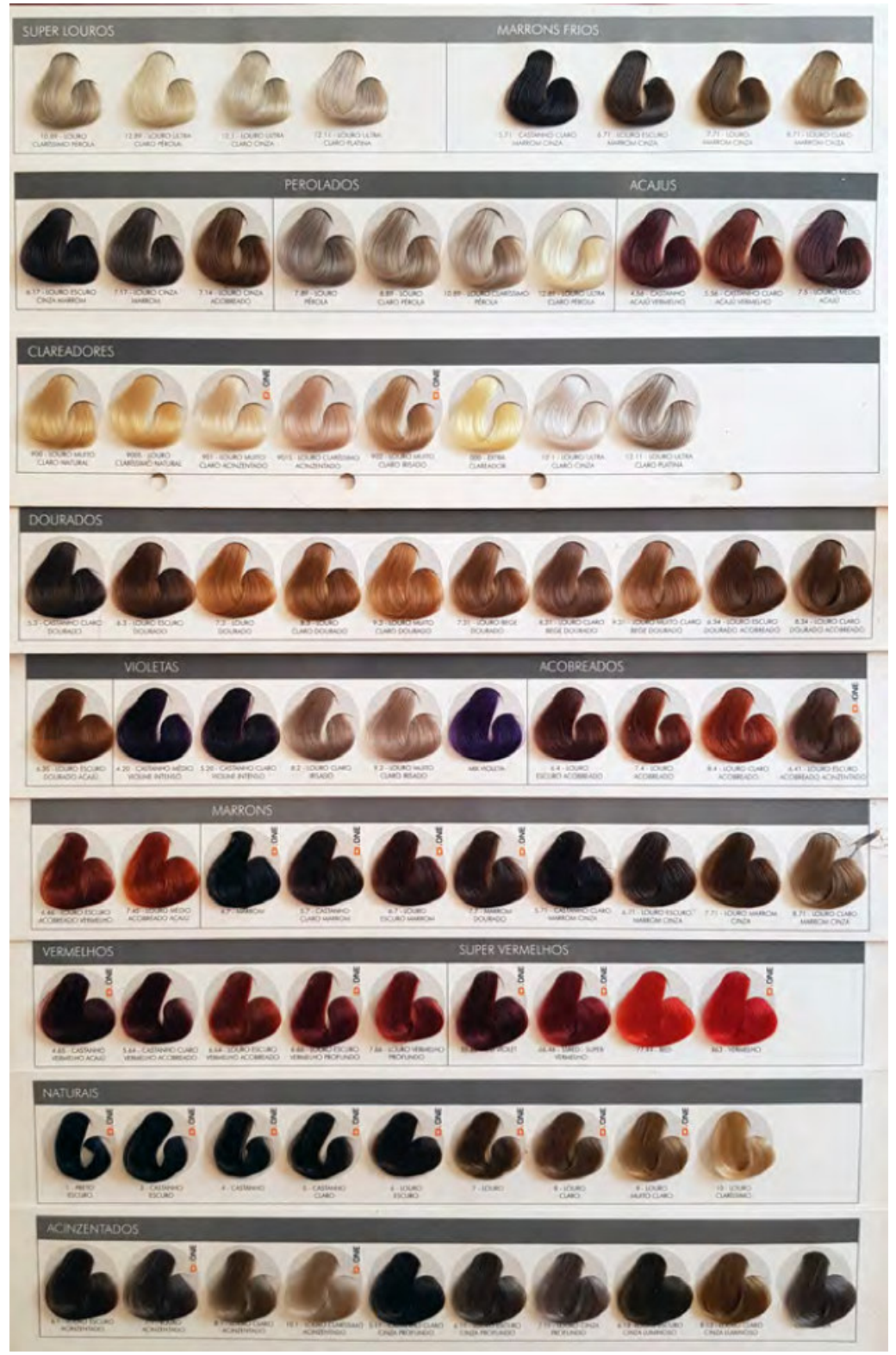

Fonte: catálogo DiColore. 
Para tanto, sugere-se que sejam aproximadas as amostras à cabeça e comparadas com a cor que mais se aproxima da cor do cabelo da pessoa. Todas as amostras foram também codificadas pelo sistema Natural Colour System (quadro 8) onde após realizada a análise é anotado o resultado.

QUADRO 8: Parte dos códigos do catálogo DiColore traduzidos para o sistema NCS.

\begin{tabular}{|c|c|}
\hline Nomenclatura DiColore & Códigos Natural Colour System \\
\hline Marrom 6.46 & 6030 Y70R \\
\hline Marrom 7.45 & 5040 Y7OR \\
\hline Marrom 4.7 & 8502 Y9OR \\
\hline Marrom 5.7 & 7010 Y9OR \\
\hline Marrom 6.7 & 8010 Y7OR \\
\hline Marrom 7.7 & 8010 Y6OR \\
\hline Marrom 5.71 & 8010 Y9OR \\
\hline Marrom 6.71 & 8005 Y5OR \\
\hline Marrom 7.71 & 8010 Y3OR \\
\hline Marrom 8.71 & 6020 Y2OR \\
\hline Vermelho 4.65 & $7020 \mathrm{R}$ \\
\hline Vermelho 5.64 & $7010 \mathrm{R}$ \\
\hline Vermelho 6.64 & 6040 Y9OR \\
\hline Vermelho 6.66 & 6030 Y9OR \\
\hline
\end{tabular}

Fonte: a autora.

Depois de realizadas todas as leituras e identificadas as tonalidades predominantes, elas podem ser agrupadas em três tipos de harmonias, conforme proposto pelo curso "A Cor na Estética Pessoal”, ministrado por Lilian Baros na Universo da Cor, em 2011. Elas trazem as características gerais da pessoa, ou seja, compostas pela síntese da Harmonia Objetiva ditada pelas colorações de pele, olhos e cabelos. Elas são: Harmonia Ouro, ou seja, com maior incidência de tons "amarelados", Harmonia Prata, com maior incidência de tons vermelhos e rosados, e Harmonia Mista ou Coringa, em que o indivíduo apresenta tanto tons dourados como tons rosados.

Esse fato vai determinar o resultado final, ou seja, a criação da cartela de cores, feita na terceira fase. Isso porque essas interpretações ajudam a definir uma paleta. Por fim, vale a 
pena dizer que, caso uma pessoa apresente Harmonia Ouro, ela pode se cercar de tons de azul, verde e roxo, assim como uma pessoa em que predomina a Harmonia Prata ou Mista.

Desse modo, essa etapa é baseada numa avaliação cuidadosa da cor natural - da pele, olhos e cabelos - o que ajuda a definir quais cores são mais complementares e vão ao encontro da própria coloração já existente em cada pessoa. Para tanto, foi desenvolvido o quadro 9.

É preciso considerar também que há nesse processo algo instintivo, por isso muitos sentem que algumas cores lhe cabem melhor do que outras, portanto a escuta ativa por parte de quem está elaborando a análise pode ser de grande valia (SHERLOCK; SPILLANE, 1995).

QUADRO 9: Análise da Harmonia Objetiva.

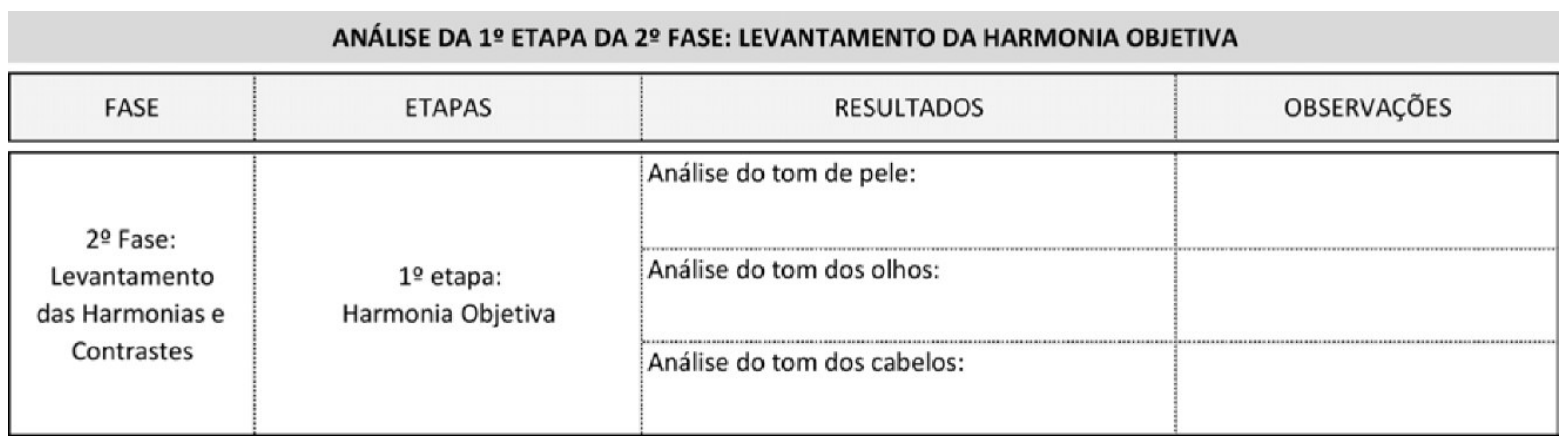

Fonte: a autora.

\subsubsection{Análise dos Contrastes}

Feita a primeira etapa da segunda fase, pode ser dado início à segunda etapa da segunda fase. É aqui que é entendido qual o nível de contraste com o objetivo de entender se a pessoa deseja enfatizar ou destacar cromaticamente, aumentando ou diminuindo essa relação, ou se deseja permanecer com a mesma intensidade. Para tanto, os contrastes foram divididos em baixo, médio e alto. Os itens analisados são os mesmos da fase anterior, compreendida pela coloração da pele, olhos e cabelos, acrescentando aqui as tonalidades das sobrancelhas, cílios e barba, caso haja.

Se o indivíduo se relaciona de forma positiva e tranquila com seus próprios contrastes, 
não precisa ser proposta nenhuma alteração. Todavia, caso a pessoa queira enfatizar algum ponto, pode ser sugerida uma mudança na cor dos cabelos, deixar a barba crescer, delinear as sobrancelhas, entre outras alternativas que sejam condizentes com as realidades individuais. Essas informações devem ser anotadas conforme proposto pelo quadro 10.

QUADRO 10: Análise dos Contrastes.

\begin{tabular}{|c|c|c|c|}
\hline \multicolumn{3}{|c|}{ ANÁLISE DA 2 } & FASE: LEVANTAMENTO DOS CONTRASTES \\
\hline FASE & ETAPAS & RESULTADOS & OBSERVAÇÕES \\
\hline $\begin{array}{c}\text { 2o Fase: } \\
\text { Levantamento } \\
\text { das Harmonias e } \\
\text { Contrastes }\end{array}$ & $\begin{array}{c}\text { 2o etapa: } \\
\text { Contrastes }\end{array}$ & & \\
\hline
\end{tabular}

Fonte: a autora.

\subsubsection{Análise da Harmonia Subjetiva}

Apesar de a luz e o aparato visual humano - que são elementos exteriores - comporem o estímulo visual, podemos dizer que a cor não depende somente do mundo externo, "mas também pode ter sua origem através do poder da imaginação do nosso mundo interior" (MAHNKE, 1996, p. 7), já que a percepção das cores "não é apenas um mecanismo de ver, mas também uma sensação que ativa simultaneamente os nossos pensamentos e nosso mecanismo cognitivo" (MAHNKE, 1996, p. 7).

Com base nessa afirmação, considera-se que existem outros fatores que contribuem para a formação da sensação cromática, visto que todo estímulo de cor recebido do mundo exterior está diretamente conectado com a mente de cada indivíduo, ou seja, a psique humana. Portanto, a cor que é experimentada e percebida está relacionada a alguns aspectos atrelados à vivência e à formação particular de cada pessoa, como, por exemplo, aspectos fisiológicos, simbólicos, culturais, associativos, emocionais e psicológicos, que, por fim, vão agregar valor à informação luminosa recebida (MAHNKE, 1996).

Tanto que, são comuns estudos e pesquisas elaborados por psicólogos e especialistas que buscaram desenvolver um esquema de significação das cores. Porém, observa-se que 
essa prática teve seu início desde a Antiguidade na tentativa de dar algum sentido psicológico às tonalidades (FARINA, 1982).

Muitas vezes, essas propostas foram ao encontro das harmonias da natureza, tendo na cor "a chave para o eu", tentando propor uma maneira de entender exatamente o indivíduo e desviar da possível rigidez, que pode ser oriunda tanto dos fatores externos como internos, para se conectar com as energias que permitem ser os mesmos. Para Jackson (1982), quanto mais se pode aceitar as mensagens coloridas nos ritmos do universo, mais autênticas e satisfeitas se tornam as pessoas. Segundo a autora (1982, p. 38):

\begin{abstract}
A teoria da cor foi inspirada nos estudos do artista e colorista Johannes Itten da famosa escola Bauhaus na Alemanha. Ele descobriu o poder da coloração física em dirigir a escolha de cores de um aluno em suas pinturas. Ele observou que as escolhas de cores pessoais eram consistentemente aquelas compatíveis com o tom de pele, cabelos e olhos, tanto em tom quanto em intensidade. Depois de anos de observação e documentação, ele enfaticamente declara em seu livro Os Elementos da Cor (página 27), que "Todos deve saber que cores são melhores para ele; essas sempre serão suas cores subjetivas e seus complementos...". Então Itten concluiu que nossa paleta pessoal, aquela em que somos naturalmente, consiste nas mesmas cores que ficam melhores em nós.
\end{abstract}

Isso porque é sabido que o homem desempenha melhor suas funções quando se sente bem física e mentalmente (BIRREN, 1978). A aplicação da cor à vida tem, portanto, um significado real que serve tanto como benefícios de propósitos simples quanto elevados, e que é tão vital para o lado físico do ser quanto para o mental, para o emocional e para a psique.

Dessa forma, Johannes Itten propôs, nas aulas dadas na Bauhaus, que as escolhas cromáticas estavam relacionadas com os anseios individuais e representavam traços de personalidade que ele denominou como sendo timbre subjetivo em que a preferência por cores poderia ser, entre tantas outras coisas, uma pista da individualidade (ITTEN, 1970).

Assim, concordando com a colocação de Itten, a análise da harmonia subjetiva proposta por esta tese foi embasada pelos tipos psicológicos introvertido e extrovertido, apresentados por Jung, e as quatro funções psíquicas que a consciência usa para fazer o reconhecimento do mundo exterior para, a partir daí, buscar um caminho e uma orientação. As quatro funções são determinadas pelo ego e desempenham relações psicológicas à medida que fornecem ao sujeito habilidades, aptidões e tendências no relacionamento do indivíduo consigo mesmo e com o mundo ao redor (JUNG, 1970). Essa fase foi dividida em quatro passos que seguem relacionadas a seguir. 
O primeiro passo dessa fase seria cercar o indivíduo e para isso foi criada uma nomenclatura para a Harmonia Subjetiva conforme proposto pelo quadro 11.

QUADRO 11: Tipos Psicológicos e nomenclatura proposta para a Harmonia Subjetiva.

\begin{tabular}{|c|c|}
\hline Nomenclatura Tipos Psicológicos & Nomenclatura Harmonia Subjetiva \\
\hline Sensação & Leveza \\
\hline Intuição & Profundidade \\
\hline Pensamento & Impacto \\
\hline Sentimento & Sutileza \\
\hline
\end{tabular}

Fonte: a autora.

Aqui, foi desenvolvido também um gráfico, a exemplo do que foi apresentado na pelo quadro 3, mas agora contendo também as denominações apresentadas pela Harmonia Subjetiva. 
QUADRO 12: Harmonias Subjetivas relacionadas aos Tipos Psicológicos sobreposto ao espaço de cor NCS.

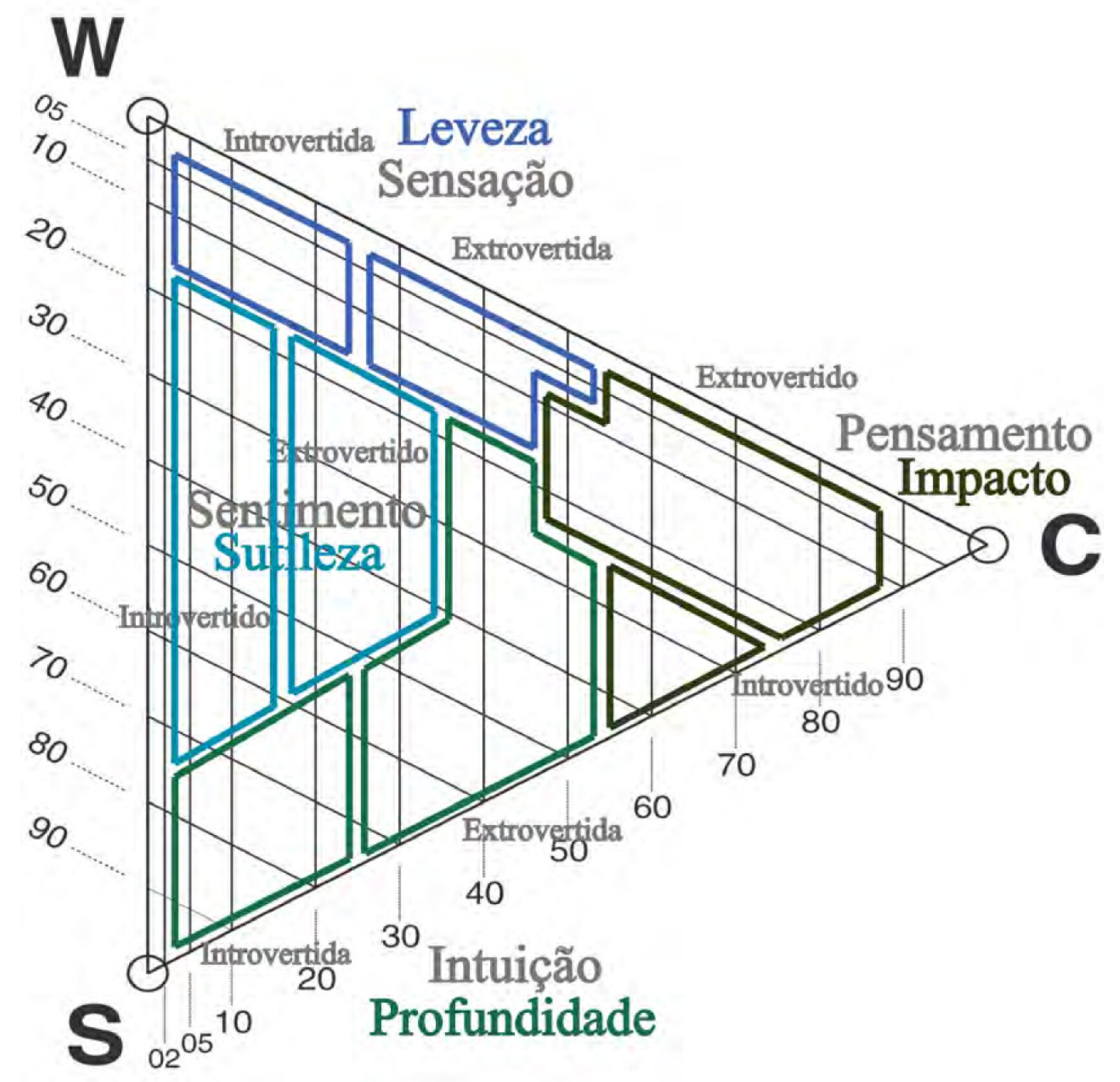

Fonte: A autora.

Na região superior do triângulo NCS "W”, estão as tonalidades mais claras, ou seja, com alta luminosidade. Já a saturação aumenta à medida que as nuances se deslocam para a direita no sentido do "C". Essa parte recebeu o nome Leveza e está relacionada ao tipo Sensação extrovertido e introvertido.

Na parte central dessa representação, as tonalidades têm uma luminosidade média e são mais dessaturadas, mais atenuadas e mais reservadas. Por essa razão, elas podem facilmente mudar de característica ao caminhar no sentido horizontal e ir em direção ao "C", quebrando, assim, o silêncio inicial. Neste caso, prevalece um novo julgamento sobre as 
qualidades cromáticas. Essa parcela foi nomeada por Sutileza e relaciona-se com o tipo Sentimento introvertido e extrovertido.

Na parte inferior mais acerca do "S" da representação NCS, estão as cores com menos luminosidade, as mais escuras. Já a saturação aumenta à medida que se aproxima do "C". Aqui, a Harmonia Subjetiva Profundidade tem conexão com o tipo Intuição introvertido e extrovertido. Já, quanto mais na ponta à direita do triângulo "C", as nuances apresentam luminosidade média e maior saturação, sendo intensas e fortes. Essa região foi nomeada por Harmonia Subjetiva Impacto e há uma proximidade com o tipo Pensamento introvertido e extrovertido. Para tanto, segue o Quadro 13, que demonstra a interação entre as nomenclaturas definidas por essa tese relacionadas com as características dos Tipos Psicológicos proposto por Jung (1971).

QUADRO 13: Integração entre as Harmonias Subjetivas com os Tipos Psicológicos de Jung.

\begin{tabular}{l}
$\begin{array}{c}\text { Harmonia } \\
\text { Subjetiva }\end{array}$ Funções \\
\begin{tabular}{|c|c|l|l|l|}
\hline Leveza & Sensação & $\begin{array}{l}\text { Está conectada com a percepção de fatos externos onde as informações que alguma coisa existe chega através dos } \\
\text { sentidos constatando o que realmente está presente. } \\
\text { São práticos e realistas, gostam de conservar o funcionamento das coisas e vivem no tempo presente. } \\
\text { Acreditam nos fatos, no real e no concreto e apresenta leveza para lembrar de tudo o que sucedeu. }\end{array}$ & Introvertido \\
\hline Sutileza & Sentimento & $\begin{array}{l}\text { Avalia as coisas com sutileza e estabelece um julgamento com base nos própprios valores ou até mesmo nos valores dos } \\
\text { outros apresentando uma avaliação e não uma emoção. Mesmo que a tomada de decisão não apresente lógica } \\
\text { aparente mediante a circunstância criada, esse grupo tende a ponderar os sentimentos, propondo uma harmonia e } \\
\text { um equilibrio. }\end{array}$ & Introvertido \\
\hline Profundidade & Intuição & $\begin{array}{l}\text { A percepção se dá através do inconsciente e não mais dos sentidos se apresentando por meio de premonições, } \\
\text { instintos e feelings. Essa função procura a profundidade dos significados através do todo e não das partes, e, por isso, } \\
\text { costuma apresentar dificuldade na percepção de detalhes. }\end{array}$ & Introvertido \\
\hline Impacto & Eentrovertido \\
\hline & $\begin{array}{l}\text { Vincula valor ao que realmente está presente através de um conceito e apresentando uma linha de conduta lógica e } \\
\text { racional dos impactos que aconteceram. Através do julgamento, classificação e segregação, define os fatos sem } \\
\text { vincular a nenhum valor afetivo, emocional e pessoal. Como são movidos pela razão, geralmente são imparciaias não } \\
\text { se vinculando a nenhuma situação pois estabelecem padrões de conhecimento de forma intelectual. }\end{array}$ & Introvertido \\
\hline
\end{tabular} \\
\hline
\end{tabular}

Fonte: A autora.

Assim, cada uma dessas quatro classificações destinadas à Harmonia Subjetiva tem uma equivalente entre as quatro funções apresentadas por Jung (1971) e os tipos psicológicos introvertidos e extrovertidos.

Nessa parte, deveria ser perguntado como ela acredita que é seu posicionamento perante o mundo, ou seja, qual das funções e tipos elencados mais a definem. Essa forma de abordar o indivíduo foi pensada porque, como afirmado por Itten (1970) cada indivíduo tem ele próprio conhecimento da sua natureza, mesmo que de forma inconsciente.

Contudo, essa maneira de abordar não apresenta uma previsão do futuro, nem um inventário de personalidade, nem serve como um meio de realizar uma espécie de teste 
psicológico e, muito menos, uma análise da psique individual. Na verdade, busca uma orientação rápida para que o próprio indivíduo possa posicionar-se perante as cores elencadas e apontar qual das amostras apresenta o campo vibracional com o qual mais ele consegue se conectar.

No segundo passo desta fase, deveriam ser apresentados para a pessoa alguns padrões de cores que foram agrupados por saturação e luminosidade contendo cada um dos oito modelos as mesmas nuances no que tange ao matiz. Isso porque, geralmente, as pessoas, com exceção das que apresentam alguma anomalia visual ou psíquica, veem na cor um meio de expressão simples. Além disso, como o envolvimento é uma forma de comunicação instantânea e de fácil acesso, ao mostrar a vibração cromática que mais se aproxima das suas próprias convicções, colaboram para o objetivo final desse método.

Naturalmente, a vibração cromática que mais está relacionada com seus próprios anseios deve ser aquela que é apontada quando lhe são apresentadas as amostras. Assim, como exemplo, o código NCS B50G foi usado nas oito amostras, mas o que foi alterado foi a relação dos outros dois atributos de cores, sendo que em uma foi usada 1005 B50G, na outra 1020 B50G, na outra 5030 B50G, na outra 3050 B50G, e assim por diante. A figura 101 ilustra essas paletas de cores. 
FIGURA 101: Amostras de cores, Leveza, Sutileza, Profundidade e Impacto, relacionadas às preferências subjetivas agrupadas por saturação e luminosidade.

\section{Leveza}
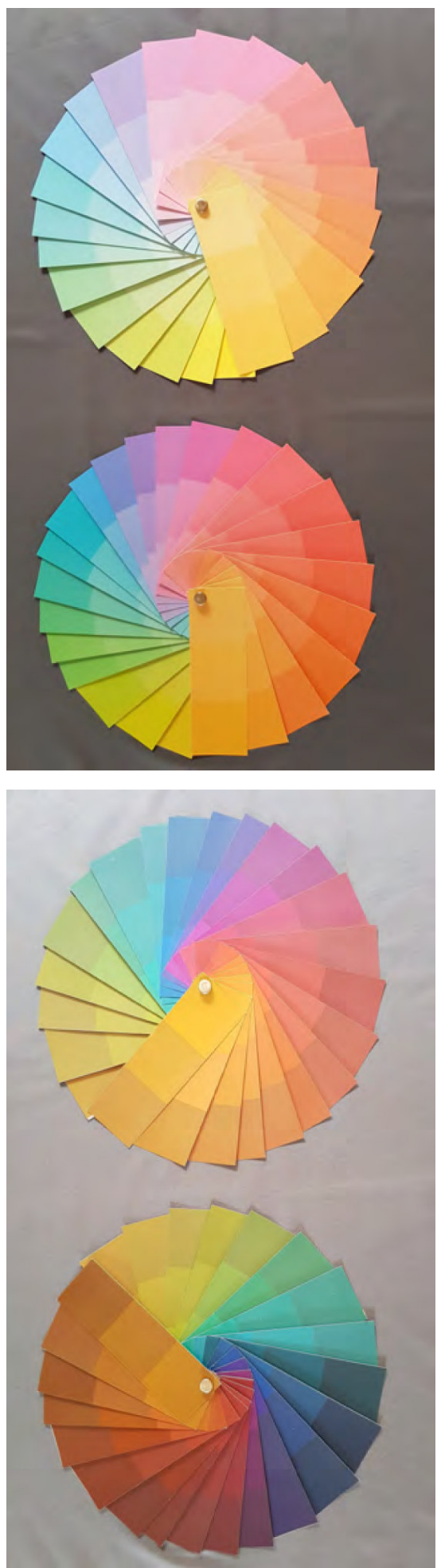

Profundidade
Sutileza
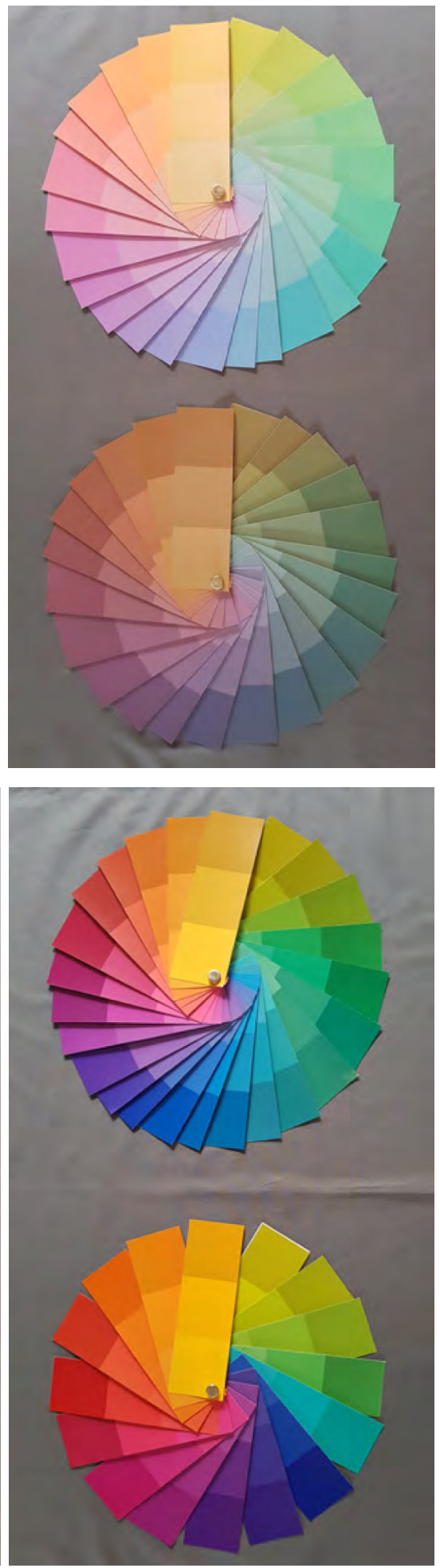

Impacto

Fonte: a autora. 
Aqui, é completamente possível uma resposta que revele tonalidades em algumas das amostras da qual ele gosta e é capaz de usar, mas ele também pode dizer que gosta de todas, porém não consegue estabelecer uma conexão com nenhuma. O importante é definir, após ser impactado pelas oito seleções montadas, qual delas é a que mais lhe causa agrado e simpatia, mesmo ele tendo capacidade de usar tons das outras paletas, como também ter dificuldade de incorporar qualquer uma das tonalidades.

Feito isso, o terceiro passo seria desenvolver uma sobreposição dos resultados obtidos no primeiro e segundo passos para verificar se as opções cromáticas vão ao encontro de como o indivíduo se posiciona perante ambos. Essa interpretação vai implicar o desenvolvimento da paleta de cores, que é o resultado final e objetivo deste trabalho.

Aqui, é admissível o indivíduo classificar-se como sendo um tipo psicológico que está referenciado com uma parcela do espaço de cores e tenha escolhido uma outra parcela de cores no segundo passo. Por exemplo, pode ser que ele tenha-se classificado como o tipo Sentimento, mas a preferência de cores contidas nas oito amostras seja pela vibração Profundidade. Outras vezes, é possível que a pessoa se classifique como o tipo psicológico Pensamento, mas sua opção cromática dentro das amostras selecionadas seja pelos tons mais neutros da parte referente à Harmonia Sutileza.

Esse fato vai ao encontro do que Jung (1971) definiu como sendo a função dominante, isto é, a forma mais eficiente de expressão individual e tem por objetivo caracterizar o Tipo Psicológico do indivíduo. Cada um utiliza preferencialmente sua função principal, a fim de obter melhores resultados que expressem mais facilmente sua existência. Além disso, existe também a função secundária ou subordinada, que também ajuda a designar esse indivíduo (SILVEIRA, 1981).

Dessa forma, tanto quando há, ou não, sobreposição entre os campos cromáticos escolhidos no primeiro e segundo passo, é legítimo. Isso porque uma escolha pode estar subordinada à outra, tendo uma função dominante, e uma outra, que é subordinada ao tipo principal. Porém, quando há uma diferença entre a escolha por determinado tipo psicológico e a vibração cromática escolhida como preferida, esse fato deve ser considerado, e as cores dessas duas regiões devem ser representadas na paleta.

Como síntese para esse terceiro passo, é aconselhado que se coloquem diante da pessoa algumas amostras de tecidos coloridos para que ela sinta o resultado das fases anteriores e visualize a região ou as regiões eleitas como pertencentes a ele próprio. Aqui, ao entrar em contato direto com determinadas frequências, vários estados emocionais podem 
ser despertados e acionados. Com isso, pode haver a possibilidade de alguns indivíduos caírem no choro ou algumas pessoas abrirem um sorriso e dizer: "é isso".

O quarto e último passo dessa etapa que necessita ser entendida é considerar as respostas dadas na primeira fase da segunda etapa quanto à postura do indivíduo frente à tendência e moda. Para tanto, consideram-se as classificações desenvolvidas por Everett Rogers (ROGERS apud SANTOS, 2013), com a Teoria da Difusão de Inovações, como sendo Inovadores, Primeiros Adotantes, Maioria Inicial, Maioria Tardia e Retardatários, ou por Henrik Vejlgaard (2008), com o Modelo de Tendência em Forma de Diamante, como sendo Criadores de Tendência, Formadores de Opinião, Seguidores de Tendência, Pessoas Menos Convencionais, Pessoas Convencionais, Pessoas Mais Convencionais e Conservadores.

Isso porque os três primeiros de ambos os modelos citados acima geralmente têm mais facilidade de incorporar cores provenientes do mundo externo e relacionarem-se tranquilamente com tais sugestões. Já os outros apresentam maiores resistências, não sendo fácil incorporar os modelos cromáticos provenientes do mundo exterior.

Assim, caso a pessoa apresente abertura para incorporar cores lançadas, esse fato deve ser trazido para dentro da paleta de cores. Porém, como cada ano o mercado destinado a esse setor lança novas tendências cromáticas, com variadas saturações e luminosidades, não há como prever qual cor será a próxima e, consecutivamente, qual cor deveria entrar na cartela.

O que é recomendado fazer é orientar o indivíduo quanto ao posicionamente dele frente às tonalidades provenientes do mundo externo e sua própria facilidade em lidar com isso. Caso o indivíduo seja mais conservador, não tendo muita abertura em incorporar cores provenientes do ambiente exterior, nenhuma cor precisaria ser adicionada nessa parte. Aqui, foi desenvolvido o quadro 14 com a síntese dessa parte. 
QUADRO 14: Análise da Harmonia Subjetiva.

\begin{tabular}{|c|c|c|c|}
\hline \multicolumn{4}{|c|}{ ANÁLISE DA $2 \circ$ FASE: LEVANTAMENTO DA HARMONIA SUBJETIVA } \\
\hline FASE & ETAPAS & RESULTADOS & OBSERVAÇÕES \\
\hline \multirow{4}{*}{$\begin{array}{c}\text { 20 Fase: } \\
\text { Levantamento } \\
\text { das Harmonias e } \\
\text { Contrastes }\end{array}$} & \multirow{4}{*}{$\begin{array}{c}\text { 3 etapa: } \\
\text { Harmonia Subjetiva }\end{array}$} & Análise dos tipos psicológicos: & \\
\hline & & Análise da saturação e luminosidade: & \\
\hline & & Análise se há cores principais e subordinadas: & \\
\hline & & Informações relevantes obtidas acima: & \\
\hline
\end{tabular}

Fonte: a autora.

\subsection{Processo de Criação de Paletas de Cores}

Depois de realizadas todas as interpretações necessárias, deve ser iniciada a terceira e última fase, que é a síntese das duas fases anteriores e destinada à criação de paletas de cores. Como cada ser humano é único, cada paleta de cores também o é. Dessa forma, por ser altamente expressiva e por suas possibilidades de associações que cada indivíduo consegue estabelecer, a cor implica em estados afetivos de sentimento e significado, quando proposta de forma consciente - no lugar de ser arbitrária e gratuita devido a um uso incoerente -, passando a assumir uma expressão extremamente importante, o que contribui, junto com outros fatores, para a sensação de identificação, bem-estar, conforto e harmonia (BIRREN, 1978).

Para tanto, nessa fase, entende-se que, para uma pessoa, a cartela seja iniciada pelas cores referentes à Harmonia Objetiva e, para outra, pelas cores preferíveis devido à possível insegurança de "sair desse lugar". Pode ser que uma outra ainda tenha seu início pelas cores levantadas pela análise da Harmonia Subjetiva, pois há um grande desejo de se conectar com sua essência.

Assim, a maneira como é montada a cartela pode variar entre um e outro indivíduo, e não só a maneira de fixar as cores, como também a quantidade de tonalidades disponíveis. Porém, o que não é recomendado é a cartela não representar todas as fases, etapas e passos colocados por essa pesquisa, em que se sugere levar em consideração o conteúdo abordado, 
pois ele é de extrema valia e direcionador de uma construção de cores de forma objetiva e metodológica.

Dessa forma, essa pesquisa não acredita que existam paletas de cores "prontas" que foram executadas anteriormente e apenas repassadas ao indivíduo como forma de ilustrar suas tonalidades. Isso porque esse jeito de interpretação pode ser falho e não leva em consideração nem a individualidade, nem o modo como cada ser se coloca perante o mundo.

Outro fator importante é que uma paleta feita hoje tem seu tempo de durabilidade e permanência diferente de indivíduo para indivíduo. Pode ser que um consiga se relacionar com as tonalidades por cerca de 10 anos e que outro fique 20 anos. Esse tempo vai depender das várias condicionantes e acontecimentos que impactam a vida e a sociedade. Isso vai ao encontro do que foi colocado por Vejlgaard (2008, p. 77):

\begin{abstract}
A aparência muda à medida que envelhecemos e obtemos mais experiência de vida ("estive lá, fiz isso"), e isso normalmente altera nossas necessidades, mas não a personalidade em si. Quando os criadores de tendências envelhecem, eles compram produtos diferentes daqueles que compraram quando eram jovens (...).
\end{abstract}

Assim, todas as filipetas de cores foram feitas em tecido de algodão e foram classificadas segundo o sistema NCS. Elas ficam soltas e foram agrupadas conforme as quatro regiões anteriormente apresentadas. Dessa forma, a primeira fileira está composta pelas cores referentes à Leveza; a segunda fileira pertence às cores classificadas como Sutileza; a terceira, à Profundidade e a quarta, a Impacto. A figura 102 traz esse agrupamente de cores. 
FIGURA 102: Painel de cores feito em tecidos agrupados por Leveza, primeira fileira, Sutileza, segunda fileira, Profundidade, terceira e Impacto, quarta.

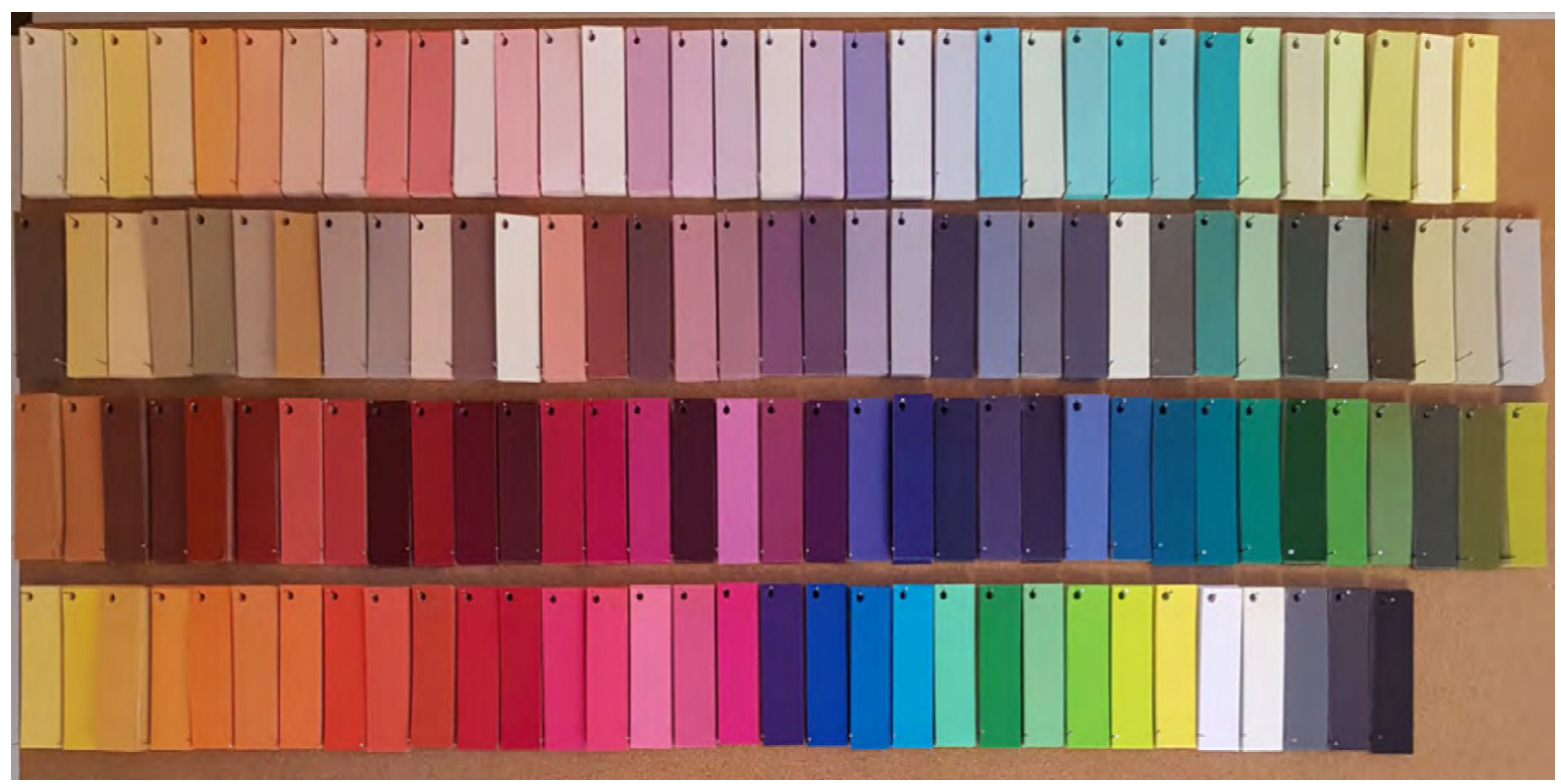

Fonte: a autora.

Como não se trata de manter uma divisão por temperatura de cores, em cada um dos quatro grupos, como observa-se na figura acima, é possível conter tons de amarelo, laranja, vermelho, azul e verde. O que difere cada uma dessas quatro faixas são os atributos de saturação e luminosidade conforme já exposto pelo quadro 13.

Nesse momento, depois de todas as análises, respostas e interpretações já terem sido elaboradas, foi criado um quadro resumo que é preenchido com as informações coletadas e que auxilia na criação da paleta de cores como colocado pelos quadros 15 e 16 . 
QUADRO 15: Síntese das respostas obtidas na primeira e segunda fases.

\begin{tabular}{|c|c|c|c|}
\hline \multicolumn{4}{|c|}{ MÉTODO DE ESPECIFICAÇÃO CROMÁTICA PARA A EXPRESSÃO HUMANA INDIVIDUAL } \\
\hline FASES & ETAPAS | PARTES & RESULTADOS & OBSERVAÇÕES \\
\hline \multirow{2}{*}{$\begin{array}{c}\text { 10 Fase: } \\
\text { Estratégia Inicial }\end{array}$} & $\begin{array}{l}\text { 10 etapa: } \\
\text { Email }\end{array}$ & Informações relevantes: & \\
\hline & $\begin{array}{c}\text { 20 etapa: } \\
\text { Questionário }\end{array}$ & Preferências: & \\
\hline \multirow{8}{*}{$\begin{array}{c}\text { 20 Fase: } \\
\text { Levantamento } \\
\text { das Harmonias e } \\
\text { Contrastes }\end{array}$} & \multirow{3}{*}{$\begin{array}{c}\text { 19 etapa: } \\
\text { Harmonia Objetiva }\end{array}$} & Análise do tom de pele: & \\
\hline & & Análise do tom dos olhos: & \\
\hline & & Análise do tom dos cabelos: & \\
\hline & $\begin{array}{l}\text { 20 etapa: } \\
\text { Contrastes }\end{array}$ & Análise dos contrastes: & \\
\hline & \multirow{4}{*}{$\begin{array}{c}3^{\circ} \text { etapa: } \\
\text { Harmonia Subjetiva }\end{array}$} & Análise dos tipos psicológicos: & \\
\hline & & Análise da saturação e luminosidade: & \\
\hline & & Análise se há cores principais e subordinadas: & \\
\hline & & Informações relevantes obtidas acima: & \\
\hline
\end{tabular}

Fonte: a autora.

QUADRO 16: Síntese cromática para a seleção de cores das paletas.

\begin{tabular}{|c|c|c|c|}
\hline \multicolumn{4}{|c|}{ SÍNTESE CROMÁTICA: MÉTODO DE ESPECIFICAÇÃO CROMÁTICA PARA A EXPRESSÃO HUMANA INDIVIDUAL } \\
\hline \multirow{4}{*}{$\begin{array}{c}\text { 3ํ Fase: } \\
\text { Criação de Paleta } \\
\text { de Cores }\end{array}$} & $\begin{array}{l}1 \text { 1ำ parte: } \\
\text { Preferências cromáticas }\end{array}$ & Cores selecionadas: & \\
\hline & $\begin{array}{c}2 \% \text { parte: } \\
\text { Harmonia Objetiva }\end{array}$ & Cores selecionadas: & \\
\hline & $\begin{array}{l}\text { 3\% parte: } \\
\text { Harmonia Subjetiva Principal }\end{array}$ & Cores selecionadas: & \\
\hline & $\begin{array}{c}\text { 30 parte: } \\
\text { Harmonia Subjetiva Subordinada }\end{array}$ & Cores selecionadas: & \\
\hline
\end{tabular}

Fonte: a autora. 
De maneira geral, recomenda-se que as paletas sejam divididas em três partes conforme os caminhos percorridos pelas três fases trabalhadas nos tópicos acima.

A primeira parte pode estar destinada às predileções e às preferências cromáticas que impactam, de alguma maneira, o indivíduo, pois nela são respeitadas essas opções e legitimada a sua existência. Aqui são trazidas as respostas dadas para as três primeiras perguntas do quadro 5, "Relação de perguntas sugeridas para a segunda etapa da primeira fase". E nessa parte também que podem ser consideradas e acresentadas algumas tonalidades, caso o indivíduo tenha abertura para incorporar as cores de tendência e da moda. Para essa seção, indica-se considerar de três a cinco tons.

Já a segunda parte é a síntese de cores referente à Harmonia Objetiva Ouro, Prata ou Mista. Aqui, na maioria das vezes, são colocadas de três a cinco tonalidades que mais beneficiam e estão em harmonia com as tonalidades de pele, olhos e cabelos. É também indicado explicar os efeitos visuais que podem ocorrer conforme as condicionantes existentes no universo particular do indivíduo. Por exemplo, se a pessoa está conectada com a Harmonia Ouro, que contém traços mais dourados, sugere-se trazer tonalidades que realcem essas condicionantes. Já se está mais ligada à Harmonia Prata e possui marcas de espinha, devem ser colocadas cores que "diminuem" tais características. Esse mesmo raciocínio é feito para a Harmonia Mista na qual as cores elencadas têm a intenção de harmonizar com as características de pele, olhos e cabelos.

Por último, a terceira parte é destinada à Harmonia Subjetiva na qual geralmente são colocadas quinze a vinte tonalidades. Porém, como o indivíduo pode ter sido classificado em um tipo psicológico, mas apresenta preferência por outra área do espaço de cores, nesses casos, essa parte deve ser dividida em Harmonia Subjetiva Dominante e Harmonia Subjetiva Subordinada, podendo cada uma receber dez tonalidades. Os quadros 17, 18, 19 e 20 e as figuras 103, 104, 105 e 106 sugerem, como síntese desta tese, a criação de paletas de cores voltadas para a expressão individual. 
QUADRO 17: Quadro síntese.

\begin{tabular}{|c|c|c|}
\hline \multicolumn{3}{|c|}{ SÍNTESE CROMÁTICA PARA CRIAÇÃO DA PALETA DE CORES } \\
\hline \multirow{8}{*}{$\begin{array}{c}\text { 30 Fase: } \\
\text { Criação de Paleta } \\
\text { de Cores }\end{array}$} & \multirow{2}{*}{$\begin{array}{l}19 \text { parte: } \\
\text { Preferências cromáticas }\end{array}$} & Cores selecionadas: \\
\hline & & 3 nuances de azul \\
\hline & \multirow{2}{*}{$\begin{array}{l}2 \circ \text { parte: } \\
\text { Harmonia Objetiva }\end{array}$} & Cores selecionadas: \\
\hline & & Harmonia Mista \\
\hline & \multirow{2}{*}{$\begin{array}{l}3^{9} \text { parte: } \\
\text { Harmonia Subjetiva Principal }\end{array}$} & Cores selecionadas: \\
\hline & & Profundidade \\
\hline & \multirow{2}{*}{$\begin{array}{l}3^{\circ} \text { parte: } \\
\text { Harmonia Subjetiva Subordinada }\end{array}$} & Cores selecionadas: \\
\hline & & Sutileza \\
\hline
\end{tabular}

Fonte: a autora.

FIGURA 103: Exemplos de paleta de cores e suas divisões contendo as predileções e preferências cromáticas, a Harmonia Objetiva e a Harmonia Subjetiva, que podem estar divididas em dominante e subordinada caso haja essa condição.

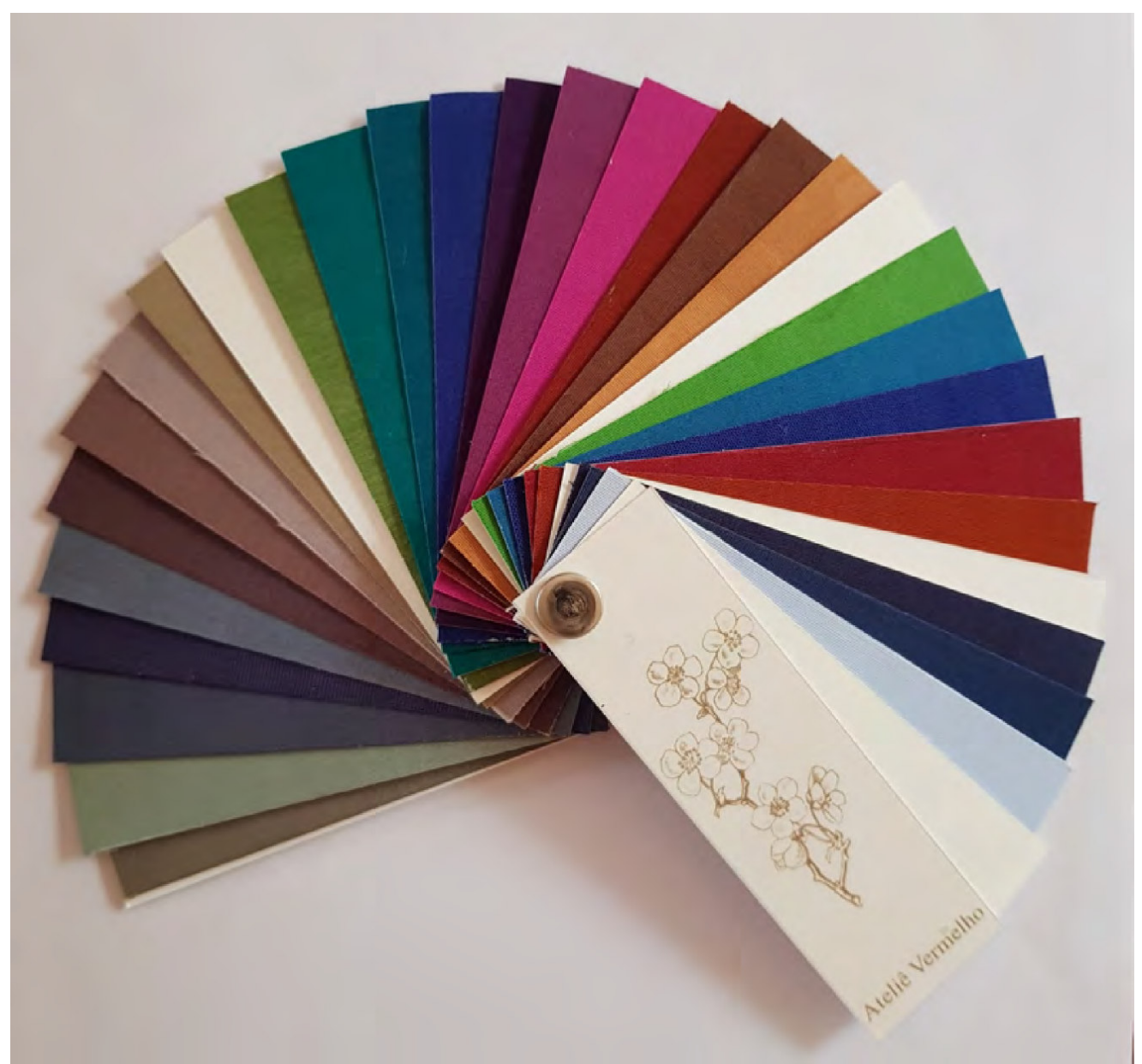

Fonte: a autora. 
QUADRO 18: Quadro síntese.

\begin{tabular}{|c|c|c|}
\hline \multicolumn{3}{|c|}{ SÍNTESE CROMÁTICA PARA CRIAÇÃO DA PALETA DE CORES } \\
\hline \multirow{6}{*}{$\begin{array}{c}3 \text { 30 Fase: } \\
\text { Criação de Paleta } \\
\text { de Cores }\end{array}$} & $\begin{array}{l}1^{\circ} \text { parte: } \\
\text { Preferências cromáticas }\end{array}$ & $\begin{array}{l}\text { Cores selecionadas: } \\
4 \text { nuances acromáticas }\end{array}$ \\
\hline & $\begin{array}{l}2^{\circ} \text { parte: } \\
\text { Harmonia Objetiva }\end{array}$ & $\begin{array}{l}\text { Cores selecionadas: } \\
\text { Harmonia Ouro }\end{array}$ \\
\hline & $3 \%$ parte: & Cores selecionadas: \\
\hline & Harmonia Subjetiva Principal & Impacto \\
\hline & 39 parte: & Cores selecionadas: \\
\hline & Harmonia Subjetiva Subordinada & Não se aplica \\
\hline
\end{tabular}

Fonte: a autora.

FIGURA 104: Exemplos de paleta de cores e suas divisões contendo as predileções e preferências cromáticas, a Harmonia Objetiva e a Harmonia Subjetiva, que podem estar divididas em dominante e subordinada caso haja essa condição.

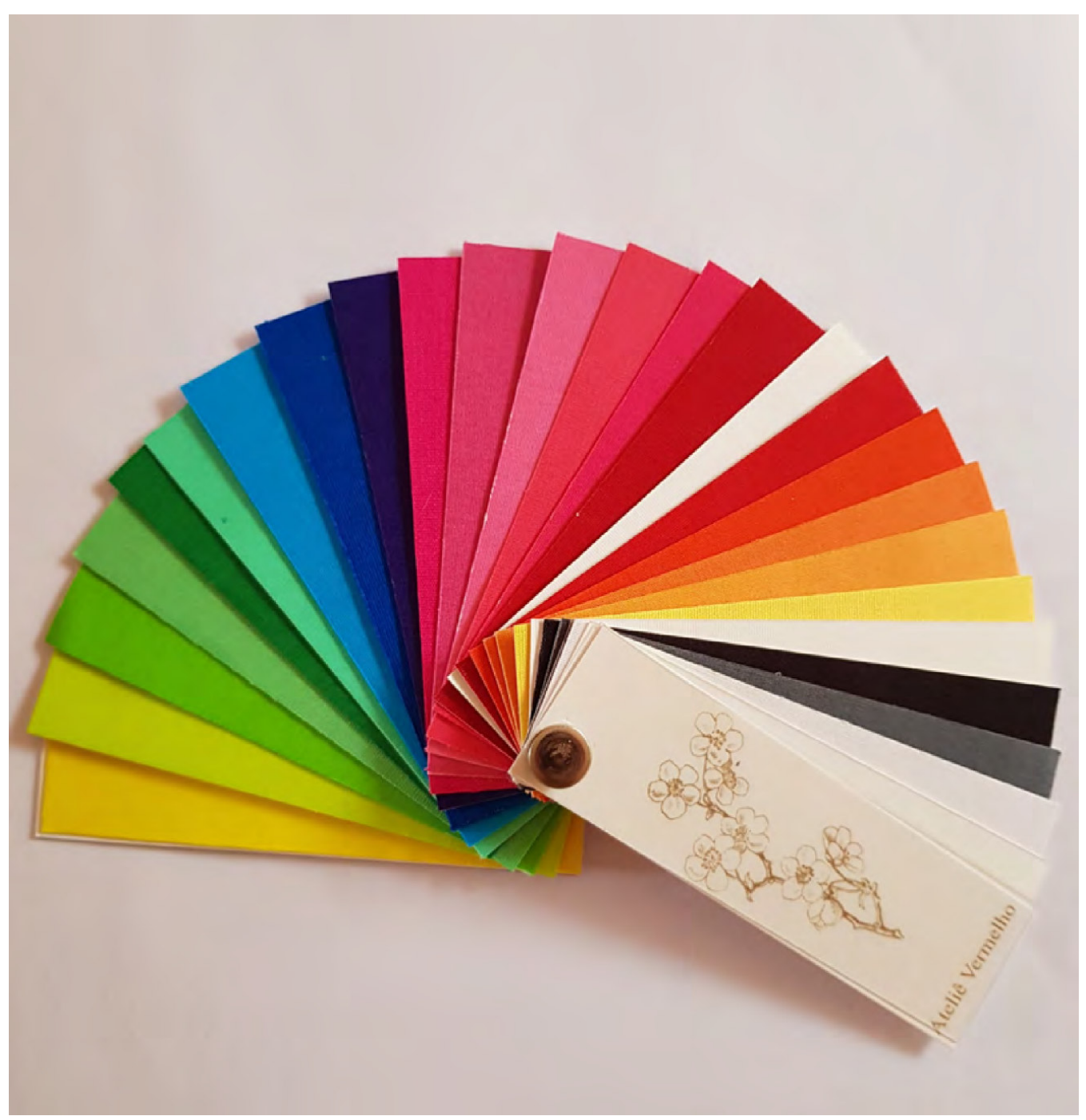

Fonte: a autora. 
QUADRO 19: Quadro síntese.

\begin{tabular}{|c|c|c|}
\hline \multicolumn{3}{|c|}{ SÍNTESE CROMÁTICA PARA CRIAÇÃO DA PALETA DE CORES } \\
\hline \multirow{8}{*}{$\begin{array}{c}\text { 30 Fase: } \\
\text { Criação de Paleta } \\
\text { de Cores }\end{array}$} & \multirow{2}{*}{$\begin{array}{l}19 \text { parte: } \\
\text { Preferências cromáticas }\end{array}$} & Cores selecionadas: \\
\hline & & 2 nuances acromáticas \\
\hline & \multirow{2}{*}{$\begin{array}{l}2 \% \text { parte: } \\
\text { Harmonia Objetiva }\end{array}$} & Cores selecionadas: \\
\hline & & Harmonia Prata \\
\hline & \multirow{2}{*}{$\begin{array}{c}3^{\circ} \text { parte: } \\
\text { Harmonia Subjetiva Principal }\end{array}$} & Cores selecionadas: \\
\hline & & Sutileza \\
\hline & \multirow{2}{*}{$\begin{array}{c}3^{\circ} \text { parte: } \\
\text { Harmonia Subjetiva Subordinada }\end{array}$} & Cores selecionadas: \\
\hline & & Profundidade \\
\hline
\end{tabular}

Fonte: a autora.

FIGURA 105: Exemplos de paleta de cores e suas divisões contendo as predileções e preferências cromáticas, a Harmonia Objetiva e a Harmonia Subjetiva, que pode estar dividida em dominante e subordinada cajo haja essa condição.

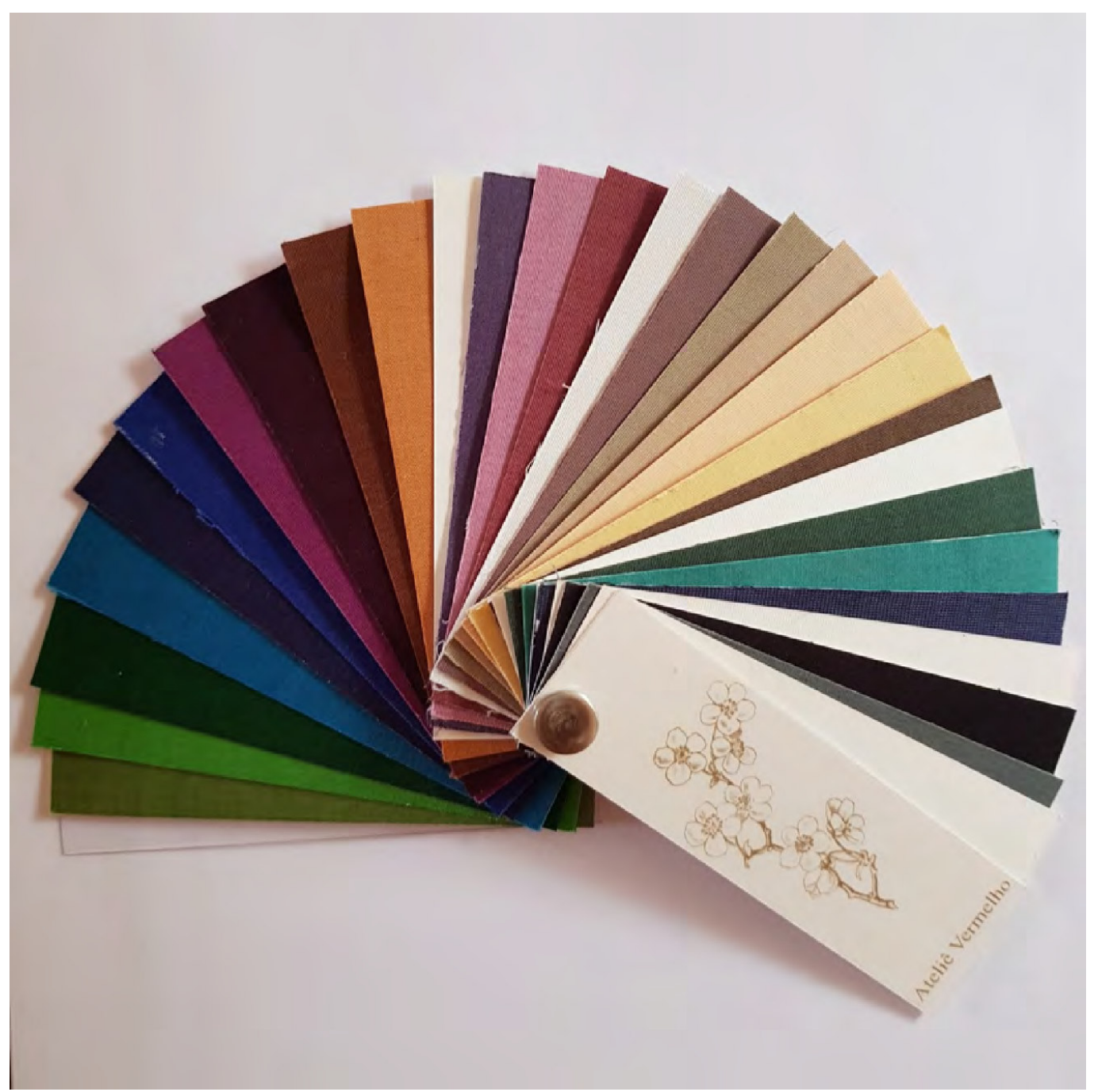

Fonte: a autora. 
QUADRO 20: Quadro síntese.

\begin{tabular}{|c|c|c|}
\hline \multicolumn{3}{|c|}{ SÍNTESE CROMÁTICA PARA CRIAÇÃO DA PALETA DE CORES } \\
\hline \multirow{6}{*}{$\begin{array}{c}\text { 30 Fase: } \\
\text { Criação de Paleta } \\
\text { de Cores }\end{array}$} & $\begin{array}{l}1 \% \text { parte: } \\
\text { Preferências cromáticas }\end{array}$ & $\begin{array}{l}\text { Cores selecionadas: } \\
\text { Não se aplica }\end{array}$ \\
\hline & $\begin{array}{l}2 \% \text { parte: } \\
\text { Harmonia Objetiva }\end{array}$ & $\begin{array}{l}\text { Cores selecionadas: } \\
\text { Harmonia Mista }\end{array}$ \\
\hline & $3 \%$ parte: & Cores selecionadas: \\
\hline & Harmonia Subjetiva Principal & Leveza \\
\hline & 30 parte: & Cores selecionadas: \\
\hline & Harmonia Subjetiva Subordinada & Não se aplica \\
\hline
\end{tabular}

Fonte: a autora.

FIGURA 106: Exemplos de paleta de cores e suas divisões contendo as predileções e preferências cromáticas, a Harmonia Objetiva e a Harmonia Subjetiva, que podem estar divididas em dominante e subordinada caso haja essa condição.

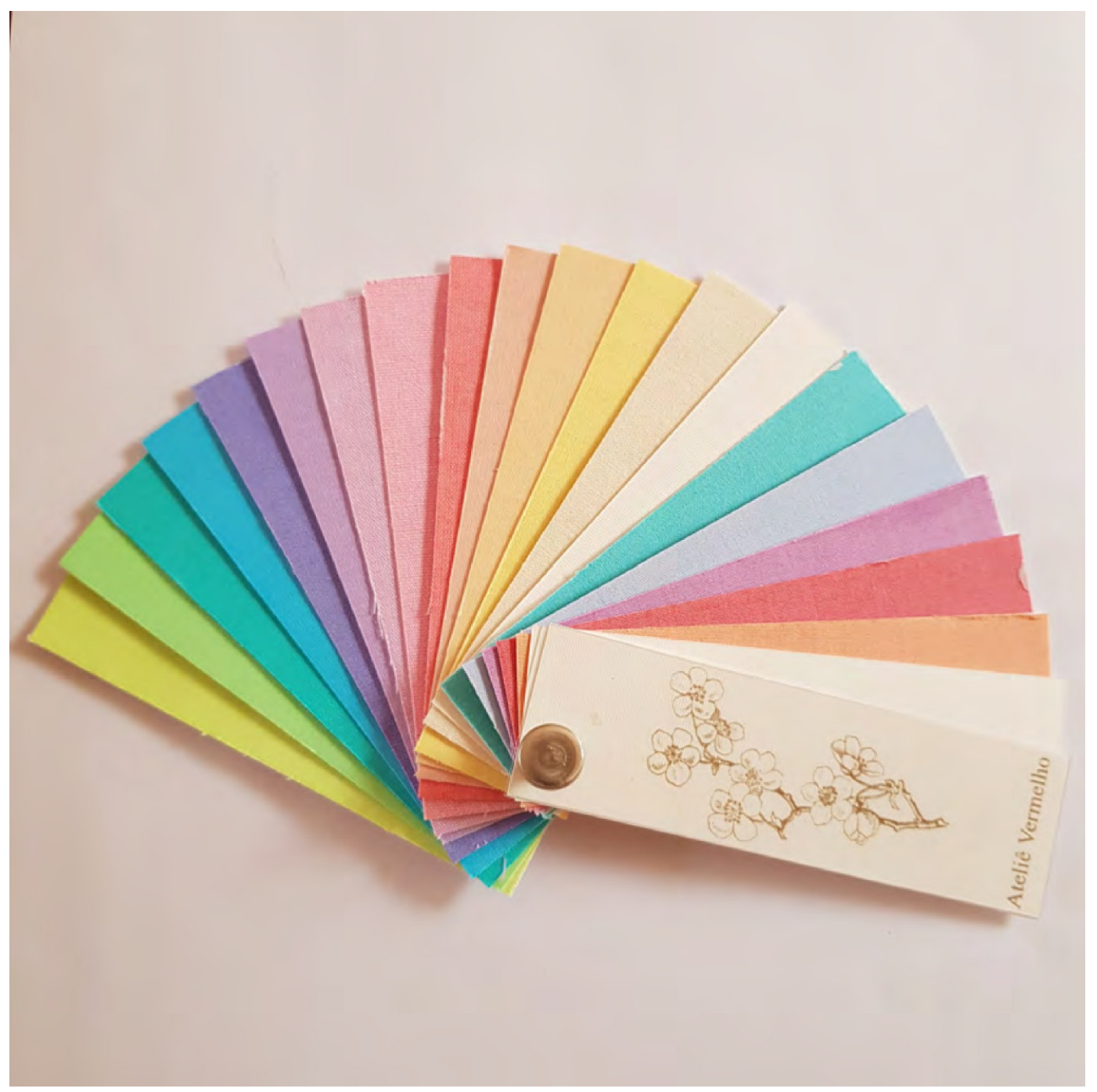

Fonte: a autora. 
Assim, a montagem das paletas de cores é a síntese de todos os caminhos e entendimentos que foram sendo dados ao longo da História, passando por várias disciplinas. Dentro desta pesquisa, esses fatores vão ao encontro dos anseios, expectativas, características e personalidades individuais, servindo como um guia, uma referência que representam o comportamento humano e suas individualidades. 


\section{CONSIDERAÇÕES}

\section{FINAIS}

"Os efeitos da cor estão nos olhos de quem vê. No entanto, os segredos mais profundos e verdadeiros dos efeitos da cor são, eu sei, invisíveis até mesmo a olho nu, sendo vistas apenas pelo coração. $O$ essencial escapa à formulação conceitual”.

(ITTEN, 1970, p. 7) 
Falar das cores é falar da relação intrínseca entre uma parcela da luz e a existência humana (PEDROSA, 2009). Isso porque a onda eletromagnética penetra através dos olhos e da pele no "cérebro, para continuar vibrando e impressionando a psique, para dar um som e um colorido ao pensamento e às coisas que o rodeiam; enfim, para dar sabor à vida, ao ambiente. É uma dádiva que lhe oferece a natureza na sua existência terrena" (FARINA, 1982, p 112).

O impacto exercido pela cor como sendo também o fundamento da expressão proporciona uma relação mútua entre os limites provenientes do mundo externo e do mundo interno de cada indivíduo. Com isso, é importante, além de verificar como determinadas predileções e preferências podem influir, entender que essas influências são a composição de várias condicionantes, como colocado pela pirâmide de Frank Mahnke (1996), em que a relação pessoal é consequência de fatores que se interconectam tanto em nível consciente como inconscientemente.

Num primeiro momento, a luz, ao penetrar através do globo ocular e da derme, desencadeia uma série de reações biológicas ao estímulo cor, que são benéficas e essenciais à vida. Essas reações colaboram para a manutenção da existência humana e determinam as condições inerentes à espécie como um todo (MAHNKE, 1996).

Indo um pouco além, no campo da biologia, observações concluíram que há uma íntima relação entre a cor e as funções biológicas, tanto que as cores dos alimentos, por exemplo, determinam o índice de maturação e é decorrente da luz e do calor do sol. Já a cor da pele muda segundo o tempo de exposição às irradiações solares indicando, além das várias raças humanas, condições de saúde (FARINA, 1982).

Num segundo momento, a psique e a mente, com suas vivências e repertórios, tanto definidos pelos arquétipos como pelas condições que foram expostas, também definem uma relação íntima que irá estabelecer uma valorização ou uma desvalorização para com todas as tonalidades existentes. Para tanto, a proposta desenvolvida por Farina (1982) e por Carl Gustav Jung (1971), com os Tipos Psicológicos, colaboram como uma espécie de guia, de roteiro e de orientação que ajudam a delimitar os anseios e as características de cada ser.

Esses tipos de personalidades foram sobrepostos aos atributos de cores definidos pelo sistema sueco Natural Colour System na busca por uma possível delimitação entre os fatores que definem e impulsionam os seres de ordem psicológica e as relações da natureza cromática. Essa interpretação foi elaborada porque ambos, tipos psicológicos e preferências por determinadas vibrações de saturação e luminosidade, podem contribuir para o entendimento do indivíduo. 
Convém ressaltar que essa forma de interpretação é uma das muitas que podem ser feitas quando há a intenção de relacionar os indivíduos com a natureza cromática. Com isso, essa comparação desenvolvida por esta tese é, junto com a pirâmide de Mahnke (1996), integrante desse trabalho e tem por intuito cercar o indivíduo e despertar nele um resultado e uma decifração quanto aos impulsos primordiais e subordinados às cores.

Obviamente, é inegável que qualquer pessoa pode se relacionar e estar conectada a todos os tipos e funções colocados por Jung (1971) sendo, por exemplo, práticos em alguns momentos, caóticos em outros. Não apenas o tipo Sentimento Extrovertido é somente Sentimento Extrovertido no qual a personalidade humana é complexa para ser cuidadosamente embalada. No entanto, o que está sendo proposto é a existência de uma característica predominante que é verdadeiramente dominante, sem excluir o fato de que, muitas vezes, existe a necessidade de abrir espaço para possíveis aberturas, incluindo a subordinação não degenerando a um uso limitado.

Num terceiro momento, os aspectos simbólicos e culturais também compõem os impulsos, tanto que, segundo Pastoureau (2011, p. 14), "é a sociedade que "faz" a cor, que lhe confere definições e significações, que constrói seus códigos e seus valores, que organiza suas práticas e determina suas implicações". Nesse sentido, muitos dos conceitos e das construções que cada período histórico estabeleceu com as tonalidades não são verdades eternas, mas sim refletem o momento em que se faz menção.

Isso porque, conforme as sociedades caminham e se desenvolvem, esses códigos sofrem alterações por acompanharem as necessidades e os acontecimentos vigentes, dizendo respeito a domínios das atividades pertencentes ao léxico, ao vestuário, aos emblemas e a heráldica, ao comércio dos pigmentos e dos corantes, à criação artística e aos discursos científicos. Essas construções ocorreram em momentos e seguem ritmos diferentes de acordo com a latitude, o clima, a utilidade, as necessidades, os objetivos simbólicos e as preocupações estéticas (PASTOUREAU, 2011).

Nessa perspectiva, os conceitos envolvendo as cores vão sendo alterados, pois a própria noção de preferência implica uma abstração, uma conceituação de cor que a Antiguidade e outros períodos históricos que se sucederam dificilmente exprimiam, pois os termos referentes às cores eram apenas adjetivos, ou seja, uma abstração ligada sempre a um objeto, a um fenômeno natural ou a um ser vivo (PASTOUREAU, 2019). Assim, era possível dizer: "Quero um ornamento vermelho" ou "Não me agrada os tecidos azuis", mas nunca "Quero vermelho" ou "Não me agrada azul". 
Já nos dias de hoje, é aceitável declarar: "Gosto de vermelho" ou "Não me agrada azul", sem especificar algo em particular, pois as designações de cores também se tornaram substantivos que nomeiam categorias cromáticas no absoluto, como se fosse uma questão de ideias ou conceitos. Dessa forma, os valores atribuídos às cores mudam no tempo e no espaço, bem como são também definidos pelas sociedades em questão. Conforme Farina (1982, p. 29):

\begin{abstract}
A cor é uma condição e, como tal, uma característica do estilo de vida de uma época - integra uma determinada maneira de ver as coisas. É inegável que toda cor tem um espaço que lhe é próprio, mas é também inegável que esse espaço faz parte da cor, de acordo com as concepções culturais que o fundamentam.
\end{abstract}

Assim, a percepção das cores não é somente um fenômeno biológico ou psíquico, mas também um fenômeno cultural que requer conhecimento, memória, imaginação, sentimentos e relações com os outros (PASTOUREAU, 2017). De maneira mais geral, é vida em sociedade e fatos de sensibilidade coletivos que geralmente são regidos por outras influências (MAHNKE, 1996).

Por isso mesmo, as influências exercidas pela moda e tendência tão presentes na sociedade atual agregam informações, conceitos e determinam, junto com todos os outros fatores elencados, a construção da reação humana à cor. Para tanto, na tentativa de entender as flutuações e os pilares estruturais que definem a moda e tendência, a Hierarquia das Necessidades de Abraham Maslow (MASLOW apud VEJLGAARD, 2008), a Curva de Difusão da Inovação de Everett Rogers (ROGERS apud SANTOS, 2013) e o Modelo de Tendência em Forma de Diamante de Henrik Vejlgaard (2008), contribuem para o entendimento de como as pessoas se portam e reagem às influências cromáticas.

Além disso, a previsão de tendência não é uma caixa preta, não sendo uma novidade quente que surgiu na semana passada, nos últimos anos, ou mesmo no último século vinte, como algo em si estagnado e imutável (VEJLGAARD, 2008). A essência da moda e da tendência é a mudança, um processo perpétuo de "destruição criativa" e vai além do têxtil e da maquiagem (BLASZCZYK; WUBS, 2018). Embora as preocupações com a beleza estejam presentes desde as primeiras civilizações humanas, foi apenas na história recente que esse negócio se envolveu na imensa indústria que reconhecemos hoje (ELDRIDGE, 2015).

$\mathrm{Na}$ verdade, hoje em dia, estudos de tendências são de enorme interesse para uma grande variedade de indústrias que parecem importar-se cada vez mais com esse universo no 
centro da sociedade comercial, que produz constantemente novos produtos, novos estilos e novos sabores.

Nos últimos séculos, ela tem sido praticada e desenvolvida por diferentes tipos de empresas e assumiu muitas formas diferentes, por isso a previsão de cores está intimamente conectada com esse universo. Tanto que as tendências cromáticas ajudam a impulsionar a moda e podem ser, num primeiro momento, atividades intuitivas que evoluíram para se adequar aos tempos (BLASZCZYK; WUBS, 2018).

Observa-se que a profissão moderna de estudos de tendência emergiu das sombras da indústria têxtil do século XIX e amadureceu junto com o triunfo do pronto-a-vestir no século XX. A Segunda Revolução Industrial, a ascensão da sociedade de consumo e o advento das fibras sintéticas trouxeram uma nova forma de racionalizar, gerenciar e prever a paleta de cores. Ao lado disso, os previsores de tendências foram aperfeiçoando o como formular soluções para o problema da informação imperfeita sobre a mudança de gostos e desenvolveram esse mercado tão essencial para os mundos do estilo, glamour e consumo de massa.

Esses estudos evoluíram de uma operação individual e autoral quase pontual no século XIX, para agências de estilo de pequeno e médio porte no século XX como a WGSN. Tanto que, segundo Blaszczyk e Wubs (2018, p.27):

\footnotetext{
Nos últimos cinquenta anos, esforços foram empreendidos para construir modelos matemáticos, como mostra o trabalho de Kentaro Kawasaki em Chori, enquanto a IBM e o Google agora pretendem usar big data para fazer previsões de tendência. Desenvolvimentos recentes parecem augurar um admirável mundo novo de estudos de moda, dominado por empresas parentes anônimas, divulgando dados e disseminação digital (...). Certamente, a tecnologia tem sido um importante motor de mudança na evolução da previsão de moda (...).

Hoje temos na web um tour na ponta dos dedos, mas a realidade é que designers, retaliers e marqueteiros vão às feiras internacionais em números cada vez maiores para interagir com os fornecedores, olhar para as cores (...).
}

Mesmo assim, os autores ainda acrescentam que "Não existem tecnologias melhores do que o olho humano, do toque humano e da mente humana (...). O elemento humano é importante e mais decisivo do que os dispositivos digitais mais recentes" (BLASZCZYK; WUBS, 2018, p.28).

Junto a tudo isso, para que se desenvolva uma construção precisa de uma paleta de cores que reflita a expressão individual, é necessário compreender os conceitos definidos por 
Michel Eugène Chevreul (1987) intitulado de A Lei do Contraste Simultâneo, a contribuição deixada por Johann Wolfgang von Goethe (2011) com as cores fisiológicas e os contrastes e o timbre subjetivo estabelecidos por Johannes Itten $(1961 ; 1970)$, que são a base das características objetivas e ajudam a detectá-las.

Assim, ao analisar todas essas condicionantes envolvidas na construção de um trabalho voltado para a expressão cromática individual, é parte desta tese propor uma forma de refletir sobre a ênfase dessa questão, possibilitando a autonomia e a personalização e evitar a visível árida sistematização. Por essa razão, a criação e a proposição de paletas de cores têm que ser individuais e espelhar as vontades e desejos interiores de cada um. Além disso, poderá ajudar a indústria, os serviços e comércios a se colocarem no mercado e a espelharem seu significado também através das cores.

Dessa forma, a importância dessa pesquisa se dá pelo fato de a cor expressar em si a individualidade, valorizando as habilidades naturais de cada indivíduo, sejam elas físicas ou imateriais. Sendo assim, esse método contribui, de forma significativa, para o aumento da autoestima, influencia o estado de ânimo e eleva a sensação de bem-estar.

Com isso, a criação de paletas de cores voltadas para a expressão individual busca abranger algumas esferas de forças cujos resultados englobam e relacionam tanto os aspectos conscientes como inconscientes, além dos interesses individuais e traços de personalidade de cada um. Assim, somente mediante a análise e interpretação dos dados levantados e coletados, pode ser proposta uma cartela cujo tempo de duração seja difícil de ser mensurado e as cores selecionadas possam sofrer alterações, dependendo tanto da época como dos acontecimentos vividos pelos seres humanos durante a própria passagem pelo tempo e pela vida.

Este trabalho também tem por objetivo propor uma consciência cromática, passando por vários campos que culminam no resultado final quanto à reação individual às cores. Isso sem ser rígido e nem propor malabarismos desnecessários ou um cientificismo perigoso que tentam trazer uma verdade única e eterna, uma vez que nem a natureza cromática e nem os seres humanos são fixos, estáticos e enrijecidos.

Portanto, a criação de paletas de cores para os indivíduos tem que levar em consideração, não só os aspectos objetivos, mas também os aspectos subjetivos que envolvem a psique humana, além dos anseios individuais e as necessidades mais íntimas e profundas (MAHNKE, 1996).

Assim, não existe uma fórmula universal que estabeleça, de maneira única e legítima, procedimentos a serem seguidos para a definição do projeto cor que atenda a todos os seres 
humanos de maneira universal e generalizante. Com isso, pode-se concluir que, por mais que não haja uma única verdade envolvendo um determinado estímulo de cor, isso não significa que alguns critérios não possam ser aplicados.

Dessa forma, essa metodologia passa por aspectos provenientes de natureza objetiva como também oriundos da percepção, sensação, sentimento e vivência atrelados à existência. Esse fato vai ao encontro do que Pastoureau defendeu ao dizer que (2019, p. 8):

\begin{abstract}
as neurociências têm se interessado pelas cores e enfatizado a importância dos fenômenos visuais e perceptuais; a cor não é simplesmente um revestimento material ou um conjunto de variações sutis de luz, é também um fenômeno de percepção. Surge da conjunção de três elementos: uma fonte de luz, um objeto sobre o qual essa luz incide, e um órgão receptor, ou seja, o ser humano equipado com um aparato complexo simultaneamente anatômico, fisiológico e cultural - formado pelo olho par de cérebros. (...) a cor não existe se não for percebida; isto é, não só é visto com os olhos, mas também é decodificado com momentâneo, conhecimento e imaginação. "Uma cor que não se vê é uma cor que não existe", declarou Goethe já em 1810, na terceira parte de seu famoso Farbenlehre.
\end{abstract}

Por outro lado, tem que haver também um aceite dos impulsos intuitivo, instintivo e criativo do indivíduo alvo da elaboração de uma cartela de cores. "Assim, chegamos à conclusão de que um fato é inegável: mesmo que haja uma parte instintiva na reação à cor, é indiscutível que o homem vai acumulando em sua memória experiências que o definem e o fazem agir de determinadas maneiras no decorrer de sua vida" (FARINA, 1982, p. 109).

Para finalizar, é importante destacar que esta pesquisa não se esgota aqui, pois a paleta de cores que se propõe nesta tese abre margem para outros estudos. Diferentemente da proposta apresentada, uma investigação possível e que fica aberta a futuros pesquisadores seria investigar a possibilidade de relacionar todos os testes psicológicos que usam como base as cores e como, a partir desses trabalhos, criar paletas de cores que levem em consideração as relações individuais. 


\section{REFERÊNCIAS BIBLIOGRÁFICAS GERAIS}

ACHENBACH, J. O Poder da Luz. Revista National Geographic, Editora Abril, ano 2, n. 18, p. 76-105, out. 2001.

ALBERS, J. A Interação da Cor. São Paulo: WMF Martins Fontes, 2009.

BARRoS, L. R. M. A Cor no Processo Criativo: um estudo sobre a Bauhaus e a teoria de Goethe. São Paulo: Editora SENAC São Paulo, 2006.

A Influência das Cores, São Paulo, 2014. Disponível em: https://universodacor.wordpress.com/category/descanso-para-os-olhos/. Acesso em: 23 set. 2015.

BATCHELOR, D. Cromofobia. São Paulo: Editora SENAC, 2007.

BIRREN, F. Color and Human Response. New York: Van Nostrand Reinhold Company, 1978 . . Color Psychology and Color Therapy. New Jersey: Citadel Press, 1961.

. The Power of Color. New Jersey: Citadel Press, 1997.

. Color in your world. New York: Collier Books, 1962.

BLASZCZYK, R; WUBS, B. The Fashion Forecasters: a hidden history of color and trend prediction. Toronto: Kobo Editions, 2018.

BRUSATIN, M. A History of Color. London: Shambhala, 1991.

CALDAS, D. Observatório de Sinais. Rio de Janeiro: Senac, 2004.

CAMPBELL, J. O Poder do Mito. São Paulo: Palas Athena, 1990.

CAYGILL, S. Color: the Essence of You. Millbrae: Celestial Arts, 1980.

CLARK, N. Como combinar e escolher cores para o design gráfico. Barcelona: Editorial Gustavo Gili, 2006.

CHASE, D. The Medically Based No-Nonsense Beauty Book. New York: Alfred A. Knoopf, 1979.

CHEVREUL, M. The Principles of Harmony and Contrast of Colors and Their Applications to the Arts. New York: Franklin Classics, 1987.

CSILLAG, P. Comunicação com Cores: uma abordagem científica pela percepção visual. 1. Ed. São Paulo: SENAI-SP Editora / ESPM, 2015. 
DROSTE, M. Bauhaus: Bauhaus Archiv. Berlim: Taschen, 2006.

EISEMAN, L.; RECKER, K. Pantone: the 20th century in color. San Francisco: Chronicle Books, 2011.

ELDRIDGE, L. Face Paint: the story of makeup. New York: Abrams Image, 2015.

FARINA, M. Psicodinâmica das Cores em Comunicação. São Paulo: Editora Edgar Blücher, 1982.

FRASER, T. O guia completo da cor: livro essencial para a consciência das cores. São Paulo: Editora SENAC São Paulo, 2007.

O Essencial da Cor no Design. São Paulo: Editora Senac São Paulo, 2012.

GAGE, J. Colour and Meaning: art, science and symbolism. London: Thames \& Hudson, 1999.

GOETHE, J. W. Doutrina das Cores. São Paulo: Nova Alexandria, 2011.

GUIMARÃES, L. A Cor como Informação: a construção biofísica, linguística e cultural da simbologia das cores. São Paulo: Annablume, 2004.

HARDIN, C.L. Color for Philosophers: unweaving the rainbow. Indianapolis/Cambridge: Hackett Publishing Company, 1988.

HARVARD ART MUSEUMS. An Atlas of Rare \& Familiar Colour. Los Angeles: Atlier Éditions, 2017.

HELLER, E. A Psicologia das Cores: como as cores afetam a emoção e a razão. São Paulo: Gustavo Gili, 2013.

HENDERSON, V; HENSHAW, P. Color me Confident: expert guidance to help you look wonderful anf feel great. New York: Hachette Book Group, 2014.

ITTEN, J. The Art of Colour: Subjective experience and Objectevive Rational of Colour. New York: Van Nostrand Reinhold, 1961.

The Element of Colors: A treatise on the color system of Johannes itten based on his book The Art of Color. New York: Van Nostrand Reinhold, 1970.

JACKSON, C. Color Me Beautiful. New York: The Random House Publishing Group, 1984.

JUNG, C. Tipos Psicológicos. Tradução Álvaro Cabral. Rio de Janeiro: Editora Vozes, 1971.

KNAPP, R; DORR, D. Beyond the Color Explosion. Washington: Rainy Day Publishing, 1985. 
LEWIS-CRUM, J; NICHOLSON, J. Color Wonderful. New York: A Bantam Book, 1986.

LICHTEnStEIN, J. (org.). A Pintura: O desenho e a cor. v. 9. São Paulo: Editora 34, 2006.

LÜSCHER, M.; SCOTT, I. O Teste das Cores de Lüscher. 1. Ed. Rio de Janeiro: Editora Renes, 1969.

MAHNKE, F. H. Color, Environment, and Human Response: An interdisciplinary understading of color and its use as a beneficial element in the design of the architectural environment. New York: John Wiley \& Sons, Inc., 1996.

depth. San Diego: IACC Seminar 4, 2010

MAZZILLI, C. T. S. A identidade cromática da paisagem urbana: as cores do Brás. 1993. 246 f. Dissertação (Mestrado em Arquitetura e Urbanismo) - Faculdade de Arquitetura e Urbanismo, Universidade de São Paulo, São Paulo, 1991.

MESTRINER, F. Gestão Estratégica de Embalagem. São Paulo: Pearson, 2008.

MIKELLIDES, B; PORTER, T. Colour for Architecture Today. New York: Taylor \& Francis, 2009.

MOCERI, F. Percepção Cromática Urbana: a cor para os arquitetos. 2016. $114 \mathrm{f}$. Dissertação (Mestrado em Arquitetura e Urbanismo) - Faculdade de Arquitetura e Urbanismo, Universidade de São Paulo, São Paulo, 2016.

MUNSELL Color. Munsel Book of Color: glossy finish collection. Baltimore: Munsell Collor Company, 1915.

OSTROWER, F. Criatividade e Processos de Criação. Petrópolis: Vozes, 2014.

PAULY, D. Barragán: space and shadow, walls and colour. Basel; Boston; Berlin: Birkhauser, 2002.

PAStoureau, M. Dicionário das Cores do nosso Tempo: simbólica e ssociedade. Lisboa: Ed. Estampa, 1997.

Preto: História de uma Cor. São Paulo: Editora SENAC São Paulo: Imprensa Oficial do Estado de São Paulo, 2011.

Press, 2014.

Green: The History of a Color. New Jersey: Princeton University Azul: História de uma Cor. Lisboa: Orfeu Negro, 2016.

2017.

Red: The History of a Color. New Jersey: Princeton University Press, 
Press, 2019.

Yellow: The History of a Color. New Jersey: Princeton University

PEDROSA, I. Da Cor à Cor Inexistente. Rio de Janeiro: SENAC Nacional, 2009.

PIPER, H. CRACKING the Colour Code: A visual exploration of how we view colours, how we make them, and the meanings they hold in our world. Written and Directed: Hugh Piper. Produced: Andrew Ogilvie e Fabrice Estève. [S.I]: Electric Pictures Ltda; Gedeon Programmes; ARTE France; S4C; Film Finance Corporation Australia Ltda; ScreenWest Inc.; Special Broading Cast Service Corporation, 2008. 1 DVD (156 min), NTSC, color, Worldwide, PCM stereo, original language: english.

RAYMOND, M. The Trend Forecaster's Handbook. London: Laurence King Publishing, 2020.

RICHMOND, J. Color Me Beautiful: 4 seasons of color, makeup and style. Maryland: Taylor Trade Publishing, 2008.

ROSSOTTI, H. Colour - Why the world isn't grey. Princeton: Princeton University Press, 1983.

ROUSSEAU, R. L. A Linguagem das Cores: A energia, o simbolismo, as vibrações e os ciclos das estruturas coloridas. São Paulo: Editora Pensamento, 1980.

SANTOS, J. Sobre tendências e o espírito do tempo. São Paulo: Estação das Letras e Cores, 2013.

SCHOPENHAUER, A. Sobre a Visão e as Cores. São Paulo: Nova Alexandria, 2003, cit., p. 60.

SILVEIRA, N. Jung Vida e Obra. Rio de Janeiro: Paz e Terra, 1981.

SPILLANE, M; SHERLOCK, C. Color Me Beautiful's: looking your best color, makeup and style. London: Madison Books, 1995.

SWIRNOFF, L. Dimensional Color. Cambridge: Birkhauser Boston, 1989.

VEJLGAARD, H. Anatomy of a Trend. New York: McGraw-Hill, 2008.

WILKINSON, P. O livro ilustrado da mitologia: lendas e histórias fabulosas sobre grandes heróis e deuses do mundo inteiro. São Paulo: Publifolha, 2002.

WITTGEnStEIN, L. Anotações sobre as Cores. 1. ed. Campinas: Editora da Unicamp, 2009.

WRIGHT, A. The Beginner's Guide to Colour Psychology. London: Colour Affects Ltd., 1999. 